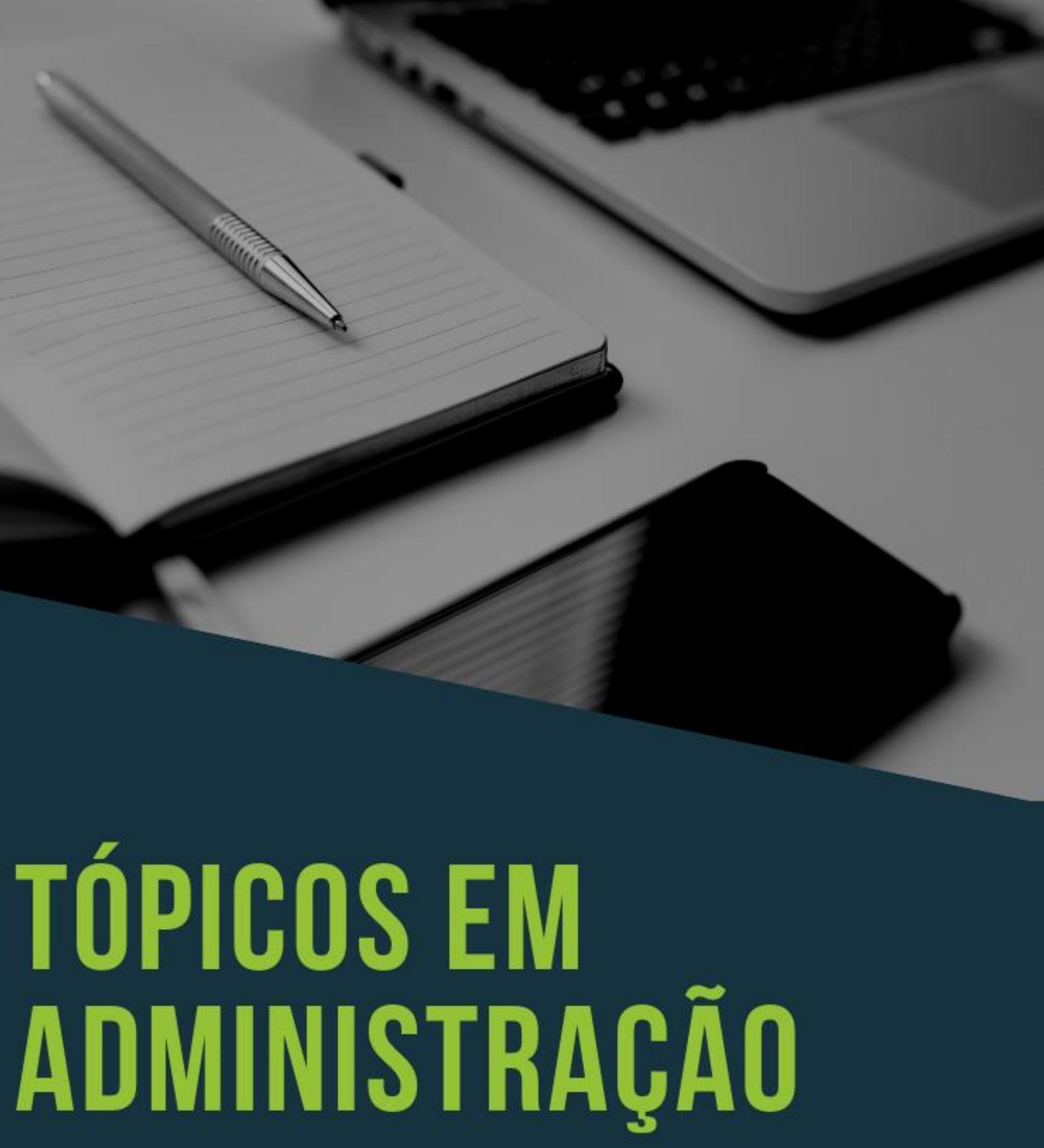

\title{
Volume 23
}

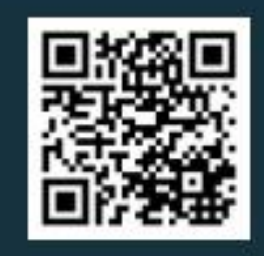

Editora Poisson 
Editora Poisson

\section{Tópicos em Administração Volume 23}

1a Edição

Belo Horizonte

Poisson

2019 
Editor Chefe: Dr. Darly Fernando Andrade

\section{Conselho Editorial}

Dr. Antônio Artur de Souza - Universidade Federal de Minas Gerais

Ms. Davilson Eduardo Andrade

Msc. Fabiane dos Santos Toledo

Dr. José Eduardo Ferreira Lopes - Universidade Federal de Uberlândia Dr. Otaviano Francisco Neves - Pontifícia Universidade Católica de Minas Gerais

Dr. Luiz Cláudio de Lima - Universidade FUMEC

Dr. Nelson Ferreira Filho - Faculdades Kennedy

Ms. Valdiney Alves de Oliveira - Universidade Federal de Uberlândia

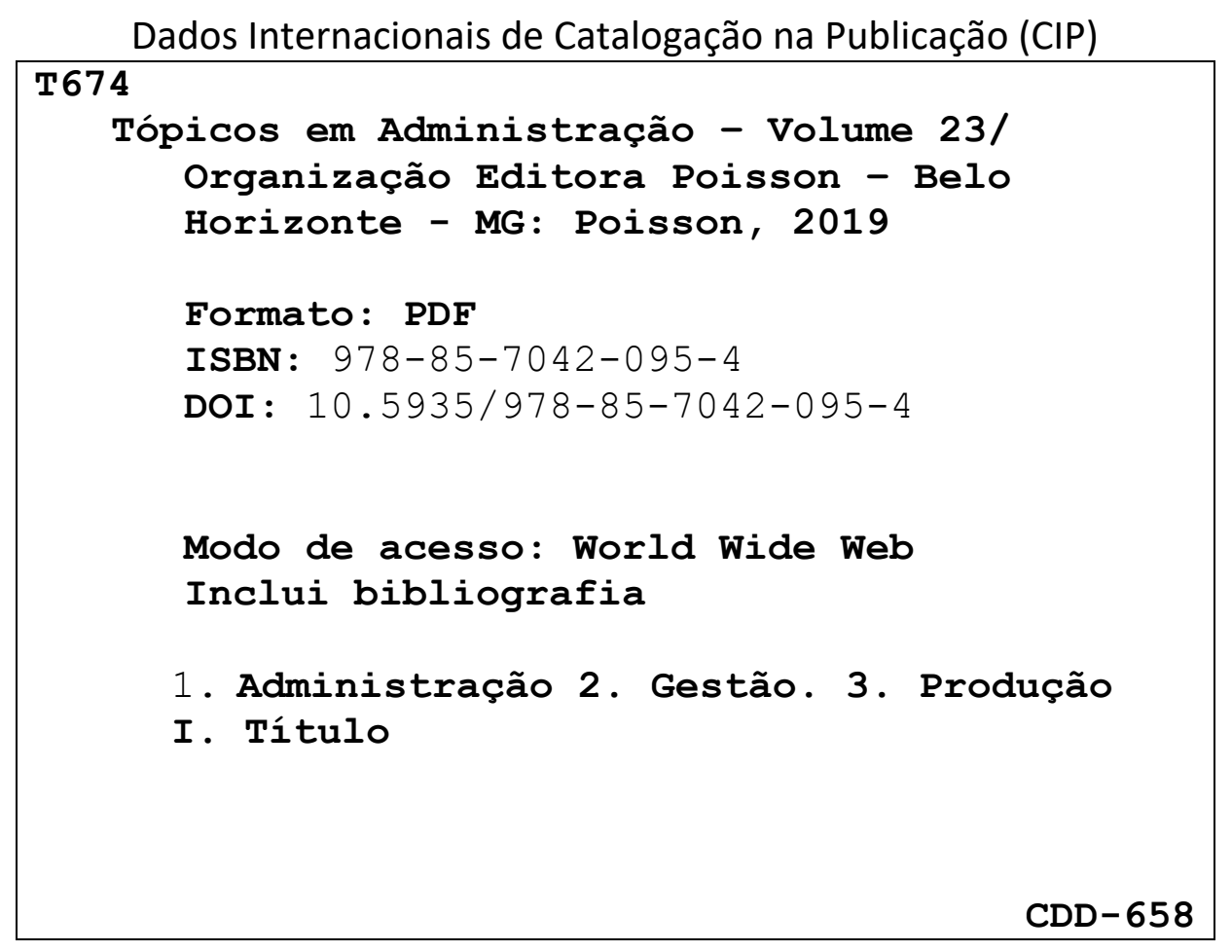

O conteúdo dos artigos e seus dados em sua forma, correção e confiabilidade são de responsabilidade exclusiva dos seus respectivos autores.

www.poisson.com.br

contato@poisson.com.br 


\section{SUMÁRIO}

Capítulo 1: Da constitucionalidade dos honorários administrativos cobrados pelo estado de Rondônia no protesto de Certidões de Dívida Ativa (CDAs).

Sérgio Fernandes de Abreu Júnior, Pedro Henrique Moreira Simões, Maria Rita Rodrigues Constâncio Menezes

Capítulo 2: Controladoria na Administração Pública: Um estudo de caso no Núcleo De Controle Interno Do Município de Salinas/MG 22

Claudiana Aparecida Leal de Araújo, Janaine de Oliveira Souto, Márcia Ferreira Silva, Marconi dos Santos Miranda, Vânia Fernandes Celestino

Capítulo 3: Imagem e Reputação da Autoridade Monetária: Uma nova abordagem para avaliação da credibilidade de bancos centrais. 32

Paulo Roberto da Costa Vieira

Capítulo 4: A evolução da sistemática aduaneira na importação: Siscomex, Portal Único e expectativas acerca dos benefícios da DUIMP 48

Marcelo de Oliveira Soares, Hellen Xavier das Chagas, Rodrigo Luiz Zanethi

Capítulo 5: Implantaçāo da saúde enxuta como técnica gerencial para melhorar o desempenho de um laboratório de análises clínicas.

Ricardo Pereira, Mehran Misaghi, Álvaro Paz Graziani

Capítulo 6: Visão Multicritério no estabelecimento da Função Utilidade para aquisição de uma Câmara de Pressão Negativa em uma Farmácia de Manipulação 82

Simone de Almeida

Capítulo 7: Comunicação empresarial por meio da identidade visual: 0 processo de construção de uma nova logomarca para uma pequena empresa do ramo de papelaria

Wledenir Calgaro, Joiceli S. Fabrício, Jaiane Aparecida Pereira, Rosely Scheffer

Capítulo 8: Estratégia de operações: Um estudo de caso em uma microempresa varejista em Tangará da Serra - MT. 100

Lidiane da Silva Souza Angola, Camyla Piran Stiegler Leinter, Josiane Silva Costa dos Santos , Juscelaine de Fátima Rodrigues Moreira 


\section{SUMÁRIO}

Capítulo 9: Análise ergonômica e de saúde no modal rodoviário: Impacto na qualidade de vida dos caminhoneiros 109

Juliana Karoline Forsan Pascotti, José Geraldo Baziles Xavier, Luiz Carlos de Ponte Junior, Ivana Salvagni Rotta

Capítulo 10: Aplicação do método RULA para análise da postura adotada por um trabalhador durante o processo de soldagem de chapas de aço pela técnica de arco submerso: Proposta de ações.

Duileu Couto, Daniele Macarini, Douglas F. Vidal, Letícia da Silva, Leonam Formento

Capítulo 11: Motivação e teorias motivacionais e sua aplicabilidade em uma instituição de ensino superior: Um estudo de caso 131

Ana Beatriz Lopes Souza, Edmilson Cavalcante Nunes, Gabriel Freitas da Costa, Ivone Pedro de Lima, Paola Rayanne Reis Fernandes

Capítulo 12: Diagnóstico de métodos de trabalho: Analíse de uma unidade administrativa universitária

Daniel Teotonio do Nascimento, Adriana Sousa Lima, Claudio Antonio Rojo

Capítulo 13: A importância do profissional farmacêutico no processo logístico para garantir a integridade dos medicamentos 158

Vitor Costa Chainça, Everaldo Luiz Alves de Souza dos Santos, Vanina Carrara Sigrist

Capítulo 14: Implantação de Internet of Things em indústria de embalagens 168

Mari Tomita Katayama, João Carlos Martins Coelho, Henrique Jun Muramatsu Seguchi

Capítulo 15: Análise comparativa da adaptabilidade da área fabril na filosofia da manufatura enxuta numa empresa aeronáutica 178

Newton Eizo Yamada, Fernando Augusto Silva Marins, Luiz Antonio Tozi

Capítulo 16: A importância da contabilidade ambiental no cursos de ciências contábeis: Um olhar para sistemas de gestão 190

Estefânie da Silva Tenório, Marileide Alexandrino Barreto, Ana Paula Lima Marques Fernandes, Marluce Alves de Almeida Salgueiro 


\section{SUMÁRIO}

Capítulo 17: Implantação de processo automático de soldagem (ASM - Auto Soldering Machine) 210

Sandro Breval Santiago, Eduardo Luiz de Oliveira, Jonathan Oliveira Dias

Capítulo 18: Estratégia como prática na produção do desfile de uma escola de samba. 221 Ana Carolina Julio da Silva Andrade

Autores: 


\section{Capítulo 1}

Da constitucionalidade dos honorários administrativos cobrados pelo Estado de Rondônia no protesto de Certidões de Dívida Ativa (CDAs)

Sérgio Fernandes de Abreu Júnior

Pedro Henrique Moreira Simões

Maria Rita Rodrigues Constâncio Menezes

Resumo: 0 presente trabalho pretende analisar, partindo-se da experiência do Estado de Rondônia, com a edição da Lei Estadual no 2.913/2012, com redação incluída pela Lei Estadual no 3.526/2015, a constitucionalidade, legalidade e legitimidade da cobrança administrativa de honorários em favor dos Procuradores do Estado de Rondônia em razão de protestos de Certidões de Dívida Ativa (CDAs).

Palavras-chave: verba honorária. procurador. receita pública. teto remuneratório. 


\section{INTRODUÇÃO}

É muito comum o enfrentamento do desafio da recuperação de passivos judiciais pelos Estados, sobretudo os passivos que versam sobre Dívida Ativa.

Prova disso é o elevado número de protestos extrajudiciais de Certidões de Dívida Ativa (CDAs) e execuções fiscais ajuizadas pelos Estados e pelo Distrito Federal em Varas, especializadas ou não, nos respectivos Tribunais de Justiça de Todo o Território Nacional.

De acordo com o Conselho Nacional de Justiça (CNJ), em notícia publicada em seu Sítio Eletrônico, na Rede Mundial de Computadores, em 20 de março de 2015, os processos de execução fiscal representavam cerca de 50\% (cinquenta por cento) dos 95,14 (noventa e cinco vírgula quatorze) milhões de feitos judiciais em tramitação no País.

Também de acordo com o Relatório Anual do Poder Judiciário de 2015, ano-base 2015 do CNJ, os executivos fiscais representam cerca de $75 \%$ (setenta e cinco por cento) de todas as execuções pendentes no Poder Judiciário Brasileiro.

Assim, não restam dúvidas no sentido de que, contemporaneamente, diante de um cenário de grave crise econômica e institucional em que está mergulhado o Brasil, a constitucional, legal e legítima cobrança de honorários administrativos oriundos do protesto como meio mais eficiente do crédito tributário surge como uma alternativa efetiva à fundamental atividade de recuperação de créditos tributários e não tributários inscritos em Dívida Ativa, na medida em que é comprovadamente mais eficiente em relação a executivos fiscais ajuizados pela Fazenda Pública.

Procura-se, assim, demonstrar, ao final deste singelo artigo, partindo-se da experiência do Estado de Rondônia, com a edição da Lei Estadual no 2.913/2012, ser constitucional, legal e legítima a cobrança administrativa de honorários em favor dos Procuradores do Estado de Rondônia em razão de protestos de Certidões de Dívida Ativa (CDAs).

\section{DA NATUREZA JURÍDICA DOS HONORÁRIOS ORIUNDOS DO PROTESTO DE CERTIDÕES DE DÍVIDA ATIVA (CDAS)}

Não se pode querer vincular os honorários advocatícios previstos no dispositivo impugnado com os honorários sucumbenciais previstos na legislação processual.

Isso, com a devida vênia, é um erro que deve ser enfrentado.

Para tanto, citamos Romeu e Julieta, de William Shakespeare, para auxiliar nossa análise.

Afinal, como disse Julieta a seu amante: De que vale um nome, se o que chamamos rosa, sob outra designação, teria igual perfume?

Buscando trazer o sentido do texto acima para o mundo jurídico, temos que o nome de um instituto jurídico não importa para fins de explicitar a sua essência ou, no mundo do Direito, sua natureza jurídica.

Contudo, forçoso reconhecer que o nome dado a determinada coisa acaba por influir na sua compreensão, já que, junto ao nome, há um contexto de compreensão em que o próprio intérprete está inserido ${ }^{1}$. Razão disso, quando o operador do direito está diante de um nome (instituto) ou de uma norma, tende a nela aplicar os conceitos que já lhe são internalizados, passando a compreender aquilo que está interpretando com seus próprios olhos². Não é por outra razão que, diante de uma indagação jurídica

No caso, diante da expressão "honorários advocatícios", não é de se surpreender que o intérprete - assim como fez o autor da inicial - busque em sua "bagagem jurídica" a adequação do termo utilizado com aquilo que lhe é familiar. Assim, desfazendo-nos dessas preconcepções, é mister investigar a natureza jurídica dessa verba.

\footnotetext{
1“[...] não há um sentido escondido na norma/texto, que possa ser alcançado de forma essencialista; tampouco há um sentido imanente, inerente, como uma espécie de elo (fundado/fundante) que liga o significante ao significado, como um objeto que possa ser buscado, através de um processo interpretativo-objetivante, pelo sujeito cognoscente (bem caracterizado pela ideia de subsunção." (STRECK, Lênio. Hermenêutica Jurídica e(m) Crise. Porto Alegre: Livraria do Advogado, 2014. p. 42).

2"o intérprete, antes até de consultar as normas pertinentes, já tende a antecipar uma solução, com base na sua précompreensão" (SARMENTO, Daniel; SOUZA NETO, Cláudio Pereira de. Direito Constitucional - Teoria, história e métodos de trabalho. Belo Horizonte, Editora Fórum, 2012. p. 372.).
} 
A cobrança dos créditos inscritos em Dívida Ativa é um ônus ao Estado, isso, com a devida vênia, parece ser induvidoso.

Afinal, cobra-se em Dívida Ativa aquilo que, no mais das vezes, deixou-se de recolher de forma regular e voluntária ao Estado pelos devedores. Inclusive, mesmo diante de créditos não tributários - como multas ambientais, oriundas de condenação penal ou administrativa -, a inscrição em Dívida Ativa somente é consubstanciada após o decurso do prazo legal de pagamento.

Com isso, insofismável o fato de que, quando atua na cobrança de Dívida Ativa, a Fazenda Pública empreende esforços para cobrar aquilo que deveria lhe ter sido pago espontaneamente.

De outro lado, afastadas interpretações pro misero que são estranhas ao Direito Financeiro e, tratando-se de Dívida Ativa, no mais das vezes, ao Direito Tributário, aquele que deixa de pagar seus débitos com o Estado, geralmente, obtém posição de vantagem na sociedade.

Isso, outrossim, parece bastante fácil de se concluir.

Diante do não pagamento de um tributo, uma taxa ou, até mesmo, uma multa, o devedor insere em seu patrimônio crédito do Estado. Esse crédito, até mesmo do ponto de vista contábil, deixará de ser empregado nas atividades típicas da Administração (custeio e investimento), passando a ser utilizado pelo devedor. Por sua vez, o devedor, apropriando-se do crédito, estará em posição de vantagem em relação ao seu concidadão que pagou, corretamente, seu débito.

Aliás, esse raciocínio serve tanto para os casos de agentes econômicos - como empresários em situação concorrencial - como também para o cidadão comum, que, além da irresignação em ver que seu concidadão não é cobrado pela mesma dívida, passa a ter menos poder de compra para aquisição de bens de consumo.

Com isso, parece certo que, ao deixar de pagar devidamente seus débitos com o Estado, o devedor inscrito em Dívida Ativa aufere benefícios por sua mora que, no mais das vezes, são superiores aos ônus regulares da dívida, como juros de mora ou multas de mora.

É em razão disso que, após a inscrição em Dívida Ativa, a Fazenda Pública insere sobre o valor do crédito principal determinados encargos. Esses encargos, cuja natureza não é sancionatória, buscam patrocinar os custos de cobrança, suprindo os recursos despendidos para recuperação de outros recursos que já deveriam estar disponíveis ao ente público.

É dizer, caso não instituídos encargos em virtude da inscrição de créditos em Dívida Ativa, o devedor do Estado teria, em muitas hipóteses, benefício em não pagar suas obrigações de forma voluntária. Por isso, os entes públicos inserem encargos quando da inscrição dos créditos em Dívida Ativa.

Aqui, cite-se o exemplo da União, que, desde o Decreto-Lei 1.025 de $1969^{3}$, prevê a incidência de encargos à razão de $20 \%$ (vinte por cento) do valor originalmente devido, após a inclusão dos créditos em Dívida Ativa da Administração Direta. Inclusive, após a Lei $11.941^{4}$, a incidência de encargos semelhantes foi prevista para quando da inscrição em Dívida Ativa dos créditos da Administração Indireta da União:

Outrossim, há interessante previsão no âmbito da União no que tange à redução do encargo à metade (10\%) quando satisfeito o crédito previamente ao seu encaminhamento, após inscrição em Dívida Ativa, ao órgão responsável pela cobrança judicial ${ }^{5}$. Esse encargo, à razão de $20 \%$ (vinte por cento), servia para,

${ }^{3}$ Art. 1o - É declarada extinta a participação de servidores públicos na cobrança da Dívida da União, a que se referem os artigos 21 da Lei no 4.439, de 27 de outubro de 1964, e 1ํ, inciso II, da Lei no 5.421, de 25 de abril de 1968, passando a taxa, no total de $20 \%$ (vinte por cento), paga pelo executado, a ser recolhida aos cofres públicos, como renda da União (BRASIL, 1969). (BRASIL, Casa Civil. Decreto no 1.025, de 21 de outubro de 1969. Declara extinta a participação de servidores públicos na cobrança da Dívida Ativa da União e dá outras providências. Diário Oficial da União, Brasília, DF, 21 out. 1969, p. 8945.Disponível em: <http://www.planalto.gov.br/ccivil_03/decretolei/Del1025.htm>. Acesso em: 28 mai. 2018.)

${ }^{4}$ Art. 37- Os créditos das autarquias e fundações públicas federais, de qualquer natureza, não pagos nos prazos previstos na legislação, serão acrescidos de juros e multa de mora, calculados nos termos e na forma da legislação aplicável aos tributos federais. (BRASIL, Casa Civil. Decreto no 11.941, de 27 de maio de 2009. Altera a legislação tributária federal relativa ao parcelamento ordinário de débitos tributários; concede remissão nos casos em que especifica; institui regime tributário de transição, alterando os Decretos [...]. Diário Oficial da União, Brasília, DF, 27 mai. 2009, p.3, (Publicação Original). Disponível em: <http://www.planalto.gov.br/ccivil_03/_ato20072010/2009/lei/l11941.htm>. Acesso em: 28 mai. 2017.)

${ }^{5}$ Art. $3^{\text {o }} 0$ encargo previsto no art. 1o do Decreto-lei no 1.025, de 21 de outubro de 1969, calculado sobre montante do débito, inclusive multas, atualizado monetariamente e acrescido dos juros e multa de mora, será reduzidopara 10\% 
facilitando a cobrança, substituir os honorários advocatícios devidos na cobrança do crédito público que, inclusive, à época, era promovida pelo Ministério Público. Nesse sentido, ainda, há verbete consolidando a jurisprudência do antigo Tribunal Federal de Recursos ${ }^{6}$. Aliás, a jurisprudência do Superior Tribunal de Justiça também entende que esses encargos - incluídos quando da inscrição em Dívida Ativa de créditos pela União - possuem natureza substitutiva aos honorários advocatícios. Cite-se aqui didático julgado da lavra do Ministro Mauro Campbell Marques ${ }^{7}$. Apenas a título de curiosidade, os encargos em questão somente perderam a destinação como verbas honorárias em 1989 com o advento da Lei 7.711/1988.

Atualmente, contudo, com a Lei 13.327/2016, os encargos retornaram a ter natureza honorária aos membros das carreiras da Advocacia-Geral da União (AGU) ${ }^{9}$. Com efeito, os advogados da União, os procuradores da Fazenda Nacional, os procuradores federais e os procuradores do Banco Central - todos, inclusive, remunerados por subsídio - auferem como honorários parcela dos encargos incidentes na inscrição de créditos em Dívida Ativa10,11. Assim, diante da similitude de institutos, não há como diferençar os "honorários advocatícios" previstos no art. 2º, § 5ํㅡㄹ da Lei Estadual 2913/2012 com aqueles

(dez por cento), caso o débito, inscrito como Dívida Ativada da União, seja pago antes da remessa da respectiva certidão ao competente órgão do Ministério Público, federal ou estadual, para o devido ajuizamento. (BRASIL, Casa Civil. 1969. op. cit.)

${ }^{6}$ TFR, súmula 168 - 0 encargo de 20\% (vinte por cento) do Decreto-Lei é sempre devido nas execuções fiscais da União e substitui, nos embargos, a condenação do devedor em honorários advocatícios (TFR, Tribunal Federal de Recursos. Súmula no 168. 0 encargo de 20\%, do decreto-lei 1.025, de 1969, e sempre devido nas execuções fiscais da união e substitui, nos embargos, a condenação do devedor em honorarios advocatícios. Disponível em: <http://sislex.previdencia.gov.br/paginas/75/TFR/168.htm> Acesso em: 20 ago. 2018).

7PROCESSUAL CIVIL. EXECUÇÃO FISCAL EM DESFAVOR DA FAZENDA ESTADUAL. DÉBITO PREVIDENCIÁRIO. INCIDÊNCIA DO ENCARGO LEGAL PREVISTO NO DECRETO-LEI № 1.025/69. DÍVIDA ATIVA CONSTITUÍDA APÓS A LEI 11.457/2007. RECURSO ESPECIAL NÃO PROVIDO. 1.0 encargo previsto no Decreto-lei 1.025/1969 engloba honorários sucumbenciais e verbas destinadas ao aparelhamento e desenvolvimento da arrecadação fiscal, nos termos dos artigos 3o, parágrafo único, e 4o da Lei 7.711/1988, combinado com Decreto-Lei 1.437/1975. 2. Em razão do caráter especial deste encargo frente ao artigo 20 , § 4을 do Código de Processo Civil, prevalece por critério de especialidade, o teor do artigo $1^{\text {}}$ do Decreto-Lei 1.025/1969 quando se tratar de execução fiscal proposta pela União em face de outras pessoas jurídicas de direito público. Nesse sentido: REsp 1538950/RS, Rel. Ministro MAURO CAMPBELL MARQUES, SEGUNDA TURMA, julgado em 19/11/2015, DJe 27/11/2015. 3. Não obstante se tratar de crédito oriundo de contribuição previdenciária, a Dívida Ativa foi constituída após a edição da Lei 11.457/2007, que atribui à Fazenda Nacional a competência para ajuizar a execução fiscal visando a cobrança do crédito. 4. Portanto, nos termos do artigo 1ํ do Decreto-Lei 1.025/1969, incide o encargo legal nas execuções fiscais promovidas pela União em face de outras pessoas jurídicas de direito público. 5. Recurso especial não provido. (ST), Supremo Tribunal de Justiça. RECURSO ESPECIAL: REsp 1.002.445 DF 2007/0257665-5. Relator: Ministro Raul Araújo. DJe 14/12/2015. Jus Brasil, $2015 . \quad$ Disponível em: <https://www.jusbrasil.com.br/diarios/documentos/126184609/recurso-especial-n-1002445-df-do-stj>. Acesso em: 28 mai. 2017. grifo nosso).

8BRASIL, Casa Civil.. Lei no 7.711, de 22 de dezembro 1988. Dispõe sobre formas de melhoria da administração tributária e dá outras providências. Diário Oficial da União, Brasília, DF, 22 dez. 1988, p. 25282, (Publicação Original).Disponível em: <http://www.planalto.gov.br/ccivil_03/leis/L7711.htm>. Acesso em: 28 mai. 2017.

9BRASIL, Casa Civil. Lei no 13.327, de 29 de julho de 2016. Altera a remuneração de servidores públicos; estabelece opção por novas regras de incorporação de gratificação de desempenho a aposentadorias e pensões; altera os requisitos de acesso a cargos públicos; reestrutura cargos e carreiras; dispõe sobre honorários advocatícios de sucumbência das causas em que forem parte a União, suas autarquias e fundações; e dá outras providências. Diário Oficial da União, Brasília, DF, 29 jul. 2016, p. 4, (Publicação Original). Disponível em: <http://www.planalto.gov.br/ccivil_03/_ato2015-2018/2016/lei/L13327.htm>. Acesso em: 28 mai. 2017.

${ }^{10}$ Art. 3ํ A partir do exercício de 1989 fica instituído programa de trabalho de "Incentivo à Arrecadação da Dívida Ativa da União", constituído de projetos destinados ao incentivo da arrecadação, administrativa ou judicial, de receitas inscritas como Dívida Ativa da União, à implementação, desenvolvimento e modernização de redes e sistemas de processamento de dados, no custeio de taxas, custas e emolumentos relacionados com a execução fiscal e a defesa judicial da Fazenda Nacional e sua representação em Juízo, em causas de natureza fiscal, bem assim diligências, publicações, pro labore de peritos técnicos, de êxito, inclusive a seus procuradores e ao Ministério Público Estadual e de avaliadores e contadores, e aos serviços relativos a penhora de bens e a remoção e depósito de bens penhorados ou adjudicados à Fazenda Nacional. (BRASIL, Casa Civil. Constituição da República Federativa do Brasil. Diário Oficial da União, Brasília, DF, 191-A, 05 out. 1988, p.1.).

${ }^{11}$ Art. 30. Os honorários advocatícios de sucumbência incluem: I - o total do produto dos honorários de sucumbência recebidos nas ações judiciais em que forem parte a União, as autarquias e as fundações públicas federais; II - até $\mathbf{7 5 \%}$ (setenta e cinco por cento) do produto do encargo legal acrescido aos débitos inscritos na Dívida Ativa da União, previsto no art. $1^{\circ}$ do Decreto-Lei no 1.025, de 21 de outubro de 1969. (BRASIL, 1969. op. cit. grifo nosso). 
previstos no âmbito da União12. Com efeito, nada mais são esses "honorários advocatícios" que um encargo incluído pela lei do ente inscritor para remuneração daqueles que atuam na recuperação de seus créditos.

Aqui, apenas a título comparativo, enquanto o Estado de Rondônia somente faz incidir 10\% (dez por cento) a título de encargo sobre o crédito inscrito em Dívida Ativa, a União faz incidir 20\% (vinte por cento).

Lado outro, no Estado são destinados 80\% dos "honorários advocatícios" incidentes sobre a Dívida Ativa para os procuradores de Estado, conforme o art. 57 da Lei Complementar Estadual 57/198713. Ou seja, 8\% do valor do crédito inscrito. Já na União, como os honorários são fixados em $75 \%$ dos $20 \%$ incidentes sobre o crédito principal, os membros da AGU recebem até $15 \%$ do valor inscrito.

A incidência dos encargos, à razão de 10\% (dez por cento) do débito, no Estado de Rondônia, somente se dá após a atuação real dos procuradores, mediante atos de cobrança extrajudicial que não se resumem ao protesto. Ao contrário, na União, bem como nos diversos entes com previsões semelhantes, os encargos já incidem quando da mera inscrição em Dívida Ativa.

Logo, não parece que subsista dúvida no sentido de que os "honorários advocatícios" do dispositivo questionado nada mais são que encargos a serem incluídos quando da cobrança administrativa extrajudicial, se preferirem - dos créditos inscritos em Dívida Ativa.

É dizer: trata-se de um meio para que o contribuinte seja compelido a pagar suas obrigações com a Fazenda em dia, bem como evita que o contribuinte se locuplete com a demora na cobrança, já que sobre o valor principal haverá incidência do encargo, chamado aqui de "honorários advocatícios", e, finalmente, remunera a atuação extrajudicial do procurador. Por oportuno, necessário consignar que não é estranha ao ordenamento jurídico a possibilidade de cobrança ao devedor dos ônus incidentes em virtude da cobrança extrajudicial, inclusive honorários advocatícios, conforme jurisprudência ${ }^{14}$.

No ensejo, em julgamento analisando a legalidade da cobrança de honorários advocatícios em cobrança extrajudicial, a 1ํㅡ Câmara Cível do Tribunal de Justiça do Estado de Rondônia também entendeu válida a

12RONDÔNIA, Governadoria. Lei no 2913, de 3 de dezembro de 2012. Autoriza a Procuradoria Geral do Estado de Rondônia a utilizar meios alternativos de cobrança de créditos fiscais do Estado, de autarquias e de fundações públicas estaduais, observados os critérios de eficiência administrativa e de custos de administração e cobrança, especialmente o disposto na lei no 9.492, de 10 de setembro de 1997, devendo encaminhar para protesto as certidões de Dívida Ativa tributária e não-tributária e os títulos executivos judiciais de quantia certa, bem como inscrever o nome dos sujeitos passivos inadimplentes com o erário em cadastros públicos ou privados de proteção ao crédito, e dá outras providências. Diário Oficial do Estado de Rondônia, Porto Velho, RO, 3 dez., 2012. Disponível em: < http://sapl.al.ro.leg.br/sapl_documentos/norma_juridica/6005_texto_integral>. Acesso em: 29 mai. 2017.

13RONDÔNIA, Governadoria. Lei no 20, de 2 de julho de 1987.Dá nova redação ao decreto no 159, de 23/04/82, que estabelece a competência e aprova a estrutura da Procuradoria Geral do Estado. Diário Oficial do Estado de

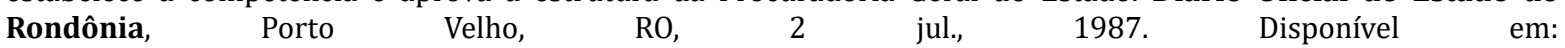
<https://sapl.al.ro.leg.br/sapl_documentos/norma_juridica/153_texto_integral>. Acesso em 28 mai. 2018.

${ }^{14}$ RECURSOS ESPECIAIS. CIVIL, PROCESSUAL CIVIL E CONSUMIDOR. AÇÃO CIVIL PÚBLICA. I - RECURSO DO BANCO PROMOVIDO: CONTRATO BANCÁRIO. LEASING. INCIDÊNCIA DE HONORÁRIOS ADVOCATÍCIOS EM CASO DE COBRANÇA EXTRAJUDICIAL. ÔNUS DECORRENTE DA MORA. RESPONSABILIDADE DO DEVEDOR. LEGALIDADE (CC/2002, ARTS. 389, 395 E 404). CONTRATO DE ADESÃO (CDC, ART. 51, XII). EXISTÊNCIA DE CLÁUSULA CONTRATUAL EXPRESSA. IMPROCEDÊNCIA DA AÇÃO. RECURSO PROVIDO. II - RECURSO DO PROMOVENTE: HONORÁRIOS ADVOCATÍCIOS EM FAVOR DO MINISTÉRIO PÚBLICO. RECURSO PREJUDICADO. 1. Inexiste abuso na exigência, pelo credor, de honorários advocatícios extrajudiciais a serem suportados pelo devedor em mora em caso de cobrança extrajudicial, pois, além de não causar prejuízo indevido para o devedor em atraso, tem previsão expressa nas normas dos arts. 389, 395 e 404 do Código Civil de 2002 (antes, respectivamente, nos arts. 1.056, 956 e 1.061 do CC/1916). 2. Nas relações de consumo, havendo expressa previsão contratual, ainda que em contrato de adesão, não se tem por abusiva a cobrança de honorários advocatícios extrajudiciais em caso de mora ou inadimplemento do consumidor. Igual direito é assegurado ao consumidor, em decorrência de imposição legal, nos termos do art. 51, XII, do CDC, independentemente de previsão contratual (STJ, Supremo Tribunal de Justiça. RECURSO ESPECIAL: REsp 1.002.445 DF 2007/0257665-5. Relator: Ministro Raul Araújo. DJe 14/12/2015. Jus $2015 . \quad$ Brasil, 2 Disponível <https://www.jusbrasil.com.br/diarios/documentos/126184609/recurso-especial-n-1002445-df-do-stj>. Acesso em: 28 mai. 2018. grifo nosso). 
fixação contratual de honorários em virtude da cobrança de créditos não pagos, inclusive como substitutivo dos honorários na fase de execução15.

Ora, se é possível a previsão em contrato do ressarcimento por despesas do credor com a cobrança extrajudicial de seus créditos, inclusive de honorários advocatícios, não parece demasiada a previsão de encargos, com a mesma finalidade, mediante lei do ente federado.

Aliás, em julgamento de Incidente de Resolução de Demanda Repetitiva (IRDR), o Egrégio Tribunal de Justiça do Distrito Federal entendeu que a cobrança de honorários pela mera inscrição do crédito em Dívida Ativa é lícita e consubstancia encargo em razão da necessidade de promoção de atos de cobrança contra o devedor. Inclusive, diga-se de passagem, o Tribunal de Justiça do Distrito Federal e Territórios 16 compreende como constitucionalmente válida a destinação dos valores recolhidos nesses encargos aos procuradores do Distrito Federal a título de "honorários", conforme a seguinte ementa.

Lado outro, necessário consignar que a cobrança desses valores em sede extrajudicial acaba por promover a isonomia entre os devedores. Afinal, caso o crédito fosse cobrado em Juízo - pela via crucis interminável da Execução Fiscal -, seriam devidos honorários advocatícios (aqui, na modalidade típica) e, ainda, seria imputado ao devedor o ônus das custas processuais.

Assim, a cobrança extrajudicial acaba por se tornar mais vantajosa financeiramente ao devedor da Fazenda. Isso porque, ainda que cobrados os encargos, o valor dos emolumentos é bastante inferior ao das custas processuais, fixadas à razão de $3 \%$ do valor do crédito principal.

Outrossim, com essa cobrança há evidentes benefícios ao Poder Judiciário, que se vê livre de um número considerável de execuções fiscais de baixo valor17. Assim, o próprio Estado passa a economizar - em virtude da redução de gastos com a máquina judiciária - e os devedores do Estado também são beneficiados pela cobrança extrajudicial.

Em conclusão, constata-se que os "honorários advocatícios" em questionamento possuem natureza administrativa (encargos de cobrança) e são substitutivos dos honorários sucumbenciais devidos na execução fiscal.

${ }^{15}$ Ação revisional. Cédula de crédito bancário. Cláusula contratual relativa a cobrança de honorários advocatícios extrajudiciais. Legalidade. Não há nenhuma ilegalidade na fixação da verba honorária contratual, uma vez que, além de ter sido estipulada em percentual inferior ao disposto no art. 85 do CPC, a cláusula foi estabelecida para ser exigida na hipótese de inadimplemento do devedor, o que aconteceu in casu, tanto que o apelado ajuizou ação executiva para reaver seu crédito, sendo certo que tal estipulação encontra arrimo nos arts. 389, 395 e 404 do CC. (TJRO. Tribunal de Justiça do Estado de Rondônia. AÇ̃̃O REVISIONAL: 1 1 a Câmara Cível, 001698708.2012.822.0001. Relator: Desembargador Raduan Miguel Filho. DJe 09/11/2016. Jus Brasil, 2016. Disponível em: $\quad$ https://tj-df.jusbrasil.com.br/jurisprudencia/149209271/acao-direta-de-inconstitucionalidade-adi20140020168258-df-0016952-9720148070000>. Acesso em: 28 mai. 2018.).

16PROCESSO CIVIL. INCIDENTE DE RESOLUÇÃO DE DEMANDAS REPETITIVAS. EXECUÇÃO FISCAL. LEI COMPLEMENTAR № 4/94. NATUREZA JURÍDICA DO ENCARGO DE 10\%. COBRANÇA CONJUNTA COM CRÉDITO TRIBUTÁRIO. DESMEMBRAMENTO. EXECUÇÃO ESPECÍFICA. DESTINAÇÃO DO VALOR COBRADO. II - Os encargos da Dívida Ativa são cobrados em juízo pela Fazenda Pública, pois o ente político (e não o advogado público integrante de seus quadros funcionais) é o credor da verba, ainda que, uma vez obtida em juízo a satisfação da Dívida Ativa, o Distrito Federal tenha legalmente optado por repassar aos seus servidores (procuradores públicos) parcela do produto obtido com a satisfação da CDA (qual seja, a parte referente aos encargos nela incluídos), nos termos da Lei 5.369/2014 e art. 42 do CTDF. III - 0 encargo de $10 \%$ do valor do crédito inscrito em Dívida Ativa, previsto no art. 42, §§ 1 e 2o da Lei Complementar n.o 4/94, não perde a natureza de encargo pelo fato de, após arrecadado pelo titular (ente público), ser destinado aos advogados públicos do Distrito Federal. IV - 0 encargo do art. 42 da CTDF, executado em conjunto com o crédito tributário pelo rito das execuções fiscais, nos termos do art. 39, § 4o da Lei $4.320 / 64$ e do art. $2^{\circ}$, $\S \S 1^{\circ}$ e e $2^{\circ}$ da LEF, ainda que não tenha natureza tributária é receita pública que Pode ser inscrita em Dívida Ativa. (TJDF. Tribunal de Justiça do Distrito Federal, Câmara de Uniformização. PROCESSO CIVIL, IRDR 20160020134714, Relator: José Divino. D.Je 12/12/2016. Jus Brasil, 2016. Disponível em: < https://tjdf.jusbrasil.com.br/jurisprudencia/353425943/20160020120149-0013347-7520168070000>. Acesso em: 29 mai. 2017. ementa parcial, grifo nosso).

17Em 2016, apenas nas Comarcas de Porto Velho, Guajará-Mirim, Ariquemes, Buritis e Machadinho do Oeste foram encaminhadas a protesto extrajudicial 12.267 CDAs. 
Assim, analisados os "honorários advocatícios" previstos no art. 2º, 5oㅡㄹ da Lei Estadual 2913/2012, com redação incluída pela Lei 3526/2015, podemos partir com segurança para a análise da constitucionalidade da cobrança destes pela Procuradoria Geral do Estado de Rondônia18,19.

\section{DA CONSTITUCIONALIDADE DA COBRANÇA DOS HONORÁRIOS NO PROTESTO PELOS ESTADOS E PELO DISTRITO FEDERAL NO QUE TOCA À COMPETÊNCIA LEGISLATIVA}

Ao se analisar a norma do artigo 22, inciso I, da Constituição da República de 1988, é possível concluir que a verba honorária cobrada pela Procuradoria Geraldo Estado de Rondônia na atividade de protesto de CDAs possui natureza administrativa, não podendo ser matéria de direito civil e processual civil ${ }^{20}$, de modo que não viola o art. 22, inciso I, da CF/88, norma estadual de natureza administrativa.

Por outro lado, a previsão de encargos na cobrança extrajudicial da Dívida Ativa é plenamente constitucional, como também o é o fato de esses encargos serem destinados aos advogados públicos.

Em primeiro plano, evitando-se repetições tautológicas, fundamental repisar o que já foi afirmado no item 2. Ademais, não parece haver dúvida de que a incidência deencargos, à razão de $10 \%$ (dez por cento) do montante inscrito em Dívida, seja plenamente constitucional.

Apenas para reforçar o já dito, é fundamental trazer à coleção julgado do Tribunal Regional Federal da $4^{a}$ Região, em incidente de arguição de inconstitucionalidade ${ }^{21}$ do encargo previsto no Decreto 1.025/69 (encargo de $20 \%$ sobre o crédito principal quando da inscrição do crédito na Dívida Ativa da União) ${ }^{22}$. Ademais, diante de norma de caráter meramente administrativo, não parece falecer ao Estado-membro competência legislativa para a fixação desse encargo. Não é por outra razão que o Pretório Excelso sequer vislumbra possibilidade de ofensa direta à Constituição no caso da cobrança dos encargos de Dívida Ativa ${ }^{23}$.

18RONDÔNIA, Governadoria. Lei no 3526, de 6 de abril de 2015.Altera a Lei no 2.913, de 3 de dezembro de 2012, que "Autoriza a Procuradoria Geral do Estado de Rondônia a utilizar meios alternativos de cobrança de créditos fiscais do Estado, de autarquias e de fundações públicas estaduais, observados os critérios de eficiência administrativa e de custos de administração e cobrança, especialmente o disposto na Lei no 9.492, de 10 de setembro de 1997, devendo encaminhar para protesto as certidões de Dívida Ativa tributária e não-tributária e os títulos executivos judiciais de quantia certa, bem como inscrever o nome dos sujeitos passivos inadimplentes com o Erário em cadastros públicos ou privados de proteção ao crédito, e dá outras providências. Diário Oficial do Estado de Rondônia, Porto Velho, RO, 6 de abr, 2015 . Disponível em: < https://www.legisweb.com.br/legislacao/?id=282880>. Acesso em: 29 mai. 2017.

${ }^{19}$ RONDÔNIA, Governadoria. 2012. op. cit.

${ }^{20}$ Aliás, isso até seria caso de inépcia da inicial, já que o segundo fundamento esposado acaba por conflitar com a causa de pedir. Contudo, mister enfrentar a matéria até mesmo como imperativo de ordem moral.

21ARGUIÇÃO DE INCONSTITUCIONALIDADE. TRIBUTÁRIO. ENCARGO LEGAL. DEC.-LEI “№ 1.025/69, DE 21-10-69. LEGALIDADE E CONSTITUCIONALIDADE. 1. Afastadas as preliminares levantadas pela Fazenda Nacional da impossibilidade de controle de constitucionalidade de normas editadas perante constituição revogada e da recepção, bem como da ausência de parâmetro para o controle de constitucionalidade. 2. Constitui o denominado encargo legal (Decreto-lei $\mathrm{n}^{\mathbf{0}} \mathbf{\text { 1.025}} / 69$, de 21-10-69) de valor exigido pelo Poder Público, tendo por base o montante do crédito da fazenda, tributário e não tributário, lançado em Dívida Ativa, sendo exigível a partir da respectiva inscrição. 0 encargo legal desde a sua origem até a Lei no $\underline{\mathbf{7 . 7 1 1}}$, de 22-12-88, possuiu natureza exclusiva de honorários advocatícios. A partir da Lei no $\mathbf{7 . 7 1 1}$ /88, passou a constituir-se em crédito da Fazenda Pública de natureza híbrida não tributária, incluída aí a verba honorária, integrante da receita da Dívida Ativa da União. 3. Tem-se por constitucional, sob os aspectos tanto formal quanto material, o encargo legal previsto no Dec-lei no 1.025/69, evidenciando-se legal e legítima a sua cobrança, na linha da jurisprudência uníssona do extinto Tribunal Federal de Recursos (Súmula no 168), dos Tribunais Regionais Federais do país e do Superior Tribunal de Justiça. Precedentes. 4. Preliminares arguidas pela Fazenda Nacional afastadas, por unanimidade, e, no mérito, por maioria, vencidos os Desembargadores Luiz Carlos de Castro Lugon e Paulo Afonso Brum Vaz, rejeitada a arguição de inconstitucionalidade, nos termos do voto do Relator. (TRF, Tribunal Regional Federal da 4⿳亠丷a Região. ARGUIÇ̃̃O DE INCONSTITUCIONALIDADE: AC 2004.70.08.001295-0/PR. Relator: Desembargador Federal Otávio Roberto Pamplona. DJe 29/09/2009. Jus Brasil, 2009. Disponível em: <https://trf4.jusbrasil.com.br/jurisprudencia/6917646/arguicao-de-inconstitucionalidade-arginc-1295-pr20047008001295-0-trf4?ref=juris-tabs>. Acesso em: 29 mai. 2018. grifos nossos).

22BRASIL, 1969. op. cit.

${ }^{23}$ Agravo regimental no recurso extraordinário com agravo. Prequestionamento. Ausência. Encargo legal previsto no Decreto-lei no 1.025/69. Infraconstitucional. 1. Não se admite o recurso extraordinário quando os dispositivos constitucionais que nele se alega violados não estão devidamente prequestionados. 
Em segundo lugar, o simples fato de a parcela desse encargo - no caso do Estado de Rondônia, 80\% (oitenta por cento) do produto são destinados aos advogados públicos e $20 \%$ (vinte por cento) permanecem para utilização pelo Centro de Estudos da Procuradoria-Geral do Estado - ser destinada aos advogados públicos não possui qualquer vício capaz de macular sua validade constitucional.

Afinal, como é cediço, o controle de constitucionalidade de leis ou atos normativos nada mais é que uma análise de pertinência do conteúdo do texto em análise frente às normas constitucionais. Não é por outro motivo que "a jurisprudência do STF adota perfil restritivo ao conceito de inconstitucionalidade, resumindo-o, para fins de controle (tanto concreto quanto abstrato), somente ao descompasso direito e frontal da norma impugnada em face da Constituição Federal"24,25.

Não se aceita no Brasil, portanto, a chamada inconstitucionalidade reflexa ou obliqua, que resulta da violação de uma norma infraconstitucional interposta entre o ato questionado e a Constituição ${ }^{26}$.

Com efeito, ainda que a inconstitucionalidade não seja mais que uma ilegalidade qualificada em virtude do parâmetro de análise (Constituição), não se pode pretender igualá-las, sendo vedada a análise constitucional de uma norma infraconstitucional quando, para isso, é necessário confrontá-la, primeiramente, com outra norma de igual status ${ }^{27}$. Oportuno dizer, nesse ponto, que inexiste entre as leis critério hierárquico, pois "cada espécie normativa atuará dentro de sua parcela de competência" 28.

Com efeito, diante do sistema de competências legislativas criado pela Constituição da República, não existe hierarquia entre leis federais, estaduais, distritais e municipais. Quando os campos de competências legislativas distintos são eventualmente violados o Supremo Tribunal Federal deve declarar a inconstitucionalidade, não em virtude da outra lei, mas, sim, da violação às regras constitucionais acerca da competência para legislar ${ }^{29}, 30$.

Incidência das Súmulas noos 282 e 356/STF. 2. A discussão acerca do encargo legal previsto no Decreto-Lei $\mathrm{n}^{\circ} 1.025 / 69$ paira no âmbito infraconstitucional, sendo que eventual ofensa ao texto constitucional seria meramente reflexa. 3. Agravo regimental não provido. Não se aplica ao caso dos autos a majoração dos honorários prevista no art. 85, § 11, do novo Código de Processo Civil, uma vez que não houve apresentação de contrarrazões. (STF, Supremo Tribunal Federal, 2ำTurma. RECURSO EXTRAORDINÁRIO COM AGRAVO: AgR no ARE 953.589/PR. Relator: Ministro Dias Toffilo. DJe 14/02/2017. Jus Brasil, 2015. Disponível em: < http://redir.stf.jus.br/paginadorpub/paginador.jsp?docTP=TP\&docID=12411556 >. Acesso em: 29 mai. 2018., grifo nosso)

${ }^{24}$ BERNARDES, Juliano Taveira. Controle Abstrato de Constitucionalidade. São Paulo: Saraiva, 2004, p. 138.

${ }^{25}$ AÇÃO DIRETA DE INCONSTITUCIONALIDADE. ADMINISTRATIVO. INTERRUPÇ̃̃O DE BEM OU SERVICCO PÚBLICO SEM AVISO PRÉVIO AO CONSUMIDOR. CONTROLE DE LEGALIDADE E NÃO DE CONSTITUCIONALIDADE DA LEI RONDONIENSE N. 1.126/2002. AÇÃO DIRETA NÃO CONHECIDA. 1. O poder constituinte dos Estados-membros limita-se pelos princípios da Constituição da República. Autonomia dos entes federados definida pelos princípios constitucionais. 2. Ausência de afronta às regras de competência privativa da União. 3. Lei rondoniense $n$. 1.126/2002 coerente com o previsto na Lei n. 8.987/95, que dispõe sobre o regime de concessão e permissão da prestação de serviços públicos. 4. Inviabilidade do exame de constitucionalidade da Lei rondoniense: questão posta para cotejar a Lei Rondoniense. 1.126/2002 com a Lei nacional n. 8.078/90 (Código de Defesa do Consumidor). Exame de legalidade que não viabiliza o controle abstrato da lei estadual por meio da ação direta. Precedentes. 5. Ação direta de inconstitucionalidade não conhecida (STF, Supremo Tribunal Federal. Tribunal Pleno. AÇÃO DIRETA DE INCONSTITUCIONALIDADE: ADI 2876/RO. Relator: Ministra Cármen Lúcia. DJe-218 de 19/11/2009. Jus Brasil, 2009. Disponível em: $<$ https://stf.jusbrasil.com.br/jurisprudencia/5661824/acao-direta-de-inconstitucionalidade-adi-2876ro?s=paid $>$. Acesso em: 29 mai. 2018. grifo nosso).

26MENAGED, M. O Fenômeno e as Formas de Controle de Constitucionalidade das Leis. In. Controle de constitucionalidade: fundamentos teóricos e jurisprudenciais segundo magistrados do Rio de Janeiro. Rio de Janeiro: EMERJ, 2011. 244 p.

${ }^{27}$ AÇÃO DIRETA DE INCONSTITUCIONALIDADE. MP 1911-9/99. NORMA DE NATUREZA SECUNDÁRIA. VIOLAÇÃO INDIRETA. IMPOSSIBILIDADE DE EXAME EM SEDE DE CONTROLE CONCENTRADO DE CONSTITUCIONALIDADE. 1. É incabível a ação direta de inconstitucionalidade quando destinada a examinar ato normativo de natureza secundária que não regule diretamente dispositivos constitucionais, mas sim normas legais. Violação indireta que não autoriza a aferição abstrata de conformação constitucional. Ação direta de inconstitucionalidade não conhecida. (STF, Supremo Tribunal Federal. Tribunal Pleno. Tribunal Pleno. AÇÃO DIRETA DE INCONSTITUCIONALIDADE: ADI 2065/DF. Relator: Ministro Maurício Corrêa. DJe 04/06/2004. Jus Brasil, 2004. Disponível em: <https://stf.jusbrasil.com.br/jurisprudencia/14755828/acao-direta-de-inconstitucionalidade-adi2065-df >. Acesso em 29: mai. 2018.)

${ }^{28}$ LENZA, Pedro. Direito Constitucional Esquematizado. 16 ed. São Paulo: Saraiva, 2012, p. 239

29Ibidem, p. 239 
De fato, os honorários previstos no Código de Processo Civil ${ }^{31}$ e no Estatuto da $\mathrm{OAB}^{32}$ possuem natureza processual e civil, respectivamente, sendo impossível ao legislador estadual neles interferir. Nesse âmbito, inclusive, destaque-se a impossibilidade de o ente federado promover a redução de honorários sucumbenciais em programas de benefícios para pagamento de dívidas tributárias já em execução fiscal33.

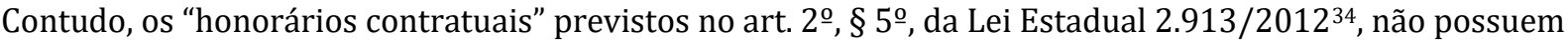
natureza civil ou processual. Ao contrário, trata-se de norma de natureza administrativa e que se encontra dentro do âmbito de competência do Estado federado.

Ora, a menos que se pretenda anular a atuação legislativa do Estado-membro, a cada nova legislação editada por nossa Assembleia Legislativa deve, sim, haver uma inovação legislativa35. Isso no sentido de que a elaboração de lei "é, em última análise, o fruto da decisão de um órgão do Estado de instaurar direito novo, de um órgão, pois, a que a Constituição concede esse poder"36.

Com efeito, não sendo a norma questionada de competência privativa da União - na verdade, competência exclusiva prevista no art. 22 da CF/88 -,o Estado-membro poderá exercer sua atividade legislativa, inclusive pela criação de novos institutos, sob pena de se restringir a atividade legislativa local, em violação ao art. 24 e art. $25, \S 1^{\circ}$, da CF/88

Nunca é demais ressaltar a possibilidade do recebimento dos honorários sucumbenciais (em todas as suas espécies) com o recebimento de proventos no regime de subsídio ${ }^{37}$. Essa parcela única foi instituída com o objetivo de expurgar o "sistema remuneratório que vem vigorando tradicionalmente na Administração

${ }^{30}$ AÇÃO DIRETA DE INCONSTITUCIONALIDADE - COMPETÊNCIA CONCORRENTE (CF, ART. 24) - ALEGADA INVASÃO DE COMPETÊNCIA DA UNIÃO FEDERAL, POR DIPLOMA LEGISLATIVO EDITADO POR ESTADO-MEMBRO NECESSIDADE DE PRÉVIO CONFRONTO ENTRE LEIS DE CARÁTER INFRACONSTITUCIONAL INADMISSIBILIDADE EM SEDE DE CONTROLE NORMATIVO ABSTRATO. Nas hipóteses de competência concorrente (CF, art. 24), nas quais se estabelece verdadeira situação de condomínio legislativo entre a União Federal e os Estados-membros (RAUL MACHADO HORTA, "Estudos de Direito Constitucional", p. 366, item n. 2, 1995, Del Rey), daí resultando clara repartição vertical de competências normativas, a jurisprudência do Supremo Tribunal Federal firmou-se no sentido de entender incabível a ação direta de inconstitucionalidade, se, para o específico efeito de examinar-se a ocorrência, ou não, de invasão de competência da União Federal, por parte de qualquer Estado-membro, tornar-se necessário o confronto prévio entre diplomas normativos de caráter infraconstitucional: a legislação nacional de princípios ou de normas gerais, de um lado (CF, art. 24, $\S 1^{\circ}$ ), e as leis estaduais de aplicação e execução das diretrizes fixadas pela União Federal, de outro (CF, art. 24, § 2º). Precedentes. É que, tratando-se de controle normativo abstrato, a inconstitucionalidade há de transparecer de modo imediato, derivando, o seu reconhecimento, do confronto direto que se faça entre o ato estatal impugnado e o texto da própria Constituição da República. Precedentes. (STF, Supremo Tribunal Federal. Tribunal Pleno. QUESTÃO DE ORDEM NA AÇÃOO DIRETA DE INCONSTITUCIONALIDADE: ADI 2344/SP. Relator: Ministro Celso de $\begin{array}{llllll}\text { Melo. DJe } 23 / 11 / 2000 . & \text { Jus } & \text { Brasil, } & 2000 . & \text { Disponível }\end{array}$ $<$ https://stf.jusbrasil.com.br/jurisprudencia/14752551/questao-de-ordem-na-acao-direta-deinconstitucionalidade-adi-2344-sp>. Acesso em: 29 mai. 2018. ementa parcial).

31BRASIL, Casa Civil. Lei no 13.105, de 16 de março de 2015. Código de Processo Civil. Diário Oficial da União, Brasília, DF, 16 mar. 2015.Disponível em: < http://www.planalto.gov.br/ccivil_03/_ato20152018/2015/lei/l13105.htm\#art1045>. Acesso em 28 mai. 2018.

32BRASIL, Casa Civil. Lei no 8.906, de 4 de julho de 1994. Dispõe sobre o Estatuto da Advocacia e a Ordem dos Advogados do Brasil (OAB). Diário Oficial da União, Brasília, DF, 4 jul. 1994.Disponível em: <http://www.planalto.gov.br/ccivil_03/Leis/L8906.htm>. Acesso em: 28 mai. 2018.

${ }^{33}$ MANDADO DE SEGURANÇA Município de Guarulhos Parcelamento do débito fiscal condicionado ao pagamento integral da verba honorária Inadmissibilidade Lei Municipal que não prevê tal condicionamento Sentença que concedeu a ordem mantida Recursos oficial e voluntário improvidos. (TJSP, Tribunal de Justiça do Estado de São Paulo. MANDADO DE SEGURANÇA: APL 00500497220118260224/SP. Relator: Desembargador Rezende Silveira. DJe 01/10/2013. Tribunal de Justiça do Estado de São Paulo, 2013. Disponível em: <http://www.tjsp.jus.br/>. Acesso em: 29 mai. 2018.)

34 RONDÔNIA, Governadoria. 2012. op. cit.

${ }^{35}$ Inovação essa que sequer é novidade no direito nacional, face à existência de diversas outras normas estaduais e municipais com o mesmo conteúdo.

${ }^{36}$ KERVÉGAN, Jean-François. Hegel, Carl Schmitt: o político entre a especulação e a positividade. Barueri, SP: Manole, 2006, p. 49.

370 subsídio é o estipêndio estatutário, fixado por lei em parcela única, com os estritos acréscimos constitucionalmente admitidos, a ser pago, obrigatoriamente, aos detentores de cargos de natureza política assim definidos na Constituição e, facultativamente, aos titulares de cargos em carreiras especificamente definidas em lei. MOREIRA NETO, Diogo de Figueiredo. Curso de Direito Administrativo. 16 ed. Rio de Janeiro: Forense, 2014, p. 59) 
Pública e que compreende o padrão fixado em lei mais as vantagens pecuniárias de variada natureza previstas na legislação estatutária"38.

Os honorários pagos em decorrência do protesto de CDAs são pagos pelos devedores da Fazenda quando da cobrança administrativa. Logo, não sendo pagos pelo Ente Público, inviável considerar os honorários violadores do regime de remuneração por subsídio.

Ora, somente é passível de ser qualificada como remuneração, inserida na sistemática dos subsídios, dos advogados públicos aquilo que lhes é pago pelo ente público, sob pena de se ter uma espécie remuneratória sui generis em que parte dos valores mensais recebidos pelos advogados públicos seria oriunda de pagamento por particulares. Aliás, questionamento semelhante é encontrado nos ensinamentos do Professor Kyoshi Harada ${ }^{39}$.

No caso de verba honorária, por expressa disposição da lei de regência (estadual ou municipal), ela não pertence ao Poder Público, pelo que não pode ser considerada receita pública. Outrossim, a sua distribuição aos integrantes da carreira de Procurador não pode ser considerada uma despesa pública, pois quem a paga não é o Poder Público, mas o sucumbente em ação judicial. Daí porque, na distribuição dos honorários da sucumbência aos Procuradores não se cogita de empenho, aliás, tecnicamente impossível por ausência de despesa pública a esse título.

Aliás, a jurisprudência de outros Tribunais já resta pacificada acerca da inexistência de violação ao regime de subsídio em virtude do recebimento de honorários ${ }^{40}$.

Inclusive, até mesmo em casos em que os honorários são cobrados de forma conjunta com a Dívida Ativa quando há inclusão dos valores na própria CDA - onde a Administração acaba recebendo os honorários e posteriormente repassando-os aos procuradores, a jurisprudência entende não haver violação ao regime de subsídio ${ }^{41}$.

38DI PIETRO, Maria Sylvia Zanella. Direito Administrativo. 18 ed. São Paulo: Atlas, 2005, pp. 463-464

${ }^{39} \mathrm{~A}$ inclusão das "vantagens pessoais ou de qualquer outra natureza" a que se refere o inciso XI, do art. 37, da CF, evidentemente, diz respeito à verba de natureza pública paga pelo erário com observância do regime da despesa pública de conformidade com a lei de regência da matéria, ou seja, da Lei no 4.320/64 [...]. (HARADA, Kiyoshi. Teto remuneratório dos Procuradores Públicos .Revista Jus Navigandi, Teresina, ano 17, n. 3338, 21 ago. 2012. Disponível em: <https://jus.com.br/artigos/22463>. Acesso em:18 jun. 2017.)

${ }^{40}$ AÇÃO DIRETA DE INCONSTITUCIONALIDADE. PROCURADORES DO ESTADO. HONORÁRIOS ADVOCATÍCIOS DE SUCUMBÊNCIA. LEI COMPLEMENTAR ESTADUAL. PRELIMINAR DE IMPOSSIBILIDADE JURÍDICA DO PEDIDO. REJEITADA. INEXISTÊNCIA DE OFENSA AO PAGAMENTO POR SUBSÍDIO. DESNECESSIDADE DE OBSERVÂNCIA DO TETO CONSTITUCIONAL. INTERPRETAÇÃO CONFORME. I - Rejeita-se a preliminar de impossibilidade jurídica do pedido tendo em vista que a norma constitucional inobservada é de reprodução obrigatória na Constituição Estadual. II - A omissão da Constituição Estadual não constitui óbice a que o Tribunal de Justiça local julgue ação direta de inconstitucionalidade contra lei que dispõe sobre a remuneração dos Procuradores de Estado. III - Os Advogados Públicos, categoria da qual fazem parte os Procuradores de Estado, fazem jus ao recebimento de honorários advocatícios de sucumbência, sem que haja ofensa ao regime de pagamento do funcionalismo público através de subsídio ou de submissão ao teto remuneratório, tendo em vista que tal verba é variável, é paga mediante rateio e é devida pelo particular (parte sucumbente na demanda judicial), não se confundindo com a remuneração paga pelo ente estatal. (TJMA, Tribunal de Justiça do Estado do Maranhão. AÇÃO DIRETA DE INCONSTITUCIONALIDADE: ADI 30.721/2010/MA. Relator: Desembargador Paulo Sérgio Velten Pereira. DJe 11/07/2012. Portal do Poder Judiciário do Estado do Maranhão, 2012. Disponível em: <http://www.tjma.jus.br/>. Acesso em: 29 mai. 2018, grifo nosso).

${ }^{41}$ AÇÃO DIRETA DE INCONSTITUCIONALIDADE. DESTINAÇÃO E REPASSE DOS HONORÁRIOS ADVOCATÍCIOS DE SUCUMBÊNCIA AOS MEMBROS INTEGRANTES DO SISTEMA JURÍDICO DO DISTRITO FEDERAL. IMPROCEDÊNCIA DO PEDIDO. 7. Ausência de incompatibilidade entre a remuneração por subsídios e a percepção de honorários advocatícios de sucumbência. A administração pública funciona como mera fonte arrecadadora da verba honorária para ulterior repasse aos legítimos destinatários, os advogados públicos. Doutrina. 8. 0 colendo STF já alertou para a circunstância de que a verba honorária de sucumbência não constitui vantagem funcional sujeita às normas gerais disciplinadoras da remuneração dos servidores públicos, mas de estímulo instituído, em valor obviamente variável, regulado por legislação específica (RE 217585, Rel. Min. Ilmar Galvão, Primeira Turma, DJ 10/12/1999). 9. A matéria em debate não reflete em aumento de despesa pública decorrente do reajuste de vencimentos, gratificações e outras vantagens remuneratórias. Não há necessidade da verificação dos requisitos fundamentais de prévia dotação orçamentária e autorização específica na Lei de Diretrizes Orçamentárias. 11. Ação Direta de Inconstitucionalidade julgada improcedente. (TJDFT, Tribunal de Justiça do Distrito Federal e Territórios. AÇÃO DIRETA DE INCONSTITUCIONALIDADE: ADI 20140020168258/DF 001695297.2014.8.07.0000. Relator: Humberto Adjuto Ulhôa. DJe 28/10/2014. JusBrasil, 2014. Disponível em: <https://tjdf.jusbrasil.com.br/jurisprudencia/149209271/acao-direta-de-inconstitucionalidade-adi-20140020168258-df0016952-9720148070000>. Acesso em: 29 mai. 2018, grifo nosso) 
Com isso, bastante certo que, se sequer quando são incluídos no crédito - como quando o seu valor é inserido na própria CDA, como ocorre no caso do Distrito Federal e da União - os honorários não violam o regime de subsídio, quanto mais quando eles são cobrados em paralelo com o crédito público - como ocorre no Estado de Rondônia, em que os honorários são pagos paralelamente ao valor principal.

Ao final, sempre mister trazer o entendimento do Pretório Excelso acerca da inviabilidade de se compreender os honorários advocatícios como verbas de natureza pública, o que poderia violar o regime de remuneração por subsídio. Razão disso, afigura-se plenamente constitucional a fixação de honorários para os advogados públicos, não havendo violação ao regime de subsídio, mormente no que tange à natureza privada da verba ${ }^{42}$.

\section{DAEXPERIÊNCIA DE RONDÔNIA COM A EDIÇÃO DA LEI ESTADUAL № 2.913/2012, COM REDAÇÃO INCLUÍDA PELA LEI 3.526/2015,ESTADO DE RONDÔNIA}

A experiência do Estado de Rondônia difere de outros entes, como a União e o Distrito Federal. Nestes, para que o devedor regularize sua situação será necessário o pagamento do valor inscrito em Dívida (crédito principal e os encargos), incluindo-se a verba honorária nos encargos, de modo que o pagamento destes será condicionante da regularização da situação do devedor.

Hipótese diametralmente oposta é ado Estado de Rondônia.

Ao contrário do que afirmado, o Estado de Rondônia não inclui em sua Dívida Ativa os valores dos honorários.

Com efeito, esses valores são cobrados paralelamente com o crédito principal e não condicionam a regularização da situação fiscal do devedor.

Os honorários são devidos em virtude da cobrança extrajudicial da dívida, à semelhança do que ocorre com a cobrança extrajudicial aos consumidores como se viu acima. Entretanto, o não pagamento dos honorários não inviabiliza a regularização da situação fiscal do devedor da Fazenda.

É dizer, caso a Fazenda promova a cobrança do crédito principal de forma extrajudicial, que o devedor poderá regularizar sua situação fiscal apenas pagando o primeiro. Assim, a dívida relativa aos honorários que permanecerá e deverá ser cobrada por outras vias - não impede a regularização da situação fiscal do devedor.

Informe-se, ainda, que, em caso de protesto extrajudicial, realizado perante os Tabelionatos de Protesto, o devedor sempre poderá pagar apenas o crédito principal para regularizar sua situação perante o Fisco (certidão negativa). Contudo, não haverá baixa do protesto sem que ele pague o valor devido de honorários e dos emolumentos.

Assim, a cobrança dos honorários não impede ou é condição para a regularização da situação fiscal do devedor, não se podendo confundir a pendência do protesto extrajudicial com a situação fiscal.

Por oportuno, repise-se a constatação de que a cobrança extrajudicial dos créditos da Fazenda, ainda que incidentes os honorários e eventuais emolumentos (em caso de protesto) é mais benéfica a todos.

Afinal, caso a cobrança dos créditos se dê na via judicial, além do pagamento do crédito principal e dos honorários advocatícios, o devedor suportará as custas processuais - que são bastante superiores aos valores com emolumentos - e ainda despesas para atuar no processo.

De igual modo, não se pode dizer que há violação a qualquer princípio constitucional, como o Princípio da Isonomia. Este, mormente quando atua na conformação da atuação do Poder Legislativo, exige "uma correlação lógica entre: 1) o traço diferencial eleito como ponto de apoio da desigualação que se pretende instaurar; e 2) a desigualdade de tratamento sugerida em função do traço ou característica adotada".

42ESTADO DE SÃO PAULO. PROCURADORES ESTADUAIS. "VERBA HONORÁRIA". PRETENDIDA INCLUSÃO NO CÁLCULO DO "TERÇO DE FÉRIAS" PREVISTO NO ART. 7ํ, XVII, C/C ART. 39, § 2º, DA CONSTITUIÇÃO. Vantagem distribuída aos membros da categoria, a título de estímulo, por meio de rateio do montante da verba paga ao Estado pelas partes sucumbentes, na forma prevista em legislação especial que não prevê a sua inclusão no cálculo do "terço de férias". Circunstância suficiente para afastar a incidência, no caso, dos dispositivos constitucionais em referência. Recurso não conhecido. (STF, Supremo Tribunal Federal, 1o Turma. RECURSO EXTRAORDINÁRIA RE 217585/SP. Relator: Ministro Ilmar Galvão. DJe 28/09/1999. Jus Brasil, 1999. Disponível em: <https://stf.jusbrasil.com.br/jurisprudencia/738700/recurso-extraordinario-re-217585-sp>. Acesso em: 29 mai. 2018.). 
No caso, o recebimento dos honorários - sucumbenciais ou substitutivos - se dá em virtude do exercício da advocacia pelos Procuradores do Estado de Rondônia, na forma prevista no Estatuto da $\mathrm{OAB}^{43}$.

Assim, possível dizer que a submissão dos procuradores ao Estatuto da OAB é o traço diferencial eleito pela legislação em questão como ponto de apoio para a previsão do recebimento desses valores pelos advogados públicos (medida de desigualação).

Lado outro, constata-se que a suposta desigualdade (recebimento dos honorários pelos procuradores em detrimento de todas as demais categorias dos serviços públicos) decorre do próprio regime jurídico dos advogados públicos, que, ao mesmo tempo, encontram-se submetidos a regras do serviço público e do Estatuto da Ordem dos Advogados do Brasil.

Assim, se o critério de desigualação (recebimento de honorários) tem como ponto de apoio a submissão dos procuradores à Lei 8.906/94 e, de outro lado, a percepção desses valores somente é dada após a atuação extrajudicial dos advogados públicos - à semelhança do que ocorre com os honorários previstos nas cobranças extrajudiciais privadas -, não há falar-se em violação à isonomia ${ }^{44}$.

Ao contrário, violadora da isonomia seria a hipótese em que outras categorias recebessem tais verbas (medida de desigualação) sem que sobre elas incidisse o traço diferencial (submissão ao regime do Estatuto da OAB).

De igual modo, violadora da isonomia seria a hipótese em que, mesmo diante do mesmo traço diferencial (submissão ao Estatuto da $\mathrm{OAB}$ ), os advogados públicos não recebessem honorários, sucumbenciais ou substitutivos, ao contrário do que fazem jus os advogados privados.

Sendo assim, inviável falar em violação à isonomia quando o recebimento dos valores se dá por particularidades no regime jurídico a que estão submetidos os advogados públicos.

Finalmente, inexiste violação à atividade do tabelião pela cobrança dos honorários.

Em primeiro lugar porque a sua incidência se dá na cobrança administrativa da Dívida Ativa, que pode, ou não, ser realizada mediante protesto extrajudicial.

Em segundo plano, o que eventualmente é levado a protesto são os valores do crédito fiscal e dos honorários incidentes. Com isso, não há subtração dos emolumentos devidos aos tabeliões e, de outro lado, o não pagamento dos honorários não implica a possibilidade de se promover a regularização da situação do devedor perante o Fisco (o que já foi analisado anteriormente).

\section{CONCLUSÕES}

Em face de todo o exposto, CONCLUI-SE que:

Ao deixar de pagar devidamente seus débitos com o Estado, o devedor inscrito em Dívida Ativa aufere benefícios por sua mora que, no mais das vezes, são superiores aos ônus regulares da dívida, como juros e multas de mora.

É em razão disso que, após a inscrição em Dívida Ativa, diversos entes federados inserem, sobre o valor do crédito principal, determinados encargos. Esses "encargos", cuja natureza não é sancionatória, buscam patrocinar os custos de cobrança, suprindo os recursos despendidos para recuperação de outros recursos que já deveriam estar disponíveis ao ente público.

Caso não instituídos encargos em virtude da inscrição de créditos em Dívida Ativa, o devedor do Estado teria, em muitas hipóteses, benefício em não pagar suas obrigações de forma voluntária.

A cobrança de honorários pela mera inscrição do crédito em Dívida Ativa é lícita e consubstancia encargo em razão da necessidade de promoção de atos de cobrança contra o devedor.

É constitucionalmente válida a destinação dos valores recolhidos nesses encargos aos procuradores do Distrito Federal a título de "honorários".

\footnotetext{
${ }^{43}$ Art. 3ํㅡ $§ 1$ 1 Exercem atividade de advocacia, sujeitando-se ao regime desta lei, além do regime próprio a que se subordinem, os integrantes da Advocacia-Geral da União, da Procuradoria da Fazenda Nacional, da Defensoria Pública e das Procuradorias e Consultorias Jurídicas dos Estados, do Distrito Federal, dos Municípios e das respectivas entidades de administração indireta e fundacional. (BRASIL, Casa Civil. 1994. op. cit.)

${ }^{44}$ Ibidem. cf.
} 
A cobrança desses valores, a título de honorários, em sede extrajudicial, acaba por promover a isonomia entre os devedores.

Afinal, caso o crédito fosse cobrado em Juízo - pela via crucis interminável da Execução Fiscal -, seriam devidos honorários advocatícios (aqui, na modalidade típica) e, ainda, seria imputado ao devedor o ônus das custas processuais.

A extrajudicial acaba por se tornar mais vantajosa financeiramente ao devedor da Fazenda. Isso porque, ainda que cobrados os encargos, o valor dos emolumentos é bastante inferior ao das custas processuais, fixadas, em média, à razão de $3 \%$ (três por cento) do valor do crédito principal.

Outrossim, com essa cobrança há evidentes benefícios ao Poder Judiciário, que se vê livre de um número considerável de execuções fiscais de valor baixo.

Assim, o próprio Estado passa a economizar - em virtude da redução de gastos com a máquina judiciária e os devedores do Estado também são beneficiados pela cobrança extrajudicial.

De igual modo, não se pode dizer que o percebimento de honorários, pelos Procuradores dos Estados e do Distrito Federal, decorrentes do protesto de CDAs, viola qualquer princípio constitucional, como o Princípio da Isonomia, na medida em que o recebimento dos honorários - sucumbenciais ou substitutivos - se dá em virtude do exercício da advocacia pelos Procuradores dos Estados e do Distrito Federal, na forma prevista no Estatuto da OAB, Lei 8.906/9445.

Em conclusão, constata-se que os "honorários advocatícios" oriundos do protesto possuem natureza administrativa (encargos de cobrança) e são substitutivos dos honorários sucumbenciais devidos na execução fiscal, sendo legítimos, constitucionais e legais, nos termos do Ordenamento Jurídico Brasileiro.

\section{BIBLIOGRAFIA}

[1] ALVIM, J. E. Carreira. Comentários ao Novo Código de Processo Civil. Curitiba: Editora Juruá, 2015, vol. IV.

[2] BERNARDES, Juliano Taveira. Controle Abstrato de Constitucionalidade. São Paulo: Saraiva, 2004.

[3] BRASIL, Casa Civil. Decreto no 1.025, de 21 de outubro de 1969. Declara extinta a participação de servidores públicos na cobrança da Dívida Ativa da União e dá outras providências. Diário Oficial da União, Brasília, DF, 21 out. 1969, p. 8945.Disponível em: <http://www.planalto.gov.br/ccivil_03/decreto-lei/Del1025.htm>. Acesso em: 28 mai. 2018.

[4] _. Decreto no 11.941, de 27 de maio de 2009. Altera a legislação tributária federal relativa ao parcelamento ordinário de débitos tributários; concede remissão nos casos em que especifica; institui regime tributário de transição, alterando os Decretos [...]. Diário Oficial da União, Brasília, DF, 27 mai. 2009, p.3, (Publicação Original).Disponível em: <http://www.planalto.gov.br/ccivil_03/_ato2007-2010/2009/lei/l11941.htm>. Acesso em: 28 mai. 2017.

[5] __ Lei no 13.105, de 16 de março de 2015. Código de Processo Civil. Diário Oficial da União, Brasília, DF, 16 mar. 2015.Disponível em: < http://www.planalto.gov.br/ccivil_03/_ato20152018/2015/lei/l13105.htm\#art1045>. Acesso em 28 mai. 2018.

[6] _. Lei no 13.327, de 29 de julho de 2016. Altera a remuneração de servidores públicos; estabelece opção por novas regras de incorporação de gratificação de desempenho a aposentadorias e pensões; altera os requisitos de acesso a cargos públicos; reestrutura cargos e carreiras; dispõe sobre honorários advocatícios de sucumbência das causas em que forem parte a União, suas autarquias e fundações; e dá outras providências. Diário Oficial da União, Brasília, DF, 29 jul. 2016, p. 4, (Publicação Original).Disponível em: <http://www.planalto.gov.br/ccivil_03/_ato20152018/2016/lei/L13327.htm>. Acesso em: 28 mai. 2017.

[7] ___. Lei no 7711, de 22 de dezembro 1988. Dispõe sobre formas de melhoria da administração tributária e dá outras providências. Diário Oficial da União, Brasília, DF, 22 dez. 1988, p. 25282, (Publicação Original).Disponível em: <http://www.planalto.gov.br/ccivil_03/leis/L7711.htm>. Acesso em: 28 mai. 2017.

[8] __ Lei no 8.906, de 4 de julho de 1994. Dispõe sobre o Estatuto da Advocacia e a Ordem dos Advogados do Brasil (OAB). Diário Oficial da União, Brasília, DF, 4 jul. 1994.Disponível em: <http://www.planalto.gov.br/ccivil_03/Leis/L8906.htm>. Acesso em: 28 mai. 2018.

[9] 1988, p.1.

. Constituição da República Federativa do Brasil. Diário Oficial da União, Brasília, DF, 191-A, 05 out.

[10] COMPARATo, Fábio Konder. O Poder de Controle na Sociedade Anônima. 3. ed. Rio de Janeiro: Forense, 1983.

45BRASIL, Casa Civil. 1994. op. cit. 
[11] COSTA MACHADO, Antonio Cláudio. Novo CPC. Sintetizado e Resumido. São Paulo: Atlas, 2015.

[12] DI PIETRO, Maria Sylvia Zanella. Direito Administrativo. 18 ed. São Paulo: Atlas, 2005.

[13] DINIZ, Maria Helena. Curso de direito civil brasileiro. 13. ed. São Paulo: Saraiva, 1999, v. 1.

[14] FERREIRA FILHO, Manoel Gonçalves. Do Processo Legislativo. São Paulo: Saraiva, 2012.

[15] KERVÉGAN, Jean-François. Hegel, Carl Schmitt: o político entre a especulação e a positividade. Barueri, SP: Manole, 2006

[16] HARADA, Kiyoshi. Teto remuneratório dos Procuradores Públicos. Revista Jus Navigandi, Teresina, ano 17, n. 3338, 21 ago. 2012. Disponível em: <https://jus.com.br/artigos/22463>. Acesso em:18 jun. 2017.

[17] LENZA, Pedro. Direito Constitucional Esquematizado. São Paulo: Saraiva, 2011.

[18] MEIRELLES, Hely Lopes. Direito Administrativo Brasileiro. 26. ed., atualizada por Eurico de Andrade Azevedo, Délcio Balestero Aleixo e José Emmanuel Burle Filho. São Paulo: Malheiros, 2001.

[19] MENAGED, M. O Fenômeno e as Formas de Controle de Constitucionalidade das Leis. In. Controle de constitucionalidade: fundamentos teóricos e jurisprudenciais segundo magistrados do Rio de Janeiro. Rio de Janeiro: EMERJ, 2011. 244 p.

[20] MOREIRA NETO, Diogo de Figueiredo. Curso de Direito Administrativo. 16 ed. Rio de Janeiro: Forense, 2014.

[21] NOVELINO, Marcelo. Direito Constitucional. São Paulo: Método, 2012.

[22] RONDÔNIA, Governadoria. Lei no 2.913/12, de 3 de dezembro de 2012.Autoriza a Procuradoria Geral do Estado de Rondônia a utilizar meios alternativos de cobrança de créditos fiscais do Estado, de autarquias e de fundações públicas estaduais, observados os critérios de eficiência administrativa e de custos de administração e cobrança, especialmente o disposto na Lei no 9.492, de 10 de setembro de 1997, devendo encaminhar para protesto as certidões de Dívida Ativa tributária e não-tributária e os títulos executivos judiciais de quantia certa, bem como inscrever o nome dos sujeitos passivos inadimplentes com o Erário em cadastros públicos ou privados de proteção ao crédito, e dá outras providências. Diário Oficial do Estado de Rondônia, Porto Velho, RO, 2 jul., 1987. Disponível em: <https://sapl.al.ro.leg.br/sapl_documentos/norma_juridica/153_texto_integral>. Acesso em: 28 mai. 2017.

[23] ___ Lei no 20, de 2 de julho de 1987.Dá nova redação ao decreto no 159, de 23/04/82, que estabelece a competência e aprova a estrutura da Procuradoria Geral do Estado. Diário Oficial do Estado de Rondônia, Porto Velho, RO, 2 jul., 1987. Disponível em: <https://sapl.al.ro.leg.br/sapl_documentos/norma_juridica/153_texto_integral>. Acesso em 28 mai. 2017.

[24] _. Lei no 2913, de 3 de dezembro de 2012. Autoriza a Procuradoria Geral do Estado de Rondônia a utilizar meios alternativos de cobrança de créditos fiscais do Estado, de autarquias e de fundações públicas estaduais, observados os critérios de eficiência administrativa e de custos de administração e cobrança, especialmente o disposto na lei no 9.492, de 10 de setembro de 1997, devendo encaminhar para protesto as certidões de Dívida Ativa tributária e não-tributária e os títulos executivos judiciais de quantia certa, bem como inscrever o nome dos sujeitos passivos inadimplentes com o erário em cadastros públicos ou privados de proteção ao crédito, e dá outras providências. Diário Oficial do Estado de Rondônia, Porto Velho, RO, 3 dez., 2012. Disponível em: < http://sapl.al.ro.leg.br/sapl_documentos/norma_juridica/6005_texto_integral>. Acesso em: 29 mai. 2017.

[25] __. Lei no 3526, de 6 de abril de 2015.Altera a Lei no 2.913, de 3 de dezembro de 2012, que "Autoriza a Procuradoria Geral do Estado de Rondônia a utilizar meios alternativos de cobrança de créditos fiscais do Estado, de autarquias e de fundações públicas estaduais, observados os critérios de eficiência administrativa e de custos de administração e cobrança, especialmente o disposto na Lei no 9.492, de 10 de setembro de 1997, devendo encaminhar para protesto as certidões de Dívida Ativa tributária e não-tributária e os títulos executivos judiciais de quantia certa, bem como inscrever o nome dos sujeitos passivos inadimplentes com o Erário em cadastros públicos ou privados de proteção ao crédito, e dá outras providências. Diário Oficial do Estado de Rondônia, Porto Velho, RO, 6 de abr., 2015. Disponível em: < https://www.legisweb.com.br/legislacao/?id=282880>. Acesso em: 29 mai. 2017.

[26] SARMENTO, Daniel; SOUZA NETO, Cláudio Pereira de. Direito Constitucional - Teoria, história e métodos de trabalho. Belo Horizonte, Editora Fórum, 2012. p. 372.

[27] STF, Supremo Tribunal Federal, 2o Turma. RECURSO EXTRAORDINÁRIO COM AGRAVO: AgR no ARE 953.589/PR. Relator: Ministro Dias Toffilo. DJe 14/02/2017. Jus Brasil, 2015. Disponível em: < http://redir.stf.jus.br/paginadorpub/paginador.jsp?docTP=TP\&docID=12411556 >. Acesso em: 29 mai. 2018.

[28] STF, Supremo Tribunal Federal, 1o Turma. RECURSO EXTRAORDINÁRI : RE 217585/SP. Relator: Ministro Ilmar Galvão. DJe 28/09/1999. Jus Brasil, $1999 . \quad$ Disponível em: <https://stf.jusbrasil.com.br/jurisprudencia/738700/recurso-extraordinario-re-217585-sp>. Acesso em: 29 mai. 2018.

[29] STF, Supremo Tribunal Federal. Tribunal Pleno. AÇÃO DIRETA DE INCONSTITUCIONALIDADE: ADI $2876 /$ RO. Relator: Ministra Cármen Lúcia. DJe-218 de 19/11/2009. Jus Brasil, 2009. Disponível em: 
<https://stf.jusbrasil.com.br/jurisprudencia/5661824/acao-direta-de-inconstitucionalidade-adi-2876-ro?s=paid>. Acesso em: 29 mai. 2018.

[30] - Tribunal Pleno. AÇÃO DIRETA DE INCONSTITUCIONALIDADE: ADI 2065/DF. Relator: Ministro Maurício Corrêa. DJe 04/06/2004. Jus Brasil, 2004. Disponível em: $<$ https://stf.jusbrasil.com.br/jurisprudencia/14755828/acao-direta-de-inconstitucionalidade-adi-2065-df >. Acesso em 29: mai. 2018.

[31] _ _ QUESTÃO DE ORDEM NA AÇÃO DIRETA DE INCONSTITUCIONALIDADE: ADI 2344/SP. Relator: Ministro Celso de Melo. DJe 23/11/2000. Jus Brasil, 2000. Disponível em: $<$ https://stf.jusbrasil.com.br/jurisprudencia/14752551/questao-de-ordem-na-acao-direta-de-inconstitucionalidadeadi-2344-sp>. Acesso em: 29 mai. 2018.

[32] STJ, Supremo Tribunal de Justiça. RECURSO ESPECIAL: REsp 1.002.445 DF 2007/0257665-5. Relator: Ministro Raul Araújo. DJe 14/12/2015. Jus Brasil, 2015. Disponível em: <https://www.jusbrasil.com.br/diarios/documentos/126184609/recurso-especial-n-1002445-df-do-stj>. Acesso em: 28 mai. 2017.

[33] _. RECURSO ESPECIAL: REsp 1.002.445 DF 2007/0257665-5. Relator: Ministro Raul Araújo. DJe 14/12/2015. Jus 2015.2 Brasil, 20 Disponível <https://www.jusbrasil.com.br/diarios/documentos/126184609/recurso-especial-n-1002445-df-do-stj>. Acesso em: 28 mai. 2018.

[34] _. RECURSO ESPECIAL: REsp 1540855 RS 2015/0155201-5. Relator: Ministro Mauro Campbell Marques. DJe 18/12/2015. Jus Brasil, 2015. Disponível em: <https://stj.jusbrasil.com.br/jurisprudencia/296840295/recursoespecial-resp-1540855-rs-2015-0155201-5?ref=juris-tabs>. Acesso em: 28 mai. 2017.

[35] STRECK, Lênio. Hermenêutica Jurídica e(m) Crise. Porto Alegre: Livraria do Advogado, 2014.

[36] TAVARES, André Ramos. Curso de Direito Constitucional. São Paulo: Saraiva, 2013. p. 458.

[37] TFR, Tribunal Federal de Recursos. Súmula no 168. 0 encargo de 20\%, do decreto-lei 1.025, de 1969, e sempre devido nas execuções fiscais da união e substitui, nos embargos, a condenação do devedor em honorarios advocatícios. Disponível em: <http://sislex.previdencia.gov.br/paginas/75/TFR/168.htm> Acesso em: 20 ago. 2018.

[38] TJDF. Tribunal de Justiça do Distrito Federal, Câmara de Uniformização. PROCESSO CIVIL, IRDR 20160020134714, Relator: José Divino. D.Je 12/12/2016. Jus Brasil, 2016. Disponível em: < https://tjdf.jusbrasil.com.br/jurisprudencia/353425943/20160020120149-0013347-7520168070000>. Acesso em: 29 mai. 2017.

[39] TJDFT, Tribunal de Justiça do Distrito Federal e Territórios. AÇÃO DIRETA DE INCONSTITUCIONALIDADE: ADI 20140020168258/DF 0016952-97.2014.8.07.0000. Relator: Humberto Adjuto Ulhôa. DJe 28/10/2014. JusBrasil, 2014. Disponível em: <https://tj-df.jusbrasil.com.br/jurisprudencia/149209271/acao-direta-deinconstitucionalidade-adi-20140020168258-df-0016952-9720148070000>. Acesso em: 29 mai. 2018

[40] TJMA, Tribunal de Justiça do Estado do Maranhão. AÇÃo DIRETA DE INCONSTITUCIONALIDADE: ADI 30.721/2010/MA. Relator: Desembargador Paulo Sérgio Velten Pereira. DJe 11/07/2012. Portal do Poder Judiciário do Estado do Maranhão, 2012. Disponível em: <http://www.tjma.jus.br/>. Acesso em: 29 mai. 2018.

[41] TJRO. Tribunal de Justiça do Estado de Rondônia. AÇão REVISIONAL: 1a a Câmara Cível, 001698708.2012.822.0001. Relator: Desembargador Raduan Miguel Filho. DJe 09/11/2016. Jus Brasil, 2016. Disponível em: $<$ https://tj-df.jusbrasil.com.br/jurisprudencia/149209271/acao-direta-de-inconstitucionalidade-adi20140020168258-df-0016952-9720148070000>. Acesso em: 28 mai. 2018.

[42] TJSP, Tribunal de Justiça do Estado de São Paulo. MANDADO DE SEGURANÇA: APL 00500497220118260224/SP. Relator: Desembargador Rezende Silveira. DJe 01/10/2013. Tribunal de Justiça do Estado de São Paulo, 2013. Disponível em: <http://www.tjsp.jus.br/>. Acesso em: 29 mai. 2018.

[43] TRF, Tribunal Regional Federal da 4a 2004.70.08.001295-0/PR. Relator: Desembargador Federal Otávio Roberto Pamplona. DJe 29/09/2009. Jus Brasil, 2009. Disponível em: <https://trf-4.jusbrasil.com.br/jurisprudencia/6917646/arguicao-de-inconstitucionalidadearginc-1295-pr-20047008001295-0-trf4?ref=juris-tabs>. Acesso em: 29 mai. 2018. 


\section{Capítulo 2}

Controladoria na Administração Pública: Um estudo de caso no Núcleo de Controle Interno do Município de Salinas/MG

\section{Claudiana Aparecida Leal de Araújo \\ Janaine de Oliveira Souto \\ Márcia Ferreira Silva \\ Marconi dos Santos Miranda \\ Vânia Fernandes Celestino}

Resumo: Partindo do pressuposto de que a Administração Pública necessita de mecanismos gerenciais que auxiliem a tomada de decisão, o Controle Interno, como função da Controladoria, exerce papel fundamental como ferramenta da gestão municipal. Destarte, o presente artigo tem como objetivo identificar o estágio atual de desempenho das atividades de Controle Interno do Município de Salinas/MG. Para atingir o objetivo proposto, realizou-se uma pesquisa descritiva mediante um estudo de caso, com abordagem qualitativa dos dados. Foi aplicado questionário ao chefe de controle interno do município, contendo no formulário as competências do órgão, em conformidade com a legislação municipal. Chegou-se ao resultado de que o Núcleo de Controle Interno do município pesquisado desempenha integralmente a maioria das atividades que lhe são propostas pela legislação municipal, o que torna evidente a eficácia operacional que envolve esse órgão. Percebeu-se que o Controle Interno proporciona aos gestores benefícios fundamentais no processo decisório das ações governamentais. Tendo em vista os resultados obtidos, afirma-se que o Controle Interno do Município de Salinas/MG contribui fundamentalmente para o sucesso da gestão pública municipal.

Palavras-chave: Controladoria. Controle Interno. Administração Pública. Tomada de decisão. 


\section{INTRODUÇÃO}

Quando se defende a aplicação de ações de controle na Administração Pública, os gestores nem sempre compreendem corretamente o tema. Muito confundida com a auditoria, a Controladoria oportuniza ao gestor a alternativa mais eficaz para o gasto e para a excelência de cada área do órgão no desempenho de suas funções, com vistas à qualidade do gasto, transparência e probidade administrativa (SILVA, 2013).

A Controladoria é considerada como um setor organizacional responsável por dar o apoio necessário ao processo de gestão, disponibilizando informações dotadas de conteúdo eficaz e eficiente (ORO et al., 2009).

No processo político os órgãos públicos, muitas vezes, são afetados, de modo que durante a mudança de gestão os fatos históricos ocorridos podem passar despercebidos e se perderem. Com a controladoria os projetos tendem a ser continuados, já que assim há uma visão geral de todos os projetos antes iniciados ou planejados, proporcionando um processo constante de mudança e de adaptação que não afete o órgão (SILVA, 2013).

Considerando que, no âmbito do setor público, os recursos são escassos e que a demanda pelos serviços é relativamente elevada, a Controladoria torna-se indispensável para auxiliar os gestores nos processos decisórios, a fim de que estes possam administrar de forma mais eficaz e que alcancem uma economicidade mais intensa.

Conforme Borinelli (2006), a Controladoria exerce 07 (sete) funções primordiais, quais sejam: Função Contábil, Função Gerencial-Estratégica, Função Controle e Proteção dos Ativos, Função Finanças, Função Custos, Função Gestão da Informação e Função Controle Interno. Esta última função "compreende as atividades referentes ao estabelecimento e monitoramento do sistema de controles internos, destinado a proteger o patrimônio organizacional e salvaguardar os interesses da entidade" (BORINELLI, 2006, p. 137).

Oliveira (2013) salienta que o controle permanente corresponde a uma função gerencial de suma importância para o sucesso de qualquer organização. Atribuir pouca relevância a esse fato se assemelha a pilotar uma aeronave sem as coordenadas necessárias do vôo.

Destarte, esta pesquisa se justifica pela necessidade de constatar quais são as atividades desempenhadas pelo Núcleo de Controle Interno do Município de Salinas/MG, sendo este um órgão que efetua funções típicas de Controladoria.

0 presente artigo tem como objetivo geral identificar o estágio atual de desempenho das atividades de Controle Interno do Município de Salinas/MG. Quanto aos objetivos específicos, têm-se: demonstrar os benefícios que a Controladoria proporciona aos gestores públicos na tomada de decisão das ações governamentais; evidenciar os órgãos de controle da Administração Pública; demonstrar o histórico do Núcleo de Controle Interno do município objeto da pesquisa.

Diante desse contexto, emerge a seguinte questão: Qual o estágio atual de desempenho das atividades de Controle Interno do Município de Salinas/MG?

Para atingir o objetivo geral, após uma revisão da literatura, foi feita uma análise dos fatores integrantes do exercício de controle no município pesquisado, mediante aplicação de questionário ao chefe de controle interno.

0 presente artigo está particionado em seis tópicos. Posteriormente a esta introdução, o tópico 02 discorre a revisão da literatura. 0 tópico 03 trata dos aspectos metodológicos utilizados no desenvolvimento da pesquisa. 0 tópico 04 discorre acerca do Núcleo de Controle Interno do Município de Salinas/MG. 0 tópico $05 \mathrm{faz}$ a análise dos dados. Por fim, o tópico 06 trata das considerações finais, finalizando o estudo com a apresentação das referências bibliográficas utilizadas.

\section{REVISÃO DA LITERATURA}

\subsection{A ORGANIZAÇÃO PÚBLICA, OS GESTORES PÚBLICOS O PROCESSO DE TOMADA DE DECISÃO}

Disponibilizando informações úteis para buscar as metas estabelecidas, a Controladoria funciona como elo entre os controles e a gestão pública (SILVA, 2013).

A controladoria no setor privado desempenha um papel preponderante na estrutura das organizações, subsidiando o planejamento e controle da gestão por parte dos gestores, mediante a manutenção de um 
sistema de informação que permita cumprir as diversas funções e missões que lhe são atribuídas. Em virtude disso, a controladoria é vista como um dos principais órgãos administrativos em diversas entidades (SOUZA et al., 2010).

Oliveira Júnior et al. (2009) salientam que as organizações públicas existem para atender às necessidades da coletividade, por meio de suas estruturas administrativas e dos agentes públicos. Desta forma, além das estruturas administrativas, é necessária a ação dos agentes públicos para que a máquina do Estado possa funcionar. Dentre esses agentes, os autores destacam o papel dos gestores públicos, sendo considerados como aqueles que estão na direção das organizações públicas, indistintamente do grau hierárquico de sua função. Há níveis de administração e níveis de poder de decisão, e o administrador público é o agente encarregado de gerir e conduzir as ações públicas. É sobre ele que pesa tal responsabilidade, fator que faz com que as ações de governo sejam de grande relevância.

“Nas organizações públicas, os resultados das decisões não afetam apenas um pequeno grupo, e sim a coletividade. [...] Tais decisões precisam estar fundamentadas. A controladoria surge como um instrumento de apoio a tais decisões" (OLIVEIRA JÚNIOR, et al., 2009, p. 41).

A tomada de decisão relaciona-se à essência do ato de administrar. Contudo, não corresponde a um processo simples, tendo em vista que compreende uma gama de fatores. Especialmente no que diz respeito a administrar órgãos públicos, exige-se uma atenção redobrada, afinal, é a sociedade quem cobra, ela contribui e que ver melhorias (REITER, 2011).

\subsection{A CONTROLADORIA}

"O controle das coisas e a contabilidade nasceram há milênios e vem se aprimorando, com o desenvolvimento da humanidade, até chegar naquilo que hoje denominamos controladoria" (SLOMSKI, 2005, p. 03).

A Controladoria é reconhecida como um órgão de coordenação e controle da cúpula administrativa. Esse órgão disponibiliza os dados e informações, que planeja e pesquisa, com vistas a mostrar a essa cúpula os pontos críticos presentes e futuros que colocam em risco a eficiência administrativa ou a reduzem (NETO, 2013).

Para Padoveze (2004), a controladoria é o órgão administrativo responsável pela gestão econômica da empresa, cujo objetivo é o de levá-la à maior eficiência, tendo como base científica a ciência contábil, onde repousam os fundamentos da gestão econômica.

Silva (2013, p. 01) define a controladoria como a:

Área que auxilia o gestor na tomada de decisão, na análise da eficiência, eficácia, economicidade e transparência dos seus atos, avaliando a conduta nas rotinas internas, garantindo tranquilidade em sua passagem pela administração do órgão, proporcionando ao cidadão garantia da boa gestão dos recursos públicos.

Como um segmento da Contabilidade, Administração e Economia, a Controladoria utiliza primordialmente o controle e o processo de planejamento e orçamento como metodologia no desempenho de suas atividades. 0 responsável pela controladoria é denominado de controller ou controlador (NETO, 2013).

Em se tratando da Controladoria Governamental, Souza et al. (2010) a conceitua como sendo "um órgão incumbido de comandar o sistema de controle interno, auditoria interna, contabilidade e aperfeiçoar os demais sistemas de controles, objetivando a busca de resultados".

Slomski (2005) faz uma analogia da controladoria a um concerto musical, isto é, aquele órgão ou departamento que fará com haja uma sinfonia, onde todos os instrumentos musicais toquem de maneira isolada, contudo sob a mesma batuta, buscando um único objetivo, que é a maximização do resultado global da organização. No entanto, para que haja a efetiva 'concertação', é necessário que o ente público se conheça internamente e externamente, saiba quem são seus servidores (suas capacidades, virtudes, fraquezas) e quantos são, quem são e quais são as necessidades dos cidadãos e a forma de atendê-las. Atualmente, é impossível continuar a administração fundamentada na teoria do achismo. 


\subsection{CONTROLADORIA NA ADMINISTRAÇÃO PÚBLICA}

Os conceitos relacionados à Controladoria aplicam-se a qualquer tipo de entidade. No que tange às organizações públicas, a controladoria diz respeito ao órgão que administra as informações (econômicas, físicas e financeiras) com o intuito de subsidiar o gestor público em uma avaliação mais correta dos resultados, especialmente nos municípios.

Martins et al. (2012) abordam que isso gera subsídio para a redução da assimetria informacional que há entre o administrador público e a sociedade. Em muitas das vezes o usuário do serviço público não tem conhecimento de qual a aplicação dos recursos provenientes de tributos, nem se estão sendo bem geridos. Desta forma, a controladoria pode auxiliar a Administração Pública quanto à sua tão desejada transparência.

\subsection{CONTROLE INTERNO E CONTROLE EXTERNO}

Parafraseando Reiter (2011), pode-se afirmar que administrar com eficácia e eficiência os recursos públicos é fator primordial, todavia, para que isso ocorra, os fluxos de informações devem ser de fácil acesso, bem como estar passíveis de clareza e precisão. É nesse sentido que surge a figura do Controle Interno, indo muito além de uma exigência legal, considerando que sua existência vai ao caminho da otimização dos recursos públicos escassos, servindo de defesa ao patrimônio público.

Na concepção de Alexandrino e Paulo (2013, p. 843), o "controle interno é aquele exercido dentro de um mesmo Poder, seja exercido no âmbito hierárquico, seja exercido por meio de órgãos especializados, sem relação de hierarquia com o órgão controlado".

Ainda segundo estes autores, a despeito do controle externo, diz-se ser aquele "exercido por um Poder sobre os atos administrativos praticados por outro Poder" (ALEXANDRINO \& PAULO, 2013, p. 844).

Silva (2013, p. 04) relata que:

Controle externo é aquele exercido por órgão estranho á administração e não integra a estrutura do órgão controlado, sendo exercido pelos Tribunais de Contas. Controle interno é aquele exercido pela própria administração a seus atos no âmbito de sua própria estrutura administrativa.

Já que esta pesquisa trata-se de um estudo de caso em um órgão integrante da Administração Pública, é relevante e indispensável que se faça considerações acerca dos tipos de controles exercidos pelos órgãos governamentais à luz das cláusulas constitucionais, já que, conforme preceitua o princípio da legalidade, o Estado apenas pode praticar o que a lei define ou autorize. Não havendo previsão legal, é impossível a atuação administrativa (ALEXANDRINO \& PAULO, 2013).

0 art. 31 da Carta Magna prevê que "a fiscalização do Município será exercida pelo Poder Legislativo Municipal, mediante controle externo, e pelos sistemas de controle interno do Poder Executivo Municipal, na forma da lei" (BRASIL, 1988).

No art. 70, a Constituição Federal dispõe que:

Art. 70. A fiscalização contábil, financeira, orçamentária, operacional e patrimonial da União e das entidades da administração direta e indireta, quanto à legalidade, legitimidade, economicidade, aplicação das subvenções e renúncia de receitas, será exercida pelo Congresso Nacional, mediante controle externo, e pelo sistema de controle interno de cada Poder (BRASIL, 1988).

Por fim, ainda em se tratando dessa matéria, o art. 74 do Texto Constitucional determina a manutenção de sistema de controle interno por parte dos Poderes de Estado, com as seguintes finalidades:

Art. 74 [...]

I - avaliar o cumprimento das metas previstas no plano plurianual, a execução dos programas de governo e dos orçamentos da União;

II - comprovar a legalidade e avaliar os resultados, quanto à eficácia e eficiência, da gestão orçamentária, financeira e patrimonial nos órgãos e 
entidades da administração federal, bem como da aplicação de recursos públicos por entidades de direito privado;

III - exercer o controle das operações de crédito, avais e garantias, bem como dos direitos e haveres da União;

IV - apoiar o controle externo no exercício de sua missão institucional (BRASIL, 1988).

Silva (2013) salienta que o controle interno é norteado por postulados fundamentais denominados princípios, sendo estes regras básicas às quais toda a estrutura do órgão deve seguir. A observância aos princípios minimiza o risco de controle, que provém das falhas existentes nos próprios mecanismos de controle interno de um órgão.

Segundo o autor (op. cit.), são princípios de controle interno:

- Relação custo/benefício;

- Qualificação adequada, treinamento e rodízio de funcionários;

- Delegação de poderes e definição de responsabilidades;

- Segregação de funções;

- Instruções devidamente formalizadas;

- Controle sobre as transações;

- Aderência a diretrizes e normas legais (SILVA, 2013).

No tópico que se segue, será feita abordagem acerca dos aspectos metodológicos desta pesquisa, seguido das considerações a respeito do Núcleo de Controle Interno do município estudado, da análise dos dados e das conclusões.

\section{ASPECTOS METODOLÓGICOS}

Para o desenvolvimento do presente artigo foi realizada uma pesquisa descritiva mediante um estudo de caso. A abordagem possui natureza qualitativa considerando que os dados obtidos não são passíveis de conversibilidade em números. A pesquisa é descritiva porque, segundo Andrade (2002), preocupa-se em observar os fatos, registrá-los, analisá-los, classificá-los e interpretá-los.

Considerando o porte do Município pesquisado, este não possui um órgão de Controladoria Geral, contudo, as funções típicas de Controladoria são exercidas pelo Núcleo de Controle Interno, vinculado ao Gabinete do Prefeito.

A realização do estudo de caso se deu em maio de 2014, mediante a utilização de um formulário que apresentava as atividades do Sistema e do Núcleo de Controle Interno, conforme previsto nas Leis municipais no 1.814/2000 e 015/2009, bem como nos Decretos municipais no 1.943/2000 e 4.864/2009.

Para cada atividade, foi solicitado aos respondentes que informassem o seu atual estágio. 0 quadro 01 apresenta o resumo dos estágios atuais que deveriam ser indicados para cada atividade desempenhada pelo órgão pesquisado. Foram apresentadas 06 (seis) opções, contemplando os diversos estágios em que cada atividade se encontra, facilitando os mecanismos de resposta por parte do servidor entrevistado. 
QUADRO 1 - Estágios atuais de desempenho das atividades do Controle Interno

\begin{tabular}{|c|l|}
\hline Alternativa & \multicolumn{1}{c|}{ Estágio atual } \\
\hline 1 & Inexiste interesse em realizar a atividade \\
\hline 2 & O Controle Interno realiza a atividade integralmente \\
\hline 3 & O Controle Interno realiza a atividade parcialmente \\
\hline 4 & A atividade é exercida por outro órgão/setor da prefeitura municipal \\
\hline 5 & A atividade é exercida por empresa terceirizada \\
\hline 6 & O Controle Interno planeja realizar essa atividade no futuro \\
\hline
\end{tabular}

Após a coleta dos dados foi feita a análise dos mesmos sob os aspectos qualitativos.

0 resultado dessa espécie de trabalho não poderá ser generalizado, tendo em vista a limitação dos estudos de caso (OLIVEIRA JÚNIOR et al., 2009; MARTINS et al., 2012).

\section{NÚCLEO DE CONTROLE INTERNO DO MUNICÍPIO DE SALINAS/MG}

Conforme já abordado no subitem 2.4, retro, o Controle Interno nos municípios é uma exigência da Constituição Federal de 1988.

Nesse sentido, para dar efetividade ao previsto nos preceitos constitucionais, bem como no determinado na Constituição Estadual, na Lei Orgânica do Município, nas Leis no 4.320/1964 e 8.666/1993 e na instrução no 02/1999 do Tribunal de Contas do Estado de Minas Gerais, foi publicado o Decreto no 1943 , de 17 de março de 2000, que criou o Sistema de Controle Interno da Prefeitura Municipal de Salinas/MG, "com a finalidade de acompanhar, fiscalizar, analisar, todos os atos administrativos do Município" (SALINAS, 2000a).

Pouco mais de 01 mês após a publicação do Decreto no 1943/2000, foi sancionada a Lei no 1.814, em 19 de abril 2000, que criou no âmbito do Executivo Municipal o Núcleo Central de Controle Interno de Salinas/MG, determinado que caberia a este órgão o "gerenciamento e fiscalização interna, dos atos administrativos de natureza contábil, financeira, orçamentário [sic], operacional e patrimonial" (SALINAS, 2000b).

Em 2009, por intermédio da Lei Complementar Municipal no 15, de 03 de março desse ano, foi privilegiado o papel do Controle Interno, considerando que esta Lei previu outras atribuições concernentes ao Núcleo.

No dia 02 de abril de abril de 2009, foi publicado o Decreto no 4.864, que regulamentou novamente as atividades competentes ao Núcleo de Controle Interno do Município de Salinas/MG.

A estrutura do órgão de controle do município pesquisado é composto por 03 servidores, sendo 01 (um) auxiliar administrativo, 01 (um) assessor jurídico e 01 (um) assessor chefe de planejamento, que integram a Comissão Municipal de Controle Interno, do Núcleo Central de Controle Interno, visando promover o controle "na busca da eficácia administrativa do governo municipal" (SALINAS, 2013).

\section{ANÁLISE DOS DADOS}

A análise dos dados da pesquisa no Núcleo de Controle Interno do Município de Salinas/MG foi realizada tendo em vista as atividades competentes ao órgão em questão, conforme a legislação que o instituiu e regulamentou.

No Quadro 2 estão relacionadas as atividades competentes ao Núcleo de Controle Interno do município de Salinas/MG, seguidas, à direita, do estágio atual em que se encontra o desenvolvimento da respectiva função, conforme respondido pelo chefe de Controle Interno do Município objeto deste estudo. 
QUADRO 2 - Desempenho das atividades do Controle Interno

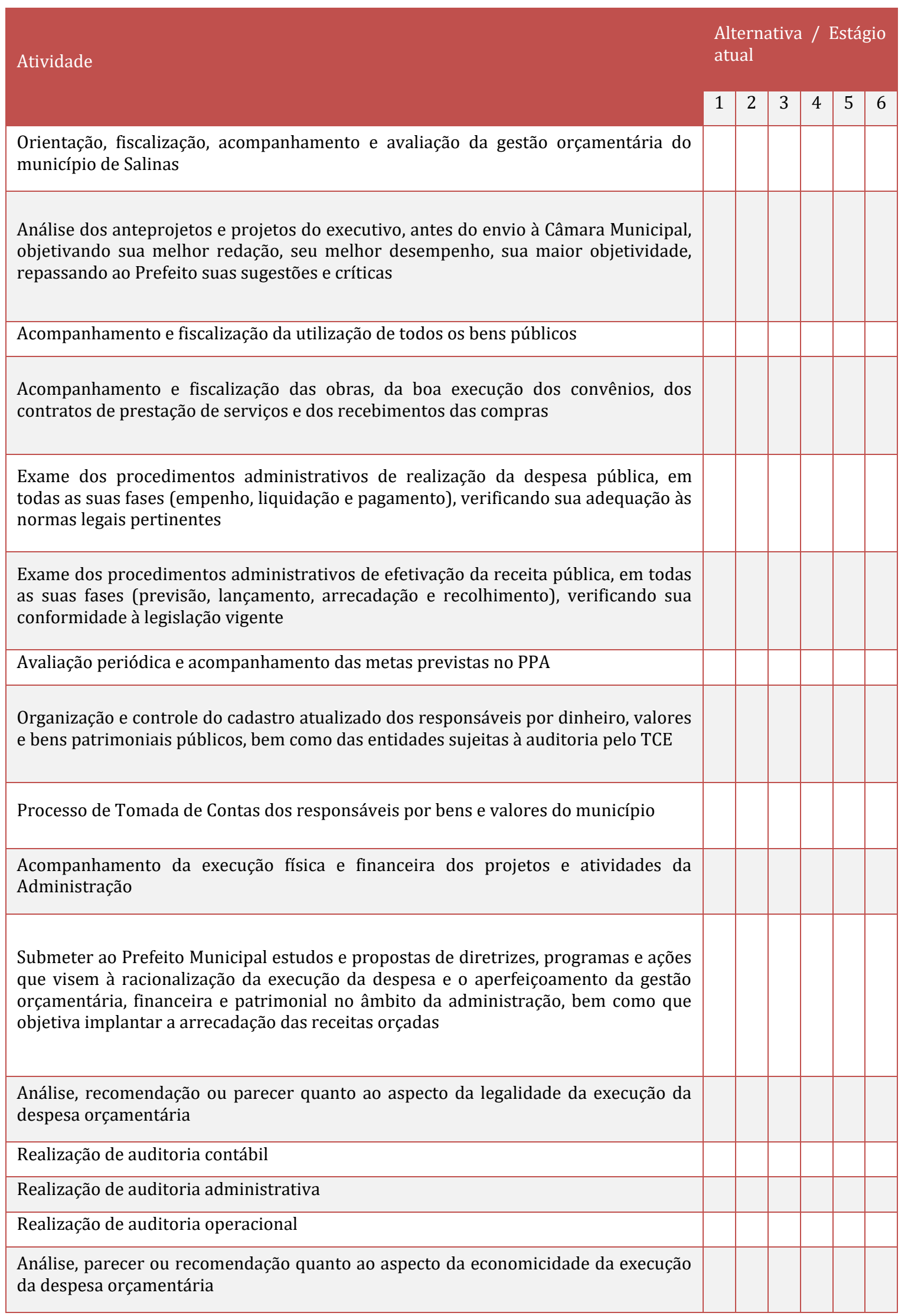


QUADRO 2 - Desempenho das atividades do Controle Interno

(continuação...)

\begin{tabular}{|c|c|c|c|c|c|c|}
\hline \multirow[t]{2}{*}{ Atividade } & \multicolumn{6}{|c|}{$\begin{array}{l}\text { Alternativa / Estágio } \\
\text { atual }\end{array}$} \\
\hline & 1 & 2 & 3 & 4 & 5 & 6 \\
\hline \multicolumn{7}{|l|}{ Adoção de medidas preventivas de modo a evitar a renúncia de receitas } \\
\hline \multicolumn{7}{|l|}{$\begin{array}{l}\text { Análise, parecer ou recomendação quanto ao aspecto da eficiência na execução da } \\
\text { despesa orçamentária }\end{array}$} \\
\hline \multicolumn{7}{|l|}{ Elaboração de controles financeiros } \\
\hline \multicolumn{7}{|l|}{$\begin{array}{l}\text { Verificação do grau de aderência entre o planejado e o realizado, colaborando na } \\
\text { adoção de medidas corretivas }\end{array}$} \\
\hline \multicolumn{7}{|l|}{ Auditoria das licitações, da origem ao término do processo } \\
\hline $\begin{array}{l}\text { Registro, mensuração, controle, análise e avaliação dos custos da organização pública, } \\
\text { incluindo análises gerenciais e estratégicas, referentes à viabilidade de ações } \\
\text { governamentais }\end{array}$ & & & & & & \\
\hline
\end{tabular}

Fonte: Dados da pesquisa.

Percebe-se, conforme evidenciado no Quadro 2, que o Núcleo de Controle Interno do Município de Salinas/MG desempenha, integralmente, uma parcela considerável das atividades que lhe compete.

Faz-se uma observação quanto à função de análise dos anteprojetos e projetos do Executivo, antes do envio à Câmara Municipal, objetivando sua melhor redação, seu melhor desempenho, sua maior objetividade, repassando ao Prefeito suas sugestões e críticas. Para esta atividade, o respondente destacou que um advogado, membro da Comissão de Controle Interno, a exerce.

Quanto à avaliação periódica e acompanhamento das metas previstas no PPA, são elaborados, mensalmente, relatórios em conjunto com a Secretaria Geral de Ações Governamentais.

No que diz respeito à submissão de estudos e propostas ao prefeito municipal, objetivando a racionalização da execução da despesa e o aperfeiçoamento da gestão, esta atividade é exercida de forma conjunta com a Secretaria de Planejamento, Gestão e Fazenda e com a Secretaria Geral de Ações Governamentais.

Em se tratando das auditorias contábil, administrativa, operacional e das licitações, o Núcleo de Controle Interno as realiza de maneira parcial, tendo em vista que atualmente o município mantém vínculo contratual com a empresa Pública - Consultores e Auditores Associados, que exerce as funções de auditoria juntamente com Controle Interno, conforme destacado no formulário de entrevista.

Quando questionado acerca da elaboração de controles financeiros, o respondente salientou que a atividade é executada pela Secretaria Municipal de Planejamento, Gestão e Fazenda, que encaminha, mensalmente, os referidos controles ao Núcleo de Controle Interno.

Foi destacado no formulário de entrevista que são realizados, periodicamente, relatórios de análises da verificação do grau de aderência entre o planejado e o realizado, colaborando na adoção de medidas corretivas.

Em se tratando do registro mensuração, controle, análise e avaliação dos custos da organização pública, incluindo análises gerenciais e estratégicas, referentes à viabilidade de ações governamentais, esta função ainda não é realizada pelo Núcleo de Controle Interno, sendo mencionado no formulário que o Núcleo planeja realizar essa atividade no futuro, considerando a sua relevância para a administração local. A não realização da atividade se materializado ao fato de inexistir recomendações do TCE/MG correspondentes a essa função específica.

No questionário aplicado, as respostas obtiveram as seguintes proporções numéricas: 
TABELA 1 - Proporção das atividades desempenhadas conforme o estágio atual

\begin{tabular}{|l|c|}
\multicolumn{1}{|c|}{ Estágio atual } & $\begin{array}{c}\text { Quantidade de } \\
\text { atividades } \\
\text { desempenhadas }\end{array}$ \\
\hline Inexiste interesse em realizar a atividade & 0 \\
\hline O Controle Interno realiza a atividade integralmente & 16 \\
\hline O Controle Interno realiza a atividade parcialmente & 4 \\
\hline A atividade é exercida por outro órgão/setor da prefeitura municipal & 1 \\
\hline A atividade é exercida por empresa terceirizada & 0 \\
\hline O Controle Interno planeja realizar essa atividade no futuro & 1 \\
\hline
\end{tabular}

Fonte: Dados da pesquisa.

Percebe-se, pela Tabela 1, que o Controle Interno do Município de Salinas/MG desempenha integralmente a maioria das atividades atribuídas ao Núcleo, o que evidencia a eficácia operacional desse órgão. 0 Núcleo de Controle Interno tem interesse em realizar todas as atividades propostas, sendo que 16 (dezesseis) são desempenhadas integralmente, 04 (quatro) parcialmente, 01 (uma) por outro órgão/setor da prefeitura e 01 (uma) é planejada para ser realizada futuramente. Observa-se que nenhuma atividade é terceirizada.

\section{CONSIDERAÇÕES FINAIS}

Considerando o fato de o Controle Interno compreender as atribuições alusivas ao estabelecimento e monitoramento do sistema de controles, destinado a proteger o patrimônio organizacional e salvaguardar os interesses da entidade, esta pesquisa objetivou identificar o estágio atual de desempenho das atividades do Núcleo de Controle Interno do Município de Salinas/MG, sendo este um órgão que subsidia a gestão pública e oferece maior transparência às ações governamentais.

Para atingir o objetivo proposto, realizou-se uma pesquisa descritiva mediante um estudo de caso, com abordagem qualitativa dos dados.

Foram discutidos assuntos relacionados à organização pública, aos gestores públicos e à tomada de decisão, à Controladoria na Administração Pública Municipal, aos tipos de controle, ao Núcleo de Controle Interno do Município de Salinas/MG e, por fim, para responder à questão do estudo, foi aplicado questionário ao chefe do Núcleo. No formulário continha as atividades competentes ao Núcleo de Controle Interno do município, conforme a legislação que o instituiu e regulamentou.

Os resultados evidenciaram que o Núcleo de Controle Interno do município pesquisado desempenha integralmente a maioria das atividades que lhe são propostas pela legislação municipal, o que torna claro a eficácia operacional que envolve esse órgão. Das atividades que foram questionados o seu atual estágio, 16 (dezesseis) são desempenhadas integralmente, 04 (quatro) parcialmente, 01 (uma) por outro órgão/setor da prefeitura e 01 (uma) é planejada para ser realizada futuramente. Nenhuma atividade é terceirizada.

Percebeu-se que o Controle Interno, como função da Controladoria, possui fundamental relevância no auxílio aos processos decisórios das entidades do setor público, conforme considerações feitas por intermédio de citações doutrinárias.

Considerando os resultados obtidos, é possível afirmar, ao final desta pesquisa, que o Controle Interno do Município de Salinas/MG contribui fundamentalmente para o sucesso da gestão pública municipal.

Recomenda-se, para futuras pesquisas, confrontar as atividades do Núcleo de Controle Interno de Salinas/MG com as funções de Controladoria apresentadas na doutrina, de forma que seja identificada a correlação entre ambas, contribuindo, ainda mais, para a eficácia do Sistema de Controle Interno do município pesquisado, fornecendo subsídios tendentes à melhoria da gestão governamental. 


\section{REFERÊNCIAS}

[1] ANDRADE, Maria Margarida de. Como preparar trabalhos para cursos de pós-graduação: noções práticas. 5. ed. São Paulo: Atlas, 2002.

[2] ALEXANDRINO, Marcelo; PAULO, Vicente. Direito administrativo descomplicado. 21. ed. rev. e atual. - Rio de Janeiro: Forense; São Paulo: Método, 2013.

[3] BORINELLI, Márcio. Estrutura conceitual básica de controladoria: sistematização à luz da teoria e da práxis. Tese (Doutorado em Ciências Contábeis) - Curso de Pós-Graduação em Ciências Contábeis, Faculdade de Economia, Administração e Contabilidade, Universidade de São Paulo. São Paulo: USP, 2006. Disponível em: <http://www.teses.usp.br/teses/disponiveis/12/12136/tde-19032007-151637/publico/Tesemarc ioborinelli.pdf>. Acesso em 28 de abril de 2014.

[4] BRASIL. Constituição Federal. Constituição da Republica Federativa do Brasil de 1988. Brasília/DF: Senado Federal, 1988. Disponível em: <http://www.planalto.gov.br/ccivil_03/constituicao/constituicao.htm>. Acesso em 01 de março de 2014.

[5] MARTINS, Pablo Luiz; ASSIS, Ana Aparecida da Costa; OLIVEIRA, Emanuela Machado de; CAMPOS, Eveline Silva; CARVALHO, Janice Alessandra. Práticas de controladoria nas organizações públicas municipais. IX Simpósio de Excelência em Gestão e Tecnologia. Resende: AEDB, 2012. Disponível em: <http://www.aedb.br/seget/artigos12/28816526.pdf>. Acesso em 25 de maço de 2014.

[6] OLIVEIRA JÚNIOR, Nilson José de; CHAVES JÚNIOR, Oswaldo Demósthenes Lopes; LIMA, Mariomar de Sales. A controladoria nas organizações públicas municipais: um estudo de caso. Revista Universo Contábil, ISSN 1809-3337, Blumenau, v. 5, n. 1, p. 38-54, jan./mar. 2009. Disponível em: <www.spell.org.br/documentos/download/6186>. Acesso em 28 de março de 2014.

[7] OLIVEIRA, Luiz Martins. Controladoria estratégica. 9ạ. ed. São Paulo: Atlas, 2013.

[8] ORO, Ieda Margarete; DITTADI, Jadir Roberto; CARPES, Antonio Maria da Silva; BENOIT, Alessandro Dias. 0 perfil do profissional de controladoria sob a ótica do mercado de trabalho brasileiro. Pensar Contábil, v. 11, n. 44, p. 5 15, abr./jun. 2009. Rio de Janeiro: CRCRJ, 2009. Disponível em: <http://webserver.crcrj.org.br/asscom/Pensarcontabil/revistaspdf/revista\%2044.pdf>. Acesso em 24 de fevereiro de 2014.

[9] NETO, José Carvalho da Silva. Controladoria na gestão pública. Timon: Ed. do autor, 2013.

[10] PADOVEZE, Clóvis Luís. Controladoria básica. São Paulo: Pioneira Thomson Learning, 2004.

[11] REITER, Mayara. A controladoria na Administração Pública: fator decisivo na tomada de decisões. Trabalho de Conclusão de Curso apresentado ao curso MBA em Gestão Financeira, Auditoria e Controladoria de Pós-Graduação lato sensu, Nível de Especialização, do Programa FGV Management como pré-requisito para a obtenção do título de Especialista. Blumenau: FGV: 2011.

[12] SALINAS/MG. Decreto no 1.943, de 17 de março de 2000. Cria o Sistema de Controle Interno da Prefeitura Municipal de Salinas/MG. Salinas/MG: Prefeitura Municipal, 2000.

[13] _. Decreto no 4.864, de 02 de abril de 2009. Regulamenta o Núcleo de Controle Interno. Salinas/MG: Prefeitura Municipal, 2009.

[14] Decreto no 6.124, de 29 de julho de 2013. Nomeia membros da Comissão Municipal de Controle Interno e dá outras providências. Salinas/MG: Prefeitura Municipal, 2013.

[15] . Lei complementar no 15, de 03 de março de 2009. Dispõe sobre a estrutura orgânica da Administração Pública do Poder Executivo do Município de Salinas e dá outras providências. Salinas/MG: Câmara Municipal, 2009.

[16] Lei no 1.814, de 19 de abril de 2000. Cria no âmbito do Executivo Municipal o Núcleo Central de Controle Interno. Salinas/MG: Câmara Municipal, 2000.

[17] SILVA, Elderson Ferreira da. Controladoria na administração pública. São Paulo: Atlas, 2013.

[18] SLOMSKI, Valmor. Controladoria e governança na gestão pública. São Paulo: Atlas, 2005.

[19] SOUZA, Fábia Jaiany Viana de; SILVA, Maurício Corrêa da; ARAÚJO, Aneide Oliveira; SILVA, José Dionísio Gomes da. Controladoria privada e governamental: uma análise comparativa. Revista do administrado Público. № 63. Julho 2010.2 Disponível em: <http://www.sigaa.ufrn.br/sigaa/verProducao?idProducao=423950\&key=bca7ce14a53005e7ab8f4f883d88ba60>. Acesso em 14 de abril de 2014. 


\section{Capítulo 3}

Imagem e Reputação da Autoridade Monetária: Uma nova abordagem para avaliação da credibilidade de bancos centrais

\section{Paulo Roberto da Costa Vieira}

Resumo: A literatura de Administração tem destacado a importância da imagem na construção da reputação corporativa. No entanto, os estudos macroeconômicos relacionados a bancos centrais sequer mencionam a imagem institucional, nem mesmo quando analisam o processo de construção da reputação da autoridade monetária e de estabelecimento da credibilidade na condução da política monetária. Fundamentado em contribuições sobre imagem institucional, reputação corporativa e bancos centrais, o presente estudo verifica se a imagem constitui dimensão relevante na percepção de especialistas do mercado financeiro nacional quanto ao desempenho da autoridade monetária. Avalia também o impacto da imagem institucional sobre a reputação da autoridade monetária. Para tanto, emprega um modelo de equações estruturais que postula a influência da imagem institucional, da percepção sobre a atuação operacional e dos compromissos institucionais sobre a reputação da autoridade monetária. 


\section{INTRODUÇÃO}

A imagem institucional representa as impressões e opiniões recentes acerca de uma organização, sintetizando um conjunto de significados complexos que influencia comportamentos e tomada de decisão. Os registros repetidos da imagem concorrem na construção da reputação institucional. Nesse contexto, a imagem influencia ativamente a edificação da reputação institucional, que é, inquestionavelmente, o elemento de destaque em investigações acerca de bancos centrais.

O comprometimento com a estabilidade, a transparência, a responsabilidade de prestação de contas e a autonomia do Banco Central têm sido tratados, na literatura macroeconômica atual, como elementos que participam na construção da reputação ou credibilidade da autoridade monetária. Reafirmamos a importância dos referidos elementos e do nexo causal que mantêm com a reputação institucional, mas acreditamos que não podem ser considerados sem a participação da imagem da autoridade monetária. A imagem interage com as demais dimensões relevantes da instituição, determinando a reputação da autoridade monetária segundo a percepção dos agentes econômicos. 0 presente estudo avalia a influência da imagem institucional na construção da reputação do Banco Central do Brasil.

\section{REVISÃO DE LITERATURA}

A literatura sobre imagem corporativa é caracterizada por apresentar contribuições de diferentes áreas acadêmicas, tais como o marketing e a estratégia empresarial. Por essa razão, há várias definições para o mesmo conceito, que dependem da perspectiva do pesquisador.

Para a finalidade da presente investigação, julgamos apropriado reunir, com base na classificação proposta por Gotsi e Wilson (2001), os principais estudos produzidos pela área de negócios em dois grandes grupos, considerando a relação entre imagem e reputação corporativa como seu marco distintivo. Dessa forma, incluímos, no primeiro grupo, aqueles estudos que consideram a imagem como sinônimo de reputação corporativa, ao passo que agregamos, no segundo grupo, os trabalhos que as julgam conceitos distintos. Em seguida, discutimos as contribuições sobre bancos centrais.

Convém tecermos algumas considerações acerca do nosso critério de organização dos estudos. Elegemos a relação entre a imagem e a reputação corporativa como elemento diferenciador das contribuições da área de negócios, não só para servir como recurso para sua organização, mas, sobretudo, para realçar uma questão de grande relevância. Ela consiste no fato de que a imagem corporativa não é tratada pela literatura econômica, ao passo que o processo de construção da reputação do banco central e da credibilidade na condução da política monetária têm sido crescentemente estudado pelos acadêmicos da área. Nos trabalhos econômicos, a reputação é concebida com a acepção de credibilidade, havendo, inclusive, revezamento dos termos em um mesmo trabalho (Cukierman, 2000).

Sendo assim, a organização da revisão de literatura objetivou, além de agrupar trabalhos de mesma natureza, construir um caminho que permitisse ao leitor verificar que a ausência da imagem corporativa na literatura econômica compromete a compreensão do processo de construção da reputação da autoridade monetária. Com esse objetivo em vista, apresentamos, inicialmente, as contribuições da área de negócios que consideram imagem e reputação conceitos intercambiáveis, de mesma acepção. Esses estudos são da maior importância para entender o significado e o papel que a imagem desempenha na corporação.

Em seguida, apresentamos os estudos que não só as consideram conceitos distintos, como julgam existir uma relação de causalidade entre ambos. As contribuições mais importantes desse grupo percebem a reputação, que é construída no decorrer do tempo, como sendo determinada pela imagem corporativa. Só após termos destacado essa relação de causalidade é que conduzimos o leitor à literatura macroeconômica sobre bancos centrais, pois este disporá, então, de subsídios que lhe permitirão constatar que o conceito de reputação da literatura econômica se assemelha àquele proposto pelos estudiosos da área de negócios que consideram a imagem uma variável determinante da reputação institucional.

\subsection{IMAGEM COMO SINÔNIMO DE REPUTAÇÃO CORPORATIVA}

Segundo Bickerton (2000), o conceito de imagem corporativa foi introduzido pelo marketing sob a perspectiva do cliente, constituindo-se, em tempo recorde, uma área de grande interesse de pesquisa."A idéia de que produtos (marcas) e corporações têm imagens foi popularizada nos Estados Unidos no final da década de 1950" (Dowling, 1993, p.101). 
Na concepção de Martineau (1958), a produção em massa conduz à padronização, intensificando o processo de destruição criadora, para destacar diferenças reais nos produtos. Como o acirramento da competição impede que a superioridade técnica ou de design constitua vantagem insuperável, a propaganda assume importância vital, uma vez que destaca atributos subjetivos do produto. Ele acredita que as dimensões psicológicas associadas ao produto são tão ou mais importantes do que os seus atributos funcionais. $\mathrm{O}$ autor adverte, todavia, que a propaganda relacionada aos atributos subjetivos do produto não é suficiente. É imprescindível fortalecer a imagem corporativa.

Kennedy (1977) ressalta o equívoco de se compensar o declínio dos mercados e o acirramento da competição com políticas de corte de gastos. Seria preciso robustecer a imagem corporativa, o que poderia ser conseguido com o mínimo de despesa, simplesmente porque os empregados são os principais vendedores da organização. Para que fosse construída uma imagem nítida, consistente e favorável, caberia à administração superior comunicar, de forma clara e transparente, a política da empresa a todos os seus empregados.

Na concepção de Dowling (1993, p. 102), a imagem depende do que "as pessoas estão falando acerca da empresa e do que a empresa está falando sobre si mesma", sendo a comunicação interpessoal mais poderosa na formação de impressões e opiniões do que as comunicações da própria empresa.

A partir do final da década de 1970, desenvolveram-se, paralelamente aos estudos sobre imagem, as investigações acerca da identidade corporativa. Embora a literatura apresente diversas definições de identidade e imagem corporativa, há alguns pontos em comum entre elas. Há quase um consenso em torno da idéia de que a identidade corporativa seria o conjunto de representações simbólicas que distingue as firmas. Quanto às imagens, concorda-se que se referem à impressão global de uma empresa por parte de seus públicos externos. Haveria, ademais, uma inter-relação íntima entre elas.

Markwick e Fill (1997, p.397) observam que "todas as organizações teriam uma identidade corporativa. Algumas buscariam administrá-la de forma planejada, ao passo que outras, menos cuidadosas, confundiriam os seus públicos (clientes, empregados, fornecedores, agências reguladoras etc.)". A forma de administração da identidade corporativa contribui, assim, para o desenvolvimento de uma reputação ou imagem negativa a seu respeito.

A identidade corporativa seria projetada para os distintos públicos, por intermédio de uma variedade de sinais, e representaria o modo como a organização gostaria de ser percebida. Esses poderiam ser planejados, de forma que mensagens deliberadamente intencionais fossem transmitidas para atingir objetivos específicos. Alguns sinais compreenderiam a identidade visual da organização. Outros estariam focalizando o seu comportamento, as suas ações e o seu posicionamento. No final do processo, "a forma como cada público percebe os sinais de identidade da organização modela a imagem corporativa" Markwick e Fill (1997, p. 398).

Seguindo linha análoga de raciocínio, Van Rekon (1997, p.410) observa que "a imagem corporativa tem como gênese a identidade corporativa." A imagem residiria na mente do público, ao passo que a identidade corporativa teria sua origem na organização. Seria a partir da percepção e da interpretação da identidade pelos seus distintos públicos que a imagem corporativa seria constituída. A estratégia de negócios da corporação deveria, dessa forma, administrar a imagem por intermédio do ajuste da identidade. Existiria, então, uma estreita inter-relação entre identidade, imagem e estratégia corporativas.

\subsection{IMAGEM E REPUTAÇÃO CORPORATIVA COMO CONCEITOS DISTINTOS}

Segundo Weigelt e Camerer (1988), as firmas devem desfrutar de boa reputação, caso desejem que os clientes os considerem fornecedores capazes e confiáveis de produtos e/ou serviços, uma vez que a reputação é o sinal visível da competência e da credibilidade da firma. A reputação seria, na concepção dos autores, particularmente relevante para as empresas instaladas em setores cuja qualidade da oferta seja de difícil avaliação.

Fombrun e Shanley (1990) supõem que as empresas competem por reputação em um mercado caracterizado por informação imperfeita, cujos distintos públicos prestam atenção aos sinais de mercado, contábeis, institucionais e estratégicos referentes à corporação, segundo seus interesses particulares. A reputação resultaria das múltiplas imagens construídas no decorrer do tempo pelos públicos-alvo. Como a reputação favorável sinaliza uma qualidade superior para os consumidores, possibilita a cobrança de preços-prêmio. Atrai também melhores candidatos às vagas disponíveis na corporação, facilita o seu acesso ao mercado de capitais e exerce atração sobre investidores. 
Fombrun (1996) observa que os ativos intangíveis encontram-se ocultos, na maior parte dos casos, nos balanços contábeis. 0 seu valor só é calculado quando a firma é vendida, subtraindo-se o valor dos ativos líquidos tangíveis do preço de venda da firma. Nos ativos intangíveis estaria incluída a reputação da firma.

A reputação corporativa, na qualidade de capital da firma, é o valor excedente de mercado de suas ações, ou seja, o montante pelo qual o valor de mercado da firma excede o valor de liquidação de seus ativos. Nesse sentido, a reputação deve ser administrada e tratada como um ativo.

De acordo com Balmer (1998, p. 971), a imagem difere da reputação corporativa na medida em que a primeira está relacionada "às opiniões mais recentes" do público acerca de determinada organização, ao passo que a última representa um julgamento de valor sobre as qualidades da corporação, sendo "construída ao longo do tempo". A reputação corporativa teria, pois, uma dimensão histórica, a qual reflete a percepção da consistência de ação e comportamento da corporação no transcurso do tempo.

Além de distinguir imagem de reputação corporativa, Balmer e Wilson (1998) também destacam o sentido de causalidade existente entre ambas, argumentando que a reputação é função da imagem corporativa. Para esses autores, a administração efetiva da identidade corporativa permitiria a construção de uma imagem favorável e, no decorrer do tempo, de uma reputação corporativa positiva. A reputação sólida estimularia a aquisição de produtos e/ou serviços ofertados pela firma, a compra de ações da empresa e uma postura favorável das agências reguladoras em relação às ações e pleitos da firma. Paralelamente, a reputação robusta possibilitaria uma comunicação oral positiva por partes das comunidades e uma publicidade favorável na mídia.

Seguindo linha análoga de raciocínio, Vendelo (1998) argumenta que a reputação é construída a partir da experiência do público externo com a firma ao longo do tempo, podendo, assim, ser considerada uma categoria de memória social. Na concepção do autor, as firmas e os seus clientes interagem em um ambiente de incerteza, no qual os clientes empregam a qualidade percebida de produtos anteriormente adquiridos como parâmetro da qualidade de produtos a serem comprados no futuro. As firmas com reputação sólida são as que mais se beneficiam do grau de incerteza do público.

Assim, a reputação seria um sinal da qualidade dos produtos da firma e, nesse sentido, representaria uma informação acerca de seu desempenho futuro. A reputação constitui, portanto, um insumo valioso para tomada de decisão de consumidores que não desejam ou podem, investir recursos na obtenção de informações detalhadas acerca do desempenho passado da empresa. Como tal, a reputação reduz custos transacionais para os clientes, facilitando o intercâmbio em um ambiente de incerteza. Nesse contexto, Vendelo (1998) postula que a reputação é um ativo intangível, podendo gerar rendimentos futuros e vantagem competitiva.

Alessandri (2001) observa que consistência e repetição são imperativos para as firmas que objetivam obter uma imagem corporativa favorável e, em última instância, uma reputação corporativa positiva na mente do público. As impressões consistentes de uma imagem positiva produzem, ao longo do tempo, uma reputação corporativa sólida.

A interação ou a experiência com a identidade corporativa é que gera a imagem na mente de seus públicos, o que leva Alessandri (2001) a concluir que, embora controlando a sua identidade, a corporação não controla a imagem. Como a reputação corporativa é formada a longo do tempo, por impressões repetidas da imagem, a corporação não tem como controlar diretamente nem uma nem outra.

Van Riel e Fombrum (2002, p. 10) destacam a natureza histórica da reputação. Sugerem que esta "é uma avaliação coletiva, subjetiva, de sua confiabilidade e honestidade", calcada em seu desempenho passado. Em razão de evoluir ao longo do tempo, a reputação não pode, ao contrário da imagem, ser moldada rapidamente.

Sanderberg (2002) também acredita que a imagem, conceituada como sendo a percepção da firma por parte de seus públicos, determina a reputação corporativa. Ele argumenta que "a reputação é o consenso de percepções sobre como uma firma se comportará em determinada situação, a partir do que as pessoas sabem sobre ela, incluindo o seu desempenho financeiro".

Em outros termos, Sandberg (2002, p. 3) julga que "a reputação refere-se à previsibilidade de comportamento e à probabilidade de a corporação atender expectativas". Nesse sentido, considera o preço das ações da firma como a medida mais universal das referidas expectativas. 0 preço da ação revelaria, então, "tudo o que o mercado espera que a empresa realize no futuro, com base nas informações disponíveis, inclusive a forma como interage com seus distintos públicos" (Sandberg, 2002, p. 3). 


\subsection{REPUTAÇÃO NA ÓTICA DA MACROECONOMIA ATUAL}

\subsection{1 -PRESSUPOSTOS MACROECONÔMICOS FUNDAMENTAIS}

Para que o conceito de reputação possa ser, sob a perspectiva da literatura macroeconômica, mais facilmente compreendido, é conveniente que os fundamentos do principal paradigma macroeconômico atual sejam apresentados.

Após a II Guerra Mundial, os formuladores da política econômica dispunham de modelos macroeconômicos keynesianos, que prescreviam as medidas que deveriam ser adotadas para atingir um nível desejado de emprego e de produto. Sob a perspectiva teórica da Curva de Phillips, haveria um tradeoff entre a taxa de desemprego e a inflação. Se o governo adotasse uma política fiscal expansionista - quer aumentando gastos quer reduzindo impostos, ou, ainda, mediante uma combinação de ambos - o resultado seria uma queda da taxa de desemprego, muito embora acompanhada de elevação da taxa de inflação.

Caso optasse por uma política monetária de redução da taxa de juros, haveria crescimento do investimento, ocorrendo a conseqüente redução da taxa de desemprego. 0 aumento da oferta monetária, que teria ocasionado a redução da taxa de juros, produziria, por seu turno, elevação da taxa de inflação. Com taxas de inflação residuais, expectativas estáticas de inflação, e uma preocupação crescente com aumento do nível de emprego, o trade-off da Curva de Phillips não preocupava no período. A aplicação desses modelos fundamentados na Curva de Phillips produziu, entretanto, notadamente na década de 1970, resultados imprevistos e adversos, pois gerou tanto a aceleração da inflação, como a elevação da taxa de desemprego (Friedman, 1985).

No início da década de 1970, surgiu, no meio acadêmico, um novo modelo, conhecido como macroeconomia novo-clássica, cuja hipótese fundamental de expectativas racionais por parte dos agentes econômicos iria influenciar profundamente a literatura econômica. Na concepção de Lucas (1972), o principal arquiteto da macroeconomia novo-clássica, as decisões que determinam as variáveis macroeconômicas de interesse dependem, essencialmente, das expectativas dos indivíduos acerca da trajetória futura da economia. Nessa abordagem, as expectativas são formadas por agentes racionais a partir de todas as informações disponíveis em dado momento do tempo (Mankiw, 1990; Cysne e Simonsen, 1995).

Nesse contexto, somente surpresas inflacionárias, decorrentes de medidas não antecipadas, poderiam, em função da existência de informação imperfeita, afetar o nível de produto real e o nível de emprego. Medidas não antecipadas, todavia, colocariam em suspeição a reputação da autoridade monetária, mostrando-se inócuas se repetidas, pois seriam previsíveis. A exploração do trade-off de curto prazo da curva de Phillips seria, assim, um grande equívoco, pois o comprometimento de reputação do Banco Central e de credibilidade na política monetária produziria conseqüências desastrosas, anulando, imediatamente, o benefício potencial que se pudesse esperar de políticas expansionistas.

Sendo assim, caberia ao Banco Central, no contexto de expectativas racionais, eleger como meta uma variável nominal para monitoramento, como a taxa de inflação no regime de metas inflacionárias, já que não teria como alterar, a longo prazo, as variáveis reais da economia.

Embora a autoridade monetária possa desejar que todos tenham expectativas de inflação reduzida, o anúncio de compromisso com uma inflação baixa não o torna, por si só, crível. Isso ocorre porque os agentes econômicos têm plena consciência de que o Banco Central poderia se sentir estimulado a descumprir o anunciado, caso visasse reduzir a taxa de desemprego. É nesse cenário que se discute o papel do Banco Central, a sua forma de atuação, os seus compromissos fundamentais, bem como o significado e a construção de sua reputação (Blinder, 1999).

\subsubsection{REPUTAÇÃO, ATUAÇÃO E COMPROMISSOS DO BANCO CENTRAL}

A percepção que o público possui do Banco Central depende da confiança que se deposita na capacidade de a instituição manter os preços estáveis. Essa confiança deve ser conquistada, preservada e confirmada por meio de ações desenvolvidas ao longo do tempo. Quanto mais bem-sucedido for no cumprimento de seu papel de guardião da estabilidade da moeda, mais robusta será a reputação institucional do Banco Central.

Existiria, observa Cukierman (2000, p.3), "uma correlação positiva entre controle de inflação e transparência da política monetária." 0 crescente interesse da literatura acadêmica pelo papel da transparência na formulação e condução da política monetária reflete a atenção cada vez maior que os 
bancos centrais têm reservado à comunicação de sua política monetária. 0 processo de ampliação da transparência é complexo e apresenta algumas dificuldades de implementação. Quando o Banco Central consegue que os agentes econômicos compreendam a sua visão do ambiente econômico, compartilhando as informações por meio de uma linguagem entendida pelos distintos segmentos do público, há ampliação da transparência. 0 estabelecimento de uma regra monetária previamente comunicada, a transparência, 0 cumprimento do anunciado, a prestação de contas à sociedade e a autonomia do Banco Central seriam elementos que concorreriam para o aumento de confiança na consecução da missão de manter a moeda estável, tornando a reputação da autoridade monetária mais sólida.

Em enquête conduzida junto à comunidade acadêmica e aos dirigentes dos principais bancos centrais, Blinder (1999) investigou como a credibilidade da autoridade monetária - concebida pelo autor como sinônimo de reputação institucional - poderia ser construída e qual seria a sua relevância na condução da política monetária. Blinder (1999) concluiu que a reputação corporativa sólida era muito considerada pelos respondentes, que teriam chegado ao consenso de que ela possibilita não só reduzir o custo de combate à inflação, como também mantê-la em patamares reduzidos. Quanto à construção de uma reputação sólida, os respondentes teriam destacado o cumprimento do anunciado e o grau de aversão à inflação como sendo os seus elementos mais importantes.

\section{METODOLOGIA}

Partindo da concepção de que a imagem institucional influencia positivamente a reputação corporativa e considerando a inexistência de estudos sobre imagem no âmbito dos bancos centrais, o objetivo fundamental de nossa pesquisa era verificar se a imagem institucional constituía uma dimensão participante da percepção dos agentes econômicos em relação ao desempenho do Banco Central, bem como a avaliar o seu impacto na reputação do banco central. Nesse sentido, foi desenvolvido um primeiro modelo de equações estruturais, no qual foi suposta a influência direta da imagem institucional, da percepção de atuação operacional do Banco Central e dos compromissos institucionais sobre a reputação do Banco Central. Realizou-se uma pesquisa de survey intersecional, com emprego de questionário estruturado e auto-administrado, o qual foi enviado aos respondentes pelo correio.

\subsection{AMOSTRA}

0 questionário foi enviado a 471 especialistas das áreas operacionais de bancos comerciais, bancos múltiplos, bancos de Investimento, Caixa Econômica Federal, Corretoras e Distribuidoras. Foram devolvidos 125 questionários, dos quais foram aproveitados 123. Todos os participantes da amostra eram membros da Associação Nacional das Instituições do Mercado Financeiro (ANDIMA).

\subsection{COLETA DE DADOS}

Dentre as técnicas de coleta de dados primários, utilizou-se o questionário estruturado e autoadministrado, tendo sido empregada a escala diferencial semântico de sete alternativas.

Os questionários foram postados nos dias 18, 19 e 20 de agosto de 2003 e o período de coleta de dados foi encerrado em 12 de setembro do referido ano, para que as expectativas em relação à reunião do Comitê de Política Monetária (COPOM) de 16 e 17 de setembro de 2003 não influenciassem as respostas dos participantes da pesquisa.

Para avaliar as qualidades psicométricas do instrumento de coleta de dados, verificando sua confiabilidade, foi calculado o alfa de Cronbach, cujo resultado de 0,8445 situou-se acima do valor crítico mínimo de 0,70 (Hair et al, 1998).

\subsection{ANÁLISE DOS DADOS}

Os dados foram inicialmente analisados por meio de técnicas estatísticas descritivas, com auxílio do SPSS for Windows, versão 10.0. Para testar a validade do modelo empregou-se a modelagem de equações estruturais, tendo sido utilizado o programa Amos 4.0. 


\subsection{VARIÁVEIS, MODELO ESTRUTURAL E DIAGRAMA DE CAMINHO DO MODELO ORIGINAL}

Na medida em que se trabalhou com a modelagem de equações estruturais foram definidas variáveis latentes e as suas respectivas variáveis observadas.

\section{Variáveis latentes independentes (ou exógenas)}

\section{1) Imagem Institucional do Banco Central (IMAGEMBC)}

Essa variável latente refere-se à imagem institucional da autoridade monetária, cuja estimação ocorreu a partir de três variáveis observadas, quais sejam: Opinião global em relação ao Banco Central (Opiglob); Contribuição do Banco Central para o bem-estar social (Contribs); e Respeito às decisões do Banco Central (Respdeci).

\section{2) Atuação Operacional do Banco Central (AOPEBC)}

Essa variável latente está relacionada à percepção dos participantes do mercado financeiro quanto à atuação operacional da autoridade monetária, cuja estimação ocorreu a partir de sete variáveis observadas, quais sejam: Condução eficiente da política monetária (Efima); Estabelecimento do patamar adequado da taxa básica de juros (Njuro); Administração eficiente de depósito compulsório sobre depósito à vista (Dcvis); Administração eficiente na concessão de redesconto (Rdesc); Atuação eficiente no mercado de câmbio (Atcam); Competência do corpo funcional do Banco Central (Cfuncio); e Imprevistos na atuação do Banco Central (Imprevat).

\section{3) Compromisso Institucional (COMPROBC)}

Essa variável latente está vinculada à percepção dos participantes do mercado financeiro quanto à observância dos compromissos assumidos pela autoridade monetária num ambiente de estabilidade de preços, incluindo o seu grau de transparência. A sua estimação ocorreu a partir de seis variáveis observadas, quais sejam: Transparência em relação aos critérios empregados na definição do patamar da taxa de juros (Transpju); Qualidade dos documentos publicados pelo Banco Central (Qualido); Qualidade gráfica dos documentos divulgados pelo Banco Central (Quagrafi); Facilidade de compreensão das estatísticas econômicas divulgadas pelo Banco Central (Claresta); Justificativas dos dirigentes do Banco Central para as decisões do Comitê de Política Monetária (Juscopom); e Prestação anual de contas pelo presidente do Banco Central (Prestcon).

\section{Variável latente dependente (ou endógena)}

\section{1) Reputação do Banco Central (REPUTBC)}

Essa variável latente refere-se à reputação da autoridade monetária, cuja estimação ocorreu a partir de seis variáveis observadas, quais sejam: Determinação com a estabilidade de preço (Destabil); Cumprimento do anunciado (Cuanum); Prestígio dos dirigentes do Banco Central (Prestidi); Fiscalização eficiente das instituições financeiras (Fiscaliz); Apoio das instituições financeiras à independência do Banco Central (Aindebc); e Determinação do governo com equilíbrio das contas públicas (Eqfiscal). A escolha da reputação como variável latente evidencia o fato de que o caráter dinâmico da reputação não aconselha que sua mensuração seja feita diretamente por meio de uma cross-section de percepções.

0 postulado fundamental do estudo é que a reputação é positivamente influenciada pela imagem institucional. A imagem se relaciona a impressões recentes em relação à instituição, ao passo que a reputação é construída ao longo do tempo.

Tal como em negócios privados, as surpresas exercem impacto sobre a reputação do banco central. Todavia, em conseqüência de suas peculiaridades, existem duas modalidades de surpresas que necessitam de distinção clara, uma vez que influenciam a reputação por caminhos distintos.

A primeira modalidade de surpresa afeta diretamente a imagem e, por seu intermédio, a opinião global em relação à instituição, e, conseqüentemente, a reputação. Essas surpresas não estão diretamente relacionadas à atuação do banco central no âmbito monetário, mas a esferas distintas de atuação, como o gerenciamento da dívida mobiliária federal. Nesse sentido, quando manobras táticas redundam em condições mais vantajosas para gerenciamento da dívida mobiliária federal, a imagem institucional sofre impacto direto favorável e, por seu intermédio, há fortalecimento da reputação, a qual afeta positivamente, por seu turno, a percepção quanto à determinação do governo com o equilíbrio das contas públicas.

A segunda modalidade de surpresa está especificamente associada à atuação do banco central na esfera monetária. Nesse caso, a surpresa tem conotação negativa, razão pela qual a denominaremos imprevisto, visto que sua ocorrência conflita com expectativas construídas a partir de compromissos assumidos pela 
autoridade monetária. Imprevistos na esfera monetária são muito graves, pois geram forte percepção negativa quanto à condução da política monetária, a qual perde credibilidade, já que os próprios compromissos são questionados, havendo enfraquecimento da reputação da autoridade monetária. Nesse caso, a ação contraria o discurso de comprometimento com a estabilidade de preços.

As equações do modelo de mensuração foram as seguintes:

- $\quad$ Efima $=\beta 1 \mathrm{AOPEBC}+$ termo de erro

- $\quad$ Njuro $=\beta 2 \mathrm{AOPEBC}+$ termo de erro

- $\quad$ Dcvis $=\beta 3$ AOPEBC + termo de erro

- $\quad$ Rdesc $=\beta 4 \mathrm{AOPEBC}+$ termo de erro

- $\quad$ Atcam $=\beta 5$ AOPEBC + termo de erro

- $\quad$ Cfuncio $=\beta 6$ AOPEBC + termo de erro

- Imprevat $=\beta 7 \mathrm{AOPEBC}+$ termo de erro

- $\quad$ Opiglob $=\beta 8$ IMAGEMBC + termo de erro

- $\quad$ Contribs $=\beta 8$ IMAGEMBC + termo de erro

- $\quad$ Respdeci $=\beta 10$ IMAGEMBC + termo de erro

- $\quad$ Transpju $=\beta 11$ COMPROBC + termo de erro

- Qualido $=\beta 12$ COMPROBC + termo de erro

- $Q$ uagrafi $=\beta 13$ COMPROBC + termo de erro

- $\quad$ Claresta $=\beta 14$ COMPROBC + termo de erro

- Juscopom $=\beta 15$ COMPROBC + termo de erro

- Prestcon $=\beta 16$ COMPROBC + termo de erro

- $\quad$ Destabil $=\beta 17$ REPUTBC + termo de erro

- $\quad$ Prestidi $=\beta 18$ REPUTBC + termo de erro

- $\quad$ Fiscaliz $=\beta 19$ REPUTBC + termo de erro

- $\quad$ Cuanun $=\beta 20$ REPUTBC + termo de erro

- $\quad$ Aindebc $=\beta 21$ REPUTBC + termo de erro

- $\quad$ Eqfiscal $=\beta 22$ REPUTBC + termo de erro

A equação estrutural foi a seguinte:

REPUTBC $=\beta 23$ IMAGEMBC $+\beta 24$ AOPEBC $+\beta 25$ COMPROBC + erro residual

\section{RESULTADOS}

Para avaliação do modelo originalmente proposto, empregou-se o programa AMOS 4.0, cujos índices de ajustamento o rejeitaram, embora tivesse apresentado convergência de solução. 0 modelo é recursivo, mais do que identificado, com 69 parâmetros, 206 graus de liberdade e uma amostra de 123 observações (Quadro 1). 
Quadro 1 Modelo original: resumo do relatório do AMOS 4.0

\begin{tabular}{|} 
Número de variáveis exógenas: 26 \\
Número de variáveis endógenas: $23:$ \\
Tamanho da amostra: 123 \\
Computação dos graus de liberdade \\
Número distinto de momentos da amostra: 275 \\
Número de parâmetros distintos a serem estimados: 69 \\
Graus de liberdade: 206
\end{tabular}

Convém notar que, não obstante o modelo original tivesse exibido escores em diversos índices de ajustamento acima do mínimo exigido para caracterizar um bom ajustamento, não atingiu o valor mínimo crítico em índices relevantes (Tabela 1).

Tabela 1 - Ajustamento do Modelo Original: resultados do AMOS 4.0

\begin{tabular}{|c|c|}
\hline Medida & Ajustamento \\
\hline CMIN/DF & 2,750 \\
\hline NFI & 0,911 \\
\hline RFI & 0,891 \\
\hline IFI & 0,942 \\
\hline TLI & 0,928 \\
\hline CFI & 0,941 \\
\hline RMSEA & 0,120 \\
\hline ECVI & \\
\hline Modelo Hipotético & 5,775 \\
\hline Modelo Saturado & 4,508 \\
\hline Modelo Independente & 52,697 \\
\hline
\end{tabular}

A razão $\chi 2$ /graus de liberdade (CMIN/DF) apresentou valor inferior $(2,750)$ ao limite máximo aceitável de 3.

O Normed Fit Index (NFI), o Incremental Fit Index (IFI), o Tucker-Lewis Index (TLI) e o Comparative Fit Index (CFI) superaram 0,90, embora o Relative Fit Index (RFI) tenha sido 0,891. O Expected Cross Validation Index (ECVI) revela que o modelo hipotético é inferior ao saturado, já que o valor do segundo é inferior ao do primeiro. A decisão de modificação torna-se inevitável quando analisamos o índice RMSEA. De fato, o índice Root Mean Square Error of Approximation (RMSEA) de 0,120 supera o limite máximo de ajustamento pobre $(0,10)$, distanciando-se, assim, significativamente do limite máximo de um ajustamento razoável $(0,08)$.

Muito embora necessitasse de modificação, o modelo originalmente proposto apresentava grande potencial para ajustamento robusto, desde que promovidas alterações que não apenas atendessem exigências estatísticas, mas principalmente permitissem sua melhor adequação ao construto teórico.

A avaliação preliminar dos resultados do modelo inicialmente proposto aponta como uma das causas de seu fraco ajustamento a inclusão das variáveis Atcam, Aindebc e Qualido. Embora a multicolinearidade seja motivo de preocupação, espera-se, em qualquer análise multivariada a existência de alguma correlação entre as variáveis, visto que são influenciadas por uma variável latente comum. No caso da variável observada Atcam, não só as correlações foram muito pequenas, mas também não apresentaram significância estatística a 10\%. Essas são razões fortes para remoção da variável.

Na reformulação do modelo original, manteve-se o modelo de mensuração, à exceção dos caminhos relacionados às variáveis observadas excluídas, alterando-se o modelo estrutural no sentido de ampliar a influência da imagem institucional e destacar a relevância dos compromissos institucionais. 
Admitiu-se, como no modelo original, que a imagem institucional influencia positivamente a variável latente Reputação do Banco Central.

Supôs-se também que a imagem institucional influenciava positivamente a variável latente Atuação operacional do Banco Central e o construto Compromisso Institucional.

Nesse sentido, a imagem se fortalece quando o Banco Central surpreende favoravelmente o mercado, influenciando positivamente a opinião global a seu respeito, como no caso em que a autoridade monetária reduz o volume de títulos atualizados pela variação cambial, oferecendo volume menor do que o resgatado, e colocando, no mesmo período, títulos prefixados com prazo mais dilatado.

0 fortalecimento da imagem institucional influencia positivamente o construto Atuação operacional do Banco Central, já que a redução na participação percentual de títulos atualizados pela variação cambial, quando acompanhada de elevação percentual de títulos prefixados com prazos mais dilatados no total da dívida mobiliária doméstica, torna a política monetária mais eficiente e mais independente de choques adversos. Com efeito, a aludida manobra tática de administração da dívida pública federal fortalece as expectativas de redução futura do serviço da dívida, tornando mais positiva a percepção de determinação do governo com o equilíbrio das contas públicas.

A imagem mais positiva exerce, dessa maneira, impacto positivo direto sobre a reputação da autoridade monetária, uma vez que quanto menos intensamente a dívida mobiliária federal for influenciada por choques adversos, que produzam elevação da taxa de câmbio, de inflação, da própria dívida e de seu serviço, mais forte é a percepção de que superávits primários reverterão a trajetória de crescimento do déficit público ao longo do tempo, destacando o efetivo comprometimento com a estabilidade de preços.

Nesse contexto, o fortalecimento da imagem institucional impacta positivamente o construto Compromisso Institucional, uma vez que os argumentos que buscam justificar as decisões tomadas para garantir estabilidade de preços são percebidos convincentes, visto que vão ao encontro das estratégias implementadas pela autoridade monetária. Quando precedidos de ações confirmatórias de intenções, os argumentos tornam-se críveis e percebidos incontestáveis.

O caminho do construto Atuação Operacional do Banco Central foi alterado, supondo-se que a atuação do Banco Central na esfera monetária influencia indireta e positivamente a reputação, via impacto positivo direto sobre a variável mediadora Compromisso Institucional. Em outros termos, a influência da variável latente Atuação Operacional do Banco Central sobre a Reputação do Banco Central, a qual esteve presente no modelo originalmente proposto, continua no modelo modificado, com a diferença que passou de direta para indireta.

Assim, o estabelecimento da taxa de juros em patamar adequado e a condução eficiente da política monetária, com emprego adequado e oportuno dos instrumentos de política monetária, influenciam positivamente à percepção quanto aos compromissos institucionais de responsabilidade e transparência.

De fato, é necessário que a autoridade monetária assegure estabilidade de preços, mediante estabelecimento de um patamar justo de taxa de juros e sua efetiva consecução, para que transparência e responsabilidade desempenhem suas funções no regime de metas inflacionárias. Transparência e responsabilidade são partes integrantes do regime de metas inflacionárias, o qual deve, necessariamente, assegurar estabilidade de preços para que sua adoção seja justificada.

Nesse sentido, quando a Ata do COPOM é divulgada à sociedade, contendo argumentos técnicos que justifiquem o patamar de taxa juros considerado mais adequado, é imprescindível que os agentes econômicos o percebam, dado o objetivo de estabilidade de preços, como o mais efetivamente ajustado às condições econômicas. Ademais, não basta estabelecer um patamar adequado para taxa de juros. É fundamental que não ocorram imprevistos e que a taxa básica fique, de fato, em sua vizinhança, o que implica dizer condução eficiente da política monetária. Somente quando essas condições forem satisfeitas é que as considerações tecidas pelo COPOM acerca da taxa serão críveis e o compromisso de transparência e de responsabilidade percebido como confiável.

No regime de metas inflacionárias, o Banco Central assume, segundo Blinder et al (2001), o compromisso de transparência e responsabilidade, estando a comunicação no âmago de ambos. Transparência e comunicação são ferramentas fundamentais para conquista de confiança.

Entretanto, o comunicado só se torna crível quando a realidade atesta congruência entre ação e discurso. Por essa razão, a atuação operacional necessita corroborar os compromissos comunicados, independentemente da força dos argumentos e legitimidade das intenções. 
Preservou-se o caminho entre Compromisso Institucional e Reputação do Banco Central, no qual o primeiro exerce impacto direto sobre o construto Reputação do Banco Central.

Admitir esse caminho significa ir ao encontro dos resultados de trabalhos realizados pelos estudiosos de banco central, que atribuem importância crescente aos compromissos institucionais, notadamente a transparência e a comunicação, para fortalecimento da credibilidade na autoridade monetária (Blinder et al, 2001; Fracasso, Genberb e Wyplosz, 2003; Fraga, Goldfajn e Minella, 2003).

Em resumo, o modelo modificado supõe a existência de efeitos diretos dos construtos Imagem Institucional do Banco Central (IMAGEMBC) e Compromisso Institucional (COMPROBC) sobre a variável latente Reputação do Banco Central (REPUTBC). A variável latente Reputação do Banco Central (REPUTBC) também sofre o impacto indireto do construto Atuação Operacional do Banco Central (AOPEBC) via influência direta e positiva dessa última variável sobre Compromisso Institucional (COMPROBC).

0 modelo modificado é recursivo, com 68 parâmetros estimados e 141 graus de liberdade. Os índices de ajustamento do modelo ficaram acima dos valores mínimos críticos de validação (Tabela 2).

Tabela 2 - Ajustamento do Modelo Modificado: resultados do AMOS 4.0

\begin{tabular}{|c|c|}
\hline Medida & Ajustamento \\
\hline Graus de Liberdade & 141 \\
\hline CMIN/DF & 1,641 \\
\hline NFI & 0,958 \\
\hline RFI & 0,944 \\
\hline IFI & 0,983 \\
\hline TLI & 0,977 \\
\hline CFI & 0,983 \\
\hline RMSEA & 0,072 \\
\hline ECVI & 3,012 \\
\hline Modelo Hipotético & 3,426 \\
\hline Modelo Saturado & 45,731 \\
\hline Modelo Independente & \\
\hline
\end{tabular}

Todos os índices de ajustamento do modelo modificado são muito mais robustos do que o do modelo original.

À exceção da estimativa do peso de regressão $\beta 7$, referente à influência direta do construto Atuação Operacional do Banco Central (AOPEBC) sobre Imprevisto na atuação do Banco Central, as demais estimativas são estatisticamente significativas ao nível de 5\% (Tabela 3). 
Tabela 3 - Modelo Modificado: pesos de regressão

\begin{tabular}{|c|c|c|c|}
\hline Caminho & Estimativa & $\begin{array}{l}\text { Razão } \\
\text { Crítica }\end{array}$ & Aceita/Rejeita \\
\hline OPIGLOB <------ IMAGEMBC & 1,000 & & Aceita \\
\hline CONTRIBS <---- IMAGEMBC & 0,423 & 3,374 & Aceita \\
\hline RESPDECI <----- IMAGEMBC & 0,916 & 7,994 & Aceita \\
\hline IMPREVAT<---- AOPEBC & $-0,118$ & $-0,989$ & Rejeita \\
\hline EFIMA <--------- AOPEBC & 1,000 & & Aceita \\
\hline NJURO <-------- AOPEBC & 0,884 & 6,762 & Aceita \\
\hline DCVIS <-------- AOPEBC & 0,623 & 4,541 & Aceita \\
\hline RDESC <-------- AOPEBC & 0,492 & 3,685 & Aceita \\
\hline CFUNCIO <------ AOPEBC & 0,469 & 3,762 & Aceita \\
\hline TRANSPJU <---- COMPROBC & 1,000 & & Aceita \\
\hline QUAGRAFI<---- COMPROBC & 0,271 & 2,922 & Aceita \\
\hline CLARESTA<---- COMPROBC & 0,366 & 4,397 & Aceita \\
\hline JUSCOPOM<---- COMPROBC & 0,841 & 10,306 & Aceita \\
\hline PRESTCON<---- COMPROBC & 0,716 & 7,900 & Aceita \\
\hline DESTABIL <---- REPUTBC & 0,692 & 4,838 & Aceita \\
\hline PRESTIDI <----- REPUTBC & 1,000 & & Aceita \\
\hline FISCALIZ <----- REPUTBC & 0,445 & 2,937 & Aceita \\
\hline CUANUN <----- REPUTBC & 0,873 & 6,773 & Aceita \\
\hline EQFISCAL <---- REPUTBC & 0,596 & 3,893 & Aceita \\
\hline COMPROBC <-- AOPEBC & 0,506 & 2,524 & Aceita \\
\hline AOPEBC <----- IMAGEMBC & 0,605 & 6,377 & Aceita \\
\hline COMPROBC<-- IMAGEMBC & 0,552 & 3,349 & Aceita \\
\hline REPUTBC <---- IMAGEMBC & 0,290 & 2,032 & Aceita \\
\hline REPUTBC <---- COMPROBC & 0,445 & 3,370 & Aceita \\
\hline
\end{tabular}

A rejeição do caminho de Atuação Operacional do Banco Central para Imprevisto na atuação do Banco Central não é inesperada. Na realidade, com o regime de metas inflacionárias a ocorrência de imprevistos na atuação do banco central no mercado monetário, visto que intervenções no mercado de câmbio são percebidas como dimensão à parte, não são julgados prováveis.

De fato, a firmeza em impedir a inconsistência temporal, evidenciada por meio de forte determinação com a estabilidade de preços e assunção do compromisso de transparência e responsabilidade, associadas à adoção de um regime de taxa de câmbio flutuante ou dele próximo, reduziu abruptamente a ocorrência de imprevistos na atuação do Banco Central no mercado monetário, revigorando, simultaneamente, a percepção de maior previsibilidade de sua atuação.Essa percepção de previsibilidade fortaleceu-se ao longo do tempo.

Embora imprevistos não sejam esperados no âmbito monetário, surpresas relacionadas a manobras táticas que visem fortalecer a percepção de determinação com a estabilidade de preços contribuem, via imagem institucional, para fortalecimento da reputação da autoridade monetária. Essas atuações influenciam fortemente a opinião global em relação à autoridade monetária, cujo peso de regressão é o mais elevado entre as variáveis que participam do construto Imagem Institucional do Banco Central (IMAGEMBC).

Atuações imprevistas no mercado de câmbio podem ocorrer sem que haja, necessariamente, impacto negativo sobre a reputação, via imagem institucional. Entretanto, as intervenções no mercado cambial devem ser realizadas com o máximo de cautela, já que o risco de interpretação desfavorável não é pequeno, dado o regime cambial ora vigente.

Com fortalecimento (enfraquecimento) da imagem institucional é desencadeado o processo de irradiação de impactos diretos e indiretos sobre a reputação. 
Tabela 4 - Efeitos Diretos: resultados do AMOS 4.0

\begin{tabular}{|c|c|c|c|c|}
\hline \multicolumn{2}{|c|}{ IMAGEMBC } & AOPEBC & COMPROBC & REPUTBC \\
\hline AOPEBC & 0,605 & 0,000 & 0,000 & 0,000 \\
\hline COMPROBC & 0,552 & 0,506 & 0,000 & 0,000 \\
\hline REPUTBC & 0,290 & 0,000 & 0,445 & 0,000 \\
\hline Imprevat & 0,000 & $-0,118$ & 0,000 & 0,000 \\
\hline Contribs & 0,423 & 0,000 & 0,000 & 0,000 \\
\hline Opiglob & 1,000 & 0,000 & 0,000 & 0,000 \\
\hline Respdeci & 0,916 & 0,000 & 0,000 & 0,000 \\
\hline Cuanun & 0,000 & 0,000 & 0,000 & 0,873 \\
\hline Eqfiscal & 0,000 & 0,000 & 0,000 & 0,596 \\
\hline Destabil & 0,000 & 0,000 & 0,000 & 0,692 \\
\hline Fiscaliz & 0,000 & 0,000 & 0,000 & 0,445 \\
\hline Prestidi & 0,000 & 0,000 & 0,000 & 1,000 \\
\hline Dcvis & 0,000 & 0,623 & 0,000 & 0,000 \\
\hline Cfuncio & 0,000 & 0,469 & 0,000 & 0,000 \\
\hline Efima & 0,000 & 1,000 & 0,000 & 0,000 \\
\hline Njuro & 0,000 & 0,884 & 0,000 & 0,000 \\
\hline Juscopom & 0,000 & 0,000 & 0,841 & 0,000 \\
\hline Quagrafi & 0,000 & 0,000 & 0,271 & 0,000 \\
\hline Claresta & 0,000 & 0,000 & 0,366 & 0,000 \\
\hline Transpju & 0,000 & 0,000 & 1,000 & 0,000 \\
\hline Prestcon & 0,000 & 0,000 & 0,716 & 0,000 \\
\hline
\end{tabular}

Na realidade, a estimativa do peso de regressão $\beta 23$ da equação estrutural, relativa à influência direta da imagem institucional sobre a reputação não apresenta magnitude expressiva. Todavia, a influência da imagem institucional sobre a reputação não se esgota em seu impacto direto, o qual iguala a estimativa do peso de regressão (Tabela 4).

O impacto total da imagem é a soma de seu impacto direto acrescido dos indiretos exercidos não apenas sobre o construto Atuação Operacional do Banco Central, como também sobre Compromisso Institucional. O AMOS 4.0 calcula os efeitos diretos, indiretos e totais entre variáveis (Tabelas 4, 5 e 6).

Tabela 5 - Efeitos Indiretos: resultados do AMOS 4.0

\begin{tabular}{|c|c|c|c|c|}
\hline & IMAGEMBC & AOPEBC & COMPROBC & REPUTBC \\
\hline AOPEBC & 0,0000 & 0,0000 & 0,0000 & 0,0000 \\
\hline COMPROBC & 0,3061 & 0,0000 & 0,0000 & 0,0000 \\
\hline REPUTBC & 0,3818 & 0,2252 & 0,0000 & 0,0000 \\
\hline Imprevat & $-0,0711$ & 0,0000 & 0,0000 & 0,0000 \\
\hline Contribs & 0,0000 & 0,0000 & 0,0000 & 0,0000 \\
\hline Opiglob & 0,0000 & 0,0000 & 0,0000 & 0,0000 \\
\hline Respdeci & 0,0000 & 0,0000 & 0,0000 & 0,0000 \\
\hline Cuanun & 0,5863 & 0,1965 & 0,3881 & 0,0000 \\
\hline Eqfiscal & 0,4001 & 0,1341 & 0,2649 & 0,0000 \\
\hline Destabil & 0,4648 & 0,1558 & 0,3077 & 0,0000 \\
\hline Fiscaliz & 0,2992 & 0,1003 & 0,1981 & 0,0000 \\
\hline Prestidi & 0,6718 & 0,2252 & 0,4448 & 0,0000 \\
\hline
\end{tabular}


Tabela 5 - Efeitos Indiretos: resultados do AMOS 4.0 (continuação)

\begin{tabular}{|c|c|c|c|c|}
\hline \multicolumn{2}{|c|}{ IMAGEMBC } & AOPEBC & COMPROBC & REPUTBC \\
\hline Rdesc & 0,2977 & 0,0000 & 0,0000 & 0,0000 \\
\hline Dcvis & 0,3766 & 0,0000 & 0,0000 & 0,0000 \\
\hline Cfuncio & 0,2838 & 0,0000 & 0,0000 & 0,0000 \\
\hline Efima & 0,6047 & 0,0000 & 0,0000 & 0,0000 \\
\hline Njuro & 0,5348 & 0,0000 & 0,0000 & 0,0000 \\
\hline Juscopom & 0,7219 & 0,4257 & 0,0000 & 0,0000 \\
\hline Quagrafi & 0,2330 & 0,1374 & 0,0000 & 0,0000 \\
\hline Claresta & 0,3139 & 0,1815 & 0,0000 & 0,0000 \\
\hline Transpju & 0,8585 & 0,5063 & 0,0000 & 0,0000 \\
\hline Prestcon & 0,6149 & 0,3626 & 0,0000 & 0,0000 \\
\hline
\end{tabular}

Na realidade, o impacto indireto da imagem institucional $(0,3818)$, por intermédio da atuação operacional e do compromisso institucional, supera seu impacto direto $(0,290)$, denotando a relação complexa existente entre imagem e reputação.

Conforme mostra a Tabela 6, o construto que exerce maior impacto total sobre a reputação da autoridade monetária é a imagem institucional $(0,672)$, seguida por compromisso institucional $(0,445)$ e, em último lugar, pela atuação operacional no mercado monetário $(0,225)$.

Convém notar que o modelo modificado admite, da mesma forma que o original, a existência de impacto da atuação operacional da autoridade monetária sobre a reputação. A diferença é que, enquanto o modelo original, pressupunha impacto direto, o modelo modificado supõe a existência de efeito indireto sobre a reputação por intermédio do construto compromisso institucional.

Tabela 6 - Efeitos Totais: resultados do AMOS 4.0

\begin{tabular}{|c|c|c|c|c|}
\hline & IMAGEMBC & AOPEBC & COMPROBC & REPUTBC \\
\hline АОРЕВС & 0,605 & 0,000 & 0,000 & 0,000 \\
\hline COMPROBC & 0,858 & 0,506 & 0,000 & 0,000 \\
\hline REPUTBC & 0,672 & 0,225 & 0,445 & 0,000 \\
\hline Imprevat & $-0,071$ & $-0,118$ & 0,000 & 0,000 \\
\hline Contribs & 0,423 & 0,000 & 0,000 & 0,000 \\
\hline Opiglob & 1,000 & 0,000 & 0,000 & 0,000 \\
\hline Respdeci & 0,916 & 0,000 & 0,000 & 0,000 \\
\hline Cuanun & 0,586 & 0,197 & 0,388 & 0,873 \\
\hline Eqfiscal & 0,400 & 0,134 & 0,265 & 0,596 \\
\hline Destabil & 0,465 & 0,156 & 0,308 & 0,692 \\
\hline Fiscaliz & 0,299 & 0,100 & 0,198 & 0,445 \\
\hline Prestidi & 0,672 & 0,225 & 0,445 & 1,000 \\
\hline Rdesc & 0,298 & 0,492 & 0,000 & 0,000 \\
\hline Dcvis & 0,377 & 0,623 & 0,000 & 0,000 \\
\hline Cfuncio & 0,284 & 0,469 & 0,000 & 0,000 \\
\hline Efima & 0,605 & 1,000 & 0,000 & 0,000 \\
\hline Njuro & 0,535 & 0,884 & 0,000 & 0,000 \\
\hline Juscopom & 0,722 & 0,426 & 0,841 & 0,000 \\
\hline Quagrafi & 0,233 & 0,137 & 0,271 & 0,000 \\
\hline Claresta & 0,314 & 0,185 & 0,366 & 0,000 \\
\hline Transpju & 0,858 & 0,506 & 1,000 & 0,000 \\
\hline Prestcon & 0,615 & 0,363 & 0,716 & 0,000 \\
\hline
\end{tabular}


Os resultados da pesquisa destacam a Imagem Institucional do Banco Central (IMAGEMBC) como o principal construto do modelo. Além de exercer influência direta sobre os principais construtos, desempenha significativa influência indireta sobre suas principais variáveis observadas.

\section{CONSIDERAÇÕES FINAIS}

Blinder (1999b) afirma que, na visão dos dirigentes de bancos centrais, credibilidade significa que os agentes econômicos acreditam nos pronunciamentos, mesmo que inexista obrigação legal para seu cumprimento e que possa haver, inclusive, incentivo de curto prazo para não respeitá-los. Segundo Blinder (1999b, p.81): "No mundo real, uma credibilidade assim [...] é dolorosamente construída sobre um histórico de atos que correspondem às palavras. Um Banco Central que sempre faz o que diz irá adquirir essa credibilidade, quase independentemente da estrutura institucional." A concepção de Blinder (1999b) sobre credibilidade se assemelha ao conceito de reputação corporativa proposto por Alessandri (2001), sem trilhar, contudo, o caminho por ela desenvolvido. Para Alessandri (2001), "tanto a consistência como a repetição é imperiosa para as firmas que tentam conquistar uma imagem corporativa favorável - e, em última análise, uma reputação corporativa positiva - na mente do público" (Alessandri, 2001, p.180). A imagem corporativa robusta é condição necessária para uma reputação forte porque "a reputação corporativa é formada ao longo do tempo por impressões repetidas da imagem corporativa, sejam positivas ou negativas." (Alessandri, 2001, p. 177)

Os resultados da pesquisa confirmaram a hipótese essencial que a imagem institucional influencia direta e positivamente a reputação do Banco Central, cuja verificação era de crucial importância no estudo. Confirmaram também que todos os construtos que participam da construção da reputação da autoridade monetária sofrem impacto positivo por parte da imagem.

A autoridade monetária deseja que os agentes econômicos formem expectativas de inflação baixa, anunciando, assim, uma política monetária voltada para geração de patamares residuais de inflação. Uma vez formadas as expectativas de inflação reduzida, a autoridade monetária se defronta com o conflito entre inflação e desemprego, sentindo-se incentivada a descumprir o anunciado, com vistas a reduzir o desemprego.

Os resultados mostram que, notadamente em países cujos bancos centrais está construindo sua reputação, é preciso que a atuação operacional corrobore os compromissos assumidos.

O Banco Central autônomo constitui, portanto, um ingrediente indispensável para assegurar a eliminação da inconsistência temporal, conferindo credibilidade à condução da política monetária e, por essa via, à imagem do Banco Central. Convém notar, que autonomia de instrumentos não constitui sinônimo de independência para definir objetivos.

A autonomia operacional do Banco Central gera, em contrapartida, a obrigação de ser transparente e de prestar contas à sociedade. Nesse sentido, compromissos institucionais são os corolários morais da independência do Banco Central (Blinder, 1996).

É recomendável sejam realizadas pesquisas sistemáticas em relação à imagem e à reputação do Banco Central, pois, só nesse caso, a condição dos construtos poderá ser verificado, para que sejam promovidas, se for o caso, as alterações necessárias à sua recondução à trajetória de fortalecimento.

\section{REFERÊNCIAS}

[1] ALESSANDRI, S.W. Modeling corporate identity: a concept explication and theorical explanation. Corporate Comunications: An International Journal, v. 16, n. 4, p. 173-182, 2001.

[2] BALMER, J.M.T. Corporate identity and the advent of corporate marketing. Journal of Marketing Management, v. 14, n. 8 , p. 963-996, 1998.

[3] BALMER, J.M.T. e WILSON, A . Corporate identity: there is more to it than meets the eye. International Studies of Management \& Organization, v. 28, n. 3, p. 12-31, 1998.

[4] BICKERTON, D. Corporate reputation versus corporate branding: the realist debate.Corporate Communications: An International Journal, v. 5, n. 1, p. 42-48, 2000.

[5] BLINDER, A.S. Central Banking in a Democracy. Federal Reserve Bank of Richmond Economic Quarterly, v. 82, n. $4,1996$. 
[6] _. Central Bank Credibility: Why do we care? How do we build it? NBER Working Paper Series n. 7161, p.1-23, June 1999.

[7] _ _ Bancos Centrais: Teoria e Prática. São Paulo: Ed.34, 1999b.

[8] BLINDER, A.S. et al. How Do Central Banks Talk? Geneve Reports on the World Economy n. 3, p. 1-122, 2001

[9] CUKIERMAN, A. Establishing a Reputation for Dependability by Means of Inflation Targets. Economics of Governance, v.1, n. 1, p. 53-76, Feb. 2000.

[10] CYSNE,R.P. e SIMONSEN, M.H. Macroeconomia. 2.ed. São Paulo:Atlas, 1995.

[11] DOWLING, G.R. Developing Your Company Image into a Corporate Asset. Long Range Planning, v. 6, n. 2, p.101-109, 1993.

[12] FRACASSO, A.; GENBERG, H.; WYPLOSZ, C. How Do Central Banks Write? An Evaluation of Inflation Targeting Central Banks. Geneve Reports on the World Economy Special Report n. 2, p. 1-43, 2003.

[13] FRAGA, A.; GOLDFAJN, I.; MINELLA, A. Inflation targeting in emerging market economies. Trabalhos para Discussão do Banco Central do Brasil n. 76, p. 1-49, jun. 2003.

[14] FRIEDMAN, M. Inflação e Desemprego: A Novidade da Dimensão Política. Literatura Econômica, v. 7, n. 3, p.381 - 408, 1985.

[15] FOMBRUN, C. Reputation: Realizing Value from the Corporate Image. Boston: Harvard Business School Press, 1996.

[16] FOMBRUM, C. e SHANLEY, M. What's in a name? Reputation building and corporate strategy. Academy of Management Journal, v. 33, p. 233-258, 1990.

[17] GOTSI, M. e WILSON, A. M. Corporate reputation: seeking a definition. Corporate Communications: An International Journal, v. 6, n. 1, p.24 -30, 2001.

[18] HAIR, J. F. et al. Multivariate data analysis. New York: Prentice-Hall, 1998.

[19] KENNEDY, S.H. Nurturing corporate images: total communication or ego trip? European Journal of Marketing, v. 11, n. 3, p. 120-164, 1977.

[20] LUCAS, R.E. Jr. Expectations and the neutrality of money. Journal of Economic Theory, v. 4, 1972.

[21] MANKIW, G. A Quick Refresher Course in Macroeconomics. NBER Working Paper Series, Working Paper n. 3256, p. 1-42, Feb.1990.

[22] MARKWICK, N. e FILL, C. Towards a framework for managing corporate identity. European Journal of Marketing, v. 31, n. 5/6, p. 306-409, 1997.

[23] MARTINEAU, P. Sharper Focus for the Corporate Image. Harvard Business Review, v. 36, n. 6, p. 49-58, Nov./Dec. 1958.

[24] SANDBERG, K. Kicking the Tires of Corporate Reputation. Harvard Management Communication Letter, p.1 4, Jan. 2002.

[25] VAN REKOM, J. Deriving an operational measure of corporate identity. European Journal of Marketing, v. 31, n. 5/6, p.410-422, 1997.

[26] VAN RIEL ,C.B.M. e FOMBRUN, C.J. Which Company is Most Visible in Your Country? An Introduction to the Special Issue on the Global R.Q - Project Nominatives. Corporate Reputation Review, v. 4, n. 4, p. 296-302, 2002.

[27] VENDELO, M.T. Narrating corporate reputation. International Studies of Management \& Organization, v. 28, n. 3, p.120-137, 1998.

[28] WEIGELT, K. e CAMERER, C. Reputation and Corporate Strategy: A Review of Recent Theory and Applications. Strategic Management Journal, v. 9, n. 5, p. 443-454, 1988. 


\section{Capítulo 4}

\section{A evolução da sistemática aduaneira na importação: Siscomex, Portal Único e expectativas acerca dos benefícios da DUIMP}

\section{Marcelo de Oliveira Soares \\ Hellen Xavier das Chagas \\ Rodrigo Luiz Zanethi}

Resumo: Segundo publicação do Governo Federal (2017), os processos de liberação de mercadorias de Comércio Exterior (COMEX) são extremamente burocráticos, configurando-se como um dos principais entraves para os importadores e exportadores. Para tornar mais célere o fluxo do comércio internacional, em dezembro de 2013 a Organização Mundial do Comércio (OMC) veiculou o Acordo de Facilitação de Comércio (AFC), com o objetivo de simplificar, agilizar e harmonizar os processos aduaneiros. Para tanto, o governo federal vem tomando providências para minimizar as burocracias relacionadas às liberações das cargas, como por exemplo a implementação de novos programas, e assim, alavancando a economia do país. Logo, este artigo tem o propósito de demonstrar a evolução do Siscomex Importação, o conceito do Portal Único de Comércio Exterior e as expectativas acerca dos benefícios com a implementação da Declaração Única de Importação - DUIMP. Esta pesquisa foi feita por meio de revisão de literatura em artigos científicos e sites publicados na internet. A metodologia utilizada foi de abordagem qualitativa, de caráter descritivo e utilizou-se de dados secundários.

Palavras-chave: DUIMP. Portal Único. Expectativa. Benefícios. Importação. Simplificação. Procedimentos. Comércio Exterior 


\section{INTRODUÇÃO}

Atualmente, com os efeitos da globalização e os avanços tecnológicos, os mercados, tanto nacional quanto internacional, necessitam de medidas que os façam ganhar em produtividade e otimização de seus processos, visando alcançar um diferencial competitivo em meio à alta concorrência internacional. Cientes dessa necessidade, os organismos internacionais vêm tomando medidas para auxiliar na melhoria do fluxo de liberação de cargas no comercio internacional.

Conforme Chagas (2017), pode-se dizer que o Brasil tenha grandes chances de reduzir seus custos logísticos por meio da otimização de procedimentos operacionais e gerenciais que já estão sendo aplicados, inclusive em países de renda baixa e média conforme o LPI - (Logistic Performance Index) relatório (Doeing Bussines) do Banco Mundial, e podem ser copiados pelo Brasil a fim de aperfeiçoar o desempenho e representatividade do comércio exterior no cenário mundial.

Em dezembro de 2013, em Bali (Indonésia), a Organização Mundial do Comércio (OMC), em sua nona conferência ministerial, teve a apresentação do "Pacote de Bali", que além de deliberações cotidianas, veiculou o Acordo de Facilitação de Comércio (AFC). Um dos objetivos com seu surgimento foi harmonizar e simplificar os processos aduaneiros, com o propósito de aumentar a movimentação do comércio internacional.

O AFC, originalmente Trade Facilitation Agreement (TFA), foi lançado sobre a ótica das importantes questões de desburocratização dos processos de comércio exterior, e seu acolhimento deve ser aceito por todas as nações participantes da OMC. Em razão disso que o Brasil vem obedecendo ao acordo com a implementação de programas e medidas para diminuir a burocracia dos processos de comércio exterior, reduzir custos e agilizar a liberação de cargas, promovendo significativamente o crescimento da economia do país. (Itamaraty, 2014).

Este artigo científico tem como objetivo demonstrar a evolução do Siscomex Importação, o conceito do Portal Único de Comércio Exterior e as expectativas acerca dos benefícios e melhorias com a implementação da Declaração Única de Importação - DUIMP.

A metodologia utilizada foi de abordagem qualitativa, de caráter descritivo e utilizou-se de dados secundários. Foi realizada revisão da literatura existente em artigos científicos; livros de especialistas da área; notícias em sites do governo e organismos internacionais publicadas na internet, tais como MDIC, RF; OMC; OMA; Banco Mundial (Doing Business, 2017).

Para tanto, o estudo está estruturado de forma que no segundo capitulo será abordada a evolução do Sistema Integrado de Comércio Exterior (Siscomex) desde 1992 até os dias atuais. No terceiro serão explorados os conceitos do Portal Único Siscomex, que foi criado visando integrar a atuação dos diversos órgãos intervenientes.

Já no quarto capitulo serão comentadas as expectativas dos possíveis benefícios advindos com a adoção da DUIMP (Declaração Única de Importação). Em seguida as considerações finais e referências bibliográficas.

\section{HISTÓRICO E EVOLUÇÃO DO SISTEMA INTEGRADO DE COMÉRCIO EXTERIOR (SISCOMEX) NO ÂMBITO IMPORTAÇÃO - 1992 À 2015}

No final do século XX o Brasil entrou na era da informação, que também pode ser chamada de era digital. Com o aumento da compra e venda de bens e serviços estrangeiros, o país foi ganhando uma importante posição dentro da economia mundial e houve um crescimento notável das exportações e importações. Para avançar dentro do comércio exterior era necessário criar um software que auxiliasse a nova realidade do país, assim surgiu o SISCOMEX. (LUZ, 2012).

o SISCOMEX é um sistema informatizado criado para a área de Comércio Exterior. Nele, é exercido o controle do comércio exterior brasileiro e também são centralizadas atividades de registro, acompanhamento de saída e ingresso de mercadorias no país e controle das operações de exportação, importação e desembaraço aduaneiro.

O SISCOMEX é uma ferramenta que facilita a integração e a troca de informações, pois automatizou todo o processo aduaneiro que antes era feito em papel, e concentrou em uma plataforma os procedimentos e os documentos necessários para análise online dos diversos órgãos competentes de fiscalização, reduzindo os custos, burocracia e otimizando o tempo. (LUZ, 2012). 
O SISCOMEX foi criado pelo decreto $\mathrm{n}^{\circ}$ 660, de 25 de setembro de 1992, pelo Governo Federal, desenvolvido pelo Banco Central, o programa começou a ser utilizado em 1993 para as operações de exportação na plataforma DOS (Sistema Operacional em Disco), e em 1997 foi ampliado para as operações de importação que eram feitas na plataforma Visual Basic, de forma que o software fosse instalado no computador do usuário, conforme Figura 1 (Brasil, 1992) que atualmente deixou de ser operacionalizado em programa instalado e passou a ser acessado via internet conforme Figura 2.

Figura 1 - Tela inicial do Siscomex Exportação ano 1993 e Importação 1997

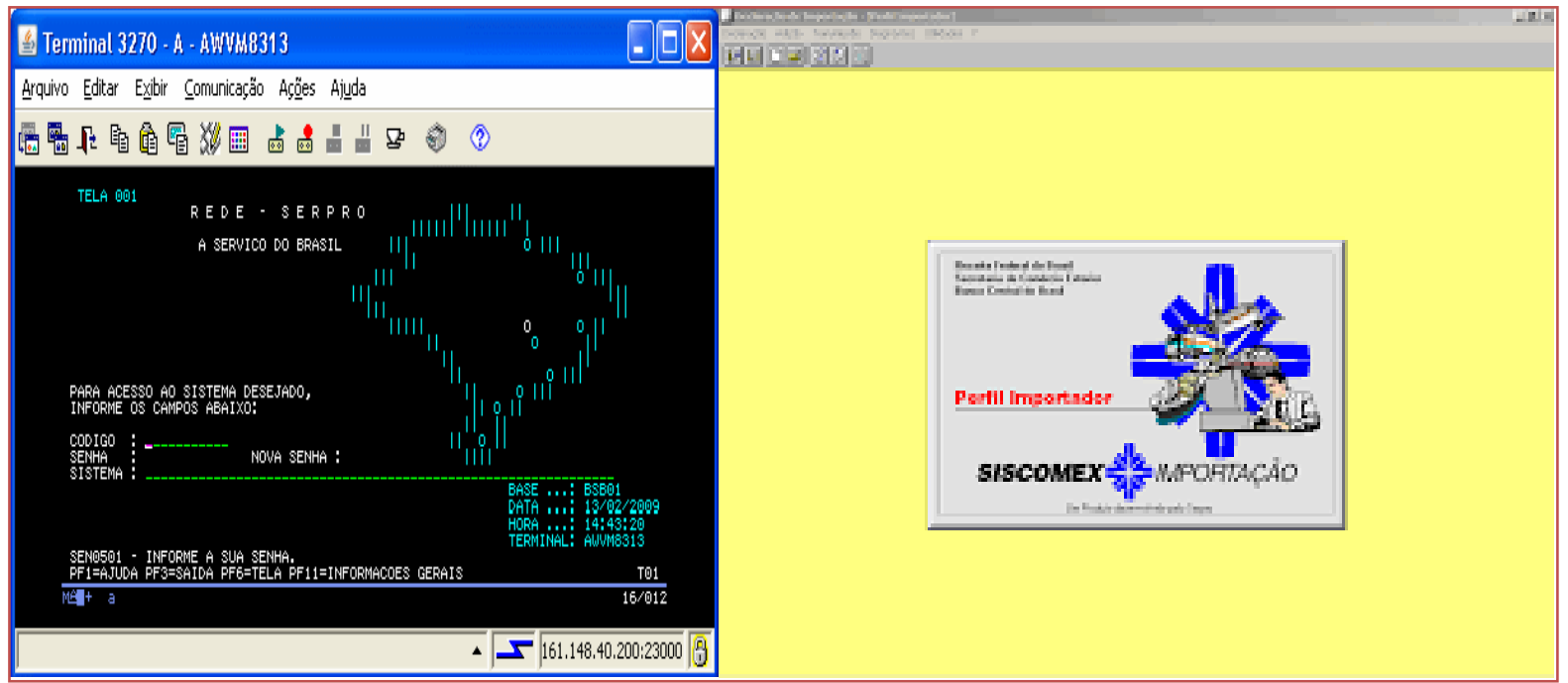

Fonte: Serviço Federal de Processamento de Dados - SERPRO, [?] e Easycomex, 2015

Figura 2 - Tela inicial do Siscomex Importação ano 2015

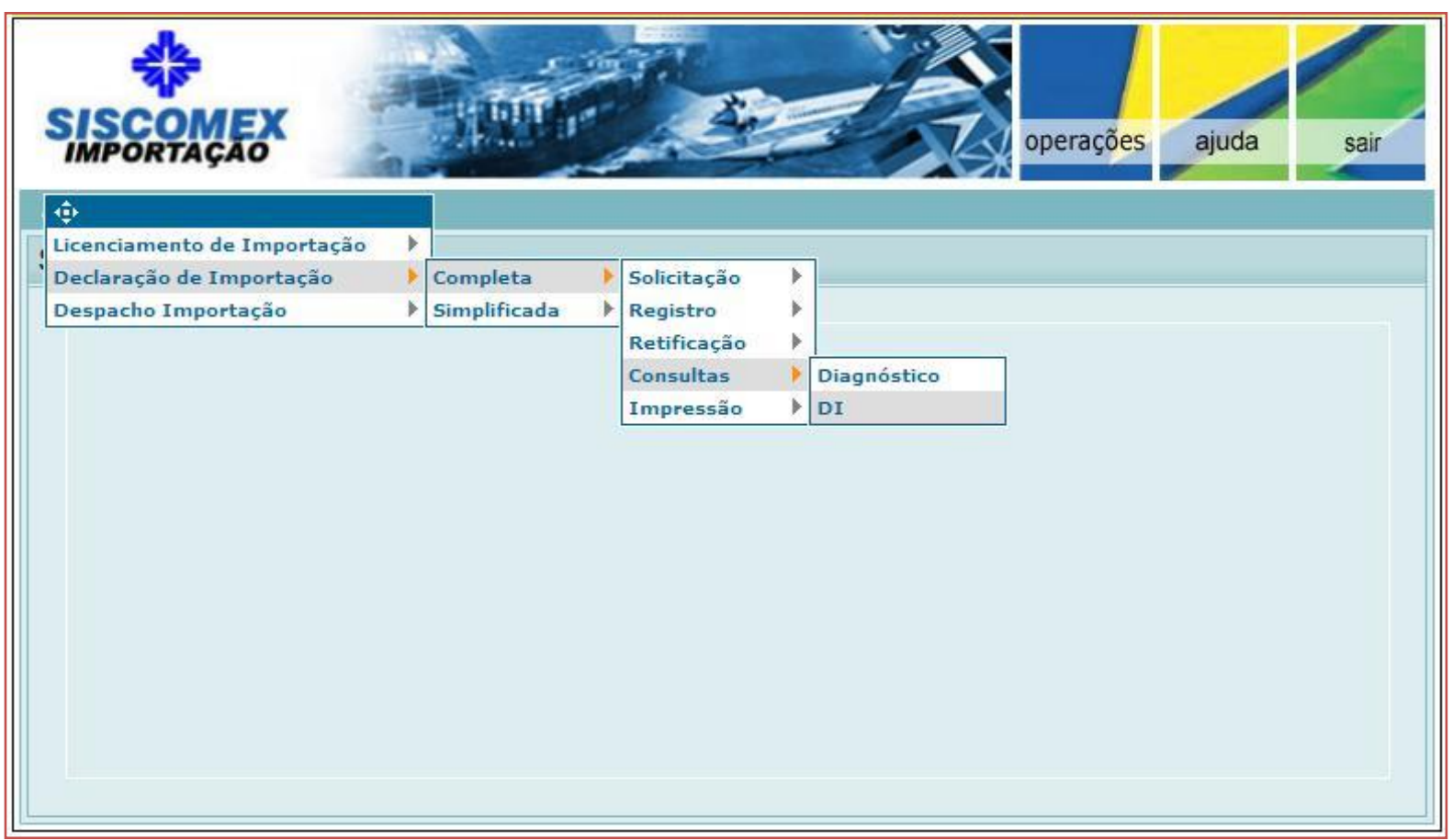

Fonte: Receita Federal, 2018 
Apesar da informatização, naquela época, os órgãos governamentais, individualmente tinham seus próprios sistemas de controle, informatizado ou não, conforme Figura 3, fazendo com que os importadores e exportadores informassem as mesmas informações diversas vezes, assim, permitindo o surgimento de erros, informações desconexas. (LUZ, 2012).

Figura 3 - Tela Comércio Exterior complexo e burocrático

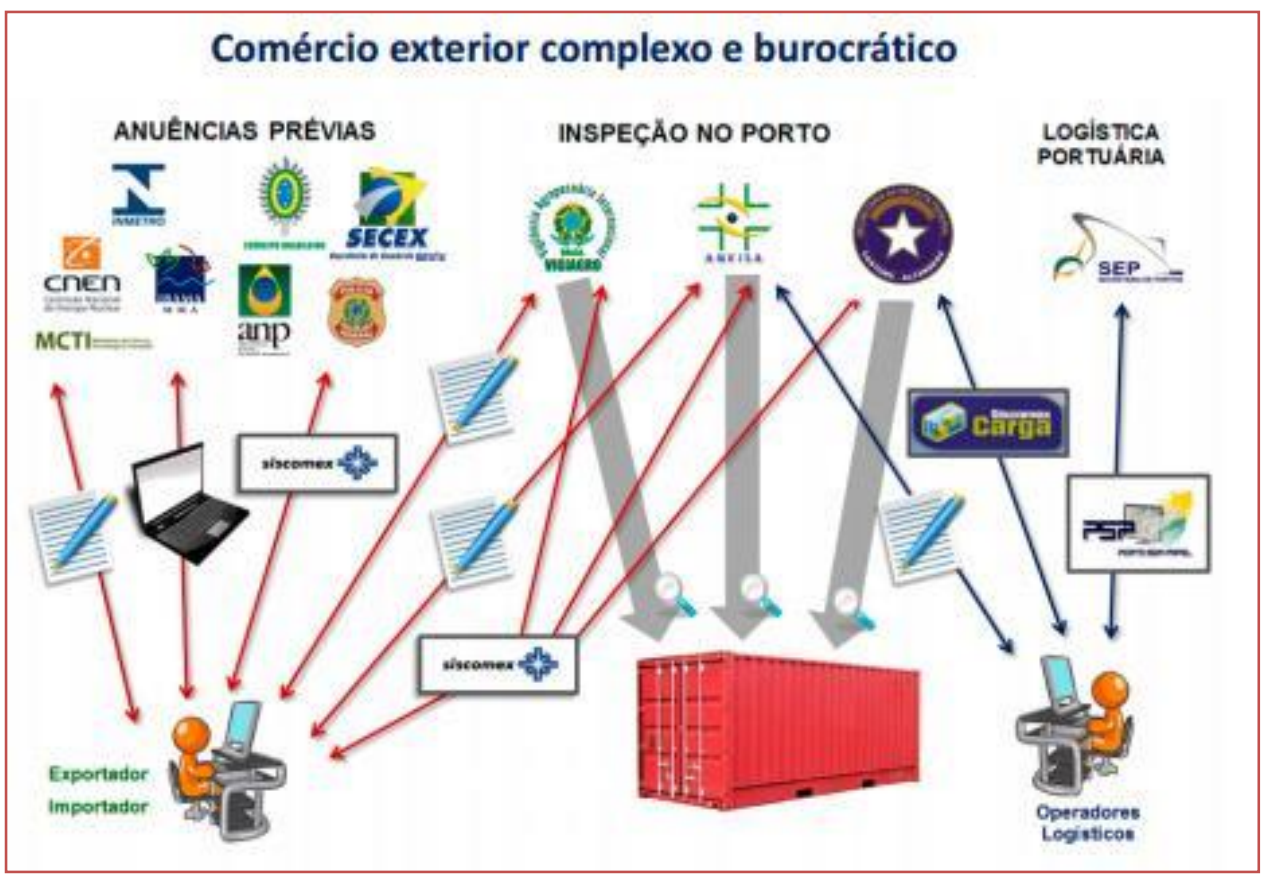

Fonte: Associação de Comércio Exterior do Brasil - AEB, [2016?]

Gradativamente, foram surgindo mais sistemas, até que fossem obtidos 8 importantes sistemas: Exportação, Mantra, Importação, Internação-ZFM, Trânsito, Carga, Drawback Integrado Web e Exportação Web - Módulo Comercial. Os módulos citados eram acessados pelos seguintes usuários: transportadores, despachantes aduaneiros, importadores, exportadores, depositários, bancos e os servidores públicos que têm função ativa no controle do comércio exterior. (LUZ, 2012).

A medida que novas necessidades comerciais foram surgindo, o sistema foi sendo modernizado e integrado, por exemplo, o SISCOMEX Web de 2015, que surgiu com o intuito de dar mais agilidade, segurança e mobilidade aos importadores sendo acessível somente por meio do certificado digital. É evidente que o SISCOMEX revolucionou o setor de comércio exterior, a criação desse sistema informatizado fez com que o Brasil estivesse à frente de inúmeros países no que se diz respeito à agilidade e confiabilidade de informações dentro do sistema. (portal siscomex, 2015).

Após 20 anos da criação do Siscomex de 1997, o Governo Federal visando atender o Acordo de Facilitação do Comércio ocorrido em Bali (Indonésia), criou o Portal Único de Comércio Exterior, programa que visa unificar de forma de single window (janela única), conforme Figura 4, todos os sistemas dos órgãos envolvidos no processo de exportação e importação (MOREIRA, 2013). 
Figura 4 - Tela Comércio Exterior não burocrático

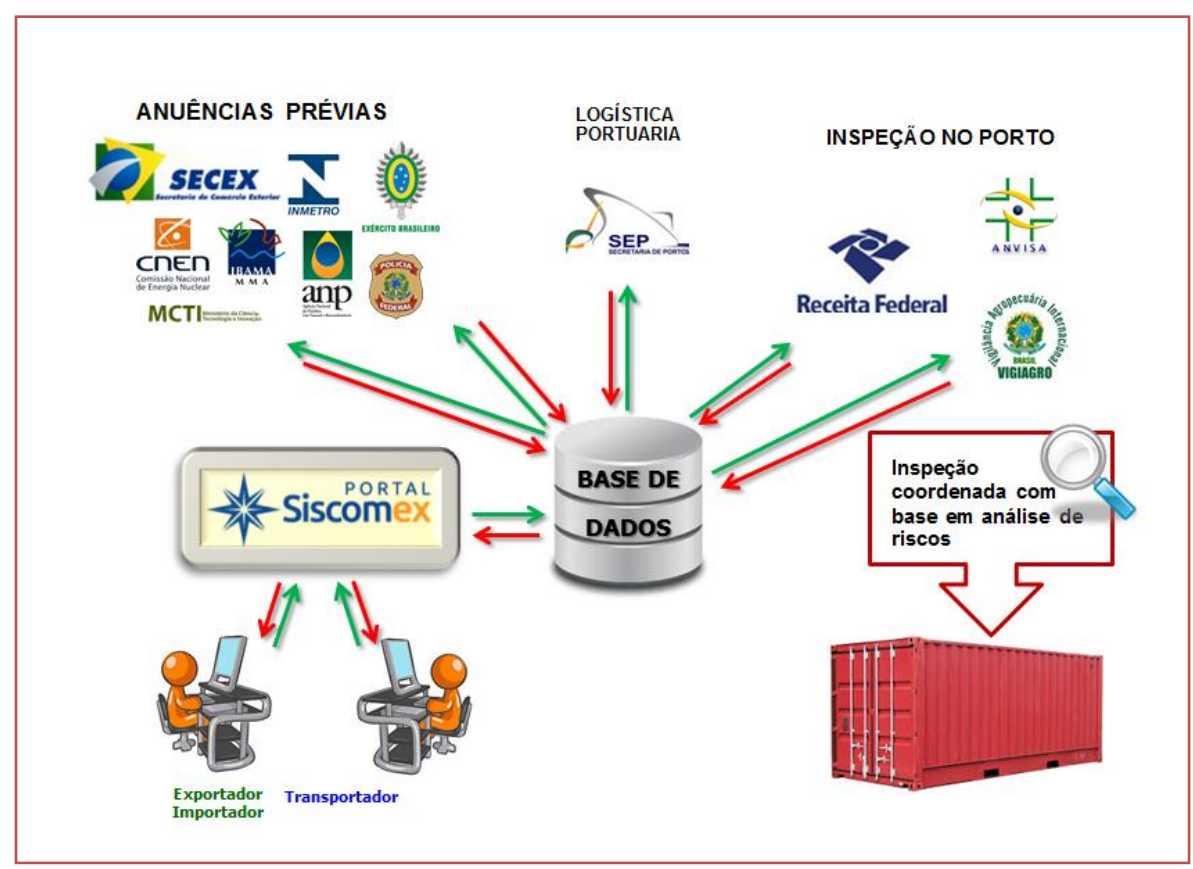

Fonte: Associação de Comércio Exterior do Brasil - AEB, [2016?]

O Portal é uma iniciativa para reduzir o Custo Brasil que encarece o investimento, elevar a competitividade da indústria nacional e reduzir burocracia e custos, pois o Brasil foi apontado como o país mais protecionista do G-20. (MOREIRA, 2013).

\section{PORTAL ÚNICO DE COMÉRCIO EXTERIOR - ABRIL DE 2014}

O Portal Único de Comércio Exterior é uma ferramenta central que foi implantada pelo Governo Federal por meio da normatização do Decreto 8.229 de 22 de abril de 2014, onde além de reformular os processos e burocracias anteriores, tem a intenção de integrar todos os sistemas dos inúmeros intervenientes existentes de Comércio Exterior. (portal siscomex, [2014]).

Assim, pode-se observar o que cita o art. 1 do Decreto 8.229 de 2014, que alterou entre outros o art. 9-9 Decreto 660 de 1992 onde já era previsto que o Portal Único de Comércio Exterior seria um sistema no qual operadores e intervenientes do comércio exterior poderiam encaminhar documentos ou dados exigidos pelas autoridades competentes para operações de comércio exterior por meio da internet (Brasil, 2014).

Conforme o Portal Siscomex (2014), a implementação vem sendo efetuada com a cooperação conjunta de diversos órgãos federais, e foi dividida em algumas etapas ao longo dos últimos anos, até que o sistema esteja absolutamente atuando com seus diversos módulos. Tela de acesso conforme Figura 5. Após a reformulação citada, o propósito é conseguir processos mais simplificados, eficientes, harmonizados e integrados com todos os operadores públicos e privados do Comércio Exterior. Isto posto, um Portal onde a intenção será a eficiência e a transparência no controle das Exportações e Importações. (portal siscomex, 2014).

É importante ressaltar que com essa nova tecnologia, o Governo Federal tem a expectativa de que haja redução nos prazos e custos nas importações e exportações, com isso, impulsionando economia brasileira. (GOVERNO DO BRASIL, 2017). É justificável também que essas melhorais tem impacto direto na sustentabilidade, pois a iniciativa além de reduzir etapas e exigências governamentais, tem a finalidade de ter um grande ganho na eliminação da necessidade de impressão de diversos documentos e relatórios, com um de seus módulos nomeado "Anexação Eletrônica de Documentos". Em 2016 e 2017, esta redução foi citada pelo Ministério da Indústria, Comércio Exterior e Serviços (MDIC) e reconhecido pelo Banco 
Mundial nos Relatórios Doing Business. Assim sendo, corrobora fortemente com a responsabilidade social e ambiental. (MDIC, 2017 e WORLD BANK GROUP. 2016).

Segundo MDIC, (2017), "Ao final da implantação e disponibilidade de todas as ferramentas do Portal Único, prevista para acontecer até o final do ano de 2018, a meta é reduzir os tempos médios das exportações brasileiras de 13 para 8 dias e das importações de 17 para 10 dias. Os processos de exportação e importação serão em média 40\% mais ágeis". Essa redução é muito importante, pois segundo um estudo de Hummels e Minor (2011), cada dia a menos no tempo entre a saída da mercadoria de sua origem e a sua chegada ao destino gera-se uma economia equivalente a 0,8\%, em média, do valor dessa mercadoria.

Figura 5 - Tela de acesso ao Portal Siscomex

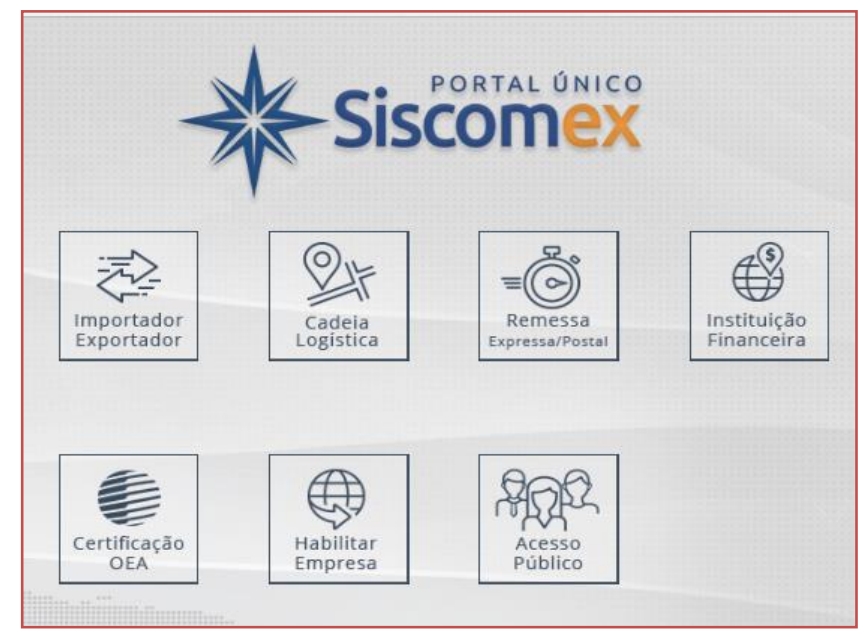

Fonte: Portal Siscomex, [2018?]

\section{1 ÓRGÃOS ANUENTES}

A logística do Programa Portal Único é executada de forma simultânea pela Secretaria da Receita Federal do Brasil e pela Secretaria de Comércio Exterior, com a comitiva da Casa Civil e atuação dos diversos órgãos do governo que contam com atuação direta sobre importações ou exportações. (APRENDENDO A EXPORTAR, [2017?])

Os órgãos anuentes são órgãos governamentais que tem a função legal de consentir ou não com a entrada e saída de bens e produtos de nosso país. Esses órgãos estão presentes tanto nas importações como nas exportações. (GUEIROS, 2013).

As operações registradas via sistema são analisadas em tempo real tanto pelos órgãos gestores, quanto pelos órgãos anuentes, que estabelecem regras específicas para o desembaraço de mercadorias dentro de sua área de competência. Os órgãos anuentes na importação têm a função de analisar as licenças de importação registradas pelos importadores no SISCOMEX. É necessária a verificação de cumprimento das condições e exigências específicas para as mercadorias sujeitas a um controle especial. Eles podem atuar simultaneamente e independente de mais de um órgão em uma mesma licença. São eles:

- ANEEL - Agência Nacional de Energia Elétrica.

- $\quad$ ANVISA - Agência Nacional de Vigilância Sanitária.

- CNEN - Comissão Nacional de Energia Nuclear.

- $\quad$ DFPC - Comando do Exército - Diretoria de Fiscalização de Produtos Controlados.

- DPF - Departamento de Polícia Federal.

- $\quad$ IBAMA - Instituto Brasileiro do Meio Ambiente e dos Recursos Naturais Renováveis.

- INMETRO - Instituto Nacional de Metrologia, Normalização e Qualidade Industrial.

- MAPA - Ministério da Agricultura, Pecuária e Abastecimento. 
- Ancine - Agência Nacional do Cinema.

- ANP - Agência Nacional do Petróleo, Gás Natural e Biocombustíveis.

- BB - Banco Central do Brasil.

- $\quad \mathrm{CNPq}$ - Conselho Nacional de Desenvolvimento Científico e Tecnológico.

- Conselho Nacional de Política Fazendária - Confaz, mediante convênio com a Secretaria da Receita Federal do Brasil e a Secretaria de Comércio Exterior.

- DNPM - Departamento Nacional de Produção Mineral.

- $\quad$ ECT - Empresa Brasileira de Correios e Telégrafos.

- $\quad$ MCTIC - Ministério da Ciência, Tecnologia, Inovação e Comunicações.

- MD - Ministério da Defesa.

- Secretaria de Aviação Civil da Presidência da República.

- $\quad$ SEP - Secretaria de Portos da Presidência da República.

- Suframa - Superintendência da Zona Franca de Manaus.

Muitos anuentes da importação também são anuentes da exportação, como ANEEL, ANVISA, CNEN, DFPC, IBAMA, entre outros. De acordo com o código da NCM do produto a ser exportado, determinados órgãos precisam autorizar a exportação.

Para saber se o produto a ser importado está sujeito à anuência governamental, de acordo com os artigos 14 e 15 da Portaria Secex $n^{\circ}$ 23/2011, existe na página da internet do MDIC (Ministério do Desenvolvimento, Indústria e Comércio Exterior) e no SISCOMEX, uma lista de produtos sujeitos a autorização. E na exportação, o artigo 197 da mesma Portaria mostra quais produtos estão sujeitos à anuência. Para cada espécie listada há um indicativo do respectivo órgão governamental. Exemplo: Para importação de um animal vivo, é necessário obter previamente uma autorização de embarque junto ao Ministério da Agricultura, Pecuária e Abastecimento (MAPA).

\subsection{VISÃO INTEGRADA DO COMÉRCIO EXTERIOR - VICOMEX - SETEMBRO DE 2014}

Com o objetivo de monitorar de forma transparente, mostrar os responsáveis e tempos de cada etapa do processo, assim, facilitando a atuação dos intervenientes das operações de comércio exterior, foi implantado o Visão Integrada do Comércio Exterior (VICOMEX), que é outro módulo integrante do Portal Siscomex. (PORTAL SISCOMEX, 2014).

No modelo anterior, os usuários precisavam acessar diferentes módulos do Siscomex para poder obter as informações das operações de comércio exterior. Com o advento VICOMEX, o usuário poderá acessar os dados em um único painel de controle conforme Figura 6, onde estará concentrado todas as informações das importações e exportações. (portal siscomex, 2014).

O módulo foi desenvolvido de forma a demonstrar o cenário de Despachos de Exportação - DE, Licenças de Importação - LI, Registros de Exportação - RE e Despachos de Importação - DI , apresentando dados como por exemplo, a data da última situação do processo, o canal de parametrização, exigências administrativas e aduaneiras, dentre outros. A plataforma detém duas formas de consulta. Uma a "Operações em Andamento", que de forma agregada, é capaz de apresentar ao o interveniente a situação atualizada dos últimos registros e mudança de status do processo. Já na outra consulta, é permitido que se faça a consulta de LI, DI, RE e DE por período ou individualmente, ainda com a facilidade de consulta histórica de cada uma das operações de comércio exterior. (portal siscomex, 2014).

Considerando a autorização pertinente, o VICOMEX pode ser acessado pelas pessoas responsáveis pelo importador e exportador, e, também pelo seu representante legal. 0 módulo continua em desenvolvimento constante, inclusive, com propósito de adicionar outras funcionalidades de consulta, para outros dados do comércio exterior. (portal siscomex, 2014). 
Figura 6 - Visão Integrada do Comércio Exterior - VICOMEX

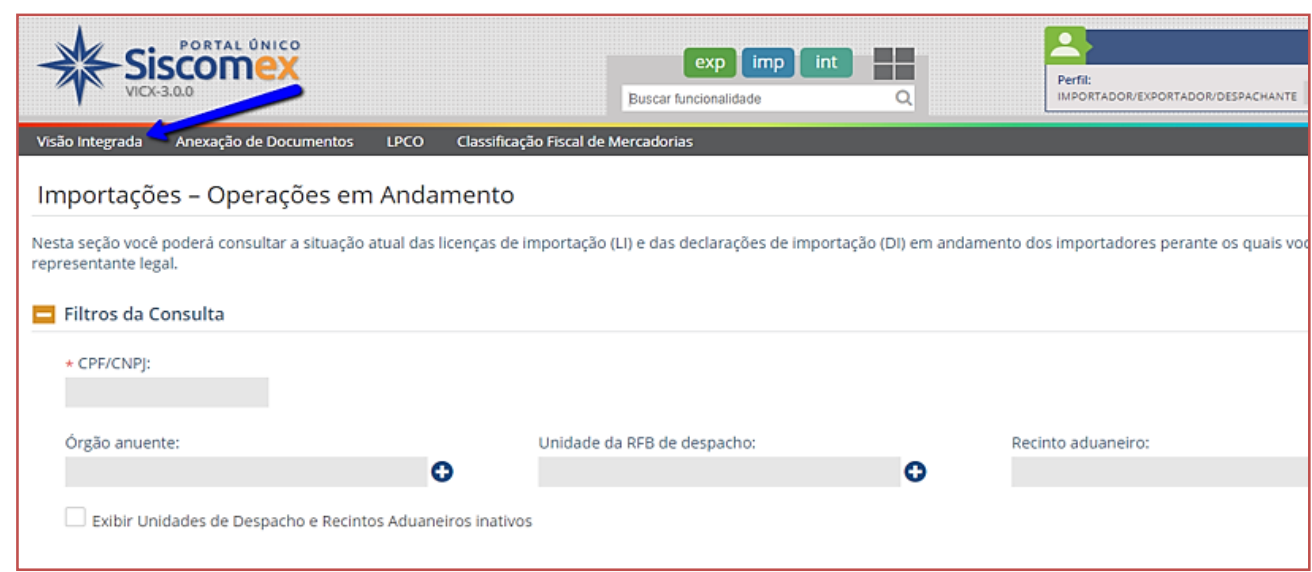

Fonte: Adaptado de Portal Siscomex, 2018

\subsection{ANEXAÇÃO ELETRÔNICA DE DOCUMENTOS - NOVEMBRO DE 2014}

Através de acesso ao Portal Único, o módulo de dossiê eletrônico, conforme Figura 7, contém engenharia que permite que as empresas compartilhem os documentos e informações uma única vez aos órgãos federais, o que certamente reduz a burocracia e os custos dos exportadores e importadores. Objetivo também é a eliminação progressiva do uso do papel nas operações de comércio exterior. 0 dossiê é um módulo do programa Portal Único de Comércio Exterior que foi implantado em todo território nacional. A coordenação e gerencia é do MDIC (Ministério do Desenvolvimento, Indústria e Comércio Exterior) e parceria com a Secretaria da Receita Federal do Brasil (RFB) e pela Secretaria de Comércio Exterior (Secex). (portal siscomex, 2015).

Conforme consta no site Portal Único (2017), especificamente as importações, o importador ou seu representante legal, poderá vincular à Declaração de Importação, os documentos digitalizados ao Portal, com exceção para as DIs que obtenham o canal verde parametrização, pois neste canal, não é necessário apresentar documentos.

Os arquivos deverão ser anexados em um dos tipos TXT, RTF, DOC, DOCx, ODT, ODP, CSV, XLS, XLSx, ODS, PDF, PPT, PPTx, XML, BMP, PNG ou JPG, com o tamanho máximo individual até 15MB. Eventualmente, por problemas de ordem técnica, segundo Portal Siscomex (2017), a entrega dos documentos poderá ser feita em papel na repartição de desembaraço aduaneiro. Para as operações de exportações, a meta é reduzir o prazo de 13 para 8 dias, e de 17 para 10 dias, para as operações de importações. Mesmo em se tratando de dossiê eletrônico, os documentos do importador e exportador, devem ser mantidos em poder pelo prazo previsto em legislação. (portal siscomex, 2015).

Figura 7 - Tela Anexação Eletrônica de Documentos

Fonte: Adaptado de Portal Siscomex, 2018

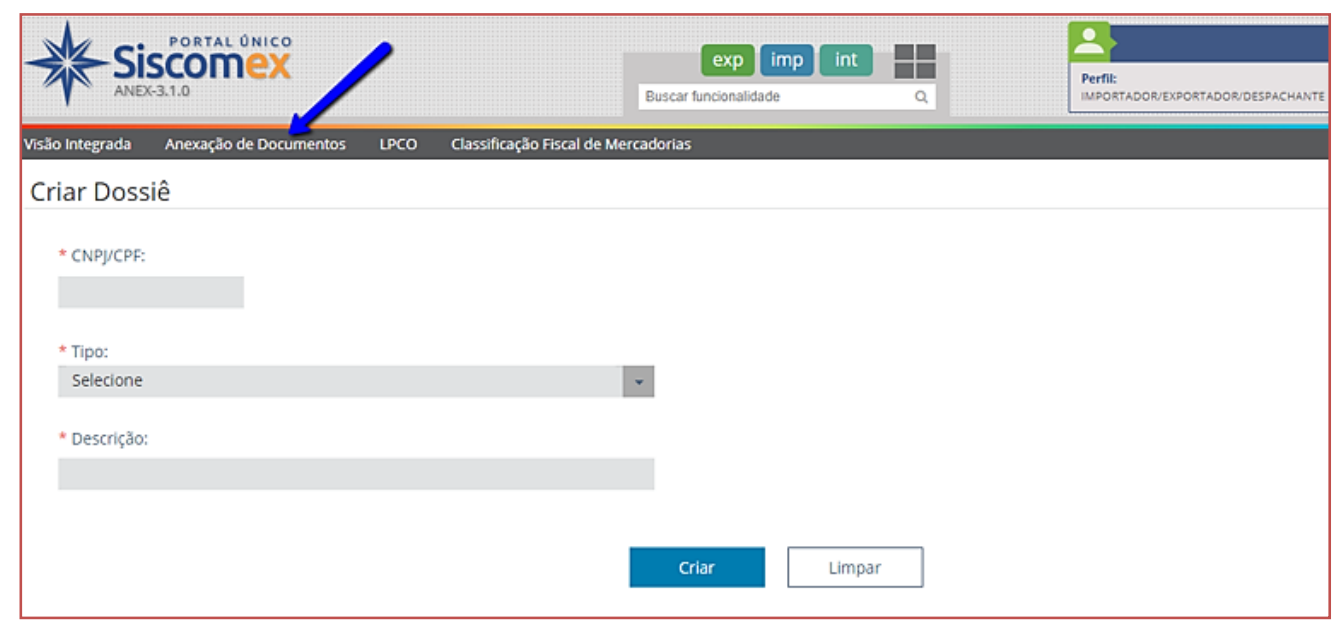




\section{DUIMP - DEZEMBRO DE 2017}

O modelo e o sistema atual de importação que foi implantado há mais de 20 anos, não tem mais atendido as necessidades de mercado. De acordo com a publicação da Receita Federal de setembro de 2017, está em andamento uma reformulação no processo de importação, será implantada a Declaração Única de Importação (DUIMP), no âmbito do Portal Único de Comércio Exterior. A implementação deverá ocorrer até o fim de 2018 e beneficiará mais de quarenta mil importadores (receita federal, 2017).

A fim de alcançar procedimentos que darão maior eficiência e celeridade ao novo processo de importação, o Governo em setembro de 2017, pelo prazo de 30 dias, efetuou consulta pública à sociedade para conseguir sugestões ao novo processo de importação (RECEITA FEDERAL, 2017).

Em conformidade com a Receita Federal (2017), a DUIMP substituirá as atuais Declaração de Importação (DI) e Declaração Simplificada de Importação (DSI). A declaração poderá ser registrada antes mesmo da chegada da mercadoria no Brasil, inclusive, paralelamente à obtenção de eventuais licenças de importação.

O importador informará todos os dados necessários à concretização de suas operações apenas uma vez, em um único ambiente. A DUIMP centralizará todas as informações aduaneiras, administrativas, comerciais, financeiras, tributárias e fiscais, necessárias ao controle das importações, que poderão ser acessadas por qualquer órgão governamental que direta ou indiretamente necessite intervir e executar suas atribuições legais (MARTARELLO e GATTAES, 2017).

Este novo processo permitirá que o gerenciamento de risco seja adiantado, bem como o fluxo da carga, uma vez que as informações serão prestadas antecipadamente. A DUIMP não permitirá redundância ou inconsistência na prestação das informações, pois ela será integrada com diversos sistemas do governo e privados (RECEITA FEDERAL, 2017).

No que tange os custos de armazenagem e tempo de permanência de mercadorias em recintos alfandegados, é possível verificar que:

A armazenagem em recinto alfandegado de mercadoria amparada por Duimp selecionada para o canal verde e que não seja objeto de inspeção física pelos órgãos anuentes não será mais obrigatória no novo processo de importação. Nesse caso, o próprio transportador ou o operador portuário poderá realizar a entrega da carga ao importador. Essa possibilidade visa desafogar os recintos alfandegados, principalmente os de Zona Primária, com uma sensível diminuição do tempo de permanência da carga nesses locais, além da redução dos custos, uma vez que o importador não mais necessitará arcar com os valores do armazenamento. (Portal Siscomex 2017, p. 34).

Aperfeiçoar os processos de importação conforme orientação do Acordo de Facilitação de Comércio Exterior, assinado pelo Brasil junto à Organização Mundial de Comércio, é o principal objetivo dessa remodelação. (SENA, 2017).

\subsection{BENEFÍCIOS}

O registro, acompanhamento, gerenciamento e o controle das importações são feitas pelo Sistema Integrado de Comércio Exterior (Siscomex), porém, nas duas últimas décadas, esse mecanismo administrativo não vem acompanhando as novas necessidades quanto as liberações de mercadorias de importação. Alguns dos principais problemas detectados são (Sena, 2017 e Receita Federal Brasil, 2017):

- Redundância ou inconsistência na prestação de informações;

- Impossibilidade de integração com outros sistemas públicos;

- $\quad$ A apresentação em papel para diferentes órgãos controladores;

- $\quad$ As normas e os procedimentos não harmonizados;

- $\quad$ O fluxo de informação desalinhado com o logístico;

- $\quad$ Os órgãos anuentes não integrados ao ambiente sistêmico;

- A prestação redundante de informações pelos formulários específicos e paralelos à Licença de Importação;

- As repetidas conferências dos campos da Licença de Importação com os dos documentos paralelos. 
De acordo com Sena (2017) e Receita Federal (Brasil, 2017), todos os itens acima relacionados, permitiram que as análises dos pedidos de licenças de importação sejam mais morosos, assim, gerando retrabalho para os setores públicos e privados. Isto posto, o governo analisou essas dificuldades e, em parceria com a iniciativa privada, vem trabalhando fortemente para uma reforma nas operações de importação. Destarte, com a implementação da DUIMP, os benefícios serão:

- Centralização num único local da solicitação e obtenção de licença de importação, sem a necessidade de o operador acessar outros sistemas ou preencher formulários em papel;

- Validação automática entre a operação autorizada (no módulo de licenciamento de importação) e os dados declarados na Duimp;

- $\quad$ Redução de tempo e burocracia nas importações com anuência;

- Flexibilização da concessão de licenças de importação em relação ao número de operações abrangidas;

- Diminuição do tempo de permanência das mercadorias em Zona Primária, com a consequente redução de custos das importações;

- Harmonização de procedimentos adotados pelos diversos órgãos da Administração Pública responsáveis pelo controle das importações;

- Recepção de informações e análise de risco antecipadas: permite que o insumo e os riscos sejam conhecidos durante o processo de importação, fazendo com que os órgãos anuentes e o importador saibam das ações a serem tomadas sobre a importação antes da sua ocorrência;

- $\quad$ Paralelismo entre os controles administrativo e aduaneiro: visa fazer com que o novo processo seja realizado de forma paralela, minimizando o tempo dos trâmites da operação. Exemplo: uma DUIMP poderá ser registrada enquanto as Licenças de Importação são analisadas pelos órgãos anuentes;

- Desvinculação da carga e mercadoria - desembaraço parcial e com pendências: quando parte da mercadoria importada não tiver pendência de liberação, o importador poderá fazer o desembaraço parcial dessa mercadoria enquanto a parte retida aguarda a fiscalização. Esse cenário gera maior destreza no processo e minimiza custos de armazenagem;

- $\quad$ Flexibilização no recolhimento dos tributos: apesar dos tributos poderem ser pagos a qualquer momento depois do registro do Documento de Importação, a comprovação desse pagamento só será exigida no desembaraço. Observação: as empresas certificadas no Operador Econômico Autorizado - OEA (Conformidade Nível 2 ou Pleno) poderão pagar os tributos mensalmente (não por processo), mas essa possibilidade depende de mudanças legais;

- Gestão de Risco intensiva e Coordenada: a gestão deverá ser feita de forma sincronizada com todos os atores envolvidos no processo (desde o governo até as aduanas internacionais) para que os riscos sejam controlados com maior previsibilidade, efetividade e agilidade nas importações;

- Uso do catálogo de produtos: o catálogo será o local onde o importador informará todas as características dos insumos/produtos que serão importados, permitindo a apresentação das informações de forma precisa e estruturada, aprimorando assim a descrição dos produtos transacionados e servindo como fonte de informação para tomada de decisão pelos órgãos intervenientes no comércio exterior.

É interessante mencionar que, com relação a este último tópico, segundo o auditor-fiscal da Divisão de Administração Aduaneira na 4aㅡ Região Fiscal e gerente de Projetos do Programa Portal Único do Comércio Exterior, Sergio Garcia da Silva Alencar, este Catálogo irá permitir a elevação da qualidade da descrição do produto, com informações organizadas em atributos (inclusive no que tange a Nomenclatura de Valor Aduaneiro e Estatística - NVE), anexação de documentos, imagens e fotos que auxiliem o tratamento administrativo, a fiscalização e a análise de riscos (CAMPOS, 2018).

0 auditor afirma ainda que, "A ideia do Catálogo é que qualquer informação que descreva o produto seja solicitada única vez", o que possibilita às empresas envolvidas a reutilização das informações em operações futuras, sem a necessidade de novo registro. Somente importadores, exportadores e despachantes aduaneiros terão acesso a este módulo do Catálogo, e caberá à empresa definir quem será o gestor do sistema, que somente poderá ser acessado por certificado digital. (CAMPOS, 2018). Para melhor entendimento das futuras mudanças, vide APÊNDICE A constante a partir da página 19. 


\subsection{EXPECTATIVAS}

No que concerne as expectativas, Sena (2017) afirma que as empresas precisarão se adequar para atuarem dentro do novo cenário de importação. Antigos conceitos burocráticos como a alta dependência dos papeis por exemplo, precisarão ser esquecidos. Em contrapartida, o novo conceito de importação promete trazer muitos ganhos para as empresas, não apenas no montante de capital, mas também em agilidade e redução de tempo.

Pode-se perceber, que muitas dessas mudanças vieram para aprimorar os métodos até então utilizados, visando solucionar os problemas identificados no decorrer dos anos, os quais encontravam-se defasados e contrários à própria atuação das empresas no cenário internacional, uma vez que restringiam o crescimento do fluxo comercial perante a demasiada burocracia nos procedimentos (MARTARELLO, 2017).

Conforme visto anteriormente, a previsão do governo brasileiro é que a DUIMP seja implementada no final de 2018, visando atender aos objetivos do AFC diminuindo o prazo de liberação de cargas importadas de 17 para 10 dias. Portanto, é necessário que as empresas se interem dessas mudanças, revisem seus procedimentos e estabeleçam quais alterações ou melhorias deverão ser realizadas (SENA e Receita Federal, Brasil 2017).

\section{CONSIDERAÇõES FINAIS}

Conforme visto até o momento, este estudo demonstrou a evolução do Siscomex Importação desde a sua criação em 1997, até os dias atuais com a implantação do Portal Único de Comércio Exterior e a DUIMP.

Foram demonstrados também as expectativas acerca dos benefícios e melhorias com a implementação da Declaração Única de Importação - DUIMP, tais como registro antecipado e pagamento antecipado dos tributos, que visam simplificar e desburocratizar o processo de importação, obedecendo às diretrizes adotadas por outros países signatários da OMC para a simplificação do comércio exterior.

Estas são iniciativas que farão com que o processo se torne mais fluido e ágil, diminuindo o custo total da importação e o prazo de entrega da mercadoria. Além disso, a integração dos diversos sistemas no Portal Único, sem dúvida colabora para que haja menor manipulação e repetição de dados de um sistema para outro. Isso faz com que o processo seja menos propenso a erros de digitação e essa integração de dados diminui as chances de corrupção.

Este artigo espera contribuir para comunidade acadêmica ampliando o conhecimento científico acerca da modernização dos procedimentos de importação, visto que há pouca bibliografia especializada disponível na literatura sobre este assunto. Sugere-se continuidade dos estudos ligados a este tema, ampliando a pesquisa abrangendo também os novos procedimentos de exportação com a DUE (Declaração Única de Exportação).

\section{REFERÊNCIAS}

[1] APRENDENDO A EXPORTAR. Portal Único de Comércio Exterior. Disponível em < http://www.aprendendoaexportar.gov.br/index.php/operacionalizando-a-exportacao/portal-unico-siscomex> Acesso em: 30 jul. 2018

[2] BRASIL. Decreto no 8.229, de 22 de abril de 2014. Altera o Decreto no 660, de 25 de setembro de 1992, que institui o Sistema Integrado de Comércio Exterior - SISCOMEX, e dispõe sobre o Portal Único de Comércio Exterior. Disponível em: < http://www.planalto.gov.br/ccivil_03/_Ato2011-2014/2014/Decreto/D8229.htm> Acesso em: 30 maio 2017

[3] CAMPOS, Andrea. Catálogo de Produtos será nova etapa do Portal Único de Comércio Exterior. Disponível em: <http://www.aduaneiras.com.br/Materias?guid=0c30ca50583bf0e9fd38df654899aba8> Acesso em: 25 jun. 2018

[4] CHAGAS, Hellen Xavier das. Os procedimentos de desembaraço aduaneiro de importação pelo porto de santos e o impacto no lead time de liberação das cargas. 92f. Dissertação (Mestrado Profissional em Gestão e Desenvolvimento da Educação Profissional). Centro Estadual de Educação Tecnológica Paula Souza, São Paulo, 2017.

[5] FIGURA 1. Tela inicial do Siscomex Exportação ano 1993 e Importação 1997. Disponível em <http://acesso.serpro.gov.br/HOD10/manual09.html>

<http://www.easycomex.net/noticias/detalhes/aplicativo-siscomex-importacao-entrara-em-seu-ultimo-mes-de-uso> pulicado em 2015. Acesso em 11 jun. 2017 
[6] FIGURA 2. Tela inicial do Siscomex Importação ano 2015. Disponível em < http://idg.receita.fazenda.gov.br/orientacao/aduaneira/manuais/despacho-de-importacao/sistemas/siscomeximportacao-web/declaracao-de-importacao/funcionalidades/elaborar-uma-soliticacao-de-di> pulicado em 2018. Acesso em 04 jul. 2018

[7] FIGURA 3. Tela Comércio Exterior complexo e burocrático. Disponível em < http://www.aeb.org.br/noticias/downloads/2041_201703-\%20\%20Expectativas\%202017\%20\%20Apresenta\%C3\%A7\%C3\%A3o\%20AEB.pdf> pulicado em [2016?]. Acesso em 04 jul. 2018

[8] FIGURA 4. Tela Comércio Exterior não burocrático. Disponível em < http://portal.siscomex.gov.br/conhecao-portal/programa-portal-unico-de-comercio-exterior-1/programa-portal-unico-de-comercio-exterior pulicado em [2016?]. Acesso em 04 jul. 2018

[9] FIGURA 5. Tela de acesso ao Portal Siscomex. Disponível em < https://portalunico.siscomex.gov.br/portal/> pulicado em [2018?]. Acesso em 04 jul. 2018

[10] FIGURA 6. Visão Integrada do Comércio Exterior - VICOMEX. Disponível em < https://portalunico.siscomex.gov.br/vicomex/private/consulta_operacoes_andamento_importacao.jsf?facesredirect=true > pulicado em [2018?]. Acesso em 04 jul. 2018

[11] FIGURA 7. Tela Anexação Eletrônica de Documentos. Disponível em < https://portalunico.siscomex.gov.br/edocex/private/dossieCriar.jsf> pulicado em [2018?]. Acesso em 04 jul. 2018

[12] GOVERNO DO BRASIL. Portal Único reduz prazos e custos do comércio exterior. Publicado em 28 de junho de 2017.Disponível em: <http://www.brasil.gov.br/economia-e-emprego/2017/03/portal-unico-reduz-prazos-e-custosdo-comercio-exterior> Acesso em 10 out. 2017

[13] GUEIROS, Haroldo. Intervenientes e Anuentes no Comércio Exterior. Disponível em <https://www.comexblog.com.br/importacao/intervenientes-e-anuentes-no-comercio-exterior/> Acesso em 11 jul. 2018

[14] HUMMELS, David L; MINOR, Peter. Time as a Barrier to Trade: A GTAP Database of Ad Valorem Trade Time Costs. Presented in 2010 at the 13th Annual Conference on Global Economic Analysis, Penang, Malaysia. Published in 2011. Disponível em: <https://www.gtap.agecon.purdue.edu/resources/download/6124.pdf> Acesso em 18 nov. 2017

[15] ITAMARATY. IX Conferência Ministerial da OMC (Bali, 2013). Disponível em: <http://www.itamaraty.gov.br/pt-BR/politica-externa/diplomacia-economica-comercial-e-financeira/697-xiconferencia-ministerial-da-omc-bali-2013> Acesso em 10 out. 2017

[16] LUZ, Rodrigo. Comércio Internacional e Legislação Aduaneira. 5. ed. Rio de Janeiro: Elsevier, 2012.

[17] MACEDO, Carolina. Novidades na Importação. S.O.S IMPORTAÇ̃̃o. Publicado em setembro de 2017. Disponível em: <http://www.sosimportacao.com.br/2017/09/novidades-na-importacao.html> Acesso em 15 jun. 2018

[18] MARTARELLO, Kelly G. e GATTAES, Nadine Viaud. Parecer Jurídico - Du-imp

[19] Desburocratização do Comércio Exterior. Martarello Advogados Associados. Itajaí/SC, 29 de outubro de 2017

[20] MDIC - Ministério da Indústria, Comércio Exterior e Serviços. MDIC publica tutoriais sobre funcionalidades do Novo Processo de Exportações do Portal Único de Comércio Exterior. Publicado em 22 de maio de 2017. Disponível em: $\quad$ <http://www.mdic.gov.br/index.php/noticias/2524-mdic-publica-tutoriais-sobre-funcionalidade-do-novoprocesso-de-exportacoes-do-portal-unico-de-comercio-exterior> Acesso em 13 nov. 2017

[21] MDIC - Ministério da Indústria, Comércio Exterior e Serviços. Palestras e Seminários. Disponível em: <http://www.mdic.gov.br/images/REPOSITORIO/secex/decex/PALESTRAS_SEMINARIOS/170424_ApresentaoPortal-nico_SeminrioDecex_25abril_Campinas_FINAL.pdf> Acesso em 18 nov. 2017

[22] MOREIRA, Assis. Brasil é apontado como o país mais protecionista do G-20. Publicado em: 11 jun. 2013. Disponível em: <https://www.valor.com.br/brasil/3156768/brasil-e-apontado-como-o-pais-mais-protecionista-do-g$20>$ Acesso em 04 jul. 2018

[23] PORTAL SISCOMEX. Conheça o sistema Visão Integrada do Comércio Exterior. Disponível em: <http://portal.siscomex.gov.br/destaque/informativos/noticias-orgaos/noticias/portal-siscomex/conheca-o-novosistema-visao-integrada-do-comercio-exterior> Acesso em 11 jul. 2018

[24] PORTAL SISCOMEX. Proposta de novo processo de importação. Consulta Pública - Novo Processo de Importação. Disponível em: <http://portal.siscomex.gov.br/destaque/consulta-publica-novo-processo-deimportacao/20170918RelatorioNPI.pdf> Acesso em 29 jun. 2018

[25] PORTAL SISCOMEX. Sobre o programa. Disponível em: <http://portal.siscomex.gov.br/conheca-oportal/programa-portal-unico-de-comercio-exterior-1/programa-portal-unico-de-comercio-exterior > Acesso em 10 out. 2017 
[26] RECEITA FEDERAL. Governo lança consulta à sociedade sobre Novo Processo de Importação. Publicado em novembro de 2017. Disponível em: <http://idg.receita.fazenda.gov.br/noticias/ascom/2017/setembro/governolanca-consulta-ao-setor-privado-sobre-novo-processo-de-importacao> Acesso em 11 jun. 2018

[27] SENA, Luís Celso de. Declaração Única de Importação (DUIMP): simplificando e facilitando as operações de importação. Disponível em: < https://www.thomsonreuters.com.br/pt/tax-accounting/comercioexterior/blog/declaracao-unica-de-importacao-duimp-simplificando-facilitando-operacoes-de-importacao1.html> Acesso em 11 jun. 2018

[28] WORLD BANK GROUP. 2016. Doing Business 2017: Equal Opportunity for All. Washington, DC: World Bank. (C) World Bank. License: CC BY 3.0 IGO. ISSN: 1729-2638. Disponível em: <https://openknowledge.worldbank.org/handle/10986/25191> Acesso em: 20 maio 2017 
APÊNDICE A - Quadro comparativo de procedimentos antes e depois da duimp

\begin{tabular}{|c|c|c|}
\hline \multicolumn{2}{|r|}{ ANTIGO PROCEDIMENTO } & NOVO PROCEDIMENTO \\
\hline DOCUMENTO & $\begin{array}{l}\text { Declaração de Importação (DI); } \\
\text { Declaração Simplificada de Importação } \\
\text { (DSI). }\end{array}$ & Declaração Única de Importação (DUIMP). \\
\hline INTERAÇÃO & $\begin{array}{l}\text { Acesso à diversos sistemas } \\
\text { informatizados. }\end{array}$ & $\begin{array}{l}\text { Não será mais necessário que o interessado preste } \\
\text { informações ou acompanhe procedimentos em diversos } \\
\text { sistemas, sendo todas as informações centralizadas em } \\
\text { um único ambiente; } \\
\text { Interação entre os sistemas, possibilidade um fluxo } \\
\text { paralelo dos procedimentos. }\end{array}$ \\
\hline DIAGNÓSTICO & $\begin{array}{l}\text { Durante a transmissão da DI é realizado } \\
\text { o diagnostico que poderá conter alertas } \\
\text { ou mensagens de erros, e que poderão } \\
\text { ser impeditivos do registro ou não. }\end{array}$ & $\begin{array}{l}\text { Ampliação das críticas, possibilitando alertas quanto a } \\
\text { pequenos erros que poderiam ser sanados antes do } \\
\text { registro da DUIMP, evitando seleção de conferência } \\
\text { aduaneira; } \\
\text { A qualquer momento durante o preenchimento da } \\
\text { DUIMP o importador poderá submetê-la a diagnóstico } \\
\text { para validar as informações prestadas. }\end{array}$ \\
\hline $\begin{array}{c}\text { REGIMES } \\
\text { ADUANEIROS }\end{array}$ & $\begin{array}{l}\text { Os regimes aduaneiros são registrados } \\
\text { em declarações próprias. }\end{array}$ & $\begin{array}{l}\text { Os regimes aduaneiros serão solicitados na própria } \\
\text { Duimp, eliminando-se, por exemplo a DTA. }\end{array}$ \\
\hline PAGAMENTOS & $\begin{array}{l}\text { Tributos federais, taxas e contribuições } \\
\text { são calculados e devem ser pagos antes } \\
\text { de se prosseguir para o processo de } \\
\text { análise de riscos e seleção do canal de } \\
\text { conferência aduaneira; } \\
\text { Pagamento descentralizado: são } \\
\text { realizados em diversos meios e } \\
\text { momentos; } \\
\text { - Tributos Federais pagos no registro da } \\
\text { DI; } \\
\text { - Taxas de análise de LI paga aos } \\
\text { órgãos anuentes; } \\
\text {-AFRMM paga via Marinha Mercante; } \\
\text { - ICMS Estadual pago via SEFAZ. }\end{array}$ & $\begin{array}{l}\text { Tributos federais, taxas e contribuições serão } \\
\text { realizados, em regra, no momento do desembaraço } \\
\text { aduaneiro, não sendo mais requisito para o início do } \\
\text { despacho aduaneiro; } \\
\text { Pagamento centralizado de tributos: permitirá o } \\
\text { pagamento de forma simples, automática e organizada } \\
\text { no Portal Único de Comércio Exterior. }\end{array}$ \\
\hline $\begin{array}{l}\text { LICENÇA DE } \\
\text { IMPORTAÇÃOO }\end{array}$ & $\begin{array}{l}\text { Licença de Importação corresponde à } \\
\text { uma única DI; } \\
\text { Alteração da LI originária é feita por } \\
\text { meio da LI substitutiva, demandando } \\
\text { novo pedido e nova atuação dos órgãos } \\
\text { anuentes; } \\
\text { Prazo de validade de } 90 \text { (noventa) dias; } \\
\text { Quando exigível, LI é condição para o } \\
\text { início do despacho aduaneiro. }\end{array}$ & $\begin{array}{l}\text { Uma única Licença de Importação poderá ser utilizada } \\
\text { para diversas operações; } \\
\text { Alteração da LI poderá ser feito no próprio formulário } \\
\text { original; } \\
\text { Prazo de validade de acordo com a regulamentação de } \\
\text { cada órgão anuente; } \\
\text { Quando exigível, LI pode ser providenciada até o } \\
\text { desembaraço aduaneiro (somente nos casos de LI após } \\
\text { o embarque). }\end{array}$ \\
\hline
\end{tabular}


APÊNDICE A - Quadro comparativo de procedimentos antes e depois da duimp (continuação...)

\begin{tabular}{|c|c|c|}
\hline \multicolumn{2}{|r|}{ ANTIGO PROCEDIMENTO } & NOVO PROCEDIMENTO \\
\hline $\begin{array}{l}\text { CATÁLOGO DE } \\
\text { PRODUTOS E } \\
\text { CADASTRO DE } \\
\text { ATRIBUTOS }\end{array}$ & $\begin{array}{l}\text { Não existe esta funcionalidade; } \\
\text { Descrição das mercadorias é livre. }\end{array}$ & $\begin{array}{l}\text { Catálogo de Produtos e Cadastro de Atributos, com o } \\
\text { registro das mercadorias importadas, podendo ser } \\
\text { reaproveitadas em futuras operações; } \\
\text { Descrição das mercadorias será padronizada. }\end{array}$ \\
\hline $\begin{array}{c}\text { GERENCIAMENTO } \\
\text { DE RISCOS }\end{array}$ & $\begin{array}{l}\text { Igualmente para todos, seleção } \\
\text { ocorre pelo cruzamento de dados. }\end{array}$ & $\begin{array}{l}\text { Proporcional ao comportamento do interveniente; } \\
\text { Alimentação de parâmetros no sistema de acordo com a } \\
\text { habitualidade das operações, mercadorias a importar, } \\
\text { valores e quantidades de importações. }\end{array}$ \\
\hline $\begin{array}{c}\text { INSPEÇÃO E } \\
\text { VERIFICAÇÃO }\end{array}$ & $\begin{array}{l}\text { Carga pode ser objeto de } \\
\text { verificações e inspeções por órgãos } \\
\text { anuentes e pela Receita Federal, em } \\
\text { momentos distintos; } \\
\text { Elaboração do documento RFV } \\
\text { (Relatório de Verificação Física); } \\
\text { A conferência aduaneira é realizada } \\
\text { na unidade local onde a carga está } \\
\text { depositada. }\end{array}$ & $\begin{array}{l}\text { Agendamento compartilhado (Janela única temporal) } \\
\text { das atividades, dispensando inúmeras movimentações } \\
\text { das cargas nos recintos alfandegados; } \\
\text { Elaboração dos documentos RIF (Relatório de Inspeção } \\
\text { Física) e RVF (Relatório de Verificação Física); } \\
\text { Quebra de jurisdição no despacho aduaneiro: A } \\
\text { conferência aduaneira poderá ser realizada em local } \\
\text { diferente daquele no qual a carga está depositada, } \\
\text { aguardando desembaraço no País. Os despachos serão } \\
\text { distribuídos pelas unidades. }\end{array}$ \\
\hline $\begin{array}{c}\text { REGISTRO } \\
\text { ANTECIPADO }\end{array}$ & $\begin{array}{l}\text { Registro antecipado da DI, nos } \\
\text { casos previstos no art. } \\
17 \text { da IN/SRF } 680 / 06 \text {. }\end{array}$ & $\begin{array}{l}\text { Registro antecipado da Duimp, antes da chegada da } \\
\text { carga ao País; } \\
\text { Despacho sobre Águas: conhecimento prévio da seleção } \\
\text { para canal de conferência aduaneira e anexação da } \\
\text { documentação. Uma vez selecionada para o canal verde, } \\
\text { a mercadoria chegará ao destino final desembaraçada; } \\
\text { Apenas para os intervenientes certificados pela OEA na } \\
\text { modalidade Nível } 2 \text { e Pleno. }\end{array}$ \\
\hline ARMAZENAGEM & $\begin{array}{l}\text { Toda mercadoria que entra no } \\
\text { Brasil é armazenada para aguardar } \\
\text { inspeção e despacho. }\end{array}$ & $\begin{array}{l}\text { Será necessário efetuar a armazenagem da carga apenas } \\
\text { para alguns casos, quando houver necessidade de } \\
\text { inspeção Física ou se importador desejar; } \\
\text { Muitas cargas poderão entrar no País já com a definição } \\
\text { do nível de conferência aduaneira. }\end{array}$ \\
\hline $\begin{array}{c}\text { TRATAMENTO } \\
\text { ADMINISTRATIVO }\end{array}$ & $\begin{array}{l}\text { Necessidade de LI; } \\
\text { Não precisa de LI. }\end{array}$ & $\begin{array}{l}\text { Importação Proibida; } \\
\text { Importação sujeita a licenciamento; } \\
\text { Importação sujeita à fiscalização, em recintos } \\
\text { alfandegados; } \\
\text { Importação sujeita a controles após o desembaraço (ex. } \\
\text { destinação de resíduos sólidos); } \\
\text { Alerta (enquadramento especifico); } \\
\text { Importação sem restrição. }\end{array}$ \\
\hline
\end{tabular}

Fonte: Adaptado de Martarello 2017 e Macedo, 2018 


\section{Capítulo 5}

\section{Implantaçāo da saúde enxuta como técnica gerencial para melhorar o desempenho de um laboratório de análises clínicas}

\section{Ricardo Pereira \\ Mehran Misaghi \\ Álvaro Paz Graziani}

Resumo: Alcançar a otimização dos processos requer uma visão abrangente. Tal abordagem deve ser tomada para garantir a sobrevivência e perenidade das organizações. 0 Pensamento Enxuto (PE) é uma metodologia que busca a identificação do valor e dos desperdícios nos ambientes empresarias. Muitas iniciativas são frustradas por não apresentarem resultados esperados, colocando assim em dúvida a sua capacidade. E no ambiente de saúde, esses desafios se tornam ainda maior. Surgem então a Saúde Enxuta (SE), que fundamentada pelos conceitos do pensamento enxuto, busca a otimização dentro dos ambientes de saúde. A pesquisa é um estudo de caso onde busca a implementação da saíude enxuta em um laboratório, assim evidenciando seus resultados e evolução. Se percebe que a busca pela melhoria contínua e a aplicação do Lean no laboratório em questão troxe bons resultados para a empresa estudada.

Palavras chave: Lean manufacturing; Lean healthcare; Pensamento enxuto. 


\section{INTRODUÇÃO}

Estudos descrevem que governos e fornecedores de serviço de saúde enfrentam grandes desafios como: redução de resíduos de papelada, redução de inventário; atrasos na sala de espera; ferramentas cirúrgicas desnecessárias na tentativa de fornecer qualidade serviços de saúde; pessoas paradas; altos custos com estruturas e fila de esperas. Isso está colocando pressão sobre governos e prestadores de serviços de saúde, enquanto os prestadores de serviços de saúde estão sendo forçados fornecer aos pacientes, médicos, enfermeiros e administradores uma alta qualidade e nível de serviço com recursos muito limitados, bem como gerenciar custos surpreendentes dos serviços de saúde. (MUHAMMAD; TEOH; WICKRAMASINGHE, 2014).

Os laboratórios de análises clínicas (LAC) são geridos em sua grande maioria por profissionais técnicos, o que ao longo do tempo fez com que o foco dessas empresas fosse voltado a procedimentos técnicos e não à gestão do negócio de forma sistêmica, de tal forma que a gestão empresarial tem sido prejudicada devido a tal fato (D'ANDREAMATTEO et al. 2014).

Esse tipo de negócio, funciona como outro qualquer, existindo entradas, processamentos e saídas, de serviços e produtos, os quais devem ser geridos com o menor custo, qualidade e no prazo estabelecido. Nota-se, porém, que nas áreas de saúde, em alguns LAC, encontram-se fatores que influenciam negativamente o desempenho empresarial.

De acordo com a gestão do LAC, pode-se enumerar, alguns desses fatores, tais como : 1) a falta de indicadores de controle e a gestão destes para a tomada de decisão; 2) a falta de treinamento e orientação da gestão em ferramentas para resolução de problemas; 3) a falta de conexão da estrutura organizacional nos níveis estratégico, tático e operacional; 4) a geração de custos desnecessários com estoque, mão de obra e equipamento devido as incertezas da gestão; 5) a falta de foco em considerar a empresa como um todo e não apenas em departamentos.

Como resultados espera-se mensurar o impacto da implantação da saúde enxuta em um laboratório de analises clinicas. Os resultados que serão abordados pretendem demonstrar a importância e os benefícios da implantação da saúde enxuta, de modo a otimizar as atividades, por meio da redução de desperdícios de qualquer natureza.

\section{FUNDAMENTAÇÃO TEÓRICA}

Nesse capitulo serão apresentados a revisão bibliográfica do conteúdo.

\subsection{PENSAMENTO ENXUTO}

São vários as traduções e sinônimos para filosofia da Manufatura Enxuta, como Lean Manufacturing, Lean, Pensamento Enxuto (PE), até porque não é aplicada apenas na manufatura, ou ainda Sistema Enxuto. 0 PE tem como objetivo o reduzir os desperdícios, na fabricação de defeitos, inventário, superprodução, movimentação, transporte, processo desnecessário, espera para se tornar altamente capaz de responder as necessidades dos clientes com qualidade da forma mais eficiente e econômica possível. A redução de custos e a melhoria da produtividade, hoje é uma das principais preocupações no ambiente industrial e de serviços. Existem vária abordagens utilizadas por especialista para escolha das ferramentas certas, mais eficaz para atendimento destas preocupações (ARUNAGIRI E GNANAVELBABU, 2014).

Várias são as ferramentas enxutas usadas nas empresas para eliminar desperdícios e máxima o valor. 0 uso dessas ferramentas está mudando ao longo tempo, estão sendo adequadas para as mais diferentes situações (MARONDIN et al., 2015).

São apresentados por Womack e Jones (2004) os cinco princípios básicos da mentalidade lean:

- Valor: definir o que é Valor. Não é a empresa e sim o cliente que define o que é valor;

- Fluxo de Valor: consiste em identificar os processos que geram valor, aqueles que não geram valor, mas são importantes para a manutenção dos processos e da qualidade e, por fim, aqueles que não agregam valor e que devem ser eliminados;

- $\quad$ Fluxo: deve-se dar "fluidez" para os processos e atividades que restaram;

- Produção Puxada: Conectam-se os processos através de sistemas puxados; 
- $\quad$ Perfeição: A busca do aperfeiçoamento contínuo em direção a um estado ideal deve nortear todos os esforços da empresa.(WOMACK e JONES, 2004).

Estudo realizado por Tyagi et al., (2015) apresentaram que as práticas de PE podem ser aplicadas isoladamente, no entanto, quando utilizadas de forma organizada e quando apoiada por um trabalho integrado da organização, aumentam potencialmente o desempenho da planta através da implementação de práticas do pensameto enxuta. A principal razão para esses benefícios é a sinergia, o trabalho integrado de todos da organização para reduzir a variabilidade.

O conceito de PE possui aplicação em toda a organização, pois criam produtos ou serviços por meio de processos que ultrapassam as fronteiras funcionais com a intenção de criar valor para os clientes que podem ser externos ou internos. 0 sistema de produção enxuta concentra-se na eficiência de criação de valor, no qual se aplica a qualquer processo na organização (MARONDIN et al., 2015).

Liker (2005) e Ohno (1997) descrevem que o STP é um sistema baseado em uma estrutura e não somente em um conjunto de técnicas e ferramentas. Essa estrutura foi representada na forma de uma casa. A base da produção enxuta é a absoluta eliminação do desperdício, sendo os seus dois pilares de sustentação o just-in-time (JIT) e a automação, identificada na Figura 1.

Iniciando pelo telhado, existem as metas de maior qualidade, custo menor e o prazo de entrega reduzido (lead time). As colunas representam o JIT, possivelmente a característica mais marcante do sistema. A filosofia JIT, de maneira simplificada, refere-se ao processo de fluxo, no qual as partes necessárias devem alcançar a linha de montagem no momento em que são necessárias e na quantidade certa (YAMACHIKA, 2010).

Figura 1: Estrutura do Sistema Toyota de Produção

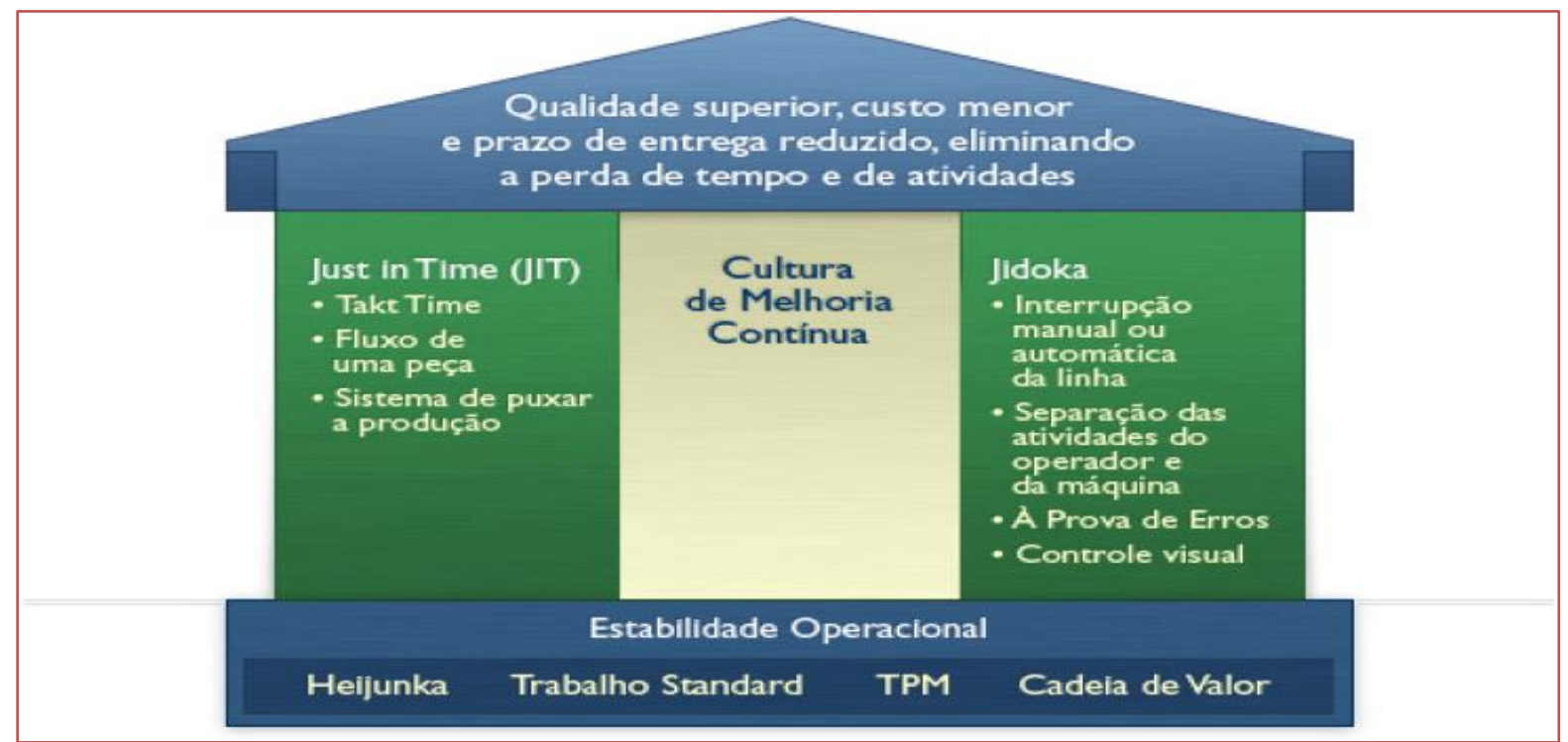

Fonte: Liker (2005)

E o Jidoka, também conhecida por autonomação (automação com um toque humano), que significa nunca deixar um defeito passar para a próxima estação, garantindo a qualidade na fonte, dando a capacidade às máquinas identificarem anomalias no processo e dessa forma interrompê-lo, evitando a produção de peças defeituosas. Com isso o Jidoka possibilita liberar as pessoas das máquinas (YAMACHIKA, 2010).

No centro do sistema existem as pessoas, quem executam as atividades, sendo fundamental a estabilidade do clima dos colaboradores e que a filosofia da PE seja amplamente disseminada, compreendida e aceita por todos para que o resultado seja positivo. A cultura da melhoria contínua (kaizen) relacionada às pessoas é a alma do negócio para a evolução da empresa, melhorando gradualmente e constantemente, envolvendo tudo e todos (LIKER, 2005).

Para Iserhard et al. (2013) o segredo para a implantação do PE é a transparência, pois depende das pessoas. 0 trabalho em equipe e pessoas comprometidas, que compreendam esta nova cultura, é fundamental para a utilização desta filosofia na empresa. 
Por último, na base, funcionando como alicerce, existem diversos processos os quais são fundamentais para manter a estabilidade e sustentabilidade do sistema. O Heijunka significa o nivelamento da produção, tanto em volume como em variedade, a qual é importante tanto para manter a estabilidade do sistema quanto manter o mínimo de estoques (YAMACHIKA, 2010). Outras ferramentas importantes que formam a base do sistema como o trabalho padronizado, manutenção produtiva total, $5 \mathrm{~S}$, entre outras, serão abordadas no decorrer do trabalho (NISHIDA, 2007).

0 principal objetivo do STP é a redução do tempo entre o pedido do cliente e o momento da entrega do produto ou serviço para ele. Está redução é obtida com o controle e eliminação dos desperdícios da produção, buscando melhores produtos com os menores custos (BROWNIG; HEATH, 2009).

A Toyota focou-se na redução dos desperdícios de produção, na redução do tempo de atravessamento (lead time) e na flexibilidade do processo produtivo para manter-se viva no mercado, e acabou por desenvolver uma nova filosofia de produção.

Observando de maneira mais ampla, o STP é muito mais que somente reduzir o lead time e eliminar os desperdícios, é uma filosofia de produção, uma maneira enxuta de pensar e agir que deve ser aplicada a toda a empresa. $\mathrm{O}$ foco inicial continua nos processos produtivos, mas os princípios da filosofia são amplos e aplicam-se tanto na engenharia e administração, quantos aos serviços (FARIA et al., 2012). Até três autores colocar todos, revisar.

Não é apenas uma técnica, é uma filosofia que representa a otimização dos recursos, melhoria da qualidade, aumento da produtividade e consequentemente menores custos de produção (WOMACK; JONES; ROOS, 2004).

\subsection{LEAN HEALTHCARE - SAÚDE ENXUTA (SE)}

Saúde enxuta é uma filosofia fundamentada nos conceitos do PE, porém aplicado nas áreas de saúde, que busca a melhoria nos serviços de saúde. 0 pensamento enxuto nas áreas da saúde também devem integrar as áreas operacionais (processos) e sócio técnica (comportamento da equipe e tecnológica) (EIRO; TORRES; JUNIOR, 2015).

Procedente da Toyota Motor Corporation, o PE é uma alternativa radical ao método tradicional de produção em massa e princípios de processamento para uma eficiência, qualidade, velocidade e custo ótimos. Em meados dos anos 2000 sua implementação transpassou os setores metalomecânicos chegando suas aplicações nas áreas de saúde (ROBINSON et al., 2012; PAUSHTER; THOMAS, 2016).

Com a disseminação dos princípios do pensamento enxuto, mais recentemente, passou-se a utilizar as ferramentas do PE em áreas diferentes das industriais, como a administrativa e serviços. Assim, também surgiram diferentes modelos de PE, dentre eles o Lean Healthcare (LH) ou Saúde Enxuta (SE). Nas áreas de Saúde, as atividades em sua maioria está relacionada à logística e informação, o que torna a identificação de desperdícios mais complexa (GUIMARÃES, 2014).

A saúde em todo o mundo está em um enigma. A escalação dos custos, o envelhecimento das populações, o aumento das doenças crônicas são alguns dos principais desafios com os quais todos os sistemas de saúde estão enfrentando. A reforma da saúde é necessária e novas estratégias, protocolos e procedimentos são necessários se a prestação de cuidados de saúde for, de fato, proporcionar acesso, qualidade e valor apropriados aos pacientes e à comunidade em geral (WICKRAMASINGHE, 2014).

Os estudos do SE foram desenvolvidos a partir de 2000, atraindo assim muitos pesquisadores de saúde após essa época. Esses estudos reconheceram a contribuição de PE na maximização do valor quanto na eliminação do desperdício, recomendando-o como uma possível resposta à necessidade de mudança no setor (D'ANDREAMATTEO et al. 2015).

É preciso reconhecer que a assistência médica está enfrentando muitas pressões, como muitas das indústrias de manufatura na década de 1990, e a saúde enxuta vem como resposta as necessidades para os cuidados de saúde. (WICKRAMASINGHE, 2014).

As áreas de saúde de um modo geral estão passando por recessão com as novas demandas do mercado. Os custos estão aumentando. Erros frequentes que poderiam ser evitados, o que acaba prejudicando e até mesmo pacientes a óbito. Com essa problemática crescendo surge a abordagem saúde enxuta para auxiliar o tratamento de tal problema, unindo um conjunto de conceitos, técnicas e ferramentas que melhoram a maneira como as instituições de saúde são organizadas e gerenciadas (PERALTA, 2014). 
As áreas de saúde necessitam de mudanças para obter melhorias significativas nos resultados e limitar os custos. Os métodos PE, inicialmente desenvolvidos na indústria de manufatura, mostraram proporcionar melhorias reais na qualidade, produtividade e segurança, ao mesmo tempo em que utilizam menos recursos nas configurações dos serviços de saúde (MARTIN et al., 2014).

As ferramentas de uso nos processos industriais estão sendo aplicadas para melhorar o atendimento ao paciente. Atualmente existem três abordagens industriais estabelecidas, o pensamento enxuto, a teoria das restrições e six sigma, que cultivam conceitos subjacentes e se relacionam com a saúde. Os três métodos têm características em comuns, uma vez que cada um enfatiza o conceito de produção como uma interação complexa de atividades individuais, e cada um reconhece que para que a produção seja eficiente e efetiva, é fundamental a eliminação de desperdícios, e busquem agregar valor sempre (D' ANDREAMATTEO et al., 2015).

Como a principal missão dos cuidados de saúde é tratar e curar pacientes que são consumidores finais no processo de saúde, argumenta-se que o paciente deve ter uma contribuição para definir o que cria valor quando se fala em saúde enxuta, assim como no pensamento enxuto, onde existe um foco no que realmente é valor para o cliente (WICKRAMASINGHE et al. 2014).

0 pensamento enxuto tem como foco na identificação e eliminação de fontes específicas de desperdícios no fluxo de valor. Esta estratégia tem sido aplicada às organizações de saúde, embora as diferenças inerentes entre os sistemas de saúde e de fabricação devem ser cuidadosamente consideradas (WICKRAMASINGHE et al. 2014).

O foco da saúde enxuta remete seus esforços no atendimento diferenciado aos pacientes, assim define Wellman et al. (2011), conforme Figura 2.

Onde em uma das colunas prega o atendimento de forma perfeita, tendo a padronização como elemento chave no processo, não deixando os problemas de qualidade interferirem no processo, e se ocorrerem devem ser evidenciados e tratados. Como base têm o 5'S e a gestão visual onde o fluxo de valor deve ser evidenciado e a busca por melhorias através da redução dos desperdícios deve ser constante.

Figura 2: Casa da saúde enxuta

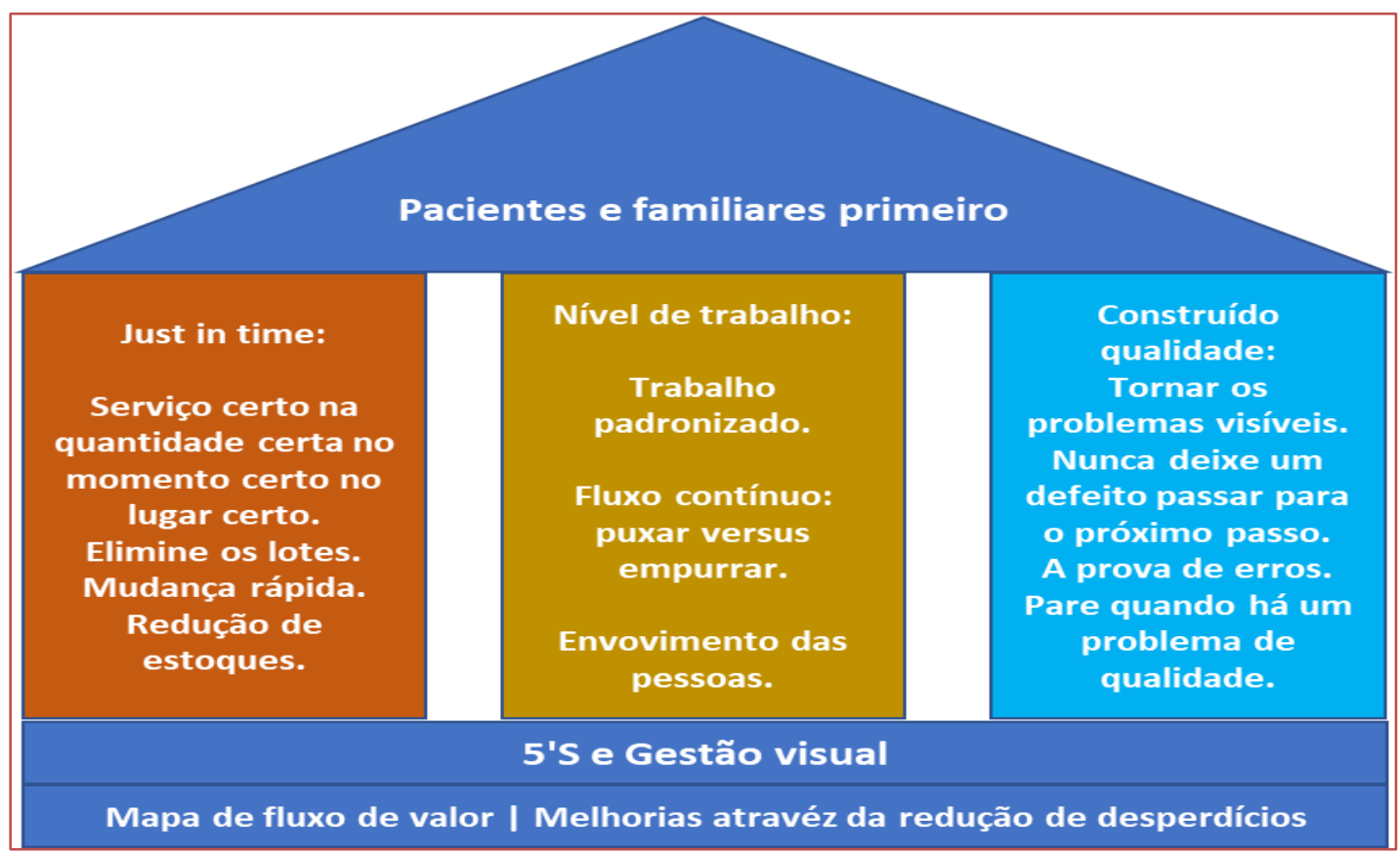

Fonte: Wellman et al. (2011), modificado pelo autor (2019)

As práticas de gestão utilizando ferramentas do PE para ás áreas de saúde podem representar um mecanismo para melhorar o desempenho dos serviços de saúde, daí então a referência do SE (MCCONNEL et al. 2014). 


\section{METODOLOGIA}

Esta pesquisa-ação configura-se como abordagem quantitativa e um estudo de caso, pois busca soluções a SE que serão implementadas em um laboratório de análises clínicas. Também pode ser caracterizada como uma pesquisa exploratória, pelo fato de permitir ao pesquisador acrescentar sua experiência em torno do problema, realizar levantamento bibliográfico e entrevistas.

A pesquisa tem o objetivo de descrever os eventos e fatos do laboratório, dos dados resultantes do processo de implantação dos conceitos da saúde enxuta. Finalizando, trata-se de uma pesquisa quantitativa, por analisar o impacto da implementação dos conceitos da saúde enxuta no desempenho empresarial dos laboratórios de análises clínicas.

Segue Quadro 1, com o fluxograma do passo a passo a implementação, correlacionando as principais etapas do processo com o descritivo das ações macro:

Quadro 1: Fluxograma de implementação

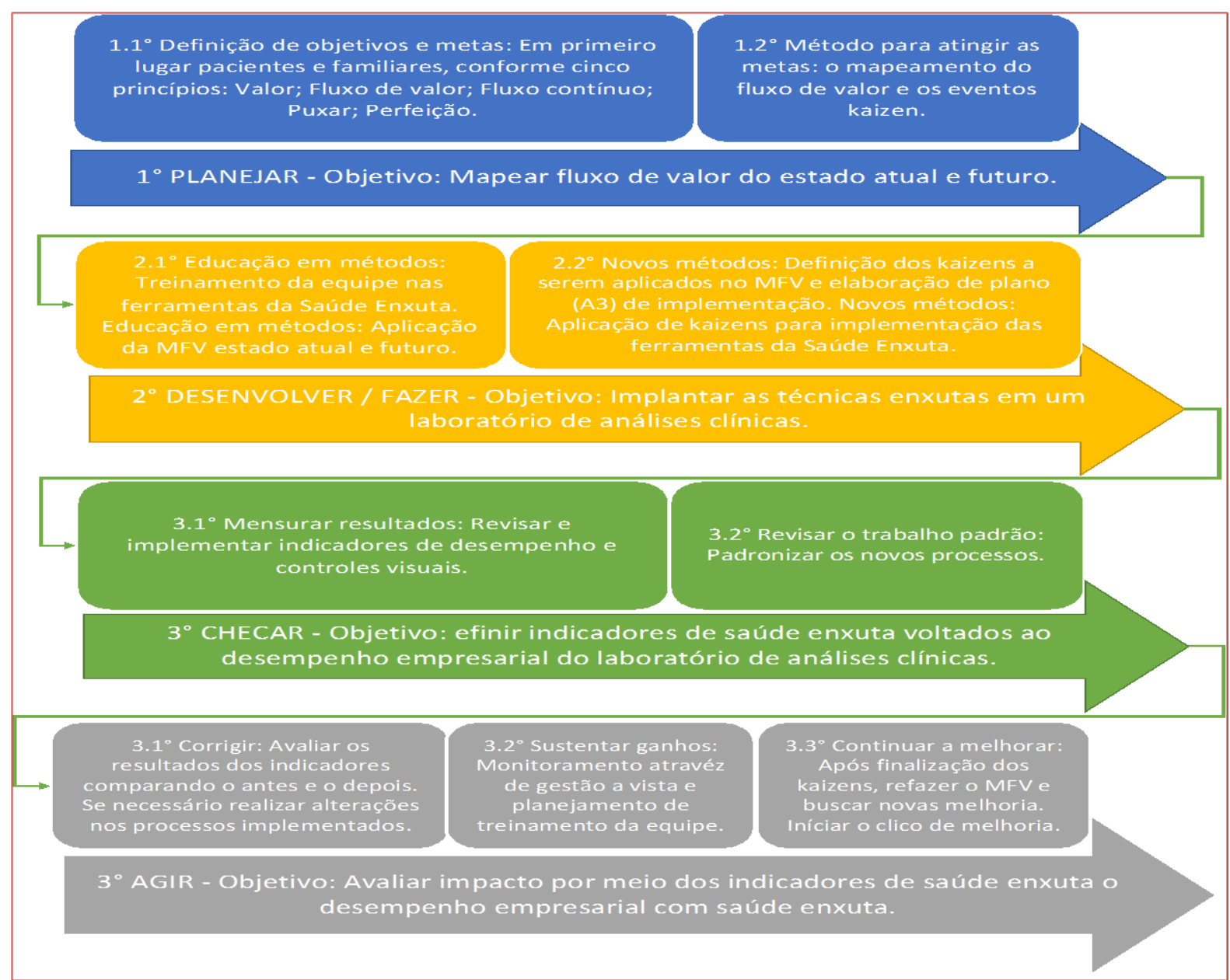

Fonte: Elaborado pelo autor (2019)

\section{RESULTADOS}

Nesse capitulo serão apresentados os resultados da aplicação do trabalho. Este está dividido em quatro etapas conforme descrito na metodologia: Planejar, desenvolver/fazer, Checar e agir.

\subsection{PLANEJAR}

Para início das atividades foi realizado um planejamento para definição das estratégias a serem adotadas ao longo do caminho que iria ser percorrido, neste momento foi definido objetivos alinhados aos propósitos da saúde enxuta e elencado algumas metas subjetivas para o acompanhamento do projeto. 
Essa reunião foi desenvolvida em conjunto com direção, gerência e supervisão do laboratório. Onde foram definidos os métodos para levantamento das informações do fluxo e oportunidades de melhorias, assim como os treinamentos iniciais e as datas para sua execução.

Ficou definido que seriam utilizados o mapeamento de fluxo de valor (MFV) para mapeamento dos processos e eventos kaizen para implantação das melhorias levantadas nos MFVs. Assim foi elaborado cronograma com passo a passo da implantação:

1ํo Treinamento de sensibilização sobre saúde enxuta - Realizar para todos os colaboradores;

2o Treinamento sobre kaizen, MFV, 8 desperdícios - Realizar para colaboradores que iriam participar do MFV e kaizen;

3ำ Aplicação do MFV;

4oㅡㄹ Apresentação para direção e definição das áreas a serem realizadas kaizens;

5ํA Aplicação dos kaizens.

Essa sequencia foi definida em cronograma com datas específicas dentro do período definido para aplicar o projeto.

\subsection{DESENVOLVER/FAZER}

Finalizado a definição dos objetivos e finalizado o planejamento das atividades foi dado início ao processo de execução, onde se iniciou com a aplicação dos treinamentos correlacionados acima no planejamento. Além do treinamento de sensibilização, foi realizado treinamento específico para as a equipe que iria aplicar o kaizen. Na Figura 3, foto de um dos dias de treinamentos realizado.

Figura 3: Treinamento para equipe do laboratório

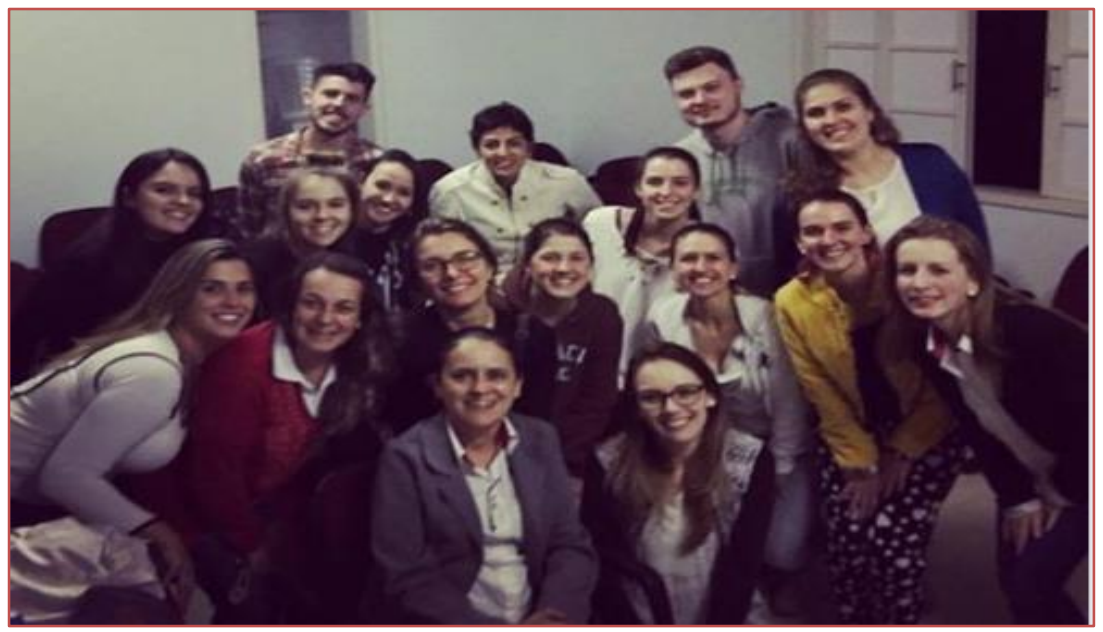

Fonte: Laboratório Verner Willrich (2019)

Foram realizados aproximadamente 80 horas de treinamentos, sem contar a aplicação prática.

Difundido o conceito da saúde enxuta, o primeiro passo foi o diagnóstico inicial, onde é o primeiro contato para o entendimento do processo de ambas as partes. Da parte receptora, os funcionários para que possam entender sobre o processo de mudança, e a parte implantadora da mudança, para ter um retrato do cenário atual da empresa.

Para registrar e compreender o processo, a primeira ferramenta utilizada na empresa foi o mapeamento de fluxo de valor (MFV) representada na Figura 4, este é utilizado para mapear os processos e deixar de forma clara a sequência das operações realizadas desde a entrada até a saída. 
Figura 4: Mapeamento de Fluxo de Valor estado atual

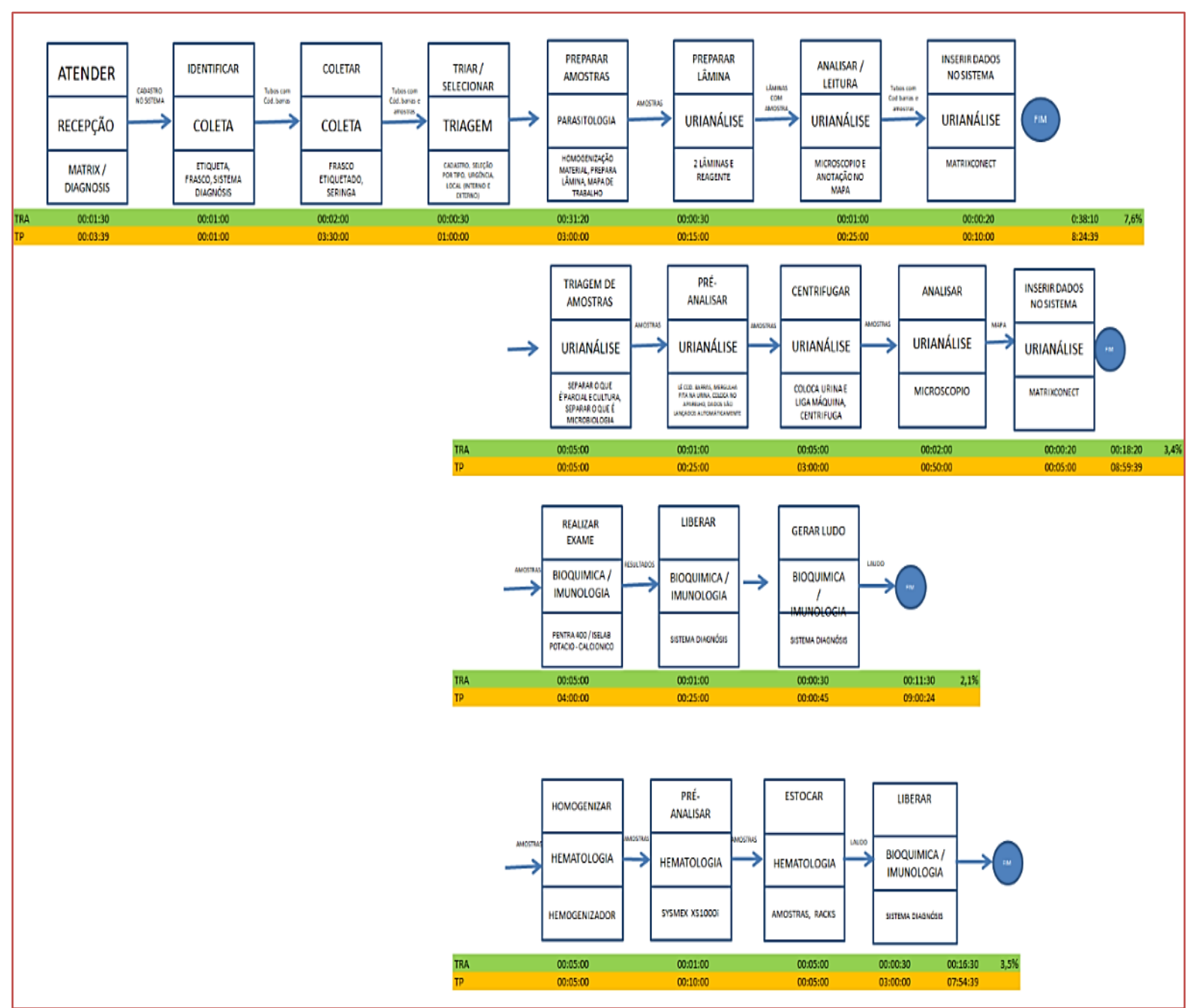

Fonte: Elaborado pelo autor (2019)

Desenhados ambos MFVs se consegue observar o lead-time total de cada processo, no MVF representado pelo tempo de processamento (TP) e o takt-time, nesse caso representado pelo tempo de realização da atividade (TRA). Aqui observamos que na média nosso takt-time representar $5 \%$ do tempo total do leadtime, ou seja, temos muitas oportunidades dentro desse processo.

O MFV também tem o intuído de identificar desperdícios e melhorias dentro do fluxo de passagem do processo, estas melhorias podem ser pontuais ou que afetam o processo como um todo, estas melhorias devem levar para o MFV do estado futuro, mostrado na Figura 5, este foi desenhado após a identificação das oportunidades do estado atual, resolvendo assim essas no estado futuro, se consegue visualizar os resultados em formato mais amplo.

Algumas das diferenças do mapeamento de fluxo de valor do estado atual para o estado futuro, são os tempos de passagens durante o processo, em dois dos quatro fluxos a proposta foi de reduzir o tempo de entrega em $50 \%$ e nos outros dois fluxos a redução proposta foi de $60 \%$ no tempo de atravessamento. 
Figura 5: Mapeamento Fluxo de Valor Estado Futuro

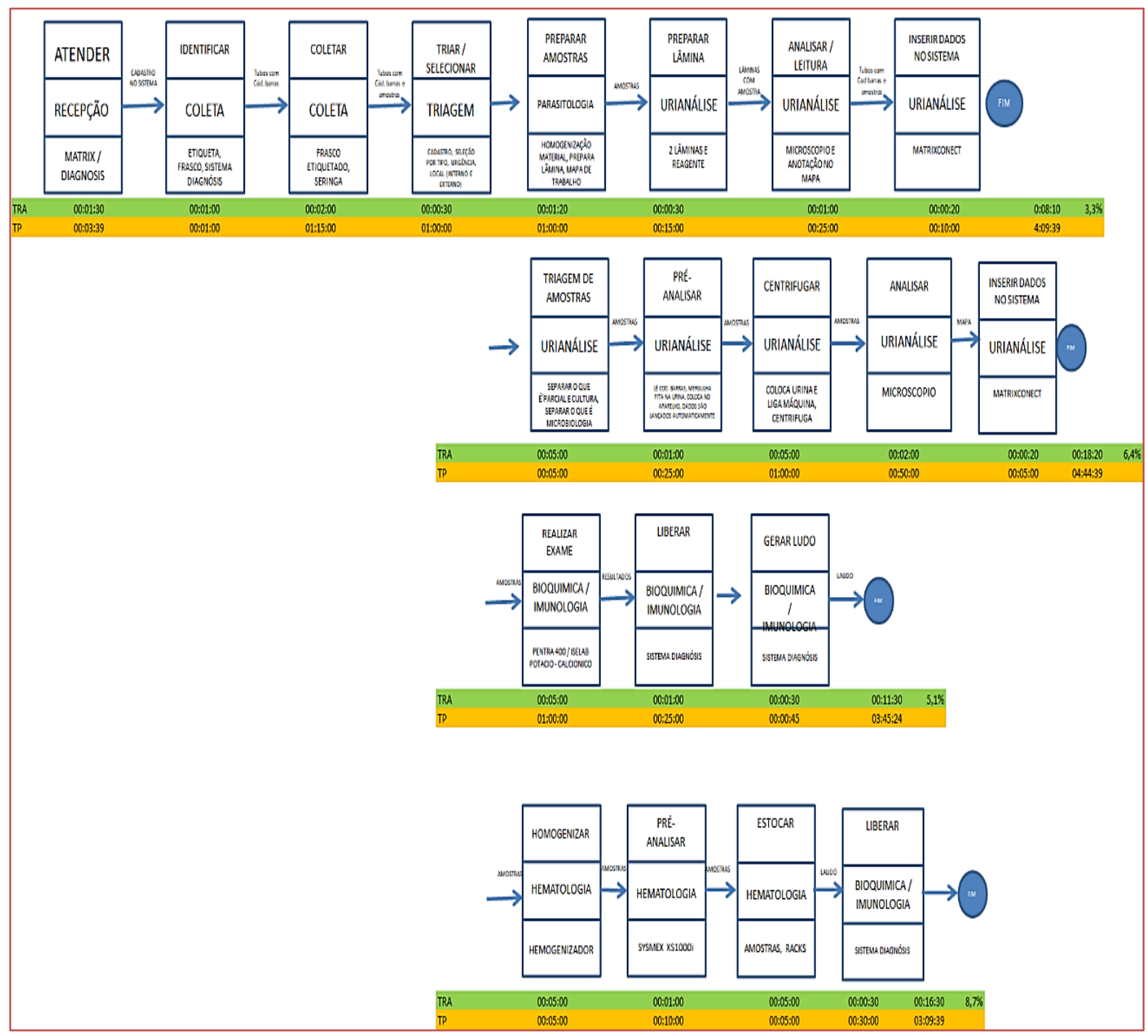

Fonte: Elaborado pelo autor (2019)

Melhorias identificadas durante o processo foram relatadas e registradas no mapeamento para que posteriormente viesse a auxiliar no atingimento das metas e aplicação dos kaizens, algumas destas oportunidades de melhorias são: Demora no atendimento dos clientes na recepção; Falta ou sobra de material nos locais de armazenamento (recepção, área técnica e estoque; Estoque excessivo no almoxarifado; Falta de controles durante o processo de fabricação; Falta de indicadores; Falta de procedimento padrão para execução dos processos; Falta de treinamento dos colaboradores; Falta da descrição dos cargos e atividades; Colaboradores não tem conhecimento das metas; Setores desorganizados e sem padrão definidos; Equipamentos não possuem monitoramento de manutenção e qualidade na fonte; Não existem controle de qualidade para as variantes do processo; Controles da qualidade não sendo realizado por todos os colaboradores; Não realizado plano de ação para ocorrências e Inexistência de método para a resolução e causa raiz dos problemas.

Feito o MFV, o segundo passo é elaborar o planejamento das atividades e efetivar os objetivos e metas, então foi construído um A3 mãe juntamente com a direção e líderes para registrar as informações do estado atual e futuro, bem como ações macros e indicadores gerenciais para análise dos resultados, este A3 está representado na Figura 6.

Com o A3 Mãe elaborado, o objetivo é desdobrar este A3 e disseminar as ações para que a implantação se torne mais rápida e o controle das ações se torne mais eficiente, foram elaborados quatro A3 que são:

- $\quad$ A3 Postos de Coletas - para melhorias nas recepções e coletas, a porta de entrada do laboratório; 
- A3 Qualidade - para padronização das atividades, controles do processo e treinamento dos colaboradores;

- A3 Área Técnica - para implantação de melhorias, controles e redução do tempo de processamento dos exames;

- A3 RH - Para desenvolvimento de planos de cargos e salários, avaliação de competências e qualificação dos colaboradores;

Figura 6: A3 Mãe - Negócio

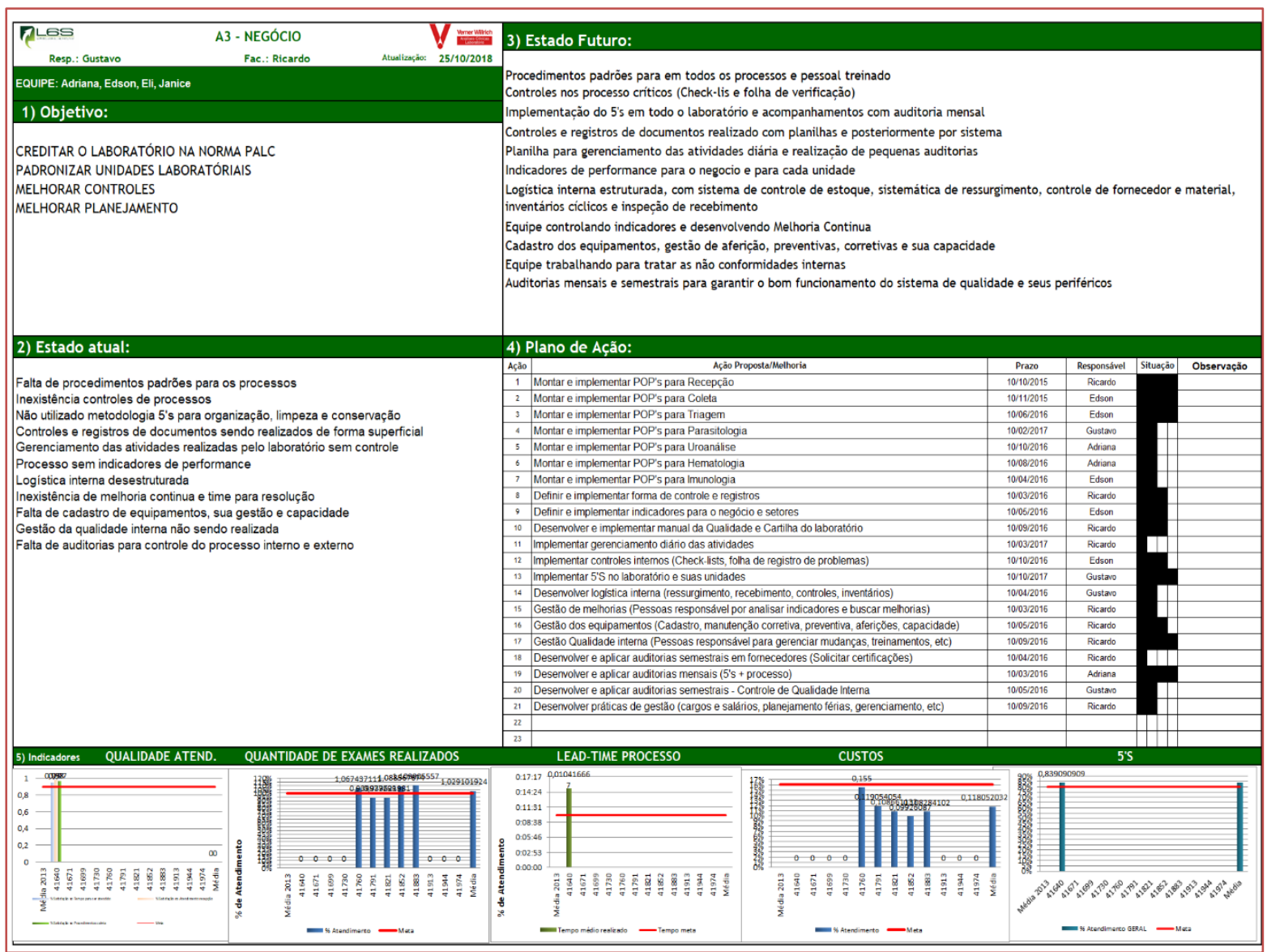

Fonte: Elaborado pelo autor (2019)

Para execução e implantação das ações de melhoria foi adotado o método Kaizen, este método tem por finalidade envolver os colaboradores da área a ser melhorada, bem como outros colaboradores de áreas distintas. A seguir temos a descrição do primeiro evento kaizen realizado no laboratório.

O primeiro evento kaizen foi realizado em um posto de coleta, pois é o inicio do processo, onde se tem o maior contato com o cliente, e se o processo começa errado a tendência é de finalizar errado.

Este evento foi realizado em uma semana, sendo que no primeiro dia foi realizado treinamentos e deixado claro os objetivos e metas da empresa e da semana kaizen, também foi realizado visita ao local para análise do estado atual com fotos, vídeos e levantamento dos dados do estado atual.

Segundo dia de kaizen foi realizado um brainstorming para geração das ideias de melhorias, após as ideias geradas foi realizado a classificação e priorização. Após a definição das ações foi construído um A3 com a descrição dos objetivos, estado atual, estado futuro, indicadores para controle e o plano de ação com prazos e responsáveis.

No terceiro e quarto dia foram executadas as ações descritas no plano, algumas destas foram:

- $\quad$ Implantação de 5s no setor; 
- $\quad$ Elaboração e Implantação de check list de controle de temperatura para recepção e coleta, pois é necessário em virtude dos matérias terem a exigência de temperatura mínima e máxima;

- $\quad$ Elaboração de Procedimento Operacional Padrão (POP) para as atividades do setor;

- Elaboração e implantação de check list para verificação da validade dos materiais utilizados;

- $\quad$ Reforma de alguns pontos da sala, pintura, instalação elétrica;

- $\quad$ Elaboração e implantação da pesquisa de satisfação dos clientes;

- C C Check-list de verificação e primeira manutenção de equipamentos;

- Implantado controles automáticos nos equipamentos onde qualquer ocasião de erro o equipamento para e gra um alerta;

- Implantação de kanban e rota de abastecimento;

- Treinamento para os colaboradores;

- $\quad$ Elaboração de indicadores de controle (tempo de espera dos clientes, satisfação dos clientes, quantidade de exames realizados);

- 0 quinto dia foi destinado aos testes, o laboratório foi aberto ao público e realizado o acompanhamento da efetividade das melhorias, após foi realizado uma reunião para apresentação dos resultados e feedback para a direção.

Ao total foram realizados quatorze eventos kaizens, um para cada unidade de coleta que totalizam oito unidades, dois para a área técnica de Brusque e dois para a área técnica de Blumenau, um para estoque de materiais e um para a parte administrativa financeira, assim se encerrou o primeiro ciclo kaizen.

Para cada eventos kaizen foi definido metas como padronização, implantação do 5'S, redução dos estoques, redução de tempo e melhoria na qualidade, onde foram implementadas várias ferramentas, abaixo serão listadas as ferramentas e melhorias implantadas ao longo do processo de acordo com os kaizens aplicados.

\subsection{CHECAR}

Após realizado o MFV e dado início a implementação dos kaizens, de porte nas informações levantadas foi definido em conjunto com direção, gerência, supervisão e alguns colaboradores quais seriam os indicadores que melhor mediriam os objetivos principais do projeto e formariam uma cultura de melhoria contínua em busca da saúde enxuta.

Para o negócio foram definidos os indicadores que envolvem eficiência e eficácia conforme atributos ligados aos valores da saúde enxuta, que busquem de forma geral a rentabilidade do negócio, bom atendimento ao cliente, a organização, eficiência e gestão dos colaboradores.

- Faturamento;

Forma de medição: Total de $\mathrm{R}$ f faturados / meta de faturamento de acordo com equipamentos e pessoas disponíveis. Indicativo: Quanto maior melhor.

- $\quad$ Custo por exame;

Forma de medição: Total de R\$ gastos custos variáveis / total de exames realizados. Indicativo: Quanto menor melhor.

- Rotatividade;

Forma de medição: Média entre colaboradores admitidos e demitidos / média do total de colaboradores no mês. Indicativo: Quanto menor melhor.

- Qualidade no atendimento geral (pesquisa de satisfação do cliente);

Forma de medição: Nota realizada / total de pontos possíveis a ser realizado. Indicador: Quanto maior melhor.

- Quantidade de exames; 
Forma de medição: Total de exames realizados / meta de exames de acordo com equipamentos e pessoas disponíveis. Indicativo: Quanto maior melhor.

- Indicador de 5s geral;

Forma de medição: Média dos requisitos alcançados em todos os setores / total de requisitos a alcançar. Indicativo: Quanto maior melhor.

Para a área técnica foram definidos os indicadores, que busquem segurança, pontualidade, centrado no paciente e igualdade, que monitorem a lead-time, atendimento, a qualidade, organização e segurança.

- Tempo de entrega dos exames (exames entregues dentro do prazo);

Forma de medição: Total de exames entregues dentro do prazo / total de exames realizados. Indicativo: Quanto maior melhor.

- Lead time de entrega dos exames para hospitais;

Forma de medição: Tempo médio dos exames realizados / méta de tempo estabelecida. Indicativo: Quanto menor melhor.

- Resultado das auditorias internas e externas de qualidade;

Forma de medição: Total de requisitos conformes / total de requisitos auditáveis. Indicativo: Quanto maior melhor.

- I Índice de incidentes (possíveis erros ocasionados no processo);

Forma de medição: Total de possíveis erros * 1.000.000 / total de pacientes atendidos (PPM - partes por milhão). Indicativo: Quanto menor melhor.

- Calibração dos equipamentos;

Forma de medição: Quantidade de repetições das calibrações / total de calibrações. Indicativo: Quanto menor melhor.

- Quantidade de laudos retificados (laudos com ajustes após a análise);

Forma de medição: Total de laudos retificados / total de laudos emitidos. Indicativo: Quanto menor melhor.

- Acuracidade na leitura dos biomédicos e bioquímicos (para verificar se a leitura de lâminas nos microscópios realizada por eles está de acordo);

Forma de medição: Total de não conformidades / Total de lâminas verificadas. Indicativo: Quanto menor melhor.

- Indicador de 5s setor;

Forma de medição: Total de requisitos alcançados / total de requisitos a alcançar. Indicativo: Quanto maior melhor.

Para as unidades de coleta foram definidos os indicadores, que busquem eficácia, eficiência e centrado no paciente, que monitorem o atendimento, a qualidade, organização e segurança.

- Quantidade de exames;

Forma de medição: Total de exames realizados / meta de exames de acordo com unidade. Indicativo: Quanto maior melhor.

- Problemas de qualidade enviado as áreas técnicas (coletas inadequadas, etiquetas erradas, cadastro de paciente com falta de informações...);

Forma de medição: Total de erros * 1.000 .000 / total de pacientes atendidos (PPM - partes por milhão). Indicativo: Quanto menor melhor.

- Satisfação do cliente;

Forma de medição: Nota realizada / total de pontos possíveis a ser realizado. Indicador: Quanto maior melhor.

- Indicador de 5s setor; 
Forma de medição: Total de requisitos alcançados / total de requisitos a alcançar. Indicativo: Quanto maior melhor.

Para os setores de compras e logística foram definidos os indicadores, que busquem igualdade, eficiência e pontualidade, que monitorem a falta de material, a qualidade dos mesmos, a organização e custos.

- Acuracidade dos estoques;

Forma de medição: Total de itens acurados / meta do total dos itens contado no mês. Indicativo: Quanto maior melhor.

- Giro de estoque;

Forma de medição: Estoque médio / total de consumo do mês. Indicativo: Quanto maior melhor.

- Volume do estoque em relação a quantidade de exames;

Forma de medição: Valor dos estoques (total consumido no mês+estoque) / total de exames realizados no mês. Indicativo: Quanto menor melhor.

- Lead de time de entrega de materiais para as unidades consumidoras;

Forma de medição: Média do tempo solicitado e entregue / meta de entrega. Indicativo: Quanto menor melhor.

- Qualificação dos fornecedores baseado no prazo de entrega, qualificações como ISO's, qualidade do produto entre outros pontos;

Forma de medição: Nota realizada / total de pontos possíveis a ser realizado. Indicador: Quanto maior melhor.

- Redução dos custos de compras;

Forma de medição: Custo insumos comprados / total de exames realizado. Indicativo: Quanto menor melhor.

Para os setores financeiro foram definidos indicadores que busquem eficiência, que monitorem a saúde da empresa.

- Ponto de equilíbrio;

Forma de medição: Total dos custos / faturamento médio dos dias. Indicativo: Quanto menor melhor.

- Lucratividade

Forma de medição: Faturamento - total de custos e investimento / total de faturamento. Quanto maior melhor.

\subsection{AGIR / MENSURAR RESULTADOS}

Nesse caípulo serão abordados os resultados após a plicação das ferramentas da Saúde Enxuta. Observando através dos indicadores a sua evolução.

\subsubsection{NEGÓCIO}

Para acompanhamento da evolução da empresa como um todo, foi definido indicadores estratégicos, estes indicadores ficam expostos na sala da direção para análise e cobrança das ações de melhorias. Os indicadores estratégicos conforme listados no capitulo anterior são:

- Faturamento;

- Custo por exame;

- Rotatividade;

- Qualidade no atendimento geral (pesquisa de satisfação do cliente);

- Quantidade de exames;

- Indicador de 5s; 
Os indicadores começaram a ser medidos em 2017 e foram levantados os históricos desde o ano de 2015, e tiveram franca evolução em virtude das melhorias implantadas e o desenvolvimento da cultura de melhoria contínua do laboratório. Em 2015 o laboratório possuía 29 colaboradores na média do ano, e em 2018 a média estava em 38 colaboradores, ou seja 31,3\% de aumento de mão de obra.

Um exemplo claro de evolução foi a quantidade de exames realizados por mês, que em 2015 tinha uma média de 44.000 mil exames mês e em 2018 passou para 75.000 mil exames mês, um aumento de 70,5\%. Outro indicador que teve evolução foi o de faturamento que em virtude do aumento de exames teve um aumento considerável de $82 \%$, importante ressaltar que o incremento de mão de obra foi apenas de $31,3 \%$, enquanto o crescimento de exames e faturamento ficou acima dos $70 \%$.

0 indicador de custo por exame também teve melhoras, reduziu em 4,7\% o custo de cada exame processado. A rotatividade não se conseguiu levantar históricos, então foi medida a partir de 2017, nesse ano obtivemos um índice de 1,4\% de rotatividade, no ano de 2018 a rotatividade ficou em 1,5\%, tendo um amento de 6,6\%. Os indicadores de 5'S e qualidade no atendimento serão apresentados seus números nos tópicos a seguir.

Para acompanhamento dos indicadores foi estipulado realizar uma reunião mensal para análise crítica, nesta reunião são analisados os indicadores que firam abaixo da meta e é feito um plano de ação para recoloca-lo dentro do estipulado.

Também são analisados os indicadores com tendência negativa, que ainda não estão fora da meta, mas por três meses consecutivos estão em declínio, indicando uma tendência negativa para o indicador. Esta reunião é registrada em ata e os planos de ação registrados em cada indicador para no mês seguinte verificar se estas foram suficientes para recoloca-lo dentro da meta.

Estes indicadores são a base para o planejamento estratégico dos anos sequentes, pois com os dados em mãos, a definição das metas para os anos posteriores fica mais assertiva.

Outro ponto importante que demostra a efetividade da saúde enxuta no laboratório é que em 2017 o laboratório passou pelo exame de certificação PALC (Programa de Acreditação de Laboratório Clínicos) e recebeu a o selo de certificado, sendo o 6⿳⺈ laboratório em Santa Catarina a ser reconhecido com esse selo.

\subsection{2 ÁREAS TÉCNICAS}

As áreas técnicas são as processadoras dos exames, onde acontece a análise dos resultados clínicos de cada paciente, estes resultados têm prazos para serem entregues não esquecendo da qualidade exigida, pois erros na análise dos resultados pode ocasionar erros médicos. Para controle das duas áreas técnicas, de Blumenau e Brusque, os indicadores abaixo foram criados conforme listado no capitulo anterior, para a aferição de vários pontos.

- $\quad$ Tempo de entrega dos exames (exames entregues dentro do prazo);

- $\quad$ Lead time de entrega dos exames para hospitais;

- Resultado das auditorias de qualidade interna e externa;

- $\quad$ Índice de incidentes (possíveis erros ocasionados no processo);

- Calibração dos equipamentos;

- Quantidade de laudos retificados (laudos com ajustes após a análise);

- Acuracidade na leitura dos biomédicos e bioquímicos (para verificar se a leitura de lâminas nos microscópios realizada por eles está de acordo);

- Indicador de 5S;

Os indicadores ficam expostos em um quadro em cada unidade, para visualização dos indicadores e visualização das ações tomadas para os que estiverem fora da meta, e os com tendências de sair fora da meta estipulada. Estas ações são sugeridas com base nos indicadores e aplicação de ferramentas da saúde enxuta, que são elaboradas mensalmente em uma reunião com a equipe que sugere melhorias e define ações para que as metas sejam atingidas.

Os indicadores apontaram melhoras com a passar do tempo, para melhor visualização foram criados os Quadros 2 e 3: 
Quadro 2 Evolução Indicadores Área Técnica Brusque

\begin{tabular}{|c|c|c|c|c|c|c|}
\hline Indicadores área técnica Brusque & $\begin{array}{c}\text { Média } \\
2015\end{array}$ & $\begin{array}{l}\text { Média } \\
2016\end{array}$ & $\begin{array}{c}\text { Média } \\
2017\end{array}$ & $\begin{array}{c}\text { Média } \\
2018\end{array}$ & $\begin{array}{l}\text { Maior } \\
\text { melhor }\end{array}$ & $\begin{array}{l}\text { Menor } \\
\text { melhor }\end{array}$ \\
\hline $\begin{array}{l}\text { - Tempo de entrega dos exames (exames entregues } \\
\text { dentro do prazo); }\end{array}$ & $91,20 \%$ & $94,60 \%$ & $97,30 \%$ & $99,10 \%$ & $\mathbf{x}$ & \\
\hline - Lead time de entrega dos exames para hospitais; & $97,00 \%$ & $97,70 \%$ & $98,20 \%$ & $99,40 \%$ & $\mathbf{x}$ & \\
\hline $\begin{array}{l}\text { - Resultado das auditorias de qualidade interna e } \\
\text { externa; }\end{array}$ & & $76,00 \%$ & $87,00 \%$ & $92,00 \%$ & $\mathbf{x}$ & \\
\hline $\begin{array}{l}\text { - Índice de incidentes (possíveis erros ocasionados no } \\
\text { processo); }\end{array}$ & & $3,20 \%$ & $2,90 \%$ & $2,50 \%$ & & $\mathbf{x}$ \\
\hline - Calibração dos equipamentos; & & $97,40 \%$ & $97,60 \%$ & $98,70 \%$ & $x$ & \\
\hline $\begin{array}{l}\text { Quantidade de laudos retificados (laudos com } \\
\text { ajustes após a análise); }\end{array}$ & & $1,10 \%$ & $0,90 \%$ & $0,70 \%$ & & $\mathbf{x}$ \\
\hline $\begin{array}{l}\text { - Acuracidade na leitura dos biomédicos e } \\
\text { bioquímicos (para verificar se a leitura de lâminas nos } \\
\text { microscópios realizada por eles está de acordo); }\end{array}$ & & $89,90 \%$ & $95,10 \%$ & $98,40 \%$ & $x$ & \\
\hline - Indicador de 5s; & & $87,00 \%$ & $91,00 \%$ & $96,00 \%$ & $x$ & \\
\hline
\end{tabular}

Fonte: Laboratório Verner Willrich (2019)

Se percebe na unidade de Brusque, principalmente no que tange tempo de entrega e lead time se obteve melhoras expressivas. Assim como os indicadores de monitoramento da qualidade também estão melhorando ao longo dos meses.

Quadro 3 Evolução Indicadores Área Técnica Blumenau

\begin{tabular}{|c|c|c|c|c|c|c|}
\hline Indicadores área técnica Blumenau & $\begin{array}{c}\text { Média } \\
2015\end{array}$ & $\begin{array}{c}\text { Média } \\
2016\end{array}$ & $\begin{array}{c}\text { Média } \\
2017\end{array}$ & $\begin{array}{c}\text { Média } \\
2018\end{array}$ & $\begin{array}{l}\text { Maior } \\
\text { melhor }\end{array}$ & $\begin{array}{l}\text { Menor } \\
\text { melhor }\end{array}$ \\
\hline $\begin{array}{l}\text { - Tempo de entrega dos exames (exames entregues } \\
\text { dentro do prazo); }\end{array}$ & $87,30 \%$ & $91,50 \%$ & $96,30 \%$ & $98,70 \%$ & $\mathbf{x}$ & \\
\hline - Lead time de entrega dos exames para hospitais; & $95,40 \%$ & $96,10 \%$ & $97,30 \%$ & $98,90 \%$ & $\mathbf{x}$ & \\
\hline $\begin{array}{l}\text { - Resultado das auditorias de qualidade interna e } \\
\text { externa; }\end{array}$ & & $74,00 \%$ & $89,00 \%$ & $93,00 \%$ & $\mathbf{x}$ & \\
\hline $\begin{array}{l}\text { - Índice de incidentes (possíveis erros ocasionados no } \\
\text { processo); }\end{array}$ & & $2,90 \%$ & $2,30 \%$ & $2,10 \%$ & & $\mathbf{x}$ \\
\hline - Calibração dos equipamentos; & & $98,10 \%$ & $98,30 \%$ & $98,80 \%$ & $\mathbf{x}$ & \\
\hline $\begin{array}{l}\text { Quantidade de laudos retificados (laudos com } \\
\text { ajustes após a análise); }\end{array}$ & & $1,40 \%$ & $1,10 \%$ & $0,80 \%$ & & $\mathbf{x}$ \\
\hline $\begin{array}{l}\text { Acuracidade na leitura dos biomédicos e } \\
\text { bioquímicos (para verificar se a leitura de lâminas nos } \\
\text { microscópios realizada por eles está de acordo); }\end{array}$ & & $89,70 \%$ & $93,60 \%$ & $98,90 \%$ & $\mathbf{x}$ & \\
\hline - Indicador de 5s; & & $84,00 \%$ & $89,00 \%$ & $94,00 \%$ & $x$ & \\
\hline
\end{tabular}

Fonte: Laboratório Verner Willrich (2019)

Na unidade de Blumenau os indicadores de qualidade estão muito bons e apresentam evolução. Os indicadores de tempo de entrega e lead time estão melhorando ao longo dos meses, mas ainda não alcançaram o alvo pretendido pelo laboratório.

Estes indicadores são controlados para visualizar a evolução das áreas técnicas e identificar pontos de melhorias no decorrer do processo. Assim gera engajamento da equipe que participa e acompanha a evolução das ações implantadas e sugeridas por eles, gerando satisfação do trabalho desenvolvido.

\subsubsection{UNIDADES DE COLETA}

A porta de entrada dos exames no laboratório são as unidades de coleta, e estas também receberam indicadores. Os indicadores foram divididos por unidade facilitando a identificação dos postos de coleta com maior eficiência e os com menor desempenho.

Os indicadores definidos para as unidades conforme listado no capitulo anterior foram: 
- Quantidade de exames;

- Problemas de qualidade enviado as áreas técnicas (coletas inadequadas, etiquetas erradas, cadastro de paciente com falta de informações...);

- Satisfação do cliente;

- Indicador de 5s;

A meta da quantidade de exames é definida levando em consideração a localização da unidade de coleta e o histórico dos meses/anos anteriores, com a meta definida cada unidade realiza ações para captação de clientes em suas localidades. A evolução da captação de exames foi notória, evoluindo 12,4\% na média de todas as unidades.

Os problemas de qualidade são detectados na entrada da área técnica em um setor chamado de triagem, este setor detecta, aponta em tabela e avisa a unidade geradora. Com o apontamento dos defeitos na tabela são gerados os indicadores e posteriormente ações para resolução dos problemas. Os problemas de qualidade obtiveram evolução com as melhorias, no inicio tinha-se uma média de 3,4\% de problemas entre as unidades, passando para 2,3\%, contabilizando assim a redução de 1,1\%.

0 indicador de satisfação do cliente é realizado através da pesquisa de satisfação preenchida pelo cliente após a realização da coleta, esta pesquisa tem três perguntas com possibilidade de resposta baseada na escala de Likert, demostrada na Quadro 4:

Quadro 4 Modelo da escala Likert utilizada na pesquisa de satisfação do cliente

\begin{tabular}{|c|c|c|c|}
\hline Excelente & Bom & Razoável & Ruim \\
\hline 4 & 3 & 2 & 1 \\
\hline
\end{tabular}

Fonte: Laboratório Verner Willrich (2019)

A satisfação dos clientes teve melhoras, no inicio da medição estava com média de 95,6\% de satisfação dos clientes em 2016, passando para 99,1\% em 2018.

Para a definição da meta de 5s foi realizado uma auditoria antes da implantação, e após foi realizado outra auditoria para comparativo, assim foi estipulado a meta para o 5s. A melhora da organização e o visual repaginado das unidades de coleta refletiu no indicador, que na primeira auditoria teve o resultado de $72,8 \%$ passando para 96,4\%. A melhora deste indicador refletiu na melhora do indicador de satisfação do cliente, pois com o $5 \mathrm{~s}$ as recepções ficaram mais organizadas e com um ar mais acolhedor.

\subsubsection{COMPRAS E LOGÍSTICA}

Os indicadores de compras e logística foram definidos para controlar a quantidade de produtos nos estoques e a velocidade de entrega para cada local estabelecido. Abaixo indicadores conforme listado no capítulo anterior para esta área são:

- $\quad$ Acuracidade dos estoques;

- Giro de estoque;

- Volume do estoque em relação a quantidade de exames;

- $\quad$ Lead de time de entrega de materiais para as unidades consumidoras;

- Qualificação dos fornecedores baseado no prazo de entrega, qualificações como ISO's, qualidade do produto entre outros pontos;

- Redução dos custos de compras;

A acuracidade dos estoques é medida através de contagem cíclicas e inventários realizados com frequência determinada. Este indicador teve melhora, partindo de 78,9\% de acuracidade em 2016 e chegando a 97,2\% em 2018.

0 giro de estoque foi implantado para verificar se os materiais ficam muito tempo parado sem utilização. A meta determinada para giro foi de 0,75 vezes por mês, isso significa que $75 \%$ do estoque tem que ser 
utilizado e renovado durante o período de 30 dias. No início do processo de implantação o giro do estoque estava em 0,38 vezes por mês, passando para 0,72 vezes por mês. Este indicador a meta ainda não foi atingido, mas a melhora foi de 0,34 , deixando o estoque com um volume menor e minimizando a possibilidade do vencimento dos materiais.

O volume de estoque foi reduzido em 19\% em relação aos exames processados, esta melhora se deu em virtude da compra mais frequente dos materiais, parcerias com fornecedores e controle dos estoques através do kanban.

As entregas realizadas para as unidades consumidoras eram realizadas semanalmente, elevando o volume dos estoques em cada unidade. Foi analisado que as rotas para coleta dos exames eram realizadas diariamente, portando, poderia ser entregue matérias todos os dias, reduzindo o prazo de entrega de 7 para 1 dia.

Para a qualificação dos fornecedores foi elaborado um FR (formulário de Registro) onde estes eram avaliados por alguns quesitos, recebendo pontuação, ao final de cada avaliação é gerado um indicador divido em classe A, B e C para verificar a confiabilidade do mesmo perante o laboratório. No final de 2017 estávamos com 8 fornecedores "A", 4 "B" e 2 fornecedores classe "C", que no caso eram os únicos fornecedores do produto, mas no início do projeto estávamos com 2 fornecedores "A", 6 "B" e 6 fornecedores classe " $\mathrm{C}$ ". Para esta melhora foi solicitado que os fornecedores se adequassem as novas normas, os que não se adequaram foram trocados. Está avaliação é realizada apenas para os fornecedores dos insumos principais.

A redução dos custos de compras foi em virtude do alto valor agregado dos produtos, o custo de compra é baseado em cima da quantidade de exames realizada no mês. As compras correspondiam a $42,6 \%$ do faturamento da empresa, e com as melhorias implantadas foi reduzido para 40,4\%, obtendo uma redução de $5,16 \%$ no valor total das compras.

\subsubsection{FINANCEIRO}

Para o setor financeiro foram definidos indicadores para controle da saúde da empresa, ou seja, verificar a rentabilidade do negócio. Os indicadores são:

- Ponto de equilíbrio;

- Lucratividade;

Para definir o ponto de equilíbrio foi necessário identificar os custos fixos e a margem de contribuição dos exames. 0 atingimento da meta do ponto de equilíbrio em 2015 estava em $71,2 \%$ passando para 105,8\% em 2018, obtendo uma melhora de 34,6\% em relação ao início do projeto.

A lucratividade do laboratório teve um aumento de 4,2\% no total do percentual comparando os anos de 2015 e 2017.

Observasse que o laboratório vem melhorando seus processos e controles, obtendo assim melhoras significativas nos seus resultados.

\section{CONSIDERAÇõES FINAIS}

Com os indicadores implantados se observa o impacto da saúde enxuta no laboratório de análises clínicas e a percepção de quanto o mesmo influencia no desempenho empresarial dessas empresas e na tomada de decisões, conseguimos perceber a evolução no resumo do Quadro 5 se consegue analisar a evolução de todos os indicadores. 
Quadro 5 Resumo dos indicadores do laboratório

\begin{tabular}{|c|c|c|c|c|c|}
\hline \multirow{2}{*}{$\begin{array}{l}\text { resumo: INDICADORES GERAIS DO LABORATÓRIO } \\
\text { Acuracidade dos estoques; }\end{array}$} & \multirow{2}{*}{$\begin{array}{c}\text { Maior } \\
\text { melhor } \\
\times\end{array}$} & \multirow[t]{2}{*}{$\begin{array}{l}\text { Menor } \\
\text { melhor }\end{array}$} & \multicolumn{3}{|c|}{ Evolução $2016 \times 2018$} \\
\hline & & & $23,19 \%$ & Aumentou & (-) \\
\hline Giro de estoque; & $x$ & & $89,47 \%$ & Aumentou & (-) \\
\hline Volume do estoque em relação a quantidade de exames; & & $\mathbf{x}$ & $19,00 \%$ & Reduziu & (-) \\
\hline Lead de time de entrega de materiais para as unidades consumidoras; & & $\mathbf{x}$ & $600,00 \%$ & Reduziu & (.) \\
\hline $\begin{array}{l}\text { Qualificação dos fornecedores baseado no prazo de entrega, qualificações como } \\
\text { ISO's, qualidade do produto entre outros pontos; }\end{array}$ & $x$ & & $300,00 \%$ & Aumentou & ()) \\
\hline Redução dos custos de compras; & & $\mathbf{x}$ & $5,16 \%$ & Reduziu & ()) \\
\hline ponto de equilibrio & $\mathbf{x}$ & & $47,50 \%$ & Aumentou & ()) \\
\hline Lucro & $\mathbf{x}$ & & $4,20 \%$ & Aumentou & (.) \\
\hline Exames percapito (colaboradores) & $\mathbf{x}$ & & $30,00 \%$ & Aumentou & (.) \\
\hline faturamento & $x$ & & $83,00 \%$ & Aumentou & (-) \\
\hline Quantidade de exames laboratório & $x$ & & $70,40 \%$ & Aumentou & (). \\
\hline Rotatividade & & $x$ & $7,10 \%$ & Aumentou & (8) \\
\hline Problemas de qualidade & & $x$ & $32,40 \%$ & Reduziu & (-) \\
\hline Atendimento & $x$ & & $3,70 \%$ & Aumentou & () \\
\hline 5'S geral & $x$ & & $20,90 \%$ & Aumentou & (-) \\
\hline Tempo de entrega dos exames (exames entregues dentro do prazo); & $x$ & & $10,81 \%$ & Aumentou & (-) \\
\hline Lead time de entrega dos exames para hospitais; & $x$ & & $3,07 \%$ & Aumentou & (-) \\
\hline Resultado das auditorias de qualidade interna e externa; & $x$ & & $23,33 \%$ & Aumentou & (-) \\
\hline Índice de incidentes (possíveis erros ocasionados no processo); & & $x$ & $32,60 \%$ & Reduziu & () \\
\hline Calibração dos equipamentos; & $x$ & & $1,02 \%$ & Aumentou & (-) \\
\hline Quantidade de laudos retificados (laudos com ajustes após a análise); & & $x$ & $66,67 \%$ & Reduziu & () \\
\hline $\begin{array}{l}\text { Acuracidade na leitura dos biomédicos e bioquímicos (para verificar se a leitura de } \\
\text { lâminas nos microscópios realizada por eles está de acordo); }\end{array}$ & $x$ & & $9,86 \%$ & Aumentou & (-) \\
\hline
\end{tabular}

Fonte: Elaborado pelo autor (2019)

Comparando anos anteriores se observa a evolução da empresa ao longo dos meses e anos podendo assim avaliar as diferenças entre eles, obtendo assim dados de desempenho empresarial para avaliação e controle.

Com o novo método se conseguiu promover melhorias no fluxo de informação e produção do laboratório, agilizando os processos, reduzindo desperdícios e proporcionando a toda a equipe um melhor desempenho com excelência.

O objetivo desse trabalho era implementar a saúde enxuta para buscar melhorar o desempenho empresarial do laboratório em questão. Esse foi realizado com êxito e a cultura da empresa em questão vem se moldando e dando continuidade as metodologias e ferramentas aplicadas.

Percebe-se em visitas e reuniões que a equipe esta engajada e fazendo da saúde enxuta o seu dia a dia, visando a otimização de recursos e controle efetivo dos processos. Dessa forma os custos se tornam reduzidos, os prazos são atendidos e a qualidade sempre preservada, fazendo o negócio mais competitivo no mercado.

A viabilidade desse estudo ficou evidente na medida que foram apresentados os resultados e comparações entre os anos.

\section{REFERÊNCIAS}

[1] ARUNAGIRI, P, GNANAVEL BABU, A; Review on Reduction of Delay in manufacturing process using Lean six sigma (LSS) systems - published at: "International Journal of Scientific and Research Publications (IJSRP), Volume 3, Issue 2, February 2013 Edition".

[2] BROWNING, Tyson R., and RALPH D. Heath. 2009. "Reconceptualizing the Effects of Lean on Production Costs with Evidence from the F-22 Program." Journal of Operations Management 27 (1): 23-44. doi:10.1016/j.jom.2008.03.009.

[3] D'ANDREAMATTEO, Antonio, LUCA, Ianni; FEDERICO, Lega; and Massimo Sargiacomo. 2015. "Lean in Healthcare: A Comprehensive Review.” Health Policy 119 (9). Elsevier Ireland Ltd: 1197-1209. doi:10.1016/j.healthpol.2015.02.002.

[4] EIRO, Natalia Yuri. TORRES, Alvair Silveira Junior. 2015. "Comparative Study: TQ and Lean Production Ownership Models in Health Services." Revista Latino-Americana de Enfermagem 23 (5): 846-54. doi:10.1590/01041169.0151.2605. 
[5] FARIA, Ana Cristina de, Vanessa Simões Vieira;, Peretti;, Luiz Celso; 2012. "REDUÇÃo DE CUSTOS SOB A ÓTICA DA MANUFATURA ENXUTA EM EMPRESA DE AUTOPEÇAS.” Revista Gestão Industrial REDUÇÃO, no. November. doi:10.3895/S1808-04482012000200008.

[6] GUIMARÃES, R. 2014. "Proposta de Implementação de Lean Healthcare Em Um Laboratório de Hospital Público." Escola de Engenharia de Lorena, 93.

[7] ISERHARD, F. Z.; KIPPER, L. M.; MACHADO, C. M. L.; STORCH, L. A.; NARA, E. O. B. Utilização da abordagem Lean e da ferramenta de mapeamento de fluxo de valor na identificação de desperdícios - Um estudo de caso. In: ENCONTRO NACIONAL DE ENGENHARIA DE PRODUCAO, 33, 2013, Salvador. Anais eletrônicos... Salvador: UNISC, 2013. Disponível em: < http://www.abepro.org.br/biblioteca/enegep2013_TN_WIC_177_013_22251.pdf >. Acessado em 10 de maio de 2016.

[8] LIKER, J. K. O modelo Toyota: 14 princípios de gestão do maior fabricante do mundo. Porto Alegre: Bookman, 2005.

[9] MARODIN, Giuliano Almeida, Tarcísio Abreu Saurin, and Carla Schwengber ten Caten. 2015. "Identificação E Classificação de Riscos Na Implantação Da Produção Enxuta." Production 25 (4): 911-25. doi:10.1590/01036513.033011.

[10] MARTIN, Lynn D., Sally E. Rampersad, Daniel K.W. Low, and Mark A. Reed. 2014. "Mejoramiento de Los Procesos En El Quirófano Mediante La Aplicación de La Metodología Lean de Toyota." Revista Colombiana de Anestesiología 42 (3). Sociedad Colombiana de Anestesiología y Reanimación: 220-28. doi:10.1016/j.rca.2014.02.007.

[11] MCCONNEL, K. John, Anna Marie Chang, Thomas M. Maddox, Douglas R. Wholey, and Richard C. Lindrooth. 2014. "An Exploration of Management Practices in Hospitals." Healthcare 2 (2). Elsevier: 121-29. doi:10.1016/j.hjdsi.2013.12.014.

[12] MUHAMMAD, Imran; TEOH, Say Yen; WICKRAMASINGHE, Nilmini. 2014. Trying to Streamline Healthcare Delivery in Australia via the Personally Controlled Electronic Health Record (PCEHR). Springer Science. DOI 10.1007/978-1-4614-8036-5.

[13] NISHIDA, L. T. Reduzindo o "lead time" no desenvolvimento de produtos através da padronização. Artigos Lean Institute Brasil. Disponível em: < http://www.lean.org.br/comuni dade/artigos/pdf/artigo_74.pdf >. Acesso em: 16 de maio de 2015.

[14] OHNO, T. O sistema Toyota de Produção: Além da produção em larga escala. Porto Alegre: Artes Médicas,1997.

[15] PAUSHTER, David M., and STEPNEN, Thomas. 2016. "Quality Assurance Methodology and Applications to Abdominal Imaging PQI.” Abdominal Radiology 41 (3). Springer US: 395-404. doi:10.1007/s00261-016-0678-y.

[16] PERALTA, Carla Beatriz da Luz. 2014. "LEAN HEALTHCARE: PESQUISA-AÇÃO PARA IMPLEMENTAÇÃO DE MELHORIAS EM UM PROCESSO DE PRONTO ATENDIMENTO INFANTIL. Florianópolis, SC.

[17] ROBINSON, Stewart, Zoe J. Radnor, Nicola Burgess, and Claire Worthington. 2012. "SimLean: Utilising Simulation in the Implementation of Lean in Healthcare." European Journal of Operational Research 219 (1): $188-97$. doi:10.1016/j.ejor.2011.12.029.

[18] TYAGI, Satish, Xianming Cai, Kai Yang, and Terrence Chambers. 2015. "Lean Tools and Methods to Support Efficient Knowledge Creation." International Journal of Information Management 35 (2): 204-14. doi:10.1016/j.ijinfomgt.2014.12.007.

[19] WELLAMAN, Joan; JEFFRIESS, Howard, HAGAN, Pat. 2011. Leading the healthcare journey: Driving culture change to increase value. Taylor and Francis Group, New York. ISBN-13: 978-1439828656. ISBN-10: 1439828652.

[20] WICKRAMASINGHE, Nilmini. 2014. Lean Principles for Healthcare. Springer Science. DOI 10.1007/978-14614-8036-5.

[21] WICKRAMASINGLE, Nilmini; AL-HAKIN, Latif; GONZALEZ, Chris; TAN, Joseph. 2014. Lean thinking for healthcare. Springer Science+Business Media New York. ISBN 978-1-4614-8036-5 (eBook) DOI 10.1007/978-1-46148036-5.

[22] WOMACK, J.P.; JONES, D.T. A Mentalidade Enxuta nas Empresas: elimine o desperdício e crie riqueza. 8 $8^{\mathbf{a}}$ ed. Rio de Janeiro: Campus, 2004.

[23] WOMACK, J. P; JONES, D. T; ROOS, D. A máquina que Mudou o Mundo: Baseado no estudo do Massachusetts Institute of Technology sobre o futuro do automóvel. Rio de Janeiro: Elsevier, 2004.

[24] YAMACHIKA, Lucas Masatoshi. Análise e comparação da proposta de implementação de algumas ferramentas da produção enxuta em uma média empresa. 2010. 52 f. Trabalho de Conclusão de Curso (Curso Engenharia de Produção) - Escola de Engenharia de São Carlos da Universidade. 


\section{Capítulo 6}

\section{Visão Multicritério no estabelecimento da Função Utilidade para aquisição de uma Câmara de Pressão Negativa em uma Farmácia de Manipulação}

\section{Simone de Almeida}

Resumo: Este trabalho tem como objetivo aplicar o método MAUT (Multiple Attribute Utility Theory) para auxiliar a tomada de decisão na implantação de uma câmara e antecâmara para o controle de contaminação cruzada na preparação de insumos farmacêuticos dentro dos laboratórios das farmácias de manipulação e para a proteção dos manipuladores e do meio ambiente. Este estudo se concentra no caso particular de uma farmácia magistral da região Sul do Brasil, considerando o contexto e procedimentos adotados nesse ramo de negócio. Esta avaliação visa identificar as implicações estratégicas da abordagem MAUT na tomada de decisão, propondo uma forma alternativa de tratar o problema, demonstrando os procedimentos para a criação de um modelo que permita ao decisor decidir pela aquisição ou não dos equipamentos e infraestrutura necessários para atender a RDC 214/2007, impostos pela ANVISA (Agência Nacional de Vigilância Sanitária).

Palavras chave: RDC 214/2007, ANVISA, Tomada de Decisão, Método MAUT (Multiple Attribute Utility Theory). 


\section{INTRODUÇÃO}

A política de saúde brasileira tem enfrentado grandes desafios devido à necessidade de integração do segmento de assistência à saúde e os segmentos industriais que o abastece, sendo ambos considerados elos de uma mesma cadeia produtiva. É possível observar diariamente nos noticiários, em diversos meios de comunicação, que são críticas as dificuldades de acesso de grande parte da população aos medicamentos essenciais para a manutenção e melhoria da qualidade de vida, podendo reduzir as taxas de mortalidade.

Para garantir a oferta de medicamentos de qualidade, tais como os medicamentos de referência e similares, e reduzir seus custos no mercado e fomentar o acesso do indivíduo a estes medicamentos, algumas iniciativas foram desenvolvidas, como a criação dos medicamentos genéricos e dos manipulados. Entende-se por medicamentos de referência aqueles que, geralmente se encontram a bastante tempo no mercado e tem uma marca comercial conhecida e muitas vezes patenteadas. Estas substâncias são produtos de anos de pesquisa e exaustivos testes para avaliar sua segurança e eficácia (ANVISA, 2007).

Medicamentos similares são aqueles que possuem mesma substância ativa, concentração, forma farmacêutica, posologia, via de administração, dosagem, mesma indicação terapêutica e qualidade dos medicamentos de referência. Já os medicamentos genéricos são aqueles que contêm o mesmo fármaco, forma farmacêutica, dose, é administrado pela mesma via, possui a mesma indicação terapêutica do medicamento de referência, e principalmente são intercambiáveis em relação ao medicamento de referência, ou seja, a troca pelo genérico é possível, sendo seu preço muito mais acessível (ANVISA, 2007). Por outro lado, medicamentos manipulados são preparados em uma farmácia magistral autorizada pela Vigilância Sanitária e contém o princípio ativo e a dose prescrita pelo médico. Estes medicamentos são apresentados pelas farmácias de manipulação como alternativas às doses padrões disponibilizadas pela indústria, ou seja, a produção de medicamentos é personalizada em relação à dose, como também a combinação de princípios ativos em uma mesma cápsula ou outras formas de apresentação do medicamento.

Os medicamentos genéricos recebem grande apoio e ampla divulgação do governo, o que acarretou seu sucesso no mercado. Diante deste cenário, onde os incentivos governamentais no que se referem as promoções, esclarecimentos em diversos meios de comunicação quanto ao uso dos medicamentos genéricos, e do poder das grandes indústrias de produção de medicamentos de referência e similares, as farmácias de manipulação (que são geralmente Micro e/ou Pequenas Empresas, devido ao perfil da própria atividade) vem sofrendo grande pressão, as quais precisam concentrar esforços no desenvolvimento de estratégias inovadoras para se manterem competitivas no mercado, visto que é um segmento de várias particularidades e desafios constantes, muitas vezes impostos pelo órgão regulamentador ANVISA (Agência Nacional de Vigilância Sanitária).

Entre as últimas exigências está a aquisição e implantação de uma câmara de pressão negativa e uma antecâmara para o controle efetivo de contaminação cruzada de insumos dentro dos laboratórios da farmácia de manipulação e para a proteção dos manipuladores e meio ambiente.

A resolução RDC214/2007, que regulamenta as Boas Práticas de Manipulação para Farmácias de Manipulação, exige que o preparo de antibióticos, hormônios e citostáticos sejam realizados em salas de manipulação dedicadas com antecâmara e pressão negativa com relação às demais. Para tanto exige a aquisição, pelas farmácias de manipulação desses equipamentos e infra-estrutura para cada laboratório dos referidos grupos de medicamentos.

Para auxiliar o processo de tomada de decisão, optou-se pela construção de modelos que utilizam o método MAUT, baseado na Teoria da Decisão, em que seu enfoque bayesiano permite tratar as incertezas inerentes aos problemas a serem analisados através do uso de conhecimento a priori de especialistas no sistema produtivo (MIRANDA \& ALMEIDA, 2004) e (RUSSEL \& SEAN \& BRENTON, 2015).

De maneira resumida, o problema do decisor consiste em escolher a alternativa $a$ em que o deixe mais satisfeito com o resultado X1(a), ..., Xn(a), onde Xi representa os atributos de avaliação. Dessa forma é necessário um índice que combine X1(a), ... Xn(a) em um índice de valor, que é a função utilidade. Portanto, deve-se obter uma função utilidade u, definida sobre o espaço de consequências, atendendo às propriedades da teoria (ALMEIDA, 2011) e (DONG \& FRANGOPOL \& SABATINO, 2015).

Segundo Fishburn (1970) a função utilidade é obtida através de um protocolo estruturado e fundamentado na estrutura axiomática da Teoria da Utilidade, incluindo a questão probabilística sobre a avaliação de escolhas entre diferentes consequências. Este protocolo é geralmente um procedimento denominado de elicitação da função utilidade, também chamado e edução (SOUZA, 2002) e (BARONS \& WRIGHT \& SMITH, 2018). Segue o procedimento adotado no estudo para auxiliar a farmácia a tomar a decisão. 


\section{PROCESSO PARA TOMADA DE DECISÃO}

Vincke (1992) destaca duas famílias principais de métodos, as que são baseadas na Teoria da Utilidade Multiatributo (MAUT - Multiple Attribute Utility Theory) e as de subordinação (Outranking), por oferecerem flexibilidade à análise multicritério e à avaliação no processo de escolha, reduzindo a subjetividade e aumentando a eficiência da decisão. 0 processo de elicitação e validação da função utilidade para atender ao problema, detalhado nesta sessão, tiveram a colaboração valiosa da especialista de uma farmácia magistral ou de manipulação. Para se chegar à obtenção da Função Utilidade, foram seguidas as seguintes etapas (KEENEY \& RAIFFA, 1976):

- Definição e estruturação do problema;

- Introdução das terminologias ao agente decisor;

- Verificando a Independência em utilidade;

- Verificando a Independência aditiva;

- Avaliando as constantes de escala;

- Checando a consistência.

\subsection{DEFINIÇÃO E ESTRUTURAÇÃO DO PROBLEMA}

A resolução RDC214/2007 abrange questões relacionadas a instalações, equipamentos, recursos humanos, aquisição e controle de qualidade da matéria-prima. Traz, ainda, as exigências para armazenamento, avaliação farmacêutica da prescrição, fracionamento, conservação, transporte, dispensação das formulações e atenção farmacêutica aos usuários.

Como já mencionado, a resolução exige ainda que o preparo de antibióticos, hormônios e citostáticos (são utilizados no tratamento de neoplasias malignas quando a cirurgia ou a radioterapia não são possíveis ou se mostraram ineficazes, ou ainda como adjuvantes da cirurgia ou da radioterapia como tratamento inicial), sejam realizados em salas de manipulação dedicadas com antecâmara e pressão negativa com relação às demais. Para tanto exige a aquisição, pelas farmácias de manipulação de uma câmara e antecâmara, de acordo com modelo apresentado na Figura 1, para a manipulação de cada uma das três classes terapêuticas: hormônios, antibióticos e citostáticos, com sistemas de ar independentes e de eficiência comprovada.

Tais salas devem possuir pressão negativa em relação às áreas adjacentes, sendo projetadas de forma a impedir o lançamento de pós no laboratório ou no meio ambiente, evitando contaminação cruzada, protegendo o manipulador e o meio ambiente. A pesagem dos hormônios, antibióticos e citostáticos deve ser efetuada na respectiva sala de manipulação. Os custos apurados para aquisição da câmara e antecâmara, do exaustor, além dos serviços de instalação e elaboração da planta baixa das instalações por um engenheiro sanitarista são: • Custo da câmara: R\$ 3.636,00 • Custo do Exaustor: R\$ 989,00 • Instalação: R\$ 400,00 - Planta baixa: R\$ 1000,00 0 valor total para a instalação de uma câmara e antecâmara será de $\mathrm{R} \$ 6.075,00$ por sala, além do espaço físico necessário para a instalação adequada das câmaras.

Figura 1: Kit de Pressão Negativa

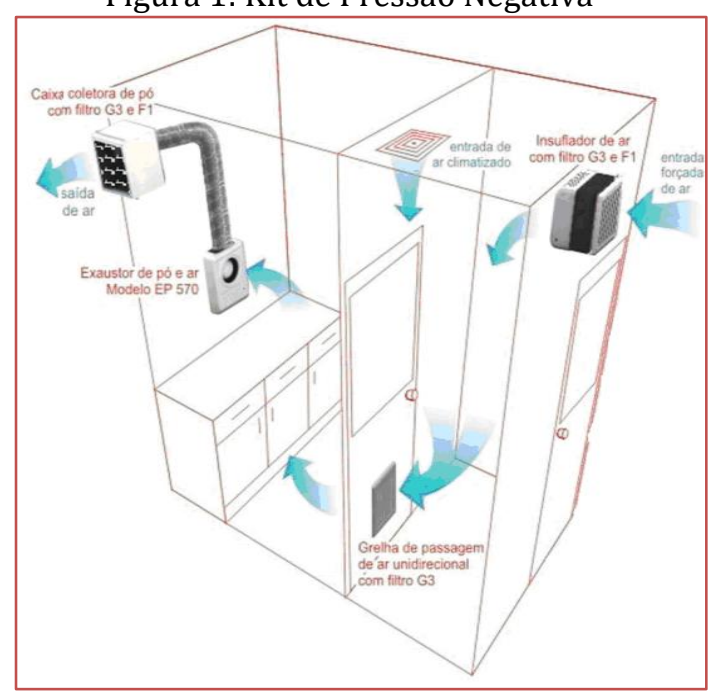


O Kit inclui: Insuflador de Ar com Filtros G3 e F1 (Modelo RARA 54), Exaustor de Pó e ar (modelo EP 570), Caixa Coletora de pós com Filtros G3 e F1, Grelha de passagem de ar unidirecional com filtro G3, Duto em alumínio flexível (2 metros), Braçadeiras de nylon e parafusos para fixação. Na Figura 2, é apresentada de forma mais detalhada o sistema de exaustão de pós, necessário em cada sala de manipulação.

Figura 2: Sistema de Exaustão de Pó

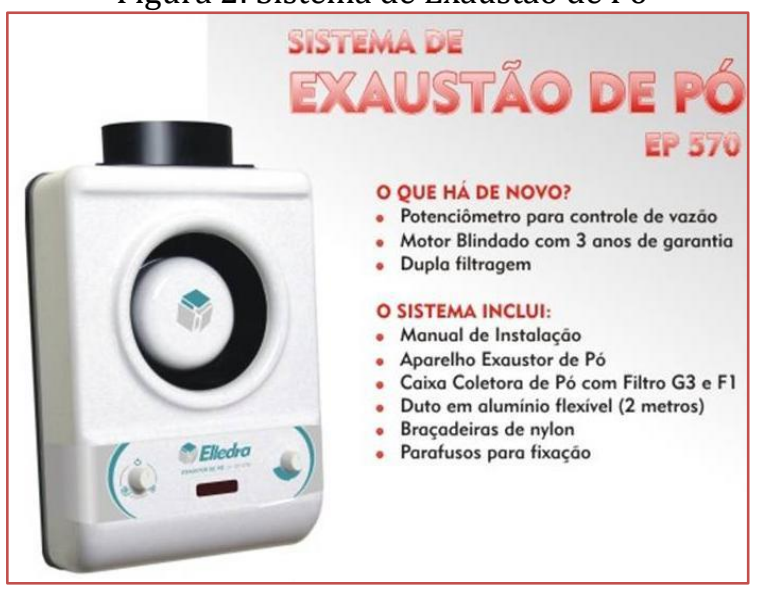

As farmácias de manipulação são classificadas conforme os 6 (seis) grupos de atividades estabelecidos no Regulamento Técnico, apresentado no Quadro 1, de acordo com a complexidade do processo de manipulação e das características dos insumos utilizados, para fins do atendimento aos critérios de Boas Práticas de Manipulação em Farmácias (BPMF). 0 descumprimento das disposições do Regulamento Técnico sujeita os responsáveis às penalidades previstas na legislação sanitária vigente, sem prejuízo da responsabilidade civil e criminal cabíveis.

Quadro 1: Grupos de Atividades Desenvolvidas pelas Farmácias

\begin{tabular}{|c|c|}
\hline Grupos & Atividades/Natureza dos Insumos Manipulados \\
\hline I & $\begin{array}{c}\text { Manipulação de medicamentos a partir de insumos/matérias primas, } \\
\text { inclusive de origem vegetal. }\end{array}$ \\
\hline II & Manipulação de substâncias de baixo índice terapêutico \\
\hline III & $\begin{array}{c}\text { Manipulação de antibióticos, hormônios, citostáticos e substâncias } \\
\text { sujeitas a controle especial. }\end{array}$ \\
\hline IV & Manipulação de produtos estéreis \\
\hline $\mathrm{V}$ & Manipulação de medicamentos homeopáticos \\
\hline VI & $\begin{array}{l}\text { Manipulação de doses unitárias e unitarização de dose de medicamentos } \\
\text { em serviços de saúde }\end{array}$ \\
\hline
\end{tabular}

Em caso de danos causados aos consumidores, comprovadamente decorrentes de desvios da qualidade na manipulação de preparações magistrais (de acordo com o receituário médico) e oficinais (segundo as farmacopeias oficiais), as farmácias estão sujeitas às penalidades previstas na legislação sanitária vigente, sem prejuízo das responsabilidades civil e criminal cabíveis dos responsáveis (ANVISA, 2007).

Ao iniciar o processo, algumas alternativas para o problema foram descartadas porque implicavam em um alto investimento além de um grande espaço físico, necessário para instalar as três câmaras e antecâmaras, tornando inviável sua implantação no que se refere a aquisição de uma antecâmara de pressão negativa para as três classes terapêuticas, ou seja, hormônios, antibióticos e citostáticos.

Os hormônios atualmente manipulados pela farmácia onde foi feito o estudo de caso são: tibolona, estradiol, estrógenos conjugados, progesterona, T3, T4. Em relação a segunda classe terapêutica de antibióticos, os que são manipulados atualmente pela farmácia são: cefalexina, minociclina, tetraciclina, 
ampicilina, amoxacilina, neomicina, gentamicina, claritromicina, doxiciclina. Os insumos da classe terapêutica dos citostáticos, não são manipulados pela farmácia.

Assim, desconsiderando a possibilidade de aquisição de três câmaras, a alternativa de aquisição de apenas uma antecâmara para a manipulação de antibióticos, visto que este insumo seria o de maior retorno financeiro atual da farmácia, assim como poderia ser feita uma parceria com outras farmácias da região onde seriam encaminhados os insumos não manipulados pela farmácia em questão e vice-versa. 0 Quadro 2 representa a estruturação inicial do problema, como os critérios e alternativas para a solução do problema proposto.

Quadro 1: Estruturação do Problema

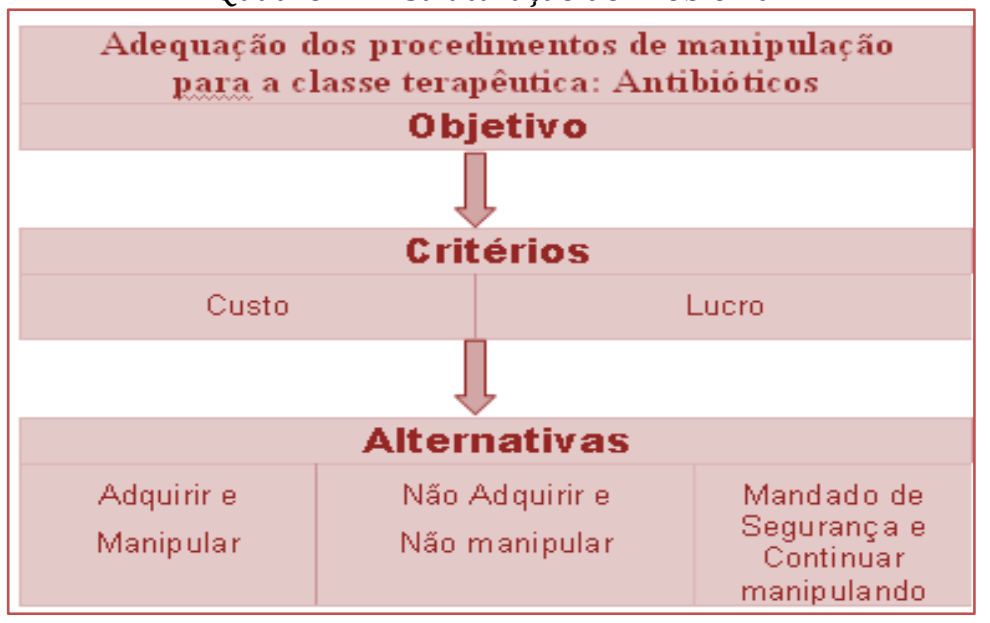

Assim os dois atributos tratados no trabalho são: Custo (de aquisição e instalação da antecâmara de pressão negativa para a manipulação de antibióticos) e Lucro (referente à manipulação e venda dessa classe terapêutica, como a possibilidade em atender outras farmácias da região como também deve ser considerado a continuidade de manipulação dessa classe para os pacientes atuais, nos quais estão incluídos todos os veterinários da região que enviam medicamentos para serem manipulados na forma de tabletes de ração com sabor apropriado para o consumo animal, o qual é hoje um diferencial da farmácia).

\subsection{INTRODUÇÃO DAS TERMINOLOGIAS AO AGENTE DECISOR}

Dando início ao processo de edução da função utilidade, foi explicado para a especialista, que passará a partir desse momento a ser referenciada apenas como decisor, todo o processo e suas particularidades, como (ZELENY, 2008):

- Não há objetivamente a preferência correta, ela representa um sentimento subjetivo do decisor.

- A qualquer momento o decisor pode se sentir desconfortável com alguma informação oferecida sobre seu sentimento subjetivo, e pode mudar o seu pensamento.

- $\quad$ Propósito da análise de utilidade: ajudar o decisor a pensar sobre suas preferências e esperar que ele as arrume na sua mente.

Quando possível, procurou-se verificar se decisor entrava em alguma contradição, o que não ocorreu em nenhum momento da entrevista. A maior dificuldade foi devido à distância física, entre o analista e o decisor, visto que o decisor se encontra na região de Ponta Grossa, estado do Paraná. 0 processo ocorreu por meio de uma avaliação direta de preferências, devido a quantidade de consequências ser considera baixa, onde foi oferecido ao decisor situações que implicavam em diversas condições a serem respondidas dentro do conceito de independência. Supondo uma escala de 0 a 1 para os valores de utilidade, de modo que $\mathrm{x}^{0} \leq \mathrm{x} \leq \mathrm{x}^{*}$ e $\mathrm{y}^{0} \leq \mathrm{y} \leq \mathrm{y}^{*}$. A condição de independência em utilidade foi a primeira a ser testada, conforme descrito a seguir. 


\subsection{INDEPENDÊNCIA EM UTILIDADE}

Considerando que um atributo X é independente de outro atributo $\mathrm{Y}$ em utilidade quando as preferências condicionais para loterias no primeiro atributo não dependem de um nível particular Y. A independência em utilidade pode ser compreendida considerando-se dois atributos $\mathrm{X}$ e $\mathrm{Y}$ no espaço de atributos $\mathrm{X}$, onde $\mathrm{Z}$ = X x Y (GARMABAKI \& AHMADI, 2016). Assume-se que:

$$
\mathrm{x}^{0} \leq \mathrm{x} \leq \mathrm{x}^{*} \text { e } \mathrm{y}^{0} \leq \mathrm{y} \leq \mathrm{y}^{*}
$$

Suponha-se que alternativa menos preferível seja $\left(\mathrm{x}^{0}, \mathrm{y}^{0}\right)$ e que a alternativa mais preferível é $\left(\mathrm{x}^{*}, \mathrm{y}^{*}\right)$. Admite-se que uma escala de 0 e 1 para os valores de utilidade de modo que:

$$
\mathrm{u}\left(\mathrm{y}^{0}, \mathrm{z}^{0}\right)=0 \text { e }\left(\mathrm{y}^{*}, \mathrm{z}^{*}\right)=1
$$

Para verificar as condições de independência, realizou-se o seguinte teste para cada par de critérios. Para verificar a independência preferencial do critério CUSTO em relação ao LUCRO. Definiram-se dois valores para CUSTO e dois valores para LUCRO. Na primeira análise, testou-se o mesmo valor de LUCRO para os dois valores de CUSTO. 0 agente de decisão foi então solicitado a fazer a escolha da melhor alternativa, ou seja, para o mesmo valor de LUCRO, ele deveria escolher o melhor valor para CUSTO.

Em seguida, mudou-se o nível do atributo LUCRO e fez-se a procura pelo equivalente certo dos mesmos pontos do outro atributo CUSTO. De forma análoga, foi realizado o mesmo processo para o atributo CUSTO.

Exemplo:

1. Atribuição dos valores para: CUSTO: R \$ 0,00 e R\$ 6000,00 LUCRO: R\$ 2500,00 e R\$ 8000,00

2. Primeira análise fixando o valor do LUCRO em R\$ 2500,00, testou-se para os dois valores de CUSTO.

3. Segunda análise fixando o valor do LUCRO em R\$ 8000,00, testou-se para os dois valores de CUSTO.

4. Terceira análise fixando o valor do CUSTO em R $\$ 0,00$, testou-se para os dois valores de LUCRO.

5. Quarta análise fixando o valor do CUSTO em R\$ 6000,00, testou-se para os dois valores de LUCRO.

Considerando a loteria em relação ao atributo LUCRO, apresentado na Figura 3:

Figura 3: Loteria x'para o Lucro

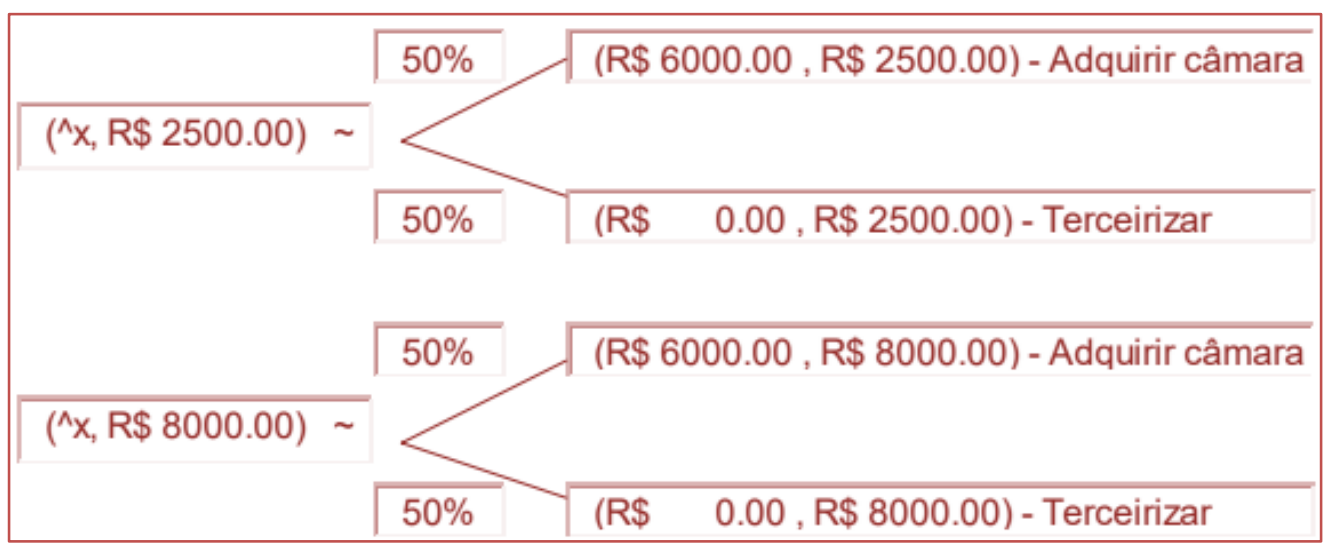

- Considerando a loteria aplicada ao atributo CUSTO ilustrado na Figura 4: 
Figura 4: Loteria para o Custo em relação ao Lucro

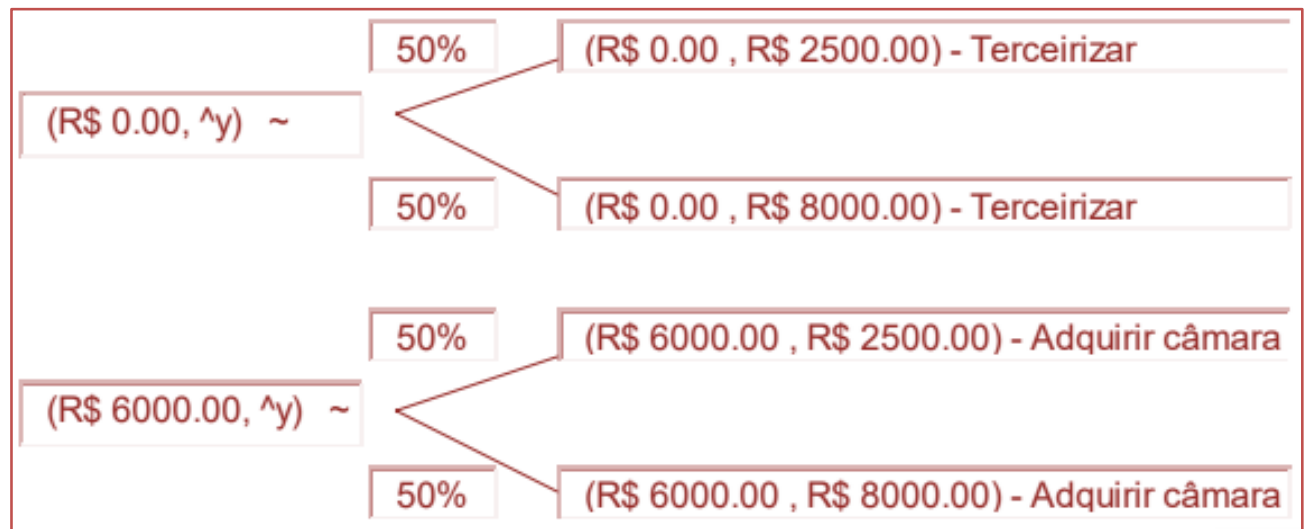

Após a realização da entrevista com o decisor, foi identificado o valor do equivalente certo para as loterias acima demonstradas. 0 valor do equivalente certo ${ }^{\wedge} x$ foi de $R \$ 200,00$ e $R \$ 800,00$, respectivamente. 0 valor do equivalente certo ^y foi de $R \$ 2000.00$ para a primeira situação e $R \$ 800,00$ para a segunda.

De acordo com a constatação do decisor, o valor do CUSTO, embora superior ao do LUCRO esperado, ele se dará apenas uma vez e o LUCRO, será verificado todo mês, além de se verificar qualitativamente com o diferencial da farmácia em relação à produção de antibióticos na forma de tabletes em ração com sabores forma ministrada para os veterinários da região.

Para que se tivesse constatado a independência preferencial entre os critérios, a escolha do decisor em relação ao CUSTO deveria ter sido a mesma nas duas análises, ou seja, deveria ser independente do valor de LUCRO.

Não foi possível obter interdependência em utilidade entre os atributos, ou seja, CUSTO não é independente em utilidade de LUCRO, nem LUCRO é independente em utilidade de CUSTO; portanto as propriedades de independência em utilidade não podem ser aplicadas para determinar a função u(x,y), dentro das opções apresentadas.

Uma forma alternativa envolveu a obtenção de novos atributos com base na transformação do dos atributos originais CUSTO e LUCRO, de maneira a permitir a aplicação das propriedades de independência em utilidade. Considerando LUCRO como um benefício, tentou identificar outro benefício que possa ser mensurado. Dessa forma, o agente decisor propôs o benefício TEMPO DE ESPERA na preparação dos medicamentos, já que esse é um critério para se decidir entre a implantação da câmara de pressão negativa ou pela terceirização.

0 processo foi refeito considerando esse novo atributo. Inicialmente, definiram-se os melhores e piores valores assumidos por esse novo atributo, ou seja, 3 horas e 36 horas respectivamente, ou seja, o paciente deveria aguardar por seu medicamento durante 3 ou 36 horas para sua preparação. Assim as loterias assumiram a seguinte forma:

Considerando o atributo TEMPO DE ESPERA mostrado na Figura 5: 
Figura 5: Loteria para o Tempo de Espera

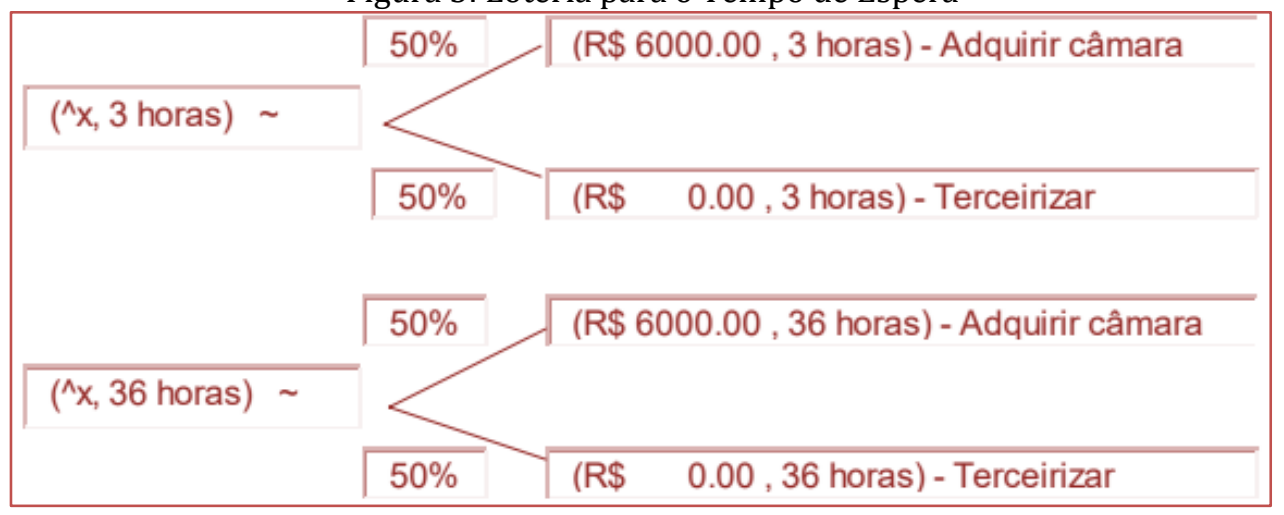

Considerando a aplicação da loteria no atributo CUSTO, conforme apresentado na Figura 6:

Figura 6: Loteria para o Custo em relação ao Tempo de Espera

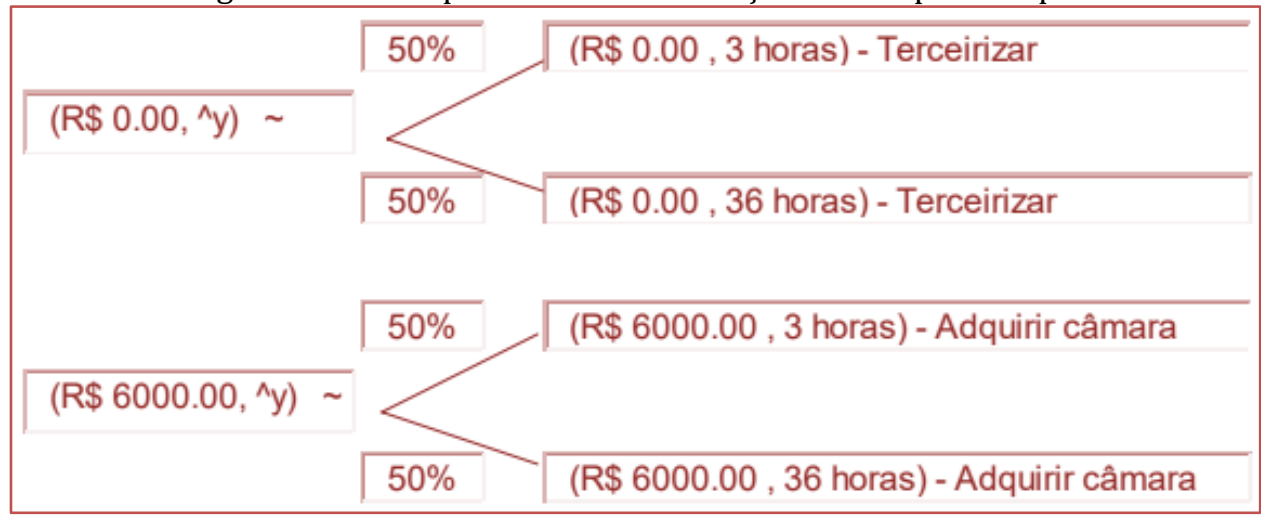

Após a nova entrevista com o decisor, foi identificado o valor do equivalente certo para as loterias acima demonstradas. 0 valor do equivalente certo ${ }^{\wedge} \mathrm{x}$ foi de $\mathrm{R} \$ 500,00$ para ambos os casos. 0 valor do equivalente certo ${ }^{\wedge} \mathrm{y}$ foi de $\mathrm{R} \$ 2000.00$ para ambas as situações.

O problema passou a ter os atributos Custo e Tempo de esperada mutuamente independentes, devido ao equivalente certo não se alterar com os novos valores especificados. Como implicação direta, a função em utilidade global para os dois atributos pode ser escrita por uma função multilinear do tipo (Teorema 5.2, Keeney \& Raiffa, p. 234):

$$
\mathrm{U}(\mathrm{x}, \mathrm{y})=\mathrm{Kx} u(\mathrm{x})+\mathrm{Ky} u(\mathrm{y})+\mathrm{Kxy} u(\mathrm{x}) \mathrm{u}(\mathrm{y})
$$

\subsection{INDEPENDÊNCIA ADITIVA}

Admitamos que tenham dois pares de consequências A, C e B, D, representados respectivamente pelos níveis das consequências $(\mathrm{y} 1, \mathrm{z} 1),\left(\mathrm{y}^{*}, \mathrm{z}^{*}\right)$ e $\left(\mathrm{y} 1, \mathrm{z}^{*}\right),\left(\mathrm{y}^{*}, \mathrm{z} 1\right)$. É possível afirmar que dois atributos $\mathrm{Y}$ e $\mathrm{Z}$ são aditivamente independentes se duas loterias representadas por e forem indiferentes ou igualmente preferíveis para todo $(\mathrm{y}, \mathrm{z})$ e para um y1 e z1 previamente escolhido (ALMEIDA \& COSTA, 2003).

A condição de independência em utilidade aditiva foi verificada utilizando o procedimento das loterias características, onde o decisor se ficar indiferente entre as loterias $\mathrm{L} 1<(\mathrm{x}, \mathrm{y}),\left(\mathrm{x}^{\prime}, \mathrm{y}^{\prime}\right)>\mathrm{e} \mathrm{L} 2<\left(\mathrm{x}, \mathrm{y}^{\prime}\right),\left(\mathrm{x}^{\prime}\right.$, y) >, é possível ter razões suficientes para assumir que os atributos são independentes aditivamente. 
Figura 7: Loteria para Análise de Independência Aditiva

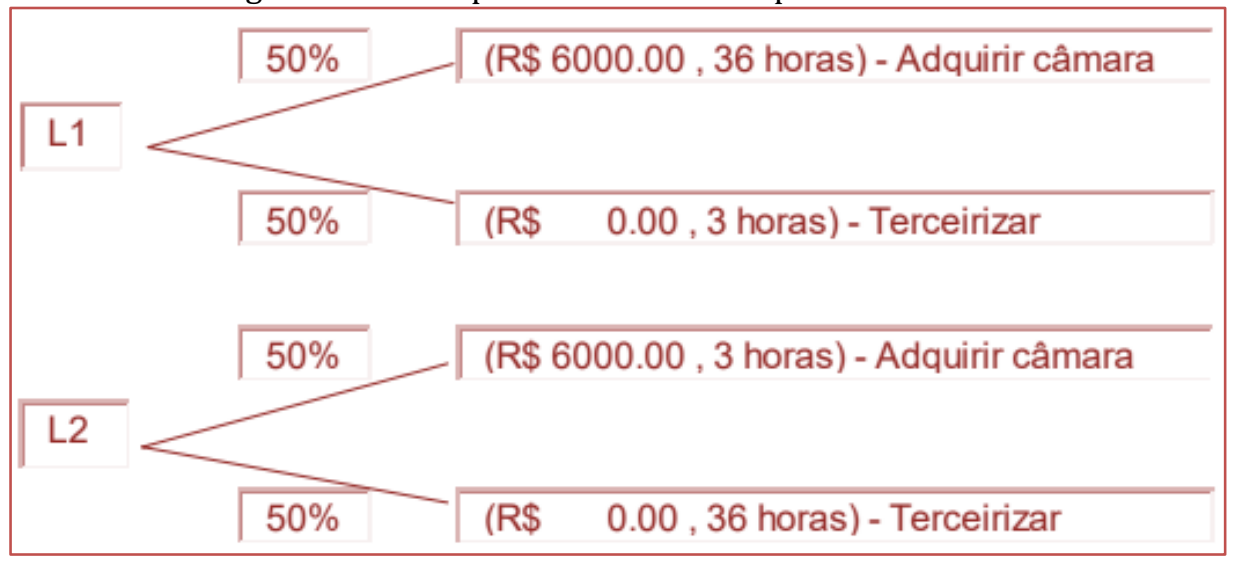

Neste problema, o decisor preferiu igualmente as duas loterias, sendo possível concluir que os dois atributos CUSTO e TEMPO DE ESPERA são aditivamente independentes, porque as preferências entre as loterias não dependem da distribuição de probabilidade conjunta CUSTO e TEMPO DE ESPERA. Como implicação direta, a função utilidade global para os dois atributos pode ser escrita por uma função aditiva do tipo (Teorema 5.1, Keeney \& Raiffa, página 231):

$$
\mathrm{U}(\mathrm{x}, \mathrm{y})=\mathrm{Ku}(\mathrm{x})+\mathrm{Ky}(\mathrm{u}(\mathrm{y})
$$

\subsection{AVALIANDO AS CONSTANTES DE ESCALA}

Prosseguindo com o processo de aplicação do método MAUT no problema da câmara de pressão negativa, foram escalonadas as duas funções individuais $\mathrm{u}(\mathrm{x})$ CUSTO e u(y) TEMPO DE ESPERA para assumirem os valores entre 0 e 1 . Resultados relevantes são:

$\mathrm{U}(\mathrm{x} 0, \mathrm{y} 0)=0, \mathrm{u}(\mathrm{x} 0)=0$ e $\mathrm{u}(\mathrm{y} 0)=0$, ou seja, $\mathrm{u}(0,3)=0, \mathrm{ux}(0)=\mathrm{uy}(3)=0$

$\mathrm{U}\left(\mathrm{x}^{*}, \mathrm{y}^{*}\right)=1, \mathrm{u}\left(\mathrm{x}^{*}\right)=1$ e $\mathrm{u}\left(\mathrm{y}^{*}\right)=1$, ou seja, $\mathrm{u}(6000,36)=1, \mathrm{ux}(6000)=\mathrm{uy}(36)=1$

$\mathrm{X}^{0} \leq \mathrm{x} \leq \mathrm{x}^{*}$ e $\mathrm{y}^{0} \leq \mathrm{y} \leq \mathrm{y}^{*}$

Um resultado importante é que $\mathrm{Kx}+\mathrm{Ky}=1$

Analisando a função aditiva para $\left(x^{*}, y^{0}\right)$ e $\left(x^{0}, y^{*}\right)$, respectivamente, tem-se:

$\mathrm{U}\left(\mathrm{x}^{*}, \mathrm{y}^{0}\right)=\mathrm{Kx}$ e $\mathrm{U}\left(\mathrm{x}^{0}, \mathrm{y}^{*}\right)=\mathrm{Ky}$, ou seja:

$\mathrm{U}(6000,3)=\mathrm{Kx}$ e $\mathrm{U}(0,36)=\mathrm{Ky}$

É possível descobrir qual é o maior: Kx ou Ky? Isso pode ser verificado perguntando para o decisor se ele prefere $\mathrm{U}\left(\mathrm{x}^{*}, \mathrm{y}^{0}\right)$ ou $\mathrm{U}\left(\mathrm{x}^{0}, \mathrm{y}^{*}\right)$. Se o primeiro for preferível então $\mathrm{Kx}>\mathrm{Ky}$, caso contrário, Ky $>\mathrm{Kx}$. Neste problema ao ser questionado sobre sua preferência entre $U(6000,3)$, ou seja, adquirir a câmara de pressão negativa e continuar atendendo seus pacientes no prazo de 3 horas ou $(0,36)$ não adquirir a câmara de pressão negativa sendo necessário portanto terceirizar a manipulação de todos os insumos referentes as classes terapêuticas: hormônios, antibióticos e citostáticos, levando um prazo aproximado de 36 horas, o decisor prefere a primeira opção, devido ao prazo de atendimento e confiabilidade no produto ser crucial para a empresa, além do diferencial da manipulação da classe terapêutica antibióticos na forma de tabletes para atender aos veterinários da região, que é hoje um diferencial da farmácia. Portanto, a constante Ky referente ao TEMPO DE ESPERA é superior ao CUSTO de aquisição da câmara de pressão negativa.

A probabilidade que deixa o decisor indiferente entre $\left(x^{*}, y^{0}\right)=(6000,3)$ é a loteria é pi $=0.7$. Pode-se concluir que $\mathrm{Kx}=\mathrm{pi}=0.7 \mathrm{ky}=0.3$. A função utilidade pode ser escrita como: $\mathrm{u}(\mathrm{x}, \mathrm{y})=0,7 \mathrm{u}(\mathrm{x})+0,3 \mathrm{u}(\mathrm{y})$. 


\subsection{CONFERINDO A CONSISTÊNCIA}

A checagem da função utilidade obtida nas etapas anteriores, procurou encontrar algum erro que significaria que a função utilidade que foi estimada para o decisor não representa suas verdadeiras preferências.

Para concluir esta etapa do processo, foi realizando perguntas ao decisor sobre suas preferências entre uma loteria e uma consequência qualquer entre duas loterias. Em ambos os casos a utilidade esperada da situação preferida foi sempre maior, portanto torna-se consistente a Função Utilidade estabelecida.

\section{CONCLUSÃO}

O principal objetivo da aplicação de um dos vários métodos analíticos do AMD não é fornecer uma solução ótima e única, mas uma sequência de ações consistentes para cada caso específico ou, simplesmente, apoiar o agente de decisão ao longo de seu processo decisório.

Obviamente, as variáveis envolvidas numa análise Multicritério como a conduzida neste trabalho devem mudar de acordo com a empresa e o produto em questão. Mas a forma de estruturar o problema e levantar os dados será basicamente a mesma. A aplicação desse modelo à empresa objeto de estudo mostrou os resultados que podem ser obtidos com o uso de uma metodologia analítica para apoiar o processo decisório. A aplicação da MAUT ensejou também maior aprendizado do decisor sobre o problema, seus valores e prioridades. Ambas as decisões envolviam subjetividades, tratadas por meio da metodologia AMD. Na impossibilidade de eliminar a subjetividade, ao explicitá-la através da modelagem do problema, garantiu-se maior transparência ao processo de decisão, o que é típico de aplicações dessa metodologia analítica (BELTON \& STEWART, 2002; GOMES et al., 2004; GOMES et al., 2006).

Neste trabalho, o agente de decisão não apresentou qualquer resistência em participar de todas as etapas do processo. A única etapa com maior dificuldade foi a entrevista e análise dos equivalentes certos, devido à distância física existente entre a analista e o decisor, isso porque, embora operacionalmente fácil de se aplicar, o procedimento de quantificar a preferência entre critérios não se mostrou tão intuitivo para o agente de decisão.

\section{REFERÊNCIAS}

[1] ALMEIDA, A.T. O conhecimento e o uso de métodos multicritério de apoio à decisão. 2 $2^{a}$ ed. Editora Universitária UFPE, 2011.

[2] ALMEIDA, A.T. \& COSTA, A.P.C.S. Aplicações com métodos multicritério de apoio a decisão. Editora Universitária, Recife, 2003.

[3] ANVISA - Agência Nacional de Vigilância Sanitária. Resolução RDC № 214, de 9 de fevereiro de 2007. Brasília (DF): Diário Oficial [da] República Federativa do Brasil; 9 fev. 2007.

[4] BARONS, M.J.; WRIGHT, S.K.; SMITH, J.Q. Eliciting Probabilistic Judgements for Integrating Decision Support Systems. In: Dias L., Morton A., Quigley J. (eds) Elicitation. International Series in Operations Research \& Management Science, Springer, Cham. v. 261, p. 445-478, 2018.

[5] BELTON, V. \& STEWART, T.J. Multiple criteria decision analysis: an integrated approach. Boston: Kluwer Academic Press, 2002.

[6] DONG, Y.; FRANGOPOL, D.M.; SABATINO, S. Optimizing Bridge Network Retrofit Planning Based on CostBenefit Evaluation and Multi-Attribute Utility Associated with Sustainability. Earthquake Spectra: vol. 31, n. 4, p. 22552280, 2015.

[7] FISHBURN, P. Utility Theory for Decision Making. Nova York: Wiley, 1970. GOMES, L.F.A.M. \& GOMES C.F.S \& ALMEIDA, A.T. Tomada de Decisão Gerencial: Enfoque Multicritério. Editora Atlas, 2aㅡ edição, Rio de Janeiro, 2006.

[8] GARMABAKI, A.H.S.; AHMADI, A.; AHMADI, M. Maintenance Optimization Using Multi-attribute Utility Theory. In: Kumar U., Ahmadi A., Verma A., Varde P. (eds) Current Trends in Reliability, Availability, Maintainability and Safety. Lecture Notes in Mechanical Engineering. Springer, p.13-25 2016.

[9] GOMES, L. F. A. M.; ARAYA, M. C. G.; CARIGNANO, C. Tomada de Decisões em Cenários Complexos. Rio de Janeiro: Pioneira Thomson Learning, 2004.

[10] KEENEY, R.L. \& RAIFFA, H. Decision with Multiple Objectives: Preferences and Value Trade-offs. John Wiley \& Sons. 1976. 
[11] MIRANDA, C.M.G.de \& ALMEIDA, A.T. Visão Multicritério da Avaliação de Programas de PósGraduação pela CAPES - 0 caso da Área de Engenharias III baseado nos Métodos ELECTRE III e MAUNT. Gestão da Produção, v. 11, n. 1, p. 51-64, 2004.

[12] SOUZA, F.M.C. Decisões racionais em situações de incertezas. Recife, ed. Universitária, 2002.

[13] VINCKE, P. Multicriteria decision-aid. Bruxelles: John Wiley\& Sons, 1992.

[14] ZELENY, M. Integrating Knowledge, Management and Systems. Palestra no REDS - Recife Decision Support School, 2008.

[15] RUSSELL, A.Ogle; SEAN, J.D.; BRENTON, L.C. Resolving inherently safer design conflicts with decision analysis and multi-attribute utility theory. Process Safety and Environmental Protection, v. 97, p. 61-69, 2015. 


\section{Capítulo 7}

Comunicação empresarial por meio da identidade visual: 0 processo de construção de uma nova logomarca para uma pequena empresa do ramo de papelaria

\section{Wledenir Calgaro}

Joiceli S. Fabrício

Jaiane Aparecida Pereira

Rosely Scheffer

Resumo: 0 objetivo do presente trabalho foi demonstrar como ocorreu o processo de construção de uma nova identidade visual para a Ideal Papelaria, uma pequena empresa do ramo de papelaria. Para isso, o referencial teórico discutiu questões sobre a comunicação empresarial e a identidade visual. Como procedimentos metodológicos adotou-se um estudo de caso de cunho qualitativo descritivo, realizado por meio de entrevista e observação. Como resultados, pode-se observar que pequenas mudanças podem refletir uma atualização para a empresa, sem contudo, onerar o empresário ou mudar totalmente sua identidade visual já consolidada. Por meio do briefing analisado, o empresário reiterou que a marca ficou mais leve, moderna e atraente. Essas pequenas mudanças também são importantes para frisar no cliente a imagem de que a empresa está evoluindo e acompanhando as tendências atuais. Ademais, discute-se a necessidade de desenvolver a identidade visual nas pequenas empresas, principalmente em ramos competitivos.

Palavras-chave: Identidade visual; comunicação empresarial; logotipo; marca. 


\section{INTRODUÇÃO}

A importância de estabelecer uma comunicação adequada com os stakeholders da empresa acentua-se à medida que as tecnologias da informação e da comunicação tornam o ambiente da maioria das organizações altamente competitivo. Embora a comunicação empresarial envolva a comunicação interna e a externa, a comunicação empresarial externa assume papel estratégico, uma vez que possibilita a interação com o ambiente e permite que as pessoas conheçam a identidade da organização (Bueno, 2003; Duarte \& Silva, 2007; Ferreira \& Malheiros, 2016).

Ainda que existam diversas formas de comunicação externa, ganha importância a identidade visual, também conhecida como identidade de marca, e a marca da empresa (Scherer \& Scherer, 2015). A identidade visual e a marca transmitem a imagem da organização ao público, o que pode ser usado para agregar valor a empresa e na construção da confiança desta com seus clientes.

Não é difícil encontrar empresas, hoje em dia, que possuem a marca como o ativo mais valioso em seu patrimônio. Conquistar tal realização não é tarefa fácil e muitas vezes nem faz parte do objetivo dos gestores, principalmente quando trata-se de pequenas empresas, que não possuem um departamento de marketing estruturado e, muitas vezes, não tem funcionários que possam se dedicar a este trabalho. Contudo, discute-se a necessidade de conscientizar as pequenas empresas sobre a relevância de ter uma marca consolidada no mercado. Isto porque "as pessoas se apaixonam pelas marcas, confiam nelas e acreditam em sua superioridade" (Wheeler, 2012, p. 12).

A confiança em uma marca ou em uma empresa podem atuar como diferencial em mercados competitivos, como o ramo de papelaria. Segundo o Serviço Brasileiro de Apoio às Micro e Pequenas Empresas [SEBRAE] (n.d.) o varejo de papelaria envolve a venda de papel, material escolar, acessórios de informática e artigos de escritório. Ele é atraente para pequenos empreendedores, pois a empresa pode ser montada em pequenos espaços e não exige grande experiência. A partir dos anos de 1990 as papelarias sofreram forte concorrência dos supermercados na oferta de material escolar e também com os governos estaduais e municipais comprando kits escolares direto na indústria. Além disso, há sazonalidade nesse mercado, pois nos meses de dezembro a março há um aumento expressivo da demanda (SEBRAE, n.d.).

Diante desse contexto, as papelarias tiveram que se adequar ao mercado e investir em novas formas de atrair os clientes. Uma das formas é a construção de uma apelo visual no sentido de transmitir a imagem da empresa e construir uma memória positiva na mente do consumidor. A empresa objeto de estudo está no mercado há 11 anos e o empreendedor compreende a necessidade de trabalhar sua identidade visual ou de marca. Portanto, o presente trabalho tem por objetivo demonstrar como ocorreu o processo de construção de uma nova identidade visual para a Ideal Papelaria.

Para alcançar o objetivo proposto, o referencial teórico aborda discussões sobre comunicação empresarial, identidade visual e marca. Depois apresentam-se os procedimentos metodológicos. Em seguida, são expostas a descrição e análise dos dados, culminando com as conclusões do estudo.

\section{COMUNICAÇÃO EMPRESARIAL E IDENTIDADE VISUAL}

A comunicação é parte inerente à natureza as organizações, pois essas são formadas por pessoas que se comunicam entre si e interagem, viabilizando o sistema funcional para sobrevivência e consecução dos objetivos da empresa (Kunsch, 2006). A comunicação torna comum uma realidade, informação, ideia, pensamento ou atitude, por meio de um conjunto de elementos: emissor ou fonte, receptor ou destinatário, mensagem, canal e objetivo (Thayer, 1976, Torquato, 1985).

A comunicação empresarial, pode ser vista como "a somatória de todas as atividades de comunicação da empresa. Elaborada de forma multidisciplinar - a partir de métodos e técnicas de relações públicas, jornalismo, lobby, propaganda, promoções, pesquisa e marketing - e direcionada à sociedade, formadores de opinião, consumidores e colaboradores" (Nassar \& Figueiredo, 1995, p. 19).

A comunicação empresarial pode ser interna, atrelada as mensagens veiculadas internamente e externa, que relaciona-se ao marketing da empresa (Bueno, 2003; Ferreira \& Malheiros, 2016). Na comunicação interna, também conhecida como institucional, ocorre a construção de um universo simbólico aliado às políticas de recursos humanos, que visa integrar o público interno aos princípios e objetivos centrais da organização (Bueno, 2003; Curvello, 2012). Na comunicação externa, também conhecida como comunicação mercadológica, incluem-se todo tipo de veiculação de informações e todos os comunicados 
emitidos pela organização para o público externo ou uma opinião pública fora dos limites internos (Bueno, 2003).

De forma geral, a empresa precisa ter clareza sobre alguns aspectos na hora de expor alguma informação, como o objetivo da informação, o público-alvo e os meios certos (canal) para atingir tal objetivo (Bahia, 1995). Isto porque, o processo de comunicação é complexo e existem diversos problemas de comunicação nas empresas.

Embora a comunicação interna seja importante para a empresa, a comunicação externa toma maiores proporções, pois liga a empresa aos seus clientes (Ruão, 1999). No caso da pequena empresa, discute-se que a comunicação interna pode ser facilitada pela proximidade entre as pessoas, o que não ocorre com a comunicação externa.

Alguns tipos de comunicação externa podem impactar, positiva ou negativamente, na imagem de uma organização como matérias de jornais impressos, televisão ou publicações online em redes sociais (Nassar \& Figueiredo, 1995). Para os autores a comunicação empresarial pode se utilizar de diversas linguagens, que nem sempre terão como objetivo direto a divulgação de um produto. Os diversos tipos de comunicação empresarial podem significar a simpatia da sociedade, a fidelidade dos consumidores e um bom relacionamento com trabalhadores, governos e sindicatos (Nassar \& Figueiredo, 1995).

Nassar e Figueiredo (1995) afirmam que uma comunicação empresarial adequada é condição primária para uma boa imagem da empresa. A imagem, por sua vez, envolve vários aspectos como a identidade corporativa. A identidade corporativa é definida como o conjunto de atributos característicos de cada empresa, por meio destes atributos pode se diferenciar uma empresa da outra, tornando-a única (Fascioni, 2004).

Esses atributos podem ser divididos em dois tipos: essenciais e acidentais (Fascioni, 2004). Para o autor, os atributos essenciais definem a identidade da empresa, enquanto que os atributos acidentais descrevem a empresa em um determinado momento, mas estes, podem mudar sem comprometer sua identidade. Os atributos contribuem para a formação da imagem corporativa. A imagem está relacionada a percepção externa da empresa, sendo construída a partir das ações e da política de comunicação da empresa (Fascioni, 2004).

Considerando que a interpretação da imagem corporativa é subjetiva, uma maneira de reforçar a mensagem a ser transmitida na imagem corporativa é trabalhar veementemente a identidade corporativa da empresa. A identidade visual é uma das formas de se transmitir uma imagem corporativa. Caracterizase identidade visual, segundo Strunck (1989), como o conjunto de elementos gráficos que formalizarão a personalidade visual de um nome, ideia, produto ou serviço.

As identidades visuais são um instrumento fundamental nas políticas de marketing das empresas. São a expressão de sua individualidade e a garantia de responsabilidade perante a sociedade. Cuidadosamente criadas e implantadas, traduzem exatamente a forma pela qual as empresas gostariam de ser vistas por seus públicos externo, seus clientes e fornecedores, e interno, os que nela trabalham (Strunck, 1989, p. 44).

Para configurar de maneira objetiva a identidade visual de uma empresa, deve-se estabelecer um Sistema de Identidade Visual (SIV) ou Programa de Identidade Visual (PIV) (Peón, 2003; Scherer \& Scherer, 2015). Esse sistema é formado pelos elementos básicos da identidade visual, a saber: logotipo, símbolo, marca, cores institucionais e o alfabeto institucional. Além disso, existem outros eventuais elementos acessórios que são aplicados em itens específicos, como material de papelaria, letreiros, uniformes, sinalização, embalagens, gráfica ambiental, entre outros (Peón, 2003).

O logotipo, o símbolo e a marca são elementos primários fundamentais para o funcionamento do sistema (Péon, 2003). Os elementos são definidos da seguinte maneira:

Símbolo: Um sinal gráfico que substitui o registro de nome da instituição. Logotipo: A forma particular e diferenciada com a qual o nome da instituição é registrado nas aplicações. Marca: 0 conjunto formado pelo símbolo e pelo logotipo, normatizado quanto à posição de um relacionado ao outro e a proporção entre eles (Peón, 2003, p. 28).

Dentre esses elementos, observa-se a importância da marca, que é a união de atributos tangíveis e intangíveis. Esses atributos gerenciados de forma adequada criam influência e geram valor (Martins, 2006). Para gerenciar a marca surge o conceito de branding, que pode ser visto como o conjunto de ações ligadas à administração das marcas. São ações que, se desenvolvidas com conhecimento e competência, 
podem levar as marcas para além da sua natureza econômica, passando a fazer parte da cultura (Martins, 2006).

Wheeler (2012) discute que deve-se considerar os pontos de contato da marca, como embalagens, exposições, e-mails, publicações, banners, papel timbrado, cartões de visita, veículos, serviços, produtos, funcionários, palestras, blogs, mídias sociais, propaganda, entre diversos outros.

Quando se trata de criar ou atualizar uma marca, algumas ferramentas são essenciais, como o briefing. 0 briefing pode ser visto de forma sucinta como a descrição da tarefa, envolvendo o projeto como um todo, incluindo formato, tamanho, prazos, objetivos, requisitos técnicos e público-alvo (Philips, 2007).

Sendo assim, de forma geral, pode-se entender a complexidade de formação de uma identidade visual e o todo que ela representa.

\section{PROCEDIMENTOS METODOLÓGICOS}

Este trabalho se caracterizou como um estudo de caso de cunho qualitativo descritivo (Yin, 2005) na tentativa de demonstrar como ocorreu o processo de construção de uma nova identidade visual para a Ideal Papelaria.

A abordagem qualitativa tem sido utilizada em estudos relativos à compreensão da vida humana em grupos. Como definição, pode-se dizer que constitui-se num enfoque naturalístico e interpretativo da realidade (Denzin \& Lincoln, 2005).

Foram coletados dados secundários e primários. Os dados secundários foram obtidos por meio de documentos internos da empresa. Os dados primários envolveram entrevista semi-estruturada, fotos e observação. A entrevista foi realizada com o proprietário da empresa in loco no mês de Outubro de 2017. Foi indagado sobre os objetivos da empresa e sobre a identidade visual que ele gostaria de passar aos seus stakeholders, incluindo dados sobre o público-alvo e sobre seus concorrentes.

A partir disso, foi desenvolvida uma proposta de elaboração de um briefing, com os seguintes passos: elaboração do briefing, desenvolvimento dos possíveis materiais gráficos e apresentação da nova logomarca. 0 material foi desenvolvido com o auxílio de uma agência de publicidade, especializada na elaboração de materiais gráficos. Por fim, o material foi apresentado ao proprietário da empresa como sugestão de melhoria para a identidade visual da papelaria.

\section{DESCRIÇÃO E ANÁLISE DOS DADOS}

A descrição e análise dos dados apresenta, primeiramente, uma breve descrição sobre a empresa, bem como da identificação visual adotada por ela antes da sugestão de melhoria. Depois, foi elaborado o briefing para a atualização da logomarca, bem como sugestões de aplicação para o modelo desenvolvido.

A empresa em questão está localizada na cidade de Palmital, região centro-sul do estado do Paraná, sul do Brasil. O município possui uma população estimada de 14.189 pessoas (IBGE, 2017). A economia no município é baseada na pecuária de leite e corte (IPARDES, 2018).

A papelaria foi fundada em 2006 e possui um funcionário. Existem apenas um concorrente direto, porém destaca-se que existem cinco supermercados na cidade que também comercializam esse tipo de produtos, caracterizando-se como concorrente indireto. Vale destacar também que a internet é um forte concorrente.

Além de produtos de papelaria, a empresa comercializa artigos para escritório, presentes, decoração, lan house e diversos artigos voltados para a linha gospel. O público-alvo da empresa são estudantes das escolas próximas. Neste nicho se encontram os principais clientes.

Sua localização é privilegiada, no centro da cidade. Segundo o entrevistado o objetivo da empresa é fornecer produtos de qualidade para um público mais exigente.

Diante dos itens que compõe a identidade visual da empresa, observou-se que o entrevistado compreende a necessidade de divulgação de uma imagem que a represente. No entanto, constatou-se a necessidade de mudança da logomarca, pois desde a fundação da empresa é constante o investimento em atualizações neste sentido. Aliado a isso, destaca-se que a comunicação externa utilizada não reflete o objetivo da empresa, o que é recomendado por diversos autores como Kunsch (2006) e Wheeler (2012). 
Na figura 1 são mostrados diversos elementos que refletem a identidade visual adotada pela empresa, incluindo a fachada e o cartão de visita.

Figura 1 - Identidade visual usada pela empresa

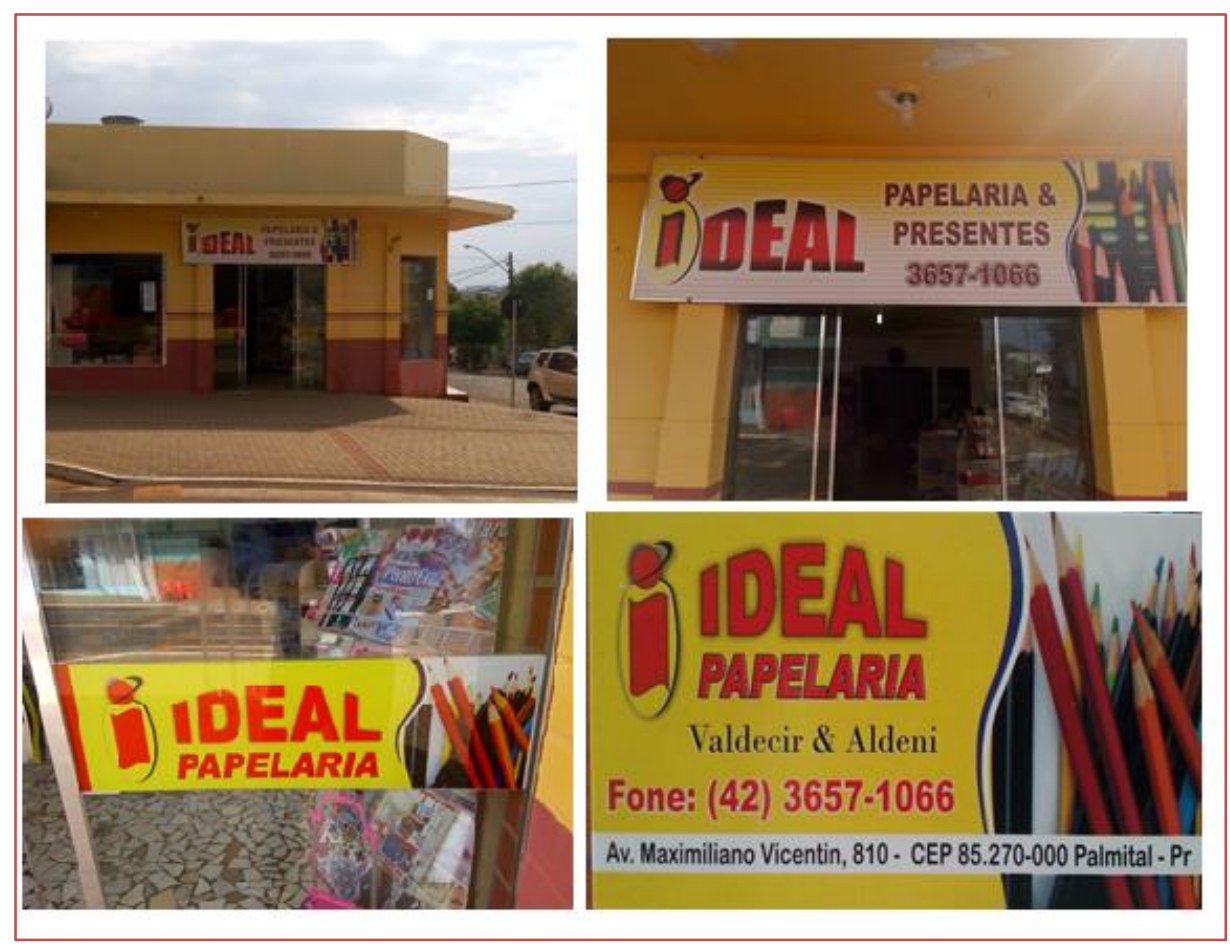

A partir da importância da identidade visual, foi proposta uma tentativa de atualização no símbolo e no logotipo da marca. Apesar da necessidade de mudança, reitera-se que o nome da empresa é conhecido no município e, por isso, a nova proposta precisa estar vinculada ao nome e as cores já consolidadas.

\subsection{PROPOSTA PARA ATUALIZAÇÃO DA IDENTIDADE VISUAL DA EMPRESA}

Com base nos dados descritos, principalmente o objetivo da empresa, público-alvo e análise dos concorrentes, foi desenvolvida uma primeira proposta de logomarca.

Na figura 2 são mostradas quatro propostas de logomarca para a empresa.

Figura 2 - Propostas de logotipo e símbolo

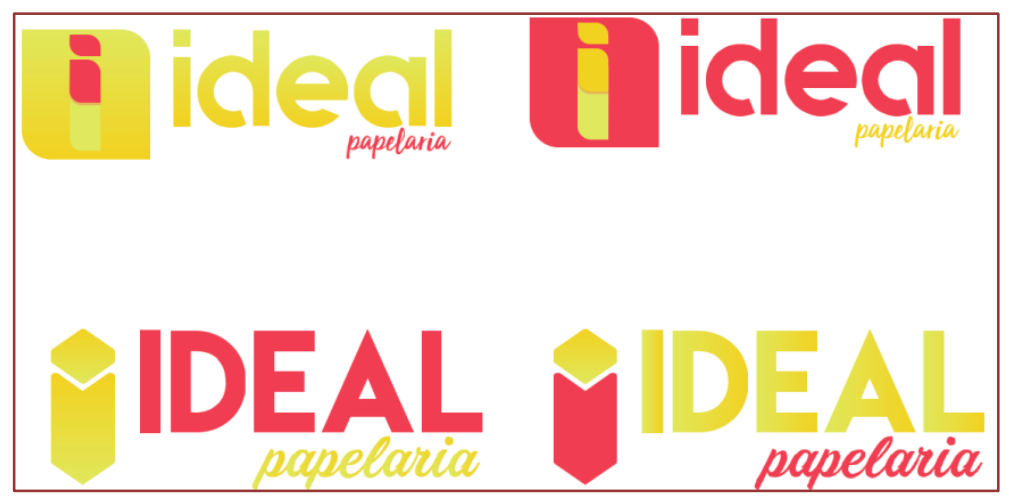


Observa-se na proposta que as cores não foram completamente mudadas, devido ao conhecimento que a marca já possui na mente do consumidor. Contudo, novos contornos foram inseridos visando uma modernização. Esses modelos foram apresentados ao empresário para que ele pudesse analisar se houve identificação da imagem com a empresa.

A escolha foi pela quarta opção, pois o empresário acredita que o logotipo e o símbolo ficaram claros e refletem a imagem da empresa. A partir da escolha foram desenvolvidos vários materiais que podem ser utilizados para refletir a identidade visual da empresa.

As aplicações mais frequentes, segundo Strunck (2001), são em impressos, identificação das instalações, viaturas, uniformes, sinalização, embalagens, produtos, assinatura de publicidade, estandes, brindes e material do ponto de venda. Na figura 3 são expostas as possíveis aplicações que podem ser adotadas pela empresa em questão, considerando o material já utilizado por ela.

Figura 3 - Possíveis aplicações da logomarca

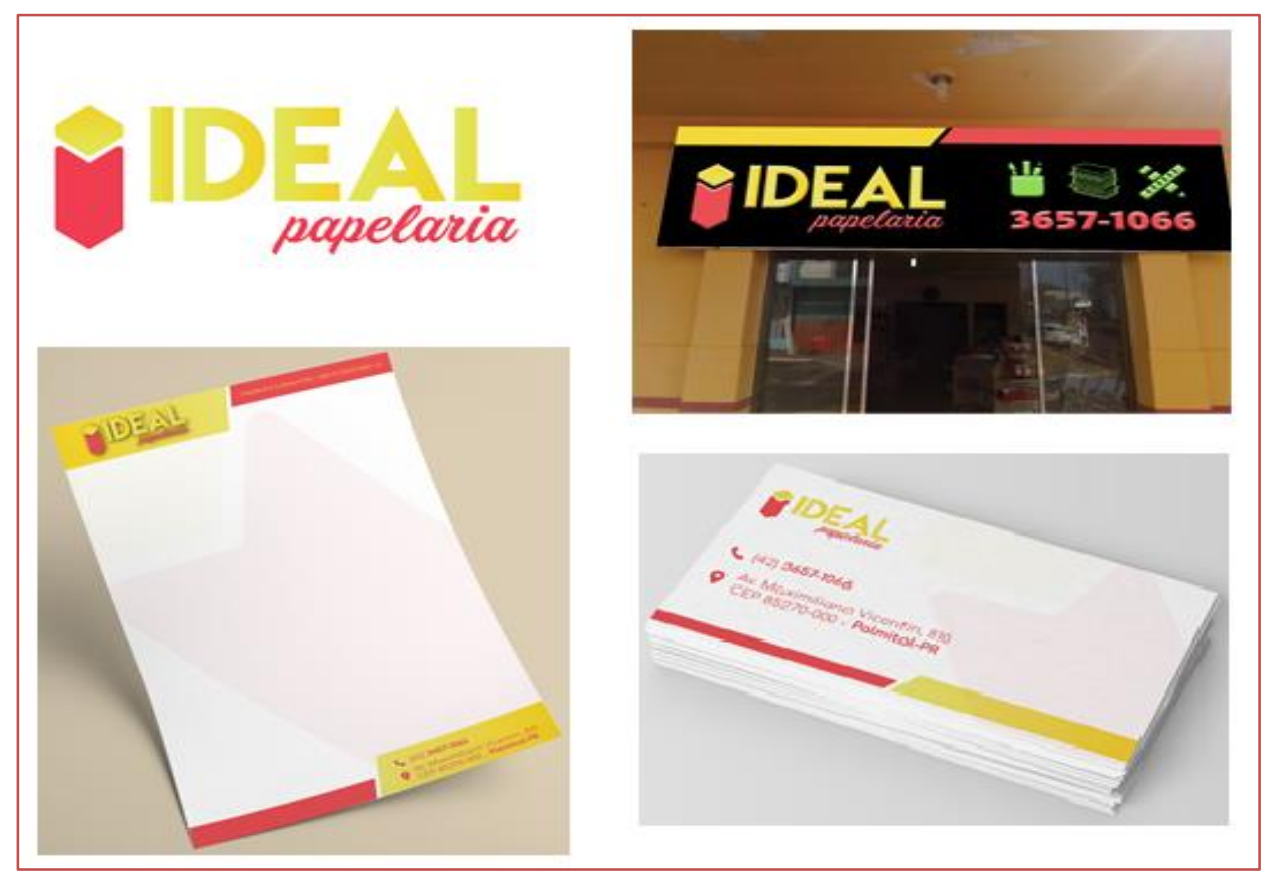

Pode-se notar que houve uma atualização da logomarca, contudo não foi perdido o vínculo com a marca já consolidada. Ressalta-se, finalmente, que foram cumpridos todos os prazos desde a elaboração do briefing até a entrega do material final, conforme sugere Philips (2007).

\section{CONCLUSÃO}

A comunicação empresarial adequada, que consegue transmitir da maneira mais clara possível a imagem que a organização quer reconhecida pelo seu público é tema recorrente na literatura, todavia a maioria dos estudos que tratam da identidade visual e da marca tem o foco nas grandes empresas (Galão \& Crescitelli, 2015; Corrêa, Vieira \& Scharf, 2016).

A partir da constatação da necessidade de desenvolver a identidade visual nas pequenas empresas, principalmente em ramos competitivos como o da papelaria, o presente estudo que teve por objetivo demonstrar como ocorreu o processo de construção de uma nova identidade visual para a Ideal Papelaria, contribuiu para reflexão sobre a necessidade de mudanças na imagem das empresas.

Como resultados, pode-se observar que pequenas mudanças podem refletir uma atualização para a empresa, sem contudo, onerar produndamente o empresário ou mudar totalmente sua identidade visual já consolidada. Por meio do briefing analisado, o empresário reiterou que a marca ficou mais leve, moderna e atraente. Essas pequenas mudanças também são importantes para frisar no cliente a imagem de que a empresa está evoluindo e acompanhando as tendências atuais. 
Por fim, destaca-se que, no decorrer do trabalho surgiram questões adicionais, que podem ser desenvolvidas em estudos posteriores, como por exemplo, acompanhar os clientes da empresa para saber como as mudanças impactaram em suas percepções. Além disso, sugere-se o acompanhamento do processo de construção de outras marcas, tanto em novas empresas, quanto naquelas que precisam de atualização.

\section{REFERÊNCIAS}

[1] Bahia, B. J. (1995). Introdução à Comunicação Empresarial. Rio de Janeiro: Mauad.

[2] Bueno, W. C. (2003). Comunicação Empresarial: teoria e prática. São Paulo: Manole.

[3] Corrêa, P. S. A., Vieira, F. G. D., \& Schart, E. R. (2016). Acta Scientiarum. Human and Social Sciences, 38, 1, pp. 13-24.

[4] Curvello, J. J. A. (2012). Comunicação interna e cultura organizacional. São Paulo: Casa das Musas.

[5] Denzin, N. K., \& Lincoln, Y. S. (2005). Handbook of Qualitative Research. (3a ed.). Califórnia.

[6] Duarte, J., \& Silva, H. D. (2007). Política de comunicação e gestão empresarial: a experiência da EMBRAPA. Organicom, 4, 6.

[7] Fascioni, L. (2004). Quem sua empresa pensa que é? Revista Amanhã, 205, 19. Nov.

[8] Ferreira, P., \& Malheiros, G. (2016). Comunicação Empresarial: planejamento, aplicação e resultados. Atlas, 05. VitalBook file.

[9] Galão, F. P., \& Crescitelli, E. (2015). Planejamento e implantação da comunicação de Marketing: uma análise comparative entre teoria e prática. REGE, 22, 3, pp. 435-452.

[10] Instituto Paranaense de Desenvolvimento Econômico e Social. (2018). Caderno Estatístico Municipio de Palmital. $\quad$ Recuperado $\quad$ em $\quad 16 \quad$ abril http://www.ipardes.gov.br/cadernos/MontaCadPdf1.php?Municipio=85270

[11] Instituto Brasileiro de Geografia e Estatística. (2017). IBGE Cidades. Recuperado em 16 abril 2018, de https://cidades.ibge.gov.br/brasil/pr/palmital/panorama

[12] Kunsch, M. M. K. (2006). Comunicação organizacional: conceitos e dimensões dos estudos e das práticas. In M. Marchiori (Org.). Faces da cultura e da comunicação organizacional (pp. 167-190). São Caetano do Sul: Difusão Editora.

[13] Martins, J. R. (2006). Branding: um manual para você criar, avaliar e gerenciar marcas. (3a ed.). São Paulo.

[14] Nassar, P., \& Figueiredo, R. (1995). O que é Comunicação Empresarial. São Paulo: Brasiliense.

[15] Peón, M. L. (2003). Sistemas de Identidade Visual. (3a ed.). Rio de Janeiro: 2AB.

[16] Philips, P. L. (2007). Briefing: a gestão do projeto de design. São Paulo: Blucher.

[17] Ruão, T. (1999). A Comunicação Organizacional e a Gestão de Recursos Humanos: evolução e atualidade. Cadernos do Noroeste, 12, 1-2, pp. 179-194.

[18] Scherer, F. V., \& Sherer, G. B. (2015). Estudo de método projetual para Sistema Integrado de Identidade Visual, design da informação e orientação. Infodesign - Revista Brasileira de Design da Informação, 12, 2, p. 171-193.

[19] Serviço Brasileiro de Apoio às Micro e Pequenas Empresas. (n.d.). Como montar uma papelaria. Recuperado em 16 abril, 2018, de http://www.sebrae.com.br/sites/PortalSebrae/ideias/como-montar-umapapelaria,f3987a51b9105410VgnVCM1000003b74010aRCRD

[20] Strunck, G. L. (1989). Identidade Visual: a direção do olhar. Rio de Janeiro: Europa.

[21] Strunck, G. L. (2001). Como criar identidades visuais para marcas de sucesso. (2a ed.). Rio de Janeiro: Rio Books.

[22] Thayer, L. (1976). Comunicação: fundamentos e sistemas. São Paulo: Atlas.

[23] Torquato, F. G. R. (1985). Comunicação empresarial/Comunicação institucional: conceito, estratégias, sistemas, estrutura, planejamento e técnicas. São Paulo: Summus Editoral.

[24] Wheeler, A. (2012). Design de Identidade da Marca. (3a ed.). Porto Alegre: Bookman.

[25] Yin, R. K. (2005). Estudo de caso: planejamento e métodos. (3a ed.). Porto Alegre: Bookman. 


\section{Capítulo 8}

\section{Estratégia de operações: Um estudo de caso em uma microempresa varejista em Tangará da Serra - MT}

\section{Lidiane da Silva Souza Angola \\ Camyla Piran Stiegler Leinter \\ Josiane Silva Costa dos Santos \\ Juscelaine de Fátima Rodrigues Moreira}

Resumo: A pesquisa tem como objetivo identificar se existe uma estratégia de operações e serviços que oriente as atividades de uma empresa do segmento de comércio varejista, sendo enquadrada como um supermercado. Trata-se de pesquisa descritiva e explicativa, quanto aos meios, estudo de caso e possui abordagem quantitativa de dados. A amostra compreendeu 290 clientes pesquisados em suas residências, através do sorteio de quarteirões e a empresária da organização. 0 intrumento de coleta de dado utilizados foi questionário estruturado fechado. Foi possível identificar, que não existe uma estratégia formalizada na entidade comercial, as ideias são discutidas e observadas de forma a colocar em pratica a que melhor se adequar a algum momento ou cenário. Comumente a empresa coloca em risco as suas operações e serviços, uma estratégia de operações e serviços formalizados podem orientar o negócio da empresa. Dessa forma, a utilização de uma estratégia de operações aumentará a vantagem competitiva sustentável na empresa, que além da adequação das estruturas organizacionais ás estratégias, deve trabalhar continuamente o processo de feedback, de forma que a função produção seja um plano de ação, afim de orientar as atividades da empresa.

Palavras-chave: Prioridade competitiva, operaç̃es e serviços, requisitos de mercado. 


\section{INTRODUÇÃO}

No Brasil e no mundo o varejo vem assumindo importância crescente no panorama empresarial e a medida que as empresas varejistas se expandem, passam a adotar avançadas tecnologias de informação e de gestão desempenhando papel cada vez mais importante na modernização do sistema de distribuição e da economia brasileira (PARENTE, 2000).

A estratégia de produção consiste em um conjunto de decisões e ações elaboradas e implementadas pela função produção nas áreas de decisão para que as prioridades competitivas possam ser atingidas (SLACK; LEWIS, 2009). 0 aumento da competitividade nos diferentes mercados devido à globalização da economia e as mudanças tecnológicas tem conduzido as empresas a adotarem uma estratégia para enfrentar os novos desafios e novas necessidades dos clientes. A estratégia de produção deve definir o segmento de mercado a ser atingindo pela empresa assim como as bases para estabelecer e manter uma vantagem competitiva sobre os competidores (CARIDADE; TORKOMIAN, 2001).

Nesse sentindo, a produção tem o papel de orientar as funções como marketing, finanças, pessoal entre outras com o propósito de evitar problemas relacionados ao funcionamento da empresa (SLACK; LEWIS, 2009). Pois um sistema de produção abrange escolhas que definem uma alternativa competitiva e que deve estar de acordo com os objetivos estratégicos da organização, no sentido de que a função produção não deve apenas servir, deve servir bem (LUSTOSA; MESQUITA; OLIVEIRA, 2008)

Para tanto a pesquisa tem como problema: Existe uma estratégia de operações e serviços que oriente as atividades da empresa? Com o objetivo de identificar se existe uma estratégia de operações e serviços que oriente as atividades da empresa do segmento de comércio varejista, sendo enquadrada como um supermercado. E mais especificamente: levantar quais os critérios competitivos que possuem maior relevância para os clientes da empresa analisada e; estruturar a estratégia de operações e serviços adequada à empresa.

Esta pesquisa justifica-se em razão da necessidade de contribuir para o aperfeiçoamento da administração da empresa no segmento varejista, podendo ser usado como instrumento de estratégia de operações. Pois, na elaboração da estratégia de operações e serviços é importante saber quais são os alvos competitivos, se eles se baseiam nos produtos, serviços; descobrir quais são os fatores para participar de um determinado mercado; e identificar os fatores decisivos da escolha do cliente.

\section{REVISÃO BIBLIOGRÁFICA}

\subsection{ESTRATÉGIA DE OPERAÇÕES}

O produto produzido ou o serviço prestado constitui o resultado final de todas as operações da empresa, pois, a produção é a função central nas organizações uma vez que a mesma, irá se encarregar de alcançar o objetivo principal da empresa, ou seja, sua razão de existir (SLACK; LEWIS 2009). Com o adequado gerenciamento das operações físicas da empresa as performances dos recursos produtivos são melhoradas envolvendo: homens, máquinas, materiais, tecnologia, sistema de administração - em qualquer atividade econômica (VEIGA; VICENTE, 1999).

A estratégia de produção refere-se a um padrão de decisões ligadas a função produção, que devem ser tanto coerentes com a estratégia competitiva da empresa, como com as outras funções administrativas que compõe (marketing, recursos humanos, setor financeiro etc.), considerando também as competências internas da função produção como instalações, capacidade, tecnologia, integração vertical, organização e planejamento, força de trabalho, suprimentos entre outras (KAPLAN; NORTON, 1997).

Além destas, outras atividades são diretas na função produção, são elas: Entender os objetivos estratégicos da produção, desenvolver uma estratégia de produção para a organização, desenhar produtos, serviços e processos de produtividade, planejar, controlar e melhorar o desempenho da produção (SLACK; LEWIS, 2009). A Figura 1 apresenta como a estratégia de produção deve ser planejada. 
Figura 1 - Perspectiva da estratégia de produção

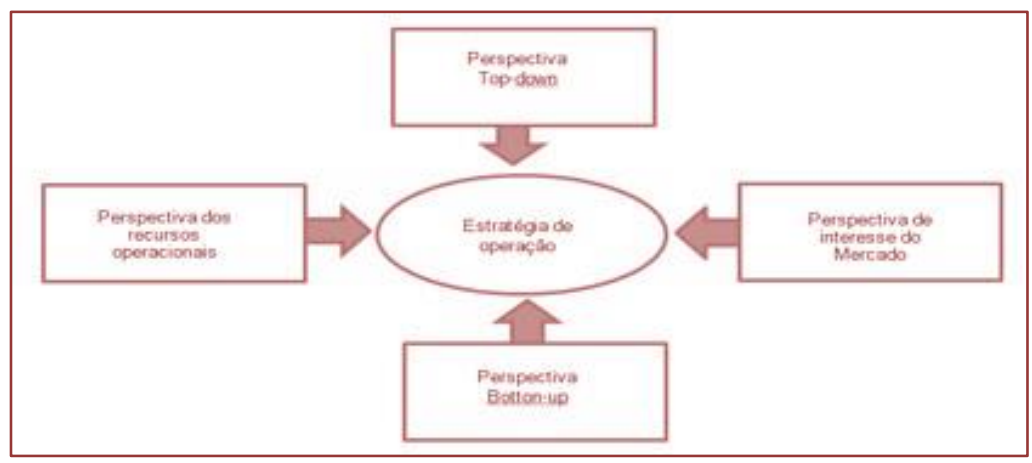

Fonte: Adaptado de Slack, Chambers e Johnston (2002)

A estratégia da produção pode ser considerada com um reflexo "de cima para baixo" (top-down) ou "de baixo para cima" (bottom-up) do que o grupo ou negócio todo deseja fazer, em que as melhorias da produção cumulativamente constroem a estratégia. Assim, a mesma envolve traduzir os requisitos do mercado em decisões da produção e ainda explorar as capacidades de recursos da produção em mercados eleitos (SLACK; LEWIS, 2009).

Ainda segundo o autor a função produção contribui para se atingir a ideia de vantagem baseada em produção através de cinco objetivos de desempenho conforme demonstrado no Quadro 1:

Quadro 1 - Objetivos de desempenho da produção

\begin{tabular}{|c|l|}
\hline \multicolumn{1}{|c|}{ Qualidade } & \multicolumn{1}{|c|}{$\begin{array}{r}\text { Fazer certo na primeira vez, isto é, não cometer erros. Se a produção for bem sucedida em } \\
\text { proporcionar isso, a empresa ganhará em qualidade. }\end{array}$} \\
\hline Rapidez & $\begin{array}{l}\text { Fazer as coisas com rapidez, minimizando o tempo entre o consumidor solicitar os bens de } \\
\text { serviços e recebê-los. Com isso, a empresa ganhará em rapidez. }\end{array}$ \\
\hline Confiabilidade & $\begin{array}{l}\text { Fazer as coisas em o tempo para manter os compromissos de entrega assumidos com os } \\
\text { consumidores. Se a produção fizer isso, proporcionará aos consumidores vantagem de } \\
\text { confiabilidade. }\end{array}$ \\
\hline Flexibilidade & $\begin{array}{l}\text { Estar em condições de mudar rapidamente para atender as exigências dos consumidores. } \\
\text { Fazendo isso, a empresa ganha vantagem competitiva em flexibilidade. }\end{array}$ \\
\hline Custo & $\begin{array}{l}\text { Fazer as coisas o mais barato possível, produzindo bens e serviços a custo que possibilite } \\
\text { fixar preços apropriados ao mercado e ainda permitir retorno para a organização, } \\
\text { representando vantagem e custo aos consumidores. }\end{array}$ \\
\hline
\end{tabular}

Fonte: Adaptado Slack (2009)

A avaliação da organização segundo esses fatores (Quadro 1) permite a elaboração de estratégias focadas para a melhoria do posicionamento competitivo da organização. Uma estratégia produtiva consiste na definição de um conjunto de políticas, no âmbito da função produção, que dá sustentação à posição competitiva da empresa. Uma vez que a mesma deve especificar como a produção surpotará uma vantagem competitiva e como complementará e apoiará as demais estratégias funcionais (LUSTOSA; MESQUITA; OLIVERA, 2008).

A perspectiva dos recursos de produção, de acordo com Slack (2009) é compreender e desenvolver seus recursos de produtividade, embora muitas vezes negligenciado, é uma perspectiva particularmente importante para a estratégia de produção. As decisões devem ser tomadas analisando:

Restrições e capacidade de recursos: em certos negócios, identifica restrições de alguns mercados, mas também identifica competências que podem ser exploradas em outros mercados e; Recursos e processos de produção: é o composto dos recursos intangíveis, que uma operação produtiva necessita dispor para satisfazer a seus mercados desenvolvendo capacidades adequadas dentro de seus recursos e processos. 


\section{METODOLOGIA}

A pesquisa caracteriza quanto aos fins como descritiva e explicativa, quanto aos meios, estudo de caso e possui abordagem quantitativa de dados. A pesquisa descritiva e explicativa tem como principal objetivo esclarecer algo, justificar os motivos e quais fatores contribuem, de alguma forma para a ocorrência de um determinado fenômeno (GIL, 2010) e estudo de caso por se caracterizar em uma pesquisa especifica que consiste em um estudo profundo e exaustivo de um ou poucos objetos de uma unidade que se analisa profundamente, a fim de identificar sua identidade própria (GIL, 2010; RODRIGO 2008). Já a abordagem quantitativa busca quantificar os dados coletados utilizando-se de método de técnicas estatísticas (RICHARDSON, 2012).

O universo compreendeu as residências cadastradas no município de Tangará da Serra-MT, de acordo com o órgão de infraestrutura do município, dos bairros que são vizinhos da empresa estudada, totalizando 1.183 residências nos seguintes bairros e quantidade de casas: Jardim Eldorado 159, Jardim Mirante 156, Jardim Pomares 94, Jardim Santiago 253, Jardim São Cristóvão 49, Jardim Santa Izabel 107, Jardim 13 de maio 265, Residencial Horizonte 72, Vila Horizonte 358 e Jardim São Paulo 41.

A amostra classifica-se como probabilística, pois foi composta de 290 pessoas que apresentou um nível de confiança de $95 \%$ e margem de erro de $5 \%$. Utilizou-se um processo de amostragem por área em um estágio, ao longo dos dias uteis do mês de maio 2016, distribuídos entre os períodos matutinos e vespertinos.

A amostragem por área em um estágio compreende os seguintes passos: 1. Listar e numerar todos os quarteirões de uma cidade (população de quarteirões $=n q$ ); 2 . Sortear uma amostra aleatória simples ou sistema de tamanho nq da população de nq da população de Nq quarteirões; 3 . Coletar dados de todas as residências do nq quarteirões sorteados. Este é um procedimento de amostragem probabilística. Todos os elementos da população (residências) tem a mesma probabilidade de $\mathrm{nq} / \mathrm{Nq}$ de serem selecionados, pois todas as residências dos quarteirões sorteados são pesquisadas (MATTAR, 2007, p.152).

Os instrumentos de coleta utilizados foram: Para a coleta de informações junto á proprietária da entidade comercial, um questionário estruturado fechado com 10 perguntas quanto aos: objetivos da organização, estratégia de marketing, infraestrutura e estrutura e; para a coleta de informações juntamente aos clientes, um questionário estruturado fechado.

\section{DISCUSSÃO DOS RESULTADOS}

A empresa em estudo, caracterizada como uma empresa familiar, que foi fundada em 1.997 na cidade de Tangará da Serra - MT, atua no segmento de comércio varejista, sendo enquadrado como um supermercado compacto, se destaca por ser um mercado de bairro, ofertando produtos de mercearia nos setores de biscoitos, massas e pães, festas (descartáveis), bazar (utilidades), perfumaria (higiene pessoal), limpeza, condimentos, cereais, bebidas, frios, laticínios, hortifrútis e açougue.

Desde sua fundação, passou por várias alterações na sua estrutura e na forma de atuar no mercado. É neste ambiente, acrescido de particular competência técnica da empresa em querer interpretar as necessidades dos clientes e no momento em que a alta direção está sensibilizada a definir estratégias para a empresa, que se justifica a pesquisa, ou seja, a prática da estratégia operacional, sendo de extrema importância nas organizações que buscam um posicionamento competitivo.

A seguir são apresentados a visão dos clientes com relação a empresa em estudo. 
Figura 2 Há quanto tempo o cliente compra na empresa.

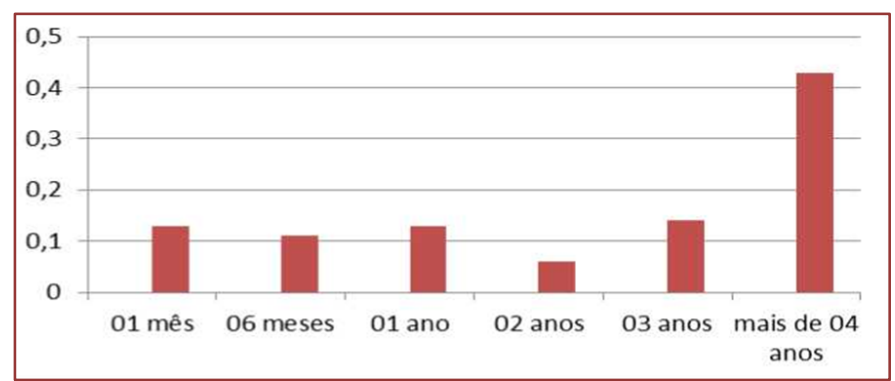

Fonte: Dados da pesquisa (2016)

Constatou-se que 13\% dos entrevistados são clientes de 01 mês, enquanto 11\% são clientes no período de 06 meses (Figura 2). Os clientes com 01 ano correspondem a 13\%, no período de 02 anos há uma baixa para 6\%. Desta forma, é importante observar o ciclo do serviço no estabelecimento para analisar o que ocorre e porque diminui a parcela de clientes no intervalo de 01 ano para 02 anos. A partir de 03 anos esse percentual corresponde a $14 \%$ e os clientes a mais de 04 anos correspondem a $43 \%$.

Figura 3 Com que frequência o cliente faz compras na empresa.

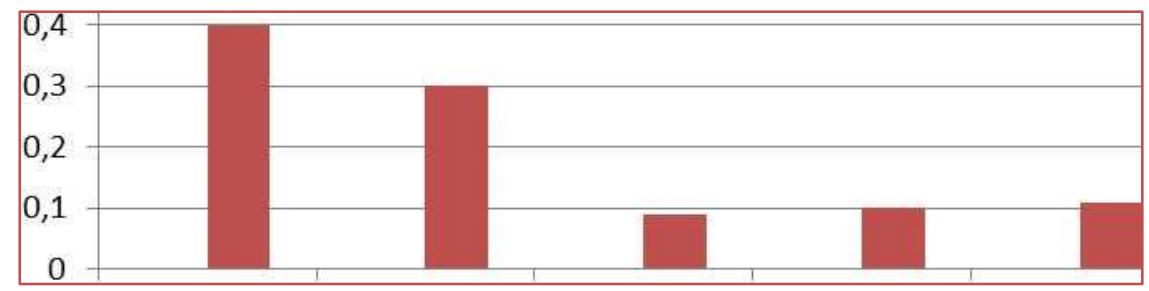

Fonte: Dados da pesquisa (2016)

A maior parte dos entrevistados (40\%) frequentam a empresa todo dia. Enquanto que 30\% frequentam 01 veze por semana, a cada 15 dias correspondem a $9 \%$. Os clientes que frequentam uma vez por mês correspondem a $10 \%$ e raramente $11 \%$ (Figura 3 ).

Figura 4 Forma usual de pagamento dos clientes em suas compras realizada na empresa.

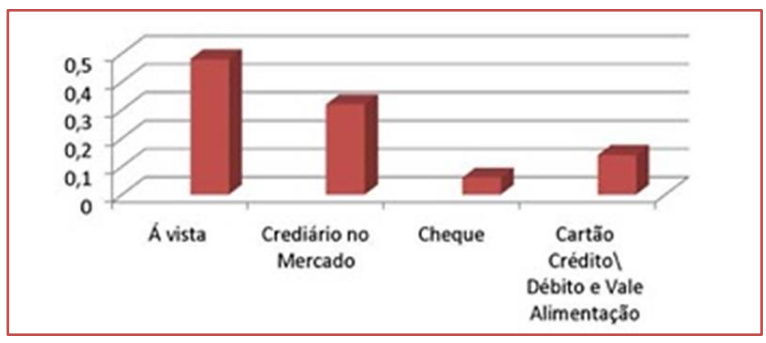

Fonte: Dados da pesquisa (2016)

A maioria dos clientes (48\%) compram a vista (Figura 4). Um fato a ser considerado é que a empresa desconhece os dados desses clientes: nome, endereço, telefone, esta é uma questão preocupante porque a exigência e o desejo dos consumidores é o atendimento personalizado. Os clientes que compram no crediário representam 32\%, no cheque são de $6 \%$ e nos cartões de débito, crédito e vale alimentação correspondem a $14 \%$. 
Figura 5 Opinião dos clientes em relação aos serviços oferecidos por este estabelecimento

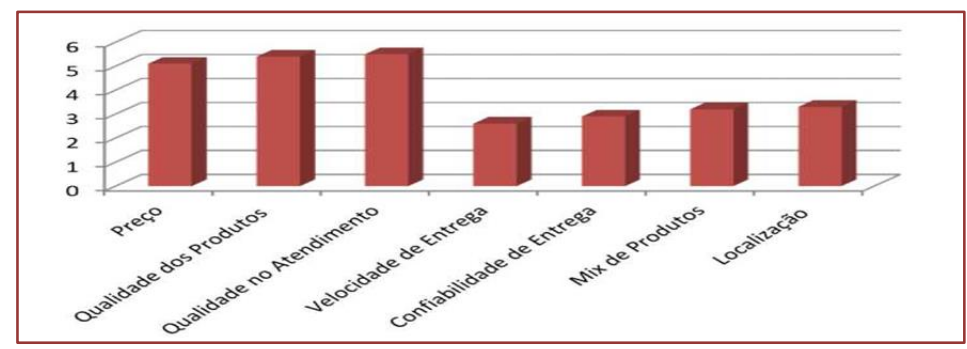

Fonte: Dados da pesquisa (2016)

Na Figura 5, pode ser observado claramente a média em relação a satisfação dos clientes em uma escala de 1 a 7 , quanto aos serviços oferecidos pela empresa. As respostas dos entrevistados foram positivas e ganhadoras de pedido: qualidade no atendimento 5,5, qualidade dos produtos 5,4 e preço 5,1. Em relação á velocidade de entrega 2,6 e confiabilidade de entrega 2,9, quanto ao mix de produtos a média foi de 3,2 e a localização de 3,3.São esses fatores que decidem a compra produto pelos clientes na hora de uma compra. Uma melhoria no desempenho de um critério ganhador de pedidos pode repercutir no aumento da demanda.

Figura 6: Sobre a linha de produtos que o cliente gostaria que o estabelecimento melhorasse para melhor lhe atender

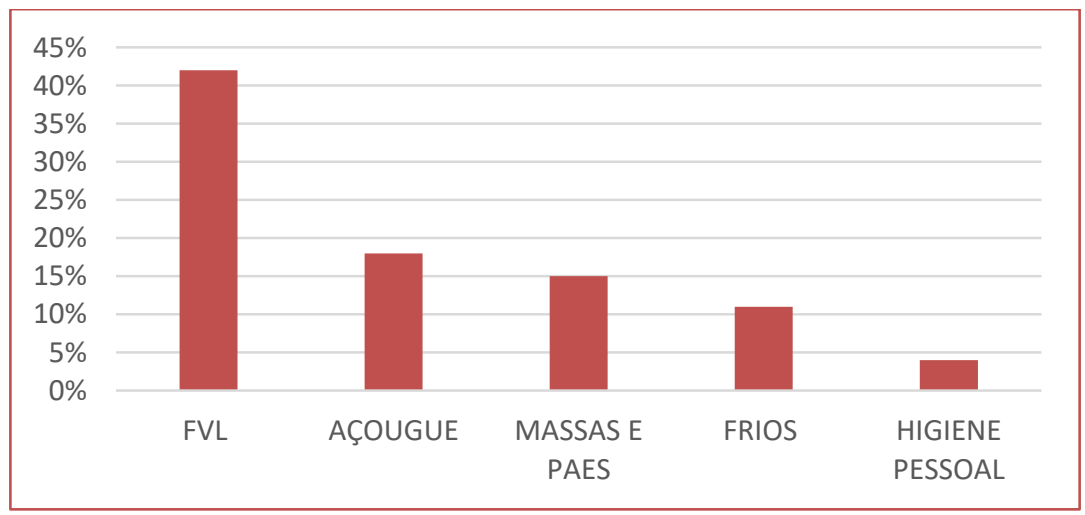

Fonte: Dados da pesquisa (2016)

Dentre os entrevistados vê-se que $42 \%$ escolheram a opção em que gostariam de ser melhor atendidos a de frutas, legumes e verduras (FVL), $18 \%$ açougue e os outros $15 \%$ a opção massas e pães, $11 \%$ frios e $4 \%$ higiene pessoal (Figura 6). Cada cliente da importância a fatores diferentes, então, é necessário que se criem estratégias de produção que irão valorizar a importância de todos os fatores relevantes para cada cliente e que irão trazer o retorno esperado pela empresa.

Todas as áreas organizacionais devem possuir papéis próprios a desempenhar para que a empresa possa chegar ao sucesso. As prioridades, identificadas por Slack (2009) como critérios "ganhadores de pedidos" são aquelas que significativamente contribuem para o sucesso da empresa junto ao seu mercado de atuação. Verificou-se como cada um destes itens são importantes no momento de competir com mercados internos e externos.

Ao focar uma estratégia de operações ao cliente, a empresa deve trabalhar com diferencial para atender as necessidades do mercado em que atua e o que pode e deve ser explorado como vantagem competitiva em cada segmento de atuação. Sendo assim, as estratégias da empresa em questão, devem ser focadas para os itens que mais ganham pedidos, que foram relacionados no questionário aplicado aos clientes.

0 enfoque deve ser direcionado ao mercado. A premissa é de que todos os serviços internos devem ter algum impacto na capacidade da empresa de oferecer produtos e serviços de qualidade ao mercado. Gerenciar estes serviços de forma míope, em relação aos custos, comunicação ou eficiência, só pode 
restringir o valor potencial de sua contribuição. Os serviços internos quando direcionados para as necessidades dos usuários, aumentam a eficácia da organização. Provedores e usuários compartilham informações, assumindo que ambos existem para servir um mercado final bem-sucedido (GIANESI, 1996).

A causa dos problemas pode ser a falta de sintonia entre a oferta de produtos e o mercado em que destina absorve-los. Essa remodelação fundamental da capacidade interna da empresa vem a modo de preservar a harmonia com suas vinculações externas. A estratégia da produção depende do sistema de normas apreendidas pelo pessoal da organização como sendo sua politica básica ou seu tipo específico de administração (MORAES, 2008).

Segundo Fleury (2001), a estratégia da empresa deve ser conhecida com base no conhecimento de suas características, sua dinâmica, suas tendências, ou seja, uma abordagem de fora para dentro (outside-in). De onde virão as mudanças em seu setor? De que forma essas mudanças podem afetar a vantagem competitiva? Como a empresa pode fazer para manter a vantagem competitiva diante das mudanças?" (TIFFANY, P.; PETERSON, 1998).

Neste sentido, prioridades competitivas são objetivos que a empresa deve buscar mais fortemente com o intuito de aumentar sua competitividade e, por consequência sua participação no mercado e sua lucratividade. No estabelecimento estudado, ficou relevante que as prioridades são:

Qualificação e capacitação da mão de obra: de acordo com a questão 1, os clientes deixam de comprar na empresa em estudo, no período que corresponde de 1 a 2 anos, elevar a qualidade no ciclo de serviço é prioridade; A importância de se manter clientes antigos, está no fato de que são mais experientes com o serviço, tem menor percepção de riscos do que os clientes novos. De acordo com Gianesi e Corrêa (1996) os clientes observam, avaliam os momentos da verdade de um ciclo de serviço, estes critérios de avaliação devem refletir os fatores que determinam à satisfação do cliente, entre eles apontados na pesquisa:

Tecnologia: para melhor atendimento aos clientes que compram a vista, porque segundo a questão 3 são a maioria e a empresa não possui os dados desses clientes; Variedade no mix de FLV: que houve pedidos pelos clientes, de acordo com a questão 5.

A empresa deve abordar o processo de formulação de estratégias para estabelecer, manter e sistemicamente renovar um conjunto de atividades distinto do de seus competidores, que entreguem maior valor para seus clientes e mercados, em permanente processo de mudança, assim como crie valor social para as comunidades como as quais interage (FLEURY, 2001).

Define-se prioridades competitivas como sendo um conjunto consistente de critérios que a empresa tem de valorizar para competir no mercado Amato Neto (2000). Devem-se definir os critérios competitivos mais adequados e estruturar a função produção, da melhor maneira possível, para que ela seja capaz de dar suporte a esta escolha.

Um dos objetivos mais evidentes para qualquer empresa é satisfazer ao mercado a que ela está servindo. Nenhuma operação produtiva quer falhar continuamente, pois servir o mercado de forma adequada possibilita a chance de sobreviver a longo prazo. Embora compreender os mercados seja normalmente associado a função de marketing, a perspectiva de mercado é também importante para a administração da produção. Sem compreender o que o mercado requer, é impossível garantir que as operações estejam alcançando o composto e o nível corretos em seus objetivos de desempenho (qualidade, rapidez, confiabilidade, flexibilidade e custo) (SLACK, 2009).

A proposta apresentada à empresa pesquisada tem como objetivo apresentar os pontos falhos identificados na pesquisa com os clientes e sugerir as estratégias de operações para correção e/ou melhoria dos processos. 
Quadro 2 - Estratégia de operações para correção ou melhoria de processos na empresa

\begin{tabular}{|c|c|}
\hline Observação dos Clientes & Estratégias de Operações \\
\hline Falha no ciclo dos serviços; & $\begin{array}{l}\text { Desenvolver um Programa de Treinamento de } \\
\text { Atendimento ao Cliente para os funcionários. Com } \\
\text { objetivo de capacitá-los para atender as necessidades dos } \\
\text { clientes da empresa. }\end{array}$ \\
\hline $\begin{array}{l}\text { Pouco conhecimento sobre o perfil dos clientes, } \\
\text { suas preferencias e necessidades. }\end{array}$ & $\begin{array}{l}\text { Identificar o perfil do cliente através da melhor utilização } \\
\text { do software de relacionamento. }\end{array}$ \\
\hline Poucas opções de frutas, legumes e verdura (FLV) & $\begin{array}{l}\text { Identificar novos fornecedores de frutas, legumes e } \\
\text { verdura (FLV) e dispor nas gondolas uma variedade } \\
\text { mínima de } 20 \text { itens diferentes. }\end{array}$ \\
\hline
\end{tabular}

Fonte: Elaborado pelos autores

O feedback estratégico aliado a estratégia de produção possibilita uma maior integração entre todas as áreas da organização. Segundo Kaplan e Norton (1997) deve-se então criar um sistema de feedback estratégico para testar, validar e modificar as hipóteses incorporadas a estratégia da unidade de negócios. É justamente este feedback, quando bem gerido, que faz a diferença, não só pela identificação das competências individuais necessárias a cada atividade, mas pela a possibilidade de compartilhar o crescimento profissional com as inovações e estratégias competitivas da empresa.

\section{CONSIDERAÇõES FINAIS}

Foi possível identificar, que não existe uma estratégia formalizada na entidade comercial, as ideias são discutidas e observadas de forma a colocar em pratica a que melhor se adequar a algum momento ou cenário. Comumente a empresa coloca em risco as suas operações e serviços, uma estratégia de operações e serviços formalizados podem orientar o negócio da empresa.

Com a pesquisa apresentada a empresa em estudo conseguiu identificar a importância da estratégia de operações e serviços. Quando a empresa identifica como satisfazer o desejo dos consumidores, e compreende suas expectativas, ou melhor, ainda, consegue alinhar as escolhas dos clientes com o que a empresa está a realizar, obtém-se uma vantagem competitiva.

A partir da definição de uma estratégia corporativa e de uma estratégia competitiva, pode-se iniciar a definição de uma estratégia de operações e serviços através das suas prioridades competitivas. Deve existir compatibilidade entre as estratégias, o nível de recurso disponível e as preferências dos consumidores para montar a estratégia adequada a empresa dessa forma, se tem a formulação e formalização de uma estratégia. A pesquisa considera uma ou mais prioridades competitivas podem ser adotadas simultaneamente dentro da organização, levando em consideração o tempo para organizá las e o esforço de melhoria contínua com o processo de feedback.

Foi possível perceber que os serviços oferecidos pela empresa estão de encontro com as perspectivas dos clientes, observou-se apenas algumas falhas em seus serviços, que podem ser corrigidas com a implantação de estratégias de operações. Sendo assim, demonstrará ao seu cliente que está interessada na melhoria dos serviços oferecidos, com objetivo de fidelizar e proporcionar ao consumidor produtos e serviços de qualidade, e por consequência aumentando a sua competitividade no mercado.

A estratégia de operações e serviços, além de gerar vantagem competitiva à empresa estudada, em face a função produção este estudo proporciona a correlação do fazer acontecer em finanças, marketing, recursos humanos, realmente um plano de ação. Toda organização precisa de algum direcionamento estratégico. 0 mesmo acontece para sua operação e para o negócio, quando este direcionamento é entendido se define os objetivos de desempenho. A integração das perspectivas da estratégia de produção deve atender as diretrizes da estratégia competitiva e de produção da empresa, pela sua equipe e gerência. Assim, avaliar como os processos existentes se ajustam aos requisitos destes mercados fazendo escolhas para satisfazer as necessidades futuras são responsabilidades estratégicas críticas. 


\section{REFERÊNCIAS}

[1] AMATO NETO, J. Redes de cooperação produtiva e clusters regionais. São Paulo: Atlas, 2000.

[2] CARIDADE, M. D.; TORKOMIAN, A. L. V.. Estratégias de produção das empresas cerâmicas de Santa Gertrudes. Cerâmica Industrial, v. 6, n. 1, p. 32-39, 2001.

[3] FLEURY, A. Estratégias empresariais e formação de competências: um quebra cabeça/ caleidoscópico da indústria brasileira/ 2. Ed. - ed. - São Paulo: Atlas, 2001.

[4] GIANESI, Irineu GN; CORRÊA, Henrique Luiz. Administração de serviços: operações para a satisfação do cliente. São Paulo: Atlas, 1996.

[5] GIL, A. C. Como elaborar projetos de pesquisa. Ed. 5 São Paulo: Atlas, 2010.

[6] KAPLAN, Robert S .; NORTON, David P. A estratégia em ação: balanced scorecard . Gulf Professional Publishing, 1997.

[7] LUSTOSA, L. J.; MESQUITA, M. A. de; OLIVEIRA, R. J. Planejamento e controle da produção. Elsevier Brasil, 2008

[8] MATTAR, Frauze N.. Pesquisa de Marketing. 4⿳ạ. ed. São Paulo: Editora Atlas. 2007.

[9] MORAES, Rodrigo do Nascimento et al. ESTRATÉGIA E COMPETITIVIDADE NUMA REDE DE HOTÉIS: UM ESTUDO DA REDE VERSARE DE HOTÉIS. 2008.

[10] PARENTE, J. Varejo no Brasil: Gestão e Estratégia. São Paulo: Atlas,2000.

[11] RICHARDSON, R. J. Pesquisa social: métodos e técnicas. ed. 3, São Paulo: Atlas, 1999.

[12] RODRIGO, J. Estudo de caso. Fundamentação Teórica. Vestcon. Brasília, 2008.

[13] SLACK, N.; CHAMBERS, S.; JOHNSTON, R. Administração da Produção. 2ª Ed. São Paulo: Atlas, 2002.

[14] SLACK, Nigel; LEWIS, Michael. Estratégia de operações. Bookman Editora, 2009.

[15] TIFFANY, P.; PETERSON, S. D. . Planejamento Estratégico: o melhor roteiro para um planejamento estratégico eficaz. Rio de Janeiro, Campus, 1998.

[16] VEIGA J.; VICENTE D. Administração da Produção e Serviços. Lavras UFLA, FAEPE, 1999. 


\title{
Capítulo 9
}

\section{Análise ergonômica e de saúde no modal rodoviário: Impacto na qualidade de vida dos caminhoneiros}

\author{
Juliana Karoline Forsan Pascotti \\ José Geraldo Baziles Xavier \\ Luiz Carlos de Ponte Junior \\ Ivana Salvagni Rotta
}

Resumo: 0 constante crescimento dos meios de transportes pelo modal rodoviário traz diversas consequências principalmente aos caminhoneiros impactando em sua qualidade de vida. 0 objetivo do estudo foi analisar as questões ergonômicas e de saúde dos caminhoneiros a fim de avaliar suas condições de trabalho. Foram aplicados questionários a 30 motoristas em um posto de combustíveis nas proximidades de araras, sp. Com os resultados obtidos pode-se constatar que a maioria dos motoristas enfrentam dificuldades da profissão decorrentes da má alimentação, baixa qualidade do sono, jornadas excessivas e dores.

Palavras-chave: Ergonomia; Saúde; Caminhoneiros; Qualidade de vida 


\section{INTRODUÇÃO}

A cada ano que passa o consumo de produtos e serviços vem crescendo. Com esse aumento de demanda a produtividade é consequência gerando o aumento dos transportes no modal rodoviário. Segundo dados da Associação Nacional das Empresas Transporte Rodoviário de Cargas (NTC) existem mais de um milhão de caminhões vinculados a empresas, e mais de 600 mil pertencentes a profissionais autônomos. Sendo a matriz de transporte dominante no território nacional, estes meios de transporte são de extrema importância para a cadeia logística (BARAT, 2007). No entanto, segundo pesquisas em uma das principais rodovias do país devido à rotina intensa de trabalho contatou-se que a maioria dos caminhoneiros que rodam as estradas possuem algum tipo de problema de saúde. Além disso, por dirigirem muitas horas sentem sono e passam a usar anfetamina, aumentando assim o risco de acidentes (INTERVIAS, 2017).

Diante deste cenário, o objetivo deste artigo foi realizar uma análise ergonômica do trabalho (AET), mostrando e analisando as condições ergonômicas e psicológicas dos caminhoneiros que impactam tanto nas condições de saúde como no ambiente de trabalho desses profissionais. A metodologia utilizada envolveu a elaboração e aplicação de questionários, assim como foram realizadas entrevistas com caminhoneiros em um posto de combustível na rodovia situado em Araras-SP. Através dos dados obtidos, pode-se identificar e pontuar o ritmo de trabalho e suas pausas, os problemas relacionados à longa jornada de trabalho relacionando-se com o desempenho e a qualidade da saúde imposta por esta profissão.

\section{REVISÃO BIBLIOGRÁFICA}

\subsection{ERGONOMIA}

O conceito de ergonomia proposto por Wisner (1987) baseia-se em "um conjunto de conhecimentos científicos relativos ao homem para a concepção de ferramentas, máquinas e dispositivos que possam ser utilizados com o máximo de conforto, segurança e eficácia.".

Para que ocorra a melhoria das condições de trabalho e a maneira como o indivíduo exerce as funções dentro de uma organização, além das considerações técnicas e ergonômicas, as questões sociológicas e psicossociológicos são necessárias para compreender as atividades de trabalho (WISNER, 1987).

É através da análise ergonômica do trabalho (AET) que se pode indicar os riscos ergonômicos nos postos de trabalho a fim de aplicar melhorias minimizando tais riscos (ROJAS, 2015). Ferreira, et al. (2009) apresenta a AET como uma intervenção no ambiente de trabalho com o propósito de estudar as consequências físicas e psicofisiológicas consequentes da atividade humana. Além de diagnosticar riscos, procura fornecer sugestões e recomendações relacionadas ao processo, ambiente de trabalho ou nos postos de trabalho minimizando possíveis ocorrências de lesões e alterações psicológicas.

Para Rojas (2015) a análise ergonômica é detalhada em três etapas:

a) análise de demanda: utilizada para compreender o problema que será estudado. É nessa etapa que deve considerar-se os indicadores de saúde, aspectos sociais além da estratégia da empresa. Com isso é possível realizar um plano de intervenção ergonômica nos postos de trabalho a fim de realizar alterações tanto organizacionais quanto relativos a equipamentos.

b) análise da tarefa: essa análise considera dois pontos: o trabalho prescrito dentre as situações ambientais, técnicas e organizacionais e a capacidade humana para a realização da tarefa. Com isso é analisado desde os espaços, equipamentos de trabalho até a carga de trabalho física e mental e as posturas para a execução.

c) análise da atividade: foca no comportamento do trabalhador conforme as regras e a cognição. Para fazer essa análise é necessário observar os comportamentos individuais analisando as capacidades físicas e funções fisiológicas e psicológicas.

Dentre os principais desafios da AET está a compreensão das relações entre o físico, cognitivo e emocional. A carga de trabalho dita como carga física e mental de trabalho foi sendo diferenciada como cognitiva e psíquica. Com isso foi possível analisar o sofrimento e o prazer no trabalho, destacando os aspectos psicológicos e afetivos. (FERREIRA, 2015). 


\subsection{ERGONOMIA NO TRANSPORTE RODOVIÁRIO}

Podem-se analisar as questões ergonômicas físicas no transporte de cargas onde os motoristas passam muitas horas na direção em uma posição fixa no assento no qual não permitem muitas mudanças na postura. Isso leva à fadiga muscular levando a deterioração da atividade motora do organismo que pode ser agravado pela monotonia devido ao motorista dirigir sempre sozinho (IIDA, 2016).

Guérin et al. (2001) declara que os postos de condução, seja em caminhões, aviões ou empilhadeiras são mal desenhados ocasionando dores aos motoristas depois de algumas horas de trabalho. É importante atentar-se à postura no local de trabalho principalmente àquela determinada pela atividade. A atividade de dirigir dos motoristas faz com que eles fiquem com os pés sobre os pedais, mãos no volante e olhar na estrada. Observa-se a constante pressão, o congestionamento e más condições nas estradas causando uma postura mais rígida e erros na estrutura dimensional dos postos de condução.

\subsubsection{JORNADA DE TRABALHO}

Pesquisas feitas mostram que as modificações nas jornadas de trabalho causam a elevação ou diminuição no rendimento do trabalho já que o trabalhador procura adaptar seu ritmo para compensar as mudanças. As jornadas de 9 a 10 horas por dia passam a levar o motorista à fadiga, prejudicando o desempenho e aumentando o nível de doenças e acidentes. (KROEMER E GRANDJEAN, 2004).

Os caminhoneiros, principalmente autônomos, não possuem um turno de trabalho específico. Pela lei no 13.103/2015 (CLT, 2015), conhecida como Lei dos Motoristas, as transportadoras são obrigadas a controlar a jornada de trabalho mediante anotações em fichas, sistemas ou meios eletrônicos instalados no caminhão. Além disso, a lei visa o intervalo para descanso de 30 minutos a cada 6 horas de condução.

Outro fator é a carga de trabalho que se baseia na relação das exigências do trabalho e as capacidades físicas e psicológicas do indivíduo. Refere-se à sobrecarga de trabalho quando essa relação é instável, ou seja, as exigências da tarefa são muito maiores do que a capacidade do funcionário em executá-la (CORRÊA E BOLETTI, 2015). Essa sobrecarga pode ser física ou mental causando o sofrimento no trabalho, desgaste, problemas de sono, fadiga entre outros.

Segundo Kroemer e Grandjean (2004) são necessárias pausas durante a jornada de trabalho sendo de extrema importância para a condição física do trabalhador. Além de uma necessidade vital do corpo, a pausa é exigida principalmente em trabalhos que utilizam toda a capacidade do sistema nervoso, ou seja, em trabalhos mentais que necessitam como exemplo dos motoristas, a atenção para longas viagens nas rodovias.

\subsubsection{SONO}

Segundo Richards (2017) ter poucas horas de sono causam transtornos físicos, mentais e comportamentais. O sono trata-se de um aspecto fundamental para o funcionamento do corpo, relacionado ao rendimento do indivíduo, ou seja, o desempenho mental. A recomendação para uma pessoa adulta, entre 26 a 64 anos é de ter de 7 a 9 horas de sono por dia e para pessoas com mais de 64 anos o correto seria dormir de 7 a 8 horas por dia.

Para o mesmo autor, a má qualidade do sono e as horas inadequadas para dormir são as principais causas da insônia. Com isso ocorrem vários problemas de saúde como a ansiedade, preocupação, estresse, tensão física e transtornos, fazendo com que a produtividade do indivíduo diminua.

Pesquisas indicam que parte dos acidentes fatais no tráfego correspondem a $45 \%$ e são causados pela sonolência no volante, tornando esses acidentes mais violentos, pois a dormência do motorista dificulta a redução da velocidade ou desvios para evitar as colisões (KROEMER E GRANDJEAN, 2004).

\subsubsection{PSICOESTIMULANTES}

Os psicoestimulantes ou estimulantes psicomotores são substâncias que aumentam a atividade psíquica e motora onde agem principalmente sobre os processos mentais ou emocionais. Pode-se dividir os psicoestimulantes em simpatomiméticos de ação direta e indireta, como a anfetamina e cocaína (DELUCIA, 2006). O uso da substância cafeína, contida no café como psicoestimulante é muito comum, sendo rapidamente absorvida pela corrente sanguínea causando o aumento da vigilância e aliviando a fadiga. 
Além de aumentar o nível de atenção, a cafeína pode provocar alterações fisiológicas elevando a temperatura do corpo, acelerando o ritmo cardíaco e aumentando o consumo de oxigênio (IIDA, 2016).

Outra droga, a anfetamina, conhecida popularmente rebite, causa efeitos psíquicos aumentando o estado de alerta, podendo causar anorexia, diminuição da fadiga além do aumento da atividade motora. Além do uso do rebite, a cocaína vem sendo muito utilizada pelos caminhoneiros por serem mais acessíveis e por aumentarem a resistência à fadiga e a atividade mental. Porém prejudicando a saúde através da anorexia, alteração da percepção do tempo e do espaço e mudanças no comportamento como alucinações e crises compulsivas (DELUCIA, 2006).

\section{METODOLOGIA}

O estudo é de caráter exploratório-descritivo com abordagem qualitativo e quantitativo feito através de levantamento bibliográfico e entrevistas a fim de compreender o tipo de trabalho estudado (GIL, 2008).

A coleta de dados foi feita através de questionário anônimo que continha 28 questões abertas e fechadas abrangendo informações pessoais dos motoristas, assuntos relacionados à jornada de trabalho, a qualidade de sono, alimentação além do uso de psicoestimulantes, problemas de saúde e dores. Os questionários foram aplicados aleatoriamente pelos próprios autores para 30 caminhoneiros sendo eles funcionários de empresas, autônomos ou agregados em um posto de combustível situado na rodovia nas proximidades de Araras/SP onde param para abastecer e descansar para prosseguirem viagem.

Além disso, utilizou-se a Análise Ergonômica do Trabalho (AET) como base para analisar os aspectos físicos do ambiente e do posto de trabalho que nesse contexto analisado são respectivamente a rodovia e o caminhão.

\section{RESULTADOS}

A amostra é composta por 30 caminhoneiros do sexo masculino, dentre eles 5 autônomos, 3 agregados e 22 funcionários de empresa (Figura 1).

FIGURA 1 - Tipo de motorista. Fonte: Autores (2018).

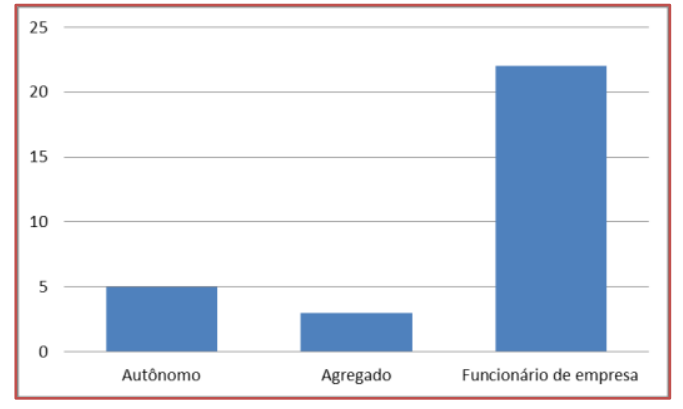

Nota-se que maior parte dos caminhoneiros corresponde a uma da faixa etária acima de 41 anos (54\%) e apenas um (3\%) têm entre 20 a 25 anos (Figura 2). Quando perguntado sobre o nível de escolaridade (Figura 3) percebe-se uma grande heterogeneidade da amostra sendo que 29\% dos entrevistados possuem ensino médio completo. Os $21 \%$ são de grande maioria compostos por autônomos e agregados de faixa etária acima dos 41 anos que cursaram o ensino fundamental incompleto, fazendo com que optassem por esta profissão como meio de sobrevivência, ocasionado pela falta de oportunidade e por não terem condições de estudo na época. 
FIGURA 2 - Faixa etária.

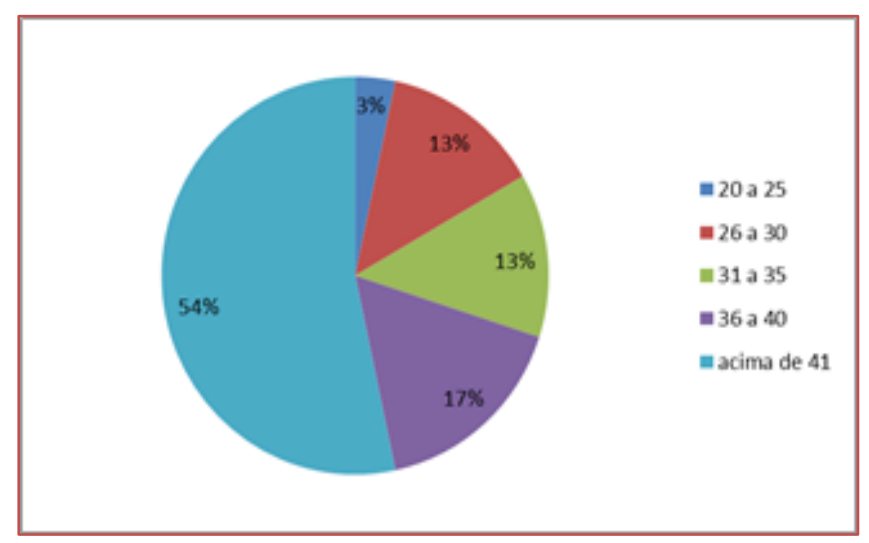

Fonte: Autores (2018).

FIGURA 3 - Nível de escolaridade.

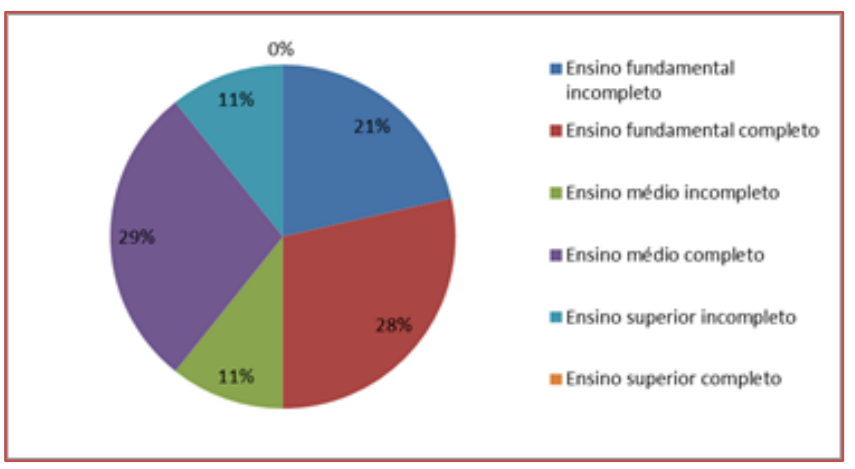

Fonte: Autores (2018).

O tempo de profissão dos caminhoneiros (Figura 5) concentra-se na faixa de mais de 20 anos (44\%) visto que a maioria afirmou começar a trabalhar desde muito novo por gostarem da profissão e pelo mercado dos transportes serem predominante na época. Pode-se notar que 13\% dos motoristas são novos nessa profissão trabalhando a menos de 5 anos devido ao desemprego.

FIGURA 5 - Anos de profissão.

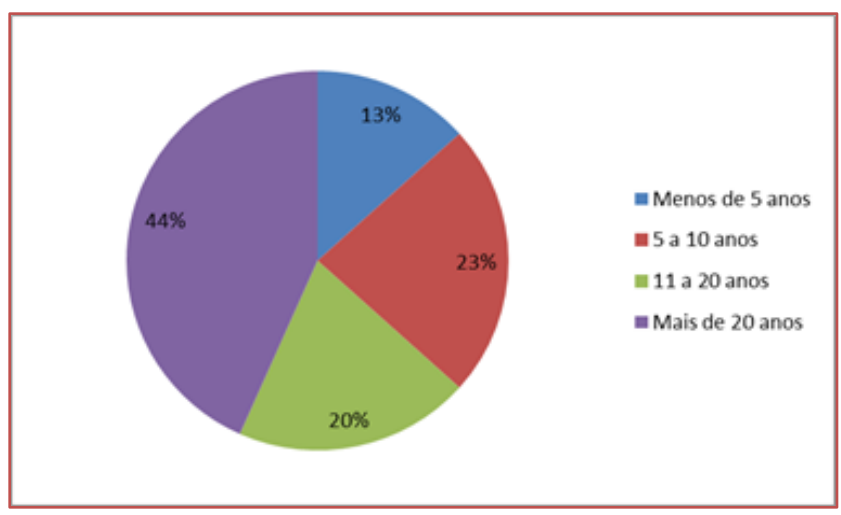

Fonte: Autores (2018).

Observa-se pela Figura 6 que 37\% dos caminhoneiros trabalham entre 7 a 11 horas por dia. Esta longa jornada de trabalho se dá principalmente a distância percorrida até o destino final para que eles consigam entregar a carga dentro do prazo além de beneficiar-se da luminosidade do dia já que a noite se torna 
perigoso trafegar. Os níveis de porcentagem são parecidos em relação à quilometragem percorrida por dia (Figura 7), sendo 33\% de 500 a $600 \mathrm{~km} /$ dia, 20\% de 900 a $1000 \mathrm{~km} /$ dia e $13 \%$ de 600 a $700 \mathrm{~km} / \mathrm{dia}$.

Porém para que a entrega ocorra dentro do tempo estabelecido, $47 \%$ dos caminhoneiros dormem de 5 a 7 horas por dia e 13\% domem até 4 horas (Figura 8).

FIGURA 6 - Horas trabalhadas por dia.

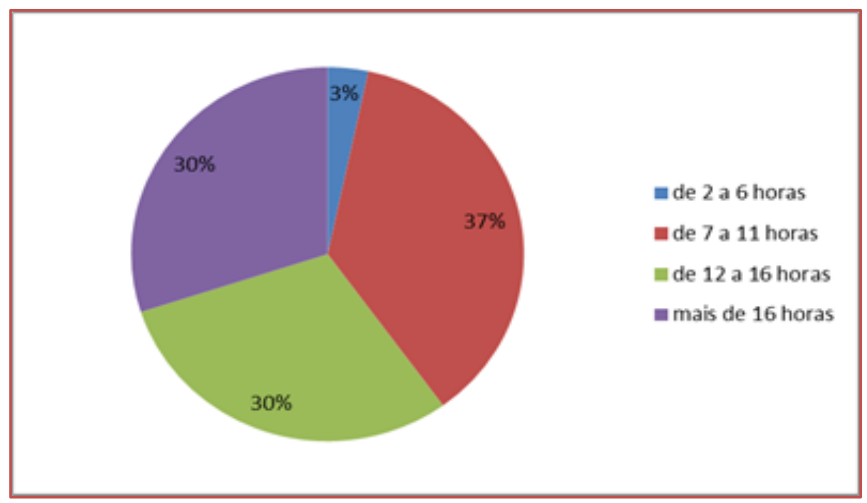

Fonte: Autores (2018).

FIGURA 7 - Quilometragem rodada por dia.

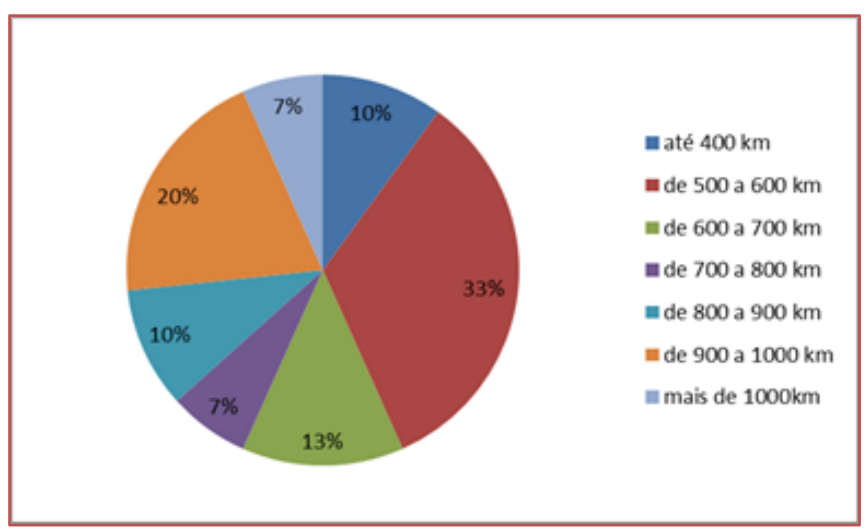

Fonte: Autores (2018).

FIGURA 8 - Horas de sono por dia.

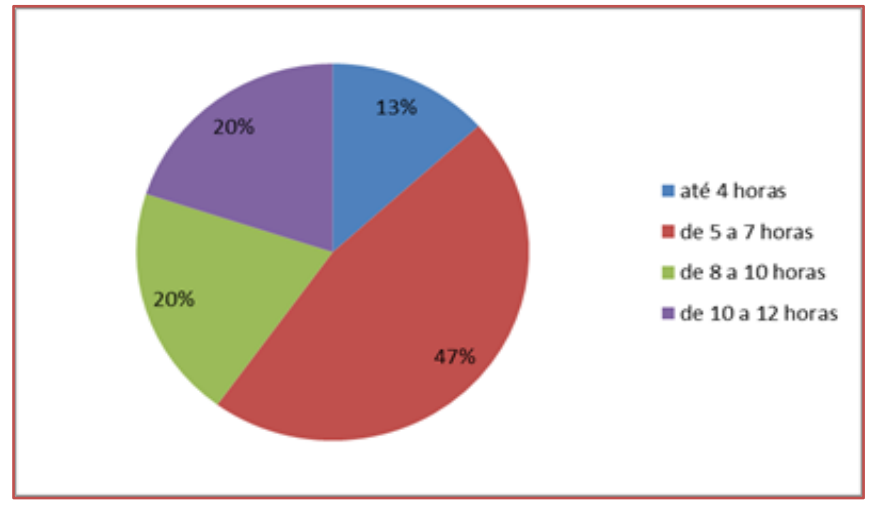

Fonte: Autores (2018).

Pode-se perceber que mesmo os caminhoneiros dormindo pouco, eles possuem a qualidade do sono boa representando 50\% (Figura 9). Segundo eles, isto ocorre pelo cansaço, onde dizem "deitar e dormir". Já $17 \%$ dos motoristas consideram a qualidade de seu sono péssima, já que não conseguem descansar o 
suficiente devido à temperatura e ao estado de conservação do caminhão por não oferecer conforto para o motorista.

FIGURA 9 - Qualidade do sono.

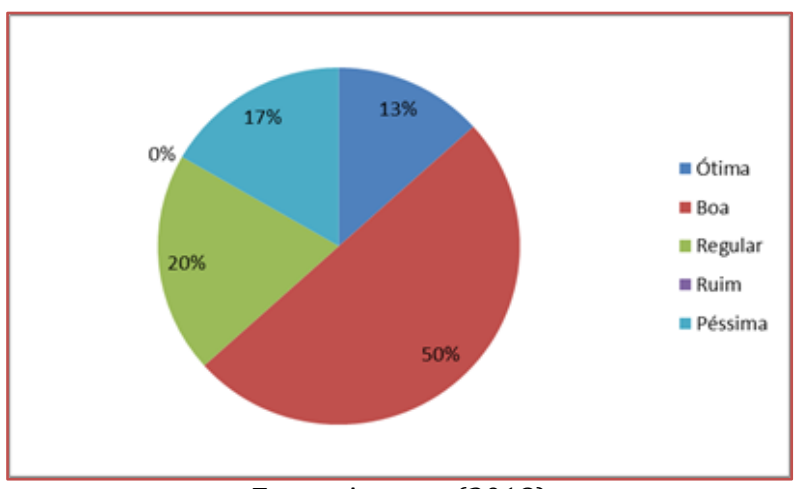

Fonte: Autores (2018).

Constatou-se que o uso de psicoestimulantes por parte dos caminhoneiros é decorrente. Quando perguntado sobre, $83 \%$ dos motoristas (Figura 10) responderam que consomem o café como estimulante impedindo durante o trajeto uma possível sensação de sonolência mantendo-se sempre em estado de alerta.

FIGURA 10 - Uso de psicoestimulantes.

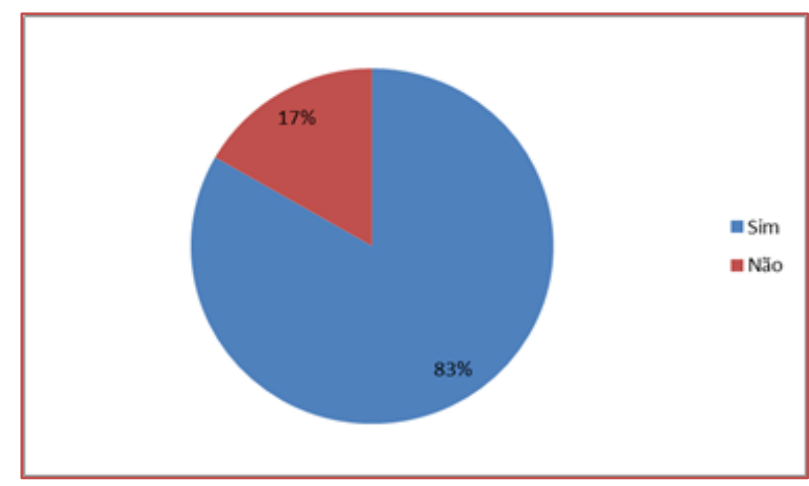

Fonte: Autores (2018).

Dos motoristas entrevistados, 30\% admitiram que já usaram o rebite (Figura 11) há algum tempo atrás e que hoje não utilizam mais este tipo de droga. Muitos justificam o uso do rebite como meio de se manterem acordados para concluírem o prazo de entrega da carga. Em alguns casos houve a afirmação do uso de cocaína, muito comum em motoristas mais jovens que passam a usar constantemente como uma maneira de refúgio por dirigem sozinhos e longe da família. 
FIGURA 11 - Uso de rebite.

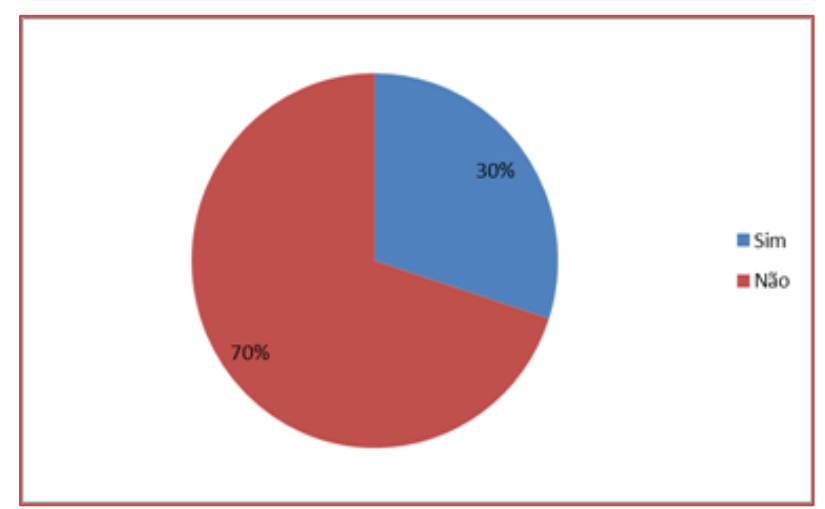

Fonte: Autores (2018).

Como mostra a Figura 12, a maioria (38\%) fazem apenas 3 paradas durante a viagem. Segundo os entrevistados essas pausas só acontecem se estiverem cansados, com sono ou uma condição imposta pelas próprias transportadoras. Alguns motoristas mencionaram que as transportadoras limitam as paradas até o destino final para evitar assaltos, roubos de carga e/ou roubo do caminhão. Com mais de 4 paradas (48\%) são motoristas que percorrem longas distâncias ou até mesmo autônomos que fazem suas próprias paradas sem pressa de prosseguir viagem.

FIGURA 12 - Quantidade de paradas por viagem.

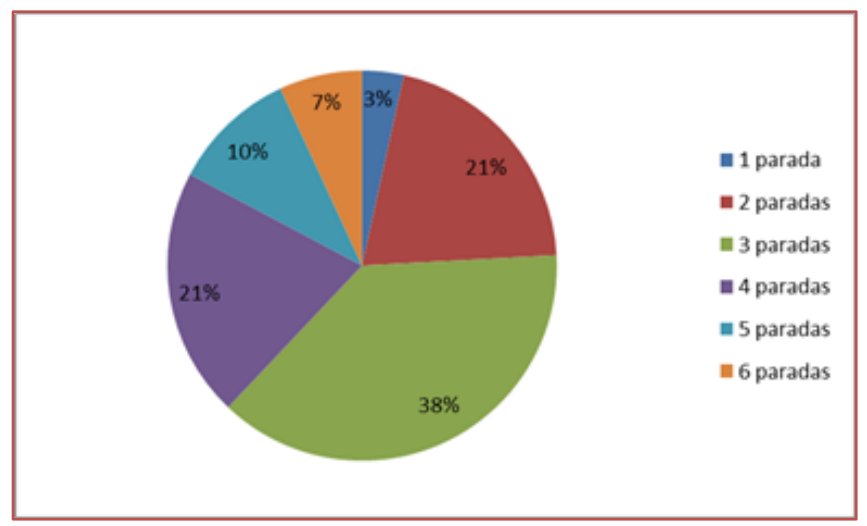

Fonte: Autores (2018).

Outro fator importante é a alimentação. Devido à pressa de chegar ao destino final, muitos caminhoneiros deixam de se alimentar ou ficam muitas horas sem comer. Na Figura 13 temos que $40 \%$ fazem apenas duas refeições diárias, sendo elas: café da manhã e o jantar ou um lanche rápido ao chegar no destino. Porém nem sempre são alimentos corretos já que eles mencionam comer lanches, salgados e beber refrigerantes. 
FIGURA 13 - Quantidade de refeições diárias.

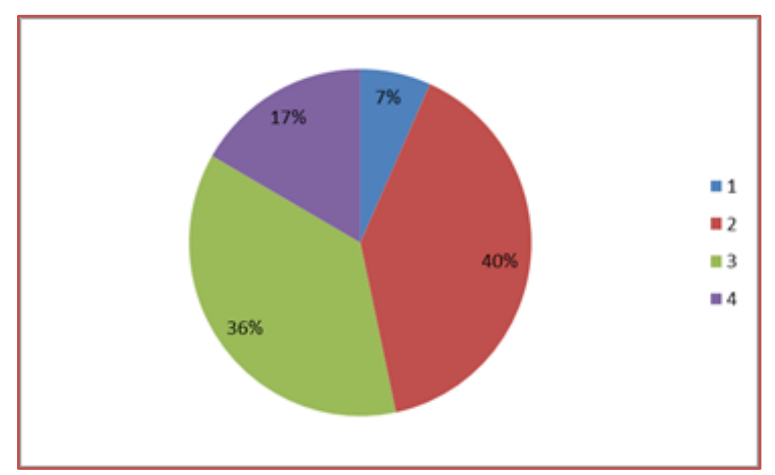

Fonte: Autores (2018).

Na Tabela 1 pode-se observar que 7 caminhoneiros estão acima do peso possivelmente devido à alimentação rica em carboidratos e gorduras, além de diabetes causadas pelo excesso de açúcar. Outra reclamação é o colesterol, causado pela falta de exercícios físicos aeróbicos e também por alimentos ricos em gordura saturada e açúcar, elevando o risco de terem o colesterol alto. 0 estresse é um problema recorrente nessa profissão, onde passam horas na rodovia tendo que ter o máximo de atenção possível e preocupações devido à violência e acidentes.

TABELA 1 - Número de reclamações decorrentes de problemas de saúde.

\begin{tabular}{|lc|}
\hline Problemas & Reclamações \\
\hline Alteração de colesterol & 3 \\
Hipertensão arterial & 2 \\
\hline Articulação & 1 \\
Diabete & 3 \\
\hline Estresse & 6 \\
\hline Sobrepeso & 7 \\
\hline Alteração de pressão & 2 \\
\hline
\end{tabular}

Fonte: próprios autores (2018).

Através do questionário nórdico dos sintomas musculoesqueléticos, notou-se pela Figura 14 que as maiores reclamações nos últimos 7 dias foram na coluna lombar, pescoço e ombros.

FIGURA 14 - Reclamações de dores.

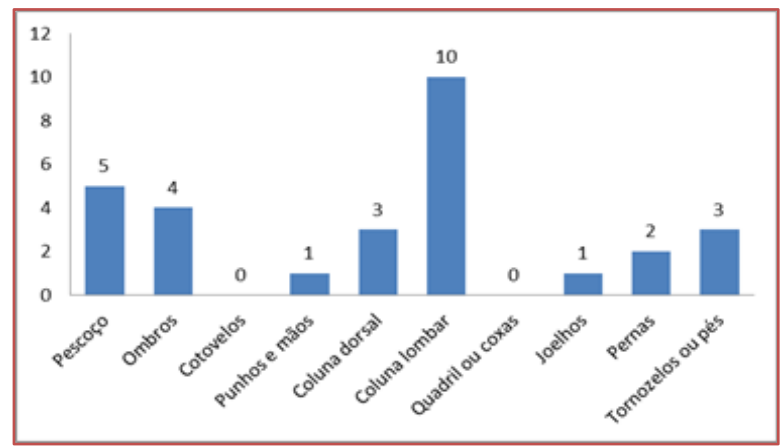

Fonte: Autores (2018). 
Na figura 15, 77\% dos motoristas alegaram que as dores sentidas por eles não são causadas pelo trabalho em virtude do caminhão oferecer tecnologias que favorecem no conforto. Os outros $23 \%$ dos entrevistados afirmaram que a falta de conforto do caminhão por serem mais antigos e situações como descarregar a entrega, acabam sendo o motivo das dores.

FIGURA 15 - As dores são causadas pelo trabalho.

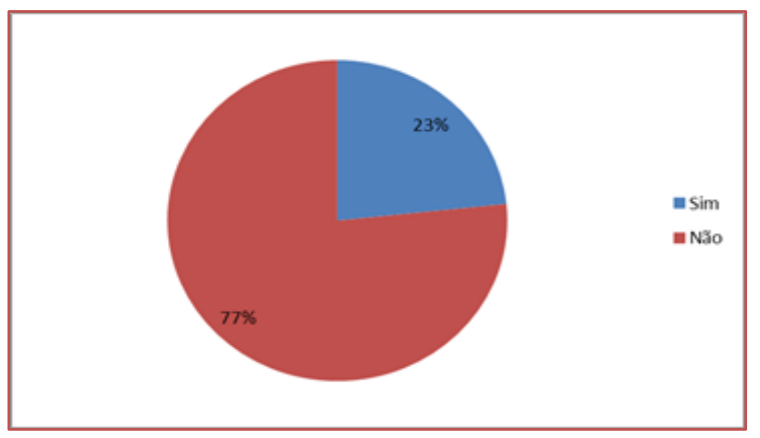

Fonte: Autores (2018).

\section{CONCLUSÃO}

Este trabalho buscou relatar as condições dos caminhoneiros relacionando-a com os fatores ergonômicos e de saúde. 0 estudo iniciou-se no período em que ocorreu a greve dos caminhoneiros.

Verificou-se que por mais que tenham muitos motoristas neste âmbito, este é um trabalho complexo e requer muito do mental, do físico e do emocional. Observou-se que vários caminhoneiros estão nessa profissão por falta de oportunidade alegando que não tinham condições de estudo na época e outros dizem gostar devido ao incentivo da família.

Com as entrevistas notaram-se as grandes dificuldades vivenciadas por eles desde a partida de casa até o destino final. Notou-se que mesmo os motoristas sendo funcionários de transportadoras, estas não cumprem com as leis trabalhistas, como a questão das pausas obrigatórias. Com isso, a falta de pausas durante a viagem além de provocar acidentes causam também problemas de saúde onde passam a usar psicoestimulantes e até drogas para inibirem o sono. Esses problemas de saúde são decorrentes da baixa qualidade de vida que a profissão oferece. Muitos acabam tornando-se depressivos pela falta de estímulos durante as viagens além de ficarem longe da família.

Muitos deles vivem jornadas exaustivas com a alimentação precária, não recebendo comissões relacionadas ao excesso de horas nas rodovias. Observou-se que a maioria dos profissionais sentem dores, porém dizem que estas não estão relacionadas ao trabalho. Sabe-se que essas dores os afetam por passarem muitas horas sentadas, em uma mesma posição e sem conforto.

Sendo assim, no cotidiano dos caminhoneiros é fundamental a conscientização dos mesmos, a fiscalização das transportadoras a fim de verificar se estão cumprindo com as leis estabelecidas e também proporem programas de atividades físicas aos motoristas por passarem a maior parte do tempo dentro do caminhão e programas de alimentação saudável.

\section{REFERÊNCIAS}

[1] BARAT, J. Logística e transporte no processo de globalização: oportunidades para o Brasil. Editora Unesp, 2007.

[2] CONSOLIDAÇÃO DAS LEIS DO TRABALHO (CLT). Decreto n. 13.103, de 2 de Março de 2015.

[3] CORRÊA, V. M., BOLETTI, R. R. Ergonomia: Fundamentos e Aplicações. Porto alegre: Bookman, 2015.

[4] DELUCIA, R. Do paraíso ao inferno das substâncias psicoativas. São Paulo: Clube dos Autores, 2006.

[5] FERREIRA, M. S.; RIGHI, C. A. R. Análise ergonômica do Trabalho. PUCRS, 2009.

[6] FERREIRA, L. L. Sobre a Análise Ergonômica do Trabalho ou AET. Revista Brasileira de Saúde Ocupacional. São Paulo: 2015. 
[7] GIL, A. C. Como elaborar projetos de pesquisa. 6 ed. São Paulo: Atlas, 2008.

[8] GUÉRIN, F. et al. Compreender o trabalho para transformá-lo: a prática da ergonomia. São Paulo: Edgar Blucher, 2001.

[9] IIDA, Itiro. Ergonomia: Projeto e Produção. 3. ed. São Paulo: Blucher, 2016.

[10] INTERVIAS. Campanha alerta caminhoneiros para riscos da sonolência ao volante. Disponível em: <http://www.intervias.com.br/?link=noticias.ver\&id=3200 >. Acesso em: 20 jun. 2018

[11] KROEMER, K. H. E.; GRANDJEAN, E. Manual de Ergonomia: adaptando o trabalho ao homem. 5 ed. Porto Alegre: Bookman, 2004.

[12] RICHARDS, K. O sono: bom demais para perder. Babelcube, 2017.

[13] ROJAS, P. Técnico em segurança do trabalho. Porta Alegre: Bookman, 2015.

[14] WISNER, A. Por dentro do trabalho - Ergonomia: método \& técnica. 1. ed. São Paulo: FTD, 1987. 


\section{Capítulo 10}

\section{Aplicação do método RULA para análise da postura adotada por um trabalhador durante o processo de soldagem de chapas de aço pela técnica de arco submerso: Proposta de ações}

Duileu Couto

Daniele Macarini

Douglas F. Vidal

Letícia da Silva

Leonam Formento

Resumo: 0 presente trabalho tem como objetivo utilizar o método RULA para avaliar a postura adotada por um trabalhador durante a realização da soldagem de chapas de aço para a produção de painéis de embarcações utilizando a técnica de soldagem a arco submerso. 0 método RULA consiste em uma técnica de análise ergonômica que avalia 0 trabalho muscular estático e as forças exercidas pelos segmentos corporais, permitindo uma avaliação rápida das posturas do pescoço, tronco e membros superiores e inferiores, juntamente com a função muscular e as cargas externas ao qual o corpo é submetido. As análises foram realizadas por meio de observações in loco e com o auxílio de fotografias e filmagens do processo de soldagem desenvolvido nas instalações da empresa Keppel Singmarine Brasil, localizada na cidade de Navegantes - SC. Os resultados da aplicação do RULA determinaram que as condições nas quais a atividade de soldagem é realizada são enquadradas como nível 4, e exigem a realização de mudanças imediatas no modo operacional estabelecido, para proteção do trabalhador. Foi proposto um conjunto de ações de melhoria fundamentadas no princípio da ergonomia de correção, e que atuam diretamente sobre as posturas dos segmentos corporais que apresentaram maior pontuação individual, visando minimizar as possibilidades de surgimento de lesões e doenças do trabalho. A simulação da aplicação do método RULA para uma condição na qual as ações propostas são implantadas, indica que o trabalho pontual das medidas de controle sobre as posturas dos segmentos corporais avaliados impacta na redução de aproximadamente $61 \%$ da pontuação final, com redução do nível de risco de 4 para 2, demonstrando a eficiência das ações de melhoria propostas.

Palavras - chave: Análise postural, Método RULA, Processo de soldagem a arco submerso, Ações de correção. 


\section{INTRODUÇÃO}

Os conceitos e benefícios da ergonomia têm sido amplamente difundidos ao longo do tempo, e vêm sendo aceitos e implantados com sucesso nas empresas, promovendo melhores condições de segurança e de conforto para os trabalhadores, o que reflete em ganhos de produtividade para as empresas (Silva et. al, 2010).

A Associação Brasileira de Ergonomia (ABERGO) adota a definição de ergonomia dada pela International Ergonomics Association (IEA), que descreve a ergonomia como sendo uma disciplina científica que estuda as interações entre os seres humanos e outros elementos do sistema de trabalho, aplicando os princípios teóricos, dados e métodos, a fim de realizar projetos para otimizar o bem-estar humano e o desempenho geral desse sistema.

Com base no conceito de ergonomia, inúmeras ferramentas foram desenvolvidas e são constantemente empregadas para avaliar as posturas dos trabalhadores durante a realização de suas atividades. Essas ferramentas permitem documentar a pesquisa e armazenar informações que podem ser comparadas posteriormente, além de possibilitar a elaboração de relatórios que evidenciam problemas ergonômicos, e servem de base para a tomada de decisão na busca de solução dos problemas (Fieldkircher, 2015). Dentre os diversos métodos destaca-se o RULA (Rapid Upper-Limb Assessment), que foi desenvolvido para avaliar as posturas adotadas pelos trabalhadores, bem como as forças e atividades musculares por eles exercidas durante suas atividades laborais (MCATEMNEY e CORLETT, 1993).

0 presente trabalho tem como objetivo realizar uma análise das características posturais e das forças musculares dos trabalhadores que realizam a soldagem a arco submerso de chapas de aço laminado para a fabricação de painéis de estruturas navais, utilizando o método RULA, e em sequência, propor ações de correção para os problemas identificados.

\section{REVISÃO BIBLIOGRÁFICA}

\subsection{ERGONOMIA}

A produção profissional está diretamente relacionada com as condições em que o trabalho é desenvolvido, o que acarreta a necessidade de oferecer postos de trabalho adequados às características e limitações humanas, evitando, assim, problemas como absenteísmo, lesões por esforços repetitivos (LER) e doenças osteomusculares relacionadas ao trabalho (DORT), (VASCONCELOS, VILLAROUCO e SOARES, 2009).

Os maiores problemas acidentários no Brasil são decorrentes dos traumas por esforços repetitivos, e as DORT são a segunda maior causa dos afastamentos do trabalho por acidentalidade (Iida et. al., 2016). 0 anuário estatístico da previdência social (AEPS) mostra que no ano de 2016, de um total de 578.935 acidentes de trabalho catalogados, $25.593(4,42 \%)$ estão associados à dorsalgia, $9.896(1,70 \%)$ são decorrentes de sinovite e tenossinovite e $4.838(0,83 \%)$ decorrentes de mononeuropatia dos membros superiores (Previdência, 2016).

Um posto de trabalho desenvolvido com base no enfoque ergonômico se caracteriza pela adaptação de máquinas, ferramentas e equipamentos à capacidade do trabalhador e às características da tarefa, visando o equilíbrio biomecânico através da diminuição das cargas estáticas da musculatura, e redução da carga mental impostas ao trabalhador (Iida et. al, 2016). 0 emprego de ferramentas e técnicas de análise ergonômica permite identificar problemas que comprometem o equilíbrio biomecânico e mental do trabalhador nas mais diversas atividades, possibilitando o desenvolvimento de ações de correção que reduzem as possibilidades de surgimento de lesões e doenças do trabalho.

\subsection{SOLDAGEM POR ARCO SUBMERSO}

O processo de soldagem por arco submerso (Fig. 1) foi desenvolvido nos Estados Unidos em 1935, com o objetivo de melhorar a qualidade da construção das embarcações (Junior, 1999). Segundo Modenesi et. al. (2004), a soldagem a arco submerso consiste em um processo no qual a coalescência dos metais é produzida pelo aquecimento destes com um arco estabelecido entre um eletrodo metálico contínuo e a peça. 0 arco é protegido por uma camada de material fusível granulado (fluxo) que é colocado sobre a peça enquanto o eletrodo é alimentado de forma contínua. Dessa forma, a fusão do fluxo protege a poça de fusão, ajuda a estabilizar o arco, reage com o metal fundido, e forma a escória sobre o cordão de solda após a solidificação. 
Figura 1: Esquema representativo do processo de soldagem a arco submerso

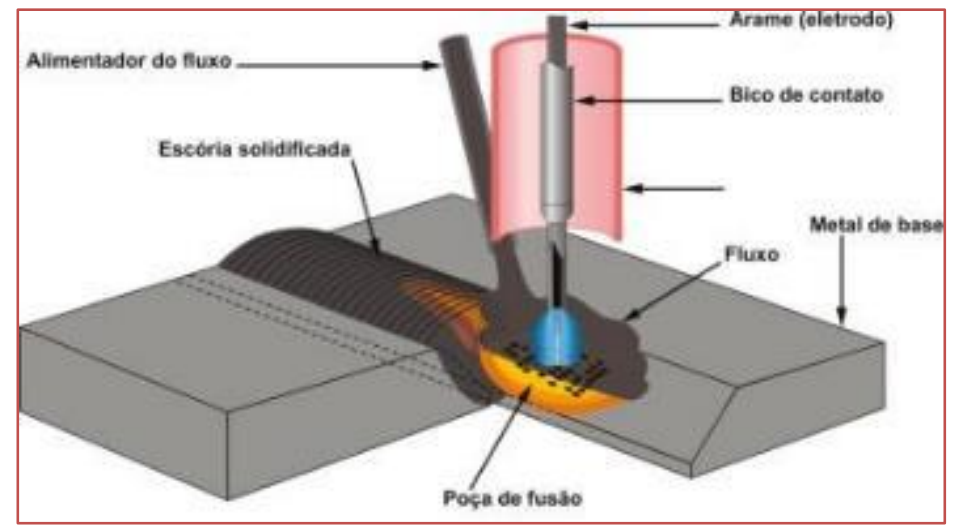

Fonte: (Modenesi et. al, 2004).

0 processo de soldagem a arco submerso apresenta como vantagens para a segurança operacional a não geração de fumos, respingos e radiação (tab. 1). Segundo Modenesi 2004, não há necessidade do uso da máscara de solda para a proteção contra a radiação, pois o arco elétrico não fica exposto, recomendandose, apenas, o uso de óculos de proteção, e demais equipamentos, como botas, luvas e aventais de raspa para proteção do contato com partes quentes.

Tabela 1: Vantagens, limitações e aplicações da soldagem por arco submerso

\begin{tabular}{|c|c|}
\hline Vantagens e Limitações & Aplicações \\
\hline $\begin{array}{l}\text { Alta velocidade de soldagem e elevada taxa de } \\
\text { deposição. }\end{array}$ & Soldagem de aços carbono, baixa e alta liga. \\
\hline $\begin{array}{l}\text { Produz soldas uniformes e de bom acabamento } \\
\text { superficial. }\end{array}$ & Soldagem de niquel e suas ligas. \\
\hline Ausência de respingos e fumos. & $\begin{array}{l}\text { Soldagem de membros estruturais e tubos de } \\
\text { grande diâmetro }\end{array}$ \\
\hline $\begin{array}{l}\text { Dispensa proteção contra radiação uma vez que } \\
\text { o arco não é visivel. }\end{array}$ & $\begin{array}{l}\text { Soldagem de recobrimento, manutenção e } \\
\text { reparo. }\end{array}$ \\
\hline Facilmente mecanizado. & - \\
\hline Elevada produtividade. & - \\
\hline $\begin{array}{l}\text { Soldagem limitada às posições plana e filete } \\
\text { horizontal }\end{array}$ & - \\
\hline $\begin{array}{l}\text { Aporte térmico elevado pode prejudicar } \\
\text { propriedades da junta em alguns casos. }\end{array}$ & - \\
\hline $\begin{array}{l}\text { Necessidade de retirada de escória entre } \\
\text { passes. }\end{array}$ & - \\
\hline
\end{tabular}

Fonte: (Modenesi et. al, 2004).

\subsection{MÉTODO RULA}

O método RULA foi desenvolvido em 1993 pelos pesquisadores Lynn McAtamney e Nigel Corlett, membros do Institute for Occupacional Ergonomics da University of Nottingham. Trata-se de uma técnica de análise ergonômica que avalia o trabalho muscular estático e as forças exercidas pelos segmentos corporais (Iida et. al, 2016).

RULA permite uma avaliação rápida das posturas do pescoço, tronco e membros superiores e inferiores, juntamente com a função muscular e as cargas (forças) externas aos quais o corpo é submetido. Sua aplicação se dá sem a necessidade do uso de equipamentos específicos, exigindo do analista, apenas o uso de papel, caneta e uma prancheta para o registro de suas observações posturais (Iida et. al. 2016).

A utilização do método RULA passa pela sequência de etapas de observação e registro das posturas de trabalho, distribuição de pontos para posturas dos segmentos corporais analisados e desenvolvimento de um plano de ação com base na pontuação final obtida (McAtamney et. al, 1993). 0 método divide os segmentos corporais em grupos e usa planilhas com diagramas com pontuação estabelecida para cada postura (fig. 2, fig. 3 e fig. 4), facilitando a identificação das amplitudes dos movimentos nas articulações 
de braços, antebraços, mãos, pescoço, tronco, pernas e pés (McAtamney et. al, 1993; Almeida, 2010; Iida et. al. 2016).

Figura 2: Diagrama de pontuação para posturas do grupo A do Método RULA.
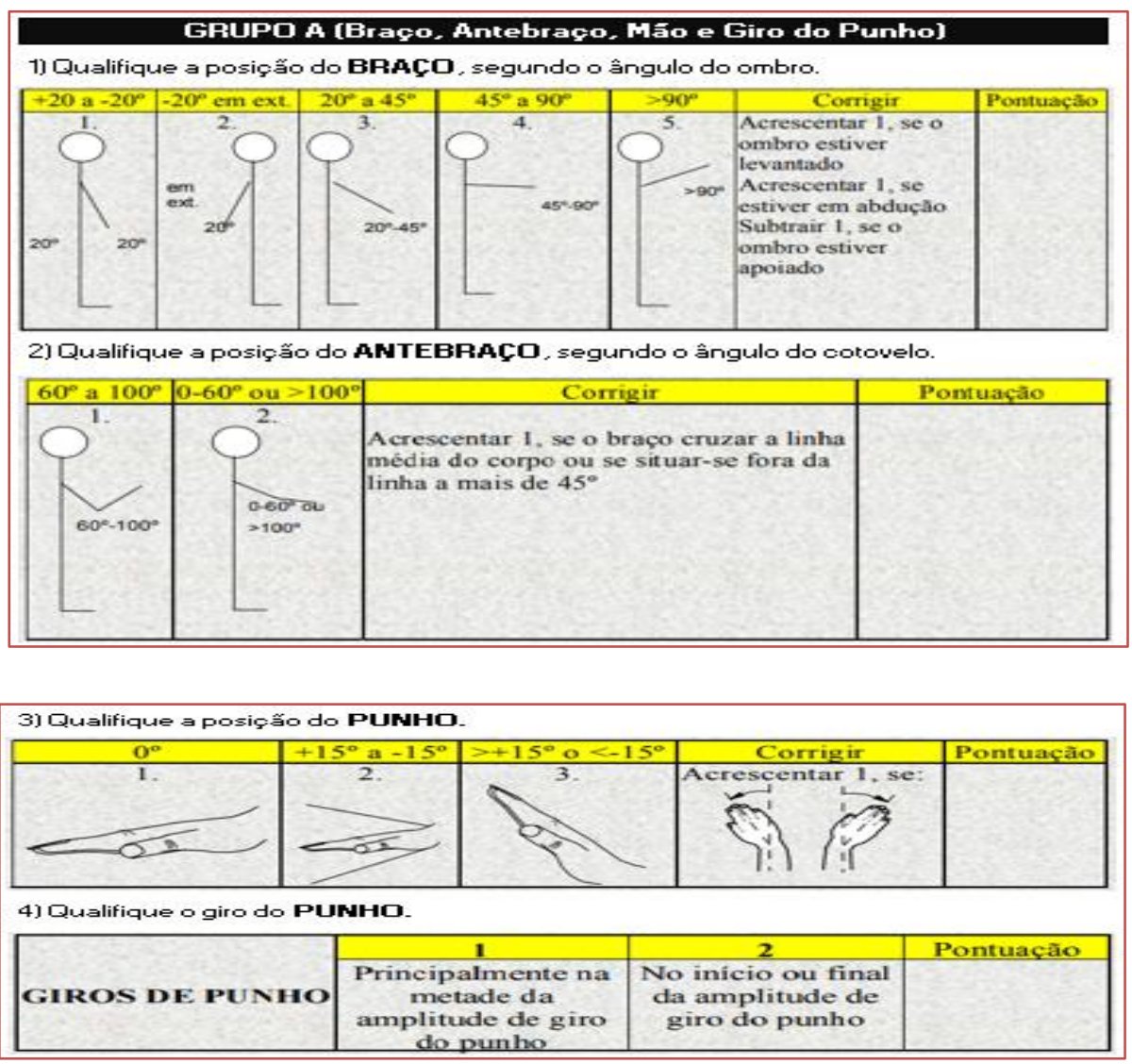

Fonte: (adaptado de Almeida, 2010).

Figura 3: Diagrama de pontuação para posturas do grupo B do Método RULA.

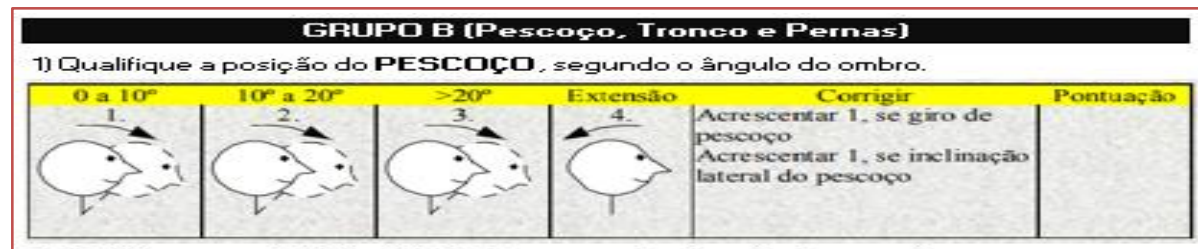

2) Qualifique a posiçẫo do TRDNCD, segundo o Ângulo do cotovelo.

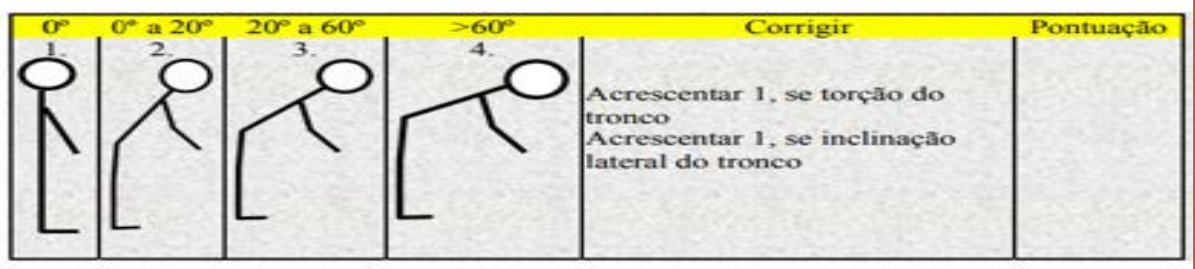

3) Qualifique a posição das PERNAS

\begin{tabular}{|c|c|c|c|}
\hline $\begin{array}{l}\text { EXTIREMIDADES } \\
\text { INFERIORES }\end{array}$ & $\begin{array}{l}\text { 1 } \\
\text { Se as per nas e os pés estâo } \\
\text { bem apoiados e equilibrados }\end{array}$ & $\begin{array}{l}\text { Se as pernas e os pés } \\
\text { nấo estiło cometamente } \\
\text { apoiados e equilibrados }\end{array}$ & Pontuacito \\
\hline
\end{tabular}

Fonte: (adaptado de Almeida, 2010). 
Figura 4: Diagrama de pontuação para posturas dos grupos A e B do Método RULA

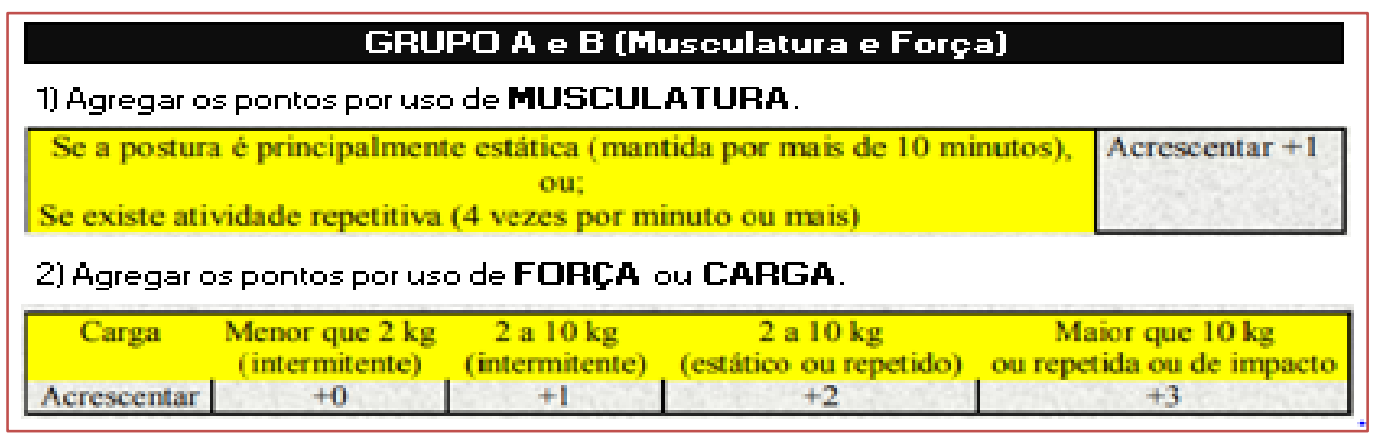

Fonte: (adaptado de Almeida, 2010).

A pontuação das posturas A e B são determinadas pela combinação dos pontos atribuídos à postura de cada segmento corporal integrante dos respectivos grupos, utilizando os dados das tabelas 2 e 3 .

Tabela 2: Determinação da pontuação da postura do grupo A.

\begin{tabular}{|c|c|c|c|c|c|c|c|c|c|}
\hline \multirow{2}{*}{\multicolumn{2}{|c|}{ A }} & \multicolumn{8}{|c|}{ Punho } \\
\hline & & \multirow{2}{*}{\multicolumn{2}{|c|}{$\frac{1}{\text { Giro }}$}} & \multirow{2}{*}{\multicolumn{2}{|c|}{$\frac{2}{\text { Giro }}$}} & \multirow{2}{*}{\multicolumn{2}{|c|}{$\frac{3}{\text { Giro }}$}} & \multirow{2}{*}{\multicolumn{2}{|c|}{$\frac{4}{\text { Giro }}$}} \\
\hline \multirow{2}{*}{ Braço } & \multirow{2}{*}{ Antebraço } & & & & & & & & \\
\hline & & 1 & 2 & 1 & 2 & 1 & 2 & 1 & 2 \\
\hline \multirow{3}{*}{1} & 1 & 1 & 2 & 2 & 2 & 2 & 3 & 3 & 3 \\
\hline & 2 & 2 & 2 & 2 & 2 & 3 & 3 & 3 & 3 \\
\hline & 3 & 2 & 3 & 2 & 3 & 3 & 3 & 4 & 4 \\
\hline \multirow{3}{*}{2} & 1 & 2 & 2 & 2 & 3 & 3 & 3 & 4 & 4 \\
\hline & 2 & 2 & 2 & 2 & 3 & 3 & 3 & 4 & 4 \\
\hline & 3 & 2 & 3 & 3 & 3 & 3 & 4 & 4 & 5 \\
\hline \multirow{3}{*}{3} & 1 & 2 & 3 & 3 & 3 & 4 & 4 & 5 & 5 \\
\hline & 2 & 2 & 3 & 3 & 3 & 4 & 4 & 5 & 5 \\
\hline & 3 & 2 & 3 & 3 & 4 & 4 & 4 & 5 & 5 \\
\hline \multirow{3}{*}{4} & 1 & 3 & 4 & 4 & 4 & 4 & 4 & 5 & 5 \\
\hline & 2 & 3 & 4 & 4 & 4 & 4 & 4 & 5 & 5 \\
\hline & 3 & 3 & 4 & 4 & 5 & 5 & 5 & 6 & 6 \\
\hline \multirow{3}{*}{5} & 1 & 5 & 5 & 5 & 5 & 5 & 6 & 6 & 7 \\
\hline & 2 & 5 & 6 & 6 & 6 & 6 & 7 & 7 & 7 \\
\hline & 3 & 6 & 6 & 6 & 7 & 7 & 7 & 7 & 8 \\
\hline \multirow{3}{*}{6} & 1 & 7 & 7 & 7 & 7 & 7 & 8 & 8 & 9 \\
\hline & 2 & 7 & 8 & 8 & 8 & 8 & 9 & 9 & 9 \\
\hline & 3 & 9 & 9 & 9 & 9 & 9 & 9 & 9 & 9 \\
\hline
\end{tabular}

Fonte: (adaptado de McAtamney et. al, 1993).

Tabela 3: Determinação da pontuação da postura do grupo B.

\begin{tabular}{|c|c|c|c|c|c|c|c|c|c|c|c|c|}
\hline \multirow{3}{*}{ B } & \multicolumn{12}{|c|}{ Tronco } \\
\hline & \multicolumn{2}{|c|}{1} & \multicolumn{2}{|c|}{2} & \multicolumn{2}{|c|}{3} & \multicolumn{2}{|c|}{4} & \multicolumn{2}{|c|}{5} & \multicolumn{2}{|c|}{6} \\
\hline & \multicolumn{2}{|c|}{ Pernas } & \multicolumn{2}{|c|}{ Pernas } & \multicolumn{2}{|c|}{ Pernas } & \multicolumn{2}{|c|}{ Pernas } & \multicolumn{2}{|c|}{ Pernas } & \multicolumn{2}{|c|}{ Pernas } \\
\hline Pescoço & 1 & 2 & 1 & 2 & 1 & 2 & 1 & 2 & 1 & 2 & 1 & 2 \\
\hline 1 & 1 & 3 & 2 & 3 & 3 & 4 & 5 & 5 & 6 & 6 & 7 & 7 \\
\hline 2 & 2 & 3 & 2 & 3 & 4 & 5 & 5 & 5 & 6 & 7 & 7 & 7 \\
\hline 3 & 3 & 3 & 3 & 4 & 4 & 5 & 5 & 6 & 6 & 7 & 7 & 7 \\
\hline 4 & 5 & 5 & 5 & 6 & 6 & 7 & 7 & 7 & 7 & 7 & 8 & 8 \\
\hline 5 & 7 & 7 & 7 & 7 & 7 & 8 & 8 & 8 & 8 & 8 & 8 & 8 \\
\hline 6 & 8 & 8 & 8 & 8 & 8 & 8 & 8 & 9 & 9 & 9 & 9 & 9 \\
\hline
\end{tabular}

Fonte: (adaptado de McAtamney et. al, 1993). 
A pontuação final é produto da combinação das pontuações $C$ e $D$, e determina o nível de ação que estabelece as diretrizes do plano de ação para solução dos problemas posturais identificados pela RULA (fig. 5).

Figura 5: Determinação da pontuação final pela combinação das pontuações C e D, e classificação do nível de ação

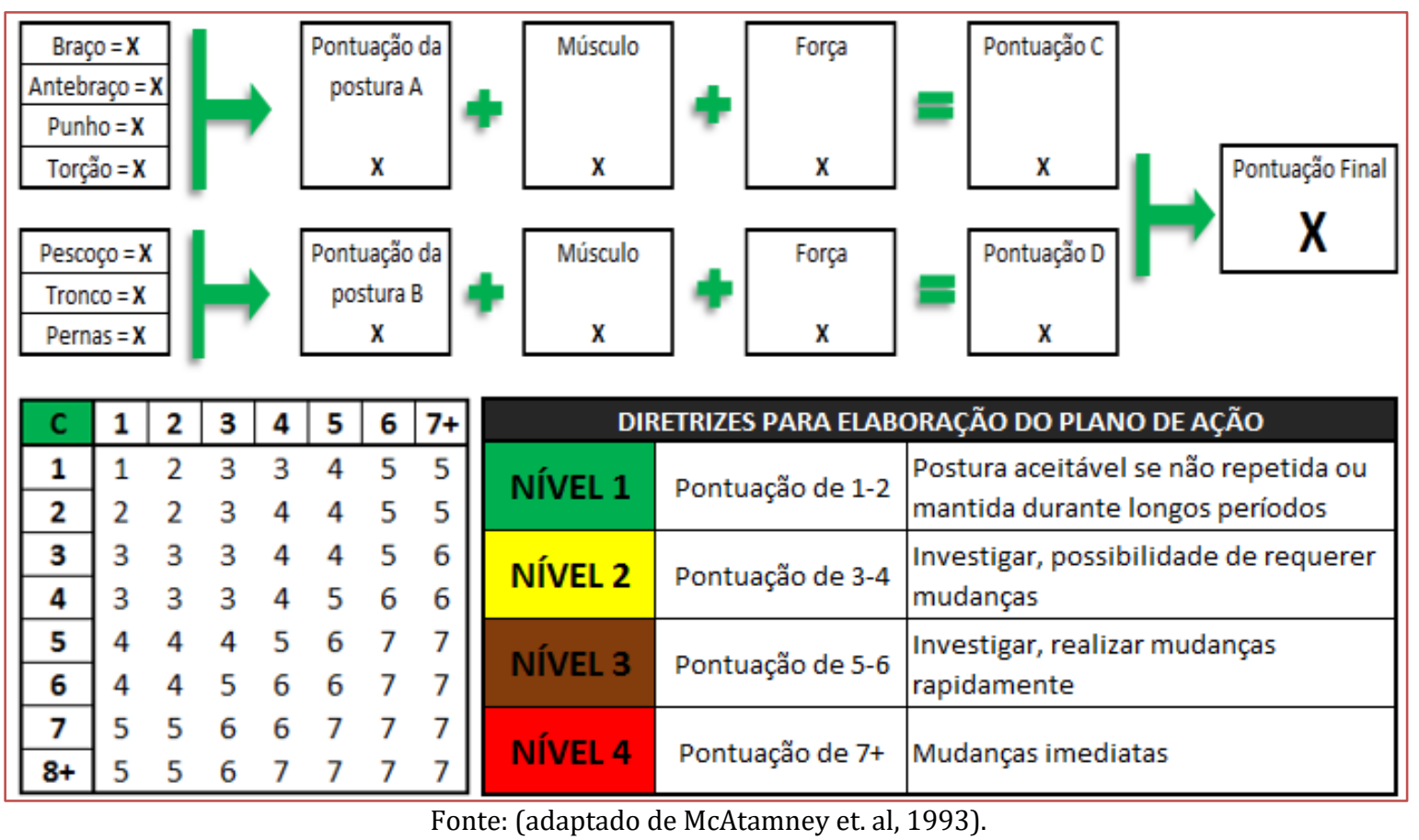

\section{MATERIAIS E MÉTODOS}

\subsection{MATERIAIS}

O presente trabalho foi realizado na empresa Keppel Singmarine Brasil, situada na cidade de Navegantes SC. A empresa atua no segmento de construção de embarcações de transporte, suprimentos e equipamentos para a indústria do petróleo. Para a realização desta pesquisa, avaliaram-se as posturas adotadas pelo operador do equipamento de soldagem a arco submerso, durante a execução da tarefa de soldagem de chapas de aço para a fabricação dos painéis de módulos das embarcações.

0 processo se divide nas etapas de inspeção das chapas, programação do equipamento de soldagem e execução da solda. Durante a etapa de inspeção de chapas, o operador faz a verificação da espessura das chapas, bem como o seu correto posicionamento. Na sequência, inicia-se a programação do equipamento de soldagem, onde são feitos os ajustes de velocidade, amperagem e quantidade de fluxo do equipamento. Por fim, tem-se a etapa de soldagem, onde o equipamento de solda se move longitudinalmente sobre um trilho, soldando as chapas. 0 movimento do equipamento de soldagem é acompanhado pelo operador, que necessita avaliar o processo de soldagem, e realiza uma série de manobras visando manter a poça de fusão ativa, bem como ajustar parâmetros de soldagem para compensar a influência de fatores ambientais que possam comprometer a qualidade da solda. As posturas assumidas pelo trabalhador durante a etapa de soldagem foram analisadas com o método RULA, e são mostradas na figura 6. 
Figura 6: Processo de soldagem de chapas utilizando arco submerso.

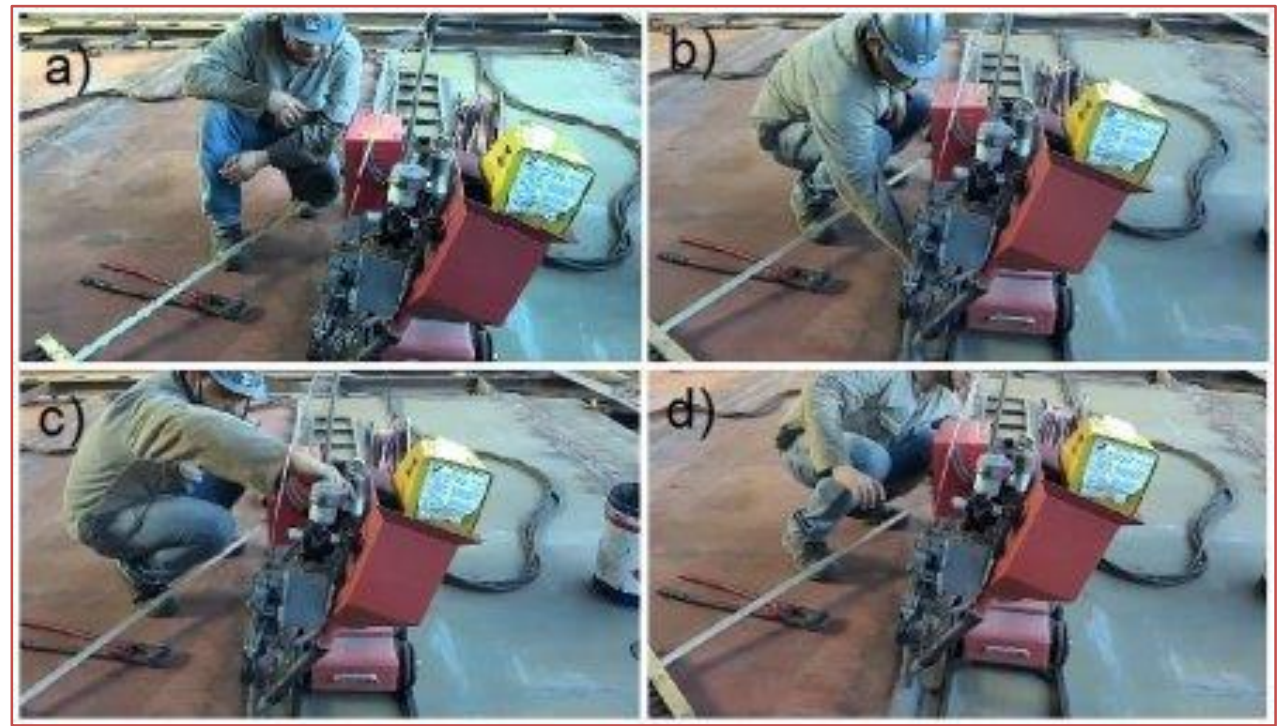

a) postura assumida pelo operador para verificar a necessidade de realização de algum ajuste no equipamento; b) postura assumida para alcançar o controle de velocidade; c) postura adotada para ajustar o fluxo; d) postura adotada para acompanhar o movimento do equipamento de soldagem.

\subsection{MÉTODOS}

Para a execução deste trabalho, empregou-se o método RULA na avaliação das posturas assumidas pelo operador do equipamento de soldagem a arco submerso durante o processo de soldagem de chapas de aço para fabricação de painéis. Realizou-se observações in loco para avaliar as etapas do processo de soldagem, bem como as posturas adotadas pelo trabalhador. Efetuou-se o registro fotográfico e a filmagem do processo, para auxiliar nas análises de posturas e esforços.

Na sequência, com base nas observações feitas in loco, e auxílio dos registros fotográficos e filmagem, realizou-se a análise postural, determinando-se a pontuação para as posturas assumidas pelo trabalhador (enquadradas nos grupos A e B), bem como a pontuação referente à musculatura empregada para a manutenção das posturas e para as cargas. A partir da pontuação estabelecida, definiu-se a pontuação total e o enquadramento do nível de risco da tarefa. Em seguida, desenvolveu-se um plano de ação para correção dos problemas encontrados, tendo como diretriz, o enquadramento do nível de ação indicado para o problema.

\section{RESULTADOS E DISCUSÃo}

\subsection{ANÁLISE DA PONTUAÇÃO DOS GRUPOS A E B}

A análise do processo demonstrou que o operador do equipamento de soldagem a arco submerso, constantemente posiciona os braços acima da linha dos ombros, com amplitude de $90^{\circ}$. Os antebraços se mantêm abaixo dos ombros posicionados entre $0^{\circ}$ e $60^{\circ}$. Os punhos são posicionados em ângulos de aproximadamente $15^{\circ}$, e realizam movimentos rotacionais. 0 pescoço se posiciona de forma inclinada, com angulação superior a $20^{\circ}$, e realiza constantes giros e inclinações laterais. 0 tronco fica posicionado com inclinação superior a $60^{\circ}$, e realiza constantes movimentos rotacionais. 0 trabalho de soldagem é executado na posição sentado, com o trabalhador apresentando pouco equilíbrio das pernas e dos pés. A pontuação para cada segmento corporal analisado e a pontuação dos grupos A e B são apresentadas nas tabelas 4 e 5. 
Tabela 4: Pontuação do grupo A para análise postural do trabalhador durante a execução do trabalho de soldagem.

\begin{tabular}{|c|c|c|c|c|c|c|c|c|c|}
\hline \multirow{2}{*}{\multicolumn{2}{|c|}{ A }} & \multicolumn{8}{|c|}{ Punho } \\
\hline & & \multirow{2}{*}{\multicolumn{2}{|c|}{$\frac{1}{\text { Giro }}$}} & \multirow{2}{*}{\multicolumn{2}{|c|}{$\frac{2}{\text { Giro }}$}} & \multirow{2}{*}{\multicolumn{2}{|c|}{$\frac{3}{\text { Giro }}$}} & \multirow{2}{*}{\multicolumn{2}{|c|}{$\frac{4}{\text { Giro }}$}} \\
\hline \multirow{2}{*}{ Braco } & \multirow{2}{*}{ Antebraço } & & & & & & & & \\
\hline & & 1 & 2 & 1 & 2 & 1 & 2 & 1 & 2 \\
\hline \multirow{3}{*}{1} & 1 & 1 & 2 & 2 & 21 & 2 & 3 & 3 & 3 \\
\hline & 2 & 2 & 2 & 2 & 2 & 3 & 3 & 3 & 3 \\
\hline & 3 & 2 & 3 & 2 & 3 & 3 & 3 & 4 & 4 \\
\hline \multirow{3}{*}{2} & 1 & 2 & 2 & 2 & 3 & 3 & 3 & 4 & 4 \\
\hline & 2 & 2 & 2 & 2 & 3 & 3 & 3 & 4 & 4 \\
\hline & 3 & 2 & 3 & 3 & 3 & 3 & 4 & 4 & 5 \\
\hline \multirow{3}{*}{3} & 1 & 2 & 3 & 3 & 3 & 4 & 4 & 5 & 5 \\
\hline & 2 & 2 & 3 & 3 & 3 & 4 & 4 & 5 & 5 \\
\hline & 3 & 2 & 3 & 3 & 4 & 4 & 4 & 5 & 5 \\
\hline \multirow{3}{*}{4} & 1 & 3 & 4 & 4 & 4 & 4 & 4 & 5 & 5 \\
\hline & 2 & 3 & 4 & 4 & 4 & 4 & 4 & 5 & 5 \\
\hline & 3 & 3 & 4 & 4 & 5 & 5 & 5 & 6 & 6 \\
\hline \multirow{3}{*}{5} & 1 & 5 & 5 & 5 & 5 & 5 & 6 & 6 & 7 \\
\hline & 2 & 5 & 6 & 6 & 6 & 6 & 7 & 7 & 7 \\
\hline & 3 & 6 & 6 & 6 & 7 & 7 & 7 & 7 & 8 \\
\hline \multirow{3}{*}{6.} & 1 & 7 & 7 & 7 & 76 & 7 & 8 & 8 & 9 \\
\hline & 2 & 7 & 8 & 8. & 8 & 8 & 9 & 9 & 9 \\
\hline & 3 & 9 & 9 & 9 & 9 & 9 & 9 & 9 & 9 \\
\hline
\end{tabular}

Fonte: (adaptado de McAtamney et. al, 1993).

Tabela 5: Pontuação do grupo B para análise postural do trabalhador durante a execução do trabalho de soldagem.

\begin{tabular}{|c|c|c|c|c|c|c|c|c|c|c|c|c|}
\hline \multirow{3}{*}{ B } & \multicolumn{12}{|c|}{ Tronce } \\
\hline & \multicolumn{2}{|c|}{1} & \multicolumn{2}{|c|}{2} & \multicolumn{2}{|c|}{3} & \multicolumn{2}{|c|}{4} & \multicolumn{2}{|c|}{5} & \multicolumn{2}{|c|}{6} \\
\hline & \multicolumn{2}{|c|}{ Pernas } & \multicolumn{2}{|c|}{ Pernas } & \multicolumn{2}{|c|}{ Pernas } & \multicolumn{2}{|c|}{ Pernas } & \multicolumn{2}{|c|}{ Pernas } & \multicolumn{2}{|c|}{ Pernas } \\
\hline Pescoço & 1 & 2 & 1 & 2 & 1 & 2 & 1 & 2 & 1 & 2 & 1 & 2 \\
\hline 1 & 1 & 3 & 2 & 3 & 3 & 4 & 5 & 5 & 6 & 6 & 7 & 7 \\
\hline 2 & 2 & 3 & 2 & 3 & 4 & 5 & 5 & 5 & 6 & 7 & 7 & 7 \\
\hline 3 & 3 & 3 & 3 & 4 & 4 & 5 & 5 & 6 & 6 & 7 & 7 & 7 \\
\hline 4 & 5 & 5 & 5 & 6 & 6 & 7 & 7 & $7 v$ & 7 & 7 & 8 & 8 \\
\hline 5 & 7 & 7 & 7 & 7 & 7 & 8 & 8 & 8 & 8 & 8 & 8 & 8 \\
\hline 6 & 8 & 8 & 8 & 8 & 8 & 8 & 8 & 9 & 9 & 9 & 9 & 9 \\
\hline
\end{tabular}

\subsection{DETERMINAÇÃo DA PONTUAÇÃO FINAL E DO NÍVEL DE RISCO DA TAREFA}

Na sequência das análises, verificou-se que a atividade de soldagem exige que o trabalhador assuma e mantenha postura estática por período prolongado. Devido a isso, atribui-se 1 ponto para musculatura, a ser somado à pontuação dos grupos A e B. A tarefa não demanda aplicação de força, o que resultou em pontuação 0 para o respectivo campo. A aplicação do RULA determinou um total de 18 pontos para o campo pontuação final, o que resultou em um nível de ação 4, indicando a necessidade de mudanças imediatas nas condições de execução da tarefa de soldagem (fig. 7). 
Figura 7: Determinação da pontuação final pela combinação das pontuações C e D, e classificação do nível de ação.

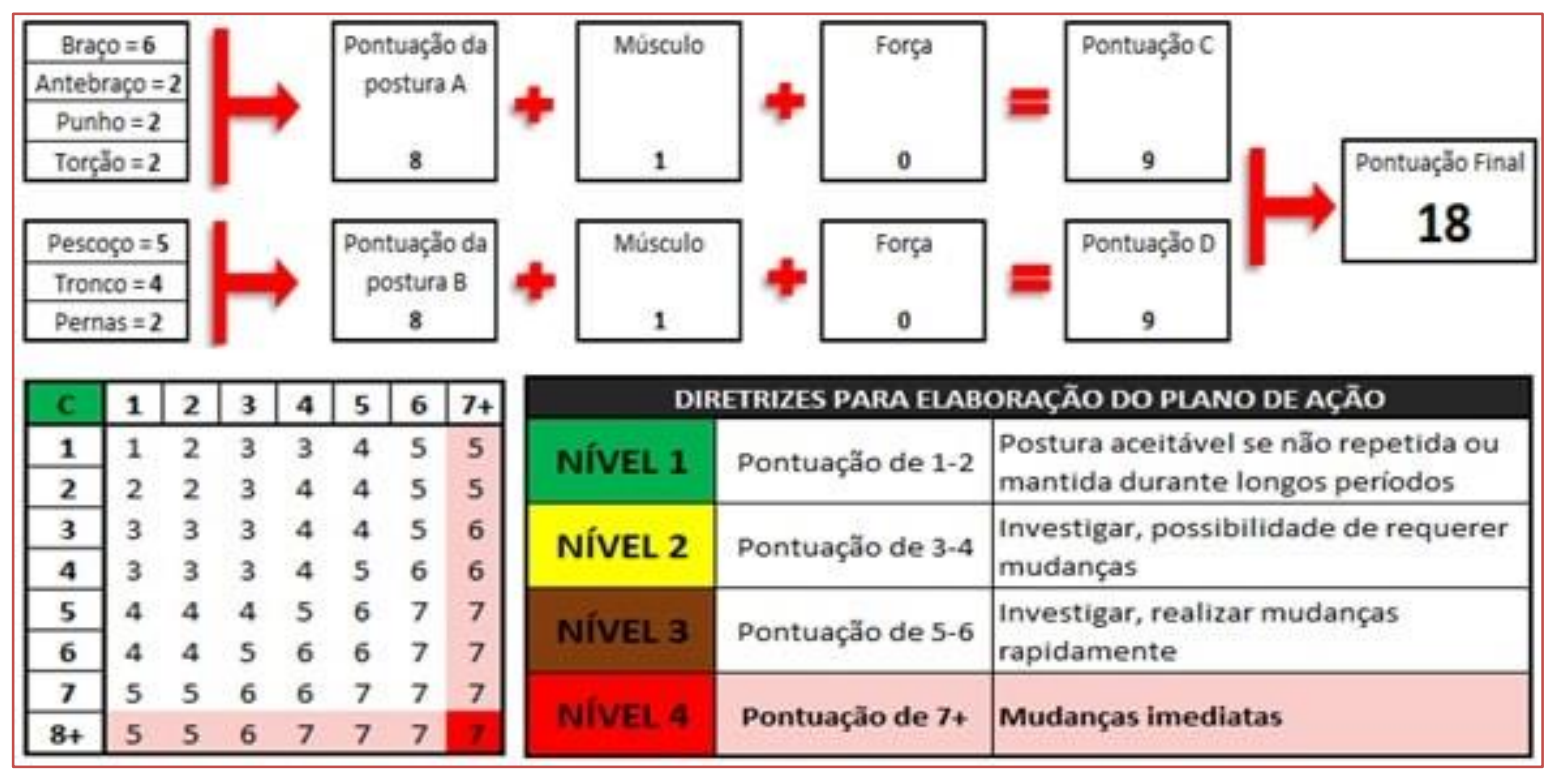

Fonte: (adaptado de McAtamney et. al, 1993).

\subsection{PROPOSTA DE AÇÕES PARA MINIMIZAR AS EXIGÊNCIAS POSTURAIS DO OPERADOR DURANTE A SOLDAGEM DE CHAPAS}

Com o objetivo de minimizar as exigências posturais do operador durante a soldagem de chapas pela técnica de arco submerso, buscou-se desenvolver ações pontuais de melhoria para o processo, visando reduzir a pontuação final. Essas ações consistem em:

- Uso de cadeira com braço, sustentada em uma base com rolamento, para que o operador possa permanecer sentado, com braços e pés apoiados, e com encosto de pescoço que possibilite ao trabalhador mantê-lo levemente inclinado. A cadeira deverá estar acoplada ao carrinho do equipamento de soldagem, de modo que possa acompanhar o processo;

- Instalação de um controle automatizado de tensão, amperagem e fluxo ao braço da cadeira, de modo que o operador não precise se mover até o carrinho do equipamento de soldagem para ajustar os parâmetros de soldagem, eliminando, assim, o giro dos punhos;

- Instalação de um sistema que aspire o fluxo para o funil do carrinho, eliminando, assim, as tarefas manuais de recolhimento do fluxo e realimentação do funil para sequência do processo de soldagem.

Estima-se que a adoção das medidas propostas influencie na pontuação das posturas atribuídas aos braços, punho, torção do punho, pescoço, tronco e pernas, de modo que a pontuação final apresente decréscimo de aproximadamente $61 \%$ da pontuação atual. A figura 8 mostra uma estimativa da pontuação final, após a adoção das ações propostas, indicando uma redução do nível de ação de nível 4 para nível 2. 
Figura 8: Estimativa da pontuação final por meio da aplicação do RULA após a implantação das ações de correção sugeridas.

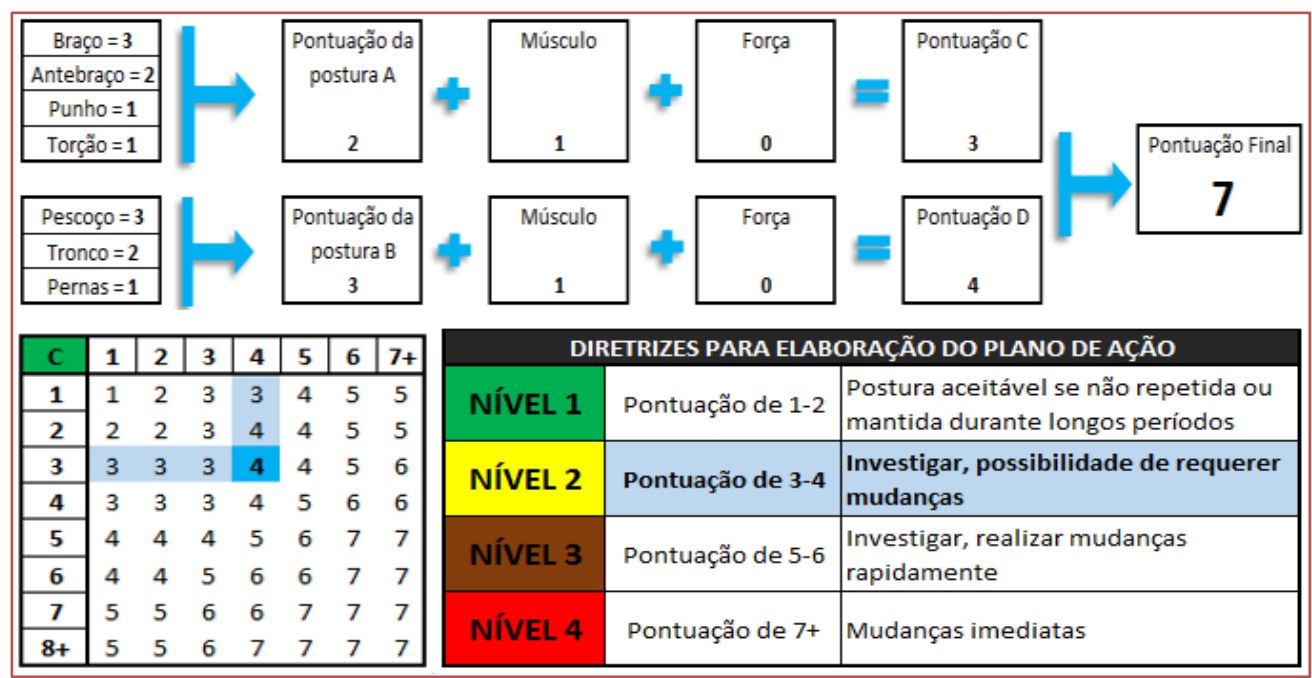

Fonte: (adaptado de McAtamney et. al, 1993).

\section{CONCLUSÃO}

A partir da análise e discussão dos resultados obtidos, conclui-se que o método RULA se mostrou adequado para a análise postural do trabalhador envolvido na tarefa de soldagem de chapas pela técnica de arco submerso, pois permitiu a avaliação detalhada das posturas de cada segmento corporal, e o desenvolvimento de ações que visem combater pontualmente os principais problemas identificados.

A aplicação do método indicou que a forma como a tarefa de soldagem das chapas é executada atualmente oferece condições bastante favoráveis ao surgimento de lesões e doenças do trabalho, pois se enquadra no nível 4, o que demanda realizar mudanças imediatas na forma de execução da atividade.

Estima-se que as ações propostas possam reduzir o nível de risco em aproximadamente 61\%, pois as mesmas atuam pontualmente nos segmentos corporais que contribuem para a elevada pontuação obtida pela aplicação do RULA na condição atual do desenvolvimento da atividade de soldagem das chapas pela técnica de arco submerso.

\section{AGRADECIMENTOS}

Agradecemos a empresa Keppel Singmarine Brasil pelo acesso ás instalações e por permitir a realização da pesquisa, a professora MSc. Nalba Lima de Souza, pela correção ortográfica.

\section{REFERÊNCIAS}

[1] AMARAL, F. G. RULA. Programa de Pós Graduação em Engenharia de Produção, UFRGS. Disponível em: http://www.producao.ufrgs.br/arquivos/disciplinas/395_RULA_grad.pdf. Acesso em 11/05/2018.

[2] Anuário Estatístico da Previdência Social 2016. Base de Dados Históricos. Disponível em http://www.previdencia.gov.br/wp-content/uploads/2018/01/AEPS-2016.pdf Disponível em: Acesso em: 10 de maio de 2018.

[3] CAPELLETTI B. H. APLICAÇÃO DO MÉTODO RULA NA INVESTIGAÇÃO DA POSTURA ADOTADA POR OPERADOR DE BALANCEADORA DE PNEUS EM UM CENTRO AUTOMOTIVO. Disponível em: <http://repositorio.roca.utfpr.edu.br/jspui/bitstream/1/3801/1/CT_CEEST_XXVI_2014_03.pdf>. Acesso em: 12 de maio de 2018.

[4] FIELDKIRCHER, É. B. ANÁLISE COMPARATIVA DE FERRAMENTAS PARA AVALIAÇÃO ERGONÔMICA- FAHOR - Faculdade Horizontina: Rio Grande do Sul 2015.

[5] IIDA, Itiro; GUIMARÃES, Lia Buarque de Macedo. Ergonomia: Projeto e Produção. 3 ed. São Paulo: Blucher, 2016. 
[6] International Ergonomics Association, Definição Internacional de Ergonomia. In: Revista Ação Ergonômica, set. 2008. Diponível em <http://www.abergo.org.br/revista/index.php/ae/article/view/61> Acesso em: 14 mai. 2018.

[7] JUNIOR, Antoine Aziz Raad, 1999 - $\quad$ ARCO SUBMERSO. Disponível em: <http://www.esab.com.br/br/pt/education/apostilas/upload/1901100rev1_apostilaarcosubmerso.pdf>. Acesso em: 07 de maio de 2018.

[8] MARQUES, P. V. TECNOLOGIA DE SOLDAGEM - Universidade Federal de Minas Gerais - 1 Edição de 1991.

[9] MCATAMNEY, Lynn; CORLETT, E.Nigel. RULA: a survey method for the investigation ofwork-related upper limb disorders. UK. Applied Ergonomics, v.24, n. 2, p. 91-99, 1993.

[10] MODENESI, P. J. et al. Introdução à metalurgia da soldagem. Departamento de Engenharia Metalúrgica e de Materiais, UFMG, Belo Horizonte, 2004.

[11] SILVA, JCP., and PASCHOARELLI, LC., orgs. A evolução histórica da ergonomia no mundo e seus pioneiros [online]. São Paulo: Editora UNESP; São Paulo: Cultura Acadêmica, 2010.

[12] VASCONCELOS, C. S. F.; VILLAROUCO, V.; SOARES, M. M.; Avaliação ergonômica do ambiente construído: estudo de caso em uma biblioteca. Disponível em: Acesso em: 10 de maio de 2018. 


\section{Capítulo 11}

Motivação e teorias motivacionais e sua aplicabilidade em uma instituição de ensino superior: Um estudo de caso

Ana Beatriz Lopes Souza

Edmilson Cavalcante Nunes

Gabriel Freitas da Costa

Ivone Pedro de Lima

Paola Rayanne Reis Fernandes

Resumo: Este artigo tem como objetivo analisar o perfil motivacional dos acadêmicos dos acadêmicos de Ciências Contábeis da Escola e Gestão e Negócios da Pontifícia Católica de Goiás. Os recursos metodológicos foram obtidos através da aplicação de questionário físico e online, e com perguntas objetivas aos alunos regularmente matriculados no curso e entrevistas com a coordenação e membro do corpo docente. Os resultados indicam que o motivo do aluno na realização de um curso superior é a possibilidade concreta de crescer, ganhar mais, ocupar cargos de destaque e manter relações sociais que o projete na sociedade. Assim, 43\% dos alunos afirmam ter escolhido o curso por identificação com a área revelando um sentimento de autorrealização ao ingressar em um cenário acadêmico em que se sentem confiantes para atuar profissionalmente. Afirmam que seu grau de motivação para prosseguir no curso recebe nota 8,0, corpo docente nota 7,0, sugerindo que para melhorar a experiência acadêmica e a motivação para concluir o curso, faz-se necessário a atualização do quadro de professores e mudanças nas dinâmicas e metodologias utilizadas nas salas de aula.

Palavras-Chave: Perfil motivacional; Satisfação; Gestão de pessoas. 


\section{INTRODUÇÃO}

A motivação tem sido destaque no contexto acadêmico, ao compreender o que leva o aluno a estar motivado na universidade, sendo possível adotar métodos teóricos para que essa motivação seja potencializada, minimizando os pontos fracos e concentrando nos fortes Neste sentido a relevância deste estudo tem por base a análise e avaliação da motivação no meio acadêmico, por meio do estudo das teorias motivacionais e aplicação de questionários na perspectiva de ouvir o acadêmico e docentes do curso como respaldo a gestão acadêmica. Neste trabalho pretende-se conhecer o grau de motivação, satisfação e interesses dos alunos de ciências contábeis da Escola de Gestão e Negócios da Pontifícia Universidade Católica de Goiás.

Sua justificativa encontra-se na necessidade em expor a importância da motivação através das teorias motivacionais, e como ela pode vir a impactar os alunos durante o curso, assim como procurar melhorias para que o curso contribua efetivamente para o desenvolvimento de competências necessárias para o exercício profissional.

Metodologicamente foi realizada uma pesquisa exploratória quanti-qualitativa, com aplicação de questionários físico e online aos alunos do período matutino, devidamente matriculados e entrevista com professores para obter informações sobre o projeto político pedagógico do curso e suas interfaces com o mercado de trabalho.

O artigo está estruturado em sua fundamentação teórica na qual serão abordados os conceitos de gestão em pessoas, motivação e as teorias motivacionais que serão discutidas e darão base teórica a pesquisa para estruturação do estudo. Em seguida a metodologia apresenta quais os métodos foram utilizados para obter os dados.

E por fim apresenta-se os resultados que foram obtidos a partir da coleta de dados. Tais dados serão devidamente tabulados e representados em gráficos, obedecendo as respostas dos alunos para se fazer a análise das questões que foram problematizadas: Principal razão que o levou a escolher o curso? Qual o grau de motivação para prosseguir o curso? Qual a nota para o curso? Como o aluno auto- avalia seu desempenho até o momento? Qual a nota para o corpo docente? Como melhorar a experiência acadêmica e motivação?

As instituições necessitam hoje de indivíduos motivados pelos objetivos que são designados a atingir. A ideia de que motivação está ligada a premiações ou pela ausência delas, caiu por terra. A motivação representa uma necessidade particular de cada indivíduo, ligada a auto identidade, autoestima e autogerenciamento (BERGAMINI, 2013). Assim, pode-se afirmar relevância da pesquisa na medida em que se trabalha a relação entre o ideal do acadêmico, suas perspectivas de trabalho e formação profissional e o resultado, onde vê seus ideais conquistados pela expansão de sua capacidade, projetando-se profissionalmente e sendo premiado. Um líder gestor empresarial ou universitário deve estabelecer metas claras, realizar supervisão, elogiar progressos, indicar pontos a melhorar, levando o indivíduo a se concentrar no que deve ser feito, potencializando seu conjunto de competências e preparando-se para lidar com as exigências do mundo do trabalho.

\section{FUNDAMENTAÇÃO TEÓRICA}

Este trabalho tem como fundamento um estudo sobre perfil motivacional e satisfatório acadêmico/profissional. Abrange perfil, satisfação e motivação dos alunos da Escola de Gestão e Negócios referente aos cursos de Administração e Ciências Contábeis da PUC - GO.

\subsection{GESTÃO DE PESSOAS}

Para analisar a satisfação e motivação dos acadêmicos, deve - se apoiar primeiramente na conceituação de Gestão de Pessoas. Os estudos desenvolvidos revelam que a gestão de Pessoas é a "função gerencial que visa à cooperação das pessoas que atuam nas organizações para o alcance dos objetivos tanto organizacionais quanto individuais". (GIL, 2011, p. 16))

Isto só será possível, através da análise das relações entre indivíduo e organização. Estas relações constituem um processo de integração o que resulta em satisfação. As empresas de sucesso hoje são aquelas que em detrimento das mudanças do mercado, proliferação de tecnologias, multiplicação de concorrentes e de produtos que se tornam obsoletos quase da noite para o dia, saibam criar novos 
conhecimentos, disseminando-os profundamente em toda a organização e de forma rápida para que sejam incorporadas em novas tecnologias e produtos (NONAKA, 2006).

Em detrimento disso as organizações modernas vêm repensando sobre a importância das pessoas e a forma como são administradas, desenvolvidas e recompensadas "diferentemente do que ocorria no passado, quando o foco recaía apenas na tecnologia do produto ou do processo, nos mercados protegidos ou regulamentados, no acesso a recursos financeiros e economias de escala" (LACOMBE, 2005, p.14).

As pessoas deveriam ser colocadas na contabilidade empresarial como ativo em vez de despesas, que por definição é algo que se pode vender e que possui valor quando a empresa é liquidada, mas não é um ativo no sentido contábil da palavra, mas sim algo que se possa agregar valor (LACOMBE, 2005). Segundo pesquisas realizadas importante se faz informar que as pessoas "bem selecionadas, treinadas e integradas e que trabalham como uma equipe tem um valor inestimável e, quando a empresa é vendida, influência no valor atribuído ao seu fundo de comércio". (LACOMBE, 2005, p.15)

Com base no momento atual em que se vive um ambiente externo, instável e mutável denominado de globalização, momento marcado pela revolução da informação e comunicação com fronteiras cada vez menos rígidas e de fácil propagação e alcance, fez com que as empresas requeressem "o desafio de aumentar a capacidade de aprender, colaborar e gerenciar a diversidade, a complexidade e a ambiguidade" do saber humano. Grandes empresas na atualidade "são valorizadas pelo que está "na mente" de seus profissionais, seu capital intelectual" (PEREIRA, 2014, pag.3).

As organizações baseadas no conhecimento necessitam hoje dedicar-se ao desenvolvimento de talentos e habilidades de seus profissionais, propiciando tempo para escutá-los, conhecê-los e orientá-los. Por fim, as empresas que investem na área de gestão de pessoas podem trazer para a organização pessoas com habilidades e competências tanto para trabalharem em prol destas quanto para se tornarem gestores capazes de convergir suas habilidades em conhecimentos, estarão a frente das demais. Importante reafirmar que a instituição de ensino superior tem essa responsabilidade e esse compromisso com a sociedade, formando profissionais comprometidos em agregar valor por meio da redução de custos ou oferta de algo singular aos clientes; que possuem talentos raros não disponíveis de forma igual no mercado e que são bem escolhidas, motivadas e treinadas para que se possa torná-las uma ferramenta de gestão efetiva (PEREIRA, 2014).

\subsection{MOTIVAÇÃO}

Motivação é um impulso que faz com que as pessoas ajam para atingir seus objetivos. A motivação envolve fenômenos emocionais, biológicos e sociais e é um processo responsável por iniciar, direcionar e manter comportamentos relacionados com o cumprimento de objetivos. ROBBINS (2010 p. 196), define a motivação como: "processo responsável pela intensidade, pela direção e pela persistência dos esforços de uma pessoa para alcançar determinada meta".

A motivação parte do sujeito, ou seja, é uma atitude interna. Sendo assim, a motivação não poderá ser inserida, ela deverá ser impulsionada, estimulada para que o indivíduo venha agir, não por obrigação, mas por atitude própria. CORTELLA (2016)

Ao definir as necessidades do homem em primarias como sendo as fisiológicas e segurança, e em secundaria as que se referem a estima, sociais e auto realização Abraham Maslow, concluiu que assim que estas necessidades são supridas, ele se motiva. Sendo assim, se faz necessário a criação de estratégias que possam identifica-las nas pessoas que compõem a organização, para oferecer soluções financeiras ou psicológicas de modo que estes estímulos venham impulsionar a motivação de cada uma delas. Para isso temos a Psicologia como apoio, contribuindo para uma análise do sujeito e suas relações sociais. (TEIXEIRA; SIQUEIRA, 2017).

\subsection{TEORIAS MOTIVACIONAIS}

\subsubsection{A TEORIA DA HIERARQUIA DAS NECESSIDADES DE MASLOW}

Proposta por Abraham H. Maslow, a teoria das necessidades fundamenta que o esforço do indivíduo dependerá da satisfação de suas necessidades pessoais e profissionais. Para Maslow o ser humano possui várias necessidades e elas podem ser classificadas nos seguintes níveis: Necessidades fisiológicas: se relacionam com o biológico do ser. Por exemplo: comer, descansar, respirar, manter relações sexuais, 
entre outras. Necessidades de segurança: estão relacionadas com as necessidades de sentir-se seguro. Por exemplo: estabilidade no emprego, condições seguras de trabalho.

Complementa ainda, as Necessidades sociais: necessidade de manter relações harmoniosas com outras pessoas. Por exemplo: sentir-se parte de um grupo, receber afeto e carinho. Necessidades de estima: reconhecimento próprio e por parte dos outros das capacidades do ser. Por exemplo: promoções, feedbacks. E por fim, as Necessidades de auto realização: localizada no topo da pirâmide das necessidades, relaciona-se com o crescimento. Por exemplo: autonomia, independência e autocontrole. (ROBBINS, 2010),

Segundo Vergara (2003), as necessidades primárias são as fisiológicas e as de segurança, essas necessidades dizem respeito a sobrevivência das pessoas e ainda, a necessidade de proteção contra alguma ameaça real ou imaginária. Já as necessidades secundárias são as sociais, estima e de auto realização, que constituem o topo da pirâmide. Assim, os estudos de Maslow indicam que "para motivar alguém é preciso saber em que nível da hierarquia a pessoa se encontra no momento e focar a satisfação naquele nível ou no patamar imediatamente superior". (ROBBINS, 2005, p.133).

\subsubsection{TEORIA DAS NECESSIDADES SOCIALMENTE ADQUIRIDAS - DAVID MCCLELLAND}

A teoria das três necessidades socialmente adquiridas originalmente desenvolvida por Davi Mcclelland para explicar o comportamento humano, afirma que as pessoas desenvolvem ao longo de suas vidas três principais necessidades sociais, tais como: A necessidade de realização, a necessidade de poder e a necessidade de afiliação. (ROBBINS - 2010)

A necessidade de realização é voltada para o sentimento de excelência, onde todos os indivíduos vão atrás de desafios de maior complexidade para realização, e ao realizarem esses desafios sentem-se realizados e felizes, sendo movidos por forças como: desejo de ser aprovado socialmente, desejo de status, conhecimentos e habilidades São pessoas "irriquietas", que na busca de objetivos com riscos moderados, procuram sempre feedback de modo a medir cada progresso e melhora no desempenho alcançado. Essas pessoas modem ser caracterizadas como fortemente motivadas ao sucesso e tendo a ser bemsucedidas como empreendedoras (FEIJÓ, 2015, p.3)

A necessidade de poder visa gerar impacto sobre outras pessoas, exercendo dominação e carisma em suas disposições e comportamentos. Podendo valer do carisma (poder pessoal) ou da dominação (poder institucional). 0 objetivo dessa necessidade é fazer com que os demais indivíduos ajam em conformidade com os desejos da pessoa (que exerce poder) e também trazer para ela o sentimento de responsabilidade por esses indivíduos. Sempre haverá uma busca constante da necessidade de poder pelo sentimento de gerar impacto nos comportamentos e emoções das outras pessoas, uma vez que essa necessidade está ligada a atividades competitivas e ao interesse em atingir e manter prestígio e reputação

A necessidade de afiliação é associada ao sentimento de aceitação e amor pelos outros. Essa necessidade busca manter bons relacionamentos com as outras pessoas, manter amizades solidas, estar próximo, poder compartilhar suas alegrias ideias livremente. As pessoas orientadas por afiliação ou associação como também pode se chamar essa necessidade, tendem a trabalhar melhor em equipe e agir amigavelmente na maioria da situação, mas em situações ameaçadoras podem atuar de forma defensiva (FEIJO; LUNCKS; ROSA - 2015)

\subsubsection{A TEORIA DOS DOIS FATORES DE HERZBERG: MOTIVAÇÃO - HIGIENE}

A teoria de dois fatores foi criada por Frederick Herzberg - psicólogo americano, ficou muito conhecida por se tratar de motivação e satisfação das pessoas. Foi feita uma grande contribuição para que fosse estudado os fatores motivacionais e fatores higiênicos. Além disso, esta teoria ficou conhecida como Teoria da Estrutura Dual. (SOUZA, 2014, p.10)

Fatores higiênicos são fatores que abrangem as condições dentro da quais a empresa desempenha seu trabalho, com essa condição é dada situação da empresa, salário, condições de trabalho e segurança. Com essa teoria, Herzberg conclui que o que causa insatisfação nos funcionários são situação do ambiente de trabalho. Fatores motivacionais ao trabalho são: realização, reconhecimento da realização, desafios, crescimento, esse fator foi criado para que o funcionário seja motivado. Foi feita uma grande verificação 
no decorrer desse estudo que fatores capazes de produzir satisfação e motivação no trabalho são independentes e distintos dos fatores que conduzem a insatisfação no seu local de trabalho. (ROBBINS, 2010)

Herzberg afirma que a motivação depende unicamente do trabalho em si, e não de recompensas que o indivíduo pode receber de seu gestor, ou seja, abrange todos os benefícios oferecidos pela empresa como o ambiente de trabalho, salários, prêmios, isso tudo pode gerar satisfação aos colaboradores, mas não motivação.

Já os fatores motivacionais são intrínsecos. Para Vergara (2003), dizem respeito aos sentimentos de auto realização, reconhecimento, oportunidade de progresso profissional, mudando o quadro de não satisfeito para satisfeito.

\subsubsection{TEORIA DA EXPECTATIVA - VICTOR H. VROOM}

Entre as teorias que têm por objetivo explicar as motivações humanas, tem-se a Teoria das Expectativas. Esta teoria foi elaborada por Victor Harold Vroom, professor de administração de empresas na Yale schoolof Management e psicólogo.

A teoria da expectativa estabelece que quando o indivíduo acredita que ao realizar determinado esforço o resultado será positivo e ele irá ser recompensado por aquilo, o mesmo se sentirá mais motivado a desenvolver uma atividade.

Vroom usa três variáveis para explicar que o comportamento resulta de escolhas sensatas entre alternativas, são elas: Expectativa: acredita-se que um esforço maior resultará no desempenho desejado pelo indivíduo. Instrumentalidade: o desempenho será maior quando houver uma recompensa, seja ela um aumento salarial, promoção ou senso de realização. Quando a recompensa, independente do desempenho for a mesma, a instrumentalidade será baixa. Valência: é a importância atribuída as recompensas. Representa o quanto determinado desejo pode influenciar na motivação do indivíduo. Para Vroom, a força motivacional equivale ao produto Expectativa x Instrumentalidade x Valência.

A partir da teoria da expectativa pode-se entender por que muitos indivíduos não se sentem motivados em suas atividades e fazem apenas o necessário. Relacionando ao estudo sobre perfil motivacional e satisfatório dos acadêmicos de Ciências Contábeis da Escola de Gestão e Negócios da Pontifícia Universidade Católica de Goiás, compreende-se a razão de alguns alunos se esforçarem mais, enquanto outros cumprem apenas com as obrigações básicas do meio universitário. (SOTILLE, 2015)

\subsubsection{TEORIA DA EQUIDADE - J. STACY ADAMS E G. C. HOMANS}

A teoria da equidade foi criada no ano 1960 por J. Stacy Adams. Está teoria surgiu a parte da necessidade de haver equidade dentro da organização, sendo este elemento de grande importância dentro das mesmas por surte impacto na motivação das pessoas no seu local de trabalho. (MORAES 2007).

Segundo Robbins (2010 p. 196), " o nível de motivação varia tanto entre os indivíduos quanto em apenas um único indivíduo em diferentes momentos ". Em muitas das organizações muitos funcionários se sente desmotivado com o seu trabalho, e para um funcionário manter-se dentro de um conjunto onde poucos participavam é um aspecto altamente motivador e incentivador.

A teoria da equidade foi criada com o objetivo de cada um possa ter os seus direitos, ou um critério de julgamento legal e imparcial. Deste modo, a teoria defende a ideia de que o indivíduo adquira direitos justos no seu local de trabalho. (ROBBINS 2010)

\section{METODOLOGIA}

Este estudo tem caráter de pesquisa aplicada, no que se refere ao objetivo e a utilização de seus frutos, por se tratar de uma pesquisa em que os resultados são voltados à aplicação prática.

Foi desenvolvida, inicialmente, pela revisão teórica, a qual possibilita uma maior compreensão dos conceitos referentes aos temas abordados. Tem como característica a pesquisa exploratória descritiva com análise qualitativa. Utilizou-se a abordagem aos alunos da Pontifícia Universidade Católica de Goiás, da Escola de Gestão e Negócios, do curso de Ciências Contábeis do $4^{\circ}$ ao $8^{\circ}$ período do turno matutino por 
meio de questionários físicos e virtuais, com a finalidade de obter informações a serem analisadas e concluídas para, desta forma, poder destacar o perfil motivacional dos acadêmicos.

A população de alunos utilizada na pesquisa é de 115 (CENTO E QUINZE) sendo a amostra estabelecida com base em dados estatísticos averiguando a aplicação de questionários nos alunos obteve -se $95 \%$ confiança sendo que a margem de erro é de 5\% - com o propósito de quantificar o perfil, avaliação e motivação dos alunos, atingindo um total de 95 (noventa e cinto) alunos.

As ferramentas utilizadas foram: questionários (físicos e virtuais) e entrevistas. Os questionários aplicados, tiveram em primeiro momento o levantamento de informações pessoais (sexo, estado civil, idade), profissionais (se trabalha, remuneração) e acadêmicas (período e turno em que estuda); e, posteriormente, informações sobre os fatores que influenciaram a escolha do curso e da universidade, assim como, os fatores que os motivam a continuar no curso e na universidade, e o quão satisfeitos se sentem com a infraestrutura e serviços disponibilizados pela universidade. E, por fim, a auto avaliação.

Juntamente com o questionário, realizou-se uma entrevista com o professor, ex-diretor do curso de Ciências Contábeis e, atualmente, coordenador da disciplina de Gestão Empresarial, e também uma entrevista com o coordenador do curso de Ciências Contábeis e professor a disciplina de Contabilidade Empresarial - Alexandre Paranaíba 0 que contribuiu significativamente para a presente pesquisa.

Por fim, após tabulação dos dados coletados, expõem-se em gráficos e faz-se a análise dos, e ao final repassa-se os resultados aos responsáveis pela Escola de Gestão e Negócios e pelo curso de Ciências Contábeis, com o intuito de melhorar os pontos que causam insatisfação e desmotivação nos acadêmicos, para que assim seja atingido um melhor desempenho.

\section{RESULTADOS: COLETA E ANÁLISE DE DADOS}

\subsection{COLETA DE DADOS}

As respostas dos questionários aplicados, revelam um perfil do acadêmico de Ciências Contábeis do $4^{\circ}$ ao $8^{\circ}$ período do turno matutino que, $63,3 \%$ são do sexo feminino e $33,7 \%$ do sexo masculino, quanto ao estado civil, a maioria são solteiros (84,2\%), apenas $11,6 \%$ são casados, ficando o restante para: divorciado (3,2\%) e União Estável $(1,1 \%)$. Com uma renda familiar destacada entre 3 a 4 salários mínimos, o que representa $30,5 \%$ das respostas, observa-se que $54,7 \%$ do total de alunos questionados trabalham, e destes apenas 7,4\% atuam na área de Contábeis. As idades dos 95 alunos variam entre 19 anos e 31 +, sendo que $61,1 \%$ tem idade entre 20 e 25 anos. Os questionários também revelam:

Figura 1: Razões para escolher o curso de ciencias contábeis

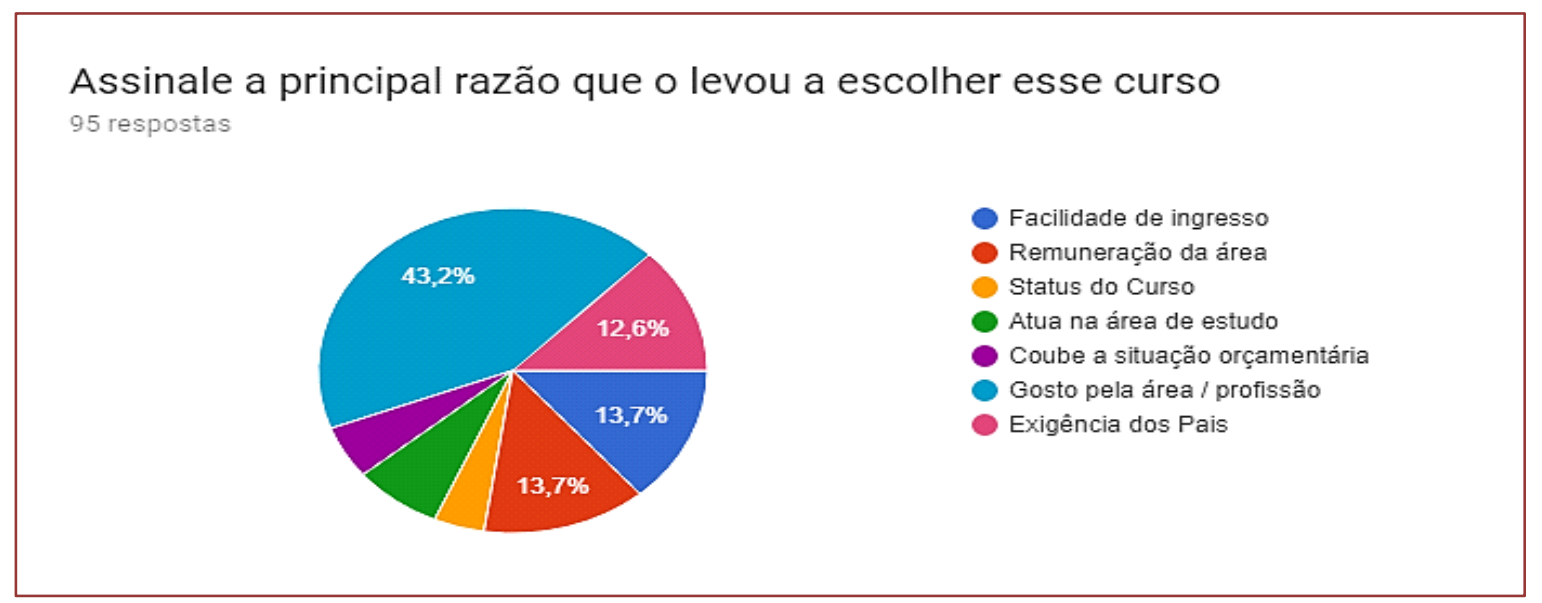

Conforme figura 1: Para os alunos questionados, a principal razão pela qual os levaram a escolha do curso de Ciências Contábeis foi a seguinte: gosto pela área com 43,2\%, seguido por 13,7\% que relatam ter sido por facilidade de ingresso, assim como também a remuneração da área obteve a mesma porcentagem de 13,7\%. Fato interessante é que 12,6\% escolheram este curso por exigência dos pais. 
Outra questão trabalhada refere-se ao conhecimento do aluno sobre projetos de pesquisa e extensão que a instituição oferece e 73,7\% tem essa informação e 26,3 não conhece. Isto é bem satisfatório, porem se faz necessário que a instituição tenha mais investimentos em divulgação para que se atinja uma porcentagem maior deste aspecto.

Ao solicitar que o aluno transmitisse seu de concordância conforme sua concepção de curso superior ideal dentro de uma escada de 1 a 5 sendo 1 para descordo totalmente e 5 para concordo totalmente, obteve-se as seguintes respostas:

$69,5 \%$ de alunos que concordam totalmente a respeito de que um bom curso superior transmite informações.

$52,6 \%$ concordam totalmente que o curso superior prepara para o mercado de trabalho;

$35,8 \%$ dos alunos avaliaram em 4, onde 1 é descordo totalmente e 5 para concordo totalmente, e 29,5\% concordaram totalmente sobre a qualidade da didática dos professores.

Quanto ao grau de satisfação pessoal e o aspecto motivacional dos alunos pediu-se uma pontuação de 0 a 10, onde obteve-se as seguintes respostas: Grau de motivação para prosseguir os estudos - em sua maioria 22,1\% pontuaram 8 em uma escala de 0 a 10. Percebe-se que no somatório de notas 7 a 10 tem-se um total de $67,3 \%$ o que indica significativa motivação dos alunos.

Assim como também para seu autoavaliação no que se refere ao desempenho no curso até o presente momento, a pontuação 8 predominou com um percentual de $24,2 \%$.

Figura 2: Grau de motivação pessoal

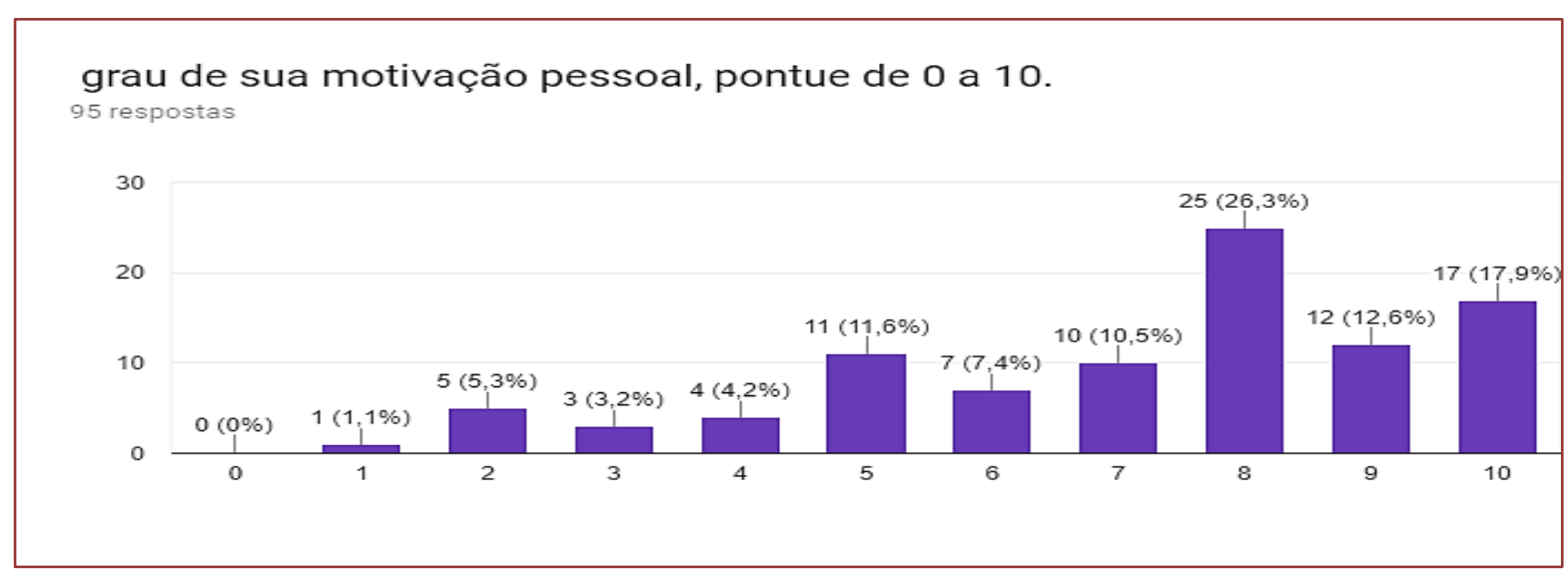

Figura 3: Nota para o curso

Qual sua nota para o curso, pontue de 0 a 10.

95 respostas

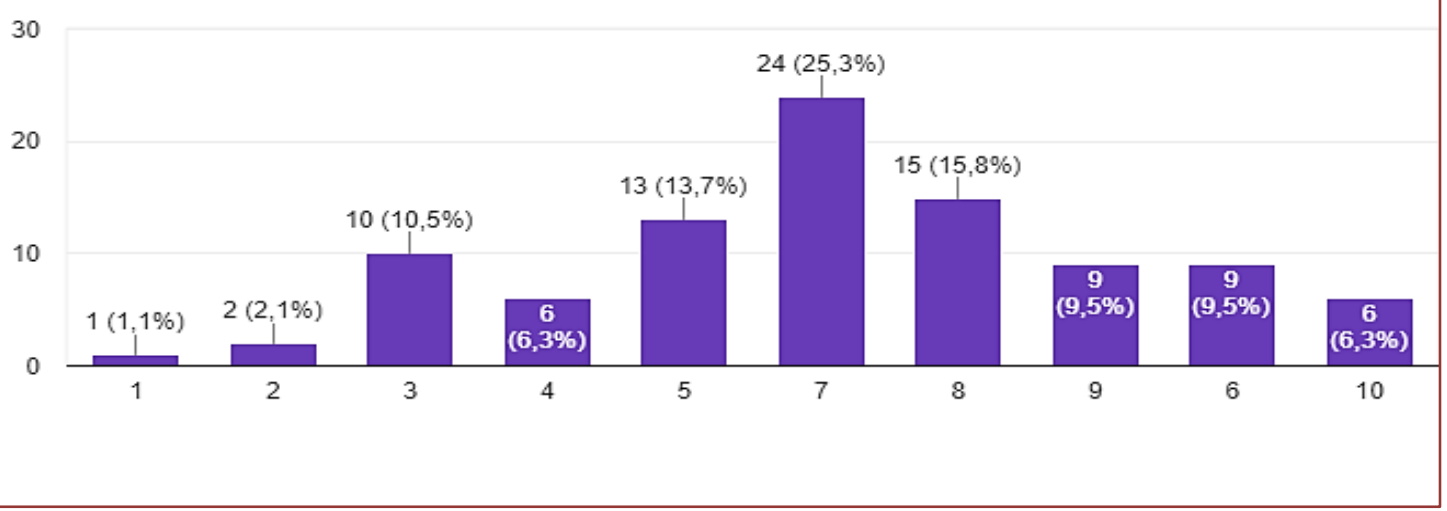


A figura 3 relata a nota que os alunos atribuem ao curso de ciências contábeis. Dos 95 alunos que responderam os questionários, em sua maioria (25,3\%) atribuíram nota 7, em seguida obteve-se de 15,8\% uma nota 8. A nota 5 ficou entre as 3 primeiras com um percentual de $13,7 \%$.

Figura 4: Corpo docente

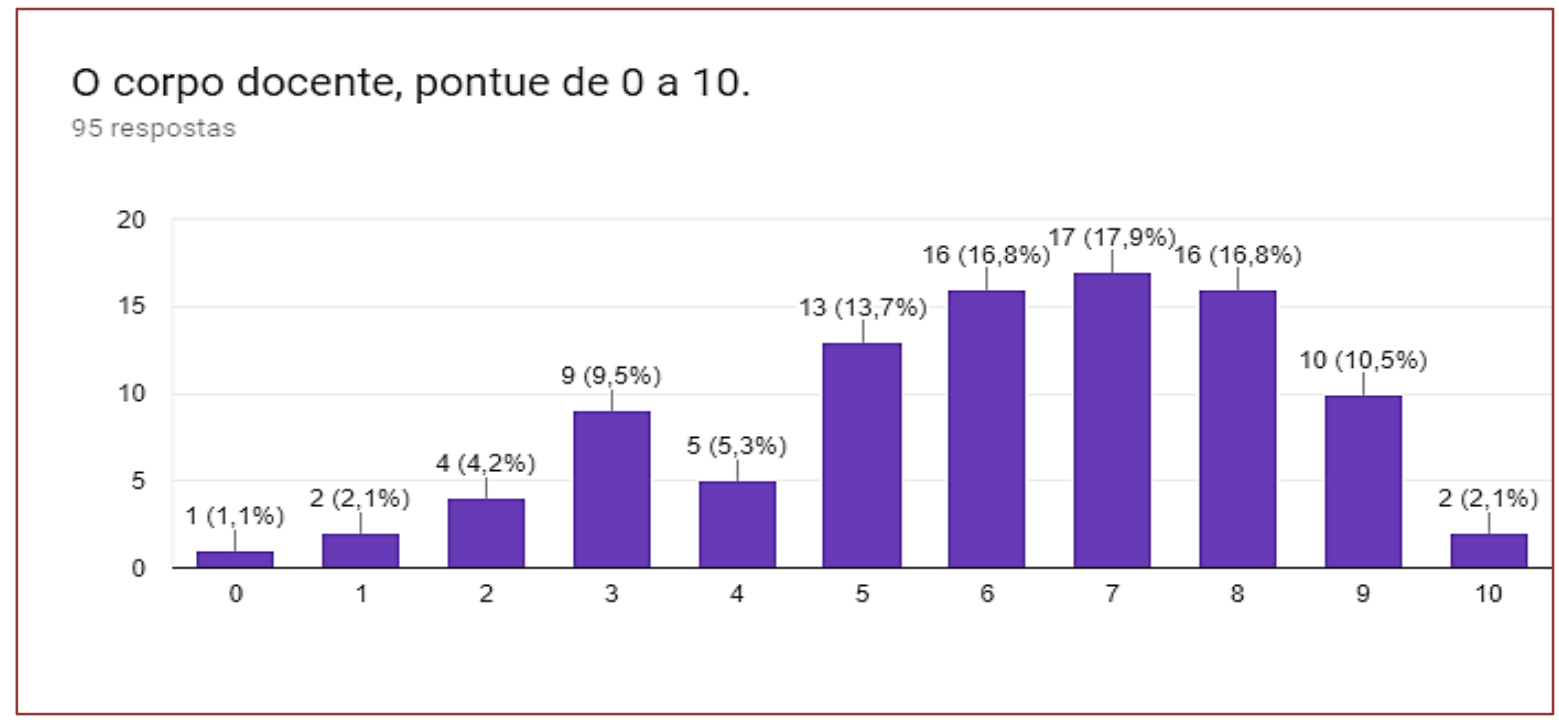

A figura 4 representa a questão que se refere ao corpo docente, a qual se solicitava uma pontuação de 0 a 10 para o corpo docente. Assim como a nota do curso, os alunos pontuaram em sua maioria, sendo 17,9\% em 7 o corpo docente, seguido de um empate para a pontuação 6 e 8 com uma porcentagem de 16,8\%

A pesquisa procurou analisar as propostas sugeridas pelos próprios alunos quanto a possíveis melhorias capazes de aumentar sua motivação e experiência no meio acadêmico e pessoal. As propostas foram descritas de acordo com as respostas de cada aluno: "Minha motivação está ligada a experiência acadêmica, pois gosto muito do curso"; "até momento tem sido satisfatória, e continuo motivada para a conclusão"; "Conhecimento na área contábil e vivência em território internacional, graças ao intercâmbio na universidade de Coimbra em Portugal. A motivação está relacionada as necessidades financeiras da família, para ter um futuro melhor".

Ao analisar as propostas dos alunos as questões persistentes que mais se repetem são quanto ao quadro de professores, mudanças na dinâmica e metodologia nas aulas. Em seguida as questões sobre utilizar mais aulas práticas no curso, e maior realização de pesquisa cientifica na universidade, foram os temas mais abordados pelos alunos.

Por fim, questionou-se sobre sua motivação e a intenção em fazer pôs graduação, 85,3\% dos alunos pesquisados responderam ter interesse. Porém, ao perguntar se tinham interesse em realiza-la na PUC, 55,8\% responderam que não fariam sua pós-graduação na instituição PUC - GO. O que sugere uma melhor reavaliação dos responsáveis pela instituição a respeito da falta de motivação dos alunos para com a universidade.

\subsection{ENTREVISTA COM O PROFESSOR DE CIENCIAS CONTÁBEIS GESTÃO EMPRESARIAL}

Na perspectiva de ampliar a coleta de dados e buscar na voz de professores sua visão sobre a temática em questão, realizou-se uma entrevista com um professor ex-diretor do curso de Ciências Contábeis e hoje coordena a disciplina de Gestão Empresarial. Quando questionado sobre o tema de motivação dos alunos, o professor afirmou que:

Primeiramente eu gostaria de deixar evidenciado que uma das motivações dos alunos virem fazer o curso de ciências contábeis é porque eles sabem que o mercado está aberto principalmente para quem faz essa área de contabilidade 
que é mais específica, regulamentada por lei e exige que a pessoa tenha passado pelo curso e que tenha registro no conselho (CRC). (Prof. Manoel Barbosa Gomes, em entrevista)

Quando questionado sobre a profissão do contador e as perspectivas de desenvolvimento do seu trabalho, o professor responde que:

O ambiente para o profissional de contábeis dada a execução dos serviços faz com que sempre ele ache um espaço, pois toda e qualquer empresa quando ele chega sempre está precisando de alguém que trabalhe com controle, e mesmo que não seja necessariamente a área contábil de registro e lançamento das operações, ele pode trabalhar em outros setores estratégicos que a contabilidade apoia, tendo a certeza dos resultados que ele pode obter se estiver fazendo o curso de contábeis, podendo também quando sair da universidade atuar como profissional liberal. (Prof. Manoel Barbosa Gomes, em entrevista)

Sobre o curso de Ciências Contábeis o professor ressalta que:

É essa perspectiva, que eu vejo dos alunos interessados pelo curso de ciências contábeis da Pontifícia Universidade Católica de Goiás, sabendo que aqui vai se tornar um verdadeiro profissional, e vai se tornar reconhecido e apreciado no mercado. E mesmo com o cenário econômico não favorável no momento, a Universidade Católica investe pesado nos cursos, em especial ela investe bastante no curso de ciências contábeis dada a magnitude que o curso representa para o mercado de trabalho, e o profissional que ela forma nesses quatro anos de graduação, totalmente capacitado e com uma bagagem gigantesca para atender toda uma sociedade com seu trabalho. (Prof. Manoel Barbosa Gomes, em entrevista)

\subsection{ENTREVISTA COM O COORDENADOR DO CURSO}

Afim de obter mais opiniões sobre a motivação dos alunos, realizou-se também uma entrevista com o coordenador do curso de Ciências Contábeis e professor da disciplina de Contabilidade Empresarial Alexandre Paranaíba

Quando questionado sobre o tema de motivação dos alunos, o professor afirmou que:

A questão do perfil motivacional dos alunos eu entendo de algumas formas, primeiro a escolha da Pontifícia Universidade Católica é pelo nome, por ser a pioneira instituição que teve o curso aqui no Estado(...) o aluno ter escolhido o curso de ciências contábeis alguns fatores podem ser considerados, primeiro pelo fator de família, alguém da família trabalha com a profissão contábil ou algum conhecido trabalha com a contabilidade e consequentemente informa as vantagens do curso para esta pessoa. Ou então existe uma situação em a pessoa pesquisou e teve vontade de aprender um pouco mais sobre contabilidade. É uma profissão que está em alta no Brasil, ela tem demanda, então as pessoas que estudam e fazem o curso de graduação em ciências contábeis e que já está se graduando ela já tem um mercado de trabalho para poder atuar.

Sobre o que o aluno de graduação pode esperar da profissão contábil, visto que já foi dito que a demanda é certa por esse profissional o coordenador/professor ressalta que:

0 conselho federal de contabilidade estima que tem uma defasagem de $500 \mathrm{mil}$ profissionais no Brasil, então na atualidade precisamos suprir essa quantidade de profissionais. Além disso a área contábil não é bem específica e exclusiva para a contabilidade da empresa, ele também pode trabalhar em outras áreas como auditoria, perícia, fazer consultoria na área de finanças, área de planejamento tributário e financeiro, e isso auxilia bastante o aluno para quando sair ele ter um campo mais vasto ou um maior campo de trabalho na sua profissão. 
Quanto a como a Universidade se posiciona quanto a sua mensalidade visto que no cenário econômico os estudantes optam por pagar menos em um curso de graduação:

A instituição ela trabalha diretamente com esse pensamento, do como atrair o aluno, inclusive nós temos um quantitativo de bolsas considerável, então são poucos discentes que não possuem nenhum tipo de benefício, então os nossos discentes ou possuem o benefício do vestibular social, ou bolsa Ovg quando não em conjunto, ou possuem o Fies, ou possuem o Pra Valer, ou o Prouni podendo ainda possuir algum outro tipo de benefício, seja ele para ter desconto em sua mensalidade, seja ele para financiamento da sua mensalidade para pagamento após sua formatura e da conclusão de seu curso. Então a instituição sempre procurou e sempre tomou cuidado em relação a atender essa demanda, a crise existe, a crise está em nossa sociedade, não é uma crise da instituição e nós temos trabalhado bastante, tido grande resultado na questão de retorno de alunos, que anteriormente tinham desistido por algum motivo e estão retornando para instituição, então é uma situação de mercado e não uma situação da instituição.

\section{CONSIDERAÇÕES FINAIS}

A partir dos dados coletados e analisados percebe-se que nos estudos desenvolvidos por Bergamini (2018), as necessidades são socialmente adquiridas podendo ser aprendidas, aperfeiçoadas ou ensinadas, possibilitando aos indivíduos uma melhoria em suas características e habilidades. Importante salientar que as necessidades variam de pessoa para pessoa, das fisiológicas até a autorrealização (MASLOW) com o higiênicas até motivacionais (HERZBERG) se apresentando como motivação para realização, afiliação ou poder (McClelland), dentre outras teorias motivacionais.

Assim, pode-se afirmar as necessidades dos alunos que os motiva através da realização de um curso superior e a possibilidade concreta de crescer, ganhar mais, ocupar cargos de destaque e manter relações sociais que o projete na sociedade.

Estudos revelam que o contador "exerce uma importante função no mercado de trabalho, seja na iniciativa privada ou na carreira pública, pode deter influência nas funções econômicas, administrativas e gerenciais que estão intimamente ligadas a sustentabilidade e competitividade" (FEIJÒ, ROSA, 2018). Assim, conhecer as necessidades dos alunos e identificar o perfil profissional e motivacional torna-se fundamental para direcionar adequadamente o contador no ambiente de trabalho, visando mantê-lo motivado e consequentemente mais produtivo e eficiente.

Observando os gráficos nota-se que o principal motivo pela escolha do curso de Ciências Contábeis pelos acadêmicos consultados foi o gosto pela área - 43,2\%, demonstrando, assim, o sentimento de autorrealização ao ingressar em um cenário acadêmico em que se sentem confiantes para atuar profissionalmente.

Quando questionados sobre qual o grau de motivação para prosseguir no curso, os acadêmicos revelam-se com alto nível de motivação. Visto que $26,3 \%$ afirma que, numa escala de 0 a 10 , se sentem motivados em 8.

Em relação à nota dada para o curso e para o corpo docente, pode-se perceber uma leve insatisfação. Tendo em vista que a maioria deu nota 7 , considera-se que os acadêmicos concordam que é um curso mediano. A pesquisa revela que estes pontos precisam de uma maior atenção para que se entenda o motivo da nota pouco acima da média, que na escala de 0 a 10 seria 5.

Na opinião dos acadêmicos, para melhorar a experiência acadêmica e a motivação para concluir o curso, faz-se necessário a atualização do quadro de professores e mudanças nas dinâmicas e metodologias utilizadas nas salas de aula.

Importante se faz registrar que o trabalho não acabou tendo em vista a necessidade de novas pesquisas como forma de manter um campo de diálogo permanente com os alunos fazendo com que a instituição inclua esses dados em seus projeto de gestão acadêmica. 


\section{REFERÊNCIAS}

[1] Bergamini, C. W. Motivação: uma viagem ao Centro do Conceito. Disponível em site: era.fgv.br/gv-executivo/vol1-num2-2002/motivação-viagem-ao-centro-do-conceito. Acesso em $27 / 03 / 2018$

[2] CORTELLA, Mario Sergio. Por que fazemos o que fazemos. 1 ed. - São Paulo: Planeta 2016

[3] FEIJó, Kristopher Bruno Feijó; LUNKES, Rogério João; ROSA, Fabricia Silva. Teoria das Necessidades Socialmente Adquiridas: Um Estudo com Alunos do Curso de Ciências Contábeis da Universidade Federal de Santa Catarina (UFSC), 2015. p. 13. Disponivel em: http://dvl.ccn.ufsc.br/congresso_internacional/anais/6CCF/38_16.pdf. Acessado em: 02 de abr. de 2018

[4] GARETH R. Jones, Jennifer M. George, Fundamentos da administração contemporânea- São PauloAMGH-editora LTDA- 2012. Pagina 285.

[5] GIL, Antônio Carlos, Gestão de pessoas, - São Paulo: Atlas, 2011. Pagina 16.

[6] LACOMBE, Beatriz Maria Braga; CHU, Rebeca Alves. Políticas e práticas de gestão de pessoas: as abordagens estratégica e institucional. RAE - Revista de Administração de Empresas, vol.8, n.1, 2008.

[7] LACOMBE, Francisco José Masset: Recursos Humanos: princípios e tendências. São Paulo: Saraiva 2005.

[8] MORAES, Reinaldo Soares da Rocha - A motivação e liderança no ambiente de trabalho Universidade Candido Mendes - Rio de Janeiro. 2007. Disponível em: http://www.avm.edu.br/monopdf/23/REINALDO\%20SOARES\%20DA\%20ROCHA\%20MORAES.pdf. Acessado em: 02 de abr. 2018

[9] NONAKA, Ikujiro. Aprendizagem Organizacional: os melhores artigos da Harvard Business Review. Rio de Janeiro: Elsevier, 2006.

[10] PEREIRA, Maria Célia Bastos. Rh essencial. São Paulo: Saraiva 2014.

[11] PERIARD, Gustavo. A hierarquia de necessidades de Maslow - O que é e como funciona. Publicado em 30 de maio de 2011. Disponível em: http://www.sobreadministracao.com/a-piramide-hierarquia-denecessidades-de-maslow/. Acesso em: 24 mar. 2018

[12] ROBBINS, S. Comportamento organizacional. São Paulo: Pearson Prentice Hall, 2010.

[13] SOTILLE, Mauro. Teoria da Expectativa de Vroom - Publicado em 24 de abr. 2015. Disponível em: http://dicasgp.pmtech.com.br/vroom. Acessado em: 24 de mar. 2018.

[14] SOUSA, C. C. D. A motivação dos empregados públicos dos Correios: uma análise com base na teoria dos dois fatores de Herzberg. 2014. Disponível em: http://dspace.bc.uepb.edu.br/jspui/bitstream/123456789/6573/1/PDF\%20\%20Caio\%20Cesar\%20Diniz\%20de\%20Sousa.pdf. Acesso em: 11 de maio 2018.

[15] TEIXEIRA, Betina W.; SIQUEIRA, Sílvia. Gestão Escolar: motivação, atitudes e possibilidades para melhorar resultados. Revista Eletrônica de Graduação/Pós-Graduação em Educação UFG/REJ. Vol. 13, n. 1, 2017.

[16] VERGARA, Sylvia Constant - Gestão de pessoas / Sylvia Constant Vergara. - 3. ed. - São Paulo: Atlas, 2003. 


\section{Capítulo 12}

Diagnóstico de métodos de trabalho: Analíse de uma unidade administrativa universitária

\section{Daniel Teotonio do Nascimento}

Adriana Sousa Lima

Claudio Antonio Rojo

Resumo: 0 objetivo deste relato é ressaltar a importância da identificação de mecanismos de trabalho em pequenas unidades administrativas. Pretendeu-se indicar a metodologia mais adequada para a modelagem e mapeamento dos processos de trabalho, quando as organizações não estivessem estruturadas dentro do conceito de Gestão de Processos. Como referencial, recorreu-se a algumas abordagens que podem auxiliar os consultores em diagnóstico situacional. Também foi foco o mapeamento de processos, com suas técnicas e principais ferramentas. A pesquisa foi caracterizada como estudo de caso e adotou as técnicas de análise documental e bibliográfica, entrevista e observação pessoal. Constatou, mediante a aplicação da metodologia de mapeamento de processos de Oliveira (2007), que a unidade administrativa investigada não possuía seus processos e subprocessos institucionalizados, e que grande parte do conhecimento, quanto às rotinas processuais, eram tácitas, estando centralizadas em apenas uma servidora. Mediante essa constatação, realizou-se a modelagem de processo Modelo AS IS, retratando a realidade dos procedimentos atuais. Como proposta de intervenção, sugeriu-se à unidade administrativa o remapeamento dos subprocessos, utilizando o modelo TO-BE, entrando em consenso com todos os atores envolvidos e validando o novo fluxo. Ademais, recomendou-se à organização a institucionalização deste novo método de trabalho, registrando-o por meio de fluxogramas e manuais.

Palavras-chave: Processos. Mapeamento. Fluxogramas. Formulários. Manuais. 


\section{INTRODUÇÃO}

Nota-se, nos últimos anos, uma maior aproximação e cooperação entre as universidades e as organizações. As universidades têm incentivado seus discentes quanto à importância de sua participação no desenvolvimento social e econômico de suas regiões. Concomitantemente, as organizações, sejam públicas ou privadas, buscam novas alternativas para adequar suas rotinas administrativas para esta Era do Conhecimento. Assim, cooperações entre universidades e organizações hoje representam uma necessidade destes agentes, visando garantir seu futuro, bem como potencializar conhecimentos e capacitações, ambos cada vez mais complexos (Cruz \& Segatto, 2009).

Nesse contexto, o conhecimento tem adquirido um papel de destaque nos processos organizacionais, passando a ser um recurso mais valioso e competitivo. Normalmente está embutido na mente dos profissionais que dominam determinados processos e tarefas. A extração desse conhecimento, de tácito para explícito, é de suma importância para a sustentabilidade e continuidade das organizações.

Para Nonaka (1991), o conhecimento tácito é altamente pessoal e difícil de formalizar, o que dificulta sua transmissão e compartilhamento. É composto por palpites subjetivos, insights, intuições, valores e experiências. Por outro lado, o conhecimento explícito pode ser expresso em palavras e números, sendo facilmente comunicado e compartilhado sob a forma de dados brutos, fórmulas científicas, princípios universais, especificações e manuais. 0 conhecimento explícito pode ser imediatamente transmitido, tanto formalmente quanto sistematicamente, entre indivíduos (Nonaka \& Konno, 1998).

Em função do acúmulo de expertise, que em muitas situações está em poder de apenas alguns profissionais nas organizações, é primordial a realização de diagnósticos e análises organizacionais, que objetivem a padronização e normatização de fluxos de trabalho, permitindo a capacitação dos demais colaboradores.

Cury (2005) destaca a importância da análise administrativa para todas as organizações privadas e públicas, pois trata-se de um processo de trabalho dinâmico, com o objetivo de efetuar diagnósticos situacionais e estudar soluções integradas para problemas administrativos. Envolve, portanto, a responsabilidade básica de planejar as mudanças, aperfeiçoando o clima e a estrutura organizacional, assim como os processos e os métodos de trabalho.

Com foco nos resultados efetivos, o controle social tem forçado as organizações públicas a apresentarem os resultados de suas ações para a sociedade. Dessa forma, as universidades têm buscado alianças estratégias, que as auxiliem a atingir suas metas, visando um reconhecimento e aprovação por parte da sociedade.

Assim, considerando a importância da celebração de parcerias para as organizações públicas, principalmente as universidades, este estudo realizou uma pesquisa, com diagnóstico e proposta de intervenção na Unidade de Convênios da Universidade Do Paraná, denominada de Universidade Alfa para efeitos de anonimato.

Aplicado o diagnóstico organizacional inicial na Unidade de Convênios, verificou-se que seu principal problema estava na falta de padronização do fluxo de trabalho, sem institucionalização e sem registro. Ademais, não havia manual de procedimentos ou cartilha explicativa para a comunidade externa. Notou-se que a melhoria desse processo organizacional permitiria à universidade uma maior possibilidade na obtenção de recursos econômicos e financeiros, dinamizando significativamente suas atividades de Ensino, Pesquisa e Extensão.

A partir dessas considerações, pretende-se responder, neste estudo, sob o arcabouço conceitual dos Métodos e Processos Administrativos, a seguinte pergunta da pesquisa: Que ações podem ser implementadas por pequenas unidades administrativas, visando melhorias em seus processos e métodos de trabalho?

0 presente relato está estruturado em cinco sessões. A próxima seção é a apresentação da fundamentação teórica que deu suporte ao estudo. Subsequentemente, consta a metodologia utilizada no desenvolvimento do estudo, terceira seção. A quarta seção apresenta a análise dos resultados obtidos e, por fim, a última, as considerações finais.

\section{FUNDAMENTAÇÃO TEÓRICA}

Esta seção trata do referencial teórico associado aos temas da presente pesquisa. Assim, é apresentada, num primeiro momento, a conceituação da Análise e Consultoria Organizacional, examinando e 
detalhando as principais metodologias que auxiliam no mapeamento de processos e métodos de trabalho. Em seguida, são descritas as definições, técnicas e ferramentas do mapeamento de processos.

\subsection{ANÁLISE E CONSULTORIA ORGANIZACIONAL}

Em virtude do acirramento da competitividade e da escassez de recursos, as organizações são forçadas a buscar um contínuo aprimoramento em seus processos administrativos, não sendo diferente essa realidade para as instituições públicas. Assim, a análise administrativa, por meio de consultoria organizacional, surge como uma das formas encontradas pelas empresas para se atualizarem.

Segundo Silva Junior et al. (2011), a consultoria possibilita, portanto, o aprendizado de novas práticas e formas de trabalhar, através da interação com o consultor, possibilitando ganhos à organização e aos indivíduos que estão envolvidos diretamente com o processo de intervenção.

Normalmente, em uma consultoria organizacional, existem algumas etapas claras de ação. Entre elas a investigação ou levantamento de informações, a identificação ou constatação de causas, o estudo de alternativas viáveis e a proposição de soluções.

A consultoria esteve presente desde o início dos tempos. As sociedades humanas sempre identificaram membros que prestavam aconselhamento nos lugares onde viviam, e as pessoas se ajudavam mutuamente. Porém, foi a partir da Revolução Industrial, com as incertezas do ambiente, que as empresas passaram a buscar auxílio, visando aprimorar seus processos. A consultoria ampliou sua atuação a partir dos anos 1960. Porém, só por volta de 1980, com o aumento e crescimento das empresas e de seus parques industriais, foi quando, realmente, tornou-se necessária enquanto ferramenta para enfrentar a globalização e um novo cenário brasileiro e internacional, muito mais competitivo, exigindo velocidade e inovação (SEBRAE, 2012).

Nesse dinamismo atual tornou-se imprescindível para as organizações a busca por melhores práticas, seja por meio de benchmarking ou de assistência de profissionais capacitados.

\subsection{METODOLOGIAS QUE AUXILIAM NO MAPEAMENTO DE PROCESSOS}

Na Literatura, há várias metodologias para diagnóstico, modelagem e mapeamento de processos. Dentre elas, este estudo enfocou e detalhou as metodologias demonstradas no Quadro 1, abaixo.

Quadro 1 - Metodologias que auxiliam no Mapeamento de Processos

\begin{tabular}{|l|l|}
\hline Metodologia & Autores \\
\hline Análise Administrativa & CURY (2005) \\
\hline Modelagem e Mapeamento & OLIVEIRA (2007) \\
\hline Diagnóstico e Mapeamento & SILVA (2011) \\
\hline Business Process Management -BPM & BPM (2014) \\
\hline
\end{tabular}

Fonte: Elaborado pelos autores

\subsection{METODOLOGIA DE CURY (2005) - ANÁLISE ADMINISTRATIVA}

Para Cury (2005) a análise administrativa se desdobra em dois momentos distintos. Em um primeiro momento, é realizado um diagnóstico situacional das causas, buscando identificar não só o clima e a estrutura da organização, mas também seus métodos e processos de trabalho. Pode ser alcançado por meio de levantamento de dados e a crítica desses respectivos dados. 0 segundo momento envolve a intervenção planejada, incluindo o estudo das soluções dos problemas, e sua respectiva crítica. Além disso, abrange o planejamento da mudança, implantação e controle de resultados, conforme Quadro 2.

Convém esclarecer que esses momentos são independentes, podendo haver superposição das fases. A intensidade das análises dependerá do escopo da consultoria, podendo inclusive finalizá-la na etapa 4 da metodologia (Crítica do Planejamento), deixando sob a responsabilidade da própria organização a implantação e controle dos resultados. 
Quadro 2 - Pontos fundamentais de análise administrativa

\begin{tabular}{|c|c|c|c|}
\hline PROCESSOS & INPUTS & METODOLOGIA & OUTPUTS \\
\hline 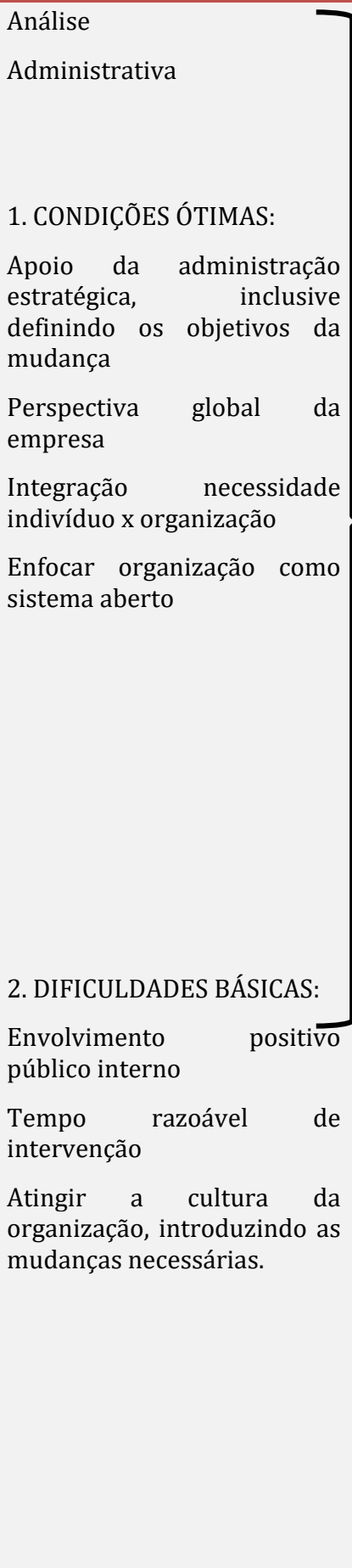 & $\begin{array}{lr}\text { ESTUDO } & \text { DA } \\
\text { SOLUÇÃOO DOS } \\
\text { PROBLEMAS }\end{array}$ & 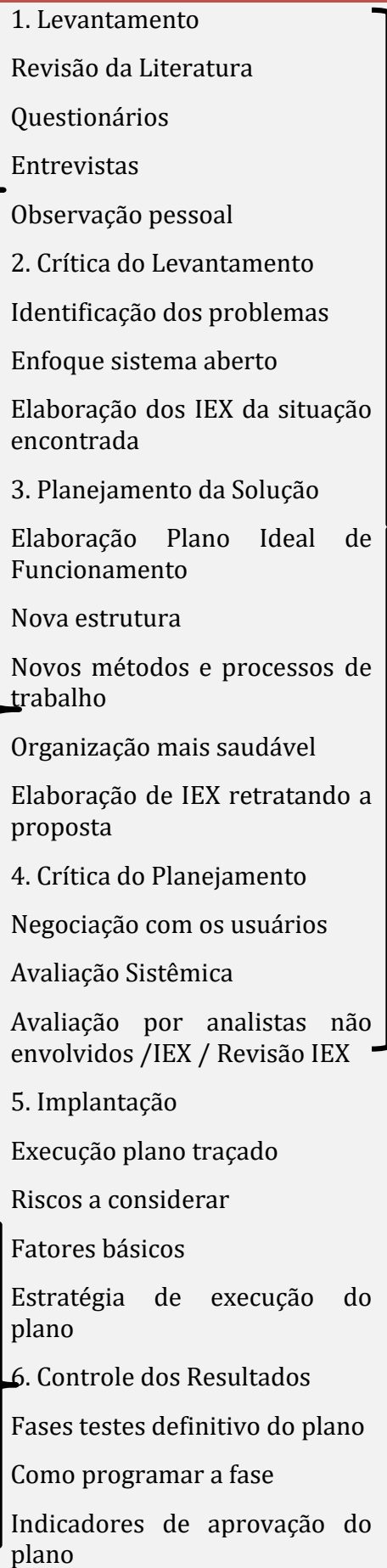 & $\begin{array}{l}\text { Aperfeiçoamento de } \\
\text { processos e métodos de } \\
\text { trabalho, de estrutura e } \\
\text { do clima organizacional, } \\
\text { envolvendo, } \\
\text { subsidiariamente: } \\
\text { Organogramas } \\
\text { Layouts } \\
\text { IEX } \\
\text { Fluxogramas } \\
\text { Formulários } \\
\text { Programas de } \\
\text { Treinamento } \\
\text { Quadro de pessoal } \\
\text { Implantação de novas } \\
\text { tecnologias (TQM, ABC, } \\
\text { APO, etc) }\end{array}$ \\
\hline
\end{tabular}

Fonte: Cury (2005)

Destaca-se, também, a importância das ferramentas de levantamento de dados. A revisão da literatura permite conhecer a atividade-fim da organização ou da unidade escolhida, facilitando o entendimento dos ambientes interno e externo, nos quais está contextualizada a organização. 0 questionário é de grande utilidade para coleta de informação, pois normalmente não é possível entrevistar todos os envolvidos no processo. Já a entrevista, segundo Oliveira (2000), possibilita estabelecer um diálogo entre o consultor e o entrevistado, visando detectar um determinado problema ou fenômeno. Quanto à observação pessoal, esse método permite comparar as informações da revisão literária, questionários e entrevistas com a realidade. 


\subsection{METODOLOGIA OLIVEIRA (2007) - MODELAGEM E MAPEAMENTO}

A metodologia desenvolvida por Oliveira (2007) é dividida em três fases. A preparação do ambiente para modelagem; a descrição de processos de negócios; e o aperfeiçoamento dos processos de negócios, como mostra a Figura 1.

FIGURA 1 - Metodologia de mapeamento de processos

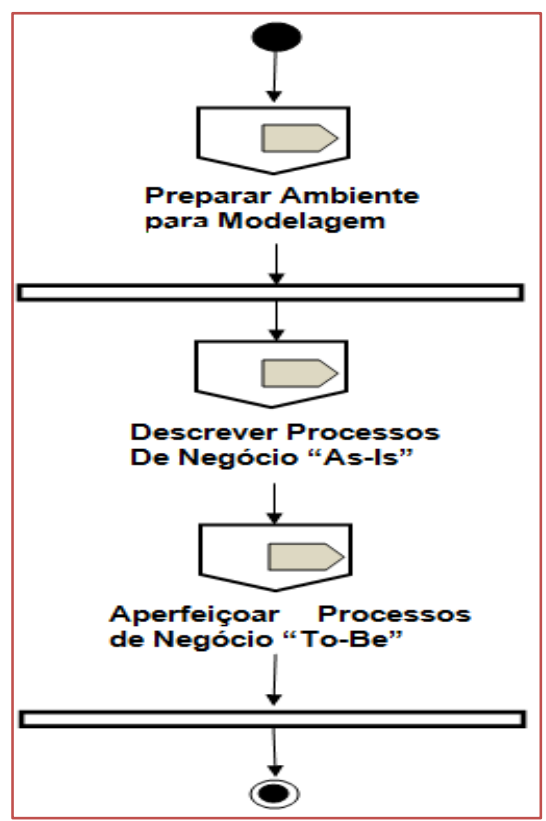

Fonte: Oliveira (2007)

Cada uma dessas três fases é composta por etapas, que deverão ser seguidas para a construção do modelo de processos atual e futuro. Entende-se, nesta metodologia, modelagem de processos como sinônimo de mapeamento de processos. Ou seja, é utilizada para a melhoria de métodos de trabalho já existentes, ou para a implantação de novos fluxos de trabalho.

A primeira fase busca a conscientização e conhecimento, por parte da organização, de todo o trabalho a ser desenvolvido para a modelagem dos processos. São realizadas reuniões, escolhidos os usuários para as entrevistas, apresentados o método de trabalho e o local para a realização das atividades de modelagem.

A segunda fase tem como finalidade o levantamento das informações para modelar o conhecimento contido nos processos atuais. É dividida em quatro etapas, conforme apresentado na Figura 2.

FIGURA 2 - Fluxo de atividades: Mapeamento As-Is

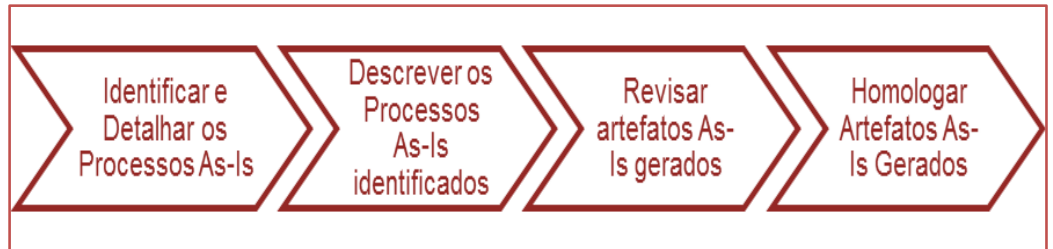

Fonte: Oliveira (2007)

Portanto, o Mapeamento As-is é o levantamento e documentação da situação atual, enquanto que o Mapeamento To-be é a discussão, definição e documentação da situação futura do processo.

Nesse sentido, a terceira fase tem como objetivo definir a decisão a ser tomada em relação aos processos identificados durante o Mapeamento As-Is, quanto às suas principais características, deficiências, etc. Essa fase também é dividida em quatro etapas, de acordo com a Figura 3. 
FIGURA 3 - Fluxo de atividades: Mapeamento To-Be

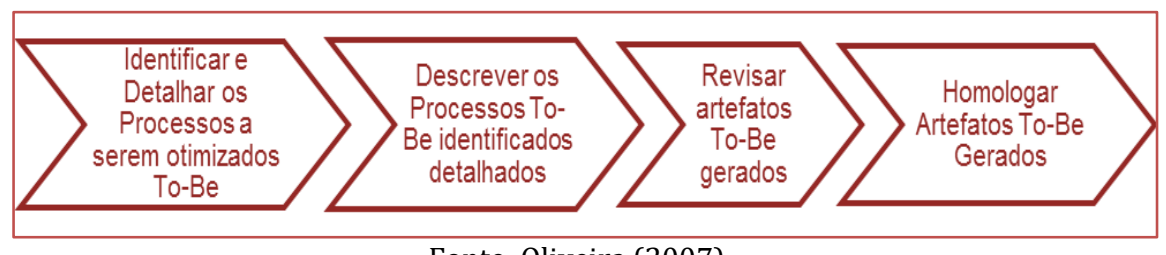

Fonte: Oliveira (2007)

\subsection{METODOLOGIA DE SILVA (2011) - DIAGNÓSTICO E MAPEAMENTO}

Já Silva (2011), indica a metodologia de diagnóstico que desenvolveu a partir da conciliação de outras metodologias, explicitadas por autores de livros, a exemplo de: Tenner and De Toro (1997), Sharp and McDermott (2009), White and Miers (2008) ou de artigos - Ahoy (1999). 0 autor indica uma metodologia composta por uma série de etapas, de maneira a se realizar um mapeamento completo e correto. Sua metodologia apresenta ainda um caráter sistemático, que deve ser seguida sempre que se pretende mapear um processo. As etapas desta metodologia são: a) recolhimento de informação e procedimentos existentes; b) interação com os intervenientes nos processos; c) levantamento de documentos associados aos processos; d) representação dos processos; e) validação do mapeamento realizado; f) disponibilização dos fluxogramas online.

\subsection{METODOLOGIA BUSINESS PROCESS MANAGEMENT (2014)}

Para analisar a metodologia de diagnóstico, mapeamento e remodelagem de processos, a Business Process Management (BPM) - ou Gestão de Processos de Negócio -, é importante considerar uma visão mais atual de processo, como um conjunto de atividades com uma ou mais espécies de entrada, visando como saída um produto com valor para o cliente. BPM é um conjunto de técnicas para a melhoria contínua e interativa de todos os processos envolvidos na gestão de uma organização. Em anos recentes, as técnicas da BPM têm ajudado a reduzir erros, diminuir custos e aumentar a produtividade nas organizações, que vão desde empresas industriais para fornecedores de telecomunicações a empresas de seguros e organizações governamentais (Omg, 2014).

As principais tarefas da Gestão de Processos de Negócio estão ligadas a um ciclo de vida contínuo, o qual inclui: planejamento, análise, desenho e modelagem, implantação, monitoramento e controle, e refinamento - ou melhoria contínua dos processos de uma organização. Em todas as suas etapas, considera-se que a BPM pode fornecer resultados mais satisfatórios, caso utilize como base a Tecnologia da Informação. Desta forma, a BPM é um campo multidisciplinar, que integra conhecimentos e práticas que vêm de disciplinas de Administração, Sistemas de Informação e Engenharia de Software (Santos, Santana \& Alves, 2012).

Uma análise administrativa ou diagnóstico organizacional, independentemente da metodologia aplicada, tem um amplo campo de aplicações dentro das grandes organizações, podendo ser direcionada para: aprovar uma estrutura organizacional, seja de uma empresa ou de uma unidade qualquer da organização; implantar novas técnicas gerenciais; permitir uma reorganização funcional; contribuir para a implantação de práticas administrativas aperfeiçoadas; redesenhar e/ou melhorar processos empresarias; e elaborar e/ou rever instrumentos normativos diversos, como manuais, normas e instruções (Cury, 2005).

Assim, neste contexto de aperfeiçoamento constante dos processos organizacionais, a importância das parceiras interinstitucionais universidade-organizações se justifica no sentido de que as organizações, normalmente, não dispõem de tempo para analisar seus próprios métodos e processos. Por outro lado, os discentes das universidades nem sempre dispõem de local adequado para exercitar os ensinamentos aprendidos em sala de aula.

Para Cruz e Segatto (2009), a cooperação universidade-organizações é caracterizada como um modelo de arranjo interinstitucional entre organizações de naturezas fundamentalmente distintas, que podem ter finalidades diferentes e adotar formatos bastante diversos. Incluem-se, nesse conceito, desde interações tênues e pouco comprometedoras - o oferecimento de estágios profissionalizantes, por exemplo -, até vinculações intensas e extensas, como grandes programas de pesquisa cooperativa. 


\subsection{MAPEAMENTO DE PROCESSOS}

Antes de explicitar a importância e as vantagens do mapeamento de processos, é necessário indicar um outro conceito atual de processo. Segundo o Guia referencial para gestão de processos no Governo Federal (2011) trata-se de um conjunto integrado e sincrônico de insumos, infraestruturas, regras e transformações, que adiciona valor às pessoas que fazem uso dos produtos e/ou serviços gerados.

O mapeamento de um processo é uma atividade intencional de formalizar rotinas, que normalmente já são realizadas de maneira informal. Apesar de parecer uma tarefa simples, essa ação permite agregar um valor altamente significativo ao produto final. Permite definir as especificações dos processos organizacionais, de modo que fique claro "O quê?", “Quando?", “Onde?", “Quem?" e como o trabalho é realizado.

Wesner, Hiatt e Trimble (1994) já indicavam que um processo deve ser definido como uma ou mais tarefas que transformam um conjunto de inputs em outputs específicos, para outra pessoa ou processo, através de uma combinação de pessoas, procedimentos e ferramentas. 0 mapeamento de processos é uma técnica para se colocar, em um diagrama, o processo de um setor, departamento ou organização, para orientação em suas fases de avaliação, projeto e desenvolvimento (Cheung \& Bal, 1998).

Os processos usualmente contêm duplicações, ineficiências e desperdício de trabalho, que podem ser facilmente corrigidos quando estes estiverem documentados e entendidos. Tosta et al. (2013) defendem a importância do mapeamento dos processos para qualquer empresa, independentemente do ramo, pois, uma vez mapeados, podem ser analisados visando à identificação de atividades, que poderão ser realizadas de maneira mais adequada, ou seja, o mapeamento de processos auxilia no efetivo conhecimento do negócio da empresa, com detalhamento de todas as suas operações e com a identificação de possíveis gargalos.

Para que um consultor ou analista possa realizar atividades de mapeamento e análise dos processos para posterior melhoria, em primeiro lugar, ele deve capturar informações. Existem várias técnicas para se levantar essas informações, podendo ser utilizadas individualmente ou em combinações. Observação direta, entrevistas individuais, reuniões estruturadas, brainstorming, $5 \mathrm{~W} 1 \mathrm{H}$ e questionários estão entre as técnicas menos complexas.

É importante ainda observar que, diferentemente da Reengenharia, que apaga todos os processos e os reiniciam desde zero, o Mapeamento de Processos, parte da observação dos processos e procedimentos atualmente executados na organização (As Is), analisa e estuda esses procedimentos para, em seguida, e com o envolvimento de todos, redesenhar ( $\mathrm{To} \mathrm{Be}$ ) os mesmos, segundo diretrizes expostas na estratégia da organização (Mello, Carvalho \& Cavalcante, 2012).

Uma das ferramentas mais úteis no mapeamento de processos é o fluxograma, que permite visualizar com clareza o fluxo de ações, facilitando que o processo seja concluído com êxito. Oliveira (2000) ressalta que o fluxograma, por meio de símbolos convencionais, representa de modo dinâmico o fluxo ou a sequência normal de trabalho.

Para a construção dos fluxogramas, a ferramenta Bizagi é uma das mais simples de se usar, além da vantagem de utilizar o padrão BPM. A Bizagi é uma ferramenta de software livre de BPMN, que dispõe das funções essenciais para o desenvolvimento de fluxogramas, atuando como ferramenta gerencial para a modelagem de sistemas de gestão dos mais diversos fins (Bizagi, 2014).

Nesse mesmo sentido, buscando uma padronização de atividades, Cury (2005) ressalta a importância de formulários para coleta, análise, processamento e disseminação de dados. Para o autor, as organizações modernas, que dependem de processos otimizados de funcionamento, como condição indispensável para sua sobrevivência e desenvolvimento, sentiram a necessidade de tratar da "papelada" com maior lucidez, introduzindo métodos adequados de implantação, supressão e racionalização de formulários. Essa ação possibilita reduzir custos operacionais e tornar mais simples os fluxos de trabalho e a manipulação de informações.

Porém, para que os fluxos de trabalho mantenham sua uniformização, indica-se que o seu funcionamento racional seja formalizado por meio de manuais de procedimentos. O Manual de Procedimentos representa a etapa de documentação formal e orienta a ação dos envolvidos no processo. Nele devem estar representados, na forma escrita e gráfica, todos os passos de execução do processo de trabalho (GESPÚBLICA, 2010). 


\section{METODOLOGIA}

Nesta seção serão abordados os delineamentos metodológicos adotados nesta pesquisa, com destaque para o tipo de estudo realizado, sua natureza, os instrumentos de coleta de informações e as técnicas de análise e interpretação de dados.

Este estudo classifica-se como teórico-empírico, pois agrega conhecimentos teóricos ao campo da pesquisa, por meio da evidência empírica. Caracteriza-se também como estudo de caso, no qual Yin (2005) o define como sendo uma estratégia de pesquisa que busca examinar um fenômeno dentro do seu contexto, através de análise mais profunda e apurada do acontecimento investigado.

Este estudo utilizou-se das pesquisas de campo, documental e bibliográfica. Segundo Lakatos e Marconi (1991), pesquisa de campo corresponde ao levantamento de dados no próprio local onde os fenômenos ocorrem - por isso a classificação deste estudo como pesquisa de campo. Os dados primários foram obtidos por entrevistas semiestruturadas, que serviram de roteiro para os autores, sendo registradas com gravador e posteriormente transcritas. A entrevista foi concedida pela Assessora responsável pelos Convênios do órgão público. As coletas dos dados ocorreram em reuniões durante o ano de 2014 e 2015.

Ainda se obteve dados secundários através de documentos disponibilizados pela instituição - em especial os processos administrativos, nos quais consta o histórico das parcerias celebradas -, bem como informações disponíveis no site da universidade. Ademais se atentou às normas e legislações pertinentes ao processo de atividade investigado. Esta abordagem possibilitou o levantamento de dados com maior riqueza de detalhes para posterior análise.

Os dados foram analisados e tratados com o que preconiza a análise de conteúdo e triangulados entre entrevista em profundidade, análise documental e observação pessoal (Bardin, 2004; Stake, 2005). Ressalta-se ainda que um dos autores desse estudo possui considerável experiência na área de parcerias e convênios interinstitucionais, o que facilitou a análise e a resposta à pergunta da pesquisa.

\section{RESULTADOS OBTIDOS E ANÁLISE}

Nesta seção, são apresentados os resultados práticos e as análises observadas no diagnóstico organizacional, realizado em uma Unidade Administrativa da UNIVERSIDADE ALFA, à luz dos ensinamentos indicados no referencial teórico.

Primeiramente apresenta-se a organização, objeto de pesquisa, bem como as principais características da Unidade Administrativa estudada. Na sequência, é caracterizado o problema investigado, e por último, recomenda-se a aplicação da metodologia mais indicada e as propostas de solução.

\subsection{PERFIL DA ORGANIZAÇÃO E DA UNIDADE ADMINISTRATIVA - OBJETO DO ESTUDO}

A Universidade Alfa conta com um total de 9.229 alunos nas 68 turmas de cursos de graduação, 28 cursos de especialização com 551 alunos matriculados e 869 alunos nos 23 programas de mestrado e doutorado.

Por meio de entrevista e observação aos documentos da organização, verificou-se que as atividades relacionadas aos Convênios, como monitoramento dos editais, comunicação internas aos coordenadores, assistência para elaboração dos planos de trabalhos, eram realizadas diretamente pela Universidade Alfa campus investigado -, sendo desempenhadas pela Assessoria - Unidade, ligada diretamente à Diretora Geral do campus, sendo integrada formalmente por uma agente administrativa e um estagiário.

Primeiramente, antes do início dos trabalhos de consultoria, a serem realizados por um acadêmico do Mestrado Profissional de Administração, formalizou-se o interesse, sendo aprovado pela da Diretora Geral do campus, estabelecendo, então, o objetivo da pesquisa, bem como, o prazo e a apresentação dos resultados.

\subsection{CARACTERIZAÇÃO DO PROBLEMA ANALISADO}

Realizado um diagnóstico preliminar, por meio de entrevista com a responsável pela unidade administrativa, foi possível identificar as principais funções e atividades desenvolvidas na unidade, compreendendo a inter-relação dos macroprocessos existentes na estrutura do campus. 
Constatou-se que o problema da unidade administrativa está na falta de padronização de seus fluxos de trabalho, o que tem prejudicado a comunicação com os demais envolvidos nos processos, ocasionando retrabalho, conflitos e lentidão na celebração de parcerias.

Muitas organizações vêm tentando implantar a gestão por processos em toda a sua estrutura. Notou-se que nas instituições públicas, devido à burocracia (excesso de formalismo), há uma morosidade na adoção desta modalidade de administração, prejudicando o desenvolvimento de unidades individuais, que buscam melhorar seu fluxo de trabalho.

Dessa forma, faz-se necessária a idealização de uma metodologia simplificada, visando atender essas unidades, mas que, ao mesmo tempo, respeite a abordagem de processos e que sejam flexíveis para se incorporarem, quando houver o mapeamento completo da organização.

Considerando as quatro metodologias apresentadas, que indicam os procedimentos para o mapeamento de processos, percebeu-se como mais adequada, para este estudo, a metodologia proposta por Oliveira (2007), sem descartar a utilização dos métodos de levantamentos de dados, proposto na metodologia de Cury (2005), que possibilita um recolhimento de informações com mais riqueza de detalhes.

\subsection{APLICAÇÃO DA METODOLOGIA MAIS INDICADA}

Aplicação da Metodologia de mapeamento de processos (Oliveira, 2007), consistindo em três fases: Fase I - Preparar o ambiente de modelagem; Fase II - Descrever processos de negócios As-Is; e Fase III Aperfeiçoar processos de negócios To-Be.

\section{Fase 1 - Preparar o ambiente de modelagem}

Foram realizadas reuniões para o conhecimento de todos; escolhidos os usuários para entrevista; apresentado o método de trabalho e o local para realização das atividades de mapeamento de processos.

Um dos primeiros passos a ser verificado em um diagnóstico organizacional, é a decomposição do processo investigado em diferentes níveis de detalhamento, para entender as funções pesquisadas tratamse de macroprocesso, processo, subprocesso, atividade ou tarefa. Macroprocesso envolve grandes conjuntos de atividades por meio das quais as organizações cumprem a sua missão, gerando valor para o cliente. Processo é um conjunto de atividades inter-relacionadas que recebem insumos, agregando-lhe valor e produzindo saídas para clientes internos e externos. Subprocesso é um conjunto de atividades relacionadas, que executa uma parte específica de um processo, dele recebendo insumos e para ele enviando os seus produtos. Atividade é uma decomposição detalhada: são ações que acontecem dentro de um processo ou subprocesso para que ele funcione. E, por fim, tarefa é o menor elemento que compõe um processo, sendo o resultado da decomposição das atividades em unidades.

Nesse sentido, as funções da unidade administrativa investigada enquadram-se em processo: recebe determinadas ações, em seguida agrega valores específicos e técnicos, e finaliza o ciclo gerando outputs. Foram diagnosticados cinco subprocessos, conforme Quadro 3, referente à celebração de parcerias. Depois, foi proposto um conceito para cada subprocesso, considerando a inexistência de uma resolução interna, com o registro das devidas denominações.

Levando-se em conta de que 5 (cinco) subprocessos foram mapeados na unidade de convênios, estabeleceu-se que o estudo se concentraria no subprocesso denominado: "Termo de Cooperação TécnicoFinanceira - SETI". Para se chegar a esta decisão, consideraram-se dois fatores críticos de preocupação da unidade: a) a maioria dos recursos financeiros da Universidade Alfa é oriunda dessa parceria e, b) o fluxo processual das atividades não está padronizado e nem predefinido aos interessados. Observou-se que os procedimentos são repassados verbalmente para os professores envolvidos no desenvolvimento dos projetos. Notou-se ainda que praticamente toda a expertise das celebrações está concentrada na "mente" da agente administrativa responsável pela unidade. 
Quadro 3 - Subprocessos diagnosticados na unidade administrativa

\begin{tabular}{|c|c|c|}
$\begin{array}{c}\text { Convênios baseados em } \\
\text { Emendas Parlamentares }\end{array}$ & $\begin{array}{c}\text { Parcerias celebradas em razão da indicação do parlamentar titular da emenda, pois os } \\
\text { deputados indicam qual estado deve ser contemplado com os recursos. }\end{array}$ \\
$\begin{array}{c}\text { Termo de Cooperação } \\
\text { Técnico-financeira - SETI }\end{array}$ & $\begin{array}{l}\text { Termos de Cooperação celebrados diretamente com a Secretaria da Ciência, } \\
\text { Tecnologia e Ensino Superior do Paraná, que fomenta por meio de recursos } \\
\text { financeiros e econômicos o aprimoramento das universidades estaduais, através de } \\
\text { programas e projetos estratégicos de governo e de interesse da sociedade, bem como } \\
\text { no fomento das atividades da área de ciência, tecnologia e inovação. }\end{array}$ \\
\hline $\begin{array}{c}\text { Acordos de Cooperação } \\
\text { Técnica }\end{array}$ & $\begin{array}{l}\text { Termo de Ajuste que permite o estabelecimento de cooperação técnica, científica e } \\
\text { cultural, com quaisquer entidades, possibilitando conjugar esforços para o } \\
\text { atendimento de ações conjuntas nos campos de ensino, pesquisa, extensão ou em } \\
\text { outras áreas de mútuo interesse, como o compartilhamento de serviços e } \\
\text { infraestruturas, permitindo ainda o repasse de recursos econômicos e financeiros } \\
\text { pela entidade parceira. }\end{array}$ \\
\hline $\begin{array}{c}\text { Convênios com Agências } \\
\text { de Fomento }\end{array}$ & $\begin{array}{l}\text { Parcerias com órgão ou instituição de natureza pública ou privada, que tenha entre } \\
\text { seus objetivos o financiamento de ações, que visem a estimular e promover o } \\
\text { desenvolvimento da ciência, da tecnologia e da inovação. }\end{array}$ \\
\hline $\begin{array}{c}\text { Convênios de Estágios } \\
\text { Nacionais e Internacionais }\end{array}$ & $\begin{array}{l}\text { Parcerias com entidades de direito privado, órgãos da administração pública e } \\
\text { instituições de ensino e/ou pesquisa (nacionais ou internacionais), com as próprias } \\
\text { unidades da Universidade Alfa e com a comunidade em geral, desde que apresentem } \\
\text { condições para ser campo de estágio. }\end{array}$ \\
\hline
\end{tabular}

Fonte: Elaborado pelos autores

\section{Fase 2 - Descrever Processos de Negócio As-Is:}

Nesta fase executaram-se as quatro etapas indicadas pela Metodologia de Oliveira (2007): identificar e detalhar os processos As-Is; descrever os processos As-Is identificados; revisar artefatos As-Is gerados; homologar artefatos As-Is revisados.

O Estado do Paraná, por intermédio de sua Secretaria de Estado da Ciência, Tecnologia e Ensino Superior, e da Unidade Gestora do Fundo Paraná, na qualidade de Órgão Titular do Crédito, apoia o Desenvolvimento Científico, Tecnológico e Inovação das universidades estaduais. As parcerias com a SETI têm por objetivo melhorar as condições de ensino, pesquisa e extensão na Universidade Alfa, criando uma infraestrutura que atenda a comunidade regional, bem como os projetos que geram inovações, produtos tecnológicos e estimulam a formação de seus recursos humanos em alto nível.

Utilizando as estratégias metodológicas, indicadas no item 3, realizou-se o levantamento de informações necessárias para a elaboração do mapeamento do processo As-Is.

Verificou-se que a parceria com a SETI é estabelecida de duas maneiras:

I - O Governo Estadual estabelece quais são os objetivos estratégicos e de importância social e econômica no Paraná, quanto às metas relacionadas à Ciência, Tecnologia e Inovação. A essa modalidade de parcerias podem candidatar-se ao apoio de projetos as Pessoas Jurídicas de Direito Público, Instituições de Ensino Superior e suas Fundações, Centro Tecnológicos e Entidades Privadas sem fins lucrativos. O plano de aplicação desses projetos pode prever a aplicação de recursos de custeio, capital e, excepcionalmente, de bolsas de pesquisa. Nessa modalidade, a Universidade Alfa - campus investigado, concorre à obtenção desses recursos como uma Instituição de Ensino Superior qualquer, no mesmo grau de igualdade que as demais entidades.

II - A SETI, por meio do Fundo do Paraná, destina às universidades estaduais um percentual da receita tributária, para auxiliá-las, principalmente nas despesas de custeio. Nesta modalidade, a SETI convoca as reitorias das universidades a apresentarem seus projetos, para obterem os recursos previamente estabelecidos e de acordo com os planos estratégicos do Governo Estadual. Nesta categoria, a Universidade Alfa, já possui uma reserva de recursos pré-determinada. Porém, deve adequar seus projetos aos requisitos exigidos pela SETI. 
Considerando que na modalidade II, apresentada no parágrafo anterior, praticamente todos os procedimentos, fluxos e prazos são concentrados na reitoria de Universidade Alfa, pois é onde se realiza a consolidação das informações dos diversos campi, somente será foco deste diagnóstico o mapeamento AS IS da modalidade I, que trata da submissão de projetos diversos na área de Ciência, Tecnologia e Inovação.

Quanto ao subprocesso de Parceria com a SETI, foram levantadas as seguintes informações:

Quadro 4 - Dados iniciais da modelagem do subprocesso

\begin{tabular}{|c|l|}
\hline \multirow{2}{*}{ Objetivos } & $\begin{array}{l}\text { a) Alcançar recursos que permitam ampliar e reformar a infraestrutura física dos campi da } \\
\text { Universidade Alfa } \\
\text { b) Por meio de parceria melhorar as condições de trabalho e inovação dos laboratórios e } \\
\text { áreas de pesquisa da Universidade Alfa } \\
\text { c) Criar condições para gerar produtos tecnológicos e inovadores para a comunidade em } \\
\text { geral }\end{array}$ \\
\hline Clientes & Reitor, diretores de campus e pesquisadores \\
\hline Fornecedores & Secretaria de Ciência, Tecnologia e Ensino Superior do Paraná - SETI \\
\hline $\begin{array}{c}\text { Entradas e } \\
\text { componentes }\end{array}$ & Documentações exigidas pela SETI, em especial Planos de Trabalho \\
\hline Saídas & $\begin{array}{l}\text { a) Liberação dos recursos, no caso de êxito da parceria } \\
\text { b) Readequações dos planos de trabalho e estabelecimento de novo calendário para } \\
\text { submissão, se a parceria não funcionar }\end{array}$ \\
\hline
\end{tabular}
Fonte: Elaborado pelos autores

Após essa definição, a descrição e a revisão do mapeamento do processo foram homologados com o especialista da unidade, conforme apresentado no Fluxograma I, retratando fielmente o processo atual. 
Fluxograma I - Processo de Captação de Recursos

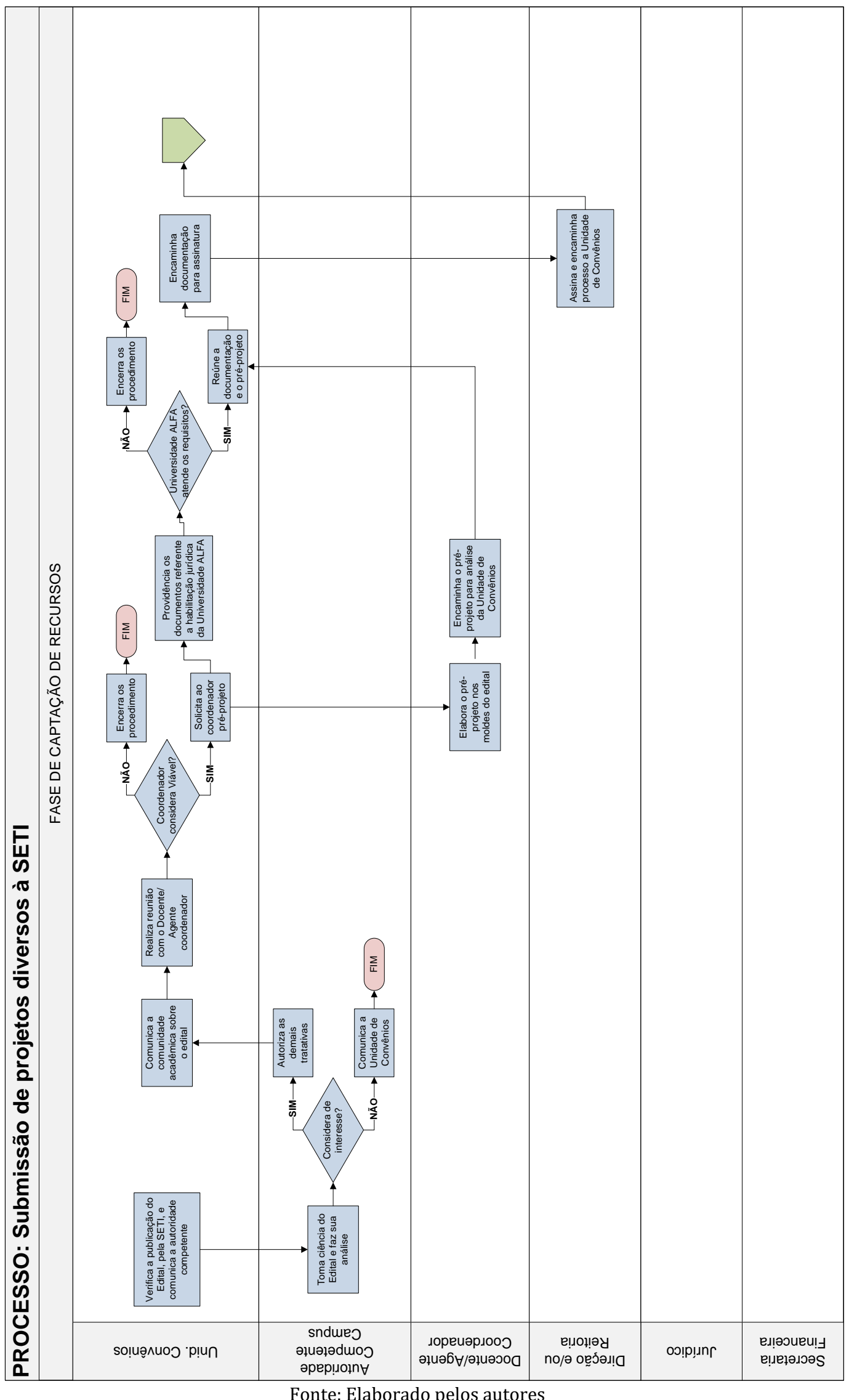


Fluxograma I - Processo de Captação de Recursos (continuação)

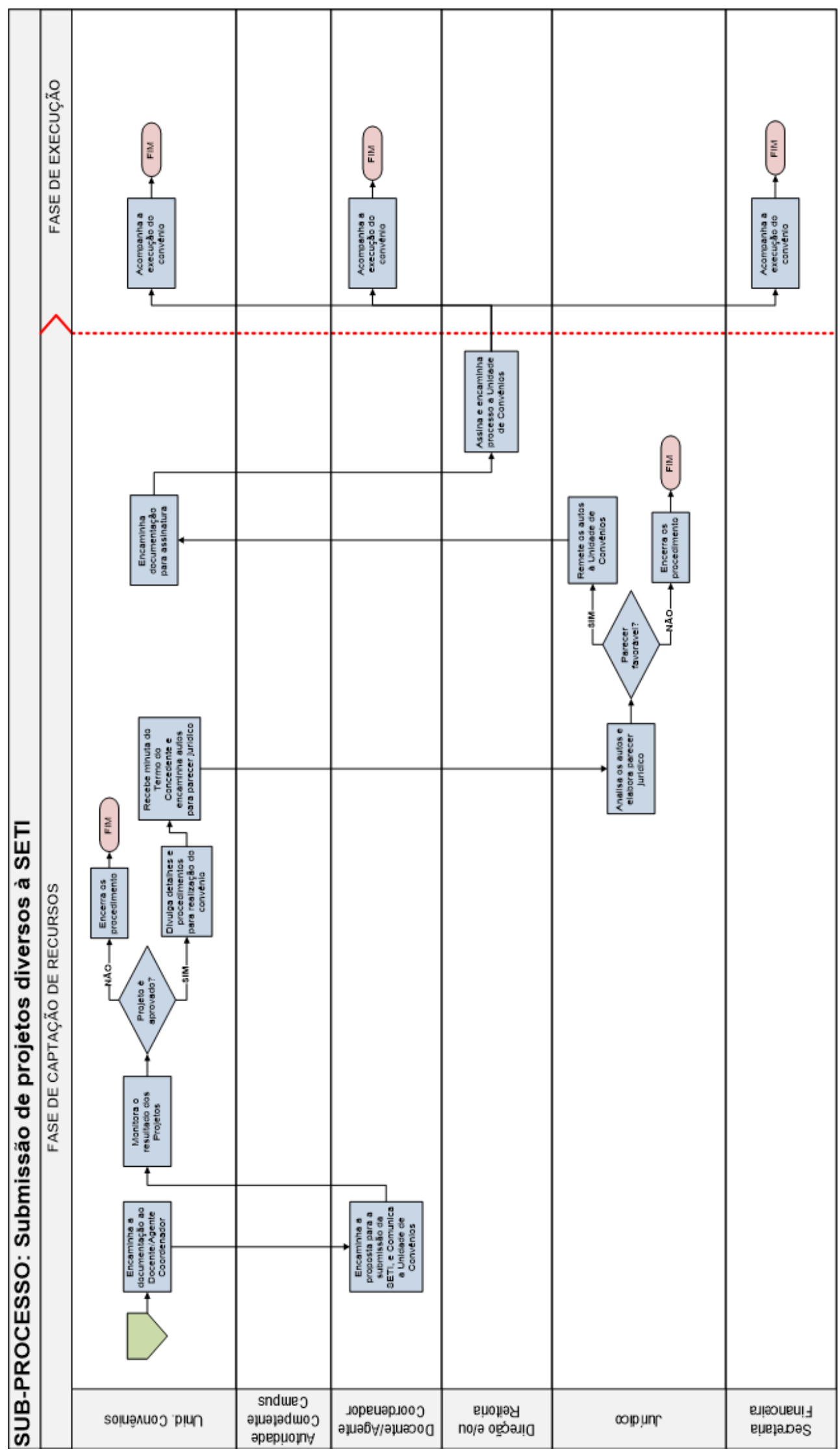

Fonte: Elaborado pelos autores 


\section{Fase 3 - Aperfeiçoar Processos de Negócio To-Be}

Considerando que o objetivo deste estudo foi diagnosticar os gargalos de um método de trabalho e apresentar uma proposta de intervenção, a Fase 3 foi adaptada, para que a organização seja capaz de implementar, por si mesma, as propostas recomendadas.

Dessa forma, esta consultoria recomenda algumas modificações necessárias no processo e métodos de trabalho da unidade administrativa investigada.

Proposta 01 - Revisar mapeamento As-Is com o envolvimento de todos os atores, detectando os gargalos, estabelecendo prazos para as fases, desenvolvendo um mapeamento To-Be e institucionalizando os procedimentos.

Dado o enfoque de sistema aberto existente atualmente nas organizações, um fluxo de trabalho estabelecido por somente um ator tem grande possibilidade de apresentar anomalias e ineficiência. Somente a partir da detecção do diagnóstico situacional, por esta consultoria, foi possível desenvolver e validar um fluxograma do subprocesso de parceria investigada.

Apesar de esta consultoria estar focada em uma pequena unidade administrativa, é de suma importância que os demais atores participantes do processo possam envolver-se na compatibilização e implantação das melhorias, no intuito de aceitar as mudanças e consolidar sua continuidade. Dessa forma, sugere-se, à unidade administrativa, o agendamento de reuniões, definindo as características desejadas para o processo, bem como a avaliação dos recursos e as limitações envolvidas.

Nesta fase de revisão de métodos, a geração de ideias é importante, pois, somente através delas, os problemas identificados em um processo específico poderão ser corrigidos. Recomenda-se, ainda, que as melhores ideias sejam documentadas. A partir dos resultados dessas reuniões, tendo como base as atas e demais documentações produzidas, será descrito detalhadamente os processos otimizados, os atores e processos associados, finalidade, grau de criticidade, prazo para as etapas e suas interações, de maneira que o método seja entendido. Portando, o objetivo é descrever as propostas de melhorias no processo modelado, bem como a expectativa de desempenho desejada.

Também é importante efetuar a revisão e descrição do modelo To-Be para, em seguida, homologar os artefatos To-Be revisados. É importante homologar, com os envolvidos, o processo descrito e diagramado, retratando fielmente as melhorias analisadas e definidas em reunião. Para tal, é necessário um encontro para apresentar todos os documentos e modelos do processo criados para formalização do conhecimento.

Após a homologação do modelo To Be, recomenda-se ainda à unidade administrativa a institucionalização do método de trabalho pactuado, seja por meio de resolução ou instrução normativa. É preciso que a autoridade competente valide os atos praticados pelo grupo, reconhecendo suas atribuições e competências. Por fim, indica-se a disponibilização do método acordado por meio da ferramenta Bizagi, a qual permite aos atores a visualização e localização no processo, e bem como suas atribuições.

\section{Proposta 02 - Implantação de formulários padrões}

Segundo Oliveira (2000), os formulários são um importante meio de comunicação, transmissão e registro de informações - principalmente as embasadas em dados quantitativos. Durante a observação pessoal deste diagnóstico situacional, verificou-se que muitas informações entre os atores eram trocadas via email, não havendo uma padronização das informações requeridas. Isto gerou problemas na comunicação, implicando retrabalhos na unidade, pois as informações recebidas não eram suficientes para dar andamento nos processos de maneira adequada.

Formulários proporcionam uniformidade e padronização de procedimentos, dando maior segurança inclusive para o usuário no preenchimento -, facilita o fluxo de informações e ainda proporciona celeridade nos processos, pois casos similares possuem um único tipo de procedimento. Neste sentido, recomenda-se à unidade administrativa a criação de formulários que atendam às suas necessidades de informações e dados indispensáveis, definindo os campos apropriados e outros aspectos relevantes.

\section{Proposta 03 - Elaboração de Manuais}

Manual é um instrumento indispensável nas organizações. Facilita significativamente o acesso à informação aos usuários. Com o aumento do número dos processos ocorrendo de forma simultânea nas empresas e o alto volume de informações inseridas, os usuários necessitam dispor de diretrizes e 
referências, que os auxiliem nos procedimentos das diversas áreas. Manual é todo e qualquer conjunto de normas, procedimentos, funções, atividades, políticas, objetivos, instruções e orientações, que deve ser obedecido e cumprido pelos executivos e funcionários da organização, bem como a forma de ser executado, quer seja individualmente, quer seja em conjunto (Oliveira, 2000).

Uma das grandes vantagens proporcionadas pelos manuais é o processo de executar os procedimentos aprovados pelas autoridades competentes. Ademais, com os manuais, evitam-se discussões e equívocos quanto às atribuições de cada unidade, pois os assuntos já foram debatidos e neles estabelecidos.

Assim, considerando que o mapeamento TO BE da unidade administrativa estará recentemente aprovado, bem como os formulários elaborados, recomenda-se a elaboração de um manual de procedimento, tornando-o um instrumento de consulta, orientação e aperfeiçoamento na organização.

\section{CONSIDERAÇõES FINAIS}

Este estudo se desenvolveu, visando realizar o diagnóstico situacional dos métodos de trabalho de uma unidade administrativa - responsável pelos Convênios -, na Universidade Alfa, campus investigado.

Observa-se que, apesar de muitas organizações tentarem migrar para uma gestão de processos, geralmente a consolidação dessa nova formatação estrutural pode demorar vários anos - principalmente quando se refere às organizações públicas que, devido às legislações e regulamentos mais rígidos, tendem a ter dificuldade na flexibilidade organizacional.

Assim, esta pesquisa analisou qual seria a metodologia mais indicada para a utilização em pequenas unidades administrativas, que pretendem usufruir dos benefícios da gestão de processos e do mapeamento de seus métodos de trabalhos, mesmo com seu alto nível de conhecimento tácito e o reduzido número de colaboradores nesses departamentos. Nesse sentido, a resposta da pergunta apresentada se deu por meio da apresentação da metodologia de Oliveira (2007), juntamente com as propostas indicadas pelos atores.

0 resultado da pesquisa, relacionado diretamente ao estudo de caso, contribuiu para evidenciar um problema que ainda é comum em muitas organizações, apesar dos avanços da comunicação e das tecnologias de sistemas. Problemas como falta de formalização, institucionalização e padronizações de procedimentos ainda são comuns em grandes corporações. 0 trabalho demonstrou que a utilização do mapeamento As-Is, mapeamento To-Be, fluxogramas, formulários e manuais podem facilitar de maneira significativa a formalização, organização e tarefas de pequenas unidades administrativas.

Como limitação, este estudo apresenta a falta de registro do comportamento, em longo prazo, das chefias dos níveis tático e estratégico, pois a gestão de processos e mapeamento originou-se de unidades administrativas situadas no nível operacional.

\section{REFERÊNCIAS}

[1] Bardin, L. (2004). Análise de conteúdo. 3. ed. Lisboa: Edições 70.

[2] Bizagi. Introdução. Recuperado em 14 de outubro, 2016, de www.bizagi.com

[3] Cheung, Y. \& Bal, J. (1998). Process analysis techniques and tools for business improvements. Business Process Management Journal, 4(4), 274-290.

[4] Cruz, E. M. K. \& Segatto, A. P. (2009). Processos de comunicação em cooperações tecnológicas universidadeempresa: estudos de caso em Universidades Federais do Paraná. Revista de Administração Contemporânea, Curitiba, 13(3), 430-449, Jul./Ago.

[5] Cury, A. (2005). Organização \& Métodos: uma visão holística. 8 ed. São Paulo: Atlas.

[6] Gespublica. Programa Nacional de Gestão Pública e Desburocratização. Recuperado em 12 de outubro, 2015, de http://www.gespublica.gov.br/Tecnologias/pasta.2010-04-

26.1767784009/anexos/guia_de_simplificacao_e_modelagem/i_modelagem_do_processo.pdf

[7] Governo Federal. Governo Eletrônico. Recuperado em 17 de outubro, 2016, de http://www.governoeletronico.gov.br/biblioteca/arquivos/guia-referencial-para-gestao-de-processos-no-governo/

[8] Lakatos, E. M. \& Marconi, M. A. (1991). Fundamentos de metodologia científica. 3. ed. São Paulo: Atlas.

[9] Mello, P. C. N. S.; Carvalho, N. L. A. \& Cavalcante, Z. P. (2011). Modelando Processos Logísticos em uma Instituição Pública de Ensino. In: Convibra Administração - Congresso Virtual Brasileiro de Administração, 8. 2011. 
Anais eletrônicos... 2011. Recuperado em 13 de outubro, 2016, de http://www.convibra.com.br/upload/paper/adm/adm_3210.pdf

[10] Nonaka, I., \& Konno, N. (1998). The concept of" ba": Building a foundation for knowledge creation. California Management Review, 40(3), 40-54.

[11] Nonaka, I. (1991). The knowledge-creating Company. Harvard Business Review, 2-9. Nov./ Dec.

[12] Oliveira, D. C. (2007). Modelagem de processo de negócio como ferramenta de reestruturação organizacional aplicada em uma fundação de pesquisa. 115 p. Dissertação (Mestrado em Engenharia de Produção) - Faculdade de Engenharia de Produção, Universidade Federal do Amazonas, Manaus.

[13] Oliveira, D. P. R. (2000). Sistemas, organização e métodos: uma abordagem gerencial. 11 ed. São Paulo: Atlas.

[14] Omg. Business process management with OMG specifications. Object Management Group. Recuperado em 13 de outubro, 2016, de http://www.bpm-consortium.org/literature.htm

[15] Santos. H. M., Santana. A. F. \& Alves, C. F. (2012). Análise de fatores críticos de sucesso da gestão de processos de negócio em organizações públicas. Revista Eletrônica de Sistemas de Informação, 11(1), jan-jun.

[16] Silva Junior, A. S. et al. (2011). Consultoria Organizacional: qual a relação existente entre a atuação do consultor e o sucesso da aprendizagem dos integrantes da organização cliente? In: ENADI - Encontro de Administração da Informação, III., 2011. Anais... Porto Alegre/RS - 15 a 17 maio 2011.

[17] Stake, R. E. (2005). Qualitative case studies. In: Denzin, N. K. \& Lincoln, Y. S. eds. The sage handbook of qualitative research. 3 ed. Thousand Oaks, CA: SAGE. p. 443-466.

[18] Strauss A. L. (1987). Qualitative analysis for social scientifics. New York: Cambridge University Press.

[19] Teixeira, G. C. (2012). Referenciais de consultoria SEBRAE / consultores conteudistas Gilmar Claret Teixeira, Rosani Coelho. Brasília: SEBRAE.

[20] Tosta, H. T. et al. (2013). Mapeamento e análise dos processos de importação de uma pequena empresa brasileira. Revista de Negócios, Blumenau, 18(4), 17-32, Out./Dez.

[21] Wesner, J. W., Hiatt, J. M. \& Trimble, D. C. (1994). Winning with Quality. Reading, Massachusetts: AddisonWesley.

[22] Yin, R. K. (2005). Estudo de caso: planejamento e métodos. 3. ed. Porto Alegre: Bookman. 


\title{
Capítulo 13
}

\section{A importância do profissional farmacêutico no processo logístico para garantir a integridade dos medicamentos}

\author{
Vitor Costa Chainça \\ Everaldo Luiz Alves de Souza dos Santos \\ Vanina Carrara Sigrist
}

Resumo: 0 mercado farmacêutico faz parte de um seleto grupo de segmentos que não fecham seu ano em déficit. De acordo com o Anuário Estatístico do Portal ANVISA (2017), este segmento movimentou $\mathrm{R} \$ 63,5$ bilhões em 2016 , não só devido à necessidade humana de buscar a cura de doenças e melhorar sua qualidade de vida, mas também devido ao seu processo logístico, que movimenta produtos cujas características físico-químicas exigem alto grau de cuidados de armazenagem, transporte e manuseio, da matéria-prima ao consumidor final. Este artigo objetiva demonstrar em que medida a participação de um profissional farmacêutico é relevante nesse processo, garantindo que seu conhecimento técnico especializado torne-o mais eficaz, evitando transtornos financeiros e pessoais tanto para a indústria, a transportadora e os pacientes. Para tanto, a pesquisa tem natureza aplicada, abordagem exploratória sob uma ótica qualitativa, por meio de aplicação de questionário em escala likert a profissionais farmacêuticos das diversas etapas da cadeia logística de medicamentos. 0 estudo demonstra que, apesar de uma certa disparidade em itens específicos, a presença desse profissional, especialmente em relação a determinados fármacos, se mostra de extrema importância.

Palavras-chave: Processo Logístico. Farmacêutico. Integridade do produto. 


\section{INTRODUÇÃO}

A necessidade humana de buscar a cura de doenças e melhorar sua qualidade de vida torna o campo da saúde uma área privilegiada para a promoção do desenvolvimento econômico e social, pois, além dessas necessidades fundamentais, tal campo proporciona um eixo de criação e difusão de tecnologias. Por conta disso, a indústria farmacêutica se mostra um elo fundamental da saúde enquanto atividade econômica, sendo responsável por toda a cadeia: pesquisa, análise, produção de novos medicamentos e desenvolvimento de novas alternativas terapêuticas (CGEE, 2017).

Segundo o Anuário Estatístico do Mercado Farmacêutico (ANVISA, 2017), a indústria farmacêutica (medicamentos e correlatos) movimentou em $2016 \mathrm{R} \$$ 63,5 bilhões apenas no setor industrial. Isso se deve à procura por novos medicamentos sintéticos ou semissintéticos, associados ou não, e por preços reduzidos devido à concorrência. Nesse cenário, dentre as vinte empresas com maior faturamento em 2016, oito são brasileiras, sendo duas governamentais. Os maiores faturamentos desse quadro encontramse entre os comércios atacadistas, farmácias, drogarias e órgãos do governo como Fiocruz e Instituto Butantã. Somente no ano de 2016, 6.300 produtos foram vendidos, em 12.798 apresentações distintas e produzidas por 214 fabricantes. Essas empresas estão espalhadas por 14 estados, sendo os maiores detentores desse faturamento São Paulo e Rio de Janeiro.

A logística dos fármacos tem características distintas, pois, diferente de outros bens, os medicamentos necessitam de cuidados específicos devido a suas características de estabilidade e sensibilidade às variações de temperatura, luminosidade, umidade e manuseio, e, caso não sejam geridos de forma correta, têm comprometidas sua integridade, qualidade e eficácia. Por essa razão, seu transporte e armazenagem devem ser diferenciados dos demais produtos (CARVALHO JUNIOR; MACEDO, 2012).

Nesse contexto, o gerenciamento no setor da saúde é muito mais complexo do que em qualquer outra organização, pois a logística de medicamentos demanda uma gestão mais criteriosa de recursos e procedimentos. 0 sistema logístico da saúde vai além de simplesmente garantir que uma mercadoria vá de um ponto de origem até seu destino: ele deve assegurar que cada cliente obtenha os produtos com total segurança e integridade, assim conciliando os diversos interesses, sendo eles: os do consumidor, que deseja produtos de qualidade, com preços acessíveis e no tempo adequado; da área econômica, que deseja o produto com o menor custo possível; e dos fornecedores, que desejam vender maiores quantidades ao maior preço possível (ANDREOLI; DIAS, 2015; USAID, 2012).

Para o acompanhamento e análise dessa cadeia, torna-se legítimo questionar se é essencial um ponto de vista técnico que garanta a integridade do fármaco até seu destino. Um profissional farmacêutico teria papel fundamental como gestor na área de logística, já que seus conhecimentos contribuem para além do mero cumprimento da legislação? Ele sempre se tornaria atuante na integração de outras áreas, proporcionando melhoria dos processos, integração das equipes, melhor formação das pessoas no ambiente de trabalho, melhor conhecimento dos fármacos e da importância do tratamento diferenciado a essa mercadoria, como afirmam Mazzali, Makiya e Cesar (2016)?.

O presente trabalho busca investigar a importância do profissional farmacêutico no processo logístico de medicamentos. Por meio de um questionário semiestruturado apresentado a profissionais farmacêuticos inseridos em diversas áreas da cadeia logística de fármacos, foi possível desenvolver uma pesquisa aplicada, exploratória e qualitativa, que busca apresentar a importância do profissional farmacêutico sob a ótica da influência de seu conhecimento técnico, de sua atuação, seguindo diretrizes preestabelecidas pelos órgãos reguladores, e de possíveis riscos à integridade do medicamento.

\section{REFERENCIAL TEÓRICO}

A indústria farmacêutica prova ser, por inúmeras razões, um setor altamente estratégico para a economia nacional. Em primeiro lugar, por ser responsável pela fabricação de produtos essenciais à saúde humana, 0 que lhe atribui, então, um importante papel social e de segurança nacional. Ainda estão atrelados à indústria farmacêutica alta intensidade tecnológica, investimento em pesquisa e desenvolvimento (P\&D) e alto percentual de faturamento. Em decorrência disso, os principais países desenvolvidos investem grande parte de seus recursos em P\&D farmacêutico, tendo essas empresas como força motriz (CUNHA, 2009; CCGE, 2017).

A produção de um medicamento depende da produção de fármacos, pois neles estão os princípios ativos. Sendo assim, a cadeia de produção de fármacos é responsável pela fabricação de substâncias obtidas por síntese química, a partir de insumos farmacêuticos que podem ser extraídos de animais, vegetais ou 
sínteses biotecnológicas. Portanto, o setor farmacêutico, baseado em P\&D, apresenta, considerando-se toda a trajetória do medicamento, da sua descoberta até seu consumo final pelo usuário, quatro estágios evolutivos (ROCHA; GALENDE, 2014; CNQ, 2015; CCGE, 2017).

O Quadro 1 apresenta os diferentes componentes da cadeia produtiva farmacêutica.

Quadro 1 - Cadeia de valor farmacêutica

\begin{tabular}{|c|c|}
\hline Estágio da Cadeia Produtiva & Competências \\
\hline Pesquisa e desenvolvimento (P\&D) & $\begin{array}{l}\text { Essa etapa inclui a P\&D de novos princípios ativos; exige elevados } \\
\text { níveis de investimento tecnológico, recursos financeiros, e envolve } \\
\text { grandes riscos. }\end{array}$ \\
\hline Produção industrial de fármacos & $\begin{array}{l}\text { Em sequência à primeira etapa, os princípios ativos são sintetizados no } \\
\text { fármaco que será comercializado; exige capacitação tecnológica, } \\
\text { conhecimentos específicos em química e ambiente industrial. }\end{array}$ \\
\hline Marketing & $\begin{array}{l}\text { Nesta etapa é necessário alto investimento para a construção da marca } \\
\text { e de tempo para adquirir a lealdade dos médicos e pacientes. }\end{array}$ \\
\hline Logística de medicamentos & $\begin{array}{l}\text { Nesta última etapa há a necessidade de integrar a indústria } \\
\text { farmacêutica com os segmentos de embalagem, transporte e } \\
\text { manipulação dos medicamentos do produtor ao destinatário final. }\end{array}$ \\
\hline
\end{tabular}

Fonte: Adaptado de CNQ (2015) e CCGE (2017).

Apesar de se caracterizar como uma indústria baseada em inovação de produtos (P\&D e marketing), a indústria farmacêutica mundial vem passando por mudanças importantes que motivam as empresas do setor a adotar novas estratégias. As empresas líderes encontram dificuldades para lançar medicamentos de alto impacto no mercado - o tempo e o custo para lançar uma nova molécula, somados ao vencimento de patentes de medicamentos de alto consumo e a fomentação dos genéricos, aumenta as incertezas e a competitividade, impondo às empresas a necessidade de ampliar a visão nesse novo cenário competitivo (SAMPAIO; CSILLAG, 2010; GOMES et al, 2014; ROCHA; GALENDE, 2014).

\subsection{CENÁRIO ECONÔMICO BRASILEIRO DO MERCADO FARMACÊUTICO}

A indústria farmacêutica tem apresentado lucros tradicionalmente maiores do que das demais indústrias. Nos últimos 32 anos, o retorno sobre o patrimônio apresentado pela indústria farmacêutica foi de 18,4\% em comparação à média de 11,9\% de todas as outras 500 indústrias (MARADEI JÚNIOR, 2008).

Segundo Castro et al. (2013), o setor apresentou um grande crescimento no mercado de medicamentos (8\%, crescendo em média 3\% ao ano). A indústria de fármacos no Brasil insere-se no contexto global das indústrias farmacêuticas como um dos mercados mais dinâmicos da última década, apresentando taxas de crescimento de dois dígitos, e assim alcançando a sexta posição mundial em 2013. Entre 2003 e 2014 , a indústria farmacêutica cresceu $345 \%$, passando de $\mathrm{R} \$ 14.780$ bilhões para $\mathrm{R} \$ 65.785$ bilhões. No ano de 2016, o mercado apresentou um faturamento de $\mathrm{R} \$ 63.547$ bilhões, mantendo-se em alta apesar da recessão econômica apresentada a partir de 2015 (CUNHA, 2009; GOMES et al., 2014; CNQ, 2015; ANVISA, 2017).

Grande parte das empresas da área farmacêutica estão concentradas no estado de São Paulo, que representa $76,6 \%$ do faturamento do país e 55,7\% da quantidade total dos produtos comercializados em 2016. Outros dois estados que se destacam são: Goiás, em termos de produtos comercializados, resultando em 18,5\% com um faturamento de 4,5\%; e Rio de Janeiro, que apresentou um faturamento de $11,2 \%$ e $8,1 \%$ dos produtos comercializados. Vale destacar que a maioria das empresas que detêm ampla parte do mercado brasileiro são de grande porte. Dessas, 52 arrecadam 83,1\% do faturamento e são responsáveis por $75,7 \%$ das vendas: grandes grupos de empresas farmacêuticas como Sanofi/Medley/Genzyme, liderando o faturamento do mercado, seguido do grupo Novartis/Sandoz/Alcon. Além desses, há a participação expressiva de laboratórios públicos como Fundação Oswaldo Cruz (Fiocruz) e Instituto Butantã (ANISA, 2017). 


\subsection{LOGÍSTICA FARMACÊUTICA}

Apesar do panorama satisfatório e das expectativas promissoras, as pressões sobre as empresas farmacêuticas devem se acentuar, demandando a necessidade de repensar as estratégias industriais (SAMPAIO; CSILLAG, 2010; GOMES et al., 2014; CNQ, 2015;). Em vista disso, a logística vem se mostrando um importante instrumento a ser desenvolvido nesse novo ambiente competitivo: "A logística empresarial vem sendo encarada pelas empresas como estratégia organizacional na busca de vantagem competitiva, assegurando às organizações alcançarem maior fatia do mercado, contribuindo assim para lucratividade" (CASTRO et al., 2013, p. 51).

Nesse novo mercado, a logística de uma empresa apresenta cada vez mais ênfase na gestão, sendo de grande importância na produtividade, ou seja, gerando vantagens competitivas. No setor farmacêutico, a logística é ainda mais importante por ser um setor que possui muitas regulamentações por parte do Estado. Dessa forma, as distribuidoras de medicamento apostam nos serviços diferenciados aos clientes e na otimização dos custos logísticos, pois, nesse novo cenário, o sucesso empresarial depende das atividades logísticas e da gestão da cadeia de suprimentos, já que esse processo é transversal a todas as áreas de uma organização, assim acrescentando valor. Observa-se, então, a necessidade de manutenção das alianças entre fornecedores e clientes, pois a colaboração efetiva agrega valores a todos os processos da cadeia, sejam elas estratégias de produção, comercialização, movimentação e entrega dos produtos (SAMPAIO; CSILLAG, 2010; CASTRO et al., 2013; ROCHA; GALENDE, 2014; MENDES, 2015; COSTA, 2016).

Em outras palavras, pode-se considerar as atividades de logística como um componente de gestão da cadeia de abastecimento, incluindo produção, distribuição, aquisição, quantificação, gestão de estoque, transporte e dispensação, gestão de frota, recolha de dados e reporte. Outrossim, a coordenação e colaboração dos trabalhadores, níveis e funções, junto aos fabricantes, nacionais e internacionais, e órgãos regulamentadores, deve sempre zelar pela responsabilidade solidária, identidade, eficácia, qualidade e segurança dos produtos farmacêuticos. Em última instância, o sistema logístico de saúde vai além de garantir que o produto vá até aonde deve ir, ele deve assegurar que cada cliente obtenha os produtos com a devida segurança e sempre que precisar (USAID, 2012; CARVALHO JUNIOR; MACEDO, 2012; CORRÊA; AGUIAR, 2012; ANDREOLI; DIAS, 2015; MAZZALI; MAKIYA; CESAR, 2016).

\subsection{OPERADOR LOGÍSTICO}

Visando a redução de custos, as empresas da indústria farmacêutica investem cada vez mais no controle das operações, o chamado Operador Logístico (OL) ou ainda Third-Party Logistics (3PL), podendo assim obter maior otimização do espaço de produção e oferecer um melhor serviço aos clientes. Resumidamente, o OL consiste do uso de companhias externas para realizar funções logísticas que anteriormente eram realizadas dentro da empresa responsável, como receber, estocar e expedir os medicamentos de acordo com os pedidos (CORRÊA; AGUIAR, 2012; MAZZALI; MAKIYA; CESAR, 2016).

As atividades dos operadores logísticos são de tamanha importância para a logística farmacêutica que a Agência Nacional de Vigilância Sanitária (ANVISA), no dia 20 de junho de 2018, reconheceu as operações do OL através da Resolução da Diretoria Colegiada. 0 Quadro 2 apresenta as resoluções que dispõem sobre o OL. 
Quadro 2 - Disposições sobre o operador logístico

\begin{tabular}{|c|l|}
\multicolumn{2}{|c|}{ CAPÍTULO I - DAS DISPOSIÇÕES INICIAIS - Seção II - Abrangência } \\
\begin{tabular}{|c|l|}
\hline Art. $2^{\circ}$ & $\begin{array}{l}\text { Esta Resolução se aplica às empresas fabricantes, embaladoras, importadoras, distribuidoras, } \\
\text { operadores logísticos, transportadoras, armazenadoras e aos laboratórios de controle de qualidade de } \\
\text { medicamentos e produtos biológicos; }\end{array}$ \\
\hline CAPÍTULO I - DAS DISPOSIÇÕES INICIAIS - Seção III - Definições
\end{tabular} \\
\hline Art. $4^{\circ}-\mathrm{X}$ & $\begin{array}{l}\text { operador logístico (OL): empresa detentora de Autorização de Funcionamento (AFE) e Autorização } \\
\text { Especial (AE), quando aplicável, capacitada a prestar os serviços de transporte e/ou armazenamento; }\end{array}$ \\
\hline Art. 25 & $\begin{array}{l}\text { As EmpítULO VIII - DOS OPERADORES LOGíSTICOS Contratadas denominadas Operadores Logísticos devem ser detentoras de Licença } \\
\text { Sanitária, AFE e, quando aplicável, AE, para as atividades de "armazenar" e "transportar", conforme as } \\
\text { atividades que forem exercidas. }\end{array}$ \\
\hline Art. 26 & $\begin{array}{l}\text { Os operadores logísticos devem cumprir as disposições da legislação vigente relativas às Boas } \\
\text { Práticas que sejam aplicáveis às atividades por eles exercidas. }\end{array}$ \\
\hline
\end{tabular}

Fonte: RDC N² 231, de 20 de junho de 2018, p. 34-35.

\section{PROCEDIMENTOS METODOLÓGICOS}

Realizou-se uma pesquisa exploratória e qualitativa, por meio de uma pesquisa de campo durante a qual foi aplicado um questionário semiestruturado com 23 (vinte e três) perguntas a 21 (vinte e um) profissionais farmacêuticos atuantes nas diversas áreas da cadeia logística de medicamentos, incluindo transportes, aeroportos, terminais marítimos, recinto alfandegário, varejo farmacêutico, importação e distribuição, fornecedores, gerentes, responsáveis técnicos e coordenadores de logística. Da amostra selecionada de 100 respondentes, apenas $21 \%$ efetivamente participaram. 0 critério de seleção dos profissionais foi o contato prévio já estabelecido em circunstâncias formais em que esteve presente um dos autores desta pesquisa.

Todos os respondentes aceitaram o Termo de Consentimento Livre e Esclarecido (TCLE) determinado pelo Comitê de Ética em Pesquisa.

O questionário semiestruturado possuía escala Likert, composta de cinco graus de opinião, que abrange da discordância total em relação a uma asserção à concordância plena. Essa opção traz mais robustez metodológica a pesquisas que lidam com opiniões ou percepções de mais difícil mensuração matemática, pois oferece uma variedade adequada de respostas, com maior detalhamento do que duplas ou trios de alternativas.

O questionário foi dividido em cinco partes: a primeira consiste de cinco perguntas sobre a importância da atuação do profissional farmacêutico em relação ao conhecimento técnico; a segunda parte consiste de cinco perguntas sobre a importância do profissional farmacêutico em relação a gestão e gerenciamento de risco da cadeia logística; a terceira parte é formada de cinco perguntas sobre a importância do profissional farmacêutico em relação a manipulação e prevenção de não conformidades; a quarta parte é composta de seis perguntas sobre o impacto da revogação da Lei 15.626/2014, esta que dispõe a respeito da não obrigatoriedade das transportadoras em contar com um farmacêutico como responsável técnico dentro da empresa; a quinta parte consiste de duas perguntas sobre as etapas e os modais da cadeia logística que mais ofertem riscos à integridade do medicamento.

A coleta dos dados se realizou via web durante o período de um mês (15 de setembro a 15 de outubro). Além do questionário, ao final de cada parte os entrevistados podiam realizar um comentário para justificar alguma das respostas.

\section{RESULTADOS E DISCUSSÃO}

Os quadros abaixo apresentam os resultados dos questionários respondidos pela amostra de profissionais farmacêuticos que participaram da pesquisa. 
Quadro 3 - Importância do profissional farmacêutico, quesito técnico

I. A atuação do profissional farmacêutico, em relação ao conhecimento técnico, se faz necessário em todas as etapas da cadeia logística pois:

a. 0 profissional farmacêutico detém do conhecimento técnico sobre a composição dos medicamentos.

b. 0 profissional farmacêutico detém do conhecimento técnico sobre as características físico-químico (tolerância a temperatura, umidade, luminosidade) dos medicamentos.

c. 0 profissional farmacêutico detém do conhecimento sobre a periculosidade e potenciais riscos à saúde dos medicamentos.

d. O profissional farmacêutico é o único que está autorizado a manipular determinados medicamentos.

e. Caso um profissional de outro segmento detivesse do conhecimento técnico e treinamento adequado sobre a manipulação de medicamentos, este estaria apto a assumir o papel do farmacêutico na cadeia logística de medicamentos.

\begin{tabular}{|c|c|c|c|c|c|}
\hline Itens de Análise & $\begin{array}{c}\text { Discordo } \\
\text { Totalmente }\end{array}$ & $\begin{array}{c}\text { Discordo } \\
\text { Parcialmente }\end{array}$ & Indiferente & $\begin{array}{c}\text { Concordo } \\
\text { Parcialmente }\end{array}$ & 2 \\
\hline a & 1 & 0 & 1 & 3 & 17 \\
\hline $\mathrm{b}$ & 0 & 1 & 1 & 1 & 1 \\
\hline $\mathrm{c}$ & 0 & 1 & 1 & 2 & 16 \\
\hline $\mathrm{d}$ & 1 & 1 & 2 & 4 \\
\hline
\end{tabular}

Fonte: dados da pesquisa

Esperava-se certa bipolaridade em algumas das perguntas, porém os dados se mostraram bastante homogêneos. No entanto alguns itens atraem a atenção. 0 item e da primeira parte no Quadro 3 teve os resultados um pouco mais dispersos do que os outros itens. Uma possível hipótese explicativa seria não o fato de o profissional poder ser substituído por outro em toda cadeia logística, mas sim substituído por um profissional capacitado e treinado, nas etapas de cross doking, uma vez que esse processo acontece geralmente em aeroportos onde são manipuladas outras cargas além dos medicamentos; o medicamento permanece por pouco tempo ali, sendo apenas transferido de um modal para outro ou de um veículo para outro.

Quadro 4 - Importância do profissional farmacêutico, gestão e gerenciamento

\section{A atuação do profissional farmacêutico, em relação a gestão e gerenciamento de risco da cadeia logística, se} faz necessário em todas as etapas da cadeia pois:

a. 0 profissional farmacêutico tem o maior preparo para integrar os interesses logísticos e de preservação da integridade dos medicamentos.

b. 0 profissional farmacêutico tem o maior preparo para a gestão de boas práticas farmacêuticas e diretrizes da ANVISA sobre o controle sanitário.

c. 0 profissional farmacêutico detém do conhecimento sobre a periculosidade e potenciais riscos à saúde dos medicamentos.

d. 0 profissional farmacêutico é o único que está autorizado a elaborar relatórios técnicos a respeito da gestão de qualidade, avarias, extravios, fraudes e não conformidades.

e. Parte da cadeia logística não opera apenas com o transporte e armazenagem de medicamentos, logo a presença de um profissional farmacêutico nas etapas de transporte e armazenagem de medicamentos de automedicação não é relevante.

\begin{tabular}{|c|c|c|c|c|c|}
\hline $\begin{array}{c}\text { Itens de } \\
\text { Analise }\end{array}$ & $\begin{array}{c}\text { Discordo } \\
\text { Totalmente }\end{array}$ & $\begin{array}{c}\text { Discordo } \\
\text { Parcialmente }\end{array}$ & Indiferente & $\begin{array}{c}\text { Concordo } \\
\text { Parcialmente }\end{array}$ & $\begin{array}{c}\text { Concordo } \\
\text { Totalmente }\end{array}$ \\
\hline a & 0 & 1 & 1 & 5 & 14 \\
\hline $\mathrm{b}$ & 0 & 1 & 0 & 4 & 16 \\
\hline $\mathrm{c}$ & 0 & 2 & 0 & 8 & 11 \\
\hline $\mathrm{d}$ & 2 & 1 & 0 & 11 & 1 \\
\hline $\mathrm{e}$ & 15 & 3 & 0 & 2 & \\
\hline \multicolumn{7}{|c|}{ Fonte: dados da pesquisa } \\
\end{tabular}

O itens c e d no Quadro acima apresentam uma concordância parcial com a afirmação mais elevada do que em outros itens. Uma hipótese seria de que o profissional farmacêutico não deve atuar sozinho, e sim fazer parte de uma equipe multidisciplinar, possivelmente composta por outros especialistas.

Já na terceira parte (Quadro 5), os itens d e e apresentam maior bipolaridade entre todos os itens, como é possível observar: 
Quadro 5 - Importância do profissional farmacêutico, atuação

III. O profissional farmacêutico, em relação a manipulação e prevenção de não conformidades, para agir de forma atuante deve:

a. Fazer cumprir rigorosamente todas as resoluções da ANVISA e aplicar sistemas de gestão de qualidade, ISO 9001:2015.

\begin{tabular}{|c|c|c|c|c|c|}
\hline \multicolumn{6}{|c|}{$\begin{array}{l}\text { b. Aplicar o conhecimento técnico sobre a composição assim como periculosidade e potenciais riscos à saúde } \\
\text { afim de preservar a segurança. }\end{array}$} \\
\hline \multicolumn{6}{|c|}{$\begin{array}{l}\text { c. Aplicar o conhecimento técnico sobre as características físico-químico dos medicamentos afim de adotar os } \\
\text { melhores procedimentos e condições de transporte a armazenagem. }\end{array}$} \\
\hline \multicolumn{6}{|c|}{$\begin{array}{l}\text { d. A gestão da cadeia logística deve integrar as diretrizes sanitárias impostas sobre os medicamentos aos } \\
\text { interesses logísticos, porem priorizando os interesses logísticos. }\end{array}$} \\
\hline \multicolumn{6}{|c|}{$\begin{array}{l}\text { e. Uma vez que a integridade dos medicamentos requer auto investimento econômico e técnico, é de interesse } \\
\text { dos laboratórios ser o elo principal e responsável pelo gerenciamento logístico dos medicamentos. }\end{array}$} \\
\hline $\begin{array}{l}\text { Itens de } \\
\text { Analise }\end{array}$ & $\begin{array}{l}\text { Discordo } \\
\text { Totalmente }\end{array}$ & $\begin{array}{l}\text { Discordo } \\
\text { Parcialmente }\end{array}$ & Indiferente & $\begin{array}{l}\text { Concordo } \\
\text { Parcialmente }\end{array}$ & $\begin{array}{l}\text { Concordo } \\
\text { Totalmente }\end{array}$ \\
\hline$a$ & 1 & 0 & 0 & 8 & 12 \\
\hline $\mathrm{b}$ & 1 & 0 & 0 & 6 & 14 \\
\hline c & 1 & 0 & 0 & 4 & 16 \\
\hline $\mathrm{d}$ & 4 & 3 & 2 & 5 & 7 \\
\hline e & 4 & 2 & 2 & 7 & 6 \\
\hline
\end{tabular}

Fonte: dados da pesquisa

No item d uma possível hipótese explicativa para tal divergência seria a relação entre o alto custo de implementação de certas diretrizes da ANVISA, que se tornam economicamente inviáveis para certos medicamentos, e a importância de se priorizar a integridade do medicamento, uma vez que pode trazer riscos à saúde humana. No item e pode-se afirmar que já era esperado que houvesse tal resultado (índice mais alto de respostas de discordância total em relação ao papel dos laboratórios), uma vez que esse item demanda um estudo mais aprofundado, por ser um tópico de grande discussão.

$$
\text { Quadro 6 - Lei 15.626/2014 }
$$

\begin{tabular}{|c|c|c|c|c|c|}
\hline \multicolumn{6}{|c|}{$\begin{array}{l}\text { a. Afetara de forma negativa a qualidade dos serviços prestados assim como na prevenção de extravios, } \\
\text { fraudes e não conformidades. }\end{array}$} \\
\hline \multicolumn{6}{|c|}{$\begin{array}{l}\text { b. Afetara de forma negativa a gestão da cadeia logística, tanto nos interesses logístico quanto na aplicação das } \\
\text { diretrizes da ANVISA e sistemas de qualidade. }\end{array}$} \\
\hline \multicolumn{6}{|c|}{ c. Afetara de forma mais grave a qualidade das etapas de transporte de medicamentos. } \\
\hline \multicolumn{6}{|c|}{ d. Afetara de forma mais grave a qualidade das etapas de armazenagem de medicamentos. } \\
\hline \multicolumn{6}{|c|}{ e. Afetara negativamente de forma acentuada os serviços prestados pelos operadores logísticos. } \\
\hline \multicolumn{6}{|c|}{ f. Afetara negativamente de forma acentuada os serviços prestados pelos centros de distribuição. } \\
\hline $\begin{array}{l}\text { Itens de } \\
\text { Analise }\end{array}$ & $\begin{array}{l}\text { Discordo } \\
\text { Totalmente }\end{array}$ & $\begin{array}{c}\text { Discordo } \\
\text { Parcialmente }\end{array}$ & Indiferente & $\begin{array}{l}\text { Concordo } \\
\text { Parcialmente }\end{array}$ & $\begin{array}{l}\text { Concordo } \\
\text { Totalmente }\end{array}$ \\
\hline $\mathrm{a}$ & 2 & 0 & 1 & 8 & 10 \\
\hline $\mathrm{b}$ & 2 & 0 & 1 & 6 & 12 \\
\hline c & 2 & 0 & 0 & 5 & 14 \\
\hline $\mathrm{d}$ & 2 & 0 & 1 & 3 & 15 \\
\hline $\mathrm{e}$ & 2 & 0 & 3 & 4 & 12 \\
\hline $\mathrm{f}$ & 2 & 0 & 2 & 8 & 9 \\
\hline
\end{tabular}

Fonte: dados da pesquisa

No quadro acima, pertencente à quarta parte, vê-se que a maioria das respostas está distribuída entre concordo parcialmente e concordo totalmente. Possivelmente, isso se deve ao fato de que uma lei por si só não interfere na preservação da integridade dos medicamentos, apesar de ser um amparo legal para tal, mas sim a fiscalização e adoção das diretrizes dos órgãos fiscalizadores. Outra hipótese seria de que a revogação dessa lei não teve impacto no cenário logístico visto que o profissional farmacêutico já é considerado uma figura representativa e indispensável no segmento.

Na última parte (representada pelo Quadro 7 abaixo), os itens a e c, em relação ao modal (V), apresentam o maior grau de risco à integridade do medicamento. 0 item a por se tratar de um modal que realmente oferece risco por conta das condições das estradas brasileiras e da dependência de um controle rigoroso de temperatura devido às altas temperaturas e a sua variação brusca; quanto ao item c, por se tratar de um modal pouco utilizado para transporte de medicamentos. 
Quadro 7 - Grau de risco à integridade dos medicamentos

\begin{tabular}{|c|c|c|c|c|c|}
\hline \multicolumn{3}{|c|}{ a. Transporte Rodoviário } & \multicolumn{3}{|c|}{ b. Transporte Aéreo } \\
\hline \multicolumn{3}{|c|}{ c. Transporte Marítimo } & \multicolumn{3}{|c|}{ d. Transporte Infoviário } \\
\hline $\begin{array}{l}\text { Itens de } \\
\text { Análise }\end{array}$ & Grau 1 & Grau 2 & Grau 3 & Grau 4 & Grau 5 \\
\hline $\mathrm{a}$ & 0 & 0 & 3 & 4 & 14 \\
\hline $\mathrm{b}$ & 1 & 6 & 5 & 3 & 6 \\
\hline $\mathrm{c}$ & 0 & 2 & 3 & 6 & 10 \\
\hline $\mathrm{d}$ & 2 & 1 & 6 & 3 & 9 \\
\hline \multicolumn{6}{|c|}{$\begin{array}{l}\text { VI. Em relação aos elos da cadeia logística, o grau de importância da atuação do profissional farmacêutico na } \\
\text { etapas ou áreas: }\end{array}$} \\
\hline \multicolumn{3}{|c|}{ a. Transporte: laboratório-Distribuição } & \multicolumn{3}{|c|}{ b. Transporte: Distribuição-Varejo } \\
\hline \multicolumn{3}{|c|}{ c. Transporte: Varejo-Consumidor } & \multicolumn{3}{|c|}{ d. Armazenamento } \\
\hline \multicolumn{3}{|c|}{ e. Cross Docking } & \multicolumn{3}{|c|}{ f. Operador Logístico } \\
\hline \multicolumn{3}{|c|}{ g. Centro de Distribuição } & & & \\
\hline $\begin{array}{l}\text { Itens de } \\
\text { Análise }\end{array}$ & Grau 1 & Grau 2 & Grau 3 & Grau 4 & Grau 5 \\
\hline $\mathrm{a}$ & 0 & 1 & 3 & 4 & 13 \\
\hline $\mathrm{b}$ & 0 & 1 & 3 & 3 & 14 \\
\hline c & 0 & 0 & 3 & 4 & 14 \\
\hline $\mathrm{d}$ & 0 & 1 & 2 & 1 & 17 \\
\hline e & 0 & 0 & 1 & 3 & 17 \\
\hline $\mathrm{f}$ & 0 & 0 & 4 & 7 & 10 \\
\hline $\mathrm{g}$ & 0 & 0 & 5 & 1 & 15 \\
\hline
\end{tabular}

Fonte: dados da pesquisa

Por sua vez, o item e - VI do Quadro 7 apresenta quase todos os pontos nos graus de risco acima de 4, levando a concluir que, na opinião dos profissionais consultados, a etapa de cross docking oferece grande risco à integridade do medicamento, principalmente aos termos sensíveis, por conta da exposição a alta temperatura.

\section{CONSIDERAÇõES FINAIS}

Apesar da dispersão das respostas em alguns do itens, os dados coletados durante a pesquisa de campo, de modo geral, apresentam tendência favorável às afirmações que buscam salientar a importância do profissional farmacêutico na cadeia logística de medicamentos a fim de garantir a integridade desses produtos.

Isso demonstra, numa perspectiva indutiva, que a presença do farmacêutico na área da logística é fundamental, pois ele está apto a trabalhar com as diversas classes farmacológicas, sempre respeitando as exigências nacionais para cada classe farmacêutica, como também conhecendo profundamente as características físico-químicas de cada droga. Ele está apto também a trabalhar com várias temperaturas de medicamentos (o que tem extrema relevância para garantir a sua integridade, especialmente os termosensíveis ou termo-lábeis), pois como conhece a estrutura físico-química dos medicamentos tem maior conhecimento sobre sua estabilidade, com isso podendo proceder com o transporte adequado sem ter problemas com a estabilidade do produto. 
O farmacêutico deve fazer parte de uma equipe multidisciplinar de forma ativa. Sendo assim, não deve ser o único a realizar relatórios técnicos, tomar decisões logísticas e outra eventual alteração no processo logístico de medicamentos. No entanto, a substituição do profissional farmacêutico por um profissional de outro segmento ainda é um tanto quanto questionável. Parte dos entrevistados concordam com a ideia de que o profissional farmacêutico pode ser substituído por outro profissional capacitado em determinados pontos da cadeia ou dependendo do medicamento que será trabalhado. Acredita-se que tal ação depende muito mais do tipo de medicamento que será manipulado. Em determinados casos, como da cadeia fria, produtos biológicos e outros fármacos de alto controle (substâncias precursoras de entorpecentes e/ou psicotrópicas), a presença do profissional farmacêutico é insubstituível devido ao alto risco à saúde. Ainda assim, nos demais casos, a substituição do profissional farmacêutico deve ser evitada.

Com base nessa análise, podem-se definir algumas recomendações para estudos futuros e elaboração de novas propostas para o gerenciamento da cadeia logística de medicamentos: estudo quantitativo do impacto que o profissional farmacêutico desempenha na cadeia logística de medicamentos; revisão da revogação da Lei 15.626/2014 e outras diretrizes da Corregedoria Regional de Farmácia do Estado de São Paulo; integração da cadeia de suprimentos da indústria farmacêutica, com foco na relação custos de operação e integridade do medicamento; dentre outros.

\section{REFERÊNCIAS}

[1] ANDREOLI, Gustavo Luís Meffe; DIAS, Cleidson Nogueira. Planejamento e Gestão Logística de Medicamentos em uma Central de Abastecimento Farmacêutico Hospitalar. Revista de Administração Hospitalar e Inovação em Saúde. Vol. 12, n.4, 2015. Disponível em: <http://revistas.face.ufmg.br/index.php/rahis/article/view/2570> Acesso em: 11 jul. 2018.

[2] ANVISA. Agência Nacional de Vigilância Sanitária. Anuário Estatístico do Mercado Farmacetico 2016. Brasília, 2017. Disponível

em: <http://portal.anvisa.gov.br/documents/374947/3413536/Anu\%C3\%A1rio+Estat\%C3\%ADstico+do+Mercado+Far mac\%C3\%AAutico+-+2016/485ddf50-a37f-469f-89e5-29643c5c9df5> Acesso em: 11 jul. 2018.

[3] CARDoso, Gabriele Carlos; MILÃO, Denise. Logística Farmacêutica e o Transporte de Medicamentos Termolábeis. Revista da Graduação. Vol. 9, n.1, 2016. Disponível em: <http://revistaseletronicas.pucrs.br/ojs/index.php/graduacao/article/view/23952> Acesso em: 11 jul. 2018.

[4] CARVAlHo JUNIOR, Saulo de; MACEDO, Sonja Helena Madeira. Logística Farmacêutica Geral: da teoria à prática. 1a ed. São Paulo: Contento Comunicação LTDA., 2012.

[5] CASTRO, E. A.; COSTA, M. A.; PIRES, I. P.; SILVA, A. J.; ZILIO, J. M. A.. Atividades Logísticas em uma Empresa do Setor Farmacêutico: estudo de caso. A Revista Eletrônica da Faculdade de Ciências Exatas e da Terra Produção/construção e tecnologia. Vol. 3, n. 5, p. 48-59, 2014. Disponível em: <https://www.unigran.br/ciencias_exatas/conteudo/ed5/artigos/05.pdf> Acesso em: 13 jul. 2018.

[6] CGEE. Centro de Gestão e Estudos Estratégicos. Competências para inovar na indústria farmacêutica brasileira. $\quad$ Brasília, $2017 . \quad$ Disponível em: <https://www.cgee.org.br/documents/10182/734063/Ind_farmaceutica.pdf> Acesso em: 11 jul. 2018.

[7] CNQ. Confederação Nacional do Ramo Químico. Panorama Indústria Farmacêutica. 2015. Disponível em: <http://cnq.org.br/system/uploads/publication/9aee2f902857d5d6467b924555af8983/file/panorama-industriafarmaceutica-b.pdf> Acesso em: 13/07/2018.

[8] CORRÊA, Gabriel Beggiato; AGUIAR, Marta M. Gontijo. Distribuição e Transporte de Medicamentos. Pós em Revista. Ed. 6, p. 210-216, 2012. Disponível em: <http://blog.newtonpaiva.br/pos/e6-farm26-distribuicao-etransporte-de-medicamentos/> Acesso em: 13 jul. 2018.

[9] COSTA, Gabriela Cé da. A APLICAÇÃO DA GESTÃO DA QUALIDADE NA LOGÍSTICA DE TRANSPORTE AÉREO DE CARGAS: Um estudo de caso da agência de cargas para o transporte aéreo de medicamentos. UNIVERSIDADE FEDERAL DO PARANÁ. CENTRO DE PESQUISA E PÓS-GRADUAÇÃO EM ADMINISTRAÇÃO. Curitiba, 2016. Disponível em: $\quad$ <https://acervodigital.ufpr.br/bitstream/handle/1884/52428/R\%20-\%20E\%20\%20GABRIELA\%20CE\%20DA\%20COSTA.pdf?sequence=1\&isAllowed=y> Acesso em: 11 jul. 2018.

[10] GOMES, Renata; PIMENTEL, Vitor; LOUSADA, Márcia; PIERONI, João Paulo. O Novo Cenário de Concorrência na Indústria Farmacêutica Brasileira. BNDES Setorial. 39, p.97-134, 2014 . Disponível em: <https://www.bndes.gov.br/SiteBNDES/export/sites/default/bndes_pt/Galerias/Arquivos/conhecimento/bnset/set 3903.pdf> Acesso em: 13/07/2018.

[11] MARADEI JÚNIOR, Fernando. Análise da Cadeia de Suprimentos do Setor Farmacêutico Brasileiro Quanto ao Nível de Colaboração Entre Laboratórios e Operadores Logísticos. FGV AESP. Disponível em: <http://bibliotecadigital.fgv.br/dspace/handle/10438/5526> Acesso em: 13 jul. 2018. 
[12] MAZZALI, Marcelo Gorri; MAKIY, Aleda Kanashiro; CESAR, Francisco Ignacio Giocondo. Cadeia Logística de Fármacos: uma análise do perfil técnico gestor. XXXVI Encontro Nacional de Engenharia de Produção. Pernambuco, 2016. Disponível em: <http://www.abepro.org.br/biblioteca/TN_STO_226_319_29679.pdf> Acesso em: 11 jul. 2018.

[13] Mendes, Felipe Nogueira. Kaizen Aplicado a Logística Farmacêutica. Coimbra: FEUC, 2015. Disponível em: <https://estudogeral.sib.uc.pt/handle/10316/30206> Acesso em: 13/07/2018.

[14] ROCHA, Tiago Galdino; GALENDE, Sharize Betoni. A Importância do Controle de Qualidade na Indústria Farmacêutica. Revista UNINGÁ Review. Vol. 20, n. 2, p. 97-103, 2014. Disponível em: <http://revista.uninga.br/index.php/uningareviews/article/view/1593> Acesso em: 13 jul. 2018.

[15] SAMPAIO, Mauro; CSILLAG, João Mario. Integração da Cadeia de Suprimentos da Industria Farmacêutica. Revista de Administração e Inovação. Vol. 7, n. 1, p.109-130, 2010. Disponível em: <http://www.revistas.usp.br/rai/article/view/79161> Acesso em: 13 jul. 2018.

[16] USAID. Projecto Deliver. Manual de logística: Um Guião Prático para a Gestão da Cadeia de abastecimento de Produtos Farmacêuticos. Arlington, $2012 . \quad$ Disponível em: <http://apps.who.int/medicinedocs/documents/s20211pt/s20211pt.pdf> Acesso em: 11 jul. 2018. 


\section{Capítulo 14}

\section{Implantação de Internet of Things em indústria de embalagens}

\section{Mari Tomita Katayama}

João Carlos Martins Coelho

Henrique Jun Muramatsu Seguchi

Resumo: 0 presente trabalho foi desenvolvido pelo Núcleo de Apoio Tecnológico à Micro e Pequena Empresa - NT-MPE do Instituto de Pesquisas Tecnológicas - IPT com foco no processo de implantação de tecnologia IoT em uma pequena empresa fabricante de embalagens, por meio de processo de corte e solda, visando aumento da sua produtividade e competitividade. Inicialmente, foram aplicados os conceitos de Gestão Avançada mediante trabalho voltado ao aprimoramento da gestão do processo produtivo visando resolver problemas clássicos de gestão, tais como a redução do lead time, e, simultaneamente, buscar o aprimoramento do processo produtivo por meio da aplicação de conhecimentos tecnológicos a esse processo. Essa ação inicial resultou na melhoria das condições operacionais da empresa a ponto de tornar viável a implantação de tecnologia IoT. A implantação dessa tecnologia se deu por meio da instalação de sensores nas máquinas para coletar informações digitais em tempo real, e por meio de uso de cartões RFID para que os operadores gerassem informações sobre o processo produtivo tais como motivos de paradas de máquina. Os dados digitais assim produzidos são transferidos a placa eletrônica responsável por promover a criptografia e encaminhar esses dados para plataforma em nuvem. Os dados assim armazenados podem ser baixados, decodificados, permitindo a emissão de relatórios gerenciais ou podem ser observados em tempo real por meio de recebimentos das informações via telefones celulares. Os resultados obtidos até o presente momento são: redução do lead time, melhor avaliação da capacidade de produção da empresa, aumento da qualidade dos produtos devido a melhorias no processo produtivo, e aumento da produtividade causado por vários fatores, dentre eles a mudança de postura dos colaboradores da empresa.

Palavras chave: IoT, gestão avançada, gestão da produção, indústria 4.0. 


\section{INTRODUÇÃO}

A indústria 4.0. tem chamado a atenção de todo polo industrial, isso porque em mercados cada vez mais competitivos, essa tecnologia está direcionada ao aumento de produtividade e a redução de custos. Segundo o relatório da Confederação Nacional da Indústria (2016, p.17), estima-se que, até 2025, as tecnologias da indústria 4.0. poderão reduzir custos de manutenção em até $40 \%$, reduzir o consumo de energia em até $20 \%$, aumentar a eficiência do trabalho em até $25 \%$, podendo impactar no PIB brasileiro em cerca de US\$39 bilhões até 2030. Portanto, essa tecnologia tem a tendência de substituir gradualmente os modelos convencionais de produção.

No Brasil, menos de $2 \%$ das empresas aplicam os conceitos da indústria 4.0., enquanto que essa tecnologia é realidade em países como Alemanha, Coreia do Sul, Estados Unidos, entre outros (ABDI apud Fiesp, 2018). Entende-se que este baixo percentual de indústrias que aplicam os conceitos da indústria 4.0. está fortemente ligado ao fato de que as micro e pequenas empresas (MPEs) representam 99\% dos estabelecimentos no Brasil (Sebrae, 2017), e possuem menor poder de investimento, e, ainda, na maioria das vezes os empresários tem a cultura de que a implantação da tecnologia da indústria 4.0., unindo os recursos físicos e virtuais com a instalação de robôs, sensores, Internet of Things (IoT), cloud computing requer altos investimentos, o que, não necessariamente, é a realidade.

Pensando neste cenário, o Instituto de Pesquisas Tecnológicas do Estado de São Paulo - IPT, por meio de seu Núcleo de Atendimento Tecnológico à Micro e Pequena Empresa - NT-MPE, desenvolveu metodologia de trabalho, denominada de extensão tecnológica rumo à manufatura avançada, visando à mudança do patamar tecnológico das empresas, especialmente das MPEs, aproximando-as efetivamente dos conceitos que caracterizam a manufatura avançada, por meio da implantação de tecnologias digitais, envolvendo, principalmente, IoT, computação em nuvem, etc.

Com a finalidade de aplicar esse conceito metodológico, está sendo conduzido um projeto piloto, encomendado pelo Ministério da Ciência, Tecnologia, Inovação e Comunicação - MCTIC, com financiamento do Conselho Nacional de Desenvolvimento Científico e Tecnológico - CNPq, com aplicação em 3 empresas do setor de transformados plásticos.

\section{SOBRE O IPT E SEU NÚCLEO NT-MPE}

O IPT é uma instituição vinculada à Secretaria de Desenvolvimento Econômico do Estado de São Paulo, e há 119 anos colabora para o processo de desenvolvimento econômico do País. O Instituto possui diversos laboratórios atuando nas seguintes grandes áreas - inovação, pesquisa, desenvolvimento e extensão tecnológica, serviços tecnológicos, metrologia, informação e educação em tecnologia.

O NT-MPE é uma unidade do IPT voltada para a resolução de problemas tecnológicos, principalmente das micro, pequenas e médias empresas - MPMEs, por meio de ações de extensão tecnológica e de desenvolvimento tecnológico, no sentido de torná-las cada vez mais competitivas e fortalecê-las para conquistar novos mercados, inclusive os internacionais, integrando tecnologia, inovação, design e cumprimento de requisitos normativos. Para as micro, pequenas e médias empresas paulistas, os atendimentos de extensão tecnológica realizados pelo NT-MPE dispõem de recursos financeiros não reembolsáveis, cabendo às empresas uma pequena contrapartida. As atividades de extensão tecnológica, classificadas em cinco modalidades de atendimentos, são executadas no âmbito da Rede Estadual de Extensão Tecnológica do Sibratec, do MCTIC/Finep, e pelo Programa de Apoio Tecnológico às MPMEs, do Governo do Estado de S. Paulo.

A saber, as seguintes cinco modalidades de atendimento:

- Gestão da produção - GESPRO. Atendimento para melhoria da gestão do processo produtivo;

- $\quad$ Projeto Unidades Móveis - PRUMO. Atendimento com a utilização de laboratório móvel para realização de ensaios visando melhoria de processo e produto;

- Q Qualificação de produtos para o mercado interno - QUALIMINT. Qualificação técnica de produtos para o mercado nacional;

- Programa de apoio tecnológico à exportação - PROGEX. Qualificação técnica de produtos para o mercado internacional; e

- $\quad$ Produção mais limpa - PROLIMP. Atendimento para melhoria de processo visando uma produção mais limpa. 


\section{METODOLOGIA}

A metodologia desenvolvida visando à implantação das ferramentas que caracterizam a indústria 4.0., parte da aplicação de duas ações independentes, porém complementares e fundamentais para a obtenção da melhor eficiência em termos de ganho de produtividade. A primeira é voltada à gestão da produção e a segunda voltada à aplicação de tecnologia ao processo produtivo. Conforme Katayama, Coelho e Seguchi (2018), essa combinação de ações é denominada Gestão Avançada.

A primeira ação consiste na aplicação de ferramentas tradicionais e dos conceitos associados à gestão da produção, que incluem, por exemplo, as ferramentas que caracterizam a lean manufacturing. A aplicação dessas ferramentas e conceitos deve ser objetiva e voltada à solução de problemas usuais de gestão. A segunda ação consiste na aplicação de conhecimentos tecnológicos no aprimoramento do processo produtivo. Note-se que a melhora do processo de gestão conduz, naturalmente, ao aumento de produtividade e de competitividade das empresas devido, inclusive, à redução de custos decorrente dessa ação, similarmente, a aplicação de conhecimentos tecnológicos ao processo também conduz ao aumento de produtividade, de competitividade e à redução de custos. Entretanto, a aplicação conjunta dessas ações potencializam as vantagens obtidas devido à sinergia, complementariedade e interdependência dessas ações, resultando em benefícios superiores aos que seriam obtidos pela simples adição dos resultados da aplicação de cada uma delas.

A Gestão Avançada se caracteriza, também, por elevar o nível de organização do processo produtivo da empresa e ao aprofundamento do conhecimento do processo produtivo, por parte dos colaboradores da empresa. Esse fato cria os fundamentos necessários para o início da aplicação dos conceitos da Indústria 4.0 e, em determinados casos, já permite a implantação inicial de, por exemplo, IoT industrial e computação em nuvem.

\subsection{GESTÃO DA PRODUÇÃO}

A primeira ação é desenvolvida com o objetivo de aprimorar a gestão do processo produtivo como um todo, buscando visualizar e corrigir falhas e inconsistências e gerar o aculturamento do seu corpo produtivo com foco no aumento de competitividade e produtividade, baseado na modalidade de extensão tecnológica, conforme Katayama et al. (2017).

Durante o desenvolvimento dessa ação, o processo produtivo deve ser mapeado, devem ser levantadas as capacidades produtivas nominais das máquinas, ser identificados todos os insumos produtivos, a qualificação do corpo operacional da empresa, identificados os indicadores de desempenho já existentes e quais seriam outros indicadores que poderiam ser avaliados no caso de se dispor das informações adicionais ou de ser possível obtê-las. Para tal, é prevista a identificação dos dados coletados para a condução do processo de gestão, como são tratados, se são confiáveis, se são armazenados de forma digital ou não. Complementarmente, devem ser identificados quais são os dados adicionais que deveriam ser coletados para o adequado aprimoramento do processo de gestão e cálculo dos indicadores de produção.

Note-se que um resultado fundamental dessa ação consiste no aprofundamento do conhecimento do processo produtivo, das suas variáveis de controle e no processo inicial de aculturamento tecnológico dos colaboradores da empresa.

Complementarmente, devem ser envidados esforços no sentido de compreender o estágio de desenvolvimento da gestão de pessoas e quais devem ser as atividades que devem ser desenvolvidas no sentido de preparar os colaboradores para uma nova visão da empresa na qual a produtividade, redução de custos e a competitividade devem ser os carros-chefes das mudanças a serem implantadas. A partir daí, preparar a equipe de colaboradores para o enfrentamento das mudanças necessárias.

\subsection{APLICAÇÃO DE TECNOLOGIA}

A tecnologia desenvolvida foi aplicada em duas frentes, por meio da ação sobre o processo produtivo e na aplicação dos conceitos de IoT.

\subsubsection{AÇÃO SOBRE O PROCESSO PRODUTIVO}

Ao longo da primeira ação, é prevista a aplicação simultânea de aprimoramentos tecnológicos ao processo produtivo de forma a, continuamente, se buscar melhorar a qualidade dos produtos, resolver problemas 
técnicos relativos à produção e propor soluções para problemas tecnológicos eventualmente identificados que, quando eliminados, levem ao aumento de produtividade e/ou redução de custos. Como exemplos desse tipo de proposição de aprimoramento, pode-se relatar: alteração de formulações de matériasprimas, ajuste de ciclos de produção para melhor aproveitamento dos equipamentos disponíveis, automação de processo, propor alterações em moldes de injeção, melhoria na regulagem das condições operacionais dos equipamentos, e outros.

\subsubsection{APLICAÇÃO DOS CONCEITOS DE INTERNET OF THINGS}

As atividades anteriormente descritas têm como fundamento buscar a estabilidade do processo produtivo, bem como a definição das informações realmente importantes e necessárias ao pleno aprimoramento do processo de gestão pelo uso de informações relevantes e confiáveis.

O caminho proposto para a obtenção, registro, armazenamento, tratamento e análise dos dados de forma confiável e, na medida do possível, isenta de erros humanos, consiste na utilização de conceitos de Internet of Things.

Assim, para a utilização desse nível de ação tecnológica, entende-se que, inicialmente, devem ser cuidadosamente definidas quais são as informações a serem coletadas nas máquinas e quais são as informações a serem fornecidas pelos colaboradores da empresa tendo em vista as necessidades estabelecidas pelo modelo de gestão a ser implantado. Complementarmente, deve ser estabelecido como essas informações devem ser armazenadas, tratadas e relatadas para os gestores. A partir dessas definições preliminares, é previsto:

- $\quad$ instalação, na medida do necessário, de sensores nas máquinas para a coleta das informações necessárias relativas ao seu processo operacional;

- $\quad$ instalação, em cada máquina, de leitor de RFID (Radio-Frequency IDentification) por meio do qual os colaboradores da empresa fornecerão informações sobre o processo produtivo como, por exemplo, qual é o produto em fabricação, qual é a ordem de serviço correspondente, qual é ciclo de produção, códigos de parada, etc.;

- disponibilização de cartões RFID adequadamente gravados com informações a serem fornecidos ao sistema pelos operadores das máquinas;

- $\quad$ instalação em cada máquina de sistema eletrônico destinado ao recebimento das informações digitais proporcionadas pelos sensores e do leitor de cartões RFID para o posterior encaminhamento, usando a internet, para plataforma em nuvem;

- disponibilização de plataforma em nuvem, para armazenamento de dados coletados ao longo do tempo por meio de sensores e de informações fornecidas por operadores com eventual tratamento parcial desses dados;

- desenvolvimento e disponibilização de software para, a partir de dados disponíveis em nuvem, realizar o tratamento com vistas à apresentação de resultados consolidados em relatórios gerenciais customizados para a empresa em questão; e

- criação de Dashboard personalizado com informações importantes de cada empresa, com diferentes níveis de acesso permitindo o acompanhamento da produção em tempo real.

Na Figura 1 é ilustrado o fluxo operacional. 
Figura 1 - Fluxo operacional

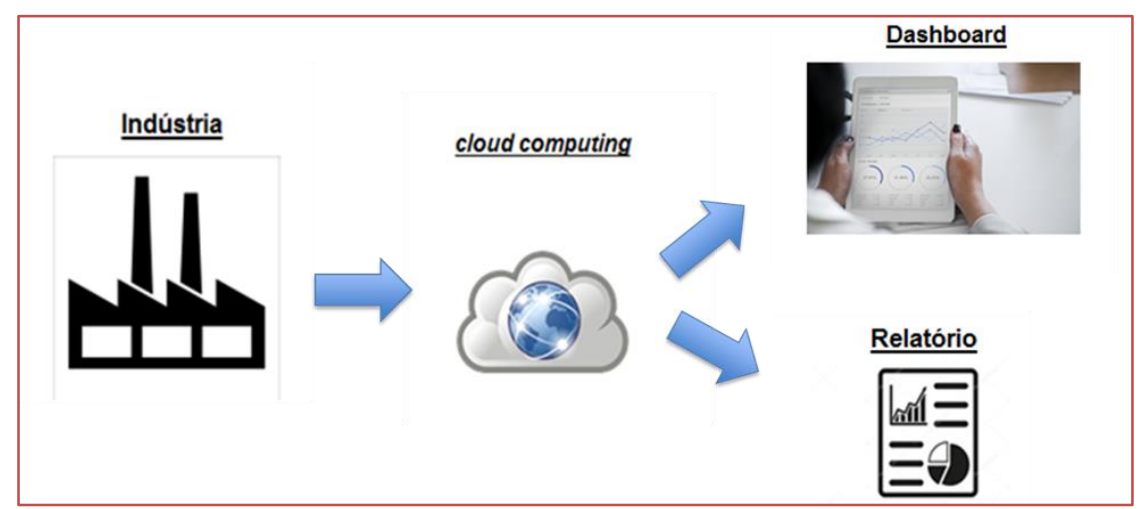

Fonte: Elaborado pelos autores

\section{APLICAÇÃO DA METODOLOGIA}

Para aplicar a metodologia, foi selecionada uma empresa fabricante de embalagens flexíveis.

\subsection{A EMPRESA}

A empresa está localizada na região de Campinas, São Paulo, fabrica produtos em PE (polietileno) de baixa e alta densidade e PP (polipropileno), de porte familiar, fundada há cerca de vinte anos. Essa empresa produz embalagens, por meio de processo de corte e solda, a partir de bobinas previamente impressas.

A fábrica opera em um turno, possui seis máquinas de corte e solda, sendo operadas por um operador para cada máquina, dois encarregados de máquinas que realizam o setup e demais ajustes relacionados à produção, uma gerente da produção e uma engenheira de produção recém contratada.

De maneira geral, os fabricantes de embalagens preferem operar fornecendo grandes lotes, o que se justifica pelo fato da menor necessidade da realização de setup, que envolve atividades como troca dos cilindros, das chapas flexográficas, de cores, preparação de tintas, limpeza da máquina e demais ajustes para início da fabricação de outro produto, acarretando em maiores tempos improdutivos. Considerando esse cenário, a empresa sob análise, optou, em seu planejamento estratégico, por atuar no nicho de mercado constituído pelos pequenos e médios volumes, no qual a concorrência não é tão acirrada como no caso de operação com grandes volumes.

\subsection{AVALIAÇÃO INICIAL DO PROCESSO PRODUTIVO}

A avaliação inicial do processo produtivo da empresa indicou a existência dos seguintes problemas principais:

- atrasos na entrega dos produtos;

- $\quad$ baixa produtividade;

- $\quad$ alto índice de refugos;

- $\quad$ alta rotatividade de funcionários;

- $\quad$ falta de informações para a tomada de decisões;

- $\quad$ Perda de tempo por paradas de máquinas, em especial pela troca de bobinas;

- Dificuldade na obtenção de dados da produção, como velocidade de corte e solda de cada máquina, tempo de produção, etc.; e

- Ociosidade na operação das máquinas por falta de material.

A partir dessa avaliação inicial, com apoio incondicional da diretoria da empresa, foram desenvolvidas atividades com foco em gestão de pessoas e gestão da produção. 


\subsection{GESTÃO DE PESSOAS}

Foi desenvolvido um trabalho complementar de gestão de pessoas baseado, inicialmente, em pesquisa de satisfação interna seguida de ações específicas, tais como:

- $\quad$ estabelecimento de canais de comunicação entre direção e colaboradores;

- $\quad$ desenvolvimento de novo organograma;

- $\quad$ elaboração de plano de carreira com a descrição de novos cargos e salários;

- $\quad$ sensibilização de toda organização a partir da difusão de planejamento estratégico;

- treinamento; e

- $\quad$ comemoração de dias festivos, e outros.

\subsection{GESTÃO DA PRODUÇÃO}

As atividades voltadas à gestão da produção envolveram:

- conhecimento dos processos internos administrativos envolvendo, por exemplo, compras e vendas;

- aplicação de ferramentas tradicionais de gestão tais como: implementação dos conceitos de 5S, mapeamento do processo produtivo tendo-se elaborado o fluxograma de produção incluindo seus processos; implantação de processo de cálculo de indicadores de produtividade, início de implantação de PCP e outras.

Essas atividades permitiram o levantamento e redução do lead time dos produtos, iniciar a implantação da manutenção preventiva, padronizar procedimentos e digitalizar informações da produção.

Complementarmente, com a finalidade de solucionar os problemas e aperfeiçoar a gestão da empresa, foram sugeridas ações de melhorias, sendo elas:

- Estabelecimento como meta o cálculo OEE (Overall Equipment Effectiveness) para avaliação de produtividade;

O indicador OEE não era utilizado pela empresa. Tendo em vista a meta estabelecida, a metodologia de cálculo foi repassada para a gerência da empresa.

Orientação para preparação da bobina com eixo reserva antes da finalização do pedido em produção;

Verificou-se na produção que os operadores esperavam finalizar o uso da bobina para iniciar os preparativos de troca, que consistiam em localizar a próxima bobina a ser utilizada, trazê-la para o local de troca e, a seguir, promover a substituição, acarretando em grande tempo de parada de máquina. Buscando reduzir este tempo improdutivo, a empresa foi orientada para a mudança de procedimento, dispondo-se da bobina substituta para troca antes do encerramento do uso da anterior.

- Orientações ao encarregado da produção sobre procedimentos de conserto/ajuste das máquinas;

e

- $\quad 0$ encarregado foi orientado para resolver um problema por vez, pois em alguns casos, os problemas eram resolvidos simultaneamente acarretando maior tempo de máquina parada. Assim a proposição deve ser a de atender outra ocorrência após o término da solução da primeira. Caso a segunda ocorrência seja de rápida solução (menor tempo para correção de problema) do que a primeira ocorrência, esta deve ser priorizada, devido à máquina poder voltar à produção mais rapidamente, evitando maiores tempos de máquinas paradas.

Orientação objetivando o aprimoramento do planejamento de produção visando redução do tempo ocioso de máquinas por falta de material.

Verificou-se a ocorrência de máquinas paradas, causando aumento de tempo ocioso, por conta de falta de matéria-prima a ser processada. Segundo informado, o tempo ocioso ocorria com mais frequência nas máquinas 3 e 5, pois possuíam menos dispositivos que as outras máquinas e, assim, processavam apenas bobinas lisas. 
Buscando minimizar esse problema, a empresa foi orientada a utilizar o conceito do PMP (Plano Mestre de Produção), prevendo-se ter disponível a quantidade de matérias-primas necessárias nos momentos adequados. Assim, torna-se possível trabalhar com níveis de estoques aceitáveis, evitando a ocorrência de ociosidade por falta de material.

\subsection{APLICAÇÃO DE SOLUÇõES TECNOLÓGICAS AO PROCESSO}

A aplicação de soluções tecnológicas deu-se por meio de duas ações. A primeira consistiu no aprimoramento do processo de manutenção das máquinas reduzindo, em consequência, o tempo improdutivo do conjunto de máquinas.

A segunda foi a solução de um problema causado pelo controle ineficiente de temperatura das barras de solda. Tal temperatura oscilava em uma faixa desconhecida, considerada muito extensa e que, por esse motivo, com frequência, não produzia a soldagem das embalagens adequadamente causando queda na qualidade. Assim foi definida, com anuência do empresário, de termopar para a avaliação correta da temperatura e do seu nível de variação. Confirmada a grande amplitude de variação da temperatura medida, foi proposta a instalação de um controlador PID em substituição ao tipo on-off existente. A solução proposta foi aceita tendo sido o problema solucionado.

\subsection{IMPLANTAÇÃO DE INTERNET OF THINGS}

Segundo Katayama, Coelho e Seguchi (2018), a entrada de uma empresa no mundo digital, se inicia com a aquisição de uma cultura digital mínima e pela busca do autoconhecimento de todo o seu processo. Esse autoconhecimento envolve o levantamento do fluxo produtivo, registro e armazenamento correto das informações e dados referentes ao processo produtivo, definição e medição de indicadores considerados importantes para a avaliação do desempenho da produção, além da realização adequada do planejamento, monitoramento e avaliação contínua do processo produtivo, de modo que os empresários passem a ter uma visão correta da realidade das suas empresas e tenham condições de tomar decisões baseadas em informações confiáveis e consistentes. Esse caminho inicial foi conduzido durante a realização de atividades de gestão da produção e de aplicação de tecnologia ao processo produtivo. E, por esse motivo, esse trabalho preliminar, juntamente com as melhorias implantadas, contribuíram com a evolução do patamar tecnológico da empresa e da sua estrutura de gestão, convertendo-a em uma unidade minimamente preparada e organizada, para receber as tecnologias de IoT.

\subsubsection{INDICADORES A SEREM AVALIADOS}

Além do indicador quantidade de matéria prima transformada por mês ( $\mathrm{kg} / \mathrm{mês})$, utilizado pela empresa, optou-se também pelo indicador constituído pela quantidade de matéria-prima processada por colaborador lotado na produção por mês. Complementarmente, foi sugerido e aceito estabelecer como meta o cálculo do OEE (Overall Equipment Effectiveness) para avaliação de produtividade.

O OEE é obtido por meio da multiplicação dos seguintes três 3 indicadores intermediários: o índice de disponibilidade de máquina, índice de desempenho de máquina e o índice de qualidade. Este indicador está alinhado com o escopo do projeto em busca do aumento de produtividade e/ou redução de custos, pois a abordagem do OEE busca conseguir a eficiência total do equipamento eliminando perdas, agrupadas em 3 classes, conforme proposto por Nakajima (1989 apud BERSSANETI, 2006):

a) perdas por tempos improdutivos ou de paradas;

b) perdas por operação a baixa velocidade; e

c) perdas por problemas de qualidade.

\subsubsection{ATIVIDADES DE IMPLANTAÇÃO DE INTERNET OF THINGS}

Nesta etapa foram realizadas as seguintes atividades:

instalação de sensores nas 6 máquinas de corte e solda para obter informações da produção, após a definição dos parâmetros julgados importantes pela empresa, a saber: 
- $\quad$ (um) sensor com a finalidade de verificar eventual queda de internet ou de parada de máquina;

- (dois) sensores para contabilizar o tempo de troca de bobina e a quantidade de embalagens produzidas; e

- (dois) sensores para medir a velocidade da esteira e a frequência de corte.

- Instalação de placa IoT no painel da máquina para captar as informações de produção, emitidos pelos sensores e leitor RFID, e enviar para a plataforma em nuvem;

- utilização de plataforma em nuvem para armazenamento e posterior acesso às informações;

- $\quad$ aquisição e instalação de leitor de cartão RFID. A função deste dispositivo é enviar as informações recebidas dos cartões para a placa IoT, para serem encaminhadas para armazenamento na plataforma em nuvem;

- utilização de cartão RFID com informações de paradas de máquinas. Os cartões RFID foram gravados (ver Quadro 1) conforme os códigos de parada das máquinas estabelecidos pela empresa, e ficam disponíveis e próximas de cada máquina. Utilizando esta tecnologia é possível registrar informações em tempo real, referentes às paradas de máquinas, seus motivos e os tempos de ociosidade;

Quadro 1 - Paradas dos cartões RFID

\begin{tabular}{|c|l|}
\hline Código de parada & \multicolumn{1}{|c|}{ Motivo de parada } \\
\hline 01 & Início/término de setup \\
\hline 02 & Início/término da produção \\
\hline 03 & Ajustes (por exemplo: de temperatura, fotocélula, bobina, barra, solda, fita, etc.) \\
\hline 04 & Trocas (por exemplo: reforço, fita, teflon, etc.) \\
\hline 05 & Manutenção corretiva \\
\hline 06 & Parada programada \\
\hline 07 & Outros \\
\hline
\end{tabular}

Fonte: elaborado pelos autores com dados da empresa (2019)

- implementação de software para tratamento de dados e elaboração de relatório gerencial, contendo informações como o total de embalagens produzidas no mês, tempo de paradas de máquinas e os respectivos motivos, máquina mais/menos produtiva, etc.; e

- $\quad$ definição e implantação do painel (dashboard) customizado para que o empresário ou pessoas da produção, conforme níveis de acesso permitido possam acompanhar em tempo real a produção, e de forma remota, através, por exemplo, de celular. As informações contidas no dashboard foram definidas pela empresa, podendo ser alterada conforme necessidade.

No dashboard é possível acompanhar em tempo real a quantidade de embalagens produzidas no período, o tempo de processamento da bobina atual e o código de parada de máquina (ver Figura 2). Lembrando que informações mais antigas ficam armazenadas disponíveis para acesso na plataforma em nuvem. 
Figura 2 - Dashboard com as informações definidas pela empresa

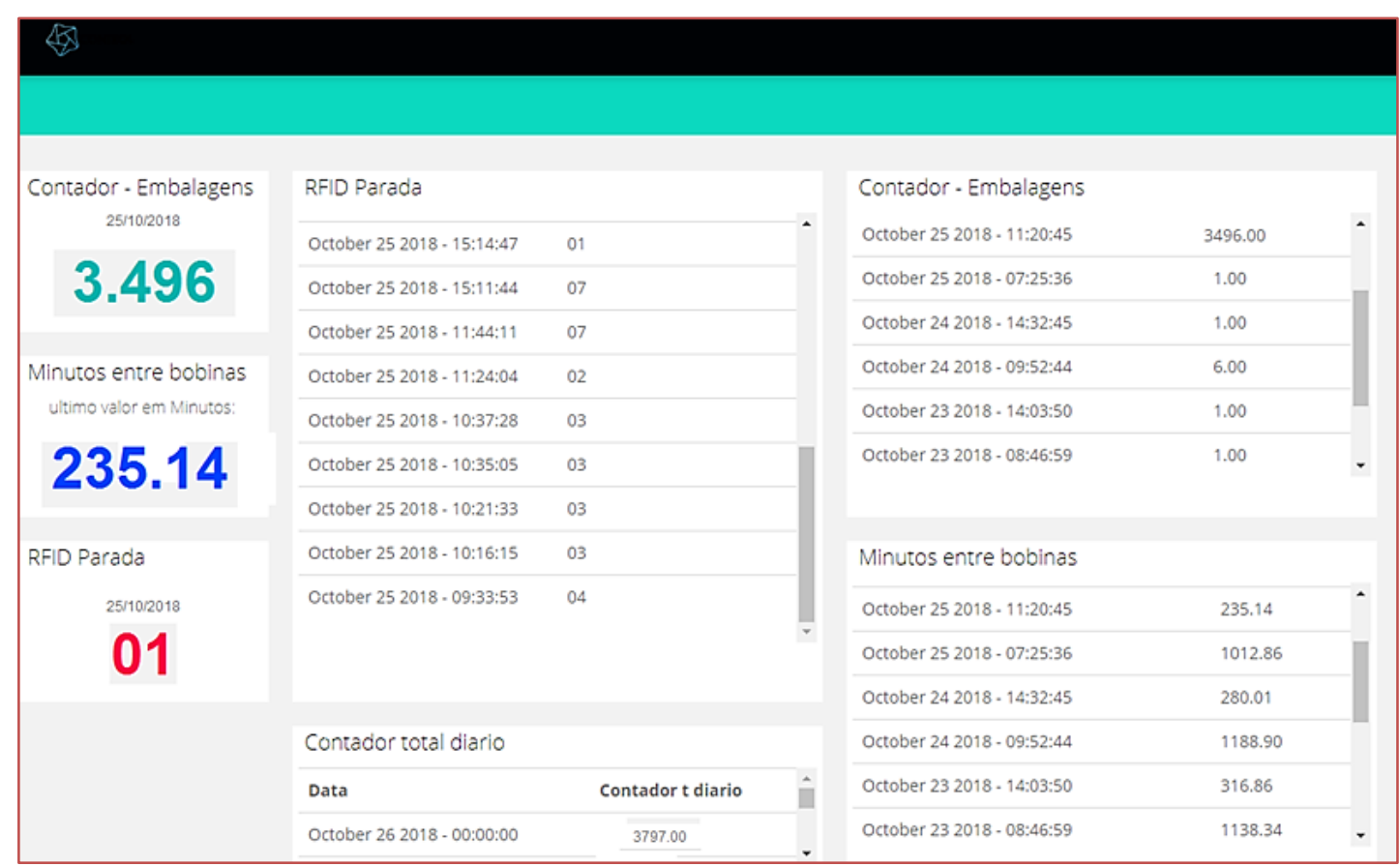

Fonte: Retirado do dashboard desenvolvido para a empresa

\subsection{POSTURA DO EMPRESÁRIO}

A postura do empresário em busca pela melhoria contínua e de novas tecnologias, resultou num melhor aproveitamento das ferramentas de extensão tecnológica, sendo possível implantar as sugestões de melhorias e realizar a aquisição de dispositivo para corrigir o problema de variação de temperatura das máquinas de corte e solda.

\section{RESULTADOS}

0 processo de implantação da tecnologia IoT foi recentemente encerrado, entretanto o projeto ainda se encontra em andamento. Tendo essa realidade em vista, verifica-se que ainda não foi criado um histórico que permita a avaliação de resultados que permitam a avaliação da evolução dos indicadores. Assim sendo, relatam-se, a seguir, os resultados já obtidos e os esperados.

\subsection{RESULTADOS OBTIDOS}

0 trabalho de gestão da produção contribuiu para coletividade ampliar o conhecimento da organização e do seu próprio processo produtivo, permitindo a identificação de falhas, inconsistências e impropriedades que levaram a:

- redução do lead time permitindo um atendimento mais preciso e de maior qualidade dos seus clientes;

- melhor avaliação da capacidade de produção da empresa permitindo operar o setor de vendas com mais segurança; produtivo; e

aumento da qualidade, ainda não quantificada, dos produtos devido a melhorias no processo - aumento da produtividade, ainda não quantificado, causado por vários fatores, dentre eles a mudança de postura dos colaboradores da empresa.

A implantação das tecnologias digitais proporcionou o aprimoramento da gestão do processo produtivo da empresa, coletando, em tempo real e com precisão, informações de máquinas, que anteriormente passavam despercebidas ou eram anotadas manualmente em fichas, passíveis de erros e havendo grande 
dificuldade no tratamento desses dados por não estarem digitalizados. Essa tecnologia esta auxiliando na rápida tomada de decisão dos seus gestores, por poderem acompanhar a produção em tempo real e com informações confiáveis.

\subsection{RESULTADOS ESPERADOS}

Espera-se que ao final do trabalho, seja de fato constatado que houve aumento considerável de produtividade, redução dos tempos improdutivos por paradas de máquinas e a redução do tempo ocioso causado pelo planejamento, anteriormente ineficiente, da produção.

Por fim, entende-se que a implantação desse sistema de gestão apoiado nos conceitos de Gestão Avançada e no uso de tecnologias digitais, demonstra a perfeita viabilidade de as pequenas empresas iniciarem seus planos e suas atividades com foco na implantação dos conceitos da Indústria 4.0 que resultam, já no início de preparação da empresa, em ganhos de produtividade, de competitividade e, em decorrência, na redução de custos. Note-se que esses ganhos são essenciais para a manutenção das pequenas empresas como unidades eficazes de geração de emprego e renda, além de, dependendo do setor, contribuir no adensamento e competitividade de sua cadeia produtiva.

\section{REFERÊNCIAS}

[1] BERSSANETI, Fernando Tobal. Gerenciamento da capacidade produtiva de um sistema de educação a distância: Coordenação das funções manutenção e gestão de contratos. 2006. Dissertação (Mestrado em Engenharia) Curso de Pós-graduação em Engenharia de Produção, Universidade de São Paulo, São Paulo, 2006.

[2] CONFEDERAÇÃO NACIONAL DA INDÚSTRIA (Brasil). Desafios para indústria 4.0 no Brasil. Brasília: CNI, 2016.

[3] FEDERAÇ̃̃O DAS INDÚSTRIAS DO ESTADO DE SÃO PAULO. Para garantir competitividade, empresas brasileiras se adaptam à indústria 4.0: Melhora na economia e diminuição de custos têm levado companhias a investir em processos de robotização e digitalização. São Paulo, Boletim técnico do departamento sindical 1357, p. 7-8, 2018.

[4] KATAYAMA, Mari Tomita; COElHO, João Carlos Martins; SEGUCHI, Henrique Jun Muramatsu. Gestão avançada como fundamento para a implantação de conceitos da indústria 4.0. In: SIMPÓSIO DE ENGENHARIA DE PRODUÇÃO, 2018, Catalão. Anais [...]. Catalão: Universidade Federal de Goiás, 2018, 7 p.

[5] KATAYAMA, Mari Tomita et al. Aumento da competitividade em pequenas empresas utilizando a ferramenta operacional GESPRO. Revista IPT: Tecnologia e Inovação, v. 1, n. 6, 2017.

[6] SERVIÇO BRASILEIRO DE APOIO ÀS MICRO E PEQUENAS EMPRESAS. Anuário de trabalho nos pequenos negócios. Brasília, ed. 8, 2017. 


\section{Capítulo 15}

\section{Análise comparativa da adaptabilidade da área fabril na filosofia da manufatura enxuta numa empresa aeronáutica}

\section{Newton Eizo Yamada}

Fernando Augusto Silva Marins

Luiz, Antonio Tozi

Resumo: A maturidade de um sistema de Manufatura Enxuta está associada principalmente pela aceitação e comprometimento dos princípios enxutos pela cultura organizacional. Para tanto o presente trabalho com metodologia estudo de caso, exploratório e survey apresenta uma pesquisa em uma empresa do ramo aeronáutico, com o objetivo de analisar comparativamente as duas fases, uma primeira, pré Manufatura Enxuta e uma outra 5 anos depois da implantação, verificando quais quesitos foram marcantes na alteração da cultura da empresa. Para isso foram distribuídos questionários de forma aleatória e randômica, para averiguar a aceitabilidade do Sistema de Produção Enxuta em 2012 e as mesmas questões colocadas novamente em 2017, o questionário estruturado na escala de Likert, tendo como foco do respondentes do nível operacional, em que o objetivo proposto foi obter as percepções referentes aos impactos decorrentes desta implantação. 0 resultado foi uma grata surpresa ao se verificar que a busca por um novo sistema de trabalho, num ambiente complexo foi muito bem aceito.

Palavras-chave: manufatura enxuta, cultura organizacional, recursos humanos 


\section{INTRODUÇÃO}

Nos meados dos anos 90, o mercado de aeronaves regionais cresceu muito rapidamente, fazendo com que empresas como Embraer e Bombardier tivessem um grande destaque no cenário mundial. Para situar o cenário de 2012, havia um crescente número de concorrentes no mercado da aviação regional, podendo citar em operação as aeronaves da brasileira Embraer, ERJ145, o Embraer 170/175/190/195, da canadense Bombardier, com seus CRJ700/900/1000, e novos entrantes, tais como a Irkut aeronave russa MS-21, a canadense Bombardier com o Serie C, a japonesa Mitsubishi MRJ, o chinês ACAC ARJ21, as aeronaves russas Antonov AN 148 e Sukhoi Superjet SSJ100. Então a empresa brasileira optou por um novo sistema de trabalho, que pudesse fazer jus a tanta concorrência, e foi escolhido a Manufatura Enxuta, mas isso significava alterar toda a cultura da empresa e pensando nisso foi elaborado questionário estruturado na escala de Likert com 16 perguntas em 2012 e repetida 5 anos mais tarde com o objetivo de confrontar os resultados e verificar o quanto as pessoas envolvidas no processo aderiram ou não ao novo estilo de trabalho.

\section{CONCEITO DE MANUFATURA ENXUTA}

O termo Manufatura Enxuta ou Lean Maufacturing surgiu com a publicação do livro A Máquina que Mudou o Mundo, por Womack e Jones (2004), no qual os autores relatam o resultado de uma pesquisa de benchmarking realizada pelo Massachusetts Institute of Technology (MIT) em empresas do setor automobilístico, os quais procuravam fazer cada vez mais com menos investimentos em seus sistemas produtivos. Este livro descreve as práticas e desempenhos aplicados nas empresas japonesas que conseguiam reduzir seus custos produtivos e obter um melhor desempenho. A organização tomada como referência foi a Toyota Motors Company, cujas práticas já eram conhecidas como Sistema Toyota de Produção (TPS) ou filosofia Just-in-Time. (MONDEN 1999).

Segundo Shah R. e Ward P. (2003), a manufatura enxuta é uma abordagem multi-dimensional que abrange uma grande variedade de práticas de gestão, incluindo just-in-time, sistemas de qualidade, equipes de trabalho, manufatura celular, gestão de fornecedores, etc, em um sistema integrado. 0 foco principal da manufatura enxuta é criar sinergia e um fluxo rápido e lógico de atividades, onde um sistema de alta qualidade possa produz produtos acabados no ritmo da demanda do cliente com poucos ou nenhum desperdício.

\subsection{MELHORIA CONTÍNUA - KAIZEN}

De acordo com Imai (1997, p.139),

"Kaizen mais do que somente melhorar algo, significa melhorar a vida pessoal, a vida doméstica, a vida social e a vida no trabalho. Quando aplicado ao local de trabalho, Kaizen significa sucessivas evoluções que envolvem todo o mundo, administradores e trabalhadores igualmente."

De acordo com Goldratt e Cox (2003) o mais importante na melhoria contínua, não é o índice, mas o momento, mesmo minimamente, algo pode ser melhorado a cada hora, a cada dia ou a cada mês. 0 importante é que isso ocorra, aprimorando ainda mais os processos e influenciando a diminuição de custos.

\subsection{ETAPAS PARA IMPLEMENTAÇÃO DO PENSAMENTO ENXUTO}

Para Seldin P, Rainho M e Caulliraux H. (2003) a década de 70, foi marcada pelas mudanças de organogramas, na criação ou modificação de cargos. Nos anos 80 os administradores perceberam que só a alteração nos cargos não trazia a eficácia pretendida, portanto com o objetivo de ganhar desempenho e muito também influenciado pelo sucesso da gestão japonesa, com as teorias de qualidade total, foi percebido que seria necessário mudar os valores comuns e as crenças dos grupos para que estes resultados surgissem. Foi então que as mudanças organizacionais passaram a ser vistas como processos de melhoria contínua.

Kaufman (2007) afirma que toda mudança mesmo pequena gera desconforto muito pelo seu desconhecimento, as mais fortes podem gerar insegurança, instabilidade emocional, autoestima, isto torna 
mais fácil compreender a razão pelo qual pessoas podem adquirir alguns estereótipos, tais como: indiferença; rejeição passiva; rejeição ativa; sabotagem; colaboração; entusiasmo.

Os dois principais diferenciais são a conscientização e a intensidade de resposta às mudanças.

A Figura 1 caracteriza o comportamento provável dos indivíduos quanto às mudanças em quatro grupos: indecisão, inércia, rejeição e adaptação, variando em conscientização e intensidade de resposta.

Figura 1 - Conscientização X Intensidade de Resposta. Fonte: Kaufman, 2007

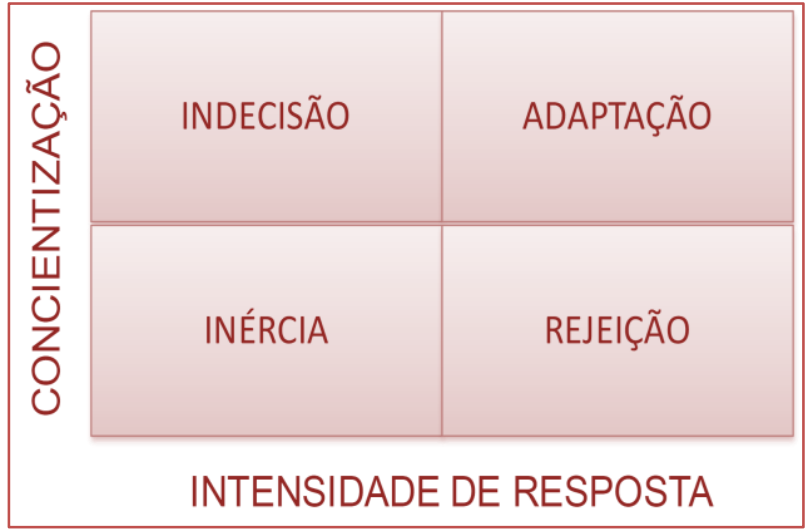

Importante frisar, conforme Shook e Rother (2005) descrevem na Figura 2, que uma análise da atual condição da empresa é primordial, visto que cada uma é diferente da outra, portanto, em estágios diferentes na compreensão do Sistema da Manufatura Enxuta é importante, também, um cronograma de trabalho e ações.

Ser enxuto significa que a empresa percorreu um caminho que jamais termina, sempre haverá espaço para a melhoria contínua, um componente necessário a qualquer sistema eficaz de gestão da qualidade essencial para se ter sucesso na economia global de hoje, altamente competitiva, de mudanças rápidas e focadas no cliente.

Figura 2 - Etapas para Implementar o Pensamento Enxuto. Fonte: Shook; Rother, 2005

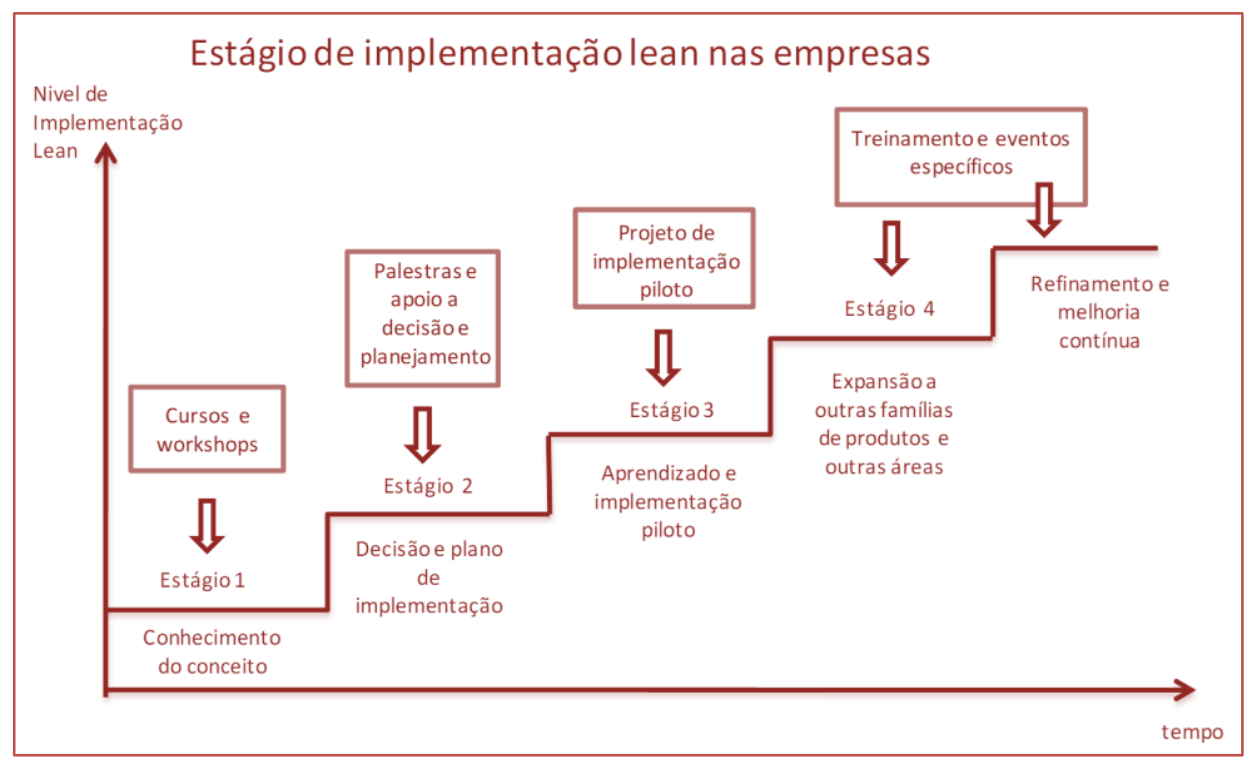




\subsection{MANUFATURA ENXUTA NA HIERARQUIA ORGANIZACIONAL}

A Manufatura Enxuta pode ser considerada uma estratégia corporativa, pois está diretamente ligada aos objetivos da empresa.

Segundo Ballou (2006), criar uma estratégia corporativa começa com uma definição clara dos objetivos da empresa, sendo necessário um entendimento geral de quais são as metas mais importantes como realização do lucro, retorno do investimento, participação no mercado ou crescimento.

Para Cantidio (2009), o sistema Manufatura Enxuta sozinho não é capaz de fazer a organização vencedora e somente pode-se chamar de estratégia, quando a mesma for bem planejada, bem absorvida e adaptada por toda a hierarquia organizacional envolvida.

Para a aplicabilidade da Mentalidade Enxuta são necessárias uma série de ações como, treinamento, que visa a melhorar a competência dos colaboradores atribuindo-lhes habilidades para decidir, flexibilidade e capacidade para sugerir melhorias, descentralizar responsabilidades, reduzir níveis hierárquicos, delegar e motivar os colaboradores a assumirem as responsabilidades pelas melhorias e o alcance das metas globais. (AHLSTROM, 1998).

Dessa forma Marion e Santos (2004) ilustram, na Figura 3, a importância do respeito às fases do comprometimento do funcionário ao novo programa ao longo do tempo, divididas em noção, aceitação e comprometimento, as exigências e cobranças, também, deverão acompanhar esta evolução.

Figura 3 - Evolução do entendimento de Colaboradores. Fonte: Marion, Santos, 2004

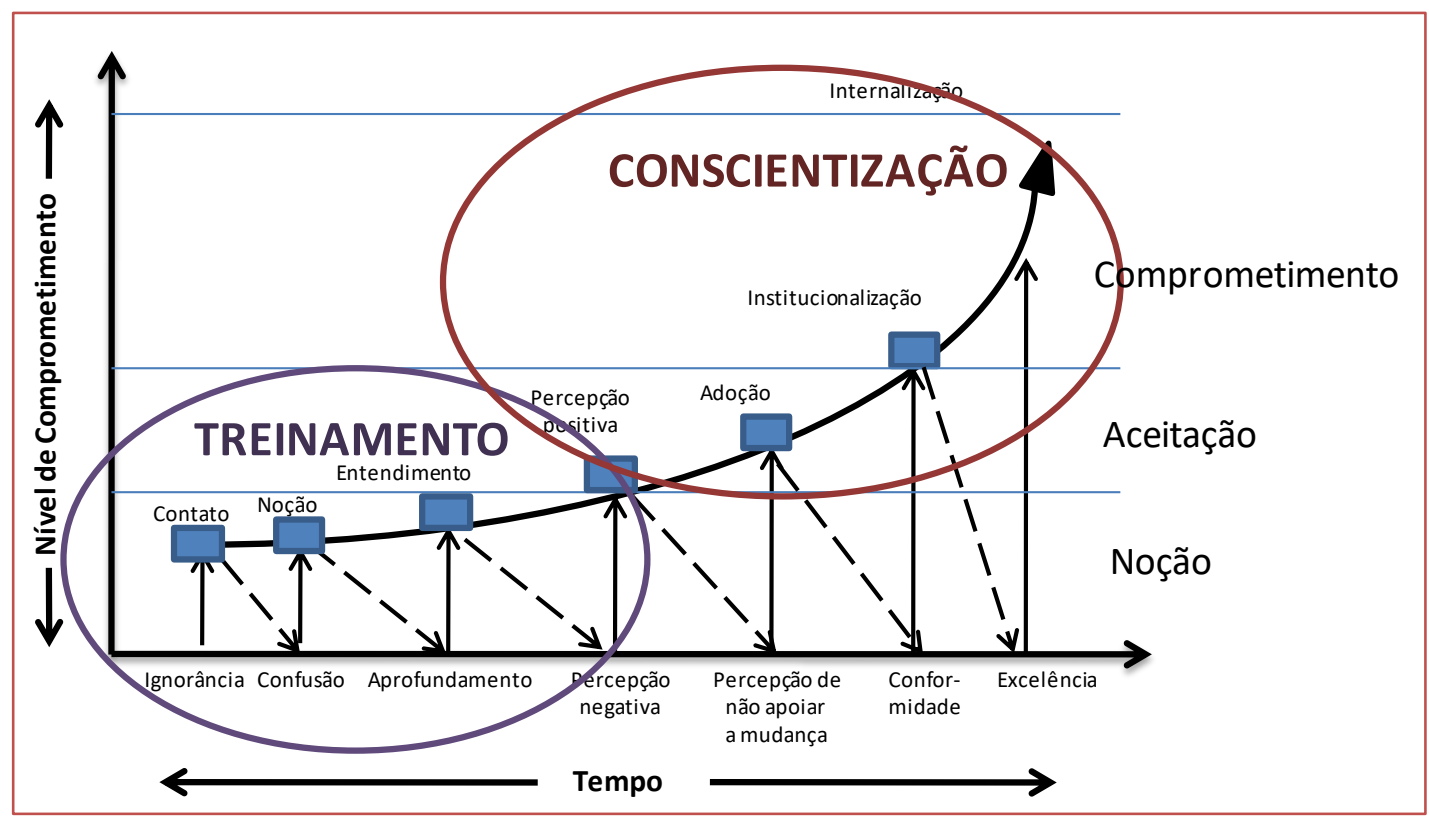

\section{FRAMEWORK DA PESQUISA}

Nesta seção será determinada a maneira como a pesquisa foi realizada, o primeiro passo foi elaborar um método de construção da fundamentação teórica da pesquisa, conforme Figura 4, que traçou o caminho a ser seguido.

A fundamentação teórica da pesquisa foi dividida em cinco etapas. 
Figura 4 - Construção teórica da pesquisa.

\begin{tabular}{|c|c|c|c|c|}
\hline $\begin{array}{c}\text { Processo de } \\
\text { Aplicabilidade } \\
\text { da } \\
\text { Manufatura } \\
\text { Enxuta }\end{array}$ & $\begin{array}{c}\text { Análise } \\
\text { Bibliométrica }\end{array}$ & $\begin{array}{l}\text { Características } \\
\text { relevantes da } \\
\text { Manufatura } \\
\text { Enxuta }\end{array}$ & $\begin{array}{l}\text { Revisão } \\
\text { Teórica }\end{array}$ & Questionário \\
\hline $\begin{array}{l}\text { Fontes de } \\
\text { incertezas }\end{array}$ & & $\begin{array}{c}\text { Aspectos relacionados } \\
\text { com as características } \\
\text { das incertezas }\end{array}$ & $\begin{array}{l}\text { Critérios para a } \\
\text { geração de } \\
\text { perguntas }\end{array}$ & $\begin{array}{c}\text { Método } \\
\text { utilizado na } \\
\text { coleta de dados }\end{array}$ \\
\hline
\end{tabular}

Fonte: Adaptado de Tozi, 2010

Buscou-se na primeira etapa identificar as principais fontes de incerteza presentes no processo de aplicabilidade da Manufatura Enxuta. Assim, verificou-se mediante uma análise bibliométrica, a revisão teórica específica com a finalidade de formular uma estrutura adequada ao tema abordado.

Procurou-se na terceira etapa, levantar as características relevantes da manufatura enxuta que pudessem determinar aspectos relacionados com as incertezas presentes no processo.

Uma vez definidos estes pontos formulou-se um questionário, que foi aplicado aos funcionários da empresa em questão.

\subsection{ANÁLISE BIBLIOMÉTRICA}

A análise bibliométrica, segundo Guedes e Borschiver (2005), consiste na aplicação quantitativa de métodos matemáticos e estatísticos tendo como base publicações e documentos da comunicação escrita. Podendo destacar-se, a identificação de uma tendência à uma certa linha de pesquisa, selecionar autores mais produtivos e significativos, medir o impacto dos diversos trabalhos.

Foi utilizado o software UCINET que realiza uma análise de dados de redes sociais, desenvolvido por Freeman, Everett e Borgatti (2002).

Com o auxílio do Microsoft Excel foram selecionados os 10 artigos mais citados pela análise bibliométrica, descartando as obras anteriores a 1996, como ilustra a Tabela 1.

Tabela 1 - Os 10 artigos mais citados.

\begin{tabular}{|c|l|l|c||}
\hline$n^{\circ}$ & \multicolumn{1}{|c|}{ OBRA } & \multicolumn{1}{|c|}{ AUTORES } & ANO \\
\hline 1 & A Maquina que mudou o mundo & Womack, J.; Jones, D. & 2004 \\
\hline 2 & $\begin{array}{l}\text { Leagility: Integração dos paradigmas de manuf atura enxuta e ágil } \\
\text { na cadeia de fornecimento }\end{array}$ & 1999 \\
\hline 3 & $\begin{array}{l}\text { Lean manufacturing: contexto, pacotes de prática e desempenho } \\
\text { Danny Berry }\end{array}$ & Rahna Shah, P eter T Ward & 2003 \\
\hline 4 & $\begin{array}{l}\text { Relações entre as práticas operacionais e de desempenho entre } \\
\text { os primeiros a adotar práticas verdes de abastecimento de } \\
\text { gerenciamento da cadeia de empresas industriais chinesas }\end{array}$ & Zh, QH, Sarkis, J & 2004 \\
\hline 5 & $\begin{array}{l}\text { Variedade de produtos e desempenho da manuf atura: Evidência } \\
\text { do Estudo de Plantas Automotive Assembléia Internacional }\end{array}$ & $\begin{array}{l}\text { MacDuffie, JP; Sethuraman, } \\
\text { K; Fisher, ML }\end{array}$ & 1996 \\
\hline 6 & $\begin{array}{l}\text { Lean e verde: A adoção de processos industriais } \\
\text { ambientalmente consciente }\end{array}$ & 1996 \\
\hline 7 & $\begin{array}{l}\text { Lean e verde? Uma análise empírica da relação entre produção } \\
\text { enxuta e desempenho ambiental }\end{array}$ & King, AA; Lenox, MJ & 2001 \\
\hline 8 & $\begin{array}{l}\text { Aprender a evoluir - Uma revisão de pensamento enxuto } \\
\text { contemporânea }\end{array}$ & Hines, P; Holwe, M; Rich, N & 2004 \\
\hline 9 & $\begin{array}{l}\text { Configuraçóes de fabricação estratégia ambiente de negócios, } \\
\text { estratégia estrutura }\end{array}$ & Ward, PT; Bickford, DJ; Leong, GK & 1996 \\
\hline 10 & \begin{tabular}{l} 
A empresa estendida - um contexto para a fabricacão \\
\hline \hline
\end{tabular} & 1998 \\
\hline
\end{tabular}




\subsection{CLASSIFICAÇÃO DAS DIMENSÕES}

A partir da análise bibliométrica passou-se a identificação dos conceitos mais pontuados no domínio bibliográfico apurado, gerando a Tabela 2 .

Tabela 2 - Seleção da Análise Bibliométrica.

\begin{tabular}{|l|c|c|c|c|c|c|c|c|c|c|}
\hline & 1 & 2 & 3 & 4 & 5 & 6 & 7 & 8 & 9 & 10 \\
\hline JT / produção contínua & $\mathrm{x}$ & $\mathrm{x}$ & $\mathrm{x}$ & & $\mathrm{x}$ & & & & & $\mathrm{x}$ \\
\hline Sistema puxado / kanban & $\mathrm{x}$ & $\mathrm{x}$ & $\mathrm{x}$ & & $\mathrm{x}$ & & & & & $\mathrm{x}$ \\
\hline Setup trocas rápidas & & $\mathrm{x}$ & & & & & & & & \\
\hline Redução do tamanho de lotes & $\mathrm{x}$ & & & & & & & & & \\
\hline Desempenho operacional & $\mathrm{x}$ & $\mathrm{x}$ & $\mathrm{x}$ & $\mathrm{x}$ & $\mathrm{x}$ & & $\mathrm{x}$ & $\mathrm{x}$ & $\mathrm{x}$ & $\mathrm{x}$ \\
\hline Equipes multi-disciplinares & $\mathrm{x}$ & $\mathrm{x}$ & $\mathrm{x}$ & & $\mathrm{x}$ & $\mathrm{x}$ & & $\mathrm{x}$ & $\mathrm{x}$ & $\mathrm{x}$ \\
\hline Produção celular & $\mathrm{x}$ & & & & & & & & & \\
\hline Gerenciamento da qualidade & $\mathrm{x}$ & & $\mathrm{x}$ & & $\mathrm{x}$ & $\mathrm{x}$ & & $\mathrm{x}$ & $\mathrm{x}$ & \\
\hline Layout & & & $\mathrm{x}$ & & & & & & & \\
\hline Melhoria continua & $\mathrm{x}$ & $\mathrm{x}$ & $\mathrm{x}$ & & $\mathrm{x}$ & $\mathrm{x}$ & & $\mathrm{x}$ & & $\mathrm{x}$ \\
\hline Manutenção preventiva & $\mathrm{x}$ & & $\mathrm{x}$ & & & & & & & \\
\hline Eliminação de Desperdícios & $\mathrm{x}$ & $\mathrm{x}$ & $\mathrm{x}$ & $\mathrm{x}$ & $\mathrm{x}$ & $\mathrm{x}$ & & $\mathrm{x}$ & $\mathrm{x}$ & $\mathrm{x}$ \\
\hline Equipes de trabalho auto-dirigidas & & $\mathrm{x}$ & $\mathrm{x}$ & & $\mathrm{x}$ & & & $\mathrm{x}$ & $\mathrm{x}$ & $\mathrm{x}$ \\
\hline Treinamento & $\mathrm{x}$ & $\mathrm{x}$ & $\mathrm{x}$ & $\mathrm{x}$ & $\mathrm{x}$ & & $\mathrm{x}$ & $\mathrm{x}$ & $\mathrm{x}$ & $\mathrm{x}$ \\
\hline Redução de Lead time & $\mathrm{x}$ & $\mathrm{x}$ & $\mathrm{x}$ & & $\mathrm{x}$ & & & & $\mathrm{x}$ & $\mathrm{x}$ \\
\hline Satisfação do cliente & $\mathrm{x}$ & $\mathrm{x}$ & & & $\mathrm{x}$ & $\mathrm{x}$ & & & $\mathrm{x}$ & $\mathrm{x}$ \\
\hline Cadeia de Suprimentos & & $\mathrm{x}$ & & $\mathrm{x}$ & & $\mathrm{x}$ & $\mathrm{x}$ & & & $\mathrm{x}$ \\
\hline Gestão Ambiental* & & & & $\mathrm{x}$ & & $\mathrm{x}$ & $\mathrm{x}$ & & & \\
\hline
\end{tabular}

Fonte: Autor (2018)

Assim foi possível caracterizar as quatro macro dimensões como sendo:

- Desempenho Operacional

- Relações Humanas

- Gerenciamento das Técnicas

- Treinamento

\subsection{DESEMPENHO OPERACIONAL}

Por mais que haja sofisticação e alta tecnologia empregada nos processos da empresa, sempre há necessidade de se saber, qual será o resultado do investimento, tanto monetário quanto esforços humanos. Leite (1997), afirma que a contabilidade é hoje um instrumento vital onde a sua essência deve ser conhecida por todos que se interessam pela produtividade das organizações.

\subsection{RELAÇÕES HUMANAS}

O homem é considerado a principal matéria prima de uma organização, no entanto ainda persiste a filosofia de investir pouco na formação, no aperfeiçoamento, na qualidade e em sua especialização, isso estimula comportamentos robotizados, estéreis e não criativos. Valorizar talentos é questão de sobrevivência corporativa em um ambiente em que a cada dia torna-se mais exigente. (ARAÚJO, 2010) 


\subsection{GERENCIAMENTO DAS TÉCNICAS}

Segundo Slack (2002) a Engenharia e Operações têm como função gerenciar e dar suporte, elencar as atividades e dar o sequenciamento lógico para as atividades de kaizen.

Para Martins e Laugeni (2010) a fábrica do futuro não será aquela que somente possuirá robôs e alta automação, mas fábricas limpas e organizadas com a aplicação do $5 \mathrm{~s}$, funcionários treinados e multifuncionais, com espírito de grupo e de compromisso mútuo.

\subsection{TREINAMENTO}

Para Abbad (1999) os modelos de treinamento podem ser divididos em três níveis de avaliação:

- Reação;

- Aprendizagem; e

- Impacto do Treinamento no Trabalho.

A reação é compreendida como o nível de satisfação dos participantes com a programação, o ambiente organizacional, da percepção do apoio gerencial ao treinamento, empenho demonstrado pelas chefias para viabilizar a sua participação em eventos instrucionais.

Aprendizagem refere-se ao grau de assimilação e retenção dos conteúdos ensinados no curso, medido pelos participantes em testes ou provas de conhecimentos aplicados pelo instrutor ao final do curso.

0 impacto do treinamento no trabalho compreende no que se refere à aplicação correta, no ambiente de trabalho, de conhecimentos, habilidades ou atitudes adquiridas em situações de treinamento.

Assim, a partir da associação de todo arcabouço teórico sensibilizado pelos resultados estruturados da pesquisa bibliométrica conduzida, foi possível, desenvolver um conjunto de perguntas capazes de endereçar as variáveis determinantes da implantação da manufatura enxuta.

\subsection{DIVULGAÇÃO DO QUESTIONÁRIO}

A pesquisa buscou apontar objetivos compatíveis com parte do conhecimento existente obedecendo a métodos científicos. 0 questionário foi composto por uma amostragem de 17 perguntas, 248 respondentes do nível operacional.

O meio utilizado para divulgação do questionário foi o Google Docs, que apresenta ferramentas com disponibilidade a todos os internautas através do site www.google.com.br.

O Google Docs é um programa gratuito e suas exigências são basicamente efetuar um cadastro de e-mail e conhecimento básico em inglês por parte do usuário.

\section{RESULTADOS E DISCUSSÕES}

As Tabelas 3 a 6 referem-se aos resultados percentuais das questões divididas de acordo com as quatro "dimensões" a saber:

- dimensão 1 - desempenho operacional

- dimensão 2 - relações humanas

- dimensão 3 - gerenciamento das técnicas

- dimensão 4 - treinamento 
Tabela 3 - Resultados Dimensão 1 - Desempenho Operacional.

\begin{tabular}{|c|c|c|c|c|c|c|}
\hline 1 & Em sua opin & to a ME foi realm & $\begin{array}{r}\text { nte necessário o } \\
\text { mesmos }\end{array}$ & $\begin{array}{l}\text { apenas um ajus } \\
\text { sultados? }\end{array}$ & no sistema ant & alcançaria os \\
\hline Escala & $\begin{array}{c}\text { Muito } \\
\text { Necessária }\end{array}$ & Necessária & $\begin{array}{c}\text { Pouco } \\
\text { Necessária }\end{array}$ & $\begin{array}{c}\text { Pouco } \\
\text { Desnecessári } \\
\text { a }\end{array}$ & Desnecessária & $\begin{array}{c}\text { Não } \\
\text { Respondera } \\
\text { m }\end{array}$ \\
\hline $\begin{array}{c}1^{\underline{a}} \\
\text { Pesquisa }\end{array}$ & $27 \%$ & $46 \%$ & $25 \%$ & $2 \%$ & $0 \%$ & $0 \%$ \\
\hline $\begin{array}{c}2^{\mathbf{a}} \\
\text { Pesquisa }\end{array}$ & $55 \%$ & $43 \%$ & $2 \%$ & $0 \%$ & $0 \%$ & $0 \%$ \\
\hline 2 & & liminação dos de & perdícios está se & do adotada por & odos com frequê & cia? \\
\hline Escala & Sempre & Geralmente & $\begin{array}{c}\text { Eventualment } \\
\mathrm{e}\end{array}$ & Raramente & Nunca & $\begin{array}{c}\text { Não } \\
\text { Respondera } \\
\mathrm{m}\end{array}$ \\
\hline $\begin{array}{c}1 \mathrm{a} \\
\frac{\mathrm{a}}{0}\end{array} \quad$ Pesquisa & $15 \%$ & $47 \%$ & $23 \%$ & $9 \%$ & $2 \%$ & $4 \%$ \\
\hline $\begin{array}{c}2^{\underline{a}} \\
\text { है }\end{array}$ & $20 \%$ & $59 \%$ & $20 \%$ & $0 \%$ & $0 \%$ & $1 \%$ \\
\hline$\stackrel{0}{0}$ & Você & ncorda que a pr & dutividade da em & resa aumentou & om a Manufatur & Enxuta? \\
\hline 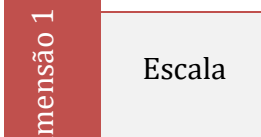 & $\begin{array}{c}\text { Concordo } \\
\text { Plenament } \\
\text { e }\end{array}$ & $\begin{array}{l}\text { Concordo } \\
\text { Levemente }\end{array}$ & Indiferente & $\begin{array}{l}\text { Discordo } \\
\text { Levemente }\end{array}$ & $\begin{array}{c}\text { Discordo } \\
\text { Completament } \\
\mathrm{e}\end{array}$ & $\begin{array}{c}\text { Não } \\
\text { Respondera } \\
\text { m }\end{array}$ \\
\hline $\begin{array}{c}1^{\underline{a}} \\
\text { Pesquisa }\end{array}$ & $35 \%$ & $47 \%$ & $14 \%$ & $2 \%$ & $0 \%$ & $2 \%$ \\
\hline $\begin{array}{c}2^{\underline{a}} \\
\text { Pesquisa }\end{array}$ & $75 \%$ & $25 \%$ & $0 \%$ & $0 \%$ & $0 \%$ & $0 \%$ \\
\hline 4 & & A Manuf & ura Enxuta trou & economia ao e & oaço físico? & \\
\hline Escala & Muito & $\begin{array}{c}\text { Razoavelment } \\
\text { e }\end{array}$ & Pouco & Pouquíssimo & Nenhuma & Não \\
\hline $\begin{array}{c}1^{\mathrm{a}} \\
\text { Pesquisa }\end{array}$ & $30 \%$ & $41 \%$ & $21 \%$ & $6 \%$ & $2 \%$ & $0 \%$ \\
\hline $\begin{array}{c}2^{\mathrm{a}} \\
\text { Pesquisa }\end{array}$ & $69 \%$ & $30 \%$ & $1 \%$ & $0 \%$ & $0 \%$ & $0 \%$ \\
\hline
\end{tabular}

Fonte: Autor (2018)

É inegável que a empresa conseguiu um excelente progresso, conforme ilustra a Tabela 3, pois pode-se notar que 3 das 4 perguntas apresentam uma evolução de mais de $100 \%$ na maior escala. Pela pesquisa a consciência de que o novo sistema de trabalho trouxe ganhos operacionais é evidente dentre os respondentes, mas ainda fica a desejar no quesito pró-atividade na procura da eliminação dos desperdícios. 
Tabela 4 - Resultados Dimensão 2 - Relações Humanas.

\begin{tabular}{|c|c|c|c|c|c|c|}
\hline 5 & \multicolumn{6}{|c|}{$\begin{array}{l}\text { Você concorda que a mentalidade da Manufatura Enxuta está bem consolidas em relação ao nível } \\
\text { de exigência cobrado pelos seus superiores? }\end{array}$} \\
\hline Escala & $\begin{array}{c}\text { Concordo } \\
\text { Plenamente }\end{array}$ & Concordo & $\begin{array}{c}\text { Concordo } \\
\text { Parcialmente }\end{array}$ & Indeciso & Discordo & $\begin{array}{c}\text { Não } \\
\text { Responderam }\end{array}$ \\
\hline $\begin{array}{c}1 \underline{\underline{a}} \\
\text { Pesquisa }\end{array}$ & $0 \%$ & $28 \%$ & $52 \%$ & $11 \%$ & $9 \%$ & $0 \%$ \\
\hline $\begin{array}{c}2^{\underline{a}} \\
\text { Pesquisa }\end{array}$ & $25 \%$ & $42 \%$ & $29 \%$ & $2 \%$ & $2 \%$ & $0 \%$ \\
\hline 6 & \multicolumn{6}{|c|}{$\begin{array}{c}\text { Caso você perceba desperdício em outras áreas, você tem a liberdade para discutir e propor } \\
\text { melhorias? }\end{array}$} \\
\hline Escala & Sempre & $\begin{array}{l}\text { Muito } \\
\text { Provável }\end{array}$ & $\begin{array}{l}\text { Provavelmente } \\
\quad \text { Sim }\end{array}$ & $\begin{array}{l}\text { Provavelmente } \\
\text { Não }\end{array}$ & Nunca & $\begin{array}{l}\text { Não } \\
\text { Responderam }\end{array}$ \\
\hline $\begin{array}{c}1 \underline{a} \\
\text { Pesquisa }\end{array}$ & $2 \%$ & $30 \%$ & $30 \%$ & $32 \%$ & $4 \%$ & $2 \%$ \\
\hline $\begin{array}{c}2^{\underline{a}} \\
\text { Pesquisa }\end{array}$ & $85 \%$ & $9 \%$ & $5 \%$ & $1 \%$ & $0 \%$ & $0 \%$ \\
\hline 7 & \multicolumn{6}{|c|}{ Com as práticas da Manufatura Enxuta as oportunidades de conhecer algum trabalho novo. } \\
\hline Escala & $\begin{array}{l}\text { Aumentou } \\
\text { Muito }\end{array}$ & Aumentou & $\begin{array}{l}\text { Não Aumentou } \\
\text { e nem } \\
\text { Diminuiu }\end{array}$ & Diminuiu & $\begin{array}{l}\text { Diminuiu } \\
\text { Muito }\end{array}$ & $\begin{array}{l}\text { Não } \\
\text { Responderam }\end{array}$ \\
\hline $\begin{array}{c}1 \underline{\underline{a}} \\
\text { Pesquisa }\end{array}$ & $4 \%$ & $15 \%$ & $45 \%$ & $28 \%$ & $8 \%$ & $0 \%$ \\
\hline $\begin{array}{c}2^{\underline{a}} \\
\text { Pesquisa }\end{array}$ & $15 \%$ & $38 \%$ & $42 \%$ & $3 \%$ & $2 \%$ & $0 \%$ \\
\hline 8 & \multicolumn{6}{|c|}{ A que você atribui às demissões ocorridas no ano de 2009/2016? } \\
\hline Escala & $\begin{array}{c}\text { Uma } \\
\text { estratégia } \\
\text { econômica }\end{array}$ & $\begin{array}{l}\text { A Crise } \\
\text { Mundial }\end{array}$ & $\begin{array}{l}\text { A Manufatura } \\
\text { Enxuta }\end{array}$ & $\begin{array}{c}\text { A } \\
\text { reestruturação } \\
\text { empresarial }\end{array}$ & Outros & $\begin{array}{c}\text { Não } \\
\text { Responderam }\end{array}$ \\
\hline $\begin{array}{c}1^{\underline{a}} \\
\text { Pesquisa }\end{array}$ & $21 \%$ & $51 \%$ & $6 \%$ & $16 \%$ & $6 \%$ & $0 \%$ \\
\hline $\begin{array}{c}2^{\mathrm{a}} \\
\text { Pesquisa }\end{array}$ & $36 \%$ & $9 \%$ & $0 \%$ & $53 \%$ & $2 \%$ & $0 \%$ \\
\hline
\end{tabular}

Fonte: Autor (2018)

A Segunda dimensão ilustrada pela Tabela 4 nos mostra que a técnica teve poucas resistências e foi bem aceita, a implementação pela empresa também foi favorecida, pois no ano anterior 2011 ela passou por uma crise no mercado, onde ela foi obrigada a naturalmente enxugar seu quadro funcional contribuindo com que os funcionários atribuíssem as demissões executadas à crise mundial. No quesito cobrança dos líderes a empresa deve averiguar se o treinamento foi suficiente e qual a atual aptidão dos funcionário ou seria uma questão natural da sensação de maior cobrança dos líderes.

Apesar do bom desempenho também na terceira dimensão, conforme mostra a Tabela 5, deve-se dar uma atenção em especial na questão 9, pois é imprescindível que os prazos acordados nos trabalhos Kaizen sejam ser colocados num mural e perseguidos a todo o custo, pois dela virá a credibilidade que os funcionários darão para a implantação de todo o sistema. Deve-se analisar o porquê os prazos não são cumpridos com frequência, podendo estar ai uma falha da empresa e portanto uma nova oportunidade de um novo Kaizen. 
Tópicos em Administração - Volume 23 cumpridas?

\begin{tabular}{|c|c|c|c|c|c|c|}
\hline Escala & Sempre & Geralmente & Eventualmente & Raramente & Nunca & $\begin{array}{c}\text { Não } \\
\text { Responderam }\end{array}$ \\
\hline $\begin{array}{c}1^{\mathrm{a}} \\
\text { Pesquisa }\end{array}$ & $0 \%$ & $26 \%$ & $49 \%$ & $23 \%$ & $2 \%$ & $0 \%$ \\
\hline $\begin{array}{c}2^{\underline{a}} \\
\text { Pesquisa }\end{array}$ & $12 \%$ & $42 \%$ & $33 \%$ & $12 \%$ & $1 \%$ & $0 \%$ \\
\hline 10 & \multicolumn{6}{|c|}{$\begin{array}{l}\text { Houve melhoria no seu dia a dia de trabalho com a implementação das práticas da Manufatura } \\
\text { Enxuta? }\end{array}$} \\
\hline Escala & $\begin{array}{l}\text { Muitas } \\
\text { Melhorias }\end{array}$ & $\begin{array}{l}\text { Algumas } \\
\text { Melhorias }\end{array}$ & $\begin{array}{l}\text { Poucas } \\
\text { Melhorias }\end{array}$ & $\begin{array}{c}\text { Não } \\
\text { percebo } \\
\text { Melhorias }\end{array}$ & $\begin{array}{l}\text { Nenhuma } \\
\text { Melhoria }\end{array}$ & $\begin{array}{c}\text { Não } \\
\text { Responderam }\end{array}$ \\
\hline $\begin{array}{c}1 \underline{a} \\
\text { Pesquisa }\end{array}$ & $17 \%$ & $47 \%$ & $21 \%$ & $9 \%$ & $2 \%$ & $4 \%$ \\
\hline $\begin{array}{c}2^{\underline{a}} \\
\text { Pesquisa }\end{array}$ & $79 \%$ & $17 \%$ & $4 \%$ & $0 \%$ & $0 \%$ & $0 \%$ \\
\hline 11 & \multicolumn{6}{|c|}{ O seu volume de trabalho com as práticas da Manufatura Enxuta } \\
\hline Escala & $\begin{array}{l}\text { Aumentou } \\
\text { Muito }\end{array}$ & Aumentou & $\begin{array}{c}\text { Não aumentou } \\
\text { nem diminuiu }\end{array}$ & Diminuiu & $\begin{array}{l}\text { Diminuiu } \\
\text { muito }\end{array}$ & $\begin{array}{c}\text { Não } \\
\text { Responderam }\end{array}$ \\
\hline $\begin{array}{c}1^{\underline{a}} \\
\text { Pesquisa }\end{array}$ & $23 \%$ & $53 \%$ & $15 \%$ & $7 \%$ & $0 \%$ & $2 \%$ \\
\hline $\begin{array}{c}2^{\underline{a}} \\
\text { Pesquisa }\end{array}$ & $12 \%$ & $59 \%$ & $28 \%$ & $1 \%$ & $0 \%$ & $0 \%$ \\
\hline 12 & \multicolumn{6}{|c|}{ As áreas que lhe dão suporte no dia a dia estão trabalhando com a Manufatura Enxuta? } \\
\hline Escala & Sim, todas & $\begin{array}{l}\text { Sim, quase } \\
\text { todas }\end{array}$ & Parcialmente & Não, poucas & $\begin{array}{c}\text { Não, } \\
\text { nenhuma }\end{array}$ & $\begin{array}{c}\text { Não } \\
\text { Responderam }\end{array}$ \\
\hline $\begin{array}{c}1 \stackrel{a}{ } \\
\text { Pesquisa }\end{array}$ & $32 \%$ & $40 \%$ & $15 \%$ & $9 \%$ & $0 \%$ & $4 \%$ \\
\hline $\begin{array}{c}2^{a} \\
\text { Pesquisa }\end{array}$ & $92 \%$ & $6 \%$ & $2 \%$ & $0 \%$ & $0 \%$ & $0 \%$ \\
\hline
\end{tabular}

Fonte: Autor (2018) 
Tabela 6 - Resultados Dimensão 4 - Treinamento.

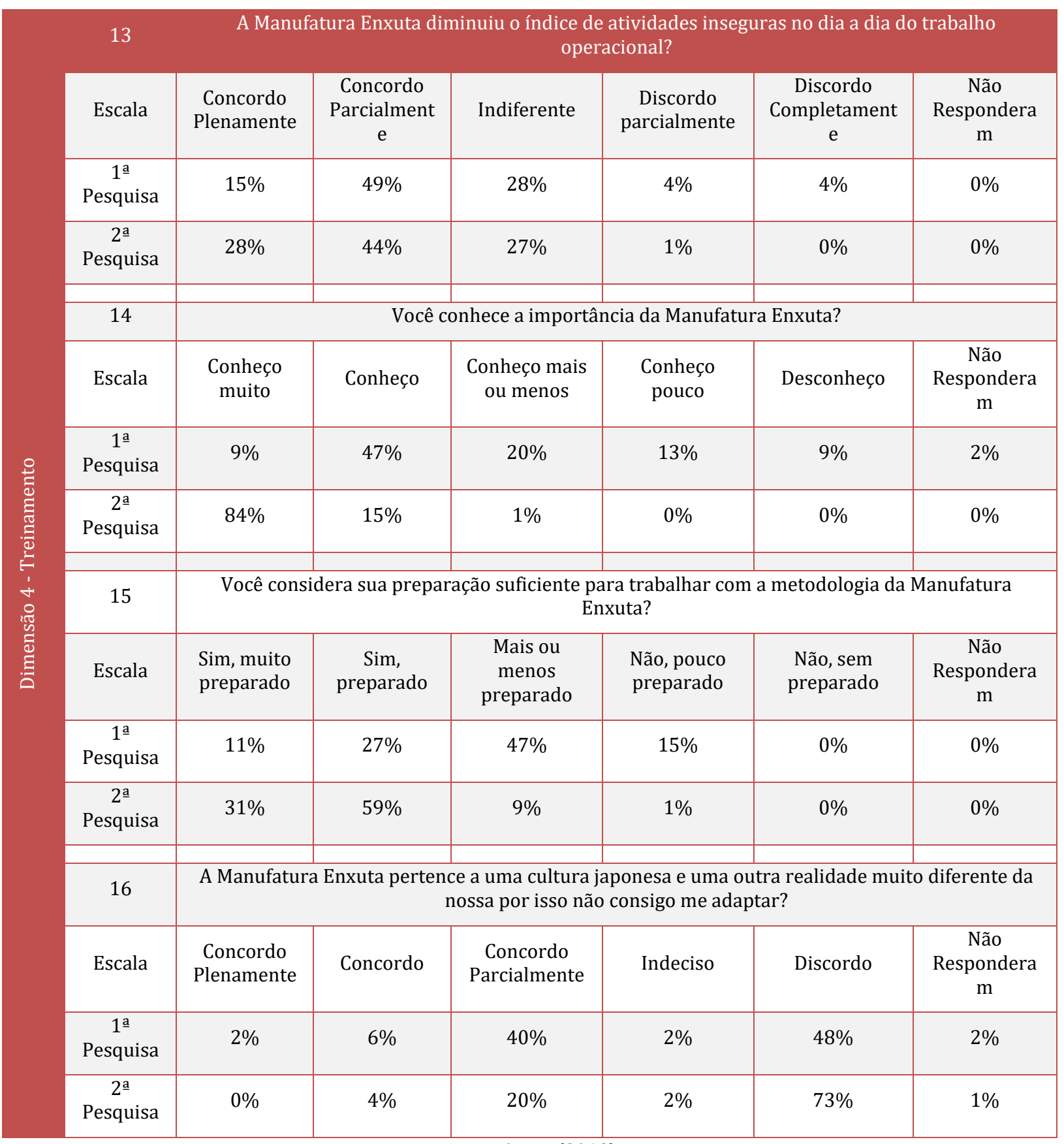

Fonte: Autor (2018)

Esta dimensão possui ótimos resultados principalmente porque $99 \%$ das respondentes sabem e reconhecem a importância da Manufatura Enxuta, fazendo com que o caminho futuro do sucesso seja mais facilmente alcançado.

\section{CONSIDERAÇõES FINAIS}

Depois de decorrer a literatura, embasar fortemente todo o trabalho no Framework, na análise bibliográfica, de onde foram retiras as 4 dimensões, o pesquisador pode chegar ao objetivo do projeto que foi obter as percepções referentes aos impactos decorrentes da implantação da filosofia da Manufatura Enxuta. 
De acordo com Marion e Santos (2004) que ilustram, a Figura 3 deste trabalho pelos resultado obtidos, a empresa ainda não chegou aos níveis do comprometimento coletivo, mas está claramente no caminho correto. Esta saiu da ignorância, termo utilizado pelo autor, passou pelas percepções negativas de resistência e não apoio às mudanças, chegando hoje à consciência, com o nível onde as pessoas já aceitam a mudança. Chegado nesta fase muitas empresas deixam as energias caírem e não atingem a sua plenitude que é a excelência, o comprometimento coletivo, onde a filosofia se torna um hábito natural e diário.

\section{REFERÊNCIAS}

[1] ABBAD, G. et al. Preditores de impacto do treinamento no trabalho - o caso do TCU. In: REUNIÃO ANUAL DE PSICOLOGIA, 29., 1999, Ribeirão Preto. Anais... Ribeirão Preto: Sociedade Brasileira de Psicologia, 1999.

[2] AHLSTROM, P. Sequences in the implementation of lean production. European Management Journal, London, v.16, n.3, p. 327-334, jun., 1998.

[3] ARAÚJO, L. Organização, sistemas e métodos: tecnologias de gestão organizacional. 3.ed. v.1 São Paulo: Atlas, 2010.

[4] BALLOU, R. Gerenciamento da cadeia de suprimentos/logística empresarial. 5. ed. Porto Alegre: Bookman, 2006.

[5] CANTIDIO, S. A dificuldade de implantação de projetos organizacionais: fatores inibidores da inovação. Disponível em: <http://sandrocan.wordpress.com/tag/manufatura-enxuta/> Acesso em: 17 jun. 2013.

[6] FREEMAN, L,C; EVERETT, M, G; BORGATTI, S, P Ucinet for Windows: Software for Social Network Analysis, ed. Analytic Technologies, 2002.

[7] GUEDES. V., BORSCHIVER, S. Bibliometria: uma ferramenta estatística para a gestão da informação e do conhecimento, em sistemas de informação, de comunicação e de avaliação científica e tecnológica In. ENCONTRO NACIONAL DE CIÊNCIA DA INFORMAÇÃO CINFORM, 6., 2005, Salvador. Anais... Salvador: 2005.

[8] GOLDRATT, E.; COX, J. A Meta. 2. ed. São Paulo: Nobel, 2003.

[9] IMAI, M. Gemba kaizen. New York: McGraw-Hill, 1997.

[10] KAUFMAN, H. - The Limits of Organizational Change, 2. nd. New Jersey: Transaction Publishers, 2007.

[11] LEITE, H. Contabilidade para administradores. 4. ed. São Paulo: Atlas, 1997.

[12] MARION, J.; SANTOS, W. Lean em produtos de consumo. Gramado: Lean Summit, 2004.

[13] MARTINS, P.; LAUGENI, F. Administração da produção. 2. ed. São Paulo: Saraiva, 2010.

[14] MONDEN, Y. Sistema de redução de custos: custo-alvo e custo-kaizen. 1. ed. Porto Alegre: Bookman, 1999.

[15] SELDIN R.; RAINHO M.; CAULLIRAUX H. O papel da cultura organizacional na implantação de sistemas integrados de gestão - uma abordagem sobre resistência à mudanças In. ENCONTRO NACIONAL DE ENGENHARIA DE PRODUÇÃO, 23.. 2003, Ouro Preto. ENEGEP 2003. Ouro Preto: ABEPRO, 2003.

[16] SHAH, R.; WARD, P. Lean manufacturing: context, practice bundles, and performance Journal of Operations Management, New York, v. 21, 2nd. ed., p.129-149, 2003.

[17] SHOOK, J.; ROTHER, M. Aprendendo a enxergar. São Paulo: Lean Institute Brasil, 2005

[18] SLACK, N. Vantagem competitiva em manufatura. 2. ed. São Paulo: Atlas, 2002.

[19] TOZI, L. A. Avaliação da importância de atributos de nível de serviço em terminais de cargas em aeroportos. 2010. 175 f. Tese (Doutorado em Engenharia Mecânica) Instituto Tecnológico de Aeronáutica, ITA, São José dos Campos, 2010.

[20] WOMACK, J.; JONES, D. A máquina que mudou o mundo. 11. ed. Rio de Janeiro: Campus, 2004. 


\title{
Capítulo 15
}

\section{A importância da contabilidade ambiental no cursos de ciências contábeis: Um olhar para sistemas de gestão}

\author{
Estefânie da Silva Tenório \\ Marileide Alexandrino Barreto \\ Ana Paula Lima Marques Fernandes \\ Marluce Alves de Almeida Salgueiro
}

Resumo: 0 objetivo geral dessa pesquisa é mostrar a importância da inserção da disciplina Contabilidade Ambiental no curso de ciências contábeis da Universidade Federal de Alagoas, e os específicos são demonstrar a necessidade da implantação da disciplina de contabilidade ambiental no respectivo curso, avaliar o grau de conhecimento dos alunos de ciências contábeis da UFAL na área de contabilidade ambiental e evidenciar a importância da Gestão Ambiental nas Empresas. A Legislação ambiental foi primordial para a existência da Contabilidade Ambiental, pois a partir de suas exigências as Entidades começaram a se preocupar com as questões ambientais, buscando medidas para minimizar as agressões ao meio ambiente, através de sistemas de Gestão ambiental, com o intuito de sanar riscos e evitar penalidades por descumprimento às Leis. A metodologia adotada de acordo com a classificação da pesquisa foi: aplicada, descritiva, quantitativa, hipotético-dedutivo, bibliográfica, documental e de levantamento. O trabalho supracitado visa demonstrar o quão importante é a ramificação da contabilidade destinada ao meio ambiente que não está na grade curricular do curso de Ciências Contábeis da Universidade, fazendo com que os futuros contadores não possam ser capazes de atender esta grande fatia do mercado, visto isso, o mesmo busca dar visibilidade e entendimento da necessidade da inserção da disciplina Contabilidade Ambiental. Por fim a conclusão deste trabalho evidencia, após análise da pesquisa, que na opinião dos graduandos que responderam é muito relevante a inserção dessa disciplina no curso, para o desenvolvimento dos futuros profissionais e conceito do próprio curso.

Palavras chave: Contabilidade Ambiental, Gestão Ambiental, Empresas. 


\section{INTRODUÇÃO}

\subsection{CONSIDERAÇÕES INICIAIS}

A presente pesquisa aborda a necessidade da implantação da disciplina de contabilidade ambiental no curso de Ciências Contábeis da Universidade Federal de Alagoas abordando como ela pode ser fundamental na formação de profissionais aptos a gestão contábil ambiental nas organizações.

\subsection{RELEVÂNCIA DO TEMA}

O meio ambiente desde a descoberta da nação já faz parte da riqueza natural, a exemplo do pau-brasil, encontrada nas terras ainda Tupi-Guaranis. Com o passar dos anos através da extração desses recursos para fabricação de produtos e/ou prestação de serviços, a exemplo das hidrelétricas, que são necessárias para atender as necessidades da população, ocasionando degradação e escassez desses recursos.

Dessa forma, a sociedade em geral representada por entidades governamentais ou não governamentais, exige que as organizações tenham responsabilidade com os danos causados ao meio ambiente em seus processos produtivos, e atividades socioeconômicas. No entanto, é necessário investir em maneiras de amenizar os impactos causados pela extração e utilização danosa dos recursos naturais.

É necessário, nesse sentido, o investimento das entidades em gestão ambiental, o que ocasiona dispêndios financeiros, por alguns órgãos, considerados elevados, para as mesmas, entretanto se for analisar cada situação individualmente, será observado que é um custo necessário.

Caso não exista o cuidado necessário com o meio ambiente, poderá sofrer com vários tipos de sansões, multas e ainda apresentar uma imagem negativa perante a sociedade. Devido a esse fato é preciso dar maior atenção ao gerenciamento dos cuidados com o meio ambiente, o que será possível, ao identificar a realidade das atividades das empresas e as suas relações com o meio ambiente ao redor.

Nesse sentido, como a contabilidade é uma ciência social, e tem o patrimônio como seu objeto, tem a responsabilidade de avaliar e mensurar a relação das empresas com o meio ambiente considerando indispensável ter um sistema de gerenciamento dos impactos causados ao meio ambiente na base de seus controles.

\subsection{FORMULAÇÃO DA SITUAÇÃO PROBLEMA}

Diante do contexto abordado anteriormente destaca-se que a contabilidade ambiental tem o papel de gerir as ações e demonstrar o empenho com o qual a entidade busca resultados.

Desta forma, a contabilidade ambiental é uma fonte de informações que auxilia na gestão dos recursos ambientais e ambientes organizacionais e não organizacionais.

Com o intuito de mostrar a relevância da disciplina de contabilidade ambiental no curso de Ciências Contábeis foi necessário a aplicação do questionário para os graduandos do curso para detectar o nível de conhecimento dos mesmos acerca dessa temática.

Tendo como base na necessidade de formar profissionais competentes dentro dessa área, que saibam gerir, contabilizar, analisar e mensurar as riquezas e dispêndios ambientais das entidades essas considerações tem-se como questão-problema: Qual o grau de conhecimento dos alunos de Ciências Contábeis da UFAL na vertente da contabilidade que trata sobre o meio ambiente, em virtude de não ter a disciplina na matriz curricular?

\subsection{OBJETIVOS}

\subsubsection{OBJETIVO GERAL}

Analisar a importância da disciplina Contabilidade Ambiental no curso de Ciências Contábeis. 


\subsubsection{OBJETIVOS ESPECÍFICOS}

Demonstrar a necessidade da implantação da disciplina de Contabilidade Ambiental no respectivo curso;

Avaliar o grau de conhecimento dos alunos do curso de Ciências Contábeis da UFAL na área da Contabilidade Ambiental;

Evidenciar a Importância da Gestão ambiental nas Empresas.

\subsection{JUSTIFICATIVA}

Como justificativa desta pesquisa, observa-se que a competitividade do mercado de trabalho aumenta a cada dia, em virtude desse fato é imprescindível a existência de profissionais aptos a atender e atuar nessa ramificação da contabilidade voltada para a área ambiental, atendendo às exigências dos órgãos fiscalizadores de preservação do meio ambiente e a legislação que regem as normas e os procedimentos das empresas, bem como auxiliando no processo gerencial, elaborando as demonstrações e controles necessários para que as entidades sejam capazes de tomar decisões assertivas baseadas em informações fidedignas, além de poder mensurar as perdas e ganhos previamente.

Não obstante, cabe salientar que para a evolução desta área um dos primeiros passos seria investir em estudos e implantar a disciplina na matriz curricular obrigatória, com o intuito de preparar profissionais para o mercado, capazes de atender as necessidades das entidades na gestão dos aspectos que geram impactos ao meio ambiente.

\section{CONSIDERAÇÕES TEÓRICAS}

\subsection{CONTABILIDADE AMBIENTAL}

É um estudo do patrimônio ambiental e suas respectivas mutações, ou seja, bens, direitos e obrigações ambientais das empresas. Tendo como objetivo fornecer informações monetárias para seus usuários sobre os eventos ambientais através de sua identificação, mensuração e evidenciação.

Como tópicos importantes de debates em todo o mundo, sejam eles econômicos, políticos ou sociais, a poluição ambiental e redução de recursos naturais tem dado uma maior relevância à contabilidade do meio ambiente (COSTA, 2012).

De acordo com Carvalho (2010, p. 101):

"A Contabilidade como ciência que controla o patrimônio das entidades tem existência milenar e a responsabilidade, ao longo desses anos, de informar a movimentação das riquezas patrimoniais das entidades. Deste modo, tem se mantido silente, para não dizer omissa, em relação à utilização do patrimônio natural como origem das riquezas de muitos empreendimentos. 0 objetivo da ciência contábil de informar a seus usuários todos os fatos que alteram o patrimônio das empresas têm sido prejudicados ao longo do tempo."

Tendo em vista que a contabilidade é uma ciência Social que tem a responsabilidade de fornecer informações fidedignas para tomada de decisões dos gestores e informação à sociedade, através da transparência das ações exercidas pelas entidades, Costa 2012 considera a contabilidade ambiental como parte da contabilidade gerencial, pois os gestores necessitam identificar e organizar os custos ambientais de forma que os investimentos rendam benefícios.

Segundo Martins e De Luca (1994, p.25):

"As informações a serem divulgadas pela contabilidade vão desde os investimentos realizados, seja em nível de aquisição de bens permanentes de proteção a danos ecológicos, de despesas de manutenção ou correção de efeitos ambientais do exercício em curso, de obrigações contraídas em prol do meio ambiente, e até de medidas físicas, quantitativas e qualitativas, empreendidas para sua recuperação e preservação."

Os objetivos da Contabilidade Ambiental, segundo Ribeiro (2005, p. 45) são: 
" [...] identificar, mensurar e esclarecer os eventos e transações econômico-financeiros que estejam relacionados com a proteção, preservação e recuperação ambiental, ocorridos em um determinado período, visando a evidenciação da situação patrimonial de uma entidade".

Segundo Carvalho (2010, p. 111):

"Contabilidade Ambiental pode ser definida como o destaque dado pela ciência aos registros e evidenciações da entidade referentes aos fatos relacionados com o meio ambiente. Não se configura em nenhuma nova técnica ou ciência, a exemplo da auditoria ou da análise de balanços, mas em uma vertente da Contabilidade, a exemplo da contabilidade comercial ou industrial, que estuda fatos mais específicos de uma determinada área, no caso área ambiental."

\subsubsection{DEMONSTRAÇÕES CONTÁBEIS AMBIENTAIS}

A partir das exigências da sociedade em geral, como consumidores cada vez mais conscientes e preocupados com o desenvolvimento sustentável a fim de garantir a preservação do meio ambiente para as gerações futuras, bem como através da intervenção dos governos através de órgãos fiscalizadores, as Empresas passaram a se preocupar com a obrigatoriedade de Demonstrar através dos relatórios contábeis de que forma estão tratando as questões ambientais.

Segundo Carvalho (2010, p. 113):

"A decisão de registrar os fatos contábeis relacionados ao meio ambiente não tem sido tomada unicamente pela entidade. Forças externas a esta têm levado a identificar, mensurar, registrar e evidenciar essas relações. As informações prestadas pelas concorrentes têm levado as demais a também realizar e evidenciar ações na área ambiental. A sociedade tem reclamado uma postura ambientalmente correta de alguns segmentos corporativos, associando isto a seus produtos."

A Contabilidade Ambiental demonstra os fatos ambientais através dos mesmos instrumentos que a Contabilidade demonstra os fatos relacionados com a entidade, como exemplos desses demonstrativos existem: Balanço Patrimonial, demonstração do Resultado do Exercício, Demonstração das Mutações do Patrimônio Líquido, Demonstração de Lucros e Prejuízos Acumulados, Demonstração do Valor Adicionado, Balanço Social e Notas Explicativas.

Segundo o item 1.5.1.1 da NBC T 15: "Esta norma estabelece procedimentos para evidenciação de informações de natureza social e ambiental, com o objetivo de demonstrar à sociedade a participação e a responsabilidade social da entidade".

Embora pareça fácil o exercício do dever social que as entidades possuem perante o meio ambiente, são encontrados vários obstáculos que dificultam a implementação da contabilidade ambiental, tais como: inexistência de definição clara de custos ambientais; dificuldade em calcular um passivo ambiental efetivo; problema em determinar a existência de uma obrigação no futuro por conta de custos pesados; falta de clareza no tratamento a ser dado aos "ativos de vida longa"; reduzida transparência com relação aos danos provocados pela empresa em seus ativos próprios, dentre outros.

Conforme Carvalho (2010, p. 112):

"Vários são os obstáculos que se apresentam às entidades para a evidenciação de informações acerca das relações entre a contabilidade e o meio ambiente. As doutrinas contábeis do Contismo, Materialismo, Personalismo, Reditualismo, Aziendalismo, Controlismo e mesmo o Patrimonialismo não visualizavam uma dimensão mais ampla para contabilidade, apegando-se apenas a fatos econômicos. Foi a partir do Neopatrimonialismo, que a contabilidade pode ser estudada através de uma visão holística, interagindo com todos que levam às transformações da riqueza patrimonial." 
De acordo com o item 1.5.1.3 da Resolução do Conselho Federal de Contabilidade nํ⒈003/04, que Aprova a NBC T 15, que trata de informações de Natureza Social e Ambiental:

"A Demonstração de Informações de Natureza Social e Ambiental, ora instituída, quando elaborada, deve evidenciar os dados e as informações de natureza social e ambiental da entidade, extraídos ou não da contabilidade, de acordo com os procedimentos determinados por esta norma".

Nessa mesma Norma NBC T 15 em seu item 15.1.2 o que são informações de natureza social e ambiental:

"Para fins desta norma, entende-se por informações de natureza social e ambiental: a) a geração de riqueza; b) os recursos humanos; c) a interação da entidade com o ambiente externo; d) a interação com o meio ambiente".

\subsubsection{BALANÇO SOCIAL}

Apesar de não ser uma demonstração obrigatória, sua finalidade é de demonstrar a dimensão da responsabilidade social da entidade perante a sociedade. Apesar de não haver exigência legal para sua divulgação, as entidades precisam informar através de relatórios os impactos ambientais de forma a demonstrar os danos causados e as ações para minimização dos mesmos, visando à transparência de suas ações perante a sociedade. Após a Conferência das Nações Unidas sobre o meio Ambiente e Desenvolvimento (CNUMAD) as questões ambientais passaram a ser exigidas pelo governo por meio de órgãos reguladores.

De modo geral Ferreira, Siqueira e Gomes (2012, p. 14):

“Concluem, portanto, que os balanços sociais são instrumentos de mensuração e evidenciação que falham em externar aos usuários dessas ferramentas o verdadeiro impacto das organizações, seja este positivo ou negativo, na sociedade."

Segundo Carvalho (2010, p.109)

“RELATÓRIOS CONTÁBEIS: como dito anteriormente, a Contabilidade Ambiental não é outra contabilidade; assim, todos os eventos econômicos ou fatos contábeis relativos a ações realizadas pela Entidade que, por consequência, causem impacto no meio ambiente, devem ser reconhecidos e registrados pelo sistema contábil. Portanto, o Balanço Patrimonial, demonstração de Resultado do Exercício e demais informes, as Notas Explicativas e, quando houver, o Balanço Social e a Demonstração do Valor Adicionado são as peças contábeis adequadas para evidenciar como essa questão está sendo tratada pela organização."

Grifo nosso

Após a ECO-92 as práticas ambientais passaram a fazer parte das responsabilidades sociais das empresas. O Balanço Social possui quatro ramificações: Balanço de Recursos humanos, Demonstração do Valor Adicionado, contribuições a sociedade em geral e Balanço Ambiental. Neste será abordado mais detalhadamente o Balanço Ambiental devido ao tema discorrido no mesmo.

No Entendimento de Iudícibus e Marion (2001, p. 25), o Balanço Social é um:

[...] relatório que contêm dados, os quais permitem identificar o perfil da atuação social da empresa durante o ano, a qualidade de suas relações com os seus empregados, a participação dos empregados nos resultados econômicos da empresa e as possibilidades de desenvolvimento pessoal, bem como a forma de sua interação com a comunidade e sua relação com o meio ambiente. Iudícibus e Marion trazem um novo item conceitual, a relação das organizações com o meio ambiente. 
Existem três modelos-padrão de balanço social disponíveis no Brasil. Dois nacionais, um deles proposto pelo Instituto Brasileiro de Análises Sociais e Econômicas (IBASE) e o outro pelo Instituto Ethos de Empresas e Responsabilidade Social e um internacional, sugerido pela Global Reporting Initiative (GRI). Os três visam definir as informações mínimas a serem publicadas para dar transparência às atividades da empresa.

\subsubsection{BALANÇO DE RECURSOS HUMANOS}

Evidencia o potencial de mão de obra que atua no setor produtivo, através da capacidade física e mental dos indivíduos que participam do processo econômico. Demonstra os dispêndios inerentes a manutenção da força de trabalho, como por exemplo: proventos, benefícios, gastos com treinamentos entre outros. Nesta demonstração também são discriminados os gastos com benefícios a sociedade adjacentes através de ações sociais em centro de recreações, escolas, creches etc.

Segundo Taylor (1980, p.13), "não é possível conceber uma empresa sem homens, nem mesmo nesta época vertiginosos progressos no campo da cibernética e o consequente processo tecnológico".

Apesar de não ter a mesma capacidade e precisão que uma máquina a mente humana possui a virtude de elaborar ações diante de situações inesperadas.

Segundo Ribeiro (2006, p.17)

"Essas informações ainda hoje refletem a realidade, até com mais ênfase. Isso porque a sociedade se conscientizou, em escala muito mais ampla, dos seus direitos e do que pode exigir das empresas, tendo em vista principalmente, o tempo que nelas passa e que a elas dedica. Assim, a empresa pode ser vista como o ambiente no qual cada indivíduo, pela execução de seu trabalho, deve poder realizar-se plenamente como pessoa.

\subsubsection{DEMONSTRAÇÃO DO VALOR ADICIONADO (DVA)}

Visa à evidenciação da contribuição da empresa para o desenvolvimento socioeconômico da região onde está inserida. Destaca o valor da riqueza gerada pela empresa e a distribuição perante a economia local.

De acordo com Santos (1999, p. 98): A Demonstração do Valor Adicionado - DVA, componente importantíssimo do Balanço Social, deve ser entendida como a forma mais competente criada pela contabilidade para auxiliar na medição e demonstração da capacidade de geração, bem como de distribuição, da riqueza de uma entidade.

Segundo Cunha e Ribeiro (2003), a DVA teve origem na Europa, mas encontra-se referência no Tesouro Americano no século XVIII. Seu desenvolvimento na Europa deu-se de uma forma urgente, já que o motivo para essa urgência era a adoção do Imposto sobre o Valor Agregado.

O Conselho Federal de Contabilidade (CFC), com a Norma Brasileira de Contabilidade (NBC) 3.7 a qual trata sobre a Demonstração do Valor Adicionado, define a DVA como um Demonstrativo Contábil que visa evidenciar de uma forma clara e objetiva os dados e as informações sobre o valor da riqueza gerada pela empresa e a distribuição da mesma em determinado período de tempo.

\subsubsection{CONTRIBUIÇÕES À SOCIEDADE EM GERAL}

Nesse aspecto o Balanço Social reflete o comprometimento das empresas com as necessidades básicas da população, através de investimentos voluntários em diversas áreas. De acordo com o item 1.5.2.3 da Resolução do Conselho Federal de Contabilidade no 1.003/04, que Aprova a NBC T 15, que trata da Interação da Entidade com o Ambiente Externo:

"Nas informações relativas à interação da entidade com o ambiente externo, devem constar dados sobre o relacionamento com a comunidade na qual a entidade está inserida, com os clientes e com os fornecedores, inclusive incentivos decorrentes dessa interação." 
Ludícibus et al. (2000, p.32) afirmam que tem por objetivo a "evidenciação do que a empresa faz em termo de benefícios sociais como contribuições a entidades assistenciais e filantrópicas, preservação de bens culturais, educação de necessitados etc.".

\subsubsection{INTERAÇÃO COM O MEIO AMBIENTE}

Ao produzir através da extração de recursos naturais as empresas utilizam patrimônio da humanidade, afetando de forma negativa o meio ambiente, causando a redução do volume de água potável, o nível de qualidade do ar e da área de terras cultiváveis, dessa forma compromete a longo prazo as condições de vida das gerações futuras. Dessa forma as empresas são cada vez mais pressionadas a melhorar seus processos de produção, com o intuito de reduzir as agressões ao meio ambiente, através de cumprimento às exigências legais; produção de biodegradáveis; tratamento dos resíduos sólidos, elaboração dos relatórios ambientais EIA (Estudo de Impacto Ambiental) e os RIMA (Relatório de Impacto Ambiental).

De acordo com Ribeiro (2006, p.19), os EIAs e os RIMAs são documentos amplamente utilizados em todo o mundo. A autorização para que uma empresa se constitua e funcione, em determinados setores econômicos, está condicionada à sua apresentação dos governos aos órgãos técnicos responsáveis. Do mesmo modo, para obter financiamento dos bancos governamentais, principalmente do Banco Nacional de Desenvolvimento Econômico e Social (BNDES), a empresa terá de cumprir a legislação ambiental em seus níveis municipais, estaduais e governamentais, inclusive pela apresentação do EIA e do RIMA. Instituições internacionais que disponibilizam linhas de crédito para projetos nessa área, como o Banco Interamericano de Desenvolvimento (BID), o Banco Mundial (Bird), o Fundo Nakasone, do Japão, e a Cooperação Técnica Alemã (GTZ), também exigem tais documentos, apesar da concessão dos recursos ser realizada por intermédio do governo.

Segundo Ferreira. (2006, p.24), a respeito de Relatórios Ambientais: Os relatórios ambientais têm como característica a descrição física sobre como determinada ação pode influenciar fisicamente o meio ambiente. Costumam apresentar um resumo do estudo da área, refletindo as conclusões do Estudo do Impacto Ambiental (EIA) em uma linguagem acessível. Outra característica é a de ser um meio de comunicação sobre esses impactos, possibilitando a agentes externos o devido conhecimento sobre o assunto.

\subsubsection{BALANÇO AMBIENTAL}

Tem a finalidade de mensurar dados que causam influencia no meio ambiente, com o objetivo de publicar as ações com ou sem fins lucrativos, para tornar possível a mensuração do desempenho das organizações, demonstrando no momento em que são identificados, custos, ativos e passivos ambientais. No balanço ambiental são expostas, através dos Ativos e passivos as atuações das empresas no relacionamento com o meio ambiente, destacando resumidamente as contas de gestão ambiental.

Concretizando a credibilidade e importância de se mensurar dados, surge o Balanço Ambiental, que tem por principal objetivo tornar pública, para fins de avaliação de desempenho, toda e qualquer atitude com ou sem finalidade lucrativa, que possa ou venha a influenciar o meio ambiente, assegurando que custos, ativos e passivos ambientais sejam reconhecidos a partir do momento de sua identificação, de acordo com os princípios fundamentais da Contabilidade (RAUPP apud HERCKERT, 2008).

Na visão de Herckert (2008), o Balanço Ambiental é um documento demonstrativo que expressa o ativo e passivo ambiental natural num determinado momento. Ele evidencia, de forma sintética, as contas da gestão ambiental natural da célula social.

\subsubsection{ATIVO AMBIENTAL}

Segundo IBRACON - NPA11- os Ativos ambientais são compostos: "o imobilizado no que se refere aos equipamentos adquiridos, visando a eliminação ou redução de agentes poluentes, com vida útil superior a um ano; e os gastos com pesquisas e desenvolvimento de tecnologias a médio e longo prazos, constituindo, a rigor, valores integrantes do ativo diferido (se envolverem benefícios e ação que se reflitam por exercícios futuros). Também integram o ativo ambiental, o estoque, quando relacionados com insumos do processo de eliminação dos níveis de poluição; componentes representados por empregos e impostos gerados; e obras de infraestrutura local, escolas, creches, áreas verdes e ajardinadas, que busquem o 
desenvolvimento e a valorização da região e que eliminando o passivo ambiental, a empresa produz ativos no local".

De acordo com Ribeiro (2005, p. 61), ativos ambientais são: "todos os bens e direitos possuídos pelas empresas, que tenham capacidade de geração de benefício econômico em períodos futuros e que visem à preservação, proteção e recuperação ambiental". É de fundamental importância enfatizar que esses ativos, deverão estar lançados em contas características devido a sua especificidade nos demonstrativos ambientais. Em virtude da tangibilidade dos bens dos ativos circulantes imobilizados ambientais e diferidos que estão sujeitos a depreciações da mesma forma ocorre com os demais ativos não circulantes permanentes, exceto os de vida útil inferior a trezentos e sessenta e cinco dias.

Segundo a Lei ${ }^{\circ} 11.638 / 07$, o ativo diferido passa a ser inexistente, contudo as empresas que realizavam seu lançamento nos demonstrativos contábeis antes da existência desta poderão amortizar ou até findar a conta.

\subsubsection{PASSIVO AMBIENTAL}

Segundo Leite (2011), "O passivo ambiental corresponde ao investimento que uma empresa deve fazer para que possa corrigir os impactos ambientais adversos gerados em decorrência de suas atividades e que não tenham sido controlados ao longo dos anos de suas operações".

Entretanto para Faria (2011), "passivo ambiental pode ser definido como qualquer obrigação da empresa relativa aos danos ambientais causados por ela, uma vez que a empresa é a responsável pelas consequências destes danos na sociedade e no meio ambiente".

A inclusão do passivo ambiental na contabilidade das empresas está relacionada ao surgimento do conceito moderno de empresa, no final do século XIX, com a negação do conceito de propriedade ilimitada e absoluta para a função social da propriedade. Dessa forma, as obrigações sociais são inseridas, visandose a implementação de transformações sociais (ARAUJO, 2008).

Os passivos ambientais são obrigações adquiridas perante terceiros caracterizando-se pela recuperação de áreas degradadas, indenizações, criação de meios para reduzir multas, danos e penalidades no caso de infrações às Leis Ambientais.

Os Passivos Ambientais, conforme Ribeiro e Gratão (2000), ficaram ampla- mente conhecidos pela sua conotação mais negativa, ou seja, as empresas que os possuem agrediram significativamente o meio ambiente e, dessa forma, têm que pagar vultosas quantias a título de indenização a terceiros, de multas e para a recuperação de áreas danificadas.

Para Carvalho (2010, p. 132): [...]

"Por passivo ambiental entendem-se as obrigações da entidade decorrentes de danos causados ao meio ambiente, de infrações ambientais ou empréstimos a serem aplicados na área ambiental, que tenham ocorrido no passado ou estejam ocorrendo no presente que delas decorram a entrega futura ou presente de ativos bem como a prestação de serviços."

\subsubsection{CUSTOS AMBIENTAIS}

Carvalho (2010, p. 195), define Custos ambientais como: "Os gastos que a empresa realiza que têm relação com o meio ambiente e que são necessários para consecução de sua atividade-fim, são geralmente classificados como custos ambientais".Segundo o princípio do poluidor-pagador, os custos de degradação ao meio ambiente devem ser incorporados pelas entidades e não exteriorizar para a sociedade. Devido ao fato dos gastos com a preservação e recuperação ambiental estarem relacionados com a atividade de produção os mesmos podem ser classificados como custos atribuídos aos bens e serviços produzidos, devendo ser incluído no valor desses bens e serviços o valor da degradação e/ou valor da preservação da natureza. 
0 princípio em referência possui assento constitucional, estando previsto no artigo 225 da CF/88, verbis:

$\S 2^{\mathrm{o}}$ - Aquele que explorar recursos minerais fica obrigado a recuperar o meio ambiente degradado, de acordo com solução técnica exigida pelo órgão público competente, na forma da lei.

$\S 3^{\text {o }}$ - As condutas e atividades consideradas lesivas ao meio ambiente sujeitarão os infratores, pessoas físicas ou jurídicas, a sanções penais e administrativas, independentemente da obrigação de reparar os danos causados.

Paulo Affonso Leme Machado (2009, página 66):

“O uso gratuito dos recursos naturais tem representado um enriquecimento ilegítimo do usuário, pois a comunidade que não usa do recurso ou que o utiliza em menor escala fica onerada. 0 poluidor que usa gratuitamente o meio ambiente para nele lançar poluentes invade a propriedade pessoal de todos os outros que não poluem, confiscando o direito de propriedade alheia."

De acordo com Tinoco e Kraemer (2004, p.168) salientam que "os custos ambientais são apenas um subconjunto de um universo mais vasto de custos necessários a uma adequada tomada de decisões".

\subsubsection{DESPESAS AMBIENTAIS}

As despesas são todos os gastos relacionados ao meio ambiente, destinados para a recuperação das áreas degradadas que não se referem à atividade produtiva da empresa como, por exemplo: degradação do ar, solo e água; depreciação de equipamento entre outros.

Carvalho (2010, p. 196) define Despesas ambientais como: "Os gastos que a empresa realiza com a área ambiental, mas que não estão relacionados com a consecução de sua atividade-fim são geralmente classificados como despesas ambientais".

\subsubsection{RECEITAS AMBIENTAIS}

São recursos alcançados decorrentes da venda de seus subprodutos ou de materiais reciclados, receita de serviços ambientais e receitas de venda de certificados de redução de emissões.

Segundo a definição de Carvalho (2010, p. 198): "a empresa com visão de responsabilidade ambiental pode, em vez de degradar o meio ambiente com os resíduos de sua atividade produtiva, agregar valor a esses resíduos e torná-los úteis a terceiros ou à própria empresa, através do aumento de seu ciclo de vida e, inclusive, pode ganhar sob vários aspectos: ambiental, de imagem (relacionada a responsabilidade social) e financeiro".

\subsubsection{PERDAS AMBIENTAIS}

As perdas podem ser entendidas como gastos que não estão relacionados às atividades básicas da empresa, ou seja, que não se pode prever como, por exemplo: uma perda causada por fenômenos naturais.

Ribeiro (apud MARION; COSTA 2007) apresenta o conceito de perda ambiental, dizendo que as "perdas refletem os gastos incorridos sem uma contrapartida em benefícios. Portanto, perdas ambientais são os gastos que não proporcionam benefícios para a empresa”.

\subsubsection{GESTÃO DOS IMPACTOS AMBIENTAIS NAS ENTIDADES}

Com o objetivo de atuar na Gestão dos Impactos Ambientais nas entidades é imprescindível a existência de profissionais qualificados para atuar nessa vertente da contabilidade os quais devem ter visão estratégica e ações eficazes. Tendo em vista que a contabilidade é uma ciência que trata e registra os fatos e alterações no patrimônio das entidades é preciso que as universidades invistam na formação de profissionais aptos a atender essas necessidades das empresas, ocasionadas pela utilização e degradação dos recursos naturais, 
visando atender às exigências legais e a cobrança cada vez mais frequente da sociedade pelo desenvolvimento sustentável.

De acordo com Santos et al., (2001, p. 90) "a contabilidade pode auxiliar os administradores no gerenciamento empresarial do meio ambiente, pois ela é considerada, atualmente, umas das principais ferramentas de gestão de negócio".

Para Pinheiro e Boscov (2015), A Conferência das Nações Unidas sobre Meio Ambiente e Desenvolvimento (Eco 92), realizada no Rio de Janeiro em 1992, 20 anos após a Declaração de Estocolmo, teve como principal objetivo obter, através de negociações, a redução na concentração de gases estufa na atmosfera limitando a interferência do homem nos sistemas climáticos.

0 Instituto Ethos (2013) esclarece que a responsabilidade social envolve o cidadão, o governo e as empresas:

"Responsabilidade social empresarial é a forma de gestão que se define pela relação ética e transparente da empresa com todos os públicos com os quais ela se relaciona e pelo estabelecimento de metas empresariais compatíveis com o desenvolvimento sustentável da sociedade, preservando os recursos ambientais e culturais para as gerações futuras, respeitando a diversidade e promovendo a redução das desigualdades sociais".

O Instituto Ethos (2015) - Agenda Global - em comemoração aos 15 anos da existência do Pacto Global, esclarece:

“O Pacto Global é uma iniciativa das Nações Unidas que reconhece a importância do papel das empresas no enfrentamento dos desafios globais. E, a partir deste reconhecimento, encoraja empresas a adotar políticas de responsabilidade social corporativa e sustentabilidade. Esse pacto pretende promover um diálogo entre empresas, organizações da ONU, sindicatos, organizações não governamentais e demais parceiros, para o desenvolvimento de um mercado global mais inclusivo e sustentável. “

Para Silva e Callado (2013, p. 88): “Com o processo de globalização e o aumento da competitividade empresarial, as empresas passaram a ter a necessidade de controlar informações relacionadas aos seus aspectos financeiros e aos aspectos não financeiros, como a responsabilidade social e ambiental da empresa".

A ISO 14001 é um Sistema de Gestão Ambiental que permite a uma organização desenvolver uma estrutura para a proteção do meio ambiente e rápida resposta às mudanças das condições ambientais. $\mathrm{A}$ norma leva em conta aspectos ambientais influenciados pela organização e outros passíveis de serem controlados por ela. A ISO 14001:2015 incorpora as questões estratégicas, a preocupação com a cadeia de valor, ciclo de vida, entre outras mudanças. Além disso, a norma proporciona ganhos econômicos, pois ao reduzir o consumo de recursos, também reduz custos, mas agora esse enfoque ganha forças, o que agregará muito valor para as empresas que conquistarem essa certificação.

\section{METODOLOGIA}

Com a finalidade de alcançar os objetivos propostos foi utilizada a seguinte metodologia, no tocante a classificação da pesquisa de acordo com GIL (2000)

- Quanto à finalidade: Aplicada;

- Quanto aos objetivos: Descritiva;

- Quanto à abordagem: Quantitativa;

- Quanto ao método utilizado: hipotético-dedutivo; e

- Quanto aos procedimentos: Bibliográfica, documental e levantamento.

Em relação à finalidade foi realizada uma pesquisa aplicada, onde foi evidenciada a necessidade da implantação da disciplina de Contabilidade Ambiental na matriz curricular do curso de Ciências Contábeis da UFAL, com intuito de formar profissionais preparados para atuar na resolução de conflitos gerados nas entidades, devido aos impactos ou possíveis danos causados à natureza. Referente à classificação da pesquisa segundo seu objetivo geral tem característica descritiva com abordagem quantitativa. 0 método de pesquisa foi hipotético-dedutivo, onde foi sugerida a inserção da disciplina Contabilidade Ambiental 
como tentativa de solucionar a deficiência de conhecimento dos graduandos nessa área. Os procedimentos utilizados na realização desta pesquisa foram: Bibliográfica, através de consulta em livros, artigos e outros textos de caráter científico. Documental, através de documentos não científicos. Levantamento, através da aplicação de questionário.

Através da utilização de métodos e técnicas foi possível sistematizar o desenvolvimento da pesquisa, possibilitando através disso a veracidade dos fatos supracitados no desenvolvimento do trabalho, pois o conhecimento científico possibilita a ordenação das ideias as quais dão origem a uma teoria. Uma das principais finalidades da existência do conhecimento científico é o princípio da verificabilidade, que possibilita a comprovação de determinada ideia ou teoria sob a ótica da ciência.

A estruturação das etapas da formulação das ideias e sua comprovação nos remetem a uma validação do método utilizado, possibilitando a evidenciação desse estudo em outro momento.

A problemática a ser estudada surge de um conhecimento prévio de determinado assunto, tendo como objetivo a análise da realidade que envolve o problema com o intuito de buscar soluções mais adequadas. Para alcançar os objetivos propostos foi elaborado um questionário, onde 111 discentes responderam.

\section{ANÁLISE E DISCUSSÃO DOS RESULTADOS}

Neste tópico será demonstrado a importância de inserir a disciplina de Contabilidade Ambiental na matriz curricular do curso de Ciências Contábeis da UFAL, onde a partir da análise dos dados coletados foi possível avaliar o nível de conhecimento dos alunos sobre aspectos da contabilidade ambiental, bem como identificar a opinião dos mesmos sobre a importância de inserir está disciplina no curso. Para mensurar o grau de conhecimento dos discentes sobre os conceitos e aplicabilidade da contabilidade ambiental foi utilizado um questionário, contendo 14 questões com indagações sobre o assunto. 0 questionário foi aplicado aos graduandos das turmas do $4^{\mathrm{O}}$ ao $10^{\mathrm{o}}$ período. A coleta de dados foi realizada através de questionário disponibilizado via Google docs, sendo aplicado no período de 30 de julho a 25 de agosto de 2018. Os dados coletados foram tratados através de estatística descritiva quantitativa.

\subsection{ANÁLISE DO NÍVEL DE CONHECIMENTO DOS DISCENTES SOBRE A CONTABILIDADE AMBIENTAL E A NECESSIDADE DA INSERÇÃO DA MESMA NO CURSO.}

Conforme evidenciado nas informações constantes no gráfico 1, identifica-se que 65,8\% dos respondentes não possui conhecimento sobre contabilidade ambiental e do total de 111 respostas apenas 34,20\% possui conhecimento nessa área.

Gráfico 1: Grau de Conhecimento dos respondentes na área de contabilidade Ambiental.

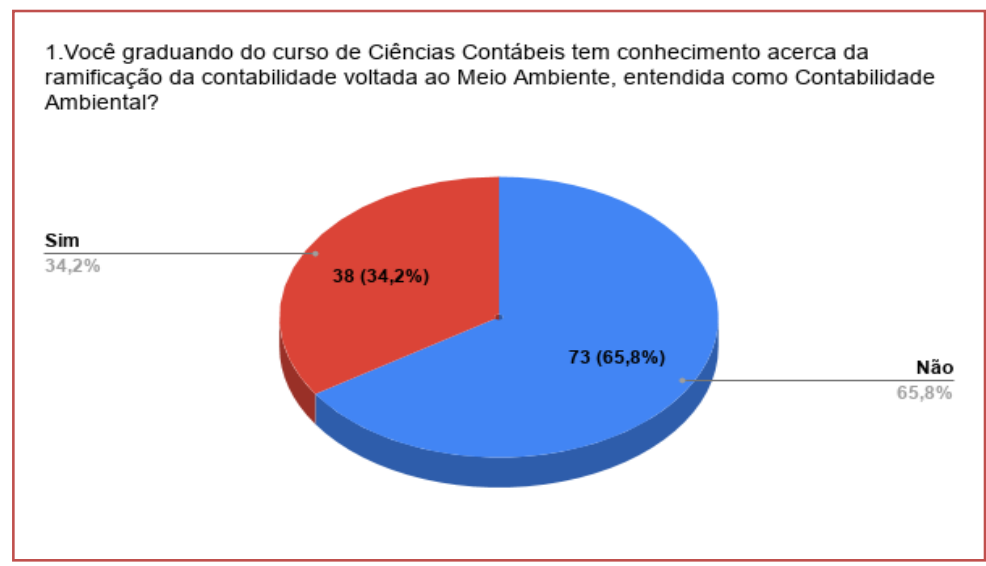

Fonte: Dados da pesquisa 2018

Foram obtidas 111 respostas para a questão 1 que busca detectar o nível de conhecimento dos graduandos nessa área da contabilidade. Neste gráfico é possível verificar que do total dos respondentes $(65,8 \%)$ não possui conhecimento sobre essa ramificação da contabilidade, o que pode gerar credibilidade 
a esta pesquisa, considerando que, alguns entrevistados já cursaram mais da metade do curso e outros são concluintes, dessa forma já cursaram praticamente todas as disciplinas da matriz curricular do curso de ciências contábeis. Os dados constantes no gráfico 2 mostram que a maior parte dos respondentes $(83,1 \%)$ não obtiveram conhecimento sobre essa ramificação da contabilidade, proporcionado pelo curso, enquanto $11,9 \%$ responderam que obtiveram algum conhecimento no curso.

Gráfico 2: Conhecimento proporcionado pelo curso na área de contabilidade Ambiental

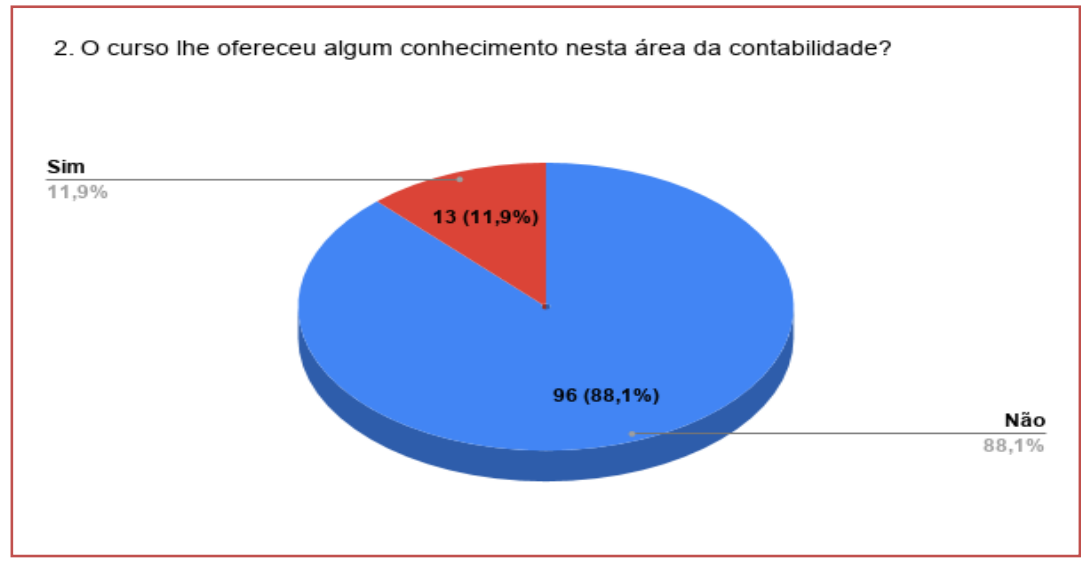

Fonte: Dados da pesquisa 2018

A partir das perguntas 1 e 2 a pesquisa buscou evidenciar informações sobre o grau de conhecimento dos alunos sobre a contabilidade ambiental e se a Universidade contribuiu para esse conhecimento. Observando as informações constantes no gráfico 2 é perceptível que a maior parte dos alunos não tem conhecimento nessa área e que o curso proporcionou pouco ou nenhum conhecimento nessa área.

Os dados constantes no gráfico 3 mostram que a maior parte dos respondentes $(82,9 \%)$ concordam com a inserção dessa ramificação da contabilidade na matriz curricular do curso de ciências contábeis da UFAL, no entanto $(17,1 \%)$ não optaram pela inserção.

Gráfico 3: Necessidade de inserir a contabilidade ambiental como disciplina no curso.

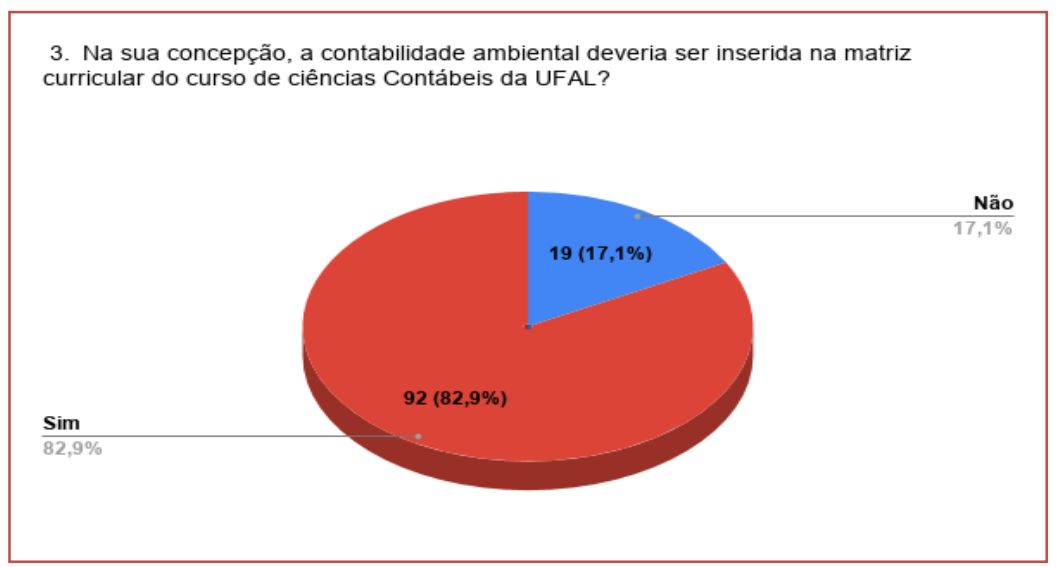

Fonte: Dados da pesquisa 2018

Com a pergunta 3 o questionário buscou evidenciar informações sobre a opinião dos respondentes sobre a necessidade de inserir a disciplina de contabilidade ambiental no curso de ciências contábeis, é possível verificar através dos dados do gráfico que a maior parte dos graduandos concordam com a inserção da disciplina no curso. 


\subsection{ANÁLISE DA OPINIÃO DOS RESPONDENTES ACERCADA NECESSIDADE DE OBTER NA GRADUAÇÃO CONHECIMENTO SOBRE GESTÃO AMBIENTAL E CONTABILIZAÇÃO DE FATOS AMBIENTAIS POR MEIO DE DEMONSTRAÇÕES E A RELEVÂNCIA DE OBTER NA GRADUAÇÃO A BASE DE CONHECIMENTO PARA ATUAR NESSA ÁREA.}

Através das informações obtidas a partir das perguntas de 4 a 9 e expostas nos gráficos abaixo será demonstrada a opinião dos respondentes sobre a importância da Gestão Ambiental nas empresas, cujas devem ser geridas por profissionais da área contábil. Será evidenciada também a relevância de obter a base na graduação para se tornar um profissional apto a atender essas demandas do mercado, devido ao fato de existir a necessidade de as entidades evidenciarem os fatos ambientais, através de exigências legais e da sociedade que cada vez mais cobra das entidades e dão credibilidade às que atentam e buscam o desenvolvimento sustentável.

No gráfico 4 foram evidenciadas as respostas dos graduandos sobre a necessidade de obter na graduação conhecimento que sirva como base para os tornarem profissionais aptos a atender as necessidades das empresas voltadas para as questões ambientais, onde foi exposto que (60\%) dos respondentes julgaram necessário adquirir esse conhecimento na graduação, (27,3\%) classificaram como indispensável e $(12,7 \%)$ acharam que não há necessidade.

Gráfico 4: Necessidade de obter conhecimento sobre gerenciamento de fatos ambientais na graduação.

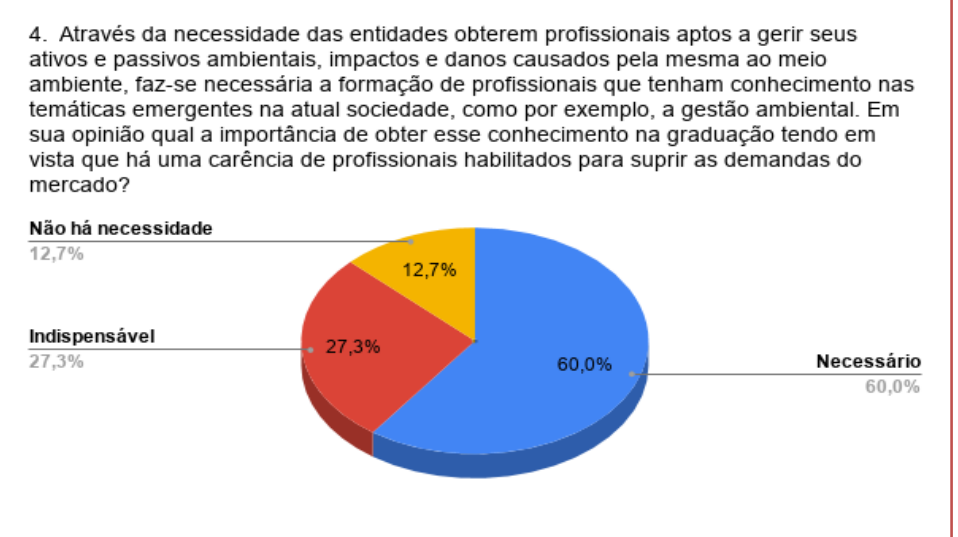

Fonte: Dados da pesquisa 2018

Dos dados obtidos no gráfico 5 (60,9\%) dos respondentes julgam necessária, (24,5\%) consideram indispensável e (14,5\%) acham que não há necessidade de abordagem da disciplina de contabilidade ambiental.

Gráfico 5: Opinião sobre a abordagem da disciplina no curso de graduação.

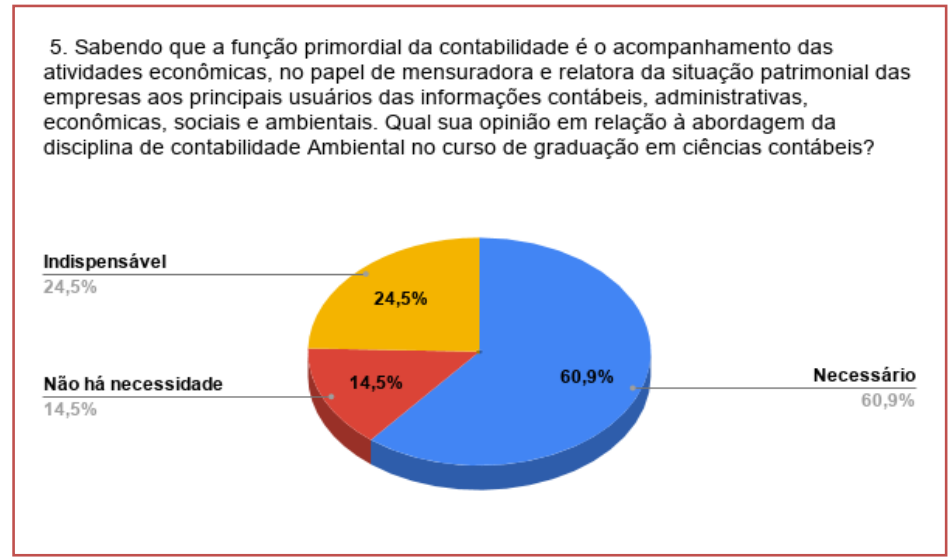

Fonte: Dados da pesquisa 2018 
0 gráfico 6 contém as informações que evidenciam que os graduandos que responderam à pesquisa em um percentual de $(91,7 \%)$ não se sentem preparados para o mercado atual, onde são cobradas pela legislação e sociedade que as empresas atentem para o desenvolvimento sustentável e demonstrem através de relatórios e demonstrações contábeis seus ativos e passivos ambientais.

Gráfico 6: Indagação se os respondestes se sentem preparados para demonstrar balanço social.

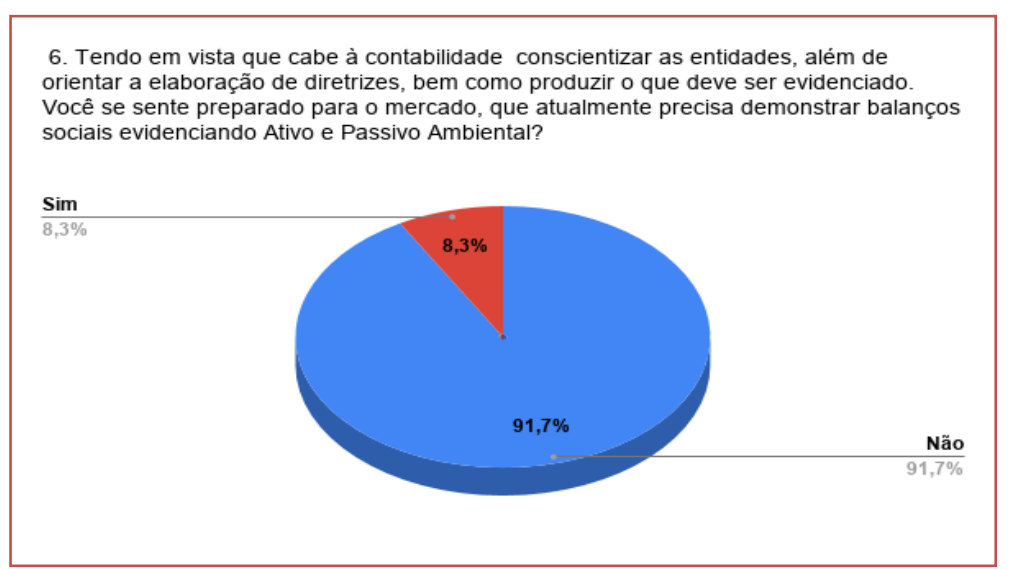

Fonte: Dados da pesquisa 2018

No gráfico 7 foi identificado que (64\%) dos respondentes consideram necessária, $(19,8 \%)$ julgam indispensável e apenas (16,2\%) acham desnecessária a existência da disciplina de contabilidade ambiental na matriz curricular do curso.

Gráfico 7: Análise da relevância de existir a disciplina de contabilidade ambiental na matriz curricular

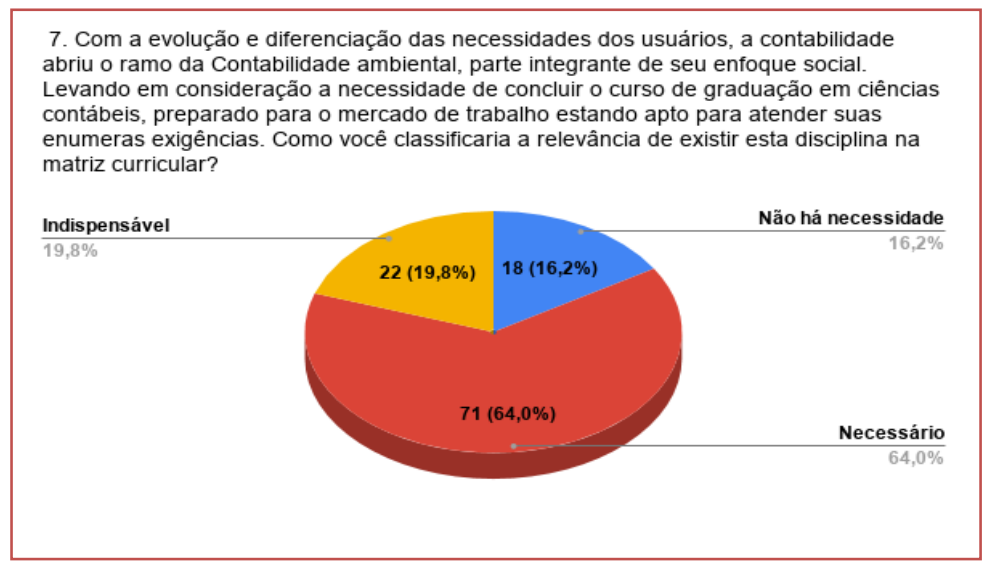

Fonte: Dados da pesquisa 2018

No gráfico 8 foram obtidos os percentuais de $(80,9 \%)$ de respostas negativas e $(19,1 \%)$ de respostas positivas a respeito do conhecimento proporcionado pelo curso sobre as exigências legais e do mercado na área ambiental. 
Gráfico 8: Conhecimento proporcionado pelo curso a respeito das exigências legais e mercadológicas na área Ambiental.

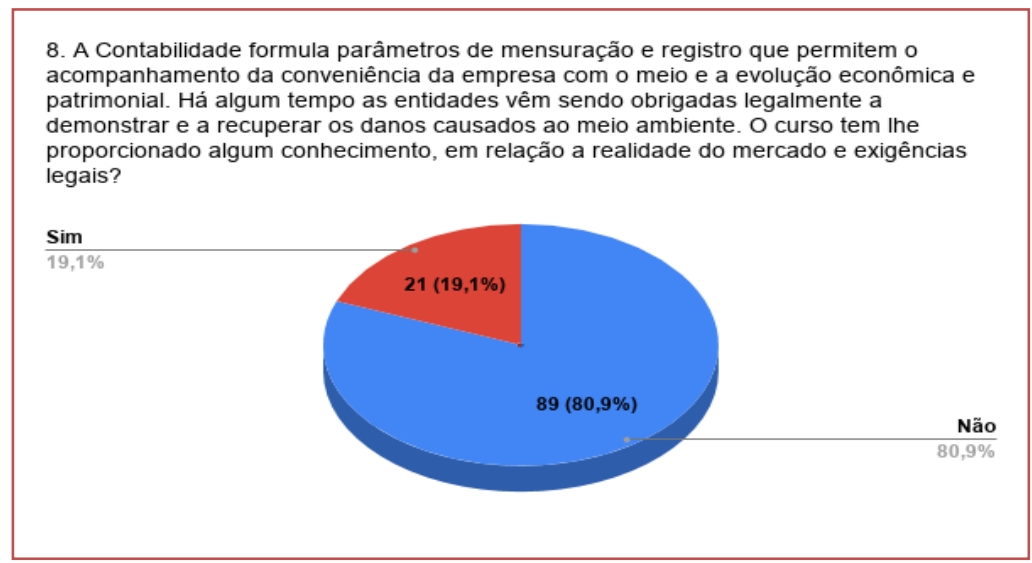

Fonte: Dados da pesquisa 2018

Considerando que a contabilidade é responsável pela formulação de registro que possibilitam o acompanhamento da conveniência das empresas com o meio e a evolução econômica e patrimonial, levando em conta também que a partir das exigências legais e sociais as entidades são obrigadas cumprir as regras e normas impostas demonstrando legalmente de que forma estão recuperando os danos causados ao meio ambiente, ao lançar na pesquisa a indagação se o curso proporcionou algum conhecimento sobre essa realidade das empresas acerca das questões ambientais e das exigências legais foi obtido um percentual de $(80,9 \%)$ informando que o curso não proporcionou conhecimento e somente $(19,1 \%)$ responderam que sim.

Tendo em vista que é a contabilidade que registra os eventos e transações econômicas das empresas através das demonstrações e relatórios contábeis e considerando que a grande maioria das empresas precisam demonstrar ativos e passivos ambientais, foi feita a pergunta aos graduandos se eles concordam que ao concluir a graduação, devem estar aptos para atender esta ramificação da contabilidade, devido ao fato de esta obrigação já está inserida nas entidades. Foram obtidos os seguintes percentuais demonstrados no gráfico 9: $(77,5 \%)$ dos respondentes acham que sim e apenas $(22,5 \%)$ acreditam que não.

Gráfico 9: Análise se os respondentes concordam que devem estar aptos a atender esta ramificação da contabilidade ao concluir a graduação

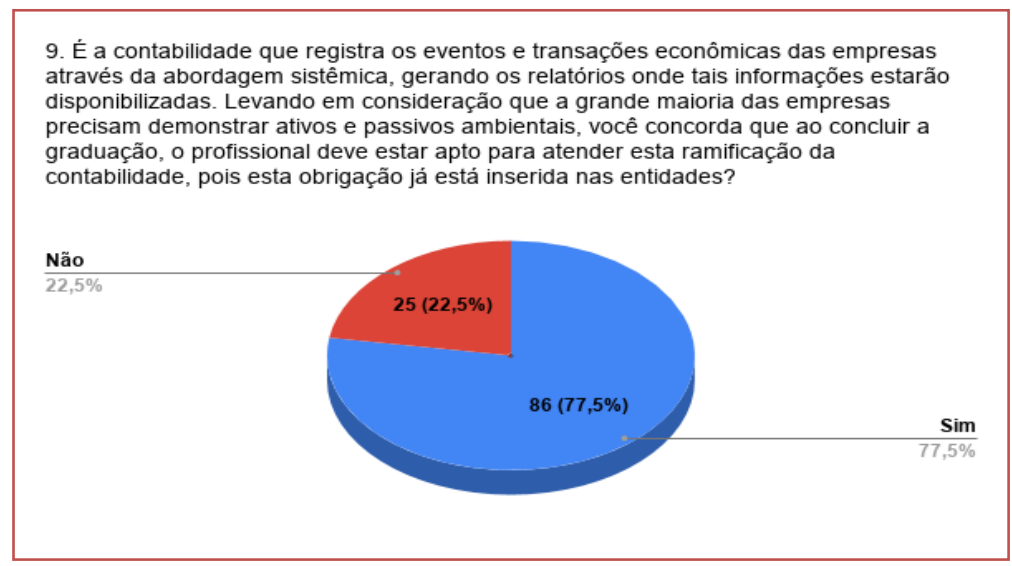

Fonte: Dados da pesquisa 2018

Ao analisar dos dados constantes nos gráficos de 4 a 9 é possível perceber que do número de alunos que responderam a grande maioria do total que responderam à pesquisa consideram necessário e indispensável que o curso proporcione a base de conhecimento necessário para a formação de profissionais, cujos poderão se especializar posteriormente para estarem aptos e capacitados para atender 
as demandas do mercado nessa área, no gráfico 5 ficou claro que para a maioria dos respondentes é necessário e indispensável que a disciplina de contabilidade ambiental seja abordada na graduação, pois observando os dados do gráfico 6 é possível verificar que $(91,8 \%)$ não se sentem preparados para o mercado atual o qual exige que as empresas atentem para o desenvolvimento sustentável e demonstrem através de relatórios e demonstrações contábeis informações aos órgãos fiscalizadores e à sociedade.

A partir dessa análise foi possível identificar que a maioria dos respondentes concorda que ao concluir a graduação devem estar preparados para gerir e elaborar demonstrações e relatórios contábeis que demonstrem com fidedignidade para os tomadores de decisões das Entidades, para os órgãos fiscalizadores, bem como para a sociedade informações claras e confiáveis que exponha com clareza a forma que as Empresas tratam seus Ativos e Passivos Ambientais e as ações que realizam para recuperar os danos causados ao meio ambiente.

No gráfico 10 foi analisado qual método de abordagem das disciplinas do curso os graduados consideram que deveria ser mais utilizado. Nesse gráfico foi constatado que (61\%) dos respondentes acham que o melhor método seria mesclar situações reais e demonstrar como elas devem ser resolvidas na prática, (20\%) julgam que o método deve ser opção do docente, $(14,3 \%)$ considera que a abordagem das disciplinas no curso deveria ser de forma prática, abordando situações reais e apenas (4,8\%) optaram que a abordagem deveria ser apenas teórica.

Gráfico 10: Opinião sobre que método de abordagem das disciplinas deveria ser abordado pelos docentes.

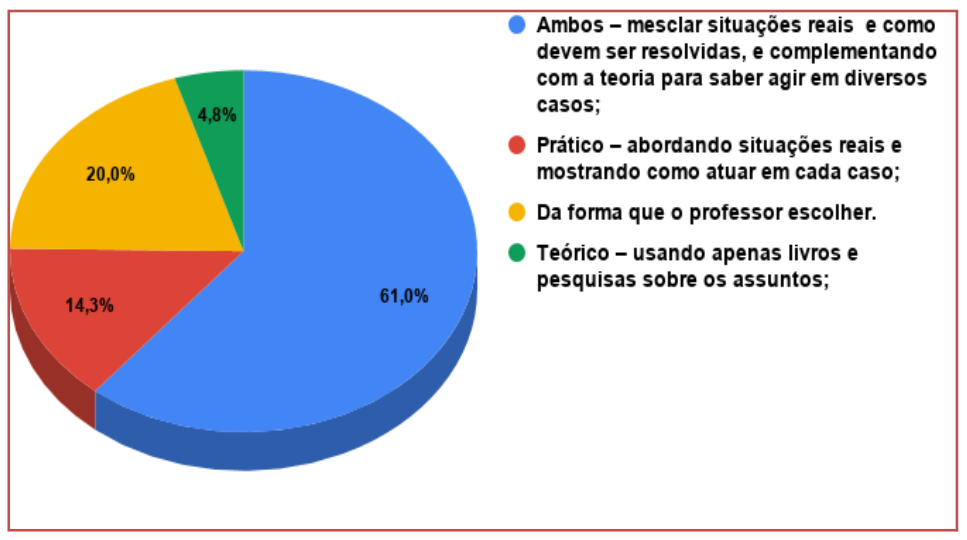

Fonte: Dados da pesquisa 2018

É possível analisar através dos dados obtidos no gráfico 10 que para os respondentes é importante que a abordagem das disciplinas no curso sejam mescladas as abordagens práticas e teóricas, através de exemplos de fatos que ocorrem atualmente nas entidades e das obrigações e normas vigentes impostas.

O gráfico 11 evidencia que $(83,8 \%)$ dos respondentes o consideram o conhecimento na área de contabilidade ambiental um diferencial no mercado atual e apenas (16,2\%) acham que não.

Gráfico 11: Análise se o conhecimento na área ambiental é considerado em diferencial.

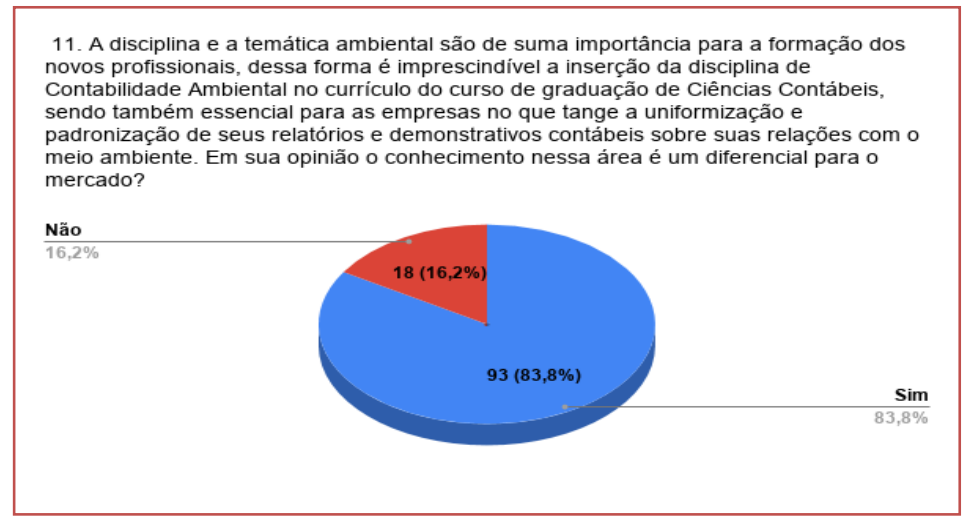

Fonte: Dados da pesquisa 2018 
Um percentual de $(83,8 \%)$ dos respondentes consideram relevante o conhecimento na área de contabilidade ambiental, considerando que há no mercado espaço para profissionais capacitados para atender às necessidades das entidades, sejam elas gerenciais, exigências legais e sociais e tendo em vista que às entidades que crescem com responsabilidade e atenção à preservação e recuperação dos recursos naturais gastos em sua produção se destacam dentre as demais. No gráfico 12 foi exposto o nível de conhecimento concedido pelo curso sobre como atender o mercado em relação às questões ambientais, $(91,8 \%)$ dos alunos que responderam à pesquisa optaram pela opção que não houve em nenhum momento do curso orientação de como atender o mercado nessa modalidade, enquanto apenas $(8,2 \%)$ responderam que sim.

Gráfico 12: Nível de conhecimento proporcionado pelo curso sobre como atender às questões ambientais nas entidades.

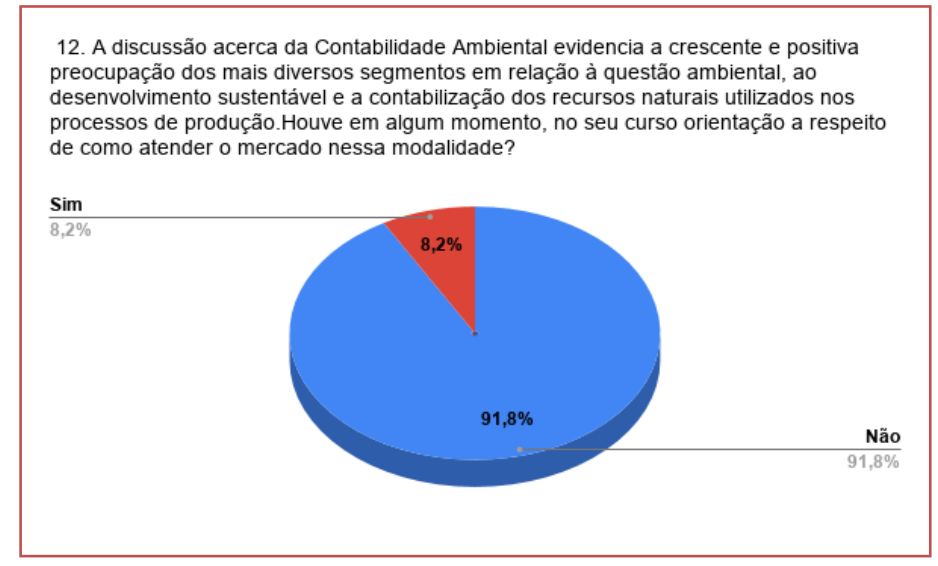

Fonte: Dados da pesquisa 2018

É crescente a discussão acerca da Contabilidade Ambiental, do desenvolvimento sustentável e da contabilização dos recursos naturais utilizados nos processos de produção. É possível verificar nessa análise que quase (100\%) dos respondentes informou que o curso não proporcionou em nenhum momento, orientação a respeito de como atender o mercado a respeito da gestão dos fatos ambientais.

No gráfico 13 o percentual de $(93,6 \%)$ dos respondentes marcaram a opção que não foi tratado no decorrer da graduação informação sobre a legislação ambiental e somente $(6,4 \%)$ responderam que o tema foi abordado

Gráfico 13: Indicação se a Legislação Ambiental foi abordada no curso.

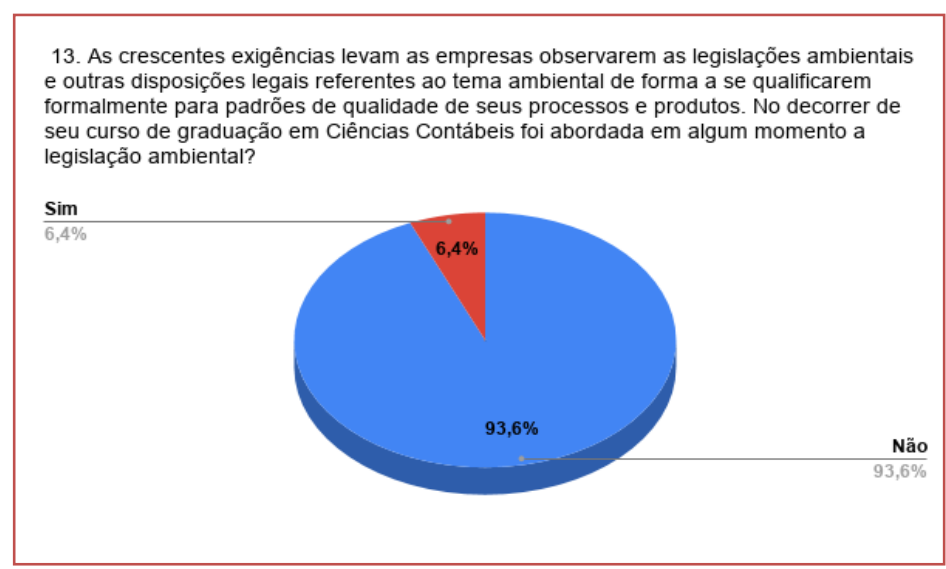

Fonte: Dados da pesquisa 2018

Considerando que a Legislação ambiental impõe várias normas e regras a serem seguidas pelas entidades, das quais inclusive depende seu funcionamento e liberação para operação é de suma importância a observação das Leis Ambientais, no entanto no gráfico13 foi demonstrado que $(93,6 \%)$ dos respondentes 
marcaram que não obtiveram no decorrer da graduação informação sobre a legislação ambiental e apenas $(6,4 \%)$ responderam que o assunto foi abordado.

A questão 14 do questionário foi aberta e buscou a opinião dos alunos sobre a forma que a Universidade deve se posicionar a respeito da inserção da contabilidade ambiental como disciplina no curso de Ciências Contábeis da UFAL, considerando que a responsabilidade ambiental passou a ser foco de preocupação e análise dos contadores, fazendo com que se torne essencial a inserção da Contabilidade ambiental no currículo do curso de Ciências Contábeis, pois conforme enfatiza Calixto (2006, p 66) "tendo em vista que a percepção de que só por meio da evolução de conceitos, discussão em sala de aula e do aprendizado teórico, a contabilidade dará um grande salto de qualidade".

A Lei Federal n 9.795 de 1999, evidencia a educação Ambiental como "um componente essencial e permanente da educação nacional, devendo estar presente, de forma articulada, em todos os níveis e modalidades do processo educativo, em caráter formal e não formal". Dentre as respostas obtidas vários respondentes consideram importante a inserção da disciplina na matriz curricular do curso, onde responderam que seria um diferencial para os futuros profissionais, alguns opinaram que universidade deveria avaliar o grau de necessidade dessa matéria na graduação, outros acham que a matriz curricular atual não atende às práticas da atualidade contábil. Uma das respostas enfatizou que Inserir a disciplina de Contabilidade Ambiental é dar um salto na qualidade do curso e no aprendizado de alunos e professores, salientando que por ser uma área nova e promissora, deve ser explorada. Por ser uma área de atuação na Contabilidade, deve ter seu espaço como disciplina, assim como Custos, Controladoria, Auditoria, comercial, entre outras.

\section{CONCLUSÃO}

O desenvolvimento dessa pesquisa possibilitou a análise da opinião dos graduandos sobre a importância de inserir a disciplina de contabilidade ambiental no curso de ciências contábeis da UFAL, devido a importância de obter na graduação uma base de conhecimento para atender esta ramificação da contabilidade, com conhecimento para gerir e elaborar demonstrações sobre os fatos ambientais, auxiliando às entidades a atender as exigências legais e sociais.

A partir dos resultados obtidos através da aplicação do questionário foi possível verificar que a grande maioria dos respondentes, ou seja, mais de (50\%) consideram importante a inserção da disciplina na matriz curricular do curso.

$\mathrm{Na}$ análise dos dados concluiu-se que a maior parte dos graduandos não tem conhecimento acerca dessa área da contabilidade. Houve a sugestão de utilização do método de abordagem prático e teórico sobre a disciplina em questão.

Também foi considerado um diferencial diante do mercado atual o conhecimento na área de contabilidade ambiental, pois de acordo com os resultados alcançados, é de suma importância concluir a graduação preparado para atender as necessidades das entidades, ou seja, as demandas do mercado.

Os alunos demonstraram bastante interesse pelo tema em questão e a maior parte deixou claro que não obteve conhecimento nessa área através do curso e consideram necessária a inserção dessa disciplina no curso, o que evidencia que o objetivo proposto foi alcançado.

Ao conferir as respostas ficou claro que para a maior parte dos graduandos é necessário obter conhecimento na área ambiental ainda na graduação, para que seja possível ao concluir o curso atender às exigências de um mercado cada vez mais exigente.

Diante dos resultados atingidos foi constatada a importância do tema, dessa forma torna-se necessário o desenvolvimento de novas pesquisas a respeito do nível de conhecimento dos docentes nessa área, bem como a criação de projetos que visem à educação continuada dos professores para que os mesmos estejam habilitados a atender os temas atuais e importantes, com o intuito de proporcionar aos discentes o conhecimento essencial que é exigido atualmente dos profissionais da área.

A partir dos resultados da pesquisa foi possível identificar que o objetivo geral foi alcançado e através dessa proposta foi sugerida a inserção do tema de contabilidade ambiental como disciplina na matriz curricular do curso de ciências contábeis da UFAL, o que proporcionará aos graduandos uma melhor capacitação profissional para atender as obrigações da contabilidade e às necessidades das Entidades. 


\section{REFERÊNCIAS}

[1] ABRAHÃO, Jorge. 15 anos de Pacto Global: um balanço. Ethos, Nova York, 29 jun. 2015. Disponível em: <https://www3.ethos.org.br/cedoc/ethos-agenda-global_15-anos-de-pacto-global-um-balanco/>. Acesso em: 10 de agosto de 2018.

[2] ARAÚJO, G. F. Estratégias de Sustentabilidade: aspectos científicos, sociais e legais: contexto global: visão comparativa. 1. ed. São Paulo: Letras Jurídicas, 2008.

[3] Brasil, Lei Complementar n. 101, de 04 de maio de 2000: Estabelece normas de finanças públicas voltadas para a responsabilidade na gestão fiscal e dá outras providências. Disponível em: <http://www.planalto.gov.br>. Acesso em: 15 jun. 2009.

[4] CALIXTO, L. O ensino da contabilidade ambiental nas universidades brasileiras: um estudo exploratório. Revista Universo Contábil, v. 2, n. 3, p. 65-78, 2006.

[5] CARVALHO, Gardênia Maria Braga de. Contabilidade Ambiental - Teoria e Prática. 2. ed. Curitiba: Jaraguá Editora, 2009.

[6] CERTIFICAÇÃO ISO. ISO 14001: sistema de gestão ambiental. Disponível em: <https://certificacaoiso.com.br/iso-14001/>. Acesso em 17 de Agosto de 2018.

[7] CONFERÊNCIA DAS NAÇÕES UNIDAS SOBRE O MEIO AMBIENTE E DESENVOLVIMENTO. 56., 1992,Rio de Janeiro. Conferência das Nações Unidas sobre o Meio Ambiente e Desenvolvimento: de acordo com a Resolução $n^{\circ}$ 44/228 da Assembleia Geral da ONU, de 22-12-89, estabelece uma abordagem equilibrada e integrada das questões relativas a meio ambiente e desenvolvimento: a Agenda 21. Brasília: Câmara dos Deputados, Coordenação de Publicações, 1995. Disponível em: <http://www.onu.org.br/rio20/img/2012/01/agenda21.pdf>. Acesso em 12 de Julho de 2018.

[8] CONSELHO FEDERAL DE CONTABILIDADE. Aprova a NBC T 15 - informações de natureza social e ambiental. Resolução n. 1.003, de $19 \quad$ de $\quad$ agosto $\quad$ de $2004 . \quad$ Disponível em:<http://www.cfc.org.br/sisweb/sre/docs/RES_1003.doc>. Acesso em: 29 mai. 2009.

[9] COSTA, C.A.G. Contabilidade Ambiental: Mensuração, evidenciação e transparência. - São Paulo: Atlas, 2012.

[10] CRUZ, Flávio da et al. Lei de responsabilidade fiscal comentada: Lei Complementar $n^{\circ} 101$, de 04 de maio de 2000. 2. ed. São Paulo: Atlas, 2001.

[11] ETHOS, Instituto. Introdução ao balanço $\quad$ social. em:<http://www.ethos.org.br/docs/conceitos_praticas/guia_relatorio/default.htm>. Acesso em 19 de julho.

[12] FARIA, Caroline. Passivo Ambiental. Disponível em: <http://www.infoescola.com/ecologia/passivoambiental>. Acesso em 2 de Junho.

[13] Ferreira, Aracéli Cristina de Sousa et al. Contabilidade Ambiental e Relatórios Sociais. 2. ed. São Paulo: Atlas, 2012.

[14] FERREIRA, Aracéli Cristina de Sousa. Contabilidade Ambiental: uma informação para o desenvolvimento sustentável. 2. ed. São Paulo: Atlas, 2006.

[15] GIL, A. C. Métodos e Técnicas de Pesquisa Social. 5.ed. São Paulo: Atlas, 1999.

[16] HERCKERT, W. 0 patrimônio e 0 desenvolvimento sustentável. $2008 . \quad$ Disponível em:<https://brasilescola.uol.com.br/geografia/o-patrimonio-desenvolvimento-sustentavel.htm>. Acesso em 20 de Julho de 2018.

[17] IUDÍCIBUS, Sérgio de \& MARION, José Carlos. Introdução à Teoria da Contabilidade. 2. ed., São Paulo: Atlas,2000.

[18] IUDÍCIBUS, Sérgio de et al. Manual de contabilidade societária: aplicável a todas as sociedades de acordo com as normas internacionais e do CPC. 2. ed. São Paulo: Atlas, 2010.

[19] LEITE, Marcelo. Há 25 anos ECO-92 tentava convencer o mundo a se salvar. Folha, São Paulo, 02 jun. 2017. Disponível em: <https://www1.folha.uol.com.br/ambiente/2017/06/1889596-ha-25-anos-eco-92-tentavaconvencer-o-mundo-a-se-salvar.shtml>. Acesso em 17 de agosto de 2018.

[20] LEITE, Mauro. Passivo Ambiental. Disponível em: <http://www.marsh.com.br/auto.cfm?myurl=marsh/Passivo\%20Ambiental.cfm>. Acesso em 10 junho de 2018.

[21] MACHADO, Paulo Affonso Leme. Direito Ambiental Brasileiro. 17. ed. São Paulo: Malheiros, 2009.

[22] MINISTÉRIO DO MEIO AMBIENTE. Legislação Básica. Disponível em: <http://www.mma.gov.br/estruturas/secex_conjur/_arquivos/108_12082008084425.pdf>. Acesso em 26 de Maio de 2018. 
[23] PINHEIRO, V. A. A.; BOSCOV, C. P. Análise de informações por segmento das empresas premiadas pelo Troféu Transparência ANEFAC/FIPECAFI/SERASA 2013. Contexto, v. 15, n. 29, p. 96-112, 2015.

[24] REVISTA DE CONTABILIDADE E FINANÇAS. Contabilidade ambiental: um estudo sobre sua aplicabilidade em empresas brasileiras. Disponível em: <http://www.scielo.br/scielo.php?script=sci_arttext\&pid=S151970772001000300007>. Acesso 12 de julho.

[25] RIBEIRO, Maísa de Sousa. Contabilidade Ambiental. 1. ed. São Paulo: Saraiva, 2006. p. 17, p. 24.

[26] RIBEIRO, MAISA DE SOUZA, GRATÃO, ÂNGELA DENISE. Custos Ambientais - o caso das empresas distribuidoras de combustíveis. Trabalho apresentado no VII Congresso Brasileiro de Custos, recife - PE - 28/07 a 04/08/00.

[27] SANDRONI, Paulo. Novíssimo Dicionário de Economia. 1. ed. São Paulo: Best Seller, 1999.

[28] SANTOS, A. D. O.; SILVA, F. B. D.; SOUZA, S. D.; SOUSA, M. F. R. D. Contabilidade ambiental: um estudo sobre sua aplicabilidade em empresas brasileiras. Revista Contabilidade \& Finanças, v. 12, n. 27, p. 89-99, 2001.

[29] SANTOS, Antônio Raimundo dos. Metodologia científica a construção do conhecimento. Rio de Janeiro: DP\&A, 1999.

[30] SILVA, M. D. O. P.; Callado, A. A. C. Análise de modelos de balancedscorecard elaborados a partir da ótica da sustentabilidade através do uso da matriz SWOT. Revista de Administração, contabilidade e sustentabilidade, 2013, v. 3, n.4, pp. 87-103.

[31] SILVA, M. D. O. P.; CALLADO, A. A. C. Análise de modelos de balancedscorecard elaborados a partir da ótica da sustentabilidade através do uso da matriz SWOT. Revista de Administração, Contabilidade e Sustentabilidade, v. 3 n. 4 , p. 87-103, 2013.

[32] TAYLOR, Robert. Balanço social: instrumental de avaliação de desempenho e correção do planejamento social na vida da empresa. In: GONÇALVES, Ernesto Lima (Org.). Balanço social da empresa na América Latina. São Paulo: Pioneira, 1980.

[33] TINOCO, João Eduardo P.; KRAEMER, Maria Elizabeth P. Contabilidade e Gestão Ambiental. São Paulo: Atlas, 2004.

[34] TINOCO, João Eduardo Prudêncio e Kraemer, Maria Elisabeth Pereira. Contabilidade e Gestão ambiental (Edição Atualizada de acordo com as Leis nos 11.638, de 28-12-2007, e 11.941, de 27-5-2009). 3. ed. São Paulo: Atlas, 2011.

[35] VERGARA, Sylvia C. Projetos e Relatórios de Pesquisa em Administração. 3.ed. Rio de Janeiro: Atlas, 2000. 


\section{Capítulo 16}

Implantação de processo automático de soldagem (ASM - Auto Soldering Machine)

\section{Sandro Breval Santiago \\ Eduardo Luiz de Oliveira \\ Jonathan Oliveira Dias}

Resumo: Este artigo tem o objetivo de demonstrar o impacto da automação - via robô na operação de soldagem, em processo fabril de componentes eletroeletrônicos, situado no Polo Industrial de Manaus. 0 procedimento adotado foi a pesquisa experimental e estudo de caso, com pesquisa documental e bibliográfica com viés exploratório, com mapeamento da variabilidade utilizando modelo de análise bivariada. Os resultados apontam um elevado grau de efetividade do manipulador robótico, comparativamente à operação manual, com base nas variáveis analisadas como tempo de solda, total de solda aplicada, velocidade do dispensador e temperatura, como também total aderência aos padrões de qualidade. 


\section{INTRODUÇÃO}

Com a expansão no uso de máquinas na indústria, principalmente após a revolução industrial, o aumento da capacidade de produção continua a expandir junto com a inovação tecnológica. Para Romano (2002) as máquinas são capazes de ajudar a automatizar o processo de manufatura, e desta forma, representam boa parte deste "aumento" de produção da indústria.

O uso de robôs em aplicações industriais tem uma curva flexiva positiva nos últimos anos. Os robôs tiveram uma popularização, não somente nas grandes indústrias , mas têm se disseminado em diferentes ramos e aplicações industriais. Porém, em muitos casos, o potencial de um robô aplicado a um processo não é completamente utilizado, devido à sua programação não permitir que o seu desempenho seja otimizado(WU et al, 2000; ÇAKIR et al, 2006).

Segundo Assis e Coelho (2009), a robótica é a tecnologia que está relacionada com o desenvolvimento de robôs ou dispositivos robóticos, um conceito multidisciplinar e altamente ativa, possibilitando a integração de diversas técnicas para a elaboração de equipamentos.

Dentre os robôs utilizados os principais setores são aqueles que desenvolvema soldagem. 0 foco em aumentar a lucratividade leva as empresas, a buscarem a minimização d oscustos de produção, evitando perdas, principalmente em áreas como a soldagem, nas quais a degradação dos materiais é elevada (PICANÇO, 2010).

Na situação do mercado atual, e com concorrência crescente aumenta a necessidade de as empresas a busca por competitividade em seu ramo de atuação. Tal fato leva as empresas buscarem a melhoria contínua de seu processo produtivo e a redução de custos passa a ser uma prioridade para a manutenção de seu mercado (SLACK e LEWIS, 2003).

Portanto, A redução de custos deve ser uma prioridade para empresas que buscam tal sobrevivência no mercado. Em períodos de crescimento econômico com demandas elevadas pode se conseguir custos mais baixos com produção maior, porém em cenários de resseção com demandas menores e baixo crescimento existe uma dificuldade maior em trabalhar com redução de custos (OHNO, 1997).

Neste sentido, o presente artigo objetiva demonstrar o impacto da automação - via robô - no processo de soldagem, em processo fabril de componentes eletroeletrônicos, no qual será demonstrado o referencial teórico, a metodologia empregada contemplando os materiais e métodos utilizados, e por conseguinte os resultados da referida implantação.

\section{REFERENCIAL TEÓRICO}

\subsection{MANIPULADORES ROBÓTICOS}

A pesquisa na indústria tem sido direcionada na criação detécnicas de automação que aplicadas em lotes de produção de pequeno e médio porte produzamresultados adequados do ponto de vista custo-benefício e flexibilidade, culminando com o desenvolvimentodas máquinas CNC, Sistemas Flexíveis de Manufatura (FMS), Robôs Móveis (AGV's) e braçosmanipuladores.

O desenvolvimento deste último grupo, tem particular importância, pela complexidadeintrínseca envolvida no desenvolvimento da habilidade de emular o comportamento da cadeia deligamentos do braço manipulador de forma a replicar os movimentos do braço humano. Existem diversas tipologias de robôs industriais e cada um desses orientados para uma atividade específica, podendo realizar tarefas específicas com precisão, racionalidade e alta produção. Esses tipos de robôs surgem por meio de combinações de mecanismos e elos para se obter a configuração angular e funcional desejada.

Robôs de coordenadas Cartesianas são dotados de três articulações deslizantes conhecidas como PPP. Esses robôs são caracterizados principalmente por sua pe-quena área de trabalho, e por possuírem um alto grau de rigidez mecânica. Além disso, esse tipo de manipulador possui grande exatidão na localização do atuador (ROSÀRIO, 2005).

São inúmeras as vantagens de um manipulador robótico quando de sua utilização na indústria, portanto, a implementação deste tipo de robô torna-se essencial pela sua capacidade de flexibilidade de operação, inteligência, e processamento de informações, possibilitando a redução de custos, mitigando acidentes, e com alto grau de precisão. As características apresentadas pelos manipuladores robóticos podem ser usadas em conjunto para substituir o trabalho do homem, em locais com dificuldades ambientais ou trabalhos repetitivos (CAMPBELL et al., 2008). 
Segundo Souza (2001), dentre as indústrias que já utilizam manipuladores robóticos, pode-se citar a do setor automobilístico, onde empregam um maior grau de uso dessa tecnologia, empregados em todo arranjo produtivo, tanto as montadoras quanto as fabricantes de autopeças. As principais funções desses robôs nessas indústrias são a de soldar, cortar, perfurar, moldar, forjar, pintar, apertar parafusos, transportar peças, entre outros, com níveis de precisão e padronização excelentes.

Ainda em relação aos elementos físicos que compõem um manipulador robótico industrial, destacam-se os atuadores e os sensores. Os atuadores são os elementos que convertem algum tipo de energia em movimento mecânico, ou seja, são responsáveis pelos movimentos dos braços robóticos, podendo ser hidráulicos e pneumáticos e eletromagnéticos (CAMPBELL e COUTINHO, 2008; INÁCIO, 2009). Os primeiros são acionados por fluidos em movimento. Os hidráulicos são acionados por algum líquido enquanto os pneumáticos por ar comprimido. Já os atuadores eletromecânicos são principalmente motores que são acionados por energia elétrica, a exemplo de motores de passo, servomotores, motores de corrente contínua, entre outros (INÁCIO, 2009).

Um exemplo, o braço robótico (Groover, 1988) é composto pelo braço e punho. 0 braço consiste de elementos denominados elos unidos por juntas de movimento relativo, onde são acoplados os acionadores para realizarem estes movimentos individualmente, com capacidade sensorial, e controlados por um sistema de controle. 0 braço é fixado à base por um lado e ao punho pelo outro. 0 punho consiste de várias juntaspróximas entre si, unidas por elos compactos, que permitem a orientação do órgão terminal nas posições que correspondem à tarefa a ser realizada. Na extremidade do punho existe um órgão terminal (mão ou ferramenta) destinada a realizar a tarefa exigida pela aplicação. A Figura 1 mostra esquematicamente uma seqüência de elos e juntas de um braço robótico. Nos braços reais, a identificação dos elos e juntas nem sempre é fácil, em virtude da estrutura e de peças que cobrem as juntas para protegê-las no ambiente de trabalho.

Figura 1 -Exemplo de estilo para uma tabela

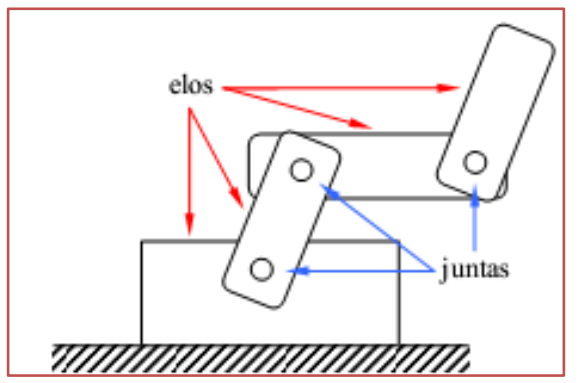

Fonte:INPE (2015)

Vale (2011) detalha que robôs manipuladores sobretudo são máquinas de posicionamento e que podem possuir inúmeros graus de liberdade, do qual a extremidade está fixada a ferramenta ou efetuador, mecanismo cuja finalidade é realizar o trabalho. Desta forma, elos oujuntas que compõem o robô determinam o grau de liberdade do conjunto, podendo elas serem de movimentos de translação (prismático) ou rotação (rotacional), sendo assim, um robô pode ser classificado pelo sentido dos movimentos e por sua alimentação.

Craig (1989) ainda afirma que manipuladores cartesianos são possivelmente a configuração mais simples de robôs, compostos de 1 a 3 juntas prismáticas, mutuamenteortogonais que correspondem aos vetores $\mathrm{X}$, Y e Z do plano cartesiano (Figura 2), o que garante que sua cinemática inversa seja trivial. Robôs deste tipo podem possuir uma estrutura muito forte, o que os permite serem muito grandes e ainda manipular desde ferramentas pequenas para manufatura até carros ou aeronaves inteiras. Haja vista que, outra vantagem é o fato de suas juntas serem independentes, o que os torna mais simples de projetar e não produz quaisquer singularidades em sua cinemática. 
Figura 2 -Robô cartesiano PPP

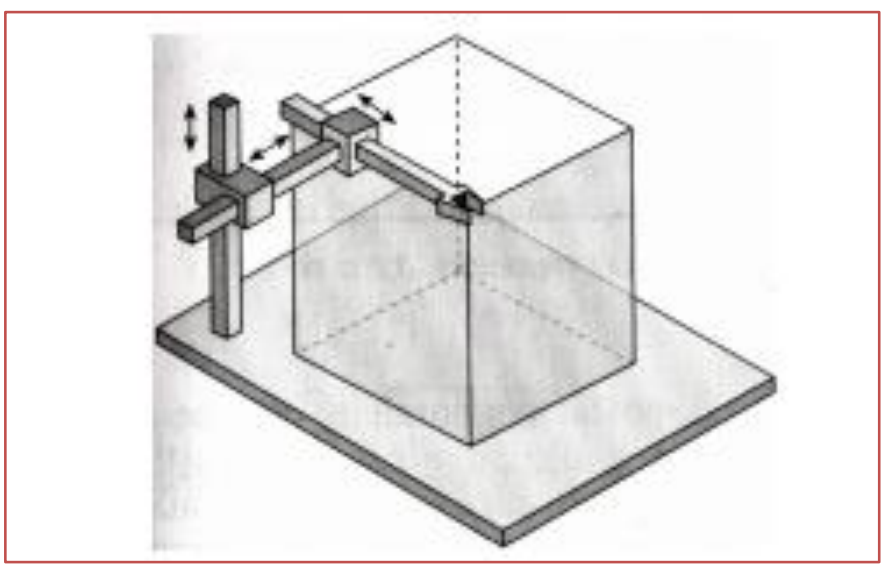

Fonte:Romano (2002, p.7)

O quadro 1, abaixo descrito, estão os principais elementos que formam um projeto de soldagem automático (Auto SolderingMachine- ASM), contemplados no projeto de automação desenvolvido.

Quadro 1 -Principais elementos do Auto SolderingMachine (ASM)

\begin{tabular}{|c|c|c|}
\hline Elemento & Características & Referencial \\
\hline $\begin{array}{l}\text { Manipulador } \\
\text { Robótico }\end{array}$ & $\begin{array}{l}\text { Na soldagem automatizada utiliza-se de programa, que quando } \\
\text { associado a um sistema de movimentação (motores de passo e seus } \\
\text { drivers de controle) pode ser capaz de movimentar-se em três } \\
\text { direções: longitudinal (x), transversal (y), e vertical (z), neste } \\
\text { projeto, especificamente utilizamos apenas dois eixos o x - executa } \\
\text { deslocamento no sentido dos pontos de soldagem, com alcance de } \\
300 \mathrm{~mm} \text { e o z - eixo que regula a distância entre o bico do ferro de } \\
\text { solda com os contatos do carregador, com alcance máximo de } 100 \\
\text { mm. A figura } 5 \text { mostra os eixos de um manipulador robótico. }\end{array}$ & $\begin{array}{l}\text { XIAO et al (2016); } \\
\text { ERAYA (2017) }\end{array}$ \\
\hline $\begin{array}{l}\text { Alimentadores } \\
\text { de solda }\end{array}$ & $\begin{array}{l}\text { Elemento microcontrolado capaz de ter controle das variáveis de } \\
\text { soldagem como velocidade de alimentação do arame de solda e } \\
\text { comprimento do arame de solda a ser depositado nos terminais dos } \\
\text { carregadores, este deslocamento é feito por } 2 \text { motores de passo, } \\
\text { controlados por um microcontrolador e atuantes por meio de seu } \\
\text { drive de controle. }\end{array}$ & ERDŐSet al (2016) \\
\hline $\begin{array}{c}\text { Esteira } \\
\text { Transportadora }\end{array}$ & $\begin{array}{l}\text { Esteira dotada de berços que levam os produtos para serem } \\
\text { soldados, após prévia fixação destes pelos operadores. A esteira } \\
\text { possui um servo motor que é um motor utilizado em processos } \\
\text { quando é necessário precisão em processos, uma vez que esta deve } \\
\text { parar constantemente para a realização de solda. }\end{array}$ & MOHSEN (2010) \\
\hline Sensores & $\begin{array}{l}\text { Dispositivos que servem para determinar o posicionamento das } \\
\text { peças a serem soldadas e garantir em conjunto com o servo o } \\
\text { posicionamento correto, para a realização de soldagem dos produtos. }\end{array}$ & $\begin{array}{l}\text { POLAJNAR et al } \\
\text { (1995); EDMONDSON } \\
\text { e REDFORD (2002); } \\
\text { HUNT (2007) }\end{array}$ \\
\hline $\begin{array}{l}\text { Controladores } \\
\text { (CLP) }\end{array}$ & $\begin{array}{l}\text { Elementos que quando previamente programados realizam a } \\
\text { automação da ASM, neste projeto foram utilizados um CLP, para } \\
\text { automação geral do processo, incluindo o sistema de segurança } \\
\text { conforme NR10 e NR12 que atua em conjunto com um } \\
\text { microcontrolador que movimenta os eixos do robô cartesiano e } \\
\text { também controlam a dispensação do arame de solda e } \\
\text { posteriormente soldam os chassis. }\end{array}$ & $\begin{array}{l}\text { SHANAHAN e } \\
\text { WITKOWSKI (2000); } \\
\text { BARKER e STUCKEY } \\
\text { (2003); }\end{array}$ \\
\hline
\end{tabular}

Fonte: os autores 


\subsection{SOLDAGEM}

O processo de soldagem consiste, segundo Machado (1996), na "união de dois materais através da fusão dos mesmos em íntimo contato; ou pela fusão de ambos e adição de outro material fundido; ou, ainda, simplesmente por contato destes materiais, nas fases sólida ou semissólida".

Segundo a AWS - American Welding Society, a soldagem está descrita como a Operação que visa obter a coalescêncialocalizada produzida pelo aquecimentoaté umatemperatura adequada, com ou sem a aplicação de pressãoe de metal de adição. De acordo com Marques, Modenesi e Bracarense (2009, p. 26), "atualmente, mais de 50 diferentes processos de soldagem têm utilização industrial e a soldagem é o mais importante método para a união permanente de metais". A quantidade de métodos se justifica pela necessidade de uma boa soldabilidade e pelo desenvolvimento de novos tipos de aços e outras ligas metálicas.

A soldagem é uma das aplicações onde comumente emprega-se robôs industriais, onde aproximadamente $25 \%$ desses robôs são empregados em diferentes aplicações de soldagem, de um outro lado, 33\% das aplicações de montagem de componentes são utilizadoss robôs industriais, e muito destes são empregados em indústrias automobilísticas e de eletrônica. (ROMANO, 2002).

Segundo ROMANO(2002), o processo de soldagem robotizado trouxe inúmeras mudanças na concepção da linha de produção, principalmente na área automobilística, pois a precisão e a produtividade aumentaram significativamente, sobretudo pela capacidade do robô de trabalhar em temperaturas extremas, possuir maior precisão na soldagem, operar durante várias semanas ininterruptamente e dentre outras vantagens que facilitam o processo de produção.

\section{METODOLOGIA}

Para Fachin (2003, p.123) a pesquisa é um procedimento intelectual em que o pesquisador tem como objetivo adquirir conhecimentos de forma empírica, de forma a buscar novas verdades sobre um fato (objeto, problema).

O presente trabalho foi realizado com o objetivo exploratório, com varredura bibliográfica e documental, visando identificar a problemática do estudo de caso, juntamente com entrevistas com pessoas capacitadas para analisar os resultados da operação de automação (GIL, 2008).Em relação aos procedimentos utilizados, pode ser classificado como uma pesquisa experimental, onde se determinou um objeto de estudo e todas as variáveis que poderiam influenciá-lo. Após as pesquisas e planejamentos, foi realizado o projeto e fabricação do dispositivo e, posteriormente, os testes.

E ainda, o estudo de caso que é definido como "um estudo empírico que investiga um fenômeno atual dentro de seu contesto de realidade, quando às fronteiras entre o fenômeno e o contexto não são claramente definidas, e no qual várias fontes de evidência são utilizada" (Yin, 2005, p.32).

Foi utilizado o estudo de caso, ainda que os casos únicos têm obstáculos, apresentam muitos limites para generalizações nas conclusões, dificultam o desenvolvimento de modelos e teorias a partir de um exclusivo caso (VOSS, TSIKRIKTSIS e FROHLICH, 2002), para a demonstração da otimização e impactos da automação no processo de soldagem.

\subsection{COLETA DE DADOS}

Dentro do processo de pesquisa, a coleta de dados deu-se através de entrevista semi-estruturada, ordenada pelo roteiro com foco à formulação questões afetas ao tema a ser investigado (TRIVIÑOS, 1987; MANZINI; BONATO, 2008).

Quanto às coletas de dados foi utilizando o instrumento de pesquisa - Entrevista - que de acordo com Miguel (2010) sugere, quando se tratar de roteiro de entrevista, verificar a pertinência de visitas à operação visando pormenorizar o fenômeno estudado. As visitas ocorreram na planta industrial da empresa localizada no Polo Industrial de Manaus. 


\subsection{MATERIAIS E MÉTODOS}

O processo consistiu em desenvolver uma solução para minimizar e/ou eliminar os pro-blemas referentes à solda manual de chassis, figura 3 , sendo estes problemas os mais frequen-tes: acumulo ou falta de solda nos terminais dos chassis e/ou solderball (esfera de solda).

A esfera de solda está diretamente relacionada com o vapor de ar ou água que escapa no processo de solda e se transforma em líquido, durante a soldagem. Se o vapor na solda escapar muito rápido, uma pequena quantidade de solda líquida será retirada da junta de solda, e uma bola de solda será formada quando ocorrer seu esfriamento.

Figura 3 -Processo Manual de Solda e exemplos de defeitos
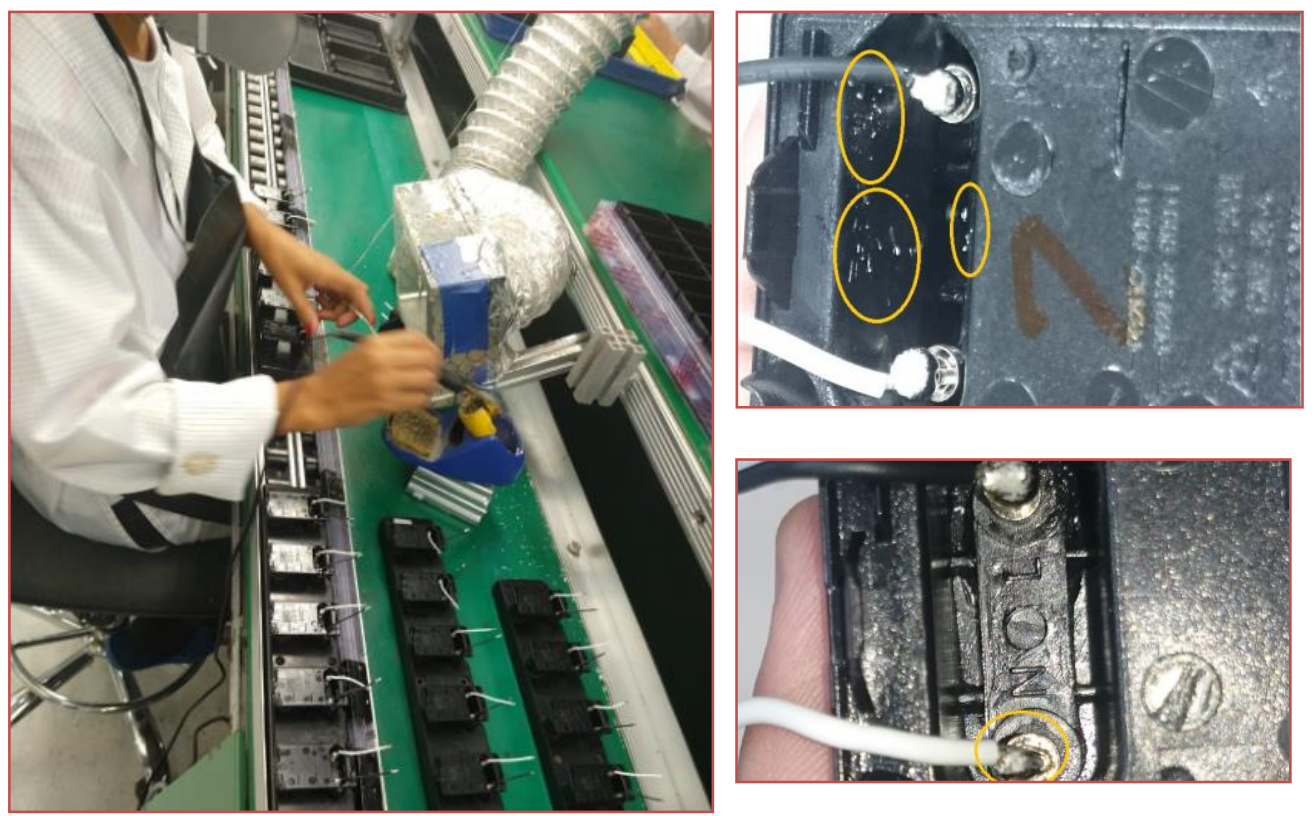

Fonte: Calcomp

Já o problema de acumulo ou falta de solda está relacionado diretamente ao manuseio inadequado do ferro de solda, pelo operador e também devido o processo manual não ter um controle na quantidade de injeção de solda nos terminais dos chassis, ocasionando assim um acumulo indevido de solda ou baixa quantidade de solda.

Com isso, constatou-se a necessidade de automatizar o processo de solda dos chassis, uma vez que o processo de solda manual, mesmo com intervenção e estudos preliminares dos Engenheiros e profissionais ligados diretamente a este processo, possui um índice de defeitos e retrabalhos maiores que $50 \%$ na sua produção.

Foi iniciado um processo de estudos envolvendo Engenharia Mecânica e Elétrica. Na equipe de Engenharia Elétrica, após estudo e verificação dos melhores modelos de automação de solda em processos, optou-se pela junção de características de quatro modelos de solda e estes foram adaptados, para garantir não somente qualidade ao processo como também maior agilidade e a possibilidade de ter um maior controle nos elementos envolvidos no processo de solda excetuando assim, os erros inerentes a solda manual.

As principais características dos modelos de solda utilizados neste projeto são:a)0 controle das variáveis de soldagem como velocidade de alimentação do arame de solda e controle de temperatura, elemento proveniente do modelo de soldagem semi-automática; e b) movimento relativo entre o ferro de solda e suas peças de trabalho é automático.

Onde optou-se pelos tipos de comando: manual (botoeira), por meio de IHM - (aplicação em uma tela (touchscreen), que facilita e torna mais eficiente a comunicação entre pessoas e máquinas), em um processo e por acesso remoto (Tablets ou Smartphones), onde comandos acionam os dispositivos de 
sequência da operação de solda e os consumíveis do processo, como o arame de solda, tem a mínima intervenção humana possível. A figura 4 mostra um diagrama típico de um sistema de solda automático.

Figura 4 - Diagrama típico de sistema de solda automático

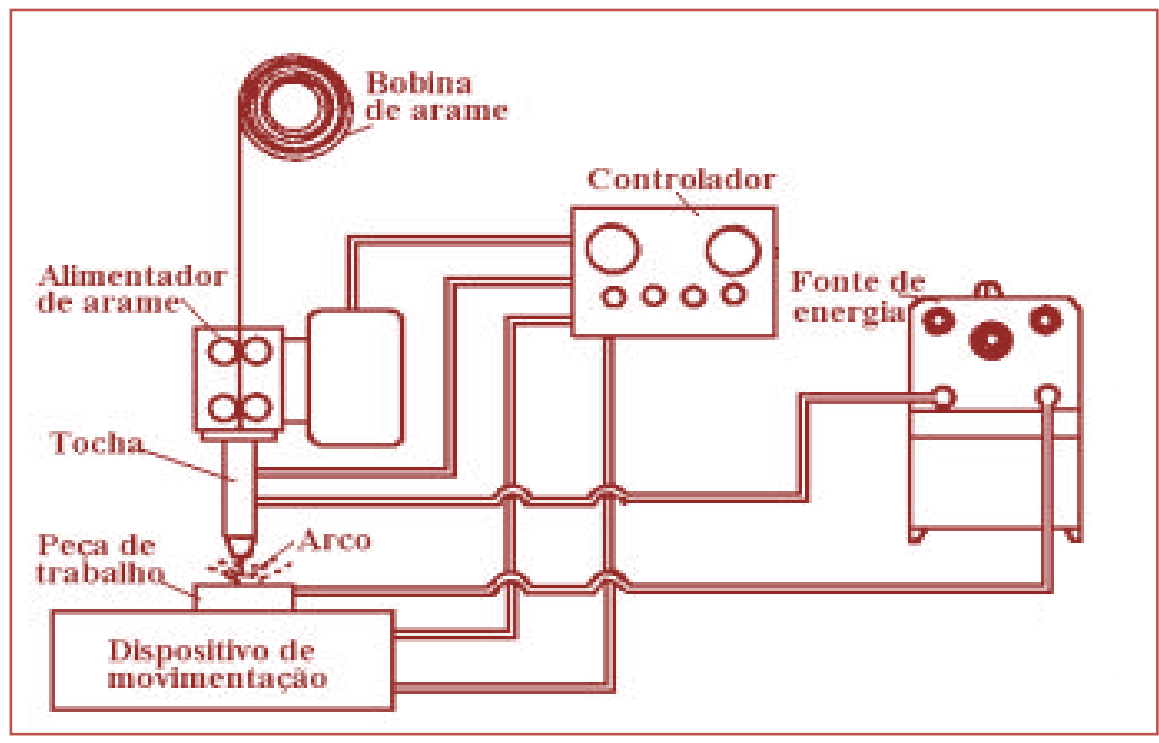

Fonte: Calcomp

A máquina de solda automática apresenta uma sequência de funcionamento e o que o operador deve fazer é passado por meio de uma IHM, que lhe informa todos os eventos realizados pela máquina e transmite a parte gestora do processo todas as atuações realizadas pela máquina em tempo real, como também seus dados de produção diária e cycle time.

A atuação humana no processo foi minimizada apenas para a inserção do produto a ser soldado e sua posterior retirada pós-processo de solda realizada, não tendo mais a ação humana no processo de soldagem. A figura 5representa a solução pronta de acordo com as normas legais de segurança e em perpectiva o IHM de controle.

Figura 5 - ASM
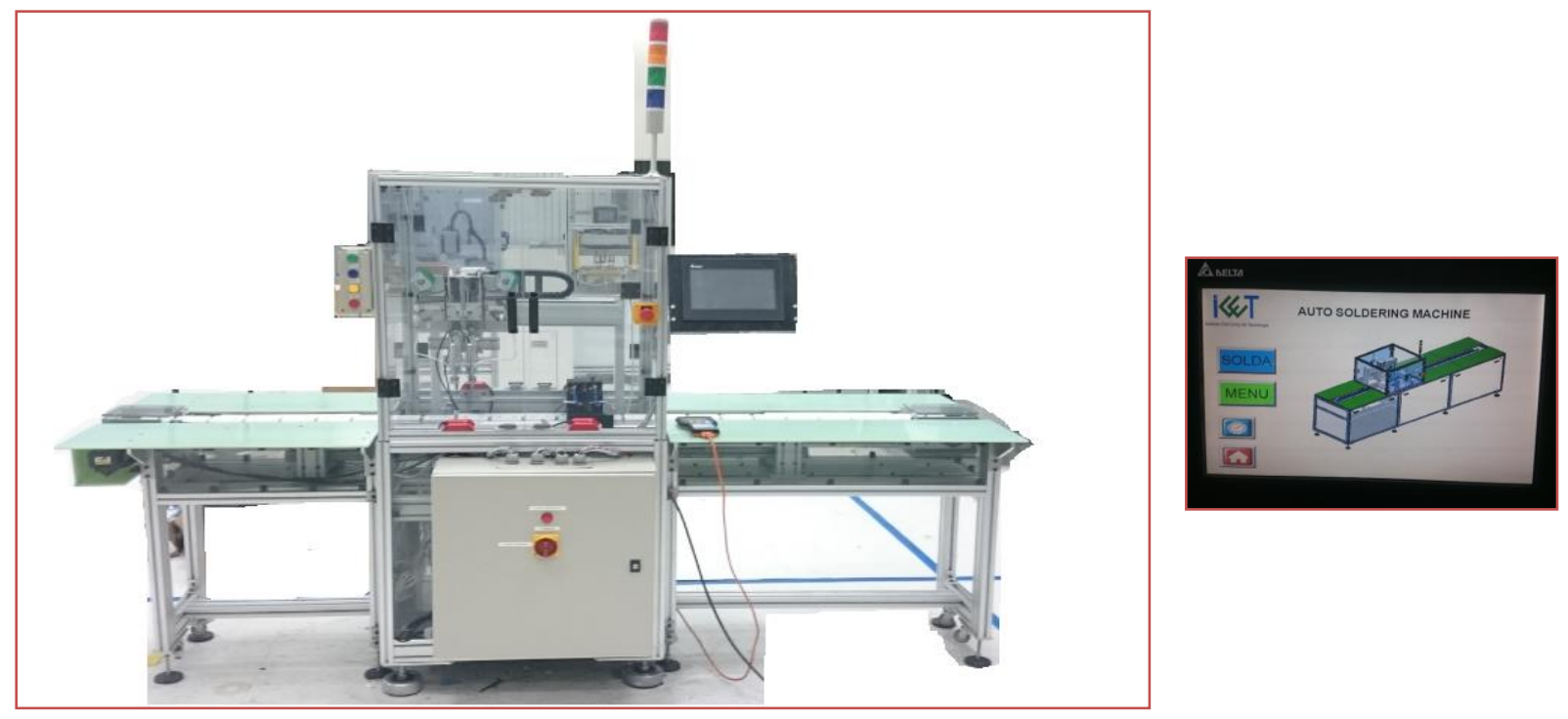
Após ligar a máquina o técnico de processo deve esperar o aquecimento dos ferros de solda e depois validar a temperatura, para isso este deve utilizar a IHM como guia e validar a temperatura após digitar uma senha alfanumérica e checar com equipamento apropriado os 2 ferros de solda.Os setups de soldagem da máquina resultantes do processo de otimização e testes (bico de $45^{\circ}$ )

Tabela 1 - Setups da máquina de soldagem

\begin{tabular}{|c|c|}
\hline Parâmetro & Configuração \\
\hline S01 - Tempo de solda & $2 \times 3,5$ (duas descidas), total de $7 \mathrm{~s}$ \\
\hline S02 - Total de solda aplicada & $2 \times 22 \mathrm{~mm}$, total de $44 \mathrm{~mm}$ de solda \\
\hline S03 - Velocidade do dispensador & $100 \mathrm{~mm} / \mathrm{s}$ \\
\hline S04 - Temperatura & \\
\hline
\end{tabular}

Com a aprovação da temperaturaoperacional , pelo técnico, a máquina está pronta para ir para a posição de Home, que é quando a máquina alinha o posicionamento da esteira (produtos nos berços), com os dois ferros de solda da máquina.A máquina após definida sua posição de origem, e pressionando o comando iniciar a máquina atua de modo automático, e solda os chassis conforme a figura 6.

Figura 6- Posição pré-operacional da ASM

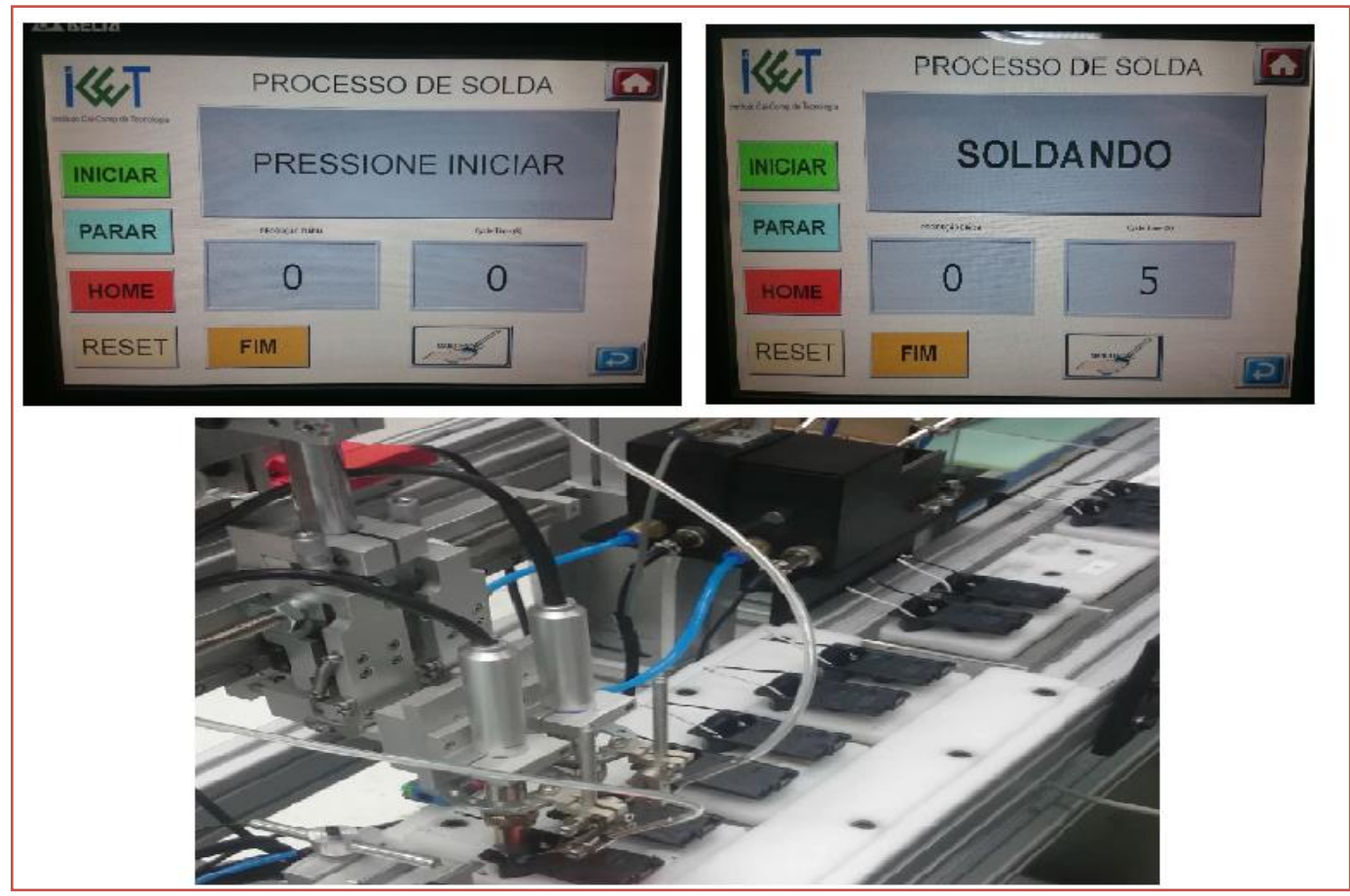

Fonte: Calcomp

\section{RESULTADOS}

A apuração dos dados relativos ao processo de otimização da máquina, demonstram sua entrada em regime de linha, na qual podemos identificar o balanceamento das variáveis (tempo de solda, total de solda aplicada, velocidade do dispensador e temperatura) com apuração das possíveis ocorrências de defeito. A tabela 2 ilustra os valores dos testes, de validação, da soldagem, considerando um período específico de operação. 
Tabela 2 - \% de Defeitos para Validação operacional

\begin{tabular}{|c|c|c|c|c|}
\hline Defeito mapeado & \multicolumn{4}{c}{ Períodos } \\
\hline & P1 & P2 & P3 & P4 \\
\hline Bola de solda & $21,61 \%$ & $0,77 \%$ & $0,00 \%$ & $1,35 \%$ \\
\hline Fio fora de posição & $0,00 \%$ & $0,77 \%$ & $1,01 \%$ & $0,00 \%$ \\
\hline Fio queimado & $1,69 \%$ & $0,00 \%$ & $0,00 \%$ & $0,00 \%$ \\
\hline Pouca solda & $68,22 \%$ & $61,54 \%$ & $15,15 \%$ & $9,46 \%$ \\
\hline Muita solda & $7,63 \%$ & $5,38 \%$ & $25,25 \%$ & $0,00 \%$ \\
\hline Fio crimpado (-) & $0,00 \%$ & $0,00 \%$ & $0,00 \%$ & $0,00 \%$ \\
\hline Resíduo Fio de solda & $0,00 \%$ & $0,00 \%$ & $13,13 \%$ & $0,00 \%$ \\
\hline
\end{tabular}

Fonte: Calcomp

Para fins de balizamento operacional, as 4 (quatro) variáveis de configuração foram utilizadas como base em análise bivariada, para fins de inferir possíveis restrições, e contrapartida às 7( sete) variáveis de defeito mapeadas. Para o referido mapeamento utilizou-se o coeficiente de Spearman que descreve a correlação entre os parâmetros e resultantes (positivas ou negativas). A tabela 3, a seguir demonstra tais relações onde têm-se $-1>\rho s>1$ nas quais o valor resultante escalar de 1 significa perfeita correlação e -1 com comportamento inverso.

Tabela 3 - Simulação - Coeficiente de Spearman entre as variáveis

\begin{tabular}{|c|c|c|c|c|}
\hline Variável Defeito & \multicolumn{5}{c|}{ Variável Parâmetro } \\
\hline & S01 & S02 & S03 & S04 \\
\hline Bola de solda & 0,02 & 0,44 & $-0,01$ & 0,58 \\
\hline Fio fora de posição & $-0,06$ & $-0,01$ & 0,00 & 0,00 \\
\hline Fio queimado & 0,04 & 0,03 & $-0,34$ & 0,19 \\
\hline Pouca solda & 0,01 & 0,00 & 0,00 & 0,00 \\
\hline Muita solda & $-0,26$ & 0,11 & 0,06 & 0,01 \\
\hline Fio crimpado (-) & 0,00 & 0,00 & 0,00 & $-0,03$ \\
\hline Resíduo Fio de solda & 0,00 & $-0,01$ & 0,03 & 0,09 \\
\hline
\end{tabular}

Fonte: Autores

O coeficiente de correlação de Spearman é o mais adequado para variáveis com escalas ordinais (HAIR JR. et al., 2005). 0 coeficiente de correlação não mede a relação causa e efeito entre as variáveis, apesarde essa relação poder estar presente (LAPPONI, 2005). 0 resultado esperado desta análise é verificar quais variáveis se relacionam com significância estatística e destas, indicara direção (positivo ou negativo) e a força daassociação (coeficiente de correlação e coeficiente de determinação).

\section{CONCLUSÕES}

Dentre os principais eixos conclusivos tem-se: 1) A viabilidade da implantação da automação no processo fabril de soldagem; e 2) A aderência de análise bivariada quanto à matriz de configuração e defeitos na otimização. Registre-se as limitações quanto ao levantamentos detalhados de testes, sobretudo quanto ao tamanho da amostra, bem como os critérios de avaliação da qualidade.

Portanto, no eixo 1, as evidências demonstram a efetividade de elaboração do modelo automatizado de soldagem (manipulador robótico), considerando as tecnologias de sensores, IHM e alimentação automática. 
E por fim, no eixo 2, indica que o uso da análise bivariada possibilitou a visualização das possíveis correlações entre as variáveis, inferindo questões importantes sobre os efeitos das combinações paramétricas da máquina.

\section{AGRADECIMENTOS}

Ao Instituto Cal-Comp de Tecnologia (ICCT) pelo apoio incondicional à elaboração desta pesquisa, juntamente com o seu corpo técnico e gerencial.

\section{REFERÊNCIAS}

[1] ASSIS, W. O.; COELHO A. D. Automação industrial e robótica. 2009.

[2] BARKER, Steve; STUCKEY, Peter J. Flexibleaccesscontrolpolicyspecificationwithconstraintlogicprogramming. ACM TransactionsonInformationand System Security (TISSEC), v. 6, n. 4, p. 501-546, 2003.

[3] ÇAKIR, M., BUTUN, E., KAYMAN, Y. Effectsofgeneticalgorithmparametersontrajectoryplanning for 6-DOF industrial robots.IndustrialRobot, Volume 33, issue 3, 2006, p 205-215.

[4] CAMPBELL, C.H; COUTINHO, C. Pinto, J. Desenvolvimento de um robô manipulador industrial. Associação Educacional Dom Bosco, Rio de Janeiro, 2008

[5] CRAIG, J. J. IntroductiontoRobotics. Ed. Addison-Wesley Publishing, Inc., 1989

[6] EDMONDSON, N. F.; REDFORD, A. H. Genericflexibleassembly system design. Assembly automation, v. 22, n. 2, p. 139-152, 2002.

[7] ERKAYA, Selcuk. Effectsof joint clearanceonmotionaccuracyofroboticmanipulators. J. Mech. Eng., in press. http://www. sv-jme. eu/article/effects-of-joint-clearance-on-motion-accuracy-of-robotic-manipulators, 2017.

[8] ERDŐS, Gábor et al. Processplanningand offline programming for roboticremote laser welding systems. InternationalJournalof Computer Integrated Manufacturing, v. 29, n. 12, p. 1287-1306, 2016.

[9] FACHIN, O. Fundamentos da metodologia. 3a ed. São Paulo: Saraiva, 2003.

[10] GIL, Antônio Carlos. Métodos e técnicas de pesquisa social. São Paulo: Atlas, 2008.

[11] GONÇALVES, Luzan Beiriz et al. Soldagem robótica aplicada a indústria automobilística: a evolução e processos adaptativos para o desenvolvimento do setor. Caderno de Graduação-Ciências Exatas e Tecnológicas-UNITALAGOAS, v. 1, n. 1, p. 85-98, 2014.

[12] GROOVER, M. P. Automation, Production, Systems, and Computer-IntegratedManufacturing.Ed. Prentice Hall, Inc., 1987.

[13] HAIR JR, J. F. et al. Análise Multi-Análise Multivariada de Dados variada de Dados. 2005.

[14] HUNT, James A. Automatedlampmanufacture. Assembly Automation, v. 27, n. 3, p. 190-197, 2007.

[15] INÁCIO, M.J. Sensores e Autuadores. FACIT, 2009

[16] LAPPONI, J. C. Estatística usando Excel. Rio de Janeiro:Elsevier, 2005.

[17] MANZINI, E.; BONATO, N. Considerações sobre a elaboração de roteiro para entrevista semi-estruturada. 2006. Marquezine: MC; Almeida, MA; Omote; S.(Orgs.) Colóquios sobre pesquisa em educação especial. Londrina: Eduel, p. 11-25, 2008.

[18] MARQUES, P.V.; MODENESE, P.J.; BRACARENSE, A.Q. Soldagem:fundamentos e tec-nologia. 3. ed. Belo Horizonte: UFMG, 2009.

[19] MIGUEL, P. A. C. Adoção do estudo de caso na engenharia de produção. Metodologia de pesquisa em engenharia de produção e gestão de operações. Rio de Janeiro: Elsevier, p. 131-148, 2010.

[20] MOHSEN; HASSAN, M. D. A framework for selectionof material handlingequipment in manufacturingandlogisticsfacilities. Journalof Manufacturing Technology Management, v. 21, n. 2, p. 246-268, 2010.

[21] OHNO, Taiichi. O sistema Toyota de produção além da produção. Bookman, 1997.

[22] POLAJNAR, Andrej; BUCHMEISTER, Borut; LEBER, Marjan. Analysisofdifferenttransportsolutions in theflexiblemanufacturingcellbyusingcomputersimulation. InternationalJournalofOperations\&Production Management, v. 15, n. 6, p. 51-58, 1995.

[23] PICANÇO, Maurício Luiz Gemaque. A robótica na indústria naval. 2010. 60f. Monografia apresentada a Faculdade de Engenharia Mecânica do Instituto Tecnológico na 
[24] Universidade Federal do Pará. Belém, 2010.

[25] ROMANO, V. F. Robótica industrial: aplicação na indústria de manufatura e de processos. Ed. Edgar Blucher Ltda, 2002, São Paulo, Brasil, 256 pp.

[26] ROSÁRIO, João Maurício. Princípios de mecatrônica. São Paulo: Prentice Hall, 2005.

[27] SHANAHAN, Murray; WITKOWSKI, Mark. High-levelrobotcontrolthroughlogic. In: International Workshop on Agent Theories, Architectures, andLanguages. Springer, Berlin, Heidelberg, 2000. p. 104-121.

[28] SLACK. N; LEWIS, M. OperationsStrategy. New Jersey: Prentice Hall, 2003.

[29] SOUZA, J. A. M. Robôs manipuladores na indústria. AGV's e LGV's na indústria. Máquinas CNC. 2001.

[30] TRIVIÑOS, A. N. S. Introdução à pesquisa em ciências sociais: A pesquisa qualitativa em educação. São paulo: Atlas, 1987.

[31] VALE, Valentina C. Controle de Posição de um Robô Cartesiano por meio de TécnicasAdaptativas. 2011.

[32] VOSS, C.; TSIKRIKTSIS, N.; FROHLICH, M. Case research in operations management.Internationaljournalofoperations\&production management, v. 22, n. 2, p. 195-219, 2002

[33] WU, L., CUI, K., CHEN, S.B. Redundancycoordinationofmultiplerobotic devices for weldingthroughgeneticalgorithm. National Key LaboratoryofAdvancedWeldingProduction Technology, Harbin Instituteof Technology, Harbin, Hei Longjiang (People'sRepublicof China), Robotica Volume 18, issue 6, 2000, p.669676.

[34] XIAO, Bing; YIN, Shen; KAYNAK, Okyay. Trackingcontrolofroboticmanipulatorswithuncertainkinematicsand dynamics. IEEE Transactionson Industrial Electronics, v. 63, n. 10, p. 6439-6449, 2016.

[35] YIN, R. K. Estudo de caso: Planejamento e métodos. 3a. edição, Porto Alegre. Bookman, 2005. 


\section{Capítulo 18}

\section{Estratégia como Prática na Produção do Desfile de}

uma Escola de Samba

\section{Ana Carolina Julio da Silva Andrade}

Resumo: As escolas de samba são organizações tipicamente brasileiras, cujo objetivo principal é desfilar no carnaval. Em um sentido amplo, o carnaval não significa apenas um festejo, mas toda sua preparação, que envolve um conjunto organizado de práticas estratégicas para que a escola consiga realizar sua apresentação na avenida. Nesse sentido, nosso objetivo é analisar a organização da prática do estrategizar na produção do desfile de uma escola de samba capixaba, mais especificamente no processo de produção dos carros alegóricos. Para tanto, utilizamos a perspectiva da estratégia como prática social, tendo como base as ideias de organização das práticas de Theodore Schatzki. Realizamos um estudo de caso qualitativo- descritivo, entre janeiro e fevereiro de 2015, por meio de observação não participante, entrevistas exploratórias e análise documental. Para a análise dos dados, utilizamos o procedimento de análise de conteúdo temático à posteriori. Os resultados indicam que a agremiação teve que lidar com uma série de problemas, à escassez de recursos principalmente, o que demandou dos praticantes criatividade no desenvolver da produção do carnaval. Concluímos que os entendimentos a respeito de como a prática do estrategizar acontece no carnaval atual foi fundamental para sua organização. Tendo em vista a valorização dos elementos visuais e estéticos, ter sensibilidade na escolha de cores, formatos e tamanhos se apresentou como um componente importante do estrategizar na produção das alegorias.

Palavras-chave: Estratégia Como Prática. Práticas Organizativas. Theodore Schatzki. Escola De Samba. Carnaval. 


\section{INTRODUÇÃO}

As escolas de samba são associações recreativas e musicais, tipicamente brasileiras, cujo objetivo principal é desfilar no carnaval (GOLDWASSER, 1975). Apesar da imagem de festa e falta de ordem ser comumente associada a essas agremiações por parte do senso comum, é interessante notar que uma escola de samba é capaz de produzir (durante todo um ano) e executar (por aproximadamente uma hora) um desfile organizado. 0 desfile carnavalesco é desenvolvido a partir da apresentação de alas ${ }^{\mathrm{I}}$ e carros alegóricos ${ }^{\mathrm{II}}$ em uma sequência lógica, de modo que seja possível contar uma história, o enredo da agremiação. Assim, em um sentido mais amplo, o carnaval não significa apenas um grande festejo, e sim "[...] toda a sua preparação, ao longo da qual um novo enredo transformar-se-á gradualmente em samba-enredo, em alegorias e em fantasias [...]" (CAVALCANTI, 1994, p. 15). Para que o desfile aconteça é necessário que muitas pessoas trabalhem intensamente ao longo do ano, fazendo com que a produção do desfile se defina a partir de um conjunto de práticas organizativas (TURETA; ARAÚJO, 2013) que ganha forma na avenida (VERGARA; MORAES; PALMEIRA, 1997).

Várias atividades são realizadas tendo em vista os objetivos da agremiação: disputar o título de campeã ou fazer uma apresentação que a mantenha no grupo especial, por exemplo. Muitas dessas atividades têm caráter estratégico e, por serem componentes do campo da prática (SCHATZKI, 2001), só podem ser entendidas a partir do cotidiano organizacional (JARZABKOWSKI, 2005). Nesse sentido, este trabalho se alinha ao movimento da prática que ganhou força nas décadas de 1970 e 1980, quando o debate entre teoria e prática tornou- se central nas ciências sociais e ocorreu uma "virada" em direção ao estudo da prática (SCHATZKI, 2001). Com isso, a ideia de que as organizações precisam ser analisadas como um processo emergente, composto por um conjunto de práticas que se encontram em constante estado de (re)constituição, resultado das interações sociais cotidianas, ganhou espaço (CZARNIAWSKA, 2004; SCHATZKI, 2006).

A virada para a prática influenciou as teorias sobre estratégia organizacional, surgindo nesse campo a abordagem da Estratégia como Prática Social (EPS) (WHITTINGTON; CAILLUET, 2008; JARZABKOWSKI; SPEE, 2009; GOLSORKHI et al., 2010; WHITTINGTON, 2011). Os trabalhos de EPS adotam diferentes perspectivas e autores da prática para analisar o estrategizar (strategizing), como a Teoria da Estruturação de Giddens (JARZABKOWSKI, 2008), a noção de capital, campus e habitus de Bourdieu (GOMEZ, 2010), a análise de discurso e poder de Foucault (KRONBERGER; CLEGG, 2011), a Teoria AtorRede (DENIS et al., 2011), etc. Apesar de apresentar uma abordagem interessante para o entendimento de como as práticas se organizam, as ideias de Theodore Schatzki foram pouco sistematizadas em termos empíricos (NICOLINI, 2013; SANTOS; SILVEIRA 2015) na análise do estrategizar. Para Schatzki (2005), as práticas são constituídas por um conjunto de atividades organizadas, em que os praticantes atuam em uma arena, na qual determinadas ações e fins são prescritos ou aceitáveis em determinadas situações, tendo cada prática uma forma própria de organização (SCHATZKI, 2002). Entender como o estrategizar se organiza passa a ser um aspecto relevante para o estudo da prática estratégica.

Diante disso, nosso objetivo é analisar a organização da prática do estrategizar na produção do desfile de uma escola de samba capixaba. Neste estudo, focamos o processo de produção dos carros alegóricos da agremiação. Para tal, a autora acompanhou a produção das alegorias, assim como o desfile carnavalesco da escola. A escolha do objeto escola de samba deve-se ao fato de o mesmo possuir características que são interessantes para o estudo da teoria da prática. Essas agremiações possuem características próprias: improviso, trabalho voluntário e fortes relações afetivas coexistem com planejamento, terceirização e contratação de profissionais especializados, o que cria a especificidade das escolas de samba (BLASS, 2007). Além disso, não há imposição rígida de objetivos, o que permite que uma escola possa se (re)inventar constantemente (VERGARA; MORAES; PALMEIRA, 1997).

Com o intuito de alcançar nosso objetivo, realizamos um estudo de caso qualitativo- descritivo, entre janeiro e fevereiro de 2015, por meio de observação não participante, entrevistas exploratórias e análise documental. Em relação à análise e interpretação dos dados, empregamos o procedimento de análise de conteúdo temático à posteriori (FRANCO, 2012; SONPAR; GOLDEN-BIDDLE, 2008).

Para realizar a discussão proposta, este trabalho está dividido nas seguintes sessões: Estratégia como prática, Organização das práticas, Metodologia, Apresentação dos resultados, Discussão dos resultados, Considerações finais e Referências. 


\section{ESTRATÉGIA COMO PRÁTICA}

A pesquisa em estratégia tem sido amplamente baseada na tradição microeconômica, que a considera como um processo top-down e deliberado (CARTER; CLEGG; KORNBERGER, 2010), tratando a estratégia como sinônimo de planejamento racional, uma propriedade das organizações, separando o pensar do agir e o planejamento da execução (WHITTINGTON, 2002; WILSON; JARZABKOWSKI, 2004; WHITTINGTON, 2006). Com a virada em direção ao estudo da prática, os estudos sobre estratégia assumiram um novo foco, interessando-se em compreender o processo de formulação, elaboração e implantação da estratégia (WHITTINGTON, 1996; WILSON; JARZABKOWSKI, 2004; JARZABKOWSKI; SPEE, 2009).

A abordagem da EPS trata a estratégia como um fenômeno social (JARZABKOWSKI; BALOGUN; SEIDL, 2007), um conjunto de atividades humanas organizadas (WHITTINGTON, 2007). O estrategizar compreende as interações e negociações dos múltiplos atores envolvidos (JARZABKOWSKI; BALOGUN; SEIDL, 2007). A estratégia, portanto, não é um atributo organizacional ou exclusiva da alta direção, sendo construída por todos e nas atividades cotidianas de uma organização (WHITTINGTON; CAILLUET, 2008; JARZABKOWSKI; SPEE, 2009; GOLSORKHI et al., 2010; CARTER; CLEGG; KORNBERGER, 2010; WHITTINGTON, 2011).

Todavia, como destacam Jarzabkowski, Balogun e Seidl (2007), o conceito de EPS abrange uma ampla gama de atividades, o que dificulta a compreensão do que é ou não estratégia. Diante disso, a estratégia pode ser definida como aquelas atividades que têm consequência para os resultados, orientação, sobrevivência e vantagem competitiva da organização, mesmo quando essas consequências não são parte de uma estratégia pretendida ou formalmente articulada (JARZABKOWSKI; BALOGUN; SEIDL, 2007; MANTERE, 2005).

O estrategizar envolve práticas, práxis e praticantes (WHITTINGTON, 2006). As práticas compreendem procedimentos internos e rotinas, bem como práticas setoriais que influenciam o estrategizar (WHITTINGTON, 2006). 0 estudo da práxis, por sua vez, foi a motivação original dos primeiros trabalhos da EPS (VAARA; WHITTINGTON, 2012). A práxis trata dos episódios (eventos ou atividades) que ocorrem durante todo o processo do estrategizar (JARZABKOWSKI; BALOGUN e SEIDL, 2007; VAARA; WHITTINGTON, 2012). 0 que os praticantes realmente fazem é a práxis da estratégia, desde a elaboração até a execução do estrategizar (WHITTINGTON, 2006). Pro fim, quanto ao praticante, a perspectiva da EPS trata de todos os atores sociais que estão envolvidos no estrategizar, considerando não somente $o$ alto escalão, ou os atores intra-organizacionais (VAARA; WHITTINGTON, 2012).

Chia e Mackay (2007) ressaltam que, ao lançar mão da lente da prática, os estudos que adotam a perspectiva da EPS deveriam se preocupar em definir o termo prática, guiando-se (teórica e empiricamente) por essa definição. Nesse sentido, este trabalho considera as contribuições de Schatzki em relação às práticas sociais e organizativas, articulando essa perspectiva com a EPS.

\section{A ORGANIZAÇÃO DAS PRÁTICAS}

Apesar de Schatzki ser um dos principais autores no campo da teoria da prática, seus trabalhos carecem de aplicação empírica e aprofundamento teórico (SANTOS, 2014; NICOLINI, 2013), o que evidencia uma lacuna de estudos. No Brasil, as ideias de Schatzki têm sido usadas na análise das práticas organizacionais ainda de forma emergente (ver SANTOS; SILVEIRA, 2015; SANTOS, 2014; OLIVEIRA; CAVEDON, 2013; TURETA, 2011). 0 termo prática social vai além da simples descrição da ação humana, referindo-se a um conjunto de ações corporais de fazer e dizer. As práticas são um conjunto de múltiplas ações situadas no tempo e no espaço, ou seja, em um dado contexto (SCHATZKI, 2001). Não há fronteiras rígidas separando as práticas, uma vez já que as mesmas estão em constante mudança, sendo abertas e melhor compreendidas através de seu dinamismo. Assim, as práticas podem se sobrepor. Ou seja, uma ação pode pertencer a mais de uma prática. Além disso, as práticas também incluem atividades irregulares, únicas e que estão em constante mudança (SCHATZKI, 2003).

Um conceito importante de Schatzki é a inteligibilidade das práticas, responsável por organizar a ação dos praticantes e as práticas sociais, que são inteligíveis por serem dotadas de finalidade (NICOLINI, 2013; SCHATZKI, 2002). Assim, a ação humana é guiada por um senso de propósito (NICOLINI, 2013; SCHATZKI, 2002). A prática seria, então, uma malha de múltiplas ações organizadas e arranjos materiais. A organização dessas práticas, por sua vez, se dá em torno de três dimensões: entendimentos, regras e estrutura teleo-afetiva (SCHATZKI, 2002 e 2005). 
0 entendimento da prática refere-se ao know-how, a habilidade de um praticante realizar atividades que compõem determinada prática, assim como a capacidade de esse praticante entender essa prática (que por sua vez, é dotada de significado e propósito para o praticante). 0 entendimento da prática é social, é compartilhado pelos praticantes dessa prática, que concordam (ou seja, têm o mesmo julgamento), pelo menos tacitamente, em relação ao que faz sentido fazer (SCHATZKI, 2002).

As regras, por sua vez, dizem respeito às instruções e normas que são formuladas e prescritas (de forma mais ou menos explícita), estando, comumente, vinculadas a mecanismos de poder e autoridade, assim como a sanções (SCHATZKI, 2002). Vale ressaltar que as regras não são necessariamente a explicitação de um entendimento. As mesmas seriam melhor compreendidas como uma forma de codificação das regularidades das ações passadas, que podem ter uma força normativa e influenciar o curso das ações futuras, especificando como e quais ações devem ser executadas (SANTOS; SILVEIRA, 2015). As regras orientam a ação dos indivíduos, uma vez que os mesmos as levam em consideração para julgar o que faz ou não sentido fazer, o que convém ou é, ao menos, aceitável fazer (SCHATZKI, 2002).

Já a estrutura teleo-afetiva refere-se ao senso de propósito (fins e meios para se alcançar esse fim), uma complexa combinação de propósitos, emoções e humor dos indivíduos. Essa estrutura é aprendida pelos indivíduos no processo de socialização, sendo reforçada pela repetição das práticas e sanções (explícitas ou tácitas) (NICOLINI, 2013; SCHATZKI, 2002). Assim, o que faz sentido para uma pessoa fazer depende da estrutura teleo-afetiva, ou seja, dos fins que ela almeja e do que ela "sente" ao se engajar em uma prática (SCHATZKI, 2001).

\section{METODOLOGIA}

Com o intuito de alcançar o objetivo da pesquisa, utilizamos o método do estudo de caso qualitativodescritivo. Por meio do estudo de caso, é possível investigar um fenômeno social em seu contexto, preservando as características holísticas e os significados dos eventos da vida real (YIN, 2001). Na pesquisa social, o pesquisador lida com problemas de pesquisa que são caracterizados por sua complexidade, o que demanda uma variedade de métodos, devido ao caráter complementar dos instrumentos de coleta de dados (BAUER; GASKELL, 2002). Diante disso, realizou-se este estudo por meio de observação não participante, entrevistas exploratórias e análise documental. Ressalta-se que as notas apresentadas estarão em primeira pessoa para destacar a presença da pesquisadora no campo.

A coleta de dados foi realizada tomando como referência as observações de Schatzki (2006), que considera que as organizações são fenômenos sociais que acontecem, estando em constante estado de (re)constituição. Portanto, o pesquisador deve vivenciar seu acontecimento na medida em que ele se desdobra. A observação foi a principal forma de acesso às práticas empregadas na produção do desfile carnavalesco. A pesquisa de campo teve início no final de outubro de 2014 e término no início de fevereiro de 2015. 0 acesso ao campo se deu em outubro, no entanto, o acompanhamento da produção dos carros alegóricos ocorreu sistematicamente a partir de janeiro.

Para que a produção dos carros alegóricos pudesse ser analisada, a pesquisadora acompanhou o cotidiano da escola de samba em diferentes espaços organizacionais: barracão pesado (onde os carros alegóricos foram produzidos) e sambão do povo (local de realização do desfile). Ao longo de 34 dias foram realizadas 12 observações, totalizando 23 horas e 15 minutos, o que gerou 53 páginas escritas em Word, com fonte Times 12 e espaçamento simples.

As entrevistas exploratórias foram outra fonte de dados. Entre os meses de outubro de 2014 e janeiro de 2015 foram realizadas sete entrevistas, com duração média de 1 hora e 18 minutos. Os sujeitos de pesquisa foram selecionados de acordo com seu envolvimento na produção do desfile, uma vez que as entrevistas tinham o intuito de realizar um contato inicial com o campo e os integrantes da escola e tirar dúvidas sobre o objeto de estudo e a produção do desfile. Não havia um roteiro estruturado ou semiestruturado. Além disso, as entrevistas não foram gravadas, mas registradas em diários de campo e depois transcrito para o Word.

Os documentos coletados foram o regulamento do carnaval"II, a setorização do desfile carnavalesco ${ }^{\mathrm{IV}}$, o script do desfile ${ }^{\mathrm{V}}$ e resultado final da apuração do carnaval. Eles foram escolhidos porque contribuíam para o entendimento de como a prática estratégica na escola de samba se organiza formalmente.

Para preservar a identidade das pessoas e da agremiação, os nomes da escola de samba, da cidade homenageada no enredo e dos entrevistados foram omitidos. Identificaremos os entrevistados por letras, conforme o Quadro 1: 
Quadro 1 - Entrevistas exploratórias

\begin{tabular}{|c|c|c|}
\hline Entrevistado & Cargo/Função na escola & Duração da entrevista \\
\hline E1 & Diretora adjunta de carnaval & 2 horas \\
\hline E2 & Diretor de carnaval & 30 minutos \\
\hline E3 & Carnavalesco & 1 hora \\
\hline E4 & $\begin{array}{c}\text { Destaque do carro abre-alas } \\
\text { e Estilista }\end{array}$ & 1 hora \\
\hline E5 & Fornecedor do Rio de Janeiro & 2 horas e 30 minutos \\
\hline E6 & $\begin{array}{c}\text { Coreógrafos da comissão de frente e } \\
\text { Aderecistas }\end{array}$ & 50 minutos \\
\hline E7 & Estilista e ex-carnavalesco da escola & 1 hora e 20 minutos \\
\hline
\end{tabular}

Fonte: Elaborado pela autora

Em relação à análise dos dados, foi utilizado o procedimento de análise de conteúdo temático à posteriori (FRANCO, 2012; SONPAR; GOLDEN-BIDDLE, 2008). Procurou-se identificar quais foram as práticas estratégicas mais marcantes na produção dos carros alegóricos. Quatro categorias centrais emergiram dos dados, sendo que uma delas foi desagregada em subcategorias, conforme pode ser observado no Quadro 2. As categorias referem-se às práticas estratégicas, enquanto que as subcategorias descrevem atividades centrais em torno das quais a prática se desdobrou.

Quadro 2 - Categorias emergentes da análise dos dados

\begin{tabular}{|l|l|}
\hline Categorias & Subcategorias \\
\hline Carnavalizando o enredo & - \\
\hline Reutilizando materiais & Aproveitando a estrutura dos carros \\
\cline { 2 - 2 } & Reutilizando esculturas \\
\hline Contratando especialistas & - \\
\hline Jogando as regras do jogo & - \\
\hline
\end{tabular}

Fonte: Elaborado pela autora

No tópico a seguir serão apresentados os resultados da pesquisa, que foram organizados de acordo as categorias e subcategorias do quadro apresentado anteriormente.

\section{APRESENTACÃO DOS RESULTADOS}

\subsection{CARNAVALIZANDO 0 ENREDO}

Em 2015, o enredo da escola de samba tinha o seguinte título: "AlfaVII: sob o caminhos das águas, às suas ordens". De acordo com o script do desfile, o enredo de 2015 era uma homenagem a cidade Alfa, um dos municípios mais antigos do Estado, que completava 200 anos. Segundo a diretoria de carnaval e o carnavalesco, o enredo foi sugerido por um dos enredistas ${ }^{\mathrm{VIII}} \mathrm{e}$ escolhido pela presidência da agremiação no início do ciclo carnavalesco de 2014/2015, em abril de 2014. A homenagem à cidade feita no enredo era uma tentativa de patrocínio. Por isso, o enredo era chamado pela diretoria escola de "enredo caça níquel".

As escolas de samba da região metropolitana de Vitória/ES recebem uma ajuda de custo do governo do estado e da prefeitura de Vitória. Todavia, esse valor é pago na véspera ou até mesmo após o desfile. Com o intuito de amenizar essa situação, o governo do estado e a prefeitura disponibilizam cartas de créditos para as escolas da Grande Vitória. Com as cartas de crédito, as agremiações podem comprar apenas parte dos materiais necessários para a produção do desfile, uma vez que as cartas são aceitas somente em alguns estabelecimentos comerciais localizados na cidade do Rio de Janeiro/RJ. Além disso, essa ajuda de custo governamental não seria suficiente para cobrir todo o custo de produção de um desfile carnavalesco. Esses fatores levaram a escola de samba a optar por um enredo patrocinado. Por exemplo, na véspera do carnaval, uma única pena de faisão (considerada a pluma mais luxuosa do carnaval) pode custar até $\mathrm{R} \$ 89$. Uma fantasia de um destaque ${ }^{\mathrm{IX}}$ central de carro alegórico é composta por até duas mil penas de faisão, ou 
seja, cerca de R\$ 175 mil. Vale ressaltar que um carro alegórico não tem apenas um destaque central, contando também com cerca de 3 semi-destaques e 15 composições de carroX.

0 problema de um enredo patrocinado é que depois que a escola grava o samba- enredo não se pode voltar atrás, ou seja, mesmo que a escola não receba o dinheiro do patrocínio, não há como mudar o enredo.

\subsection{REUTILIZANDO MATERIAIS}

Até a véspera do desfile de Vitória/ES, a escola de samba em análise não havia recebido a ajuda de custo do governo do estado e da prefeitura. Além disso, a promessa de patrocínio por parte do prefeito da cidade homenageada também não havia se concretizado. Este parecia ser o "pior ano da escola" em função dos problemas financeiros. Diante desse cenário, a diretoria e o carnavalesco optaram por reduzir o número de alas e alterar o projeto dos carros alegóricos. Coube ao carnavalesco repensar as fantasias, a estrutura, as esculturas e os adereços dos carros alegóricos. Durante uma observação, por exemplo, o carnavalesco afirmou que:

"eu entro [no barracão pesadoxI] e começo olhar o que tem e o que dá pra aproveitar. Eles iam dá isso aqui tudo [esculturas] pros outros [outras agremiações]. Se dessem... Não ia ter nada aqui pra fazer... As escolas que eu trabalhei nunca tiveram dinheiro. Aí quando eu venho pra cá, que era uma [escola] que tinha dinheiro, não tem! (risos). Eles [a diretoria da escola] falaram bem assim: é por isso que a gente te contratou, a gente sabia que você ia conseguir fazer o carnaval sem dinheiro" (notas de campo).

Havia, ainda, uma grande preocupação por parte do carnavalesco em manter a interpretação do enredo. A história que seria contada na avenida não poderia ser alterada, ainda que a forma de contar essa história sofresse transformações. Essa preocupação existia pelo fato de a escola enviar antecipadamente o script do desfile à liga das escolas de samba, descrevendo a apresentação do desfile, assim como o que cada elemento do desfile (dentre eles os carros alegóricos) representaria. Para lidar com isso, dentro dessa prática estratégica ocorreram duas atividades centrais em torno das quais a produção dos carros alegóricos aconteceu: aproveitando a estrutura dos carros e reutilizando esculturas.

\subsubsection{APROVEITANDO A ESTRUTURA DOS CARROS ALEGÓRICOS}

Para que a produção das alegorias pudesse ser iniciada, a escola precisava comprar ferragem, madeira, isopor, cola, pregos, tintas e adereços (tecidos, pedrarias, passamanarias, etc.). Além disso, a mão-de-obra que executaria a produção dos carros alegóricos (ferreiros, escultores, pintores e aderecistas) também precisava ser contratada. Por conta da crise financeira, a agremiação precisou levantar recursos - com a bilheteria e a venda de bebidas dos ensaios, promovendo feijoadas e com seus integrantes, que doaram parte do material que seria usado na produção das alegorias - para obter materiais e contratar mão-deobra. Isso fez com que o barracão pesado fosse "aberto" apenas na segunda quinzena de janeiro de 2015, três semanas antes do desfile.

O carnavalesco e a diretoria de carnaval optaram, então, por reaproveitar a estrutura de ferro dos carros alegóricos do carnaval de 2014, fazendo apenas pequenas modificações. 0 projeto inicial dos quatro carros alegóricos do desfile de 2015, que havia sido feito pelo carnavalesco e estava representado em quatro maquetes de isopor, não foi seguido. Durante as três semanas em que os carros alegóricos foram produzidos, esse projeto foi modificado inúmeras vezes, sem que outras maquetes fossem feitas.

A produção do segundo carro alegórico, intitulado "Águas que abençoam e alimentam a fé", ilustra bem a atividade "aproveitando a estrutura dos carros alegóricos". Essa alegoria representava a igreja matriz da cidade de Itapemirim.

"Ao acompanhar o dia-a-dia do barracão identifiquei que um dos carros alegóricos de 2014 representava uma igreja, uma vez que o enredo daquele ano falava sobre uma cidade nordestina. Para o carnaval de 2015, a estrutura de ferro da igreja e dos altares seriam mantidas, representando a Igreja de Alfa. Dessa forma, boa parte da estrutura desse carro foi conservada, sem que a história a ser contada na avenida fosse modificada" (notas de campo).

A prática de aproveitar as estruturas das alegorias também foi observada na produção dos demais carros alegóricos de 2015. Alguns carros alegóricos tiveram sua estrutura inicial apenas complementada com mais ferragem soldada. Em outros casos, a estrutura de uma alegoria foi retirada e soldada em um segundo carro alegórico. Dessa forma, ambos os carros eram transformados por meio da reutilização de 
estruturas. Comparada à produção de novos carros alegóricos, a reutilização de estruturas já existentes é mais barata e rápida.

\subsubsection{REUTILIZANDO ESCULTURAS}

De acordo com o regulamento do carnaval 2015, não é permitido que uma agremiação empregue em seu desfile esculturas ou carros alegóricos já utilizados por ela mesma em desfiles anteriores. Todavia, diferentes escolas podem trocar esculturas, o que é uma prática comum entre as agremiações da Grande Vitória. Outra opção seria fazer uma "releitura" de esculturas já utilizadas, o que exige muita criatividade por parte do carnavalesco, habilidade por parte dos escultores e não é uma prática comum.

Diante da já mencionada crise financeira e há apenas 3 semana do desfile, reutilizar esculturas foi uma das atividades que orientou a produção dos carros alegóricos da agremiação. No barracão havia várias esculturas usadas em carnavais passados: cisnes negros, anjos cor de rosa, baianas, escravos, orixás e uma cabeça de coruja. Em outra ocasião, escultores trabalhavam, lixando peças de isopor e retirando as camadas de papelão e tinta que cobriam as esculturas usadas no carnaval de 2014.

"Foi muito interessante observar a produção do 20 carro alegórico, que representava a Igreja de Alfa. Todas as esculturas que estavam nesse carro foram retrabalhadas [...] Mas o que mais me encantou foi o processo de criação dos anjos azuis maiores [...]. Em 2014, o enredo da escola falava sobre a uma cidade nordestina e havia um carro com esculturas de orixás. Em 2015, esses mesmos orixás foram transformados em anjos. As pernas dos orixás deram lugar a uma saia, que foi adereçada com tecido azul. Os corpos dos orixás foram encaixados nessas saias. Os rostos das esculturas foram recortados, restando apenas suas cabeças. Novos rostos foram feitos [...] e encaixados nas cabeças dos orixás. Por fim, os orixás ganharam asas, espadas e foram pintados de azul" (notas de campo).

A reutilização de esculturas também foi observada na produção dos demais carros alegóricos da agremiação em análise. Houve troca de esculturas entre diferentes escolas, assim como outros exemplos de "releitura" de esculturas já utilizadas em carnavais anteriores. Quando comparada ao processo de esculpir novas esculturas, a reutilização (seja por meio de troca ou releitura de esculturas) é mais barata e rápida.

\subsection{CONTRATANDO ESPECIALISTAS}

Em relação à mão-de-obra contratada, uma das coisas mais interessantes na produção dos carros alegóricos foi a capacidade de execução do carnavalesco e das equipes que trabalhavam no barracão (soldadores, escultores, pintores e aderecistas). Em curtos intervalos de tempo (a cada dois dias) era possível perceber que os carros ficavam visivelmente diferentes (eram soldados, ganhavam novas estruturas, esculturas e adereços, eram pintados e iluminados, etc.).

"Enquanto eu observava o abre-alas, um dos soldadores percebeu que eu estava deslumbrada com os detalhes do carro. Ele se aproximou e me disse: "vai ganhando vida, né?!", referindo-se as transformações que eu visualizava durante a produção das alegorias. Além disso, na véspera do desfile tive a oportunidade de ir ao barracão duas vezes em um mesmo dia e pude perceber a mesma capacidade de execução. Em menos de três semanas, três carros alegóricos e três tripés ${ }^{\mathrm{XII}}$ foram produzidos" (notas de campo).

carnavalesco contar com duas grandes equipes especializadas e experientes contribuiu para essa capacidade de execução. Cada uma das equipes tinha, aproximadamente 15 profissionais; sendo uma formada por soldadores, escultores e pintores e a outra por aderecistas. Os soldadores eram profissionais capixabas, os escultores (que também eram pintores) eram da cidade de Parintins/AM, enquanto que a equipe de aderecistas era formada por profissionais do Rio de Janeiro/RJ e integrantes da comissão de frente. Em cada uma das duas equipes havia um coordenador, que recebia do carnavalesco as instruções gerais de como as alegorias deveriam ser produzidas. Os escultores também trabalhavam na "Festa do Boi de Parintins" e em outras escolas

de samba de São Paulo/SP e do Rio de Janeiro/RJ. Os aderecistas do Rio de Janeiro/RJ, por sua vez, também trabalhavam na escola de samba carioca "Beija-Flor". Os integrantes da comissão de frente também trabalhavam como aderecistas. Segundo um dos coreógrafos, a maioria dos membros da comissão começaram no Grupo de Acesso, em 2008. Do grupo de acesso, eles passaram para uma escola do Grupo B e depois para o Grupo Especial. Devido a falta de condições financeiras das agremiações, especialmente das do grupo de acesso, os integrantes da comissão aprenderam a fazer suas próprias fantasias, assim 
como as alegorias que usariam na coreografia da comissão de frente. Segundo um dos integrantes: "sempre sobra pra gente ajudar a fazer o que vamos usar na coreografia".

\subsection{JOGANDO AS REGRAS DO JOGO}

Havia um entendimento compartilhado por parte dos integrantes da agremiação de que seria difícil "brigar" pelo campeonato do carnaval 2015. Os integrantes da escola também relataram que, nos últimos anos, a disputa pelo carnaval estava cada vez mais acirrada, uma vez que uma escola poderia ganhar ou perder posições por décimos. Em 2014, a escola de samba objeto deste estudo ficou em 40 lugar na disputa, perdendo o 3o lugar por poucos décimos. Diante disso, a diretoria de carnaval se reuniu para analisar as notas de cada um dos dez quesitos de julgamentoXIII. "A gente fez uma análise das notas. Aí a gente percebeu: não podemos mais perder pontos em quesitos primordiais” (notas de campo).

A diretoria de carnaval e a presidência da escola decidiram que era necessário dar mais atenção a alguns quesitos de julgamento, contratando novos profissionais: carnavalesco (responsável pelos quesitos fantasia e alegoria), coreógrafos (responsáveis pelo quesito comissão de frente) e casal de mestre sala (MS) e porta bandeira (PB) - responsáveis pelo quesito MS e PB. A diretoria e a presidência entendiam que essas contratações poderiam garantir notas altas para quatro dos dez quesitos de julgamento, o que poderia fazer a diferença. Os integrantes da escola costumavam dizer: “Comissão é quesito! Casal é quesito! Carnavalesco é quesito!”, ressaltando a importância desses profissionais para o desfile. Assim, mesmo acreditando que seria difícil "brigar" pelo campeonato, a escola não pretendia ficar mais uma vez em 4 o lugar na disputa pelo carnaval, o que foi tido como um resultado ruim.

Quanto ao carnavalesco, os diretores de carnaval relataram que observavam o trabalho do profissional contratado há alguns anos, uma vez que sempre o acharam muito talentoso. "A gente ficava impressionado! Ele [o carnavalesco] vinha conseguindo fazer bons desfiles, com qualidade de fantasia e alegoria. A gente via um monte de ferro e de repente saia um carro [...]. como é que esse cara [o carnavalesco] consegue?" (notas de campo), referindo-se ao fato de, mesmo sem recursos financeiros e em uma pequena escola do grupo de acesso, o carnavalesco conseguir apresentar fantasias e alegorias bem feitas. É interessante ressaltar que antes de se dedicar ao carnaval, o carnavalesco atuava em quadrilhas juninas da Grande Vitória, produzindo fantasias. Assim, como ocorre nas pequenas escolas do grupo de acesso, as quadrilhas possuem poucos recursos financeiros para produzir sua apresentação. Portanto, o carnavalesco contratado estava habituado a lidar com situações de restrição orçamentária. Um bom desfile dependeria de dinheiro, mas também de um bom carnavalesco. Segundo o diretor adjunto de carnaval: "Quando cê sabe que uma escola não tem dinheiro e mesmo assim ela consegue fazer um bom desfile. Onde é que tá o ponto chave? É um bom carnavalesco que consegue administrar os recursos!" (notas de campo).

Um dos traços do carnavalesco contratado era o uso de uma mistura de cores. Vale ressaltar, que as fantasias e os carros alegóricos projetados para o carnaval 2015 eram bem coloridos. De acordo com alguns integrantes da escola, esse colorido é a assinatura do carnavalesco. Para alguns, nos últimos anos, o carnaval da escola estava "muito tradicional", uma vez que as alas e os carros alegóricos eram majoritariamente de uma mesma cor, com um suave degrade de cores entre os setores da escola (ver setorização). De acordo com um dos estilistas da escola, o novo carnavalesco "grita" por meio de uma mistura de cores, sendo mais vivo e vibrante, ao mesmo tempo em que usa como base as cores da escola (o verde, o vermelho e o branco).

O colorido não era apenas um traço do trabalho do carnavalesco, mas também uma forma de compensar o uso de materiais mais simples nas fantasias e nas alegorias. Segundo o carnavalesco: "A minha sacada do colorido é isso... porque quando você trabalha com uma escala monocromática, é gritante quando uma fantasia ou alegoria não tá completa [mais simples]" (notas de campo).

Além da mistura de cores, havia uma preocupação por parte do carnavalesco em relação aos detalhes do acabamento dos carros alegóricos. Durante as observações no barracão, era comum ouvir a seguinte afirmação: "Não adianta ter carro grande e mal acabado".

"Há 2 dias do desfile, observei que o carro abre-alas estava praticamente pronto. No carro havia uma escultura de cabeça de coruja (a mascote da escola), que estava sendo pintada por um dos escultores de Parintins. A coruja, que tinha barbatanas, estava ficando colorida, uma mistura de azul, roxo e amarelo. Todavia, o carnavalesco afirmou que ainda faltava um "tcham" (detalhes do acabamento), dizendo que não sabia ainda o que iria fazer, mas que estava pensando" (notas de campo). 
"No dia seguinte voltei ao barracão e pude observar que pedras e confetes prateados e azuis brilhantes foram colocados na coruja, que também ganhou detalhes pretos (pintura) nos olhos, no bico e na testa. No desfile pude perceber mais um detalhe, havia uma pequena máquina instalada entre a cabeça e a barbatana da escultura, fazendo com que a coruja do abre-alas soltasse bolhas de sabão" (notas de campo).

Percebe-se assim que por meio das cores e do acabamento, o carnavalesco buscava compensar o fato de a escola, por questões financeiras, ter carros alegóricos e esculturas considerados pequenos.

\section{DISCUSSÃO DOS RESULTADOS}

A organização da prática do estrategizar vai além da performance do desfile, uma vez que a produção de um desfile pode ser subdividida em dois conjuntos de atividades que organizam essa prática: produção do desfile e o desfile propriamente dito. É nesse sentido que "o carnaval acontece o ano todo" (CAVALCANTI, 1994), que a escola de samba e o desfile carnavalesco vão além da performance desse desfile.

A escolha por carnavalizar um "enredo caça níquel” foi uma das estratégias adotadas pela escola de samba. A possibilidade de patrocínio por parte da cidade homenageada foi determinante para a escolha desse enredo, uma vez que havia um entendimento (SCHATZKI, 2002) por parte da presidência e da diretoria da agremiação (estrategistas) de que o carnaval era uma festa cara. A escolha do enredo não levou em conta apenas aspectos culturais ou históricos, uma vez que a diretoria estava preocupada em "colocar a escola na avenida". Essa preocupação reflete o objetivo principal de uma escola de samba: desfilar (GOLDWASSER, 1975), estando diretamente relacionada a estrutura teleo-afetiva (SCHATZKI, 2002) que organizou essa prática. Além disso, percebe-se que, ao prometer o patrocínio, o prefeito, mesmo sendo um ator externo (JARZABKOWSKI; BALOGUN e SEIDL, 2007), que está fora da estrutura formal da organização, influenciou indiretamente a estratégia da escola, podendo ser considerado um estrategista. Todavia, conforme mencionado, um enredo caça níquel não garante patrocínio, uma vez que a escola pode não receber o dinheiro prometido. Foi justamente o que ocorreu durante a observação. Até a véspera do desfile de Vitória/ES, a promessa de patrocínio por parte do prefeito da cidade Alfa não havia se concretizado.

Diante desse cenário, havia um entendimento de que 2015 estava sendo o "pior ano da escola", um ano de crise financeira, e de que seria preciso produzir o carnaval mesmo sem dinheiro. Assim, a diretoria de carnaval e o carnavalesco (também tidos como estrategistas) optaram por usar como estratégia a reutilização de materiais, produzindo as alegorias por meio de duas atividades centrais: o aproveitamento da estrutura dos carros e a reutilização de esculturas. Mais uma vez, a preocupação de "colocar a escola na avenida" estava presente, relacionando-se com a estrutura teleo-afetiva (SCHATZKI, 2002) que organizou essa prática. Evidencia-se, também, que a estratégia inicial de produzir as alegorias de acordo com o primeiro projeto feito pelo carnavalesco não foi seguida. Havia, ainda, um cuidado por parte do carnavalesco em manter a interpretação do enredo, uma vez que a escola já havia enviado o script do desfile à liga das escolas de samba, descrevendo o que cada elemento do desfile (dentre eles os carros alegóricos) representaria. Esse cuidado com a interpretação do enredo, por sua vez, relaciona-se com as regras (SCHATZKI, 2001) que organizaram essa prática.

É interessante ressaltar que nem todos os elementos e práticas importantes na produção de um desfile estão abarcados nas regras explícitas e formais que organizam sua produção. A possibilidade de reutilizar materiais é um exemplo de prática relevante que não constam no regulamento do carnaval. Apesar disso, havia um entendimento compartilhado (por parte da diretoria de carnaval, do carnavalesco e dos escultores, todos tidos como estrategistas) acerca da importância desse elemento na produção do desfile de 2015.

Para que a reutilização de materiais (ou seja, da estrutura dos carros e de esculturas) fosse exequível, há apenas 3 semanas do desfile, a diretoria de carnaval e o carnavalesco buscaram a contratação de equipes especializadas. Tanto a diretoria quanto o carnavalesco entendiam (SCHATZKI, 2002) que as equipes eram capazes de produzir três carros alegóricos e três tripés em apenas 3 semanas, uma vez que os escultores e os aderecistas eram muito experientes e também trabalhavam na "Festa do Boi de Parintins" e em outras escolas de samba de São Paulo/SP e do Rio de /RJ.

É possível afirmar que os escultores e os aderecistas eram praticantes da prática de produzir alegorias, sendo por isso hábeis na realização das atividades que compõem essa prática, nesse caso, esculpir e adereçar alegorias. Tais habilidades referem-se, ainda, ao know-how, aos entendimentos desses praticantes (SCHATZKI, 2002) em relação à prática. As práticas mencionadas eram, ainda, dotadas de significado e propósito para os praticantes (estrutura teleo-afetiva), que também desejavam "colocar a 
escola na avenida" (SCHATZKI, 2001). Evidenciamos, também, que os integrantes das equipes eram estrategistas, e não só o carnavalesco. Conforme mencionado, para a EPS, os níveis hierárquicos mais baixos também são importantes atores no processo do estrategizar, a pesar de não terem, necessariamente, um papel formal como estrategistas (VAARA; WHITTINGTON, 2012).

Outra estratégia adotada pela presidência e pela diretoria de carnaval foi jogar as regras do jogo, ou seja, se preocupar com os quesitos de julgamento que seriam levados em conta na apuração do desfile. Identificamos que essa prática estava organizada em torno dos entendimentos (SCHATZKI, 2002) de que a disputa pelo carnaval era acirrada, de que para garantir notas altas era preciso dar atenção aos quesitos, e de que o carnavalesco era um profissional "chave", já que influenciava diretamente dois quesitos (fantasia e alegoria). A presidência e a diretoria optaram por jogar as regras do jogo com o intuito de colocar a escola na avenida e obter uma boa colocação na disputa pelo carnaval. 0 que evidencia a estrutura teleoafetiva (SCHATZKI, 2001) que organizou essa prática.

Para que a estratégia de jogar as regras do jogo pudesse acontecer, a diretoria de carnaval passou a observar o trabalho dos carnavalescos que se destacavam no desfile das escolas da Grande Vitória. Assim, observar o trabalho dos carnavalescos foi uma das atividades que compôs essa prática. Havia um entendimento por parte da diretoria de que o carnavalesco a ser contratado deveria ser hábil em administrar recursos e capaz de produzir um bom desfile mesmo sem dinheiro. Tais habilidades referemse, ainda, ao know-how, aos entendimentos (SCHATZKI, 2002) do carnavalesco como um praticante da prática de carnavalizar o enredo.

Ao produzir alegorias coloridas e preocupar-se com os detalhes do acabamento dos carros, o carnavalesco realizou atividades que compuseram a prática de carnavalizar o enredo. Outros exemplos que ilustram o know-how do praticante (SCHATZKI, 2002) carnavalesco foram os entendimentos de que as cores e o acabamento compensam o uso de materiais mais simples e os carros pequenos, assim como de que não adianta ter carro grande e mal acabado. A prática de carnavalizar o enredo era, ainda, dotada de significado e propósito para o praticante (estrutura teleo-afetiva), que também desejavam "colocar a escola na avenida" (SCHATZKI, 2001 e 2002).

\section{CONSIDERAÇÕES FINAIS}

O objetivo deste artigo foi analisar a organização da prática do estrategizar na produção do desfile de uma escola de samba capixaba, especificamente na produção de carros alegóricos. Para tanto, utilizamos a perspectiva da estratégia como prática, a partir dos conceitos de organização das práticas de Theodore Schatzki. Apresentamos um estudo de caso qualitativo em uma escola de samba do grupo especial capixaba. Destacamos, no caso analisado, o conjunto de atividades que compõem o estrategizar na produção de alegorias e como a escola teve que lidar com uma série de problemas, à escassez de recursos principalmente. 0 que demandou dos praticantes improviso e criatividade no desenvolver da produção do carnaval, habilidades próprias das práticas carnavalescas.

Fundamental para a organização da prática do estrategizar na escola pesquisada foram os entendimentos a respeito de como ela acontece no carnaval atual. Tendo em vista os elementos visuais e estéticos que passaram a ser altamente valorizados nos últimos anos, ter sensibilidade na escolha de cores, formatos e tamanhos se apresentou como um componente importante do estrategizar na produção carnavalesca. Apenas alguns profissionais especializados, que incorporaram esse elemento da prática, são capazes de desempenhar adequadamente as atividades que podem conduzir a escola a uma apresentação que atenda as exigências das regras (formais e informais) do desfile.

Uma das limitações do estudo foi a ausência de entrevistas com roteiro previamente definido, que pudessem contribuir para o aprofundamento de como as práticas se organizam, a partir do relato dos praticantes. Outra limitação do trabalho foi o recorte na produção de alegorias, tendo em vista que a produção do desfile de uma escola de samba é composta por várias atividades inter-relacionadas e um recorte como este pode deixar escapar aspectos relevantes da produção de carros alegóricos. Dado que este é um trabalho em construção, as entrevistas já foram realizadas e outras atividades observadas, sendo que ambos os dados estão em fase de tratamento e análise.

Estudos futuros poderiam empregar a abordagem de Theodore Schatzki para entender como o estrategizar se organiza em outras formas de organização (empresas, organizações não governamentais, órgãos públicos, etc.), a fim de que seja possível traçar semelhanças e diferenças entre os elementos que organizam a prática estratégica nas mais diversas organizações. 


\section{REFERÊNCIAS}

[1] BAUER, M. W.; GASKELL, G. Pesquisa qualitativa com texto, imagem e som. Rio de Janeiro: Vozes, 2002.

[2] BLASS, L. M. S. Desfile na avenida, trabalho na escola de samba: a dupla face do carnaval. São Paulo: Annablume, 2007.

[3] CARTER, C.; CLEGG, S. R.; KORNBERGER, M. Um livro bom, pequeno e acessível sobre estratégia. Bookman, 2010.

[4] CAVALCANTI, M. L. V. C. Carnaval carioca: dos bastidores ao desfile. Rio de Janeiro: Minc/Funarte, 1994

[5] CHIA, R.; MACKAY, B. Post-processual challenges for the emerging strategy-as- practice perspective: Discovering strategy in the logic of practice. Human relations, v. 60, n.1, p.217-242, 2007

[6] CZARNIAWSKA, B. On time, space, and action nets. Organization, v.11, n.6, p.773- 791, 2004.

[7] DENIS, J., DOMPIERRE, G., LANGLEY, A., \& ROULEAU, L. Escalating indecision: Between reification and strategic ambiguity. Organization Science, 22(1), 225-244, 2011.

[8] FLICK, U. Uma introdução à pesquisa qualitativa. Porto Alegre: Bookman, 2004.

[9] FRANCO, M. L. P. B. Análise de Conteúdo. 4a. Brasília: Liber Livro, 2012.

[10] GOLDWASSER, M. J. O palácio do samba: estudo antropológico da escola de samba Estação Primeira de Mangueira. Rio de Janeiro: Zahar Editores, 1975.

[11] GOLSORKHI, D. et al. Introduction: What is Strategy as Practice? In: Strategy as Practice. Cambridge: Cambridge University Press, 2010. . Cambridge Handbook of

[12] GOMEZ, M. L. A Bourdieusian Perspective on Strategizing. In: GOLSORKHI, D.; ROULEAU, L.; DEIDL, D.; VAARA, E. Cambridge Handbook of Strategy as Practice. Cambridge: Cambridge University Press, 2010.

[13] JARZABKOWSKI, P. Strategy as practice: an activity-based approach. London: Sage, 2005.

[14] JARZABKOWSKI, P.; BALOGUN, J.; SEIDL, D. Strategizing: the challenges of a practice perspective. Human Relations, v.60, n.1, p.5-27, 2007.

[15] JARZABKOWSKI, P. Shaping Strategy as a Structuration Process. Academy of Management Journal, v.51, n.4, p.621-650 2008.

[16] JARZABKOWSKI, P.; SPEE, A.P. Strategy - as - practice: A review and future directions for the field. International Journal of Management Reviews, v.11, n.1, p. 69-95, 2009.

[17] KRONBERGER, M. \& CLEGG, S. Strategy as Performative Practice - The Case of Sydney 2030. Strategic Organziation, 2011.

[18] MANTERE. S. Strategic Practices as Enablers and Disablers of Championing Activity, Strategic Organization, v.3, n.2, p.157 -184, 2005.

[19] MINTZBERG. H. Structure in 5'S: a synthesis of the research on organization design. Management Science. v.26, n. 3, p.322-341, 1980.

[20] NICOLINI, D. Practice Theory, Work, \& Organization: an introduction. Oxford: Oxford University Press, 2013

[21] RECKWITZ, A. Toward a Theory of Social Practices A development in culturalist theorizing. European journal of social theory, v.5, n.2, p.243-263, 2002.

[22] SANTOS, L. L. S. O trem não pode parar: reformando uma oficina de locomotivas. 311f. Tese (Doutorado em Administração) - Escola de Administração de Empresas de São Paulo da Fundação Getúlio Vargas, São Paulo, 2014.

[23] SANTOS, L. L. S.; SILVEIRA, R.. Por uma Epistemologia das Práticas Organizacionais: A contribuição de Theodore Schatzki. Organizações \& Sociedade, v. 22, n.72, 2015.

[24] SCHATZKI, T. R. Introduction: Practice Theory. In: SCHATZKI, T. R.; KNORR- CETINA, K.; VON SAVIGNY, E. The Practice Turn in Contemporary Theory. London/NewYork: Routledge, 2001. 
[25] SCHATZKI, T. R. The site of the social: a philosophical account of the constitution of social life and change. Pennsylvania: Pennsylvania State University, 2002.

[26] _. A New Societist Social Ontology. Philosophy of the Social Sciences. 33(2), 2003.

[27] _ . The Sites of Organizations. Organization Studies. 26(3), 2005

[28]

. On organizations as they happen. Organization Studies, 27(12), 1863-1873,

[29] 2006.

[30] SONPAR, K. \& GOLDEN-BIDDLE, K. Using Content Analysis to Elaborate Adolescent Theories of Organization. Organizational Research Methods, 11(4), 795- 814, 2008.

[31] SOU ES (2015). Portal de entretenimento do Espírito Santo. Disponível em: http://www.soues.com.br. Acesso em: 19 jan. 2015.

[32] TURETA, C. Práticas Organizativas em Escolas de Samba: o Setor de Harmonia na Produção do Desfile do Vai-Vai. 325 f. Tese (Doutorado em Administração) - Escola de Administração de Empresas de São Paulo da Fundação Getúlio Vargas, São Paulo, 2011.

[33] TURETA, C.; ARAÚJO, BFVB de. Escolas de samba: trajetória, contradições e contribuições para os estudos organizacionais. Organizações \& Sociedade, v.20, n.64, p. 111-129, 2013.

[34] V AARA, E.; WHITTINGTON, R. Strategy-as-practice: taking social practices seriously. The Academy of Management Annals, v.6, n.1, p.285-336, 2012.

[35] VERGARA, S. C.; MORAES, C. M.; PALMEIRA, P. L. A cultura brasileira revelada no barracão de uma escola de samba: o caso da família Imperatriz. In: MOTTA, F. C. P.; CALDAS, M. P. (Org.) Cultura organizacional e cultura brasileira. São Paulo: Atlas, 1997.

[36] WhitTington, R. Strategy as Practice. Long Range Planning, v.29, n.5, p.731- 735, 1996.

[37] C. Completing the practice turn in strategy research. Organization Studies, v.27, n.5, p.613634, 2006.

[38] _ Strategy practice and strategy process: family differences and the sociological eye. Organization Studies, v.28, n.10, p.1575-1586, 2007.

[39] - The practice turn in organization research: Towards a disciplined transdisciplinarity. Accounting Organization and Society, v.36, n.3, p.183-186, 2011.

[40] WhITTINGTON, R.; CAILLUET, L. The crafts of strategy: Introductions to special issue. Long Range Planning, v.41, n.3, p.241-247, 2008.

[41] WILSON, D. C.; JARZABKOWSKI, P. Thinking and acting strategically: New challenges for interrogating strategy. European Management Review, v.1, n.1, p.14- 20, 2004.

[42] YIN, R. K. Estudo de caso: planejamento e métodos. Porto Alegre: Bookman, 2001.

I. Dezenas de pessoas que desfilam com uma mesma fantasia. As alas representam parte do enredo que está sendo contado no desfile.

II. São carros ornamentados que também representam parte do enredo. Nesses carros há pessoas desfilando com fantasias de destaque, semi-destaque e composição de carro.

III. Documento público disponibilizado pela liga das escolas de samba a todas as escolas.

IV. Documento interno da escola que trata da ordem sequencial de apresentação do desfile. A setorização é produzida pela diretoria de carnaval e disponibilizada para as demais diretorias.

V. Documento produzido pela diretoria de carnaval e enviado para a liga das escolas de samba. 0 envio do script é uma obrigação das escolas e está previsto no regulamento do carnaval. 0 documento descreve o enredo, o samba-enredo, a ordem sequencial de apresentação do desfile (setorização) e o que cada elemento do desfile (alas, carros alegóricos, etc.) representa.

VI. Primeiro carro alegórico de uma escola. Costuma ser o maior e mais luxuoso dos carros. 
VII. Para preservar a identidade da cidade homenageada no enredo a identificaremos pelo codinome Alfa.

VIII. Autor do enredo.

IX. Pessoas que desfilam com fantasias luxuosas nos pontos mais altos dos carros ou no chão, em frente as alas. Nos carros há um destaque central (cuja fantasia é a mais luxuosa) e alguns semidestaques.

X. Uma alegoria também conta com composições, pessoas que desfilam em cima dos carros com fantasias mais simples, que compõem os adereços desses carros.

XI. Local onde os carros alegóricos são produzidos.

XII. Pequeno carro alegórico no qual não há pessoas desfilando.

XIII. São quesitos previamente definidos e levados em conta na apuração do desfile. No carnaval de Vitória/ES, os quesitos são: Bateria; Samba-Enredo; Harmonia; Evolução; Enredo; Conjunto; Alegorias e Adereços; Fantasias; Comissão de Frente e Mestre-Sala e Porta-Bandeira. 


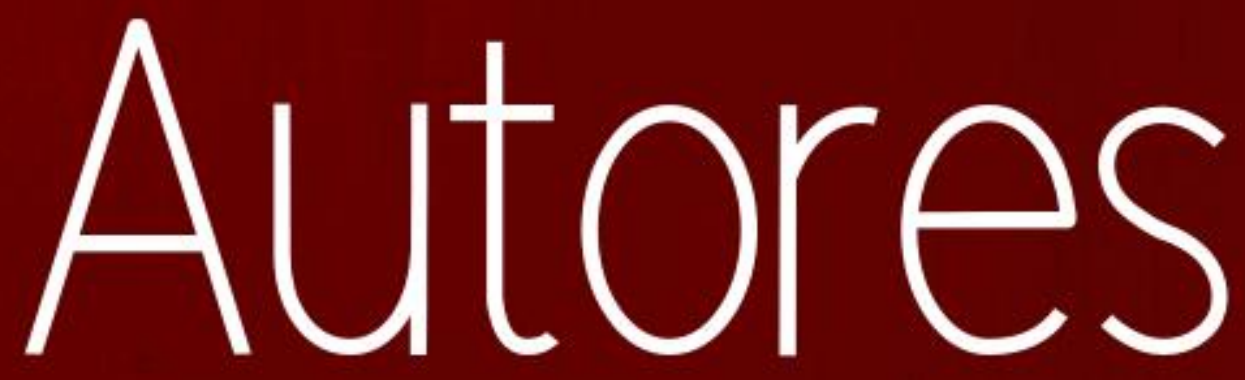




\section{ADRIANA SOUSA LIMA}

Mestre em Administração pela Universidade Estadual do Oeste do Paraná - UNIOESTE (2015). MBA em Gestão de Pessoas pela UNIOESTE (2009). Graduada em ADMINISTRAÇÃO pela UNIOESTE (2007). Atualmente é servidora da UNIOESTE - campus de Foz do Iguaçu, atua como agente universitário, exercendo a função de Assessora de Projetos e docente do Curso de PósGraduação "Intervenção Breve em Psicologia". Tem interesse em pesquisas na área de Administração, principalmente no campo de Gestão de Pessoas, Estratégia como Prática e Gestão Universitária.

\section{ÁLVARO PAZ GRAZIANI}

Bacharel em Engenharia Mecânica pela instituição UFRGS, Pós-graduação em Engenharia de Produção pela instituição UDESC, Mestrado em Administração de Negócios pela instituição Universidade de Cardiff (Reino Unido), Mestrado em Engenharia de Produção pela instituição SOCIESC, Especialização em Metodologia e Didática pela instituição SOCIESC, Especialização em Ensino e Aprendizagem pela instituição Universidade de Tampere (Finlândia). Profissional com expertise em gestão de produção, manutenção industrial, gerenciamento de equipes, gerenciamento de projetos e implantação de sistemas ERP. Trabalhou em empresas como Hercules, Tigre, Minâncora, Intercontinental e Movelar. Atualmente é professor de Engenharia na UniSociesc e Administração de Empresas pela FGV. Coordenador da pós-graduação em Lean Manufacturing da UniSociesc. É autor dos livros: Planejamento, Programação e Controle da Produção (Unisul), Instalações Industriais (Unisul), Sistemas de Produção (Unisul), Compras e Negociação (UniSociesc) e Materiais (UniSociesc).

\section{ANA BEATRIZ LOPES SOUZA}

Acadêmica de Ciências Contábeis na Pontifícia Universidade Católica de Goiás.

\section{ANA CAROLINA JÚLIO DA SILVA ANDRADE}

Doutora e Mestre em Administração

\section{ANA PAULA LIMA MARQUES FERNANDES}

Graduada em Engenharia Civil e Direito. Mestrado em Meteorologia e Doutorado em Engenharia. na COPPE - UFRJ. Docente da FEAC - UFAL.

\section{CAMYLA PIRAN STIEGLER LEINTER}

Possui doutorado em Engenharia de Produção na Universidade Federal de São Carlos (2015) na linha de pesquisa Gestão da Tecnologia e da Inovação, mestrado em Engenharia de Produção pela Universidade Federal de São Carlos (2010) e graduação em Administração pela Universidade Federal de Mato Grosso (2004). Professora adjunta da Universidade do Estado de Mato Grosso, atuando nas áreas de Gestão de Operações e serviços, principalmente nos seguintes temas:Gestão de Serviços, Gestão da Qualidade e Produtividade, Certificações e Garantia da Qualidade, Estratégia de Operações, Gestão de filas, Mapeamento e Análise de Processos, Planejamento Estratégico e ferramentas de execução, Gerenciamento de projetos e Gestão Agroindustrial.

\section{CLAUDIANA APARECIDA LEAL DE ARAÚJO}

Graduada em Ciências Contábeis (2008) e Mestre em Desenvolvimento Social (2014) pela Universidade Estadual de Montes Claros. Atua na Docência do ensino superior dos cursos de Ciências Contábeis, Gestão Pública e Tecnólogo em Agronegócio da Unimontes e nos cursos técnicos em EAD pelo Instituto Federal de Norte de Minas. Tem experiência na área de Administração com ênfase em Ciências Contábeis, atuando principalmente nos seguintes temas: planejamento e orçamento na administração pública, gestão de projetos e políticas públicas em entidades do Terceiro Setor. 


\section{CLAUDIO ANTONIO ROJO}

PhD. Pós-Doutor (2012) pela Universidade de São Paulo - FEA / USP. Doutor (2005) em Engenharia de Produção pela Universidade Federal de Santa Catarina - UFSC. Mestre (2001) pela UFSC. MBA pela Universidade Estadual de Maringá - UEM. Bacharel (1990) em Administração pela Universidade Estadual do Oeste do Paraná - UNIOESTE. É professor Associado da UNIOESTE, onde ministra Planejamento Estratégico na graduação e Cenários Estratégicos e Competitivos no Mestrado Profissional em Administração e no Mestrado em Contabilidade. Foi vendedor, supervisor de vendas e empresário. Desde o início da carreira buscou se aprofundar na administração geral de empresas. Tem experiência como administrador e consultor nos campos público e privado.

\section{DANIEL TEOTONIO DO NASCIMENTO}

Doutor em Administração pela Universidade Federal de Mato Grosso do Sul-UFMS (2018). Mestre em Administração pela Universidade Estadual do Oeste do Paraná-UNIOESTE (2015). Especialista em Gestão Pública pela UFMS (2012). Graduado em Administração - Comércio Exterior pela Universidade Católica Dom Bosco. Membro do Grupo de Pesquisa em Sustentabilidade no Agronegócio - GPSA - UNIOESTE e do Grupo de Estudo e Pesquisa sobre Organizações, Trabalho e Educação - GEPOTE - UFMS. Tem experiência na área de Administração, Administração Pública, Auditoria, Alianças e Parcerias, Agricultura Familiar e Políticas Públicas. Trabalhou em empresas, nacionais e internacionais, públicas e privadas, como: Banco do Brasil, City Bank, Footfall Ibérica e Correios. Desde 2011 é Servidor Público e atualmente é Servidor Federal no cargo efetivo de Administrador na Universidade da Integração Latino-Americana - UNILA. Atua também como Docente no Centro de Ensino Superior de Foz do Iguaçu (CESUFOZ)

\section{DANIELE MACARINI}

Graduanda em Engenharia de Produção pela Faculdade SINERGIA, iniciou sua jornada universitária em 2006 com a graduação de Construção Naval pela Universidade do Vale do Itajaí. Possuí diploma de Projetista Naval. Atualmente trabalha na empresa multinacional Lear Corporation ao qual ocupa o cargo de analista de produto II e líder de projeto do cliente Daimler (Mercedes). Desenvolve atividades como liderança e gestão de projeto de chicote do cliente Daimler, liderança de equipe composta por analistas e desenhistas, abertura de estudo de custos para análise de impacto e valorização de modificações solicitadas pelo cliente, iniciação e desenvolvimento de estrutura modular (KSK) de chicotes, participação em projetos de melhorias contínuas entre outros.

\section{DOUGLAS FERREIRA VIDAL}

Graduado em engenharia de produção pela Universidade Salgado de Oliveira - UNIVERSO (2010), engenheiro de segurança do trabalho pela Universidade Cândido Mendes - UCAM (2018), mestre e doutor em Engenharia e Ciência dos Materiais pela Universidade Estadual do Norte Fluminense Darcy Ribeiro - UENF (2013 e 2017). Tem experiência na área de engenharia de materiais e metalurgia física, em processos de produção e análise estrutural e propriedades mecânicas de ferros fundidos nodulares. Experiência em gestão de riscos ocupacionais em processos industriais, e em docência em instituições de ensino técnico e superior. Atualmente desenvolve pesquisa na área de metalurgia física, com foco na caracterização e análise estrutural e propriedades mecânicas de ferros fundidos.

\section{DUILEU EDEMILSON COUTO}

Graduado em Construção Naval pela Universidade do Vale do Itajaí - UNIVALI (2010). Tem experiência na área de Engenharia de produção, com enfase em Engenharia de Produção.

\section{EDMILSON CAVALCANTE NUNES}

Acadêmico de Ciências Contábeis na Pontifícia Universidade Católica de Goiás. 


\section{EDUARDO LUIZ DE OLIVEIRA ALMEIDA}

MBA em gerenciamento de projetos pela Universidade Uninorte, Bacharelado em Engenharia em Controle e Automação pelo Instituto Federal do Amazonas (IFAM). Experiência em controle e automação, robótica, sistemas supervisórios e redes industriais.

\section{ESTEFÊNIE DA SILVA TENÓRIO}

Graduada em Ciências Contábeis.

\section{EVERALDO LUIZ ALVES DE SOUZA DOS SANTOS}

Estagiário em recinto alfandegado na área de transporte rodoviário e discente do curso de tecnologia em logística da Faculdade de Tecnologia da Baixada Santista.

\section{FERNANDO AUGUSTO SILVA MARINS}

Possui graduação em Engenharia Mecânica pela UNESP - Universidade Estadual Paulista Júlio de Mesquita Filho, mestrado pelo Instituto Tecnológico de Aeronáutica, doutorado pela Universidade Estadual de Campinas e Pós-doutorado pela Brunel University - Londres - Inglaterra. É Professor Titular no Departamento de Produção da Faculdade de Engenharia - Campus de Guaratinguetá da UNESP e Pesquisador PQ2 do CNPq. Atua na área de Engenharia de Produção, com ênfase em Pesquisa Operacional e Logística.

\section{GABRIEL FREITAS DA COSTA}

Acadêmico de Ciências Contábeis na Pontifícia Universidade de Goiás.

\section{HELLEN XAVIER DAS CHAGAS}

Mestra em Gestão e Tecnologia em Sistemas Produtivos pelo Centro Paula Souza - São Paulo/SP (Linha de pesquisa: Gestão de Operações e Logística); Pós-graduada com MBA em Comércio Exterior, com bolsa-mérito, pelo Centro Universitário Monte Serrat - Unimonte; Graduada em tecnologia em: Logística e Transportes pela Faculdade de Tecnologia da Baixada Santista - Fatec Rubens Lara / Centro Paula Souza, e profissional atuante na área de comércio exterior com mais de 10 anos de carreira como Analista, Gestora de importação e Classificadora fiscal de mercadorias e atualmente atuando como Docente de Comércio Exterior e Logística.

\section{HENRIQUE JUN MURAMATSU SEGUCHI}

Graduação em Engenharia de Produção pela Universidade Anhembi Morumbi (2014) e pós graduado em produtividade e qualidade pela Fundação Vanzolini (2018). Atualmente é Pesquisador no Núcleo de Atendimento Tecnológico à Micro e Pequena Empresa (NT-MPE) do (IPT). Atua em atendimento as empresas, em especial as MPEs, pela modalidade de atendimento GESPRO - Gestão da produção.

\section{IVANA SALVAGNI ROTTA}

Possui graduação em Engenharia de Produção Materiais pela Universidade Federal de São Carlos (1994), mestrado em Engenharia Mecânica pela Universidade de São Paulo (1998) e doutorado em Engenharia de Produção pela Universidade Federal de São Carlos (2004). Atualmente é docente dos Cursos de Engenharia de produção, Mecânica, Química e Civil do Centro Universitário Herminio Ometto de Araras. Tem experiência na área de Engenharia de Produção, com ênfase em Organização do Trabalho, atuando principalmente nos seguintes temas: ergonomia, organização do trabalho, ferramentas lean manufacturing, e qualidade de vida no trabalho. 


\section{IVONE PEDRO DE LIMA}

Acadêmica de Ciências Contábeis na Pontifícia Universidade Católica de Goiás.

\section{JAIANE APARECIDA PEREIRA}

Doutora em Administração pela UEM - Universidade Estadual de Maringá (2019). Mestre em Administração pela UEM (2011). Graduação em Administração Pública (2002) e Especialização em Gestão Financeira e Contábil (2005) pela FECEA - Faculdade Estadual de Ciências Econômicas de Apucarana. Professora da Universidade Federal de Mato Grosso do Sul UFMS - Câmpus de Naviraí. Possui experiência no ensino presencial e à distância (EAD). Principais áreas de interesse: Estratégia, Inovação, Produção, Agronegócio, Redes Sociais.

\section{JANAINE DE OLIVEIRA SOUTO}

Graduada em Ciências Contábeis pela Universidade Estadual de Montes Claros (2015).

\section{JOÃO CARLOS MARTINS COELHO}

Graduação em Engenharia Mecânica pelo Instituto Tecnológico de Aeronáutica (1974) e mestre em Engenharia de Processos Químicos e Bioquímicos pelo Instituto Mauá de Tecnologia (2006). Atualmente é professor associado da Escola de Engenharia Mauá e Coordenador Operacional do Progex - Programa de apoio à Exportação conduzido no Estado de S. Paulo pelo Instituto de Pesquisas Tecnológicas do Estado de São Paulo S.A.

\section{JOICELI S. FABRÍCIO}

Administradora, empresária e professora. Formou-se em Administração pelas Faculdades de Palmas. Fez mestrado em Administração pela Universidade Estadual de Maringá e cursa doutorado em Administração pela Universidade Positivo de Curitiba. É também Especialista em Marketing e Gestão Empresarial. Atua como diretora dos Jornais Correio do Povo do Paraná, de Laranjeiras do Sul e Extra Guarapuava. É professora de graduação e pós-graduação na Faculdade Guiaracá, em Guarapuava. Exerce ainda a função de delegada do CRA-Conselho Regional de Administração do Paraná, desde 2002 e foi presidente da Associação dos Jornais do Interior do Paraná e do Conselho da Mulher Empresária de Laranjeiras do Sul. Faz parte do Conselho Deliberativo da ADI Associação dos Jornais Diários do Interior do Paraná.

\section{JONATHAN OLIVEIRA DIAS}

Jonathan Oliveira Dias.MBA em gerenciamento de projetos pela Universidade Unopar, bacharel em Engenharia Mecatrônica pela Universidade do Estado do Amazonas (UEA), Especialização em Tecnologias e Métodos de Fabricação Mecânica pela Universidade do Estado do Amazonas (UEA). Experiência em protótipo de desenvolvimentos de projetos de automação.

\section{JOSÉ GERALDO BAZILES XAVIER}

Graduando em Engenharia de Produção pela Fundação Hermínio Ometto | FHO, técnico em Administração pela Escola Técnica Estadual de São Paulo. Campeão do Desafio ERPO - 2018 realizado pela FCA/Unicamp e FlexSim Brasil. Atuou como diretor jurídico|financeiro e como diretor presidente da StartUP! Engenharia, empresa júnior de engenharia da FHO, também foi conselheiro na Federação de Empresas Juniores do Estado de São Paulo (FEJESP). Possui interesse pelas áreas de gestão de risco, finanças e auditoria. 


\section{JOSIANE SILVA COSTA DOS SANTOS}

Bacharel em Ciências Contábeis pela Universidade do Estado de Mato Grosso (2009), MBA Planejamento Tributário (2012), Mestre em Ambiente e Sistemas de Produção Agrícola (2017) . Atualmente é professora efetiva na Universidade do Estado de Mato Grosso - UNEMAT, Campus Tangará da Serra-MT, no curso de Ciências Contábeis. Ministra as disciplinas de Contabilidade Tributária I, Contabilidade Geral I e Trabalho de Conclusão de Curso I.

\section{JULIANA KAROLINE FORSAN PASCOTTI}

Graduanda em Engenharia de Produção pelo Centro Universitário Hermínio Ometto (FHO). Participou do Programa Institucional de Iniciação Científica e Apoio a Pesquisa PIC-FHO no Projeto Lean e Ergonomia e do Grupo de Projetos na área de Organizações, Trabalho, Tecnologia nos Processos Produtivos. Além do Grupo de Pesquisa em Gestão de Operações e Simulação. Equipe premiada em primeiro lugar no Desafio ERPO 2018 organizado pela FlexSim Brasil.

\section{JUSCELAINE DE FATIMA RODRIGUES MOREIRA}

Bacharel em Administração pela Universidade do Estado de Mato Grosso (2008), MBA Gestão de Pessoas (2019), Acadêmica do Curso de Psicologia FAEST (2019) . Atualmente Coordenadora de Gestão de Pessoas em empresa privada.

\section{LEONAM FORMENTO}

Graduando de Engenharia de Produção-6º período.

\section{LETÍCIA APARECIDA DA SILVA}

Graduanda de Engenharia de Produção-6o período, formada em Técnico em Segurança do Trabalho, Compradora na empresa Portonave.

\section{LIDIANE DA SILVA SOUZA ANGOLA}

Mestranda em Administração pela FUCAPE BUSINESS SCHOOL. Especialista em Finanças, Auditoria e Controladoria pela UNEB (União Educacional de Brasília). Possui graduação em administração pela UNEMAT (Universidade do Estado de Mato Grosso) (2008). Atualmente é professora na UNEMAT no campus de Tangará da Serra - MT. Trabalha nos Departamentos de Administração e Ciências Contábeis onde orienta Trabalhos de Iniciação Científica /Conclusão de Curso. Disciplinas Ministradas: Fundamentos da Administração; Organização, Sistemas e Métodos; Operações e Serviços; Orçamento Empresarial, Administração Financeira e Estágio. Atualmente é Membro do Núcleo de Pesquisa, Extensão e Estudos da Complexidade no Mundo do Trabalho (NECOMT).

\section{LUIZ ANTONIO TOZI}

Doutorado em Pesquisa Operacional e Transporte Aéreo pelo Instituto Tecnológico de Aeronáutica, Brasil(2010). Diretor da Faculdade de Tecnologia de São José dos Campos

\section{LUIZ CARLOS DE PONTE JUNIOR}

Graduando em Engenharia de Produção no Centro Universitário Hermínio Ometto (UNIARARASFHO). Possui experiência em Logística e Controle de Frotas. Desenvolveu um estudo cientifico sobre Ergonomia e Saúde dos motoristas caminhoneiros no modal rodoviário além de minicursos realizados na instituição como Simulação Discreta por Eventos em FlexSim, Introdução ao CNC, Lean Manufacturing e em São Paulo/SP o minicurso de White Belt Six-Sigma realizado no 3 o Encontro de Engenharia de Produção. 


\section{MARCELO DE OLIVEIRA SOARES}

Despachante Aduaneiro com mais de 20 anos de experiência; Diretor Adjunto de uma Comissária de Despachos Aduaneiros em Santos/SP; Palestrante e Professor convidado em assuntos Aduaneiros em eventos no Senac Santos e no Programa de Pós graduação Lato Sensu da Universidade Católica de Santos (UniSantos); Pós graduando em Direito Marítimo e Portuário pela UniSantos; Pós graduado com MBA em Comércio Exterior e Negócios Internacionais pela UniSantos e; Graduado em Tecnologia em Informática pelo Centro Universitário Lusíada (UniLus); além de diversos cursos livres e de extensão complementares. Após uma trajetória que iniciou como office-boy, em sua carreira já ocupou cargos de auxiliar de escritório, assistente, analista, classificador fiscal de mercadorias, conferente, Ajudante de Despachante Aduaneiro e Coordenador de operações de comércio exterior.

\section{MÁRCIA FERREIRA SILVA}

Graduada em Ciências Contábeis pela Universidade Estadual de Montes Claros (2015). Possui especialização em Informática na Educação pelo Instituto Federal do Norte de Minas Gerais.

\section{MARCONI DOS SANTOS MIRANDA}

Possui graduação em Ciências Contábeis pela Universidade Estadual de Montes Claros (2015) e Especialização em Contabilidade, Perícia e Auditoria pela Universidade Pitágoras Unopar e em Gestão Municipal pelo Instituto Federal do Norte de Minas Gerais (IFNMG). É Pós-Graduando em Gestão em Saúde pelo IFNMG. Atualmente é contador (CRC-MG 111727/0-4) do Quadro Permanente de Servidores Efetivos do Município de Salinas/MG, instrutor de ensino superior na Universidade Pitágoras Unopar e perito-contador (CNPC/CFC 541) do juízo nomeado em Varas Cíveis, Criminais e JIJ do Tribunal de Justiça do Estado de Minas Gerais. Atuou como professor de ensino superior na Unimontes/Campus Salinas.

\section{MARI TOMITA KATAYAMA}

Graduação em Ciências da Computação pela Universidade de São Paulo (1974). Atualmente é consultora ad hoc - Financiadora de Estudos e Projetos e Diretora do Núcleo de Atendimento Tecnológico à Micro e Pequena Empresa- NT-MPE do IPT. Tem experiência na coordenação e execução de projetos de âmbito nacional, no apoio tecnológico às MPEs, na coordenação de trabalhos de adequação/desenvolvimento de produtos de diversos setores.

\section{MARIA RITA RODRIGUES CONSTANCIO MENEZES}

Possui graduação em DIREITO pelo INSTITUTO LUTERANO DE ENSINO SUPERIOR DE PORTO VELHO (2017) e graduação em LETRAS pela Faculdade de Educação de Porto Velho (2004). É concursada/estatutária - SECRETARIA MUNICIPAL DE EDUCAÇÃO, Professora Classe C, e Pós Graduada em Metodologia e Didática do Ensino Superior e em Letras e suas Literaturas. Tem experiência na área de Educação, com ênfase em Ensino-Aprendizagem. Atualmente está lotada na CONTROLADORIA GERAL DO ESTADO, desempenhando suas funções de Fiscalização e Auditoria em Comissões de trabalho e Tomada de Contas especial, desde de 2013. É aluna da Escola da Magistratura do Tribunal de Justiça do Estado de Rondônia. OAB n. 9662 CONTATOS: (69) 984474546 e-mail: mr.constancio15@ymail.com

\section{MARILEIDE ALEXANDRINO BARRETO}

Graduada em ciências contábeis pela UFAL, com pós- MBA em liderança e Coaching na Gestão de pessoas pela UNOPAR e cursando especialização em e-social social pela NITH Treinamento. Atuo na Área de Departamento pessoal e RH. 


\section{MARLUCE ALVES DE ALMEIDA SALGUEIRO}

Possui graduação em Ciências Contábeis pelo Centro de Estudos Superiores de Maceió (1986) e mestrado em Administração pela Universidade Federal de Alagoas (2000). Atualmente está cursando Doutorado em Sistemas de Informações Contábeis na Universidade de Oviedo-Espanha. Professora Assistente A da Universidade Federal de Alagoas-UFAL, lotada na Faculdade de Economia, Administração e Contabilidade-FEAC, atualmente exercendo a função de Coordenadora do Curso de Contabilidade. Tem experiência na área de Gestão e Contabilidade Pública e ministra disciplinas nas áreas de orçamento público e contabilidade governamental.

\section{NEWTON YAMADA}

Engenheiro graduado pela FEI, pós-graduação pela FECAP e MBA pelo ITA, com 32 anos de experiência profissional em indústrias do ramo aeronáutica, mecânico, plástico e automobilístico nas áreas de planejamento e desenvolvimento de processos industriais. Tendo atuado em empresas de renome mundial, tais como Pirelli, NEC e Embraer, paralelamente atuando a 12 anos como professor universitário da Fatec de São José dos Campos

\section{PAOLA RAYANNE REIS FERNANDES}

Acadêmico de Ciências Contábeis na Pontifícia Universidade Católica de Goiás.

\section{PAULO ROBERTO DA COSTA VIEIRA}

Doutor em Administração (COPPEAD/UFRJ). Funcionário inativo do Banco Central do Brasil, onde trabalhou por mais de 36 anos. Professor Adjunto do Mestrado em Administração e Desenvolvimento Empresarial (MADE) da Universidade Estácio de Sá.

\section{PEDRO HENRIQUE MOREIRA SIMÕES}

Mestrando em Direito pela Faculdade Autônoma de Direito de São Paulo (FADISP). Graduado em Direito pela Universidade de São Paulo (2007), Especialista em Direito Público (2009), Direito Tributário e Financeiro (2010), Direito Processual Civil (2011) e Direito Eleitoral (2012). Atualmente, é Professor dos Cursos de Graduação e Pós-Graduação em Direito, Ciências Contábeis e Administração da União das Escolas Superiores de Rondônia (UNIRON) e da Escola Superior da Advocacia (ESA) da Ordem dos Advogados do Brasil (OAB) - Secção de Rondônia. Foi Professor Substituto do Departamento de Ciências Jurídicas (DCJ) da Universidade Federal de Rondônia (UNIR) entre abril de 2018 e janeiro de 2019.

\section{PROFA. DRA. VANINA CARRARA SIGRIST}

Professora de Ensino Superior Nível III C na Faculdade de Tecnologia da Baixada Santista, membro da Comissão de Iniciação Científica nessa instituição, Doutora em Teoria e História Literária pela Unicamp.

\section{RICARDO PEREIRA}

Formado Técnico em Comércio Exterior pela instituição SENAC, Bacharel em Administração de Empresas com ênfase em Comercio Exterior pela instituição UNIASSELVI, MBA em Lean Manufacturing pela instituição SUSTENTARE e Mestre Engenharia de Produção pela instituição SOCIESC. Formando em Coach pela Associação Latino Americana de Coach - SLAC. Profissional com expertise em gestão industrial, gerenciamento e desenvolvimento de equipes, desenvolvimento de modelos e formas de gestão para resultados. Trabalhou em empresas como Zen SA, OSX SA, BMS SA, e atualmente é empresário no ramo de consultoria com sua empresa L6S CONSULTORIA E TREINAMENTO. Já atendeu mais de 60 empresas em todo o Brasil, onde atua na Gestão Industrial, Logística e Coach. Conta com equipe multidisciplinar para o desenvolvimento da gestão, coach e liderança nas empresas onde atua. É coautor dos livros: Cartas para o Sucesso; Coletânea Brasileira de Engenharia de Produção; Gestão do Conhecimento - Perspectiva 
Multidisciplinar; Melhores práticas dos Fórum Discuta Lean; Mentalidade vencedora II; Essa tal felicidade.

\section{RODRIGO LUIZ ZANETHI}

Doutor em Direito; Advogado; Coordenador de Pós Graduação e Professor titular na UNISANTOS; Coordenador da Câmara Setorial de Assuntos Portuários e Aduaneiros da Associação Comercial de Santos - Gestão 2017/2020; Coordenador da Comissão de Direito Aduaneiro da OAB/SANTOS Gestão 2013/2016; Coordenador das Prerrogativas Federais da OAB/Santos - Gestão 2019/2021. Mestre em Direito; Palestrante; Integrante da Banca de Avaliadores "ad hoc" da Revista de Constitucionalização do Direito - RECONTO (ISSN 2594-9489) - UNIFATECIE. Avaliador do CONPEDI; Colunista mensal do jornal "A Tribuna" de Santos na coluna "Porto \& Mar." Membro da UJUCASP; Autor do livro: "Governança Global e o papel da OMC", editora Appris, 2015.

\section{ROSELY SCHEFFER}

Possui graduação em Administração pela Faculdade Estadual de Ciências e Letras de Campo Mourão (1993), é especialista em Redes de Computadores pela UNIPAR - Universidade Paranaense (2006) e possui aperfeiçoamento em Tecnologia da Informação e INTERNET pela Faculdade Estadual de Ciências e Letras de Campo Mourão (2000). Mestre em Governança e Sustentabilidade pelo Instituto Superior de Economia e Administração do Mercosul - ISAE/FGV (2015). Doutoranda em Administração pela Universidade Positivo. Atualmente, é coordenadora de curso de Tecnologia em Análise e Desenvolvimento de Sistemas da Faculdade Integrado de Campo Mourão e atua principalmente nos seguintes temas: ensino superior, graduação, informática, tecnologia em sistemas de informação.

\section{SANDRO BREVAL SANTIAGO}

Professor Adjunto da UFAM. Pós-Doutorado, em andamento, em Gestão Industrial - Indústria 4.0 na Faculdade de Engenharia do Porto, Doutorado em Engenharia de Produção pela Universidade Federal de Santa Catarina (UFSC). Formação internacional na Universidade de Chicago, Wharton School e INSEAD. Experiências em empresas de grande porte da área Logística, consultoria financeira e industrial e Projetos de Pesquisa, Desenvolvimento e Inovação.

\section{SÉRGIO FERNANDES DE ABREU JÚNIOR}

Procurador do Estado. Bacharel em Direito pela Universidade Federal de Minas Gerais, 2010. Especialista em Direito Penal pela PUC/MG, 2011.

\section{SIMONE DE ALMEIDA}

Bacharel em Processamento de Dados pela Universidade Estadual de Ponta Grossa (1991), Especialista em Ciência da Computação pela Universidade Estadual de Ponta Grossa (1992), Mestre em Engenharia de Produção pela Universidade Tecnológica Federal do Paraná (2005) e Doutora em Engenharia de Produção na Universidade Federal de Pernambuco (2012). Atualmente é professora da Universidade Tecnológica Federal do Paraná. Tem experiência na área de Engenharia de Software, Banco de Dados, Gerenciamento de Projetos e Análise e Desempenho de Processos atuando principalmente nos seguintes temas: Desenvolvimento de Sistemas de Informação, Tomadas de Decisão, Avaliação de Desempenho.

\section{VÂNIA FERNANDES CELESTINO}

Graduada em Ciências Contábeis pela Universidade Estadual de Montes Claros (2015). Formada em Técnico em Magistério pela Escola Estadual Doutor Osvaldo Prediliano Sant'anna. 


\section{VITOR COSTA CHAINÇA}

Profissional Farmacêutico com experiência em estudos clínicos, atuação em recinto alfandegado, membro do comitê farmacêutico da Abralog (Associação Brasileira de Logística) e discente do curso de tecnologia em logística da Faculdade de Tecnologia da Baixada Santista.

\section{WLEDENIR CALGARO}

Bancário e Administrador. Formou-se em Ciências Contábeis pela UTFPR - Universidade Tecnológica Federal do Paraná e em Tecnologia em Análise e Desenvolvimento de Sistemas pela FADEP. Cursou um MBA Executivo em Liderança Coaching e Gestão Empreendedora pela Faculdade Guairacá. 
